Historic, Archive Document

Do not assume content reflects current scientific knowledge, policies, or practices. 
- 


\title{
A Field Guide To Port Orford Cedar Plant Associations In Northwest California
}

\author{
Thomas M. Jimerson \\ Ecologist, Zone 1 \\ Forest Service, Pacific Southwest Region \\ Six Rivers National Forest \\ 1330 Bayshore Way \\ Eureka, CA 95501 \\ Sabrina L. Daniel \\ Production Editor \\ DRAWINGS BY: \\ Christina Ericksen \& Rosemary Bauman
}

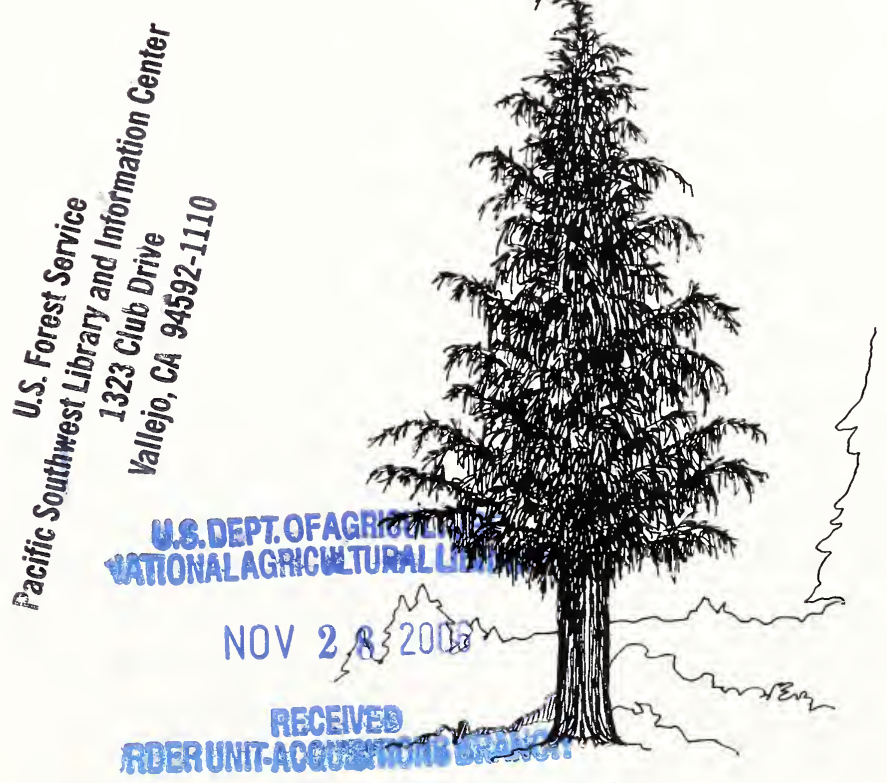


-

-

-

-

-

-

- 


\section{Acknowledgments}

This field guide was sponsored by the Six Rivers and Klamath national forests in northwest California. I thank the following individuals for their assistance in the study: Max Creasy-for data collection and manuscript review; David Imper, Steven Matthews, Elizabeth McGee, Ken Simeral, Jay Brown, Mark Branscom, Annette Parsons, Misha Schwartz, Chris Adair, Diane Sutherland, Anthony O'Geen, Thomas Quinn, Phillip Bono, Fred Fischer, Jeff Jones, Bruce Bryan, and Robert McNab-for data collection; Kathy Heffner and Richard McClellan-for socio-cultural context input; Gregg DeNitto-for comments on Port Orford cedar root disease; Stephanie Gomes, Dennis McKinnon, Linda Hungerford, Donna Dell'Ario, and Caroline Tudor for desktop publishing and layout advice; Meredith Smith and Peggi Lawrence-for manuscript review.

The United States Department of Agriculture (USDA) Forest Service is a diverse organization committed to equal opportunity in employment and program delivery. USDA prohibits discrimination on the basis of race, color, national origin, sex, religion, age, disability, political affiliation and familial status. Persons believing they have been discriminated against should contact the Secretary, US Department of Agriculture, Washington DC 20250, or call (202) 720-7327 (voice) or (202) 720-1127 (TDD). 
-

-

-

-

-

-

0 


\section{Table of Contents}

INTRODUCTION

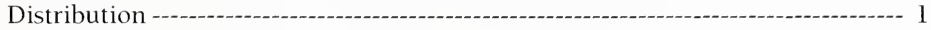

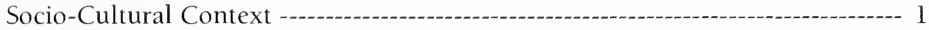

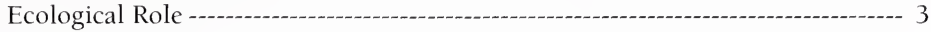

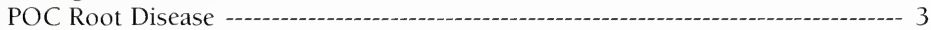

Resource Protection Alert --_-_-_-_- 4

USING THIS GUIDE -

Plant Association Nomenclature --- 5

Plant Association Descriptions --- 5

Vegetation Variables -- 6

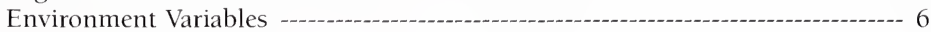

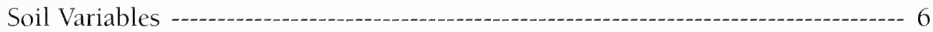

Stand Structure Variables --_- 6

Management Implications --_-_-_-o 6

USING THE VEGETATION KEYS --

KEY TO PLANT ASSOCIATIONS CONTAINING GREATER THAN 10\% PORT-ORFORD-CEDAR 8-c

Tanoak Series Key --

Port-Orford-Cedar Series Key --_-_-_-

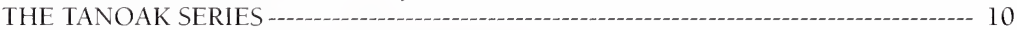

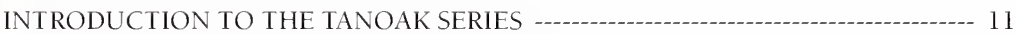

Tanoak-Port-Orford-Cedar-California Bay/Evergreen Huckleberry --------------- 16

Tanoak-Port-Orford-Cedar/Evergreen Huckleberry-Western Azalea ------------- 18

Tanoak-Port-Orford-Cedar/Evergreen Huckleberry -----o- 20

Tanoak-Port-Orford-Cedar/Dwarf Oregon-grape/Twinflower ------------------- 22

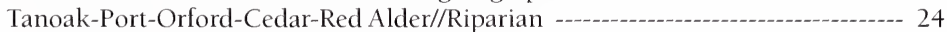

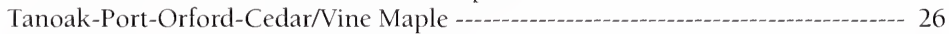

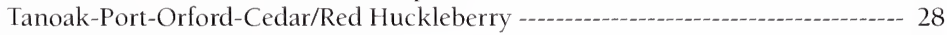

Tanoak-Port-Orford-Cedar/Salal -_- 30

Tanoak-Port-Orford-Cedar-Western Hemlock/Evergreen Huckleberry -_-_-_-_-_ 32

Tanoak-Port-Orford-Cedar-Redwood/Evergreen Huckleberry ---_-_-_--- 34-d

Tanoak-Port-Orford-Cedar/Huckleberry Oak ---

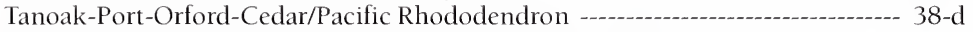

Tanoak-Western Red-Cedar/Evergreen Huckleberry-Salal ------------------------ 40-d

THE PORT-ORFORD-CEDAR SERIES -- 34

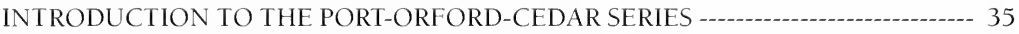

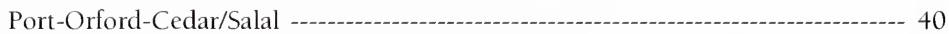

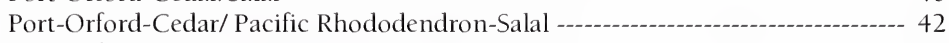

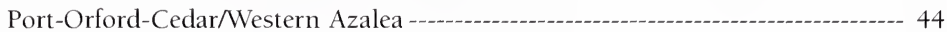

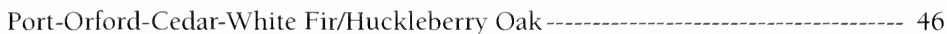

Port-Orford-Cedar-White Fir-Western White Pine/Huckleberry Oak------------ 48

Port-Orford-Cedar-White Fir/Western Azalea --_-_-_- 50

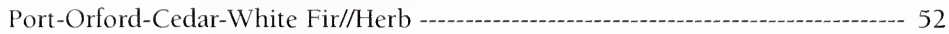

Port-Orford-Cedar-White Fir/Sadler Oak ----------------------------- 54

Port-Orford-Cedar-Red Fir/Sadler Oak-Thin-Leaved Huckleberry ---------------- 56

Port-Orford-Cedar-Douglas-fir/Huckleberry Oak --_-_- 58

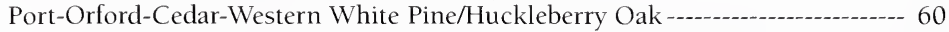

Port-Orford-Cedar-Incense Cedar-White Alder --_-- 62

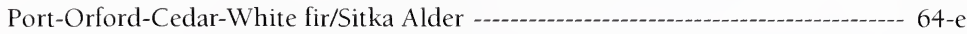

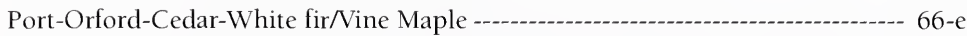

Port-Orford-Cedar-Red fir-Brewer's Spruce/Sadler Oak-Huckleberrry Oak ------ 68-e

Port-Orford-Cedar-Red fir/Sitka Alder-Sadler Oak ---_-a-

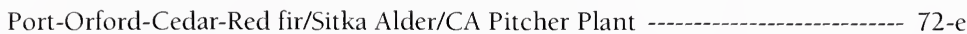

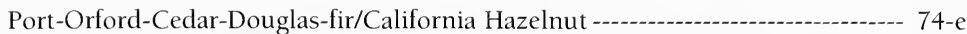

Port-Orford-Cedar-Douglas-fir-Alder/Vine Maple-Oregon-grape ----------------- 76- 
Port-Orford-Cedar-Western White Pine/Western Azalea-

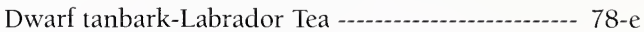

Port-Orford-Cedar-Western White Pine/Labrador Tea/

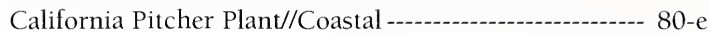

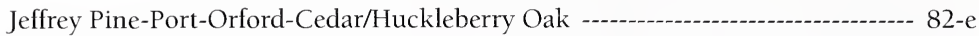

LITERATURE CITED -.-.-- 65

APPENDIX I: PLANT SPECIES LIST -

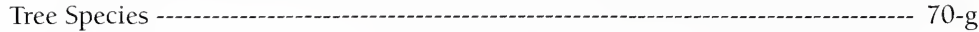

Shrub Species - -

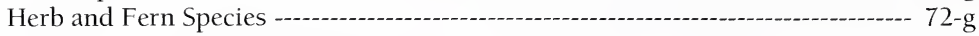

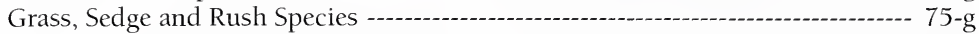

APPENDIX II: ENVIRONMENT SUMMARY --------------- 77 -g

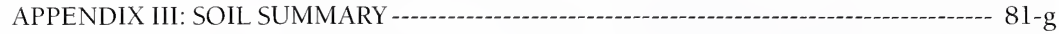

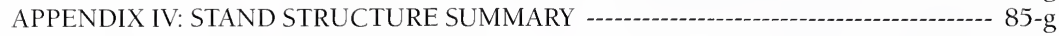

APPENDIX V: VEGETATION SUMMARY --.-- 89-g

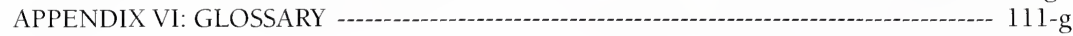

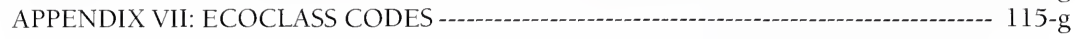




\section{INTRODUCTION}

The USDA Forest Service has changed its approach to management of the National Forests and Grasslands under its jurisdiction. This new strategy, labeled "Ecosystem Management," is based on ecological principles and is designed to conduct management and research with emphasis on maintenance of ecosystem process and function. To begin understanding ecosystem process and function requires a vegetation classification system. The Pacific Southwest Region of the Forest Service has begun a long term project to develop ecological classifications for the 20 million acres it manages in California. These classifications follow those developed by Federal Agencies throughout the United States. The California classifications will describe potential natural plant communities in a hierarchical manner. This hierarchy includes series, sub-series, and plant association classifications. Each level of the hierarchy is distinguished from the other by differences in species composition, soils, productivity, physiography, and expected response to management (Allen, 1986). These potential natural vegetation (PNV) units are used to analyze ecosystems through coarse filter analysis. It is thought that maintaining representative examples of various PNV types and their seral stages will protect viable populations of most species (85-90\%) and maintain biological diversity (Noss 1987, Hunter 1991).

This field guide is one part of the California classification effort. It describes plant associations containing greater than $10 \%$ cover of Port Orford cedar (Chamaecyparis lawsoniana) that occur in Northwest California. It is a reduced version of the more detailed desktop version (Jimerson and Creasy 1990), and is designed for field use. For more detailed information on Port Orford cedar communities please refer to the desktop version.

\section{Distribution}

Port Orford cedar is the largest member of the Cypress family (Zobel and others 1985). Fossil records in western North America date back 50 million years and indicate that it was once widespread (Edwards 1983). Currently, Port Orford cedar is found from coastal central Oregon to Northwest California (Atzet and Wheeler 1984).

\section{Socio-Cultural Context}

Port Orford cedar plays a significant role in the religious and medicinal life of the Karuk and Hupa indigenous people of Northwestern California.

The wood of the Port Orford cedar tree was used for two of the most essential aspects of everyday life: housing the family and spiritual purification for religious training. While the "living home" (see photo page 2) is no longer used as a primary residence, it is still constructed by local indigenous people; the sweathouse (see photo page 2 ) is still actively used by individuals, families, and the community. These two structures and what they represent 


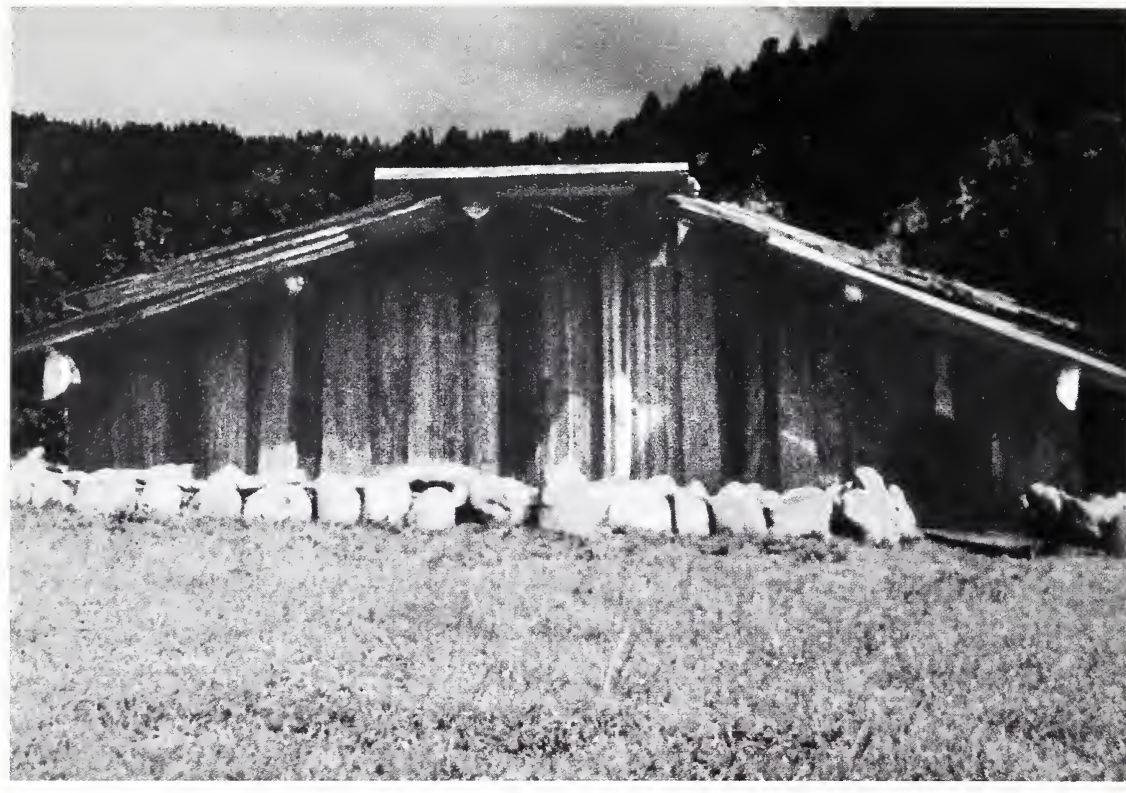
The "living home" used by Northwest California indigenous people.
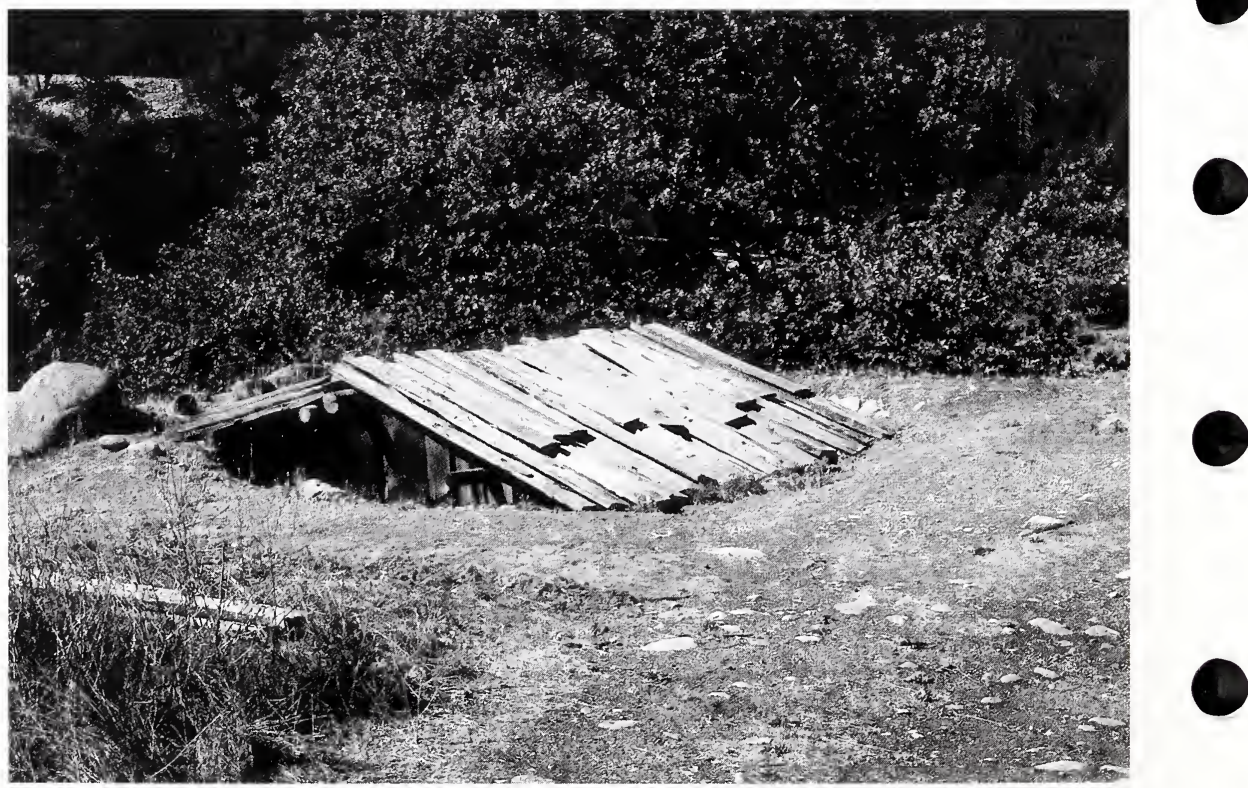

Sweatlodge used by Northwest California indigenous people for spiritual and physical cleansing. 
are the keystones that their religion was built upon. In the manuscript "Learning to Care," (1986) Richard McClellan, a Hupa-Karuk spiritual doctor, wrote:

"The basis that our religion is built upon is the family and individual spiritual achievement. Dedication to those two keystones is the pursuit of individual, family, and community religious preparation and achievement. The sweathouse is one of the more important forms of cleansing one from the contaminations of daily existence. This cleansing of mind and body is required in order to achieve spiritual enlightenment. It takes place in the sweathouse as part of a daily routine, in preparation for spiritual mountain quests, in preparation for doctor ing, and in preparation and performance of the religious ceremonies. The Port Orford cedar tree has certain medicinal qualities to it that assists in creating the environment needed to achieve this. We have tremendous respect for the spirituality of the cedar tree and look at it as a partner in religious trainings."

Every part of the Port Orford cedar tree is utilized. The buds are used to heal sore lungs, toothaches, and sore throats. The leaves are used to heal coughs. The bark and twigs are used to heal kidney problems. Some regalia items used in religious ceremonies and dances are made of the wood. Other religious regalia items such as various feathers and hides are stored in trunks constructed from the wood of Port Orford cedar because the wood's smell repels insects.

\section{Ecological Role}

The ecological role of Port Orford cedar includes being the primary shade tolerant conifer species found along many of northwest California's streams. Here it regenerates naturally under its own canopy, providing stream shading and habitat for a variety of wildlife species. Because of its resistance to decay, Port Orford cedar snags and logs are long-lived components of wildlife habitat (Jimerson 1989). Port Orford cedar logs also provide in-stream structure as well as organic input to streams containing anadromous fish.

Port Orford cedar is a major tree component of six vegetation sub-series found from near sea level to over 6000 feet elevation. It is found on a variety of parent materials usually in stream side positions where it is a significant riparian component. It is also found in upslope mesic positions. In a study conducted by Jimerson and Creasy (1991), Port Orford cedar appeared to have the highest species richness of the five primary vegetation series found in Northwest California.

\section{POC Root Disease}

During the 1950s the root fungus Phytophthora lateralis was introduced into the United States. This fatal root disease has spread throughout much of the range of Port Orford cedar (Roth and others 1987). The disease is spread through water, through root-grafted trees, and through the movement of earth containing fungus spores. Often the earth containing spores is attached to 
construction equipment used in road maintenance and logging operations. Additional vectors of the disease include cattle and wildlife. The potential impacts of this disease on Port Orford cedar communities are immense. Many of the low elevation examples of these communities have already been infected. The result is the replacement of this shade tolerant species by less tolerant species such as Douglas-fir (Pseudotuga menziesii) and alder (Alnus sp.) and a change in the plant species composition of these diverse communities.

\section{Resource Protection Alert}

If you have been travelling the backroads of southwest Oregon and northwest California during wet periods, please be aware that you could be transporting the spores of a disease which is fatal to Port Orford cedar. The disease spreads from infected to uninfected areas by the transport of its spores trapped in the mud on the bottom of vehicles and on equipment. Once introduced into a drainage, the disease can spread rapidly downstream and kill entire stands of Port Orford cedar.

Before venturing out on the backroads, contact the nearest Ranger District office to determine if your travel route passes through infected areas. On the Six Rivers National Forest, Port Orford cedar occurs on the Smith River National Recreation Area (SRNRA) within the Gasquet Ranger District, and on the Orleans and Lower Trinity ranger districts. On the Klamath National Forest, Port Orford cedar is found on the Ukonom and Happy Camp Ranger Districts. To date, the disease is only present in specific areas within the SRNRA. If there is any doubt as to whether you have been in an infected area, please make it your responsibility to pressure wash the underside (including the fender walls, bumpers etc.) of your vehicle at the nearest car wash before and after driving backroads in wet weather.

\section{USING THIS GUIDE}

The guidebook is based on field sampling throughout the range of each Port Orford cedar plant association. It is designed for field identification of plant associations with greater than 10 percent cover of Port Orford cedar. It includes keys to, and descriptions of, each plant association including vegetation composition, environment, soils, stand structure, and management implications.

Each plant association has an abbreviated name described below and a regional number for identification purposes. The regional identification number is used to correlate the plant association with any type of survey work. Examples include ecological unit inventory, wildlife habitat relationships, forest inventory analysis, soil survey, vegetation mapping, and oldgrowth inventory. 
Species were assigned to structural categories, such as tree, shrub, herb, or grass, and given an abbreviated code according to the "Electronic Data Processing Codes (EDP) For California Wildland Plants" (Reed and others 1963). These EDP Codes are used throughout the ecological classification program in California to standardize identification of plant species and naming of plant associations. The codes use the first two letters of the genus and first two letters of the specific epithet (species) and a numeric code if necessary to distinguish species. Using Port Orford cedar as an example, Chamaecyparis lawsoniana, would be represented as CHLA (no numeric code is needed here).

The plant association name is broken down into two parts, the biotic and the abiotic (Appendix I). The biotic segment is subdivided by strata, while the abiotic is separated by a double "//". Within the biotic portion of the name, a " $/$ " is used to represent a stratum change, while a "-" represents species in the same stratum. Examples of different plant association names include; LIDE2-CHLA/BENE1/LIBOL, CHLA/GASH and LIDE2-CHLAALRH//Riparian. In the first case, LIDE2-CHLA/BENE1/LIBOL, three strata are present (tree-tree/shrub/herb). In the second case CHLA/GASH includes only two strata (tree/shrub). The third case, LIDE2-CHLA-ALRH/Riparian, involves one strata and a special feature (tree-tree-tree//Riparian). The abiotic portion of the name may be added to describe some special feature of the plant association, such as the previous example where the community is found in riparian locations.

The order of species in the plant association name identifies the vegetation series and sub-series. The first name listed identifies the series, while the second name identifies the sub-series. The series is the naturally reproducing species that will dominate a site as the end product of succession. The subseries is the indicator of the position of the plant association along the environmental gradient within the series. Using the plant associations described above the LIDE2-CHLA/BENE1/LIBOL type is included within the Tanoak series. Within this type Tanoak is the naturally reproducing species that dominates late seral stands. The sub-series modifier, Port Orford cedar, indicates the moist end of the Tanoak series environment gradient. The CHLA/GASH plant association is included in the Port Orford cedar series. The sub-series modifier salal indicates the mesic end of the moisture gradient.

\section{Plant Association Descriptions}

Each plant association is described as to vegetation, environment, soils, stand structure, and management implications. Drawings of the indicator species are included as well as a photograph of each plant association. Summary tables that allow comparison of plant associations by the variable categories described below are also provided in the appendices. Terms used in this document are highlighted and defined in the glossary (Appendix VI). 


\section{Vegetation Variables}

Vegetation is first described by total percent cover for each layer including overstory and understory trees, shrubs, forbs and grasses. Species with greater than 20 percent constancy are listed for each plant association. All plants were identified to species where possible. Species nomenclature follows Munz (1973), and common names used follow Abrams (1968), Munz (1973), and Atzet and Wheeler (1984). A complete list of species encountered during this study is included in Appendix I.

\section{Environment Variables}

The physical environment is defined by elevation, aspect, percent slope, slope position, surface rock percent, and radiation index (ratio of total annual radiation on a given aspect and slope to total annual radiation received on a flat surface for a given latitude) (Frank and Lee 1966). Radiation index is a way of comparing the relative temperature conditions by plant association. High radiation indices indicate warm sites, while low radiation indices indicate cool sites. The effects of slope and aspect can be ameliorated by topographic shading. In some situations, adjacent slopes can provide shading for much of the day. The topographic shading reduces the amount of sunlight reaching the ground and thereby alters the effect of aspect. Comparisons of each plant association by environment variables are contained in Appendix II.

\section{Soil Variables}

Soils are described by depth to a maximum depth of 40 inches or to bedrock, available water holding capacity (AWC), A horizon thickness, A horizon coarse fragment percent, A horizon texture, and parent material. Each plant association is compared by soil variables in Appendix III.

\section{Stand Structure Variables}

Stand structure is described by mean values for stand age, trees/acre by diameter class, layers, height, conifer and hardwood cubic volume and basal area, Dunning site class (base age 300 years), and stand density index. Stand structure is compared by plant association in Appendix IV.

\section{Management Implications}

Management implications are provided for each plant association to supply the reader with predictive information on each plant association's response to treatment and any special problems that may be encountered. Management implications are located under the corresponding plant association variable description. For example, management considerations related to soil would be contained in the soils description. 


\section{USING THE VEGETATION KEYS}

A key to the plant associations containing greater than $10 \%$ cover of Port Orford cedar is found below. In the key, series are based on the species which are reproducing successfully, and/or the species that are the primary regenerating species. To reach a plant association, the key uses the presence of, or percent cover of, the indicator species.

Before attempting to use the key, you should walk around the stand and familiarize yourself with the vegetation. The key and vegetation descriptions are constructed from data collected in late seral stage stands. Therefore, if you are trying to use them in younger or disturbed stands, you should be aware that the percent species cover may not apply. The indicator species however, should all be present.

The key is structured as a choice between two statements. To use the key, first read both choices carefully, then choose the one that applies to the stand. This process is repeated until you end up at a plant association name. From here, proceed to the description of the selected plant association and check the description (environment and vegetation) to make sure that you have keyed to the correct vegetation type. If the description does not fit, go back and try the key again.

Characteristic cover is used in this document rather than average cover. Characteristic cover is defined as the percent cover one could expect to find in a plant association if the species were present in this type. It is the average cover of stands containing the species. For example plant association $\mathrm{X}$ includes 10 plot samples; on 5 of these plots species Y had 10 percent cover. Its characteristic cover would be 10 percent. Characteristic cover is displayed along with constancy. Constancy is the percent of times a species was found to occur in a plant association among the plots sampled. Using the same example from above, species $Y$ would have a constancy of 50 percent, that is, it occurred in 50 percent of the plots sampled. 


\section{KEY TO PLANT ASSOCIATIONS CONTAINING GREATER THAN 10 PERCENT COVER OF PORT-ORFORD-CEDAR}

la. Tanoak present and reproducing successfully Tanoak Series Key (below)

lb. Tanoak absent or not as above Port-Orford-cedar Series key (p.9-c)

\section{Tanoak Series Key}

la. Evergreen huckleberry present and greater than $10 \%$ cover 3

3a. Western hemlock present and greater than $10 \%$ cover

LIDE2-CHLA-TSHE/VAOV (p.32)

3b. Western hemlock absent or not as above

4a. Western azalea present and greater than $2 \%$ cover

LIDE2-CHLA/VAOV-RHOC (p.18)

4b. Western azalea absent or not as above

5a. Coast redwood present and greater than $2 \%$ cover

LIDE2-CHLA-SESE2/VAOV (p.34-d)

5b. Coast redwood absent or not as above

6a. Western red cedar present and greater than $10 \%$ cover

LIDE2-THPL/VAOV-GASH (p.40-d)

6b. Western red cedar absent or not as above

7a. Pacific rhododendron present and greater than $10 \%$ cover

7b. Pacific rhododendron absent or not as above LIDE2-CHLA/RHMA (p.38-d)

8a. California bay present and greater than $2 \%$ cover

LIDE2-CHLA-UMCAl/VAOV (p.16)

8b. California bay absent or not as above LIDE2-CHLA/VAOV (p.20)

1b. Evergreen huckleberry absent or less than $10 \%$ cover 9

9a. Alder present and greater than $10 \%$ cover

9 b. Alder absent or less than $10 \%$ cover

LIDE2-CHLA-ALRH//Riparian (p.24)

10a. Vine maple present and greater than $10 \%$ cover

10b. Vine maple absent or less than $10 \%$ cover

1la. Dwarf Oregon-grape present and greater than 2\% cover and Salal less than $10 \%$ cover LIDE2-CHLA/BENE1/LIBOL (p.22)

11b. Dwarf Oregon-grape absent or not as above 12

12a. Salal present and greater than $10 \%$ cover LIDE2-CHLA/GASH (p.30)

12b. Salal absent or not as above 
13a. Red huckleberry present and greater than $2 \%$ cover

13b. Red huckleberry absent or not as above

14a. Huckleberry oak present and greater than $10 \%$ cover

LIDE2-CHLA/QUVA (p.36-d)

14b. Huckleberry oak absent or not as above

15a. California Bay present in overstory, huckleberry oak absent

LIDE2-CHLA-UMCA1/VAOV (p.16)

15b. California bay absent or not as above

Please go back and try again

\section{Port-Orford-Cedar Series Key}

16a. White fir present and greater than $5 \%$ cover

17a. Red fir present in overstory and understory

18a Sitka alder present and usually greater than $10 \%$ cover

19a. California pitcher plant present and greater than $10 \%$ cover .

CHLA-ABMAS/ALSI2/DACA2 (p.72-e)

19b. California pitcher plant absent or not as above

CHLA-ABMAS/ALSI2-QUSA (p.70-e)

18b. Sitka alder absent or not as above

20a. Brewer's spruce present, Sadler oak and huckleberry oak dominant shrubs CHLA-ABMAS-PIBR/QUSA-QUVA (P.68-e)

20b. Brewer's spruce absent, Sadler oak and thinleaf huckleberry dominant shrubs CHLA-ABMAS/QUSA-VAME (p.56)

17b. Red fir absent in overstory and understory

21a. Western white pine present and greater than $5 \%$ cover

CHLA-ABCO-PIMO3/QUVA (p.48)

21b. Western white pine absent or not as above

22a. Sadler oak present and greater than $5 \%$ cover

CHLA-ABCO/QUSA(p.54)

22b. Sadler oak absent or not as above

23a. Western azalea present and greater than $10 \%$ cover

23b. Western azalea absent or not as above

CHLA-ABCO/RHOC (p.50)

24a. Huckleberry oak present and greater than $5 \%$ cover.....

CHLA-ABCO/QUVA(p.46)

24b. Huckleberry oak absent or not as above

25 a. Forest floor $>25 \%$ herb cover CHLA-ABCO//Herb (p.52)

25b. Not as above 26 
27a. Vine maple present and greater than $10 \%$ cover

CHLA-ABCO/ACCI (p.66-e)

$27 \mathrm{~b}$. Vine maple absent or not as above Please go back and try again

16b. White fir absent or not as above

28a. Huckleberry oak present and greater than $5 \%$ cover

29a. Jeffrey pine present and cover usually greater than Port-Orford-cedar PIJE-CHLA/QUVA (p.82-e) 29b. Jeffrey pine absent or not as above

30a. Western white pine present in overstory and understory

3la. Labrador-tea and California pitcher plant present, cover greater than $10 \%$ and $2 \%$ respectively ......... CHLA-PIMO3/LEGL1/DACA2//Coastal (p.80-e)

3lb. Labrador-tea or California pitcher plant absent or not as above 32

32a. Western azalea present and greater than $10 \%$ cover, dwarf tanbark present .. CHLA-PIMO3/RHOC-LIDEE-LEGLl (p.78-e) 32b. Western azalea or dwarf tanbark absent or not as above CHLA-PIMO3/QUVA(p.60)

30b. Western white pine absent or not as above

33a. Douglas-fir greater than $10 \%$ cover and codominant with Port-Orford-cedar ... CHLA-PSME/QUVA(p.58)

33b. Douglas-fir absent or not as above 34

28b. Huckleberry oak absent or less than $5 \%$ cover 34

34a. Salal present and greater than $10 \%$ 35

35a. Pacific rhododendron present and greater than $10 \%$ cover...

CHLA/RHMA-GASH(p.42)

35b. Pacific Rhododendron absent or not as above

36a. Western azalea present and greater than $10 \%$ cover CHLA/RHOC (p.44)

36b. Western azalea absent or not as above CHLA/GASH (p.40)

34b. Salal absent or not as above

37a. Incense cedar and alder present

CHLA-LIDE3-ALRH(p.62)

37b. Incense cedar or alder absent 
38a. Western azalea present and greater than $10 \%$ cover

CHLA/RHOC (p.44)

38b. Western azalea absent or not as above

39a. Hazel present and greater than $10 \%$ cover

CHLA-PSME/COCOC (p.74-e)

39b. Hazel absent or not as above.

40a. Alder and vine maple present, cover greater than $10 \%$ and $5 \%$

respectively

CHLA-PSME-Alder/ACCI-BENE1 (p. 76-e)

40b. Alder or vine maple absent or not as above

Please go back and try again 
-

-

-

-

-

-

- 


\section{THE TANOAK SERIES}

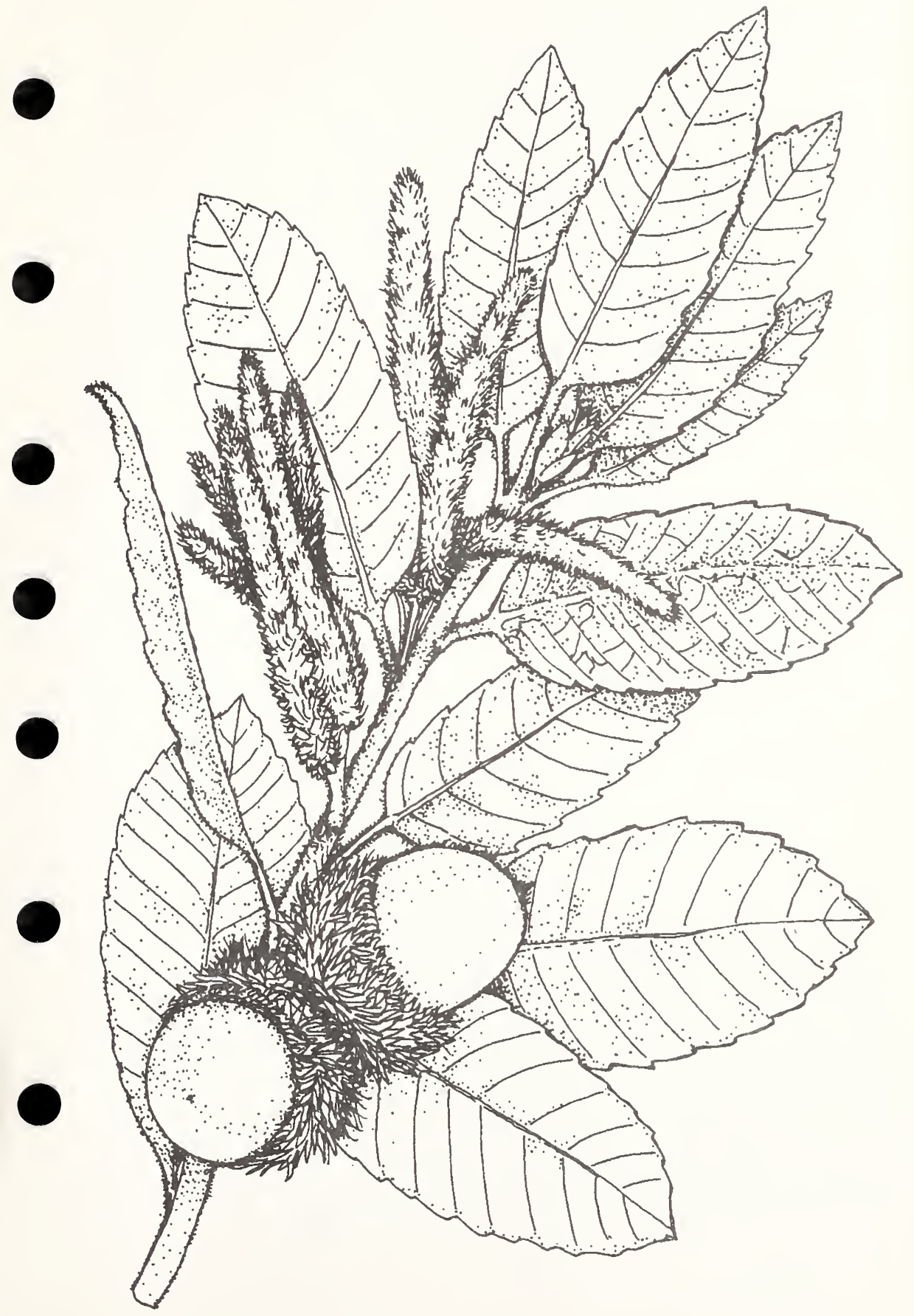


-

-

-

-

-

-

- 


\section{INTRODUCTION TO THE TANOAK SERIES}

The tanoak (Lithocarpus densiflora) series was found at low elevations where moisture conditions favored this mesic species. Port Orford cedar fell within the moist end of the tanoak series moisture gradient, in the tanoakPort Orford cedar sub-series. This sub-series was of limited extent within Northwest California, but of high ecological importance due to its high diversity of plant associations (Jimerson In Press). It was found along stream sides and in lower one-third slope positions, with linear, concave, and undulating micro-relief. It spanned an elevation range from 900 to $3540 \mathrm{ft}$.

Soils in the tanoak-Port Orford cedar sub-series were derived from metamorphic (55\%), igneous intrusive (31\%), and mixed (11\%) parent materials. The metamorphic rocks were primarily phyllite, schist, serpentine, and greenstone. The igneous intrusive rocks included mafic and ultramafic rocks. The effect of these variable parent materials was a wide range of soil $\mathrm{pH}$. The surface $\mathrm{pH}$ averaged 6.2 and ranged from 5.0 to 7.0 , sub-surface $\mathrm{pH}$ averaged 6.4 and ranged from 5.5 to 7.5 . Soil depths were primarily deep (52\%) and moderately deep (41\%), with loamy-skeletal (62\%) and fine loamy (32\%) textures. Soils were classified in the Inceptisol (65\%), Entisol (19\%), and Alfisol (16\%) orders, and found in the mesic soil temperature regime. Available water holding capacity (AWC) was moderate, averaging 3.4 inches, and ranged from 1.5 to 5.1 inches. AWC may not be as important to this subseries as it was to upland sub-series because of its proximity to water. A horizon thickness was also moderate; it averaged 6 inches and ranged from 2 to 10 inches. A horizon coarse fragments averaged 39 percent and generally ranged from 14 percent to 70 percent. Sub-surface coarse fragments averaged 38 percent and ranged from 15 percent to 65 percent.

Stand age frequency in the tanoak-Port Orford cedar sub-series showed a dominance by older stands (Fig. 1), with a mean stand age of 353 years. The highest frequency of stands sampled occurred in the 276-425 year range (59\%). The proportion of stands greater than 300 years stand age was 65 percent, compared to 8 percent of the stands below 200 years stand age. This was due to the tendency for this sub-series to occur in stream-side locations that have low stand replacing fire frequencies due to the moist environment.

Stand structure within the tanoak-Port Orford cedar sub-series reflects the age distribution described above and the tendency to occur on high site quality locations. The mode for all sites was site class 1, Dunning base age 300 years. Because of the high site class, the mixture of conifers and hardwoods, and the advanced age, stands tended to have both high vertical and horizontal structural diversity. This was demonstrated by the presence of both softwoods and hardwoods in most diameter classes. Softwoods dominated the overstory and diameter classes above 11 inches, while hardwoods dominated the mid layer and the 0-5.9" size class (Fig. 2). 


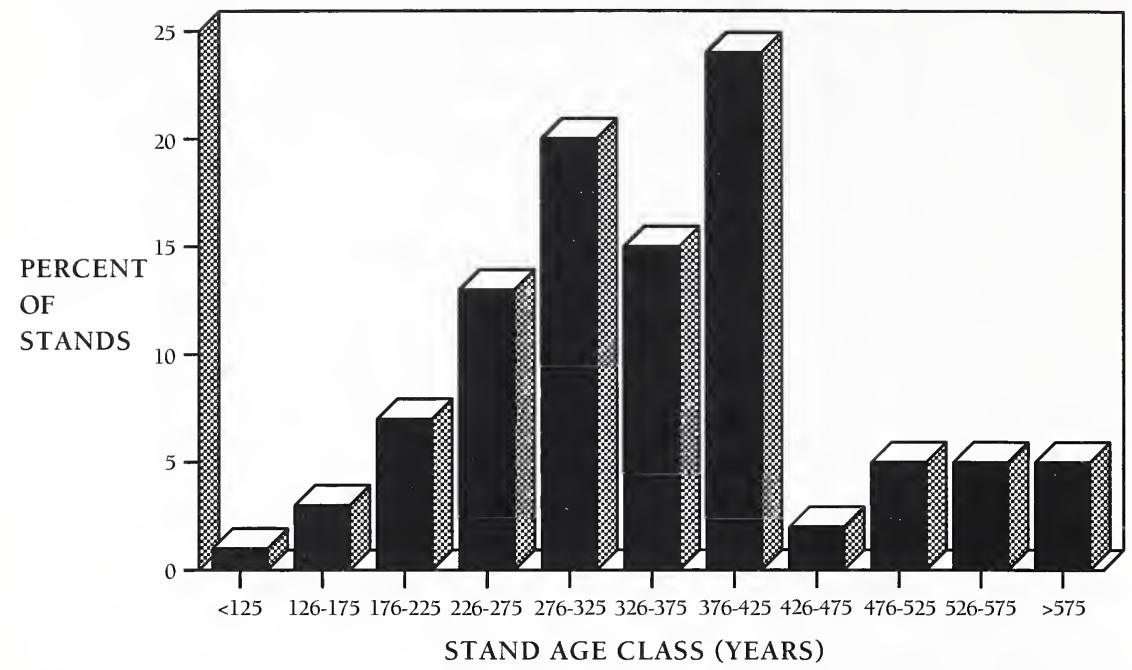

Figure 1. Percent of stands by stand age class category in the Tanoak-Port Orford cedar sub-series.

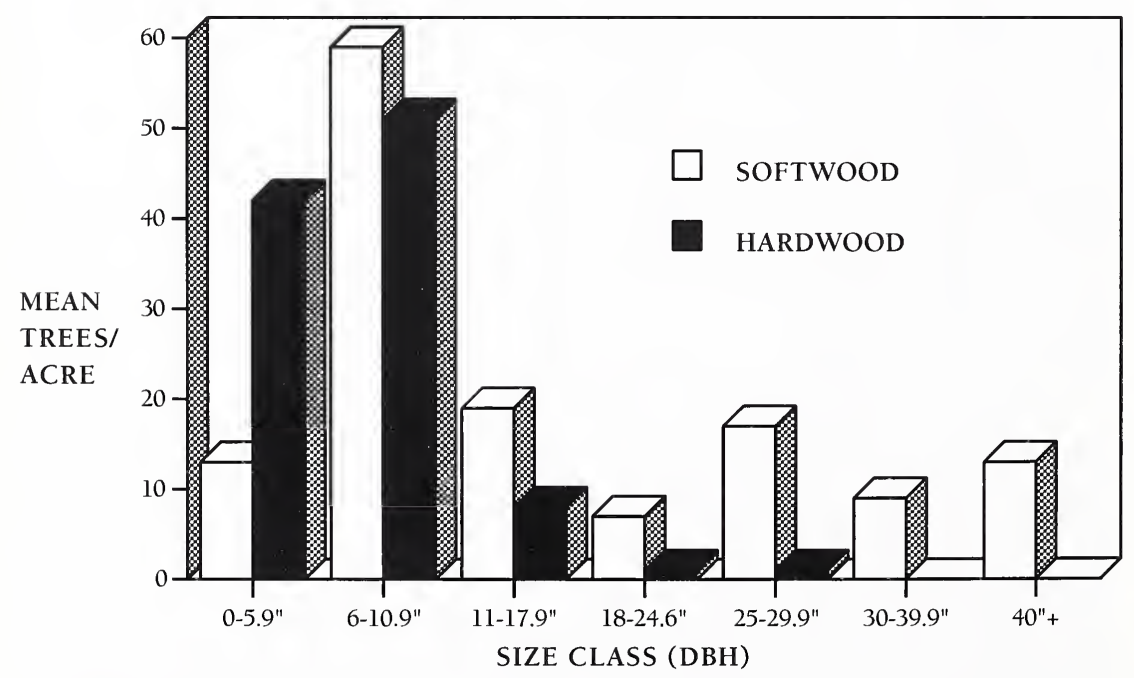

Figure 2. Mean trees/acre by size class, for softwoods and hardwoods in the Tanoak-Port Orford cedar sub-series. 
Large snags and logs were a common feature of this sub-series and tended to persist for long periods of time due to the resistance of Port Orford cedar to decay. The density of snags $>20$ inches diameter and $>15$ feet tall was 3 snags/acre. They averaged 35 inches in diameter and 56 feet tall, and were found primarily in decay classes 3 and 4 (63\%). Logs > 20 inches diameter and $>10$ feet long had a mean density of 16 logs/acre and a mean volume of $2040 \mathrm{ft}^{3}$ and were included mainly in decay classes 3 and 4 .

Vegetation cover in the tanoak-Port Orford cedar sub-series is characterized by a dense tree layer averaging 89 percent total cover. It was dominated by conifer species in the overstory averaging 73 percent and hardwoods in the mid layer averaging 33 percent. The shrub layer was generally dense, averaging 46 percent, while the herb layer was moderate, averaging 16 percent cover. The grass layer was sparse ( $2 \%$ cover) due to the cool, moist environment in the stream-side positions and dense cover of trees and shrubs.

The tanoak-Port Orford cedar sub-series was dominated in the overstory by the conifer species Port-Orford cedar along with Douglas-fir (Pseudotsuga menziesii), and sugar pine (Pinus lambertiana). The mid layer was dominated by hardwoods including tanoak, bigleaf maple (Acer macrophyllum), dogwood (Cornus nuttallii), Pacific madrone (Arbutus menziesii), giant chinquapin (Castanopsis chrysophylla), California bay (Umbellularia californica), and white alder (Alnus rhombifolia). Pacific yew (Taxus brevifolia) was frequently found in this sub-series as an understory tree or in shrub form. Shrub layer dominance was determined by available moisture and elevation. It included vine maple (Acer circinatum), western azalea (Rhododendron occidentale), and hazelnut (Corylus cornuta) on the wettest sites. The mesic sites were dominated by evergreen huckleberry (Vaccinium ovatum), Pacific rhododendron (Rhododendron macrophyllum), salal (Gaultheria shallon), and red huckleberry (Vaccinium parviflorum). The driest parts of this moisture gradient were dominated by dwarf Oregon-grape (Berberis nervosa), wild rose (Rosa gymnocarpa), and trailing blackberry (Rubus ursinus). The herb layer also corresponded to this moisture gradient. It contained white trillium (Trillium ovatum), redwood sorrel (Oxalis oregana), twinflower (Linnaea borealis), vanilla leaf (Achyls triphylla), and swordfern (Polystichum munitum) on the wettest sites. The mesic sites included starflower (Trientalis latifolia), insideout flower (Vancouveria planipetala), Hooker's fairybells (Disporum hookeri), rattlesnake plantain (Goodyera oblongifolia), and prince's pine (Chimaphila umbellata). The drier sites contained western modesty (Whipplea modesta), bracken fern (Pteridium aquilinum), and beargrass (Xerophyllum tenax). The grass/sedge layer was dominated by sedges (Carex spp.). 
Nine plant associations were identified within the tanoak-Port Orford cedar sub-series (Table 1). Mean elevation by plant association ranged from 1232 to 2885 feet. The low elevation plant associations included the tanoakPort Orford cedar-California bay/evergreen huckleberry (1232 ft.), tanoakPort Orford cedar-western hemlock/evergreen huckleberry (1567 ft.), and tanoak-Port Orford cedar/evergreen huckleberry-western azalea types (1692 ft.). The high elevation plant associations were the tanoak-Port Orford cedar/ red huckleberry (2885 ft.), tanoak-Port Orford cedar/dwarf Oregon-grape/ twinflower (2815 ft.), and the tanoak-Port Orford cedar/salal (2658 ft.) types.

Mean slope in the tanoak-Port Orford cedar sub-series ranged from 19 to 53 percent. Plant associations with gentle slopes included the tanoak-Port Orford cedar/salal (19\%), tanoak-Port Orford cedar-white alder//riparian (25\%), and tanoak-Port Orford cedar/red huckleberry (25\%). Plant associations with steep slopes included the tanoak-Port Orford cedar-western hemlock/evergreen huckleberry (53\%) and tanoak-Port Orford cedar/dwarf Oregon-grape/twinflower (46\%).

Mean radiation index ranged from a low of .360 in the tanoak-Port Orford cedar/dwarf Oregon-grape/twinflower type to a high of .490 in the tanoak-Port Orford cedar-western hemlock/evergreen huckleberry type. Because of slope position the higher radiation indices were often moderated by topographic shading.

Surface rock was generally low with the exception of the tanoak-Port Orford cedar-white alder//riparian type (27\%) and the tanoak-Port Orford cedar/vine maple type (8\%). Both of these types are found in streamside positions where surface rock cover tends to be high.

Due to the dense hardwood and conifer layers, stand structure within the tanoak-Port Orford cedar sub-series was generally complex, with both high vertical and horizontal diversity. This was reflected in the range of stand density indices, from low (358) in the tanoak-Port Orford cedar/vine maple type to high (533) in the tanoak-Port Orford cedar/red huckleberry type. Mean softwood volume ranged from moderate $(8,089 \mathrm{ft} .3)$ in the tanoak-Port Orford cedar/evergreen huckleberry-western azalea type to very high $(12,678$ ft.3) in the tanoak-Port Orford cedar/dwarf Oregon-grape/twinflower type. Hardwood volume had a wide range, from low (69 ft.3) in the tanoak-Port Orford cedar/red huckleberry type to very high ( $974 \mathrm{ft} .3$ ) in the tanoak-Port Orford cedar-California bay/evergreen huckleberry type. Dunning site class (base age 300 years) mode also reflected this variation in productivity. The tanoak-Port Orford cedar-California bay/evergreen huckleberry and tanoakPort Orford cedar/red huckleberry both had site class modes of 1A. The tanoak-Port Orford cedar/evergreen huckleberry-western azalea and tanoakPort Orford cedar-white alder//riparian reflected the low end of the site class range with modes of 3 . 
Four of the tanoak-Port Orford cedar sub-series plant associations were found almost entirely in riparian positions. They included the tanoak-Port Orford cedar-California bay/evergreen huckleberry, tanoak-Port Orford cedar/ evergreen huckleberry-western azalea, tanoak-Port Orford cedar-white Alder// riparian, and tanoak-Port Orford cedar/vine maple types. The other five types were found in upslope mesic positions, where site conditions are somewhat drier than in the riparian zone.

Table 1. Plant associations found in the tanoak-Port Orford cedar sub-series.

\begin{tabular}{|ll|}
\hline EDP CODE & PLANT ASSOCIATION NAME \\
\hline LIDE2-CHLA-UMCAI/VAOV & $\begin{array}{l}\text { Tanoak-Port Orford cedar-California } \\
\text { Bay/Evergreen Huckleberry }\end{array}$ \\
LIDE2-CHLA/VAOV-RHOC & $\begin{array}{l}\text { Tanoak-Port Orford cedar/Evergreen } \\
\text { Huckleberry-Western Azalea }\end{array}$ \\
LIDE2-CHLA/VAOV & Tanoak-Port Orford cedar/Evergreen \\
& Huckleberry \\
LIDE2-CHLA/BENE1/LIBOL & Tanoak-Port Orford cedar/Dwarf \\
& Oregon-grape/Twinflower \\
LIDE2-CHLA-ALRH//Riparian & Tanoak-Port Orford cedar-White \\
& Alder//Riparian \\
LIDE2-CHLA/ACCI & Tanoak-Port Orford cedar/Vine \\
& Maple \\
LIDE2-CHLA/VAPA & Tanoak-Port Orford cedar/Red \\
& Huckleberry \\
LIDE2-CHLA/GASH & Tanoak-Port Orford cedar/Salal \\
LIDE2-CHLA-TSHE/VAOV & Tanoak-Port Orford cedar-Western \\
& Hemlock/Evergreen Huckleberry \\
\hline
\end{tabular}




\section{LIDE2-CHLA-UMCA1/VAOV Association, EcoCode HT0CCO11}

\section{Tanoak-Port Orford Cedar-California Bay/Evergreen Huckleberry}

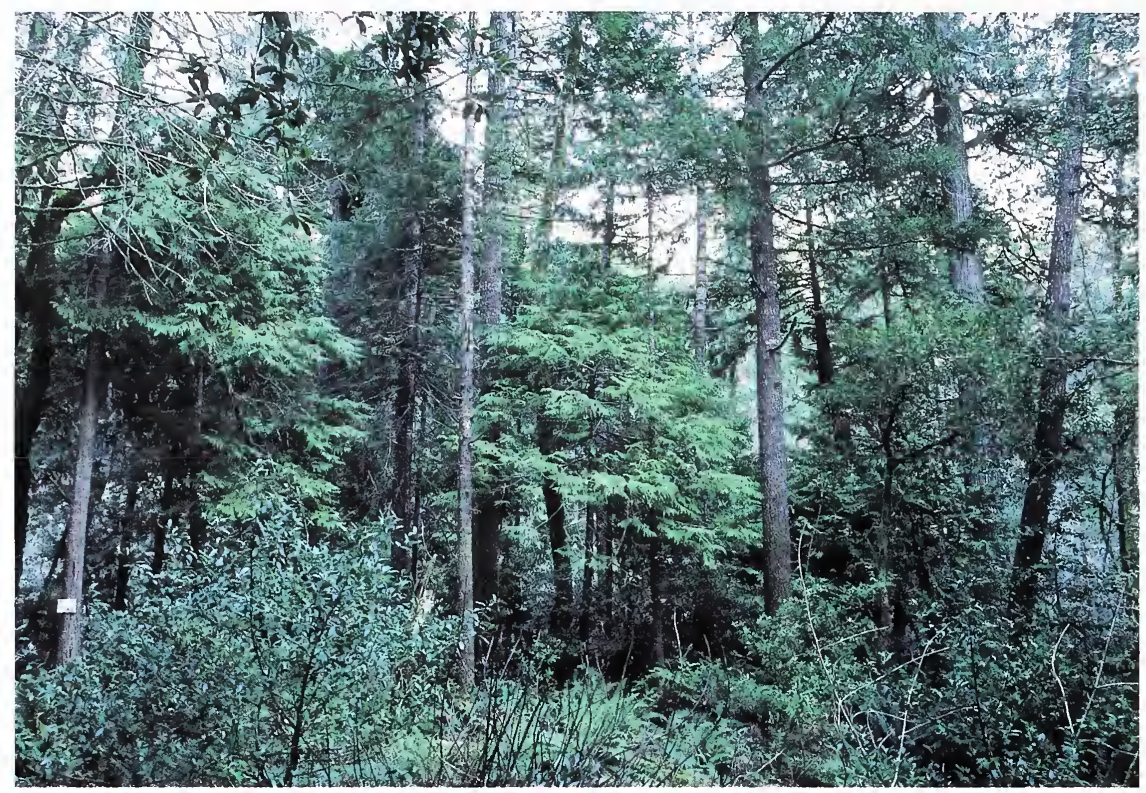

ENVIRONMENT: Elevation: 600-1600 ft.; Aspect: W., N.E.; Slope: 10-75\%; Slope Position: lower 1/3; Surface Rock: 0-4\%

\section{SUMMARY TABLE}

(Sample size: 14)

COVER

CON

Tree Overstory Layer

CHLA Port Orford Cedar

33

PSME Douglas-fir

39

LIDE2 Tanoak

UMCA1 California Bay

Tree Understory Layer

LIDE2 Tanoak

UMCA1 California Bay

CHLA Port Orford Cedar

PSME Douglas-fir

\section{Shrubs}

$\begin{array}{llr}\text { VAOV } & \text { Evergreen Huckleberry } & 40 \\ \text { COCOC } & \text { Hazelnut } & 3 \\ \text { GASH } & \text { Salal } & 12\end{array}$

100

71

64

Herbs \& Grasses

$\begin{array}{lll}\text { POMU1 } & \text { Sword Fern } & 8 \\ \text { TROV2 } & \text { White Trillium } & 1 \\ \text { ASCA2 } & \text { Wild Ginger } & 2 \\ \text { OXOR1 } & \text { Redwood Sorrel } & 7\end{array}$

92

85

57

50

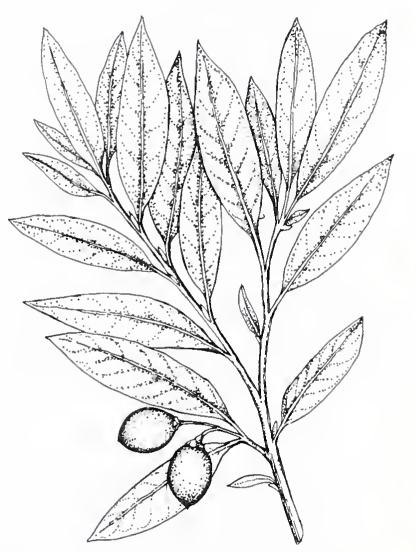

California Bay

(Umbellularia californica)

SOILS Pit Depth: 25->40 in.; Coarse Fragments: 40-85\%; Textures: vgl, xgl, vgsl; Parent Material: serpentine, mafic, greenstone, phyllite 
DISTRIBUTION/ENVIRONMENT: This association was found mostly on the Gasquet Ranger District and occasionally on the Orleans Ranger District, between 900 and 1600 feet elevation. It had the lowest mean elevation (1232 ft.) of all Port Orford cedar plant associations, and was found on lower one-third, moderately steep (37\%), west and northeast facing slopes with topographic shading, on streamside terraces. Radiation index was moderate (.440) due to the west facing slope component, but was offset by topographic shading.

VEGETATION SUMMARY: Total vegetation cover was very dense (99\%), and overstory cover of 92 percent was among the highest of all Port-Orford cedar plant associations. Overstory conifer species include Douglas-fir (39\%), which was codominant with Port-Orford cedar cover (33\%). Hardwood cover values in the mid layer were among the highest of all Port-Orford cedar types. Tanoak (30\%) dominated the hardwood layer, followed by California bay (12\%) and bigleaf maple ( $8 \%)$. The tree regeneration layer was dominated by tanoak (8\%), California bay (3\%), Port Orford cedar (3\%), Pacific dogwood (2\%), and Douglas-fir (1\%). Pacific yew was found here with 100 percent constancy as a small tree or in shrub form. The shrub layer averaged 53 percent cover, which was high for the tanoak-Port-Orford cedar subseries. Evergreen huckleberry (39\%) dominated here followed by salal (12\%), hazel (3\%) and dwarf Oregon-grape (2\%). Total forb cover $(21 \%)$ was among the highest in this sub-series. It includes sword fern $(8 \%)$ and redwood sorrel $(7 \%)$ as the dominant species, with twinflower (3\%), wild ginger (2\%), starflower (1\%), and white trillium $(1 \%)$ as associates.

SOIL SUMMARY: Soils in this type were derived from fine textured metamorphic parent materials such as phyllite, greenstone, and serpentine. They were primarily deep and moderately deep, very gravelly to extremely gravelly loams, with high AWC (3.6"), thick A horizons (8"), and high A horizon coarse fragments (51\%). They were found entirely in the mesic soil temperature regime and were highly to moderately productive for conifer growth. They present few major limitations for management except for areas with very high A horizon coarse fragments, or very steep slopes where plantability or regeneration may be inhibited. They are occasionally susceptible to compaction when soils are moist. The dominant soil groups were Goldridge deep (45\%); Kistirn moderately deep (25\%); and Clallam moderately deep $(20 \%)$; with about 10 percent other soils (shallow soils, poorly drained soils, ultramafic soils).

STAND STRUCTURE SUMMARY: Stands found in this type had the same average age as that of the tanoak-Port Orford cedar sub-series, 330 years, and ranged from 190 to 440 years stand age. The highest frequency of stands (49\%) were found between 276 and 375 years of age. The frequency of stands above 300 years was 57 percent; the frequency of stands below 200 years was 7 percent.

Due to a mixture of uneven-aged, tolerant and somewhat intolerant tree species, stands in this type have dense overstory cover often resulting in multiple layers. The overstory is usually composed of at least two layers of different aged conifers, averaging 184 feet tall in the top layer and 145 feet tall in the second layer. It had a high density of large conifers, with an average of 24 trees/acre greater than 30 inches diameter. The mid layers were dominated by hardwood species; they ranged from 35 to 70 feet tall. Most hardwood species were found in the smaller diameter classes with an average of 91 trees/acre in the 6-10.9 inch diameter class and an average of 22 trees/ acre greater than 11 inches diameter. The regeneration layer was low to moderate and limited by dense shrub cover.

Softwood cubic volumes range from moderate to high with an average of 10,658 $\mathrm{ft}^{3} / \mathrm{acre}$. Hardwood cubic volume of $974 \mathrm{ft}^{3} /$ acre was the highest among all Port-Orford-cedar types. Dunning site class was $1 \mathrm{~A}$, with site index of 200 at 300 years. Stand density index was moderate with an average of 473 . 
LIDE2-CHLA/VAOV-RHOC Association, EcoCode HT0CCO12 Tanoak-Port Orford Cedar/Evergreen Huckleberry-Western Azalea

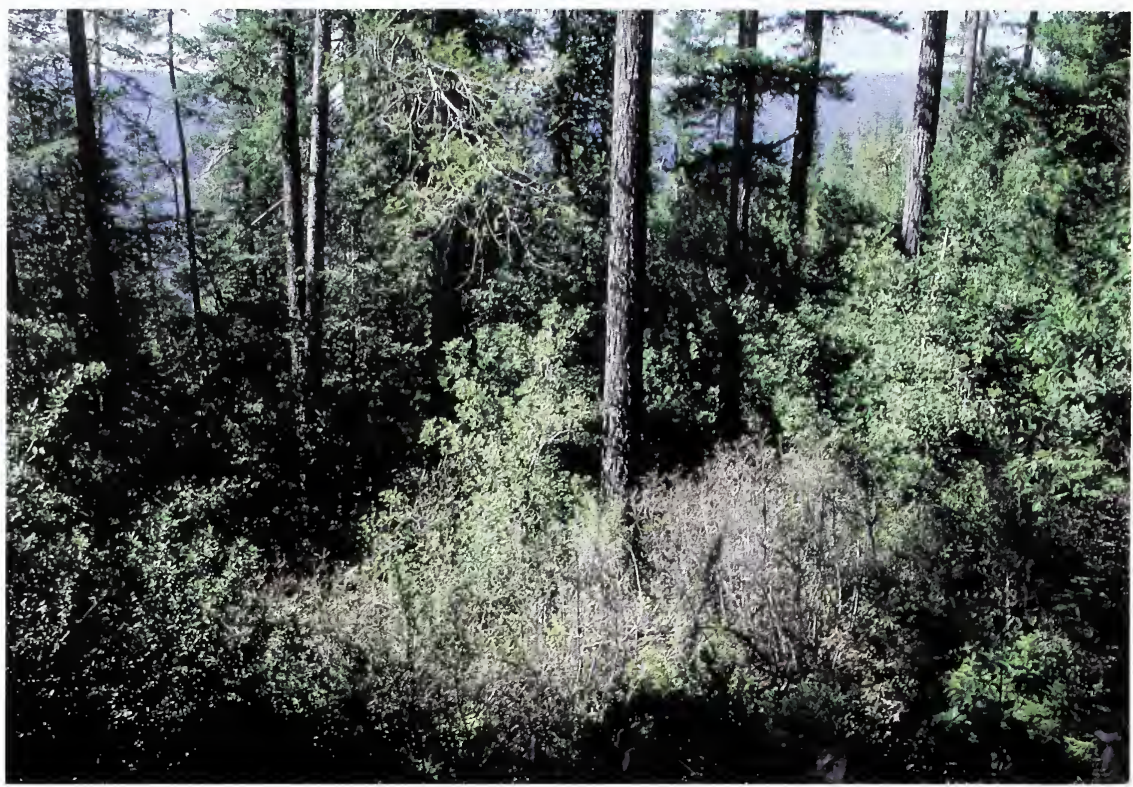

ENVIRONMENT: Elevation: 1210-2170 ft.; Aspect: N., S.E.; Slope: 15-55\%; Slope Position: lower and middle 1/3; Surface Rock: 0-7\%

SUMMARY TABLE

(Sample size: 10)

COVER

$\mathrm{CON}$

Tree Overstory Layer

CHLA Port Orford Cedar 34

PSME Douglas-fir 37

LIDE2 Tanoak 22

Tree Understory Layer

LIDE2 Tanoak 8

$\begin{array}{lllr}\text { CHLA } & \text { Port Orford Cedar } & 2 & 80 \\ \text { TABR } & \text { Pacific Yew } & 1 & 70\end{array}$

Shrubs

VAOV Evergreen Huckleberry 24

GASH Salal 18

RHOC Western Azalea 12

RHMA Pacific Rhododendron 6

100

100

100

100

100

100

100

80

Herbs \& Grasses

POMUl Sword Fern

OXORl Redwood Sorrel

GOOB Rattlesnake Plantain

WHMO Western Modesty
80

70

70

60

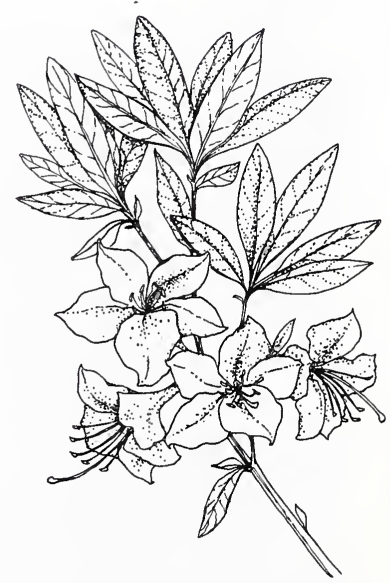

Western Azalea

(Rhodendron occidentale)

SOILS Pit Depth: 23->40 in.; Coarse Fragments: 10-60\%; Textures: 1, gl, vgl; Parent Material: serpentine 
DISTRIBUTION/ENVIRONMENT: This type was found on the Gasquet and Orleans ranger districts in the lower and middle one-third slope positions with concave and undulating micro-relief. It had the third lowest mean elevation of 1692 feet and ranged from 1210 to 2170 feet elevation. Slopes were generally moderately steep $(41 \%)$, north and southeast facing, with topographic shading. Radiation index was moderate (.450) as a result of the southeast facing slope component. Topographic shading partially offsets the effects of the southeast facing slopes by providing shading for much of the day, thereby simulating more northerly aspects. The presence of western azalea and high moss cover indicates that surface water or a high water table is usually present.

VEGETATION SUMMARY: Total vegetation cover is very high (99\%) as is total tree cover $(88 \%)$. Port-Orford cedar and Douglas-fir were co-dominants in the overstory with 34 and 37 percent cover, respectively. Tanoak was the most common tree in the hardwood layer (22\%), followed by Pacific madrone $(3 \%)$. The tree regeneration layer included tanoak (8\%), Port Orford cedar (2\%), and Douglas-fir $(2 \%)$. Pacific yew was present in many of these stands as an understory tree or in shrub form. The shrub layer was also dense (58\%) and comprised mostly of evergreen huckleberry (24\%), salal (18\%), western azalea (12\%), Pacific rhododendron (6\%), and red huckleberry (3\%). Average cover for the herb layer was 14 percent and comprised mainly of swordfern $(5 \%)$, redwood sorrel $(3 \%)$, beargrass $(2 \%)$, rattlesnake plantain $(1 \%)$, and starflower $(1 \%)$. The grass layer included California sweetgrass $(2 \%)$.

SOIL SUMMARY: Soils in this type were derived from serpentine parent rocks. They were well drained, primarily deep and moderately deep loams to very gravelly loams, with high AWC (4.0"), moderately thick A horizons (4"), and moderate A horizon coarse fragments $(32 \%)$. They were found entirely in the mesic soil temperature regime and were low to moderately productive for conifer growth due to the chemical imbalance of serpentine soils. The major limitations for these soils were fertility imbalances due to the ultramafic parent material, areas of steep slopes, potentially high erodibility, and susceptibility to compaction when soils are moist. In some areas, the soils may have up to 60 percent surface coarse fragments, which inhibits plantability and regeneration. The dominant soil groups were Weitchpec moderately deep (60\%); and Walnett moderately deep (20\%); and about 10 percent other soils (non-ultramafic soils, deep soils). Parent material mode of origin was colluvium or alluvium, which tends to offset the fertility imbalance by mixing with other parent materials.

STAND STUCTURE SUMMARY: Mean stand age for this type was 283 years, and ranged from 230 to 390 years. It had the lowest mean stand age of all plant associations in the tanoak-Port Orford cedar sub-series. The highest frequency of stands (33\%) were found in the 226-278 year age class. The frequency of stands above 300 years was 33 percent; the frequency of stands below 200 years was 11 percent.

This type includes a mixture of conifers and hardwoods, which are uneven-aged, composed of tolerant and somewhat intolerant species, which results in multiple layers. The overstory is usually composed of at least two layers of different aged conifers, averaging 119 feet tall in the top layer and 82 feet tall in the second layer. It had a low density of large conifers, with an average of 10 trees/acre greater than 30 inches diameter. The mid layers were dominated by hardwood species; they ranged from 25 to 60 feet tall. Most hardwood species were found in the smaller diameter classes with an average of 24 trees/acre in the 6-10.9 inch diameter class and an average of 6 trees/acre greater than 11 inches diameter. The regeneration layer was very low to low and limited by dense shrub cover.

Softwood cubic volumes range from very low to moderate with an average of $8,089 \mathrm{ft}^{3} /$ acre, the lowest softwood volume in the tanoak-Port Orford cedar sub-series. Hardwood cubic volume of $381 \mathrm{ft}^{3} /$ acre was also low. Dunning site class was 3 , with a site index of 125 at 300 years. Stand density index was moderate to high with an average of 494 . 


\section{LIDE2-CHLA/VAOV Association, EcoCode HT0CCO13}

\section{Tanoak-Port Orford Cedar/Evergreen Huckleberry}

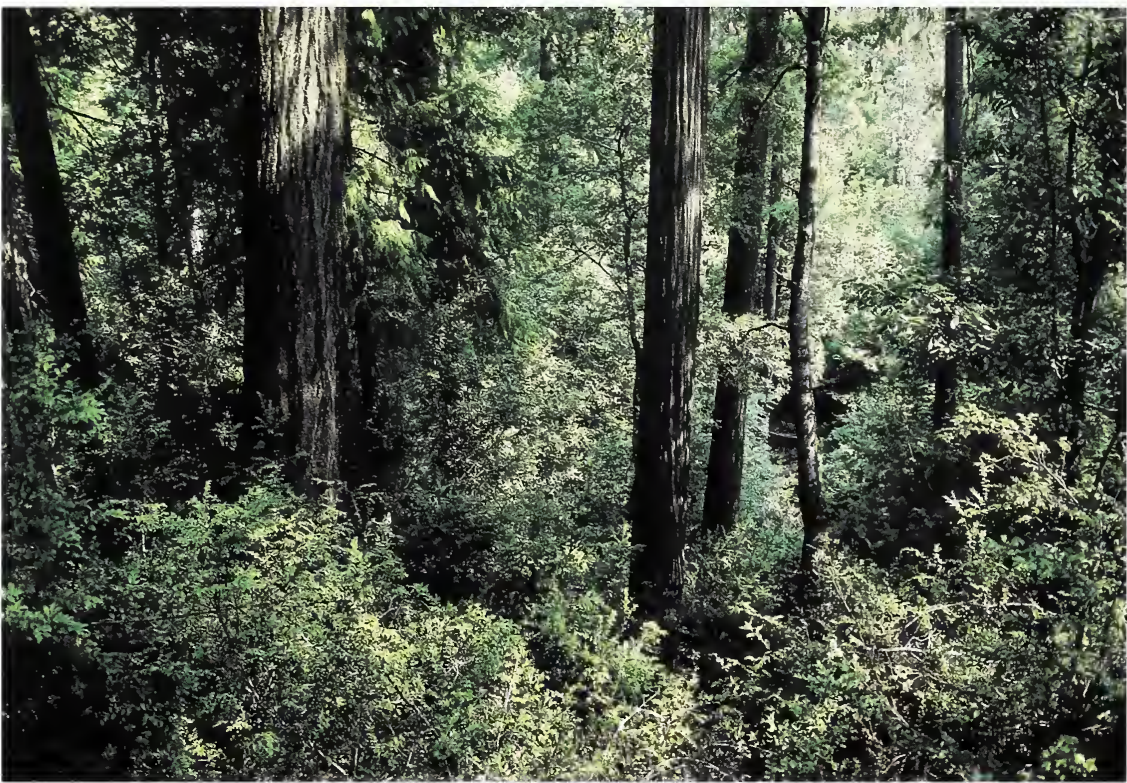

ENVIRONMENT: Elevation: 1400-2660 ft.; Aspect: N.E., N.W.; Slope: 0-70\%; Slope Position: lower and middle 1/3; Surface Rock: 0-8\%

SUMMARY TABLE

(Sample size: 21)

COVER

CON

\section{Tree Overstory Layer}

CHLA Port Orford Cedar $\quad 36 \quad 100$

PSME Douglas-fir $\quad 35 \quad 100$

LIDE2 Tanoak $26 \quad 100$

Tree Understory Layer

LIDE2 Tanoak 10

CHLA Port Orford Cedar $\quad 3 \quad 100$

PSME Douglas-fir $\quad 1 \quad 52$

Shrubs

$\begin{array}{llr}\text { VAOV } & \text { Evergreen Huckleberry } & 31 \\ \text { GASH } & \text { Salal } & 16 \\ \text { RHMA } & \text { Pacific Rhododendron } & 9 \\ \text { BENE1 } & \text { Dwarf Oregon-grape } & 3\end{array}$

100

\section{Herbs \& Grasses}

POMUl Sword Fern 4

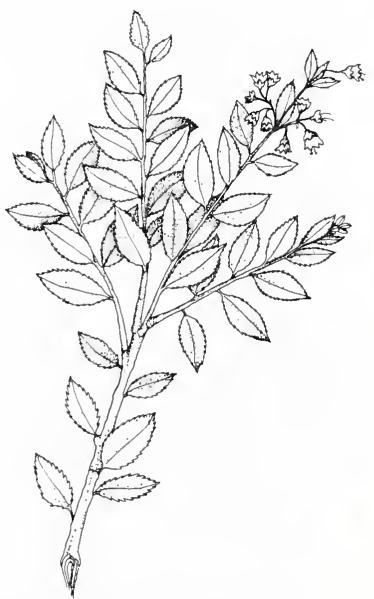

Evergreen Huckleberry (Vaccinium ovatum)

SOILS Pit Depth: 23->40 in.; Coarse Fragments: 15-50\%; Textures: gl, vgl; Parent Material: phyllite, greenstone, serpentine, mafic 
DISTRIBUTION/ENVIRONMENT: This type was found on the Gasquet and Orleans Ranger Districts in middle and lower one-third slope positions with undulating, linear, and concave micro-relief. Elevation averaged 1983 feet and ranged from 1400 to 2660 feet, on moderately steep (35\%), northeast and northwest facing slopes. Radiation index is low (.418) as a result of north facing aspects.

VEGETATION SUMMARY: Total vegetation cover was high with a mean value of $98 \%$. Tree cover (88\%) was high with Douglas-fir and Port-Orford cedar sharing the overstory dominance with 35 percent and 36 percent cover, respectively. The mid layer was dominated by tanoak (26\%), and occasionally Pacific madrone (5\%) and bigleaf maple (5\%). The tree regeneration layer was dominated by tanoak $(10 \%)$ and Port Orford cedar (3\%). Shrub cover was dense (53\%) and included evergreen huckleberry (31\%), salal (16\%), dwarf Oregon-grape (3\%), and occasionally Pacific rhododendron (9\%) and red huckleberry (4\%). The herb layer was well developed (14\%) with swordfern (4\%), redwood sorrel (8\%), small inside-out flower (2\%), rattlesnake plantain $(1 \%)$, bracken fern $(1 \%)$, starflower $(1 \%)$, and occasionally beargrass $(2 \%)$, as the main components.

SOIL SUMMARY: Soils in this type were derived from fine textured metamorphic parent materials such as phyllite, greenstone, and serpentine. They were well drained, primarily deep and moderately deep, gravelly to very gravelly loams, with moderate AWC (3.2"), moderately thick A horizons (5"), and moderate A horizon coarse fragments (39\%). They were found entirely in the mesic soil temperature regime and were highly productive to moderately productive for conifer growth. They presented few major limitations for management except for areas with very high A horizon coarse fragments, or very steep slopes where plantability or regeneration could be inhibited. They are occasionally susceptible to compaction when soils are moist. The dominant soil groups were Clallam moderately deep (40\%); Goldridge deep (35\%); and about 25 percent other soils (ultramafic soils, shallow soils, Clallam deep, Goldridge moderately deep).

STAND STRUCTURE SUMMARY: Stands found in this type had a similar average age to that of the tanoak-Port Orford cedar sub-series, 327 years, and ranged from 180 to 460 years stand age. The highest frequency of stands (23\%) were found between 276 and 375 years of age. The frequency of stands above 300 years was 65 percent; the frequency of stands below 200 years was 11 percent.

This type had a mixture of uneven-aged conifers and hardwoods in a variety of diameter classes and tolerance groups that resulted in a multiple layered forest. The overstory was composed of at least two layers of different aged conifers, averaging 191 feet tall in the top layer and 148 feet tall in the second layer. It had the highest density of large conifers in the tanoak-Port Orford cedar sub-series, with an average of 27 trees/acre greater than 30 inches diameter breast height. The mid layers were dominated by hardwood species; they ranged from 40 to 85 feet tall. Most hardwood species were found in the smaller diameter classes with an average of 53 trees/acre in the 6-10.9 inch diameter class and an average of 11 trees/acre greater than 11 inches diameter. The regeneration layer was low due to a dense shrub layer.

Softwood cubic volume was among the highest in the sub-series with an average of $11,808 \mathrm{ft}^{3} /$ acre. Hardwood cubic volume was also high with $533 \mathrm{ft}^{3} /$ acre. Dunning site class was 1 , with site index of 175 at 300 years. Stand density index ranged from moderate to high and averaged 492. 


\section{LIDE2/CHLA/BENE1/LIBOL Association, EcoCode HT0CCO14 Tanoak/Port Orford Cedar/Dwarf Oregon-grape/Twinflower}

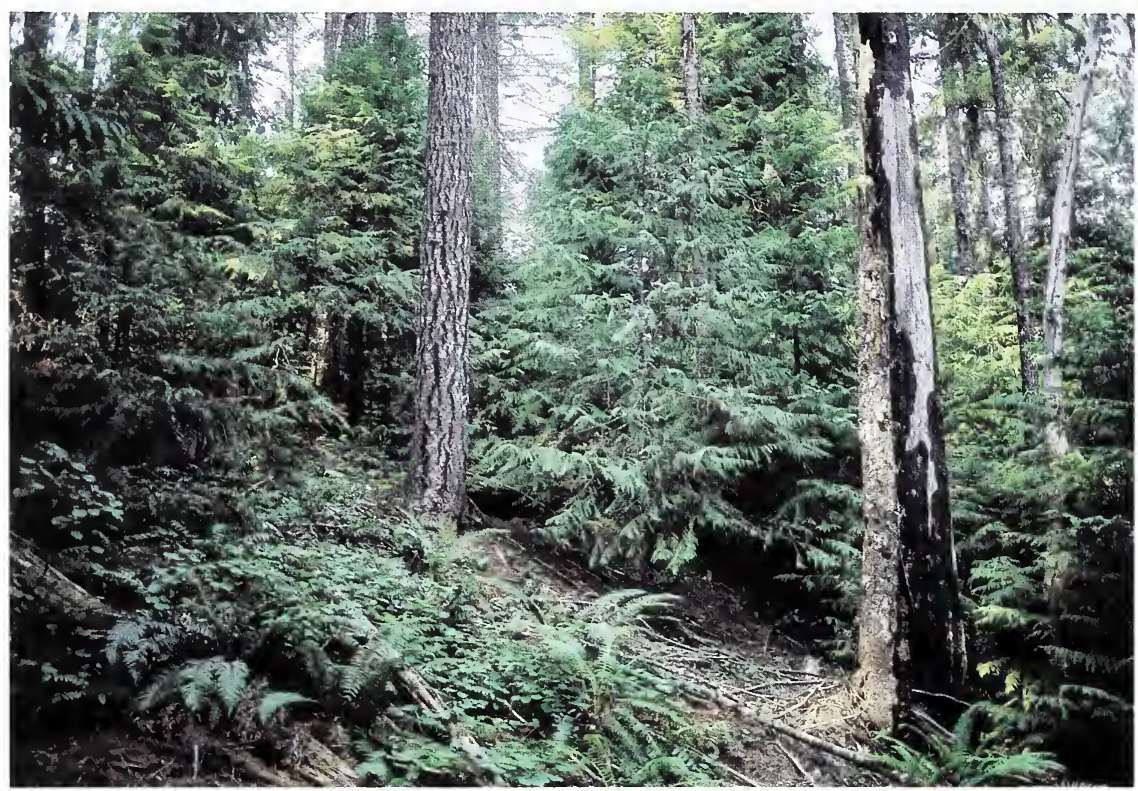

ENVIRONMENT: Elevation: 2170-3150 ft.; Aspect: N.; Slope: 22-70\%; Slope Position: lower and middle 1/3; Surface Rock: 0-5\%

SUMMARY TABLE

(Sample size: 10)

COVER

$\mathrm{CON}$

Tree Overstory Layer

CHLA Port Orford Cedar

PSME Douglas-fir 38

LIDE2 Tanoak 8

Tree Understory Layer

LIDE2 Tanoak

CHLA Port Orford Cedar

PSME Douglas-fir 1

Shrubs

$\begin{array}{llrr}\text { BENEl } & \text { Dwarf Oregon-grape } & 11 & 100 \\ \text { VAPA } & \text { Red Huckleberry } & 2 & 80 \\ \text { GASH } & \text { Salal } & 4 & 60 \\ \text { COCOC } & \text { Hazelnut } & 2 & 60\end{array}$

Herbs \& Grasses

$\begin{array}{llll}\text { LIBOL } & \text { Twinflower } & 5 & 80 \\ \text { ACTR } & \text { Vanilla Leaf } & 3 & 80 \\ \text { TRLA3 } & \text { Starflower } & 1 & 80 \\ \text { DIHO21 } & \text { Hooker's Fairybell } & 1 & 70\end{array}$

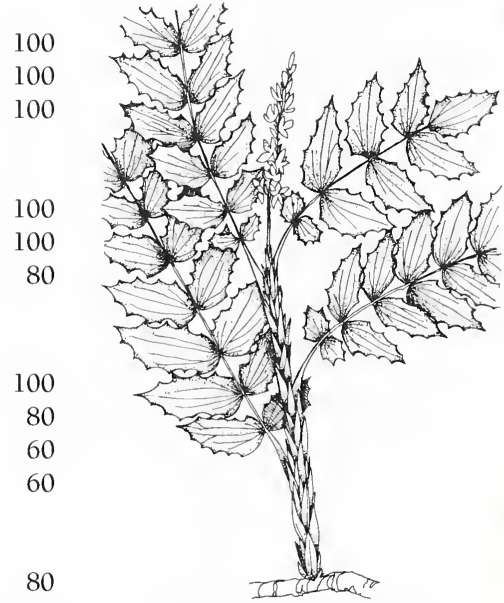

Dwarf Oregon-grape

(Berberis nervosa)

SOILS Pit Depth: 23->40 in.; Coarse Fragments: 20-43\%; Textures: gl, vgl; Parent Material: greenstone, schist 
DISTRIBUTION/ENVIRONMENT: This type was found on the Gasquet, Orleans, and Happy Camp ranger districts in middle and lower one-third slope positions, with undulating and linear micro-relief. Elevation was the second highest in the tanoak-Port Orford cedar sub-series. It averaged 2815 feet and ranged from 2170 to 3150 feet, on moderately steep (46\%), north facing slopes. Radiation index was very low (.360) as a result of north facing aspects.

VEGETATION SUMMARY: Total vegetation cover was high at 96 percent, but not as high as most Port-Orford cedar types due to a relatively low shrub cover. Total tree cover was high at 90 percent. Port-Orford cedar and Douglas-fir share the overstory dominance at 40 percent and 37 percent cover, respectively. The mid layer was dominated by tanoak ( $8 \%$ ) with other occasional hardwoods of lesser cover. The regeneration layer was dominated by tanoak (11\%) and included Port Orford cedar (3\%) and Douglas-fir (1\%). The shrub layer was moderately low (12\%), with dwarf Oregon-grape (11\%) dominating, and red huckleberry (2\%), salal (4\%), hazelnut $(2 \%)$, and wild rose (1\%) as associates. The herb layer was moderately developed $(13 \%)$ with twinflower $(5 \%)$ as the major herb. Other commonly found herbs were vanilla leaf $(2 \%)$, swordfern (3\%), small inside-out flower (2\%), starflower ( $1 \%)$, rattlesnake plantain (1\%), and Hooker's fairy bell (1\%).

SOIL SUMMARY: Soils in this type were derived from the fine textured metamorphic parent materials schist and greenstone. They were primarily deep and moderately deep, gravelly to very gravelly loams, with moderate AWC (3.1"), moderately thick A horizons (4"), and low A horizon coarse fragments (34\%). They were found entirely in the mesic soil temperature regime and are highly productive to moderately productive for conifer growth. They present few major limitations for management except for areas with very high A horizon coarse fragments, or very steep slopes where plantability or regeneration can be inhibited. They are occasionally susceptible to compaction when soils are moist. The dominant soil groups were Clallam deep (50\%); Weitchpec moderately deep (30\%); with about 20 percent other soils (Goldridge deep, shallow soils).

STAND STRUCTURE SUMMARY: Stands of this type had an average age of 339 years and ranged from 175 to 450 years stand age. The highest frequency of stands (30\%) were found between 376 and 425 years of age. The frequency of stands above 300 years was 70 percent; the frequency of stands below 200 years was 20 percent.

The mixture of conifer and hardwood species of different ages and diameter classes resulted in multiple layers. The overstory was usually composed of at least two layers of different aged conifers, averaging 168 feet tall in the top layer and 127 feet tall in the second layer. It had a high density of large conifers, with an average of 25 trees/acre greater than 30 inches diameter breast height. The mid layers were dominated by hardwood species; they ranged from 30 to 65 feet tall. Most hardwood species were found in the smaller diameter classes with an average of 29 trees/acre in the 0-5.9 inch diameter class and 39 trees/acre in the 6-10.9 inch diameter class and an average of 3 trees/acre greater than 11 inches diameter. The regeneration layer was moderate.

Softwood cubic volume had the highest mean value for the tanoak-Port Orford cedar sub-series with an average of $12,678 \mathrm{ft}^{3} / \mathrm{acre}$. Hardwood cubic volume was low and averaged $254 \mathrm{ft}^{3} /$ acre. Dunning site class was 1 , with site index of 175 at 300 years. Stand density index was high and averaged 517 , second highest in the subseries. 
LIDE2-CHLA-ALRH/Riparian Association, EcoCode HT0CCO15 Tanoak-Port Orford Cedar-White Alder//Riparian

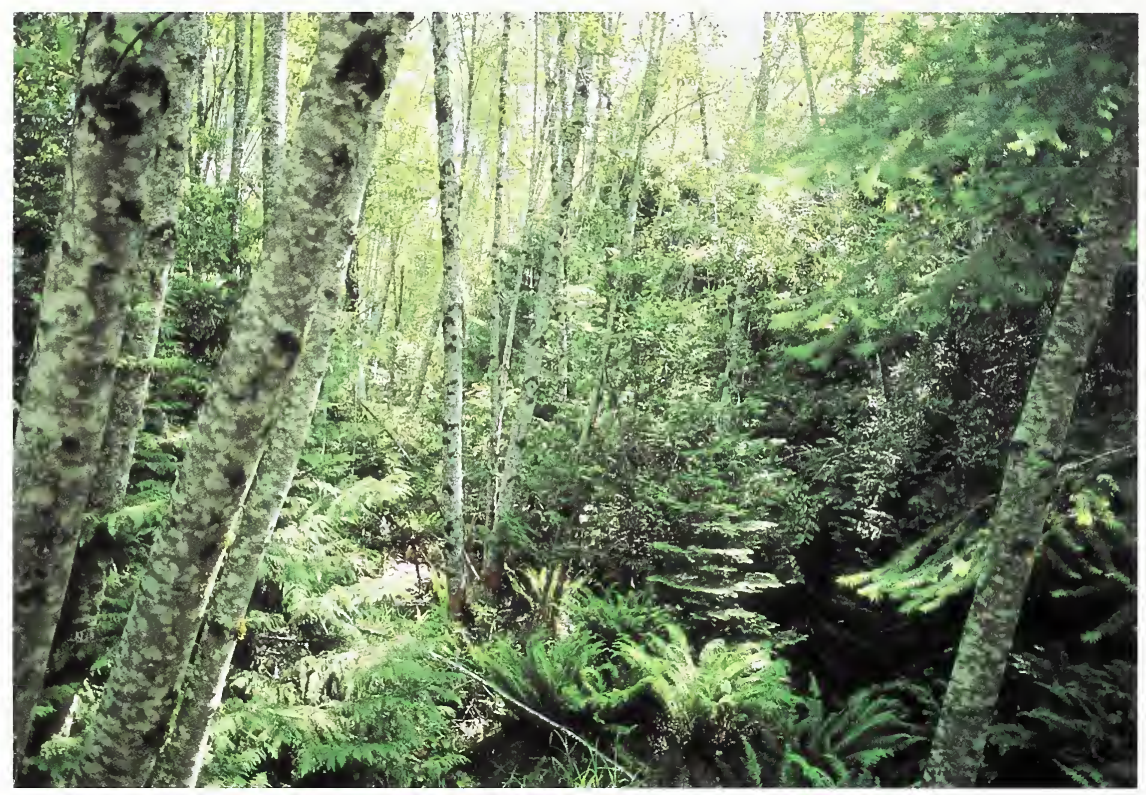

ENVIRONMENT: Elevation: 1900-3520 ft.; Aspect: E., S.E.; Slope: 10-50\%; Slope Position: lower 1/3; Surface Rock: 0-70\%

\section{SUMMARY TABLE}

(Sample size: 10)

Tree Overstory Layer

CHLA Port Orford Cedar

PSME

ALRH

Douglas-fir

ACMA

Big Leaf Maple

COVER

CON

Tree Understory Layer

CHLA Port Orford Cedar

LIDE2 Tanoak

ALRH White Alder

QUCH2 Canyon Live Oak

37
21
36
4

37

36

4

4
14
7
1

Shrubs

RUUR Trailing Blackberry

GASH

ACCI

Salal

Vine Maple

RUPA2 Thimbleberry

Herbs \& Grasses

$\begin{array}{ll}\text { ACTR } & \text { Vanillaleaf } \\ \text { LIBOL } & \text { Twinflower } \\ \text { POMU1 } & \text { Sword Fern } \\ \text { IRI } & \text { Iris spp. }\end{array}$

2
11
39
3

100

80

70

50

70

50

90

50

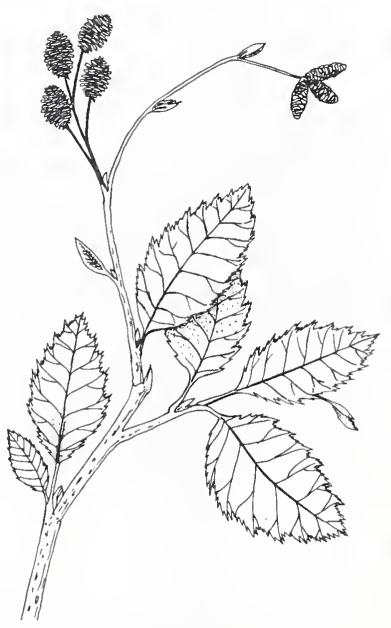

White Alder

(Alnus rhombifolia)

SOILS Pit Depth: 21->40 in.; Coarse Fragments: 30-37\%; Textures: gl, vgl; Parent Material: mafic, serpentine 
DISTRIBUTION/ENVIRONMENT: This type was found along stream courses on the Gasquet, Orleans, Ukonom, and Happy Camp ranger districts in lower one-third slope positions with linear and concave micro-relief. Elevation averaged 2476 feet and ranged from 1900 to 3520 feet, on gentle (27\%), east, southeast facing slopes. Radiation index was moderate (.453) as a result of southeast facing aspects, but was moderated by the streamside positions with topographic shading. High surface rock averaging 27 percent is a feature of this riparian type.

VEGETATION SUMMARY: Total vegetation cover was high (96\%) with the tree layer contributing the most cover $(85 \%)$. The overstory was dominated by Port Orford cedar (37\%) and Douglas-fir $(21 \%)$. The mid layer was dominated by red or white alder $(36 \%)$ and tanoak $(9 \%)$. The regeneration layer was dominated by tanoak (14\%), red and white alder (7\%), and Port Orford cedar (4\%). Pacific yew was found in most stands as an understory tree or shrub. The shrub layer was moderate with an average cover of 34 percent. It included vine maple (39\%), salal (11\%), and thimbleberry (3\%). The herb layer was moderately well developed (12\%), and included twinflower (3\%), vanillaleaf (2\%), swordfern (5\%), and iris (1\%). High moss cover averaging 20 percent was a characteristic of this type.

SOIL SUMMARY: Soils in this type were derived from both coarse and fine textured parent materials, mafic and serpentine. They were well drained to somewhat excessively well drained, primarily deep and moderately deep, gravelly to very gravelly loams, with moderate AWC (3.0") and high accessibility to water due to their streamside positions. They had thin A horizons (3"), and moderate A horizon coarse fragments (34\%), with high surface rock. They were found entirely in the mesic soil temperature regime and were moderately productive for conifer growth. They present major limitations to management due to stream side locations, high water table, and high surface rock. The soils fell into two groups; the well drained soil groups were Clallam moderately deep (25\%); Wilshire deep (25\%); and a poorly drained unclassified soil $(25 \%)$.

STAND STRUCTURE SUMMARY: Stands found in this type had the highest average age in the tanoak-Port Orford cedar sub-series, 384 years. They ranged from 200 to 410 years stand age. The highest frequency of stands (50\%) were found between 376 and 425 years of age. The frequency of stands above 300 years was 75 percent; the frequency of stands below 200 years was $0 \%$.

The streamside position of this type results in an open overstory of conifers with a dense mid layer of hardwoods. The result of this was a multiple layered canopy. The overstory was composed of at least two layers of different aged conifers, averaging 145 feet tall in the top layer and 95 feet tall in the second layer. It had a moderate density of large conifers, with an average of 18 trees/acre greater than 30 inches diameter. The mid layers were dominated by hardwood species, they ranged from 20 to 55 feet tall. Most hardwood species were found in the smaller diameter classes with an average of 83 trees/acre in the 6-10.9 inch diameter class. The regeneration layer was very low due to the high density of intermediate sized hardwoods.

Softwood cubic volume ranged from low to moderate with an average of $8,532 \mathrm{ft}^{3} /$ acre, second lowest in the tanoak-Port Orford cedar sub-series. Hardwood cubic volume was also low with an average of $235 \mathrm{ft}^{3} /$ acre. Dunning site class was 3, with site index of 125 at 300 years. Stand density index was low to moderate and averaged 406 , second lowest in the sub-series. 


\section{LIDE2-CHLA/ACCI Association, EcoCode HT0CCO16}

\section{Tanoak-Port Orford Cedar/Vine Maple}

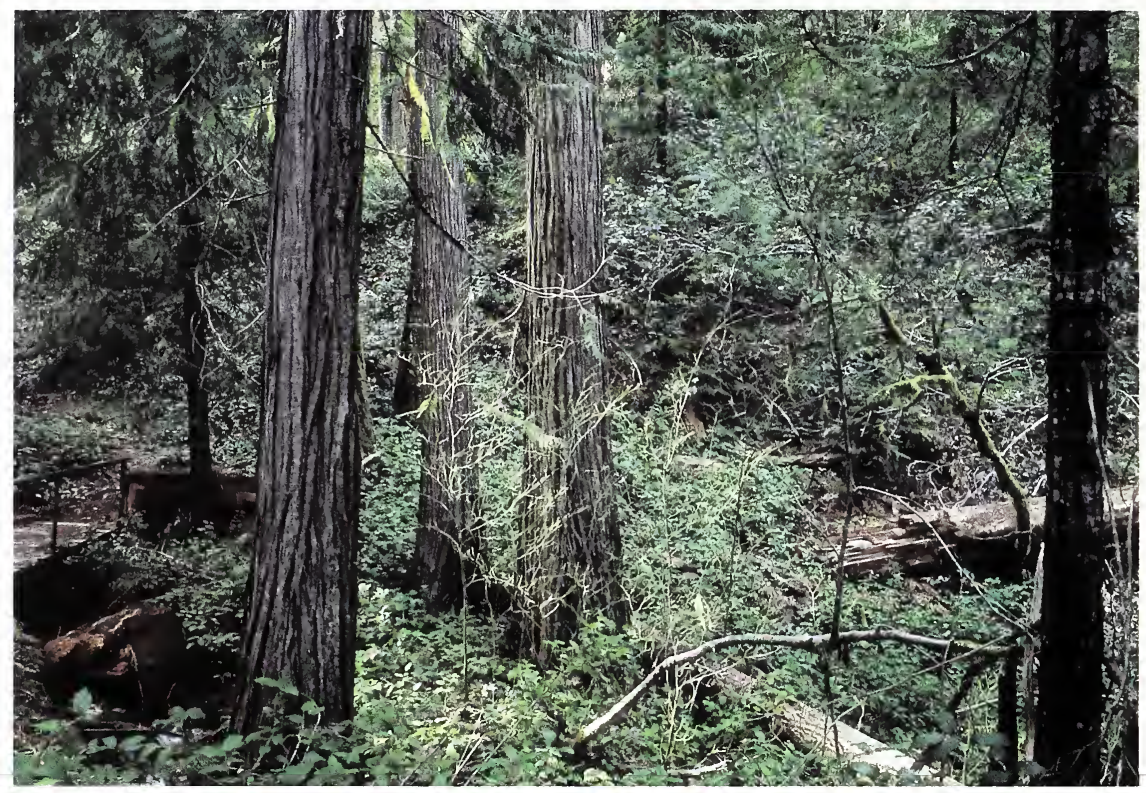

ENVIRONMENT: Elevation: 1400-2830 ft.; Aspect: N.W.; Slope: 17-80\%; Slope Position: lower 1/3; Surface Rock: 0-11\%

\section{SUMMARY TABLE}

(Sample size: 10)

COVER

CON

Tree Overstory Layer

PSME Douglas-fir

LIDE2 Tanoak

29
36
18

100
100
100

Tree Understory Layer

LIDE2 Tanoak

CHLA Port Orford Cedar

Shrubs

BENE1 Dwarf Oregon-grape 12

90

ACCI Vine Maple

Herbs \& Grasses

$\begin{array}{llr}\text { POMUl } & \text { Sword Fern } & 4 \\ \text { LIBOL } & \text { Twinflower } & 10 \\ \text { WHMO } & \text { Western Modesty } & 4 \\ \text { ACTR } & \text { Vanillaleaf } & 3\end{array}$

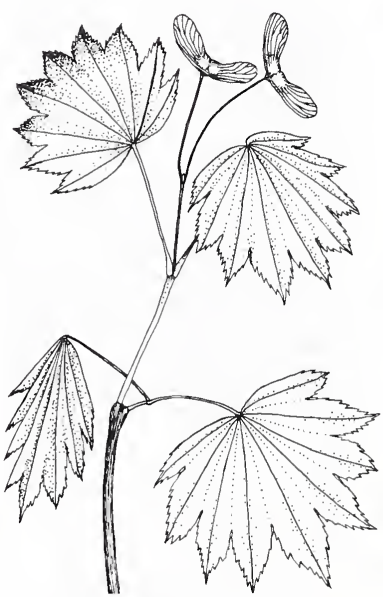

Vine Maple

(Acer circinatum)

SOILS Pit Depth: 34->40 in.; Coarse Fragments: 30-70\%; Textures: xgsl, vgl; Parent Material: mafic, greenstone 
DISTRIBUTION/ENVIRONMENT: This type was found along stream courses on the Gasquet, Orleans, and Happy Camp ranger districts in lower one-third slope positions with concave and linear micro-relief. Elevation averaged 2693 feet and ranged from 1400 to 2830 feet, on moderately steep (33\%), northwest facing slopes. Radiation index was very low (.374) as a result of northwest facing aspects with topographic shading. Surface rock is moderate overall averaging 8 percent, but can be considerably higher in streamside positions.

VEGETATION SUMMARY: Total vegetation cover was high (96\%), along with total tree cover $(73 \%)$. Douglas-fir was the dominant overstory tree $(36 \%)$ followed by Port-Orford cedar (29\%). Tanoak occupies most of the mid layer (14\%) and was often joined by bigleaf maple (11\%), Pacific dogwood (3\%), and chinquapin (2\%). The regeneration layer included high cover of tanoak (10\%), along with Port-Orford cedar (3\%), and Pacific dogwood (2\%). Pacific yew (3\%) was found infrequently in this type as a small tree. The shrub layer was very dense ( $71 \%$ cover) with a variety of shrub species contributing. Vine maple (55\%) contributed the highest cover, followed by salal $(20 \%)$, dwarf Oregon-grape (19\%), hazelnut (4\%), wild rose (3\%), and red huckleberry $(2 \%)$. The herb layer was moderately developed $(11 \%)$ with twinflower contributing the highest cover $(10 \%)$, followed by other mesic species: swordfern (4\%), vanillaleaf (3\%), starflower (1\%), and Hooker's fairybells (1\%).

SOIL SUMMARY: Soils in this type were derived from the coarse and fine textured parent rocks mafic and greenstone. They were well drained, primarily deep and moderately deep, very gravelly to extremely gravelly loams, with moderate AWC (3.5"), thick A horizons ( $\left.7^{\prime \prime}\right)$, and high A horizon coarse fragments (36\%). They were found entirely in the mesic soil temperature regime and were highly productive to moderately productive for conifer growth. They present few major limitations for management except for areas with very high A horizon coarse fragments, or very steep slopes where plantability or regeneration can be inhibited. The dominant soil groups were Goldridge deep (40\%); and Hugo, moderately deep (40\%); with about 10 percent other soils (shallow soils, deep soils).

STAND STRUCTURE SUMMARY: Stands found in this type averaged just below the mean for the tanoak-Port Orford cedar sub-series, 318 years, and ranged from 220 to 405 years stand age. The highest frequency of stands (42\%) were found between 326 and 375 years of age. The frequency of stands above 300 years was 57 percent; the frequency of stands below 200 years was 0 percent.

Dense cover of uneven aged conifers and hardwoods in a variety of diameter classes resulted in multiple layers. The overstory includes at least two layers of different sized conifers, averaging 185 feet tall in the top layer and 151 feet tall in the second layer. It had a moderate density of large conifers, with an average of 19 trees/ acre greater than 30 inches diameter. The mid layers were dominated by hardwood species, they ranged from 30 to 75 feet tall. Most hardwood species were found in the smaller diameter classes with an average of 79 trees/acre in the 0-5.9 inch diameter class and 49 trees/acre in the 6-10.9 inch diameter class. The regeneration layer was low to moderate and dominated by hardwoods.

Softwood cubic volume ranged from low to moderate with an average of $8,679 \mathrm{ft}^{3} /$ acre. Hardwood cubic volume of $511 \mathrm{ft}^{3} /$ acre was among the highest of all Port-Orford cedar types. Dunning site class was 1, with site index of 175 at 300 years. Stand density index was low and averaged 358. It was the lowest value in the tanoak-Port Orford cedar sub-series. 


\section{LIDE2-CHLA/VAPA Association, EcoCode HT0CCO17}

\section{Tanoak-Port Orford Cedar/Red Huckleberry}

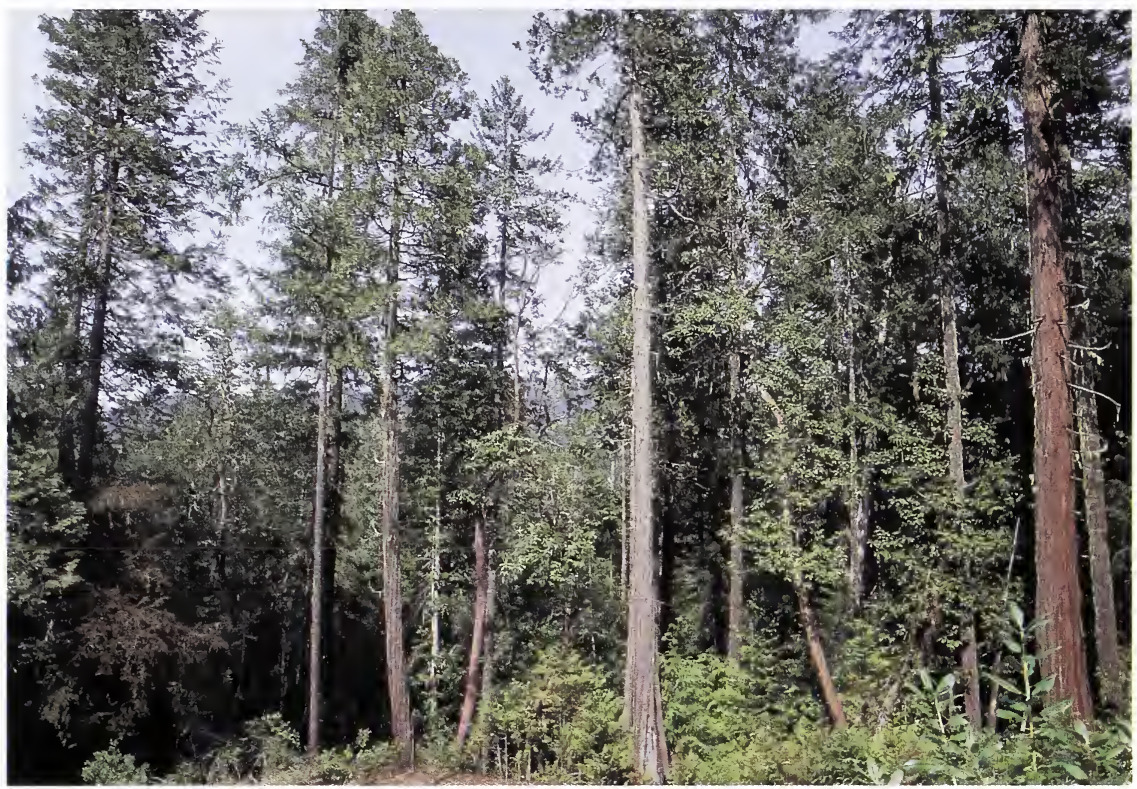

ENVIRONMENT: Elevation: 1900-3200 ft.; Aspect: N, E, S.E.; Slope: 5-35\%; Slope Position: lower $1 / 3$ and middle 1/3; Surface Rock: $1-6 \%$

\section{SUMMARY TABLE}

(Sample size: 10)

COVER

CON

Tree Overstory Layer

CHLA Port Orford Cedar 33

PSME Douglas-fir 32

LIDE2 Tanoak 13

ARME3 Madrone 7

PILA Sugar Pine 12

Tree Understory Layer

LIDE2 Tanoak 30

CHLA Port Orford Cedar 5

PSME Douglas-fir

Shrubs

$\begin{array}{ll}\text { VAPA } & \text { Red Huckleberry } \\ \text { ROGY } & \text { Baldhip Rose } \\ \text { GASH } & \text { Salal } \\ \text { VAOV } & \text { Evergreen Huckleberry }\end{array}$

Herbs \& Grasses

XETE Beargrass

WHMO Western Modesty

CHUMO Prince's Pine

POMUl Sword Fern

100
100
100
70
70

90

90

70

100

60

50

50

90

70

60

60

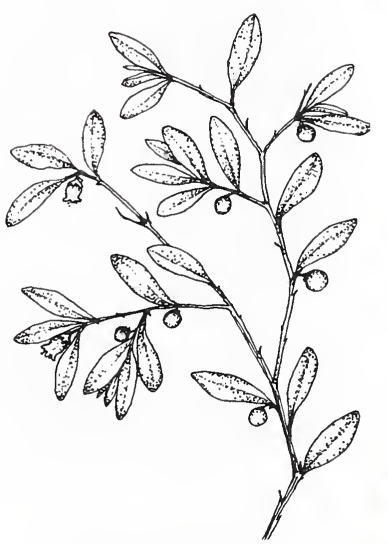

Red Huckleberry

(Vaccinium parviflorum)

SOILS Pit Depth: 30->40 in.; Coarse Fragments: 35-60\%; Textures: vgsl; Parent Material: serpentine 
DISTRIBUTION/ENVIRONMENT: This type was found on the Gasquet, Orleans, and Ukonom ranger districts in lower and middle one-third slope positions with undulating micro-relief. Elevation averaged 2526 feet, the highest in the tanoakPort Orford cedar sub-series and ranged from 1900 to $3200 f e e t$, on gentle (20\%) slopes with north, east, and southeast aspects. Radiation index was moderate (.455) as a result of southeast facing aspects.

VEGETATION SUMMARY: Total vegetation cover was high (95\%) here, along with total tree cover (89\%). Port Orford cedar and Douglas-fir were the dominant overstory trees with $33 \%$ and $32 \%$ cover, they were followed by sugar pine (12\%), with incense cedar $(11 \%)$ on $1 / 3$ of the plots. Tanoak was the dominant hardwood in the mid layer (13\%) and was often joined by Pacific madrone $(7 \%)$. The regeneration layer included high cover of tanoak (30\%), along with Port-Orford cedar (5\%), Douglas-fir (1\%), and chinquapin (8\%). Pacific yew (5\%) was found frequently in the regeneration layer $(70 \%)$. The shrub layer was sparse $(17 \%)$, with red huckleberry $(9 \%)$, bldhip rose (1\%), salal (5\%), and evergreen huckleberry (3\%) as the dominant shrubs. The herb layer was moderately well developed (9\%) with beargrass (4\%), western modesty $(1 \%)$, prince's pine $(2 \%)$, swordfern $(2 \%)$, false solomon's seal $(1 \%)$, iris $(1 \%)$, rattlesnake plantain $(1 \%)$, and starflower $(1 \%)$ contributing. The grass layer was dominated by sedges (1\%).

SOIL SUMMARY: Soils in this type were derived from serpentine parent material. They were well drained, primarily deep and moderately deep, very gravelly silt loams, with moderate AWC (2.8"), moderately thick A horizons (4"), and moderate A horizon coarse fragments (43\%). They were found in the mesic soil temperature regime and were highly productive to moderately productive for conifer growth. The dominant soil groups were Weitchpec moderately deep (25\%) and Weitchpec deep (75\%).

STAND STRUCTURE SUMMARY: Stands found in this type averaged 361 years, above the average for the tanoak-Port Orford cedar sub-series, and ranged from 325 to 420 years stand age. The highest frequency of stands (25\%) were found between 276 and 325 years of age. The frequency of stands above 300 years was 75 percent; the frequency of stands below 200 years was 25 percent.

Multiple layers were present in this type due to the combination of a conifer dominated overstory and an open hardwood mid layer. The overstory was usually composed of at least two layers of different aged conifers, averaging 160 feet tall in the top layer and 132 feet tall in the second layer. The density of large conifers over 30 inches in diameter averaged 18 trees/acre. The mid layers were dominated by hardwood species; they ranged from 25 to 55 feet tall. Most hardwood species were found in the smallest diameter class with an average of 35 trees/acre in the 0-5.9 inch class. The regeneration layer was very high for conifer regeneration due to an open hardwood mid layer.

Softwood cubic volume ranged from moderate to high with an average of 11,458 $\mathrm{ft}^{3} /$ acre. Hardwood cubic volume was the lowest of all types in the tanoak-Port Orford cedar sub-series, $69 \mathrm{ft}^{3} /$ acre. Dunning site class was 1A, with site index of 200 at 300 years. Stand density index averaged 533, highest in the sub-series. 


\section{LIDE2-CHLA/GASH Association, EcoCode HT0CCO18}

\section{Tanoak-Port Orford Cedar/Salal}

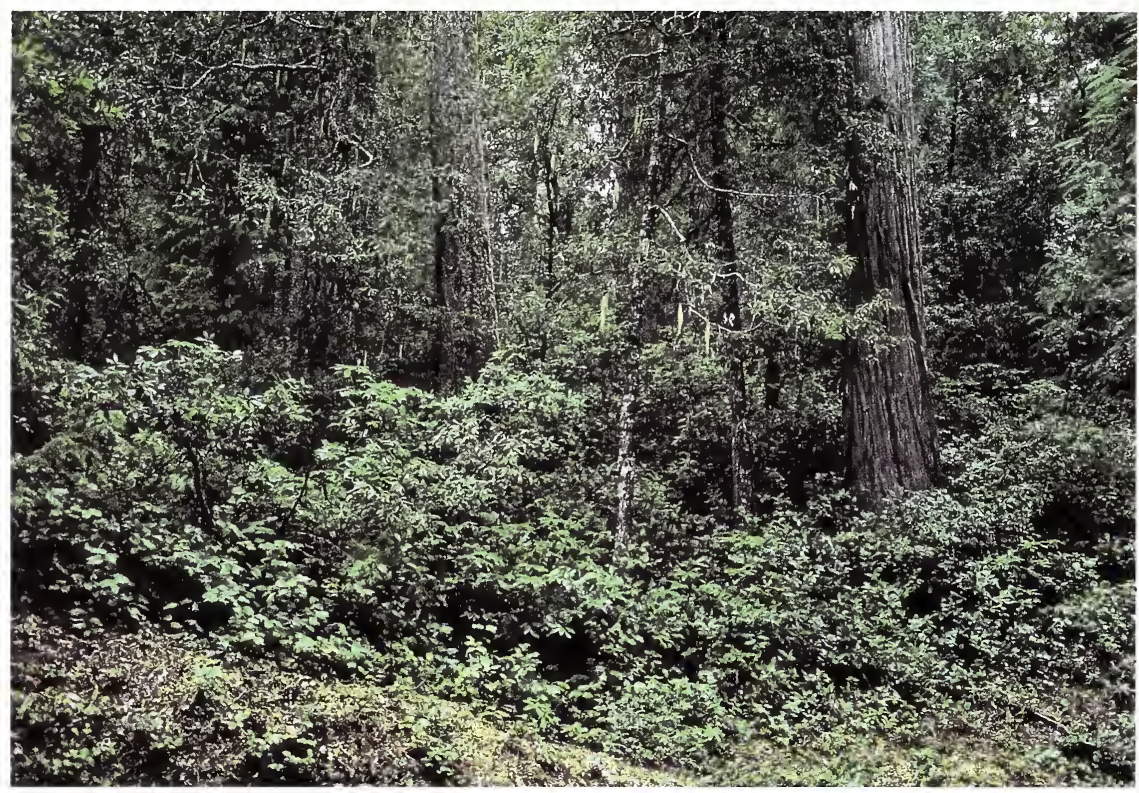

ENVIRONMENT: Elevation: 1700-3540 ft.; Aspect: N.E.,E, Slope: 5-35\%; Slope Position: lower and middle1/3; Surface Rock: 0-3\%

SUMMARY TABLE

(Sample size: 10)

COVER

CON

Tree Overstory Layer

$\begin{array}{lllr}\text { CHLA } & \text { Port Orford Cedar } & 29 & 100 \\ \text { PSME } & \text { Douglas-fir } & 48 & 100 \\ \text { LIDE2 } & \text { Tanoak } & 20 & 100 \\ \text { CACH2 } & \text { Canyon Live Oak } & 18 & 70\end{array}$

Tree Understory Layer

CHLA Port Orford Cedar 2

PSME Douglas-fir 1

100

LIDE2 Tanoak

Shrubs

GASH Salal 70

100

RHMA Pacific Rhododendron 8

VAPA Red Huckleberry 2

BENE1 Dwarf Oregon-grape 7

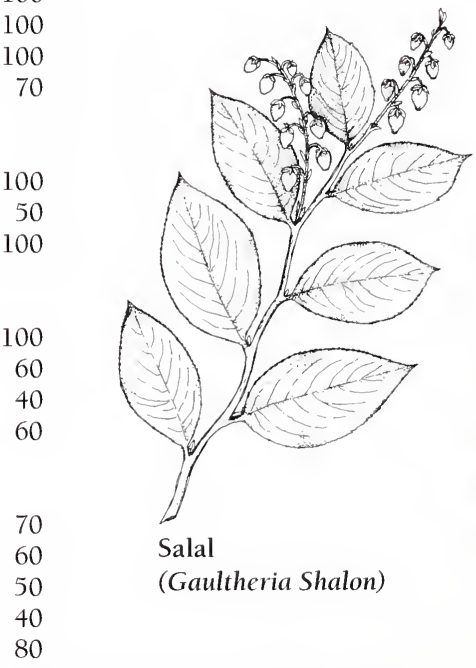

SOILS Pit Depth: 33->40 in.; Coarse Fragments: 10-45\%; Textures: 1, gl; Parent Material: mafic, phyllite, schist, sandstone 
DISTRIBUTION/ENVIRONMENT: This type was found on the Orleans, Ukonom, and Lower Trinity ranger districts in middle and lower one-third slope positions with linear micro-relief. Elevation averaged 2668 feet and ranged from 1700 to 3540 feet, on gentle (21\%) slopes with northeast and east facing aspects. Radiation index was high (.451) as a result of southwest aspects. This type tends to be drier and occur uplsope from wetter Port Orford cedar types.

VEGETATION SUMMARY: Total vegetation cover was high (97\%) here, along with total tree cover (90\%). Douglas-fir was the dominant overstory tree $(48 \%)$ followed by Port-Orford cedar (29\%). Tanoak was the dominant hardwood in the mid layer $(20 \%)$ and was often joined by chinquapin (18\%). The regeneration layer included tanoak (6\%), along with Port-Orford cedar (2\%), and Douglas-fir (1\%). The shrub layer had the highest cover of all plant associations in the tanoak-Port Orford cedar sub-series (74\%). It was dominated by salal (70\%), and often included Pacific rhododendron $(8 \%)$, and red huckleberry $(2 \%)$. The herb layer was sparse due to the high shrub density (4\%), with prince's pine (2\%), beargrass $(2 \%)$, white inside-out flower $(2 \%)$, bracken fern $(1 \%)$, and rattlesnake plantain ( $1 \%)$.

SOIL SUMMARY: Soils in this type were derived from coarse and fine textured mafic, schist, phyllite, and sandstone parent rocks. They were well drained, primarily deep and moderately deep, loam to gravelly loams, with moderate AWC (3.6"), thick A horizons ( $7^{\prime \prime}$ ), and low A horizon coarse fragments (23\%). They were found in the mesic soil temperature regime and were moderately productive for conifer growth. They present few major limitations for management. The dominant soil groups were Madd moderately deep (25\%); Madd deep (25\%); Doerock moderately deep (25\%); and Fiddletoe deep (25\%).

STAND STRUCTURE SUMMARY: Stands found in this type had an average stand age of 405 years and ranged from 260 to 650 years stand age. The highest frequency of stands (50\%) were found between 250 and 325 years of age. The frequency of stands above 300 years was 63 percent; the frequency of stands below 200 years was 0 percent.

This type had a dense mixture of uneven-aged, tolerant and somewhat intolerant tree species, from a variety of diameter and age classes, this resulted in multiple layers. The overstory included at least two layers of different aged conifers, the first layer was dominated by Douglas-fir and the second layer by Port Orford cedar. They averaged 196 feet tall in the top layer and 143 feet tall in the second layer. The overstory had a moderate density of large conifers, with an average of 22 trees/acre greater than 30 inches diameter. The mid layers were dominated by the hardwood species; they ranged from 25 to 80 feet tall. Most hardwood species were found in the smaller diameter classes with an average of 69 trees/acre in the 0-5.9 inch diameter class and 50 trees/acre in the 6-10.9 inch diameter class. The larger hardwoods, greater than 11 inches diameter, averaged 12 trees/acre. The regeneration layer was very high and was composed of both conifers and hardwoods.

Softwood cubic volume ranged from low to moderate with an average of 10,083 $\mathrm{ft}^{3} /$ acre. Hardwood cubic volume was also low with an average of $486 \mathrm{ft}^{3} /$ acre. Dunning site class was 1, with site index of 175 at 300 years. Stand density index averaged 444 , among the lowest in the sub-series. 


\section{LIDE2-CHLA-TSHE/VAOV Association, EcoCode HTOCCO19}

\section{Tanoak-Port Orford Cedar-Western Hemlock/Evergreen Huckleberry}

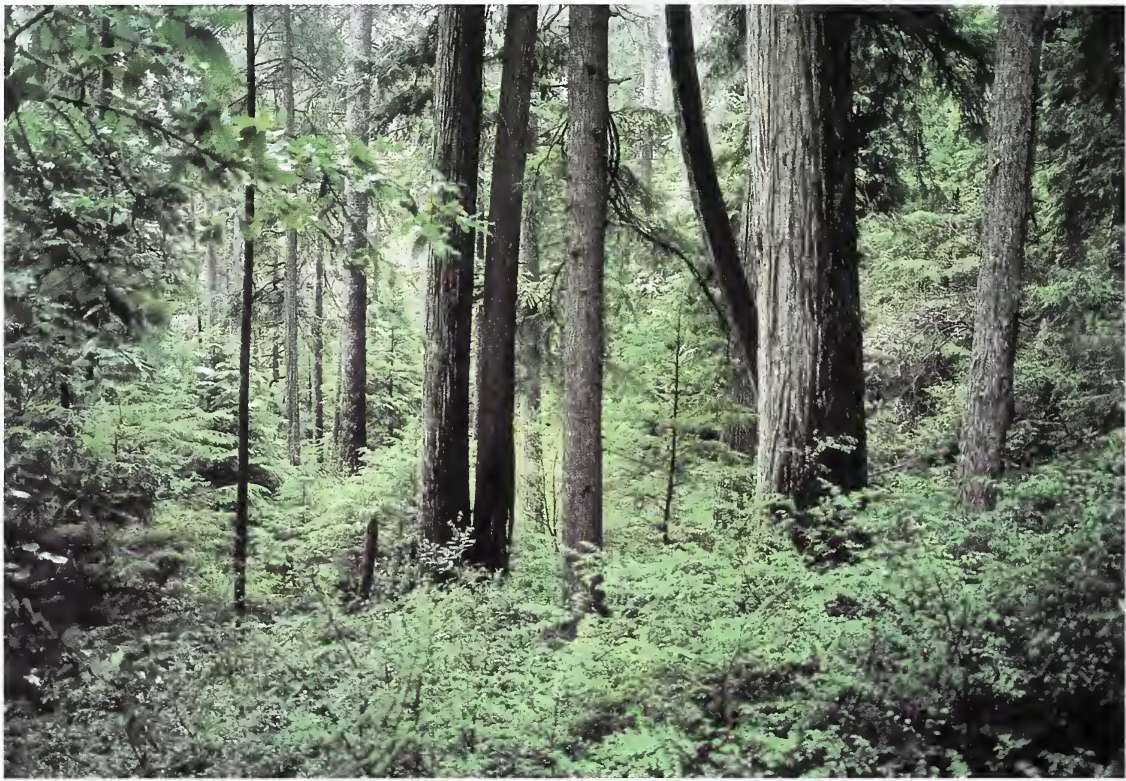

ENVIRONMENT: Elevation: 1300-2000 ft.; Aspect: E.; Slope: 35-75\%; Slope Position: lower and middle 1/3; Surface Rock: 1-4\%

SUMMARY TABLE

(Sample size: 15)

COVER

CON

Tree Overstory Layer

$\begin{array}{llll}\text { CHLA } & \text { Port Orford Cedar } & 30 & 100 \\ \text { PSME } & \text { Douglas-fir } & 34 & 100 \\ \text { LIDE2 } & \text { Tanoak } & 23 & 100 \\ \text { TSHE } & \text { Western Hemlock } & 20 & 100\end{array}$

Tree Understory Layer

LIDE2 Tanoak

TSHE Western Hemlock

CHLA Port Orford Cedar

$\begin{array}{rr}7 & 100 \\ 3 & 100 \\ 2 & 80\end{array}$

Shrubs

$\begin{array}{ll}\text { VAOV } & \text { Evergreen Huckleberry } \\ \text { RHMA } & \text { Pacific Rhododendron } \\ \text { BENEl } & \text { Dwarf Oregon-grape }\end{array}$

Herbs \& Grasses

$\begin{array}{llrl}\text { POMU1 } & \text { Sword Fern } & 10 & 80 \\ \text { GOOB } & \text { Rattlesnake Plantain } & 1 & 60 \\ \text { VAPL } & \text { Inside-out flower } & 2 & 40 \\ \text { TROV2 } & \text { White Trillium } & 1 & 40\end{array}$

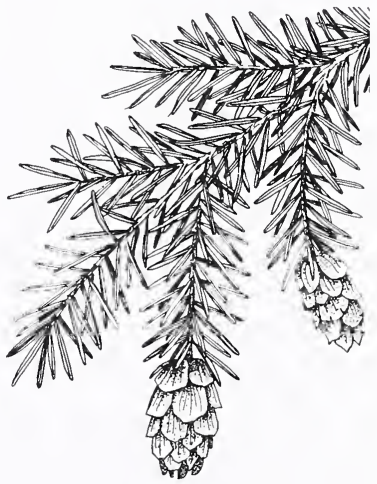

Western Hemlock (Tsuga heterophylla)
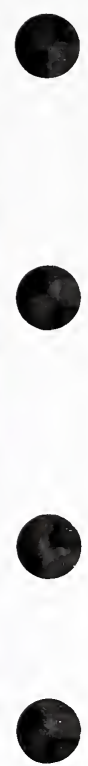
DISTRIBUTION/ENVIRONMENT: This type was found on the west side of the Orleans and Gasquet ranger districts where coastal fog contributes to moist conditions favorable to western hemlock. It was found in middle and lower one-third slope positions with linear micro-relief. Elevation averaged 1553 feet, second lowest in the tanoak-Port Orford cedar sub-series and ranged from 1300 to 2000 feet, on moderate (46\%) slopes with east facing aspects. Radiation index was high (.416) as a result of east aspects, but was moderated by coastal fog and topographic shading. The natural range of this plant association probably includes the extensive private lands situated between the National Park and National Forest boundaries.

VEGETATION SUMMARY: Total vegetation cover was high (97\%) here, along with total tree cover (92\%) due to the moist coastal locations. Douglas-fir was the dominant overstory tree (34\%), followed by Port Orford cedar (30\%), and western hemlock (20\%). Tanoak was the dominant hardwood in the mid layer (23\%) along with bigleaf maple (8\%). The regeneration layer included tanoak $(7 \%)$, along with western hemlock (3\%) and Port-Orford cedar (2\%). Pacific yew was often found in this type as an understory tree or shrub. The shrub layer was dense (61\%). It was dominated by evergreen huckleberry (47\%) and Pacific rhododendron (12\%). The herb layer was variable and can be the highest of all tanoak-Port Orford cedar plant associations. It had an average cover of 16 percent and could be dominated by redwood sorrel $(75 \%)$, sword fern $(10 \%)$, or inside-out flower $(15 \%)$.

SOIL SUMMARY: Soils in this type were derived from fine textured schist, phyllite, and greenstone parent rock. They were well drained, moderately deep to deep, of loam texture, with low AWC (3.1"), thick A horizons (5"), and low A horizon coarse fragments $(31 \%)$. They were found entirely in the mesic soil temperature regime and were highly productive to moderately productive for conifer growth. They present few major limitations for management. The dominant soil group was Hurlbutt moderately deep.

STAND STRUCTURE SUMMARY: Stands found in this type had an average stand age of 375 years and ranged from 255 to 550 years stand age. The highest frequency of stands (66\%) were found between 226 and 325 years of age. The frequency of stands above 300 years was 66 percent; the frequency of stands below 200 years was 0 percent.

This type was composed of a mixture of uneven-aged, tolerant and somewhat intolerant tree species, in a variety of diameter classes; which resulted in multiple layers. The overstory was composed of at least two layers of different aged conifers, averaging 199 feet tall in the top layer and 148 feet tall in the second layer, tallest of all types in the tanoak-Port Orford cedar sub-series. It had a moderate density of large conifers, with an average of 18 trees/acre greater than 30 inches diameter. The mid layers were dominated by conifers and hardwoods; they ranged from 35 to 100 feet tall. Most hardwood species were found in the smaller diameter classes with an average of 9 trees/acre in the 6-10.9 inch diameter class and an average of 14 trees/acre greater than 11 inches diameter. The regeneration layer was low due to the dense cover of hardwoods and conifers in the other layers.

Softwood cubic volume ranged from moderate to high with an average of 10,345 $\mathrm{ft}^{3} /$ acre. Hardwood cubic volume was moderate with an average of $485 \mathrm{ft}^{3} /$ acre. Dunning site class was 1 , with site index of 175 at 300 years. Stand density index was moderate with an average of 453 . 
-

-

-

-

-

-

- 
New Tanoak

Plant Associations 
LIDE2-CHLA-SESE2/VAOV Association, EcoCode: HTOCCO20

\section{Tanoak-Port-Orford-cedar-Redwood/Evergreen Huckleberry}

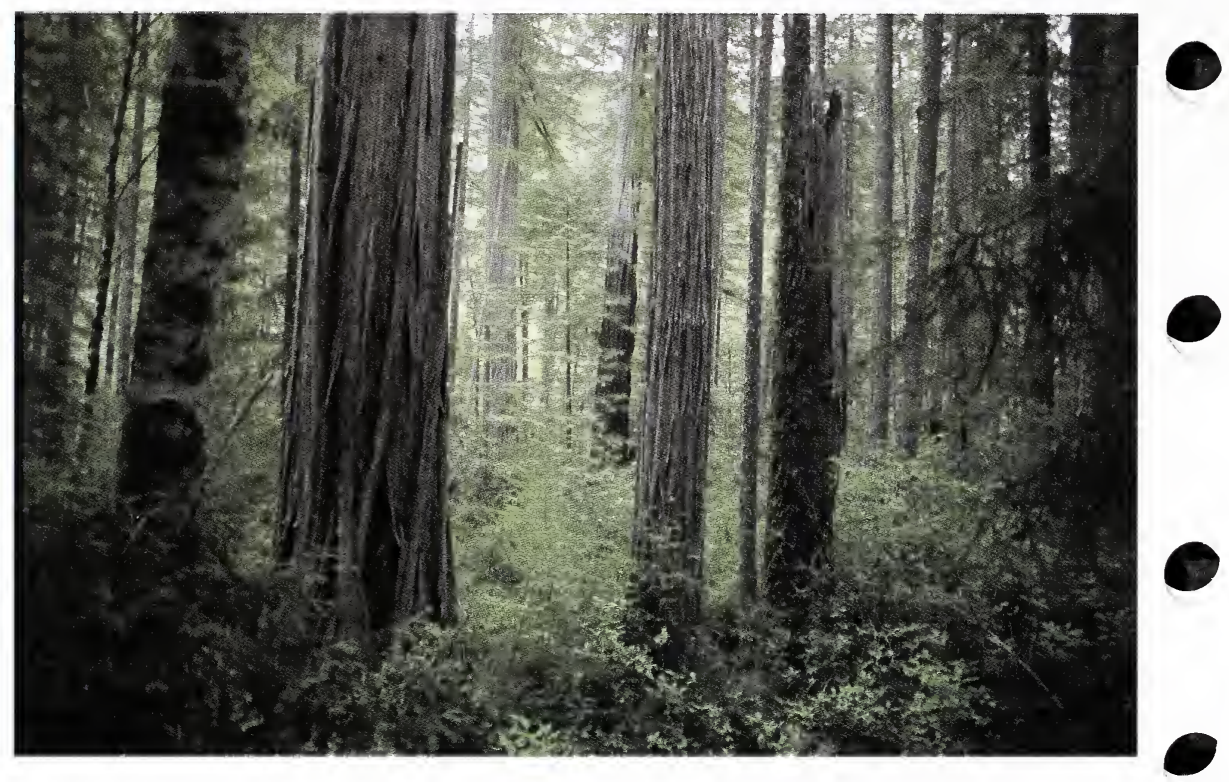

\section{SUMMARY TABLE}

(Sample size: 9)

Tree Overstory Layer

LIDE2 Tanoak

PSME Douglas-fir

SESE2 Redwood

CHLA Port-Orford-cedar

COVER CON

Tree Understory Layer

$\begin{array}{ll}\text { LIDE2 } & \text { Tanoak } \\ \text { CHLA } & \text { Port-Orford-cedar } \\ \text { PSME } & \text { Douglas-fir } \\ \text { SESE2 } & \text { Redwood }\end{array}$

Shrubs

$\begin{array}{llrr}\text { VAOV } & \text { Evergreen Huckleberry } & 24 & 100 \\ \text { GASH } & \text { Salal } & \text { I2 } & 100 \\ \text { COCOC } & \text { California Hazelnut } & 4 & 67\end{array}$

Herbs \& Grasses

POMU1 Swordfern

OXOR1 Redwood Sorrel 


\section{DISTRIBUTION/ENVIRONMENT:}

This plant association was a minor component in the western portion of the range of Port-Orford-cedar. It covered 141 acres and was found on the west side of the Gasquet Ranger District, Six Rivers National Forest where coastal fog contributes moist conditions favorable to coast redwood. Sites were in middle and lower one-third slope positions with linear and concave slope shapes. Mean distance to the Pacific Ocean was 10.4 miles and ranged from 7.0 to 13.1 miles. Elevation averaged 1219 feet and ranged from 120 to 2200 feet. Slopes were typically steep averaging $49 \%$ and ranged from $8 \%$ to $80 \%$. Radiation index was a warm .490 as a result of mainly west and south aspects but was moderated by coastal fog and the close proximity to the Pacific Ocean.

\section{VEGETATION SUMMARY:}

Total vegetation cover was dense (95\%) and was composed of primarily trees (74\%) and shrubs (45\%). The tree layer was dominated by Port-Orford-cedar (33\%), Douglasfir $(26 \%)$, coast redwood $(12 \%)$ and tanoak $(35 \%)$. The shrub layer included salal (12\%) and evergreen huckleberry (24\%) as the primary species. Total forb cover was high $(26 \%)$ and included swordfern, redwood sorrel, starflower and western modesty. The grass layer was of low cover $(1 \%)$ and dominated by sedge.

\section{SOIL SUMMARY:}

Soils in this type were mesic, moderately deep and well drained. They formed in bedrock and alluvium from fine textured metamorphic parent material. The litter layer thickness averaged $0.8 "$ at $87 \%$ cover. Surface rock and gravel averaged $7 \%$ cover. The average surface horizon thickness was 3", texture was gravelly sandy loam, coarse fragment content averaged $25 \%$ and $\mathrm{pH}$ averaged 6.9 .

Subsoil textures were gravelly loam, coarse fragment content averaged $30 \%$ and $\mathrm{pH}$ averaged 7.1. The soils were $100 \%$ non-skeletal.

\section{STAND STRUCTURE SUMMARY:}

Late seral stands in this type often had 4 or more layers of trees, while early mature and mid mature stands usually had 3 layers. Medium sized conifers dominated the top two layers with an average of 30 trees/acre $>21$ inches dbh, 8 trees/acre $>30$ inches dbh, and 2 trees/acre $>40$ inches dbh. Hardwoods dominated the lower layers and included 155 trees/acre $>5$ inches dbh, 39 trees/acre $>11$ inches $\mathrm{dbh}$ and 9 trees/acre $>21$ inches dbh..

The stand structure characteristics by layer were as follows. The top layer averaged 313 years old with an average diameter of 45.9 inches and average height of 170 feet. It was made up of dominant Douglas-fir and Port-Orford-cedar. The second layer had an average age of 277 years with a mean diameter of 34.2 inches and a mean height of 125 feet. It included codominant Port-Orford-cedar and coast redwood. The third layer had an average age of 151 years with a mean diameter of 28.6 inches and a mean height of 84 feet. The third layer included intermediate Port-Orford-cedar and coast redwood. The fourth layer was dominated by intermediate tanoaks.

Overall biomass production (conifer + hardwoods + shrubs) was generally high. Modal Dunning site class was 1 with site index of 175 at 300 years. Conifer productivity was generally low with an average volume of $4743 \mathrm{ft}^{3}{ }^{3}$, it ranged from 3414 to $5530 \mathrm{ft} .^{3}$. Softwood basal area averaged $180 \mathrm{ft}^{2}$ and ranged from 100 to $266 \mathrm{ft}^{2}{ }^{2}$ Hardwood volume averaged $1649 \mathrm{ft}^{3}$ and ranged from 1017 to $2487 \mathrm{ft}^{3}$ Hardwood basal area averaged 93 $\mathrm{ft}^{2}$ and ranged from 67 to $146 \mathrm{ft}^{2}{ }^{2}$ Stand density index was 535 and fell in the middle of the Port-Orford-cedar series. Quadratic mean diameter was 15.5 inches and fell in the middle of the Port-Orford-cedar series. 


\section{LIDE2-CHLA/QUVA Association, EcoCode: HT0CCO21 Tanoak-Port-Orford-cedar/Huckleberry Oak}

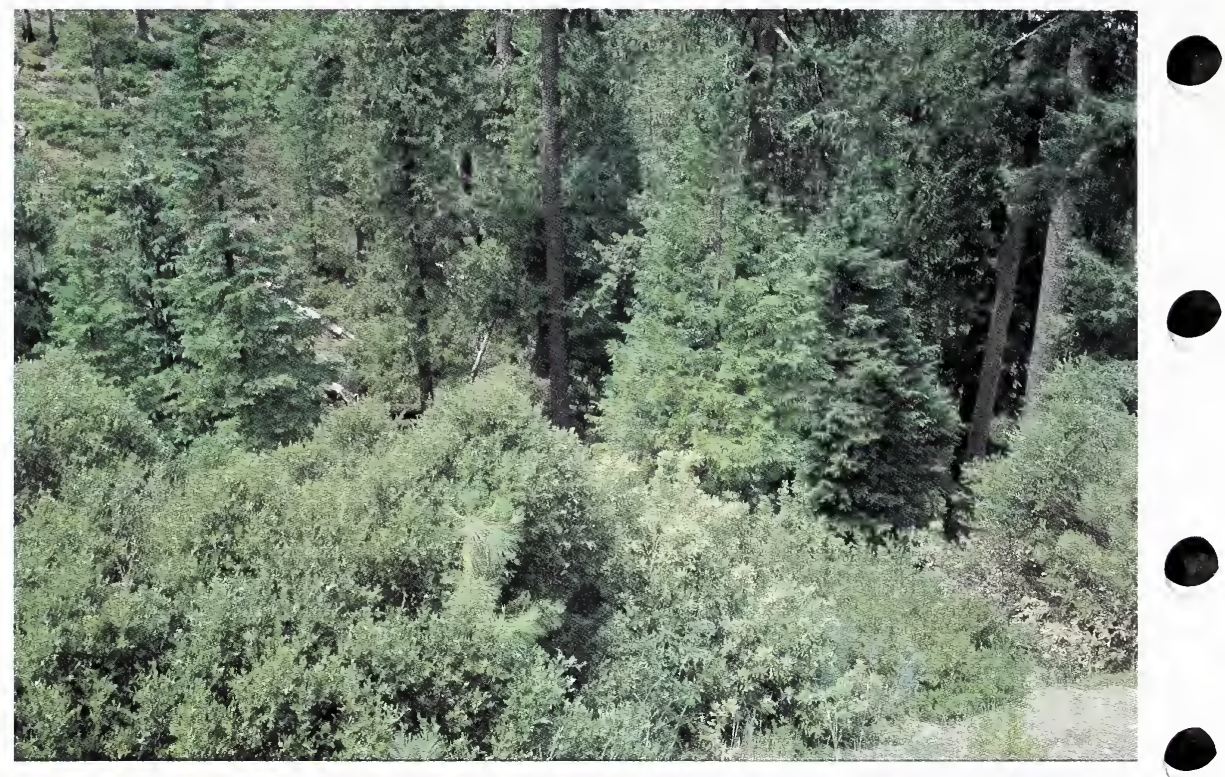

\section{SUMMARY TABLE}

(Sample size: 9)

\section{Tree Overstory Layer}

IIDE2 Tanoak

CHLA Port-Orford-cedar

PSME Douglas-fir

\section{Tree Understory Layer}

\section{LIDE2 Tanoak}

CHLA Port-Orford-cedar

PSME Douglas-fir

\section{Shrubs}

QUVA Huckleberry Oak

RHOC Western Azalea

VAPA Red Huckleberry

\section{Herbs $\&$ Grasses}

POMU1 Swordfern

WHMO Western Modesty

ADPEA Five-finger Fern

TRLA3 Starflower
COVER CON

ENVIRONMENT:

Elevation: 2180-3750;

100 Aspect: S.E., N.W., S.;

100 Slope: $10-60 \%$;

100 Slope Position: middle 1/3, lower 1/3,

Draw

Surface Rock: $15-20 \%$

$18 \quad 100$

Distance to Ocean: 14.3-23.2 miles

$4 \quad 78$

SOILS:

Pit Depth: 18-25in.;

AWC: 0.9-2.5in.;

Parent Material: ultramafic, granitic A Horizon:

Coarse Fragments: $31-45 \%$; Textures: $x g l$; Thickness: 1.0-4.0 in.;

Surface PH: 6.2-7.3 


\section{DISTRIBUTION/ENVIRONMENT:}

This plant association was a minor component in the western portion of the range of Port-Orford-cedar. It covered 99 acres and was found on the Gasquet, Orleans and Lower Trinity Ranger Districts of the Six Rivers National Forest. Sites were coastal and inland, in middle and lower one-third slope positions with linear slope shapes. Mean distance to the Pacific Ocean was 20.0 miles and ranged from 14.3 to 23.2 miles. Elevation averaged 3083 feet and ranged from 2264 to 3750 feet. Slopes were typically moderately steep averaging $35 \%$ and ranged from $10 \%$ to $60 \%$. Radiation index was a warm .479 due to southeast aspects.

\section{VEGETATION SUMMARY:}

Total vegetation cover was dense (92\%). It was made up of primarily trees (79\%) and shrubs (38\%). Port-Orford-cedar (27\%), Douglas-fir (29\%) and tanoak (13\%) dominated the tree layer. The shrub layer was dominated by huckleberry oak $(18 \%)$ and western azalea (23\%). Total forb cover was high (14\%) and included swordfern, five-finger fern, western modesty and starflower. The grass layer was of low cover (2\%) and dominated by grasses.

\section{SOIL SUMMARY:}

Soils in this type were mesic, shallow to moderately deep and well drained. They formed in bedrock and colluvium from fine textured serpentine parent material. The litter layer thickness averaged $1.2 "$ at $80 \%$ cover. Surface rock and gravel averaged $31 \%$ cover. The average surface horizon thickness was 3", texture was extremely gravelly loam, coarse fragment content averaged $40 \%$ and $\mathrm{pH}$ averaged 6.6 .

Subsoil textures were extremely gravelly loam, coarse fragment content averaged $50 \%$ and $\mathrm{pH}$ averaged 7.0. The soils were 100\% skeletal.

\section{STAND STRUCTURE SUMMARY:}

Late seral stands in this type often had 3 or more layers of trees, while early mature and mid mature stands usually had 2 layers. Large sized conifers dominated the top two layers with an average of 49 trees/acre $>21$ inches dbh, 14 trees/acre $>30$ inches dbh, and 5 trees/acre $>40$ inches dbh. Hardwoods dominated the lower layers and included 17 trees/acre $>5$ inches dbh.

The stand structure characteristics by layer were as follows. The top layer averaged 320 years old with an average diameter of 37.8 inches and average height of 138 feet. It was made up of dominant Douglas-fir and Port-Orford-cedar. The second layer had an average age of 236 years with a mean diameter of 26.9 inches and a mean height of 102 feet. It included codominant Port-Orford-cedar and Douglas-fir. The third layer had an average age of 146 years with a mean diameter of 20.5 inches and a mean height of 74 feet. The third layer often included intermediate Port-Orford-cedar. The fourth layer was dominated by small tanoaks.

Overall biomass production (conifer + hardwoods + shrubs) was generally moderate. Modal Dunning site class was 3 with site index of 125 at 300 years. Conifer productivity was generally moderate with an average volume of $8386 \mathrm{ft}^{3}$, it ranged from 5270 to $11681 \mathrm{ft}^{3}{ }^{3}$ Softwood basal area averaged $275 \mathrm{ft}^{2}$ and ranged from 173 to $373 \mathrm{ft}^{2}{ }^{2}$ Hardwood volume averaged $78 \mathrm{ft}^{3}$ and ranged from 0 to $260 \mathrm{ft}^{3}{ }^{3}$ Hardwood basal area averaged 5 $\mathrm{ft}^{2}$ and ranged from 0 to $13 \mathrm{ft}^{2}{ }^{2}$ Stand density index was 479 and fell in the low end of the Port-Orford-cedar series. Quadratic mean diameter was 16.4 inches and fell in the middle of the Port-Orford-cedar series. 


\section{LIDE2-CHLA/RHMA Association, EcoCode: HT0CCO22}

\section{Tanoak-Port-Orford-cedar/Pacific Rhododendron}
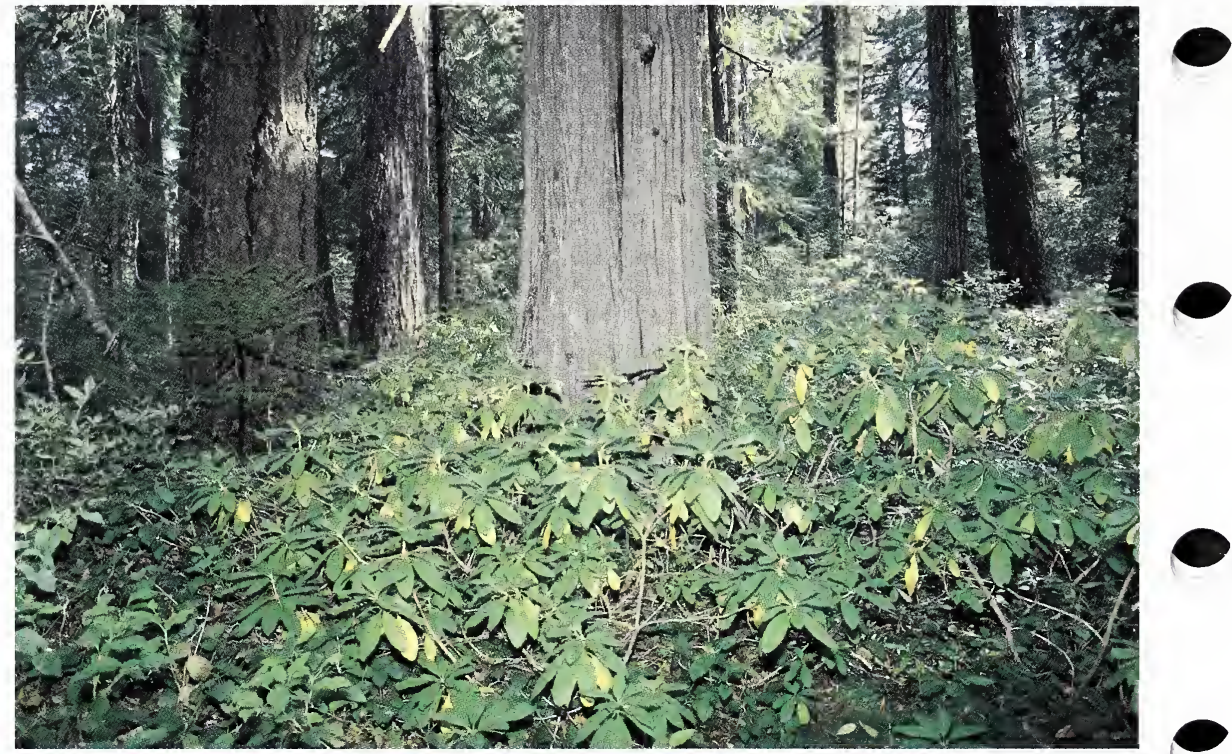

\section{SUMMARY TABLE}

(Sample size: 7)

COVER CON

Tree Overstory Layer

LIDE2 Tanoak

CHLA Port-Orford-cedar 33

PSME Douglas-fir

Tree Understory Layer

LIDE2 Tanoak

CHLA Port-Orford-cedar

PSME Douglas-fir

Shrubs

RHMA Pacific Rhododendron 2

GASH Salal 17

BENEl Dwarf Oregon-grape 2

Herbs \& Grasses

POMU1 Swordfern

TRLA3 Starflower

OXORl Redwood Sorrel

$\begin{array}{rl}12 & 71 \\ 2 & 71 \\ 4 & 57\end{array}$

100

100

71

1

71

\section{ENVIRONMENT:}

Elevation: 1800-3100 ft: Aspect: N.E., N.W., S.W.;

Slope: 5-55\%;

Slope Position: lower $1 / 3$, bottom, upper $1 / 3$;

Surface Rock: 1-30\%;

Distance to the Ocean: 10-22 miles

SOILS:

Pit Depth: $32-40+$ in.;

AWC: 3.0-7.0 in.;

Parent Material: granitic, semishist, mixed

A Horizon:

Coarse Fragments: $10-40 \%$; Textures: 1, gl, gsil, vgl; Thickness: 1-10 in.;

Surface PH: 5.4-6.0 


\section{DISTRIBUTION/ENVIRONMENT:}

This plant association was a minor component in the western portion of the range of Port-Orford-cedar. It covered 197 acres and was found on the Gasquet and Orleans Ranger Districts of the Six Rivers National Forest. Sites were coastal in lower one-third slope positions with linear and undulating slope shapes. Mean distance to the Pacific Ocean was 14.8 miles and ranged from 10.4 to 19.0 miles. Elevation averaged 2158 feet and ranged from 1320 to 2710 feet. Slopes were typically moderately steep averaging $30 \%$ and ranged from $0 \%$ to $55 \%$. Radiation index was a cool .390 due to north facing aspects.

\section{VEGETATION SUMMARY:}

Total vegetation cover was very dense (98\%) and was composed of primarily trees $(87 \%)$ and shrubs (62\%). Port-Orford-cedar (33\%), Douglas-fir (30\%) and tanoak (30\%) dominated the tree layer. The shrub layer was dominated by Pacific rhododendron (24\%), salal (17\%) and evergreen huckleberry (28\%). Total forb cover was high $(21 \%)$ and included swordfern, rattlesnake plantain, starflower, and inside-out flower. The grass layer was of low cover $(1 \%)$.

\section{SOIL SUMMARY:}

Soils in this type were mesic, deep and moderately deep and well drained. They formed in bedrock and colluvium from fine textured greenstone parent material. The litter layer thickness averaged $0.8 "$ at $87 \%$ cover. Surface rock and gravel averaged 15\% cover. The average surface horizon thickness was $5 "$, texture was loam to very gravelly loam, coarse fragment content averaged $26 \%$ and $\mathrm{pH}$ averaged 5.7 .

Subsoil textures were clay loam, silty clay loam and extremely cobbly sandy loam. Subsoil coarse fragment content averaged $26 \%$ and $\mathrm{pH}$ averaged 6.3 . The soils were $50 \%$ skeletal.

\section{STAND STRUCTURE SUMMARY:}

Late seral stands in this type often had 4 or more layers of trees, while early mature and mid mature stands usually had 3 layers. Large sized conifers dominated the top two layers with an average of 50 trees/acre $>21$ inches $\mathrm{dbh}, 18$ trees/acre $>30$ inches $\mathrm{dbh}$, and 10 trees/acre $>40$ inches $\mathrm{dbh}$. Hardwoods dominated the lower layers and included 215 trees/acre $>5$ inches dbh, 55 trees/acre $>8$ inches $\mathrm{dbh}$.

The stand structure characteristics by layer were as follows. The top layer averaged 379 years old with an average diameter of 60.2 inches and average height of 218 feet. It was made up of predominant Douglas-fir and dominant Port-Orford-cedar. The second layer had an average age of 287 years with a mean diameter of 41.1 inches and a mean height of 157 feet. It included codominant Port-Orford-cedar and Douglas-fir. The third layer had an average age of 225 years with a mean diameter of 17.2 inches and a mean height of 103 feet. The third layer included intermediate Port-Orford-cedar. The fourth layer was made of intermediate sized tanoaks.

Overall biomass production (conifer + hardwoods + shrubs) was generally high. Modal Dunning site class was 1 with site index of 175 at 300 years. Conifer productivity was generally high with an average volume of $15,915 \mathrm{ft}^{3}$, it ranged from 12,924 to $18,906 \mathrm{ft}^{3}{ }^{3}$ Softwood basal area averaged $420 \mathrm{ft}^{2}{ }^{2}$ and ranged from 347 to $493 \mathrm{ft}^{2}$ Hardwood volume averaged $1250 \mathrm{ft}^{3}$ and ranged from 1200 to $1300 \mathrm{ft}^{3}{ }^{3}$ Hardwood basal area averaged $75 \mathrm{ft}^{2}$ and ranged from 70 to $80 \mathrm{ft}^{2}$ Stand density index was 531 and fell in the middle of the Port-Orford-cedar series. Quadratic mean diameter was 27.1 inches and fell in the high end of the Port-Orford-cedar series. 


\section{LIDE2-THPL/VAOV-GASH Association, EcoCode: HT0CCO23 Tanoak-Western Red cedar/Evergreen Huckleberry-Salal}

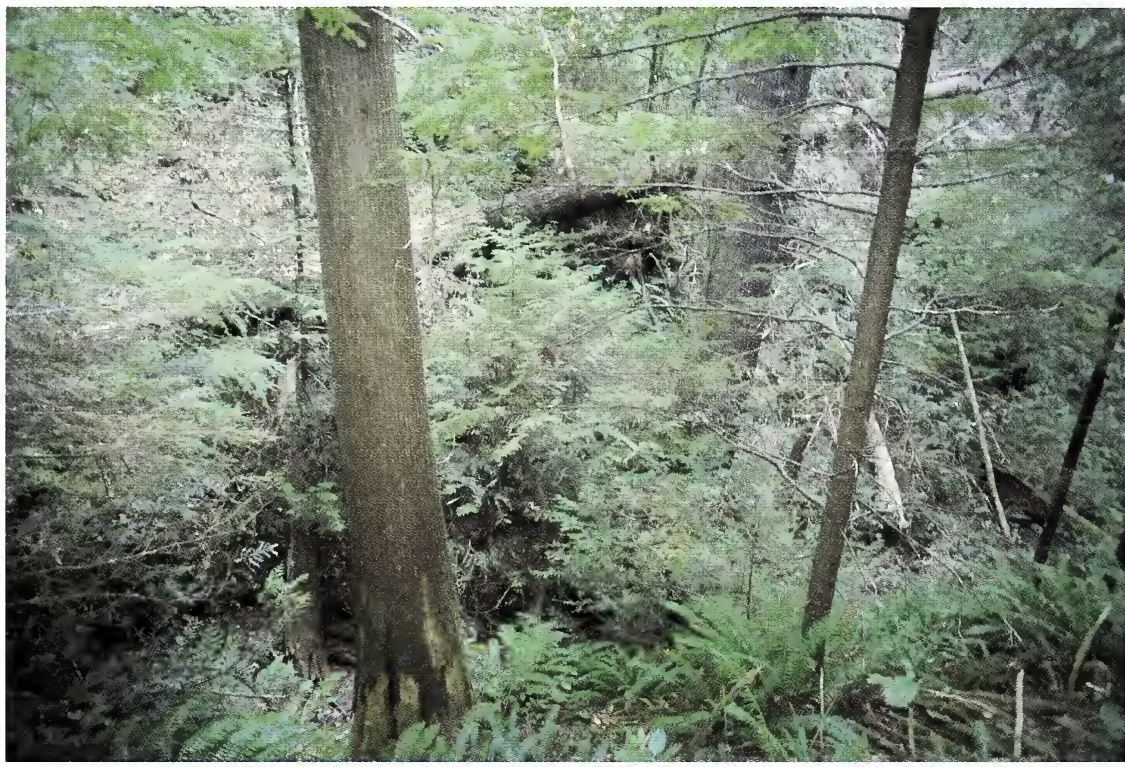

\section{SUMMARY TABLE}

(Sample size: 3 )

COVER CON

\section{Tree Overstory Layer}

LIDE2 Tanoak

PSME Douglas-fir

THPL Western Red Cedar $21 \quad 100$

CHLA Port-Orford-cedar $\quad 10 \quad 33$

\section{Tree Understory Layer}

LIDE2 Tanoak

PSME Douglas-fir

8

THPL Western Red Cedar

CHLA Port-Orford-cedar

Shrubs

$\begin{array}{llrr}\text { GASH } & \text { Salal } & 10 & 100 \\ \text { VAOV } & \text { Evergreen Huckleberry } & 15 & 100 \\ \text { VAPA } & \text { Red Huckleberry } & 1 & 67\end{array}$

Herbs \& Grasses

$\begin{array}{llll}\text { POMU1 } & \text { Swordfern } & 40 & 33 \\ \text { BLSP } & \text { Deer fern } & 20 & 33 \\ \text { OXOR1 } & \text { Redwood Sorrel } & 15 & 33\end{array}$

\section{ENVIRONMENT:}

Elevation: 1800-2000 ft.; Aspect: N.W., N.E.;

Slope: $30-60 \%$;

Slope Position: middle 1/3, lower $1 / 3$ Surface Rock: 0-2\%;

Distance to the Ocean: 14.8-19.3 miles

SOILS:

Pit Depth: 40+ in.;

AWC: 5.0 in.;

Parent Material: phyllite

A Horizon:

Coarse Fragments: 58\%;

Textures: gcl;

Thickness: 6.0 in.;

Surface PH: 6.8 


\section{DISTRIBUTION/ENVIRONMENT:}

This plant association was a minor component in the western portion of the range of Port-Orford-cedar. It was found on the Gasquet Ranger District of the Six Rivers National Forest, on coastal sites in lower one-third slope positions with linear slope shapes. Mean distance to the Pacific Ocean was 16.3 miles and ranged from 14.8 to 19.3 miles. Elevation averaged 1910 feet and ranged from 1800 to 2000 feet. Slopes were typically steep averaging $50 \%$ and ranged from $30 \%$ to $60 \%$. Radiation index was a cool .326 due to northwest and northeast facing aspects.

\section{VEGETATION SUMMARY:}

Total vegetation cover was very dense $(99 \%)$. It was made up of primarily trees (93\%) and shrubs (26\%). Western red cedar (21\%), Douglas-fir (32\%), Port-Orfordcedar $(10 \%)$, and tanoak (48\%) dominated the tree layer. The shrub layer was dominated by evergreen huckleberry (15\%) and salal (10\%). Total forb cover was high $(33 \%)$ and included swordfern, deerfern, iris, five-finger fern, redwood sorrel and white trillium. The grass layer was absent.

\section{SOIL SUMMARY:}

Soils in this type were mesic, deep and moderately well drained. They formed in colluvium from fine textured phyllite parent material. The litter layer thickness averaged $1.9 "$ at $89 \%$ cover. Surface rock and gravel averaged $9 \%$ cover. The average surface horizon thickness was 6", texture was gravelly clay loam, coarse fragment content averaged $58 \%$ and $\mathrm{pH}$ averaged 6.8

Subsoil textures were very gravelly clay loam, coarse fragment content averaged $47 \%$ and $\mathrm{pH}$ averaged 7.2 . The soils were $100 \%$ skeletal.

\section{STAND STRUCTURE SUMMARY:}

Late seral stands in this type often had 4 or more layers of trees, while early mature and mid mature stands usually had 3 layers. Large sized conifers dominated the top two layers with an average of 37 trees/acre $>21$ inches $\mathrm{dbh}, 16$ trees/acre $>30$ inches $\mathrm{dbh}$, and 10 trees/acre $>40$ inches $\mathrm{dbh}$. Hardwoods dominated the lower layers and included 230 trees/acre $>5$ inches $\mathrm{dbh}, 50$ trees/acre $>8$ inches $\mathrm{dbh}$.

The stand structure characteristics by layer were as follows. The top layer averaged 326 years old with an average diameter of 45.6 inches and average height of 168 feet. It was made up of Douglas-fir and western red cedar. The second layer had an average age of 250 years with a mean diameter of 31.2 inches and a mean height of 121 feet. It included codominant western red cedar, Port-Orford-cedar and Douglas-fir. The third layer had an average age of 161 years with a mean diameter of 22.2 inches and a mean height of 88 feet. The third layer included intermediate western red cedar. The fourth layer was made of small sized tanoaks.

Overall biomass production (conifer + hardwoods + shrubs) was generally moderate. Modal Dunning site class was 1A with site index of 200 at 300 years. Conifer productivity was generally moderate with an average volume of $9129 \mathrm{ft}^{3}{ }^{3}$, softwood basal area averaged $320 \mathrm{ft}^{2}$. Hardwood volume averaged $1400 \mathrm{ft}^{3}$ and basal area averaged $85 \mathrm{ft}^{2}$ Stand density index was 489 and fell in the lower end of the Port-Orford-cedar series. Quadratic mean diameter was 15.8 inches and fell in the middle of the Port-Orford-cedar series. 


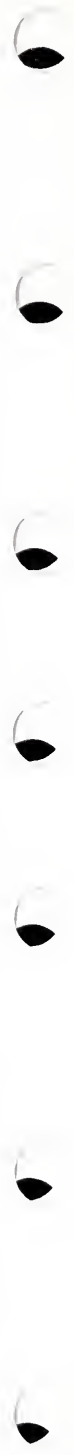




\section{THE PORT ORFORD CEDAR SERIES}

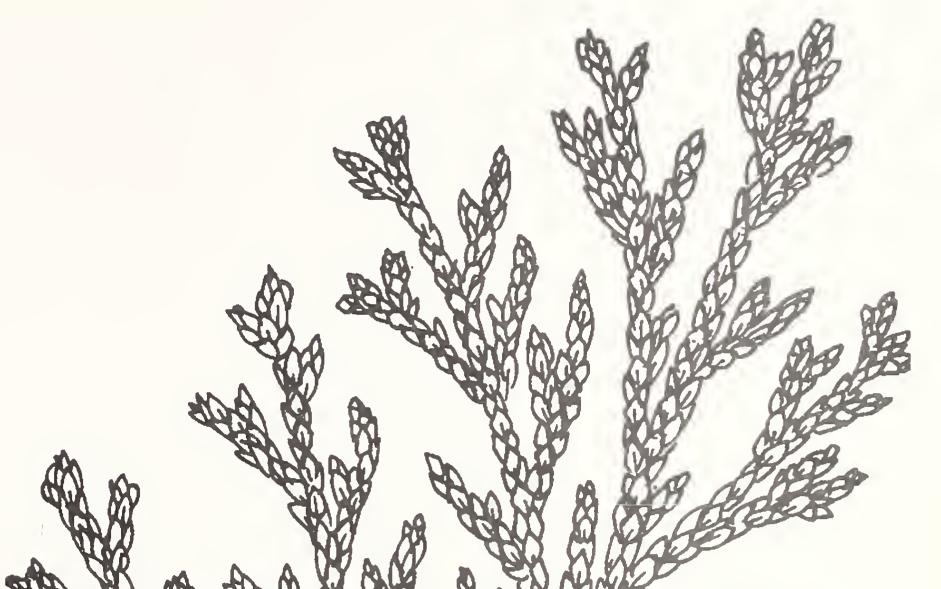

2
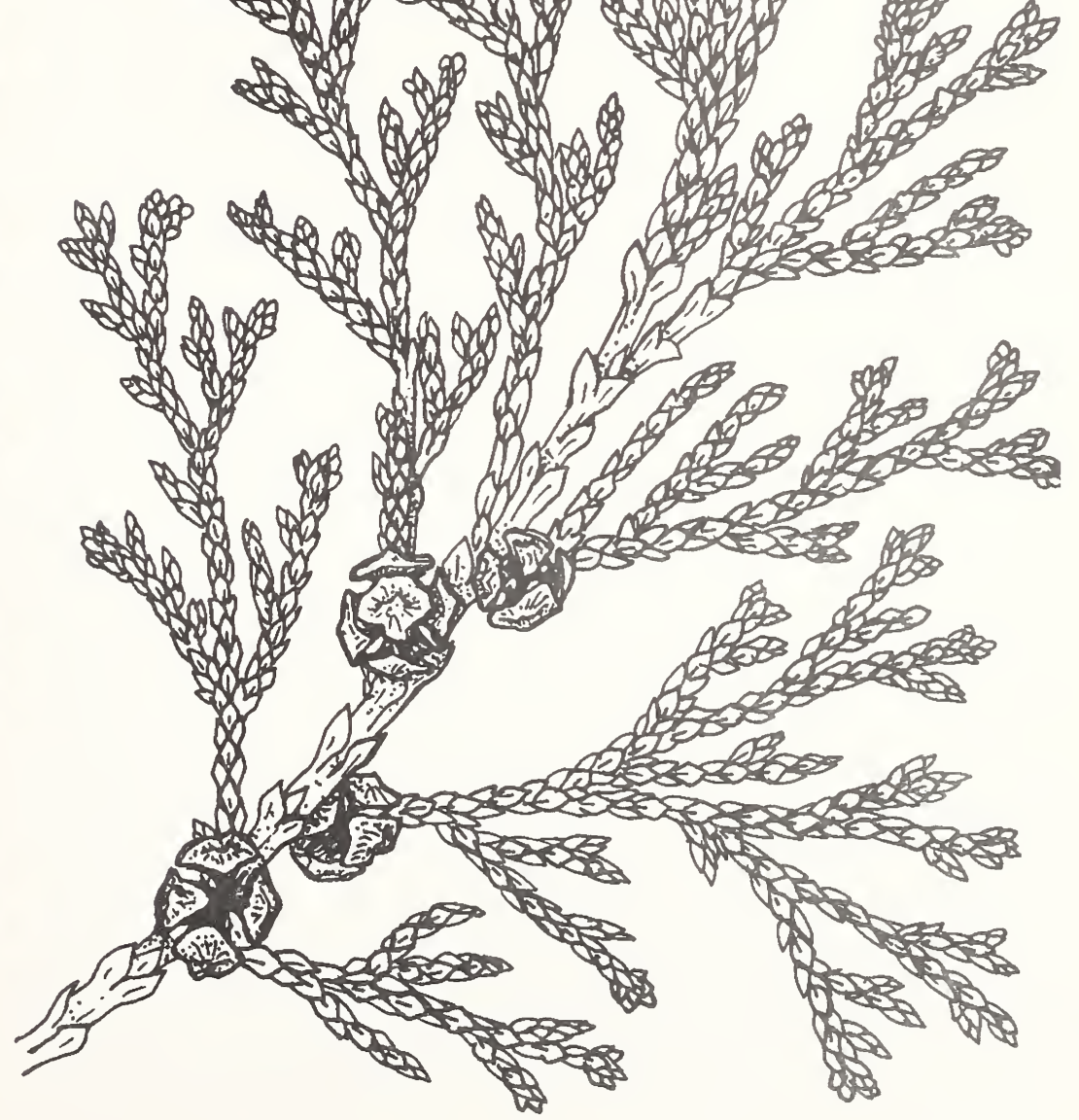
-

-

6

-

-

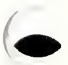

- 


\section{INTRODUCTION TO THE PORT ORFORD CEDAR SERIES}

The Port Orford cedar series is of limited extent within Northwest California, but of high ecological importance due to its high diversity of plant species and associations (Jimerson \& Creasy 1991, Jimerson In Press). It is found along stream sides and in lower and middle one-third slope positions, with undulating, linear, and concave micro-relief. It spans an elevation range from 2500 to 5200 feet.

Soils in the Port Orford cedar series were derived from metamorphic (51\%), igneous intrusive (34\%), sedimentary (7\%), and mixed (7\%) parent materials. The metamorphic rocks were primarily phyllite, schist, semischist, gneiss, serpentine, and greenstone. The igneous intrusive rocks included granite, mafic, and ultramafic rocks. The sedimentary rocks were dominated by sandstone. The effect of these variable parent materials was a wide range of soil $\mathrm{pH}$. The surface $\mathrm{pH}$ averaged 6.3 and ranged from 4.9 to 8.0; subsurface $\mathrm{pH}$ averaged 6.6 and also ranged from 4.9 to 8.0. Soil depths were primarily deep (47\%) and moderately deep (42\%), with loamy-skeletal (66\%) and fine loamy (29\%) textures. Soils were classified in the Inceptisol (78\%), Alfisol (11\%), and Entisol (9\%) orders, and found in the mesic (20\%) and frigid (80\%) soil temperature regimes. Available water holding capacity (AWC) was moderate, averaging 3.1 inches, and ranged from 1.0 to 7.1 inches. AWC may not be as important to this series as it is to upland series because of its proximity to water. A horizon thickness was also moderate; it averaged 6 inches and ranged from 1 to 27 inches. A horizon coarse fragments were generally skeletal, with an average of 37 percent and range of 5 to 95 percent. Subsurface coarse fragments averaged 44 percent and ranged from 7 to 96 percent .

Stand age frequency in the Port Orford cedar series showed a dominance by older stands (Fig. 3), with a mean stand age of 352 years. The highest frequency of stands sampled occurred in the 326-425 year range (40\%). The proportion of stands greater than 300 years stand age was 78 percent, compared to 6 percent of the stands below 200 years stand age. This is due to the tendency for this series to occur in streamside locations that have low stand replacing fire frequencies due to the moist environment.

Stand structure within the Port Orford cedar series is variable. It reflects the variability of environment and age distribution described above. Site quality also varied by environment; the mode for all sites was site class 3, Dunning base age 300 years. The frequency of sites in site classes 1A-2 was 56 percent, compared to site class 3-5 with 44 percent. Because of the variable site classes, the mixture of conifer species of various diameter classes (Fig. 4), and their advanced age, these stands tend to have both high vertical and horizontal structural diversity. This is demonstrated by the presence of various conifer species in most diameter classes. 


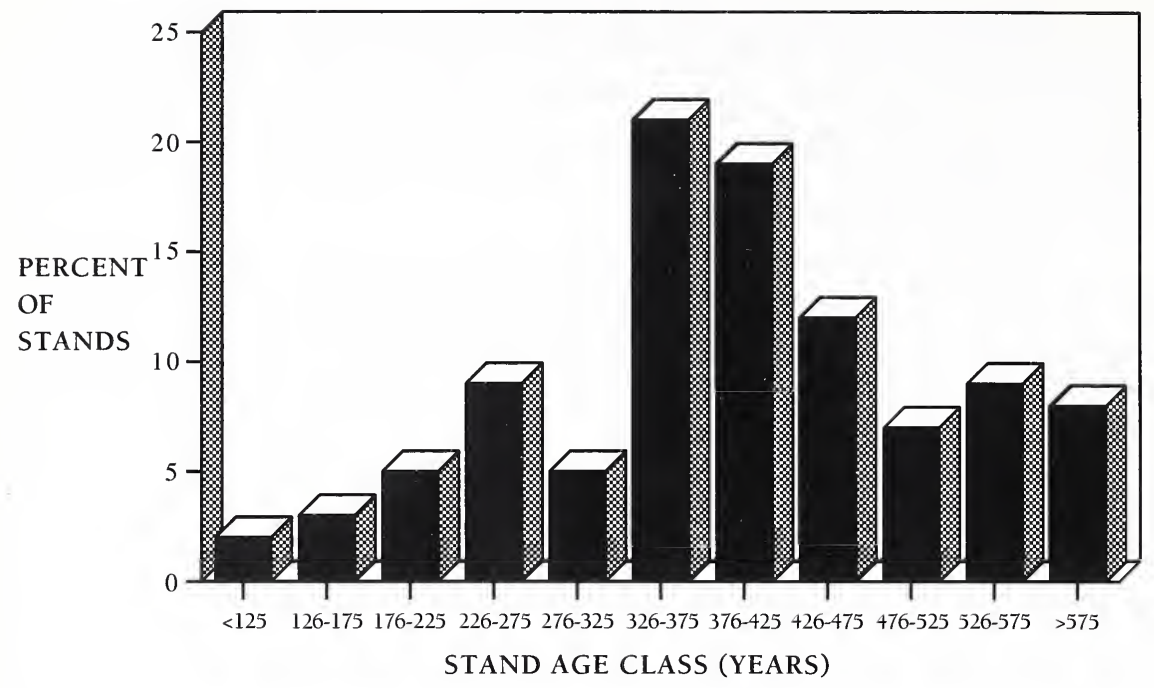

Figure 3. Percent of stands by age class category in the Port Orford cedar series.

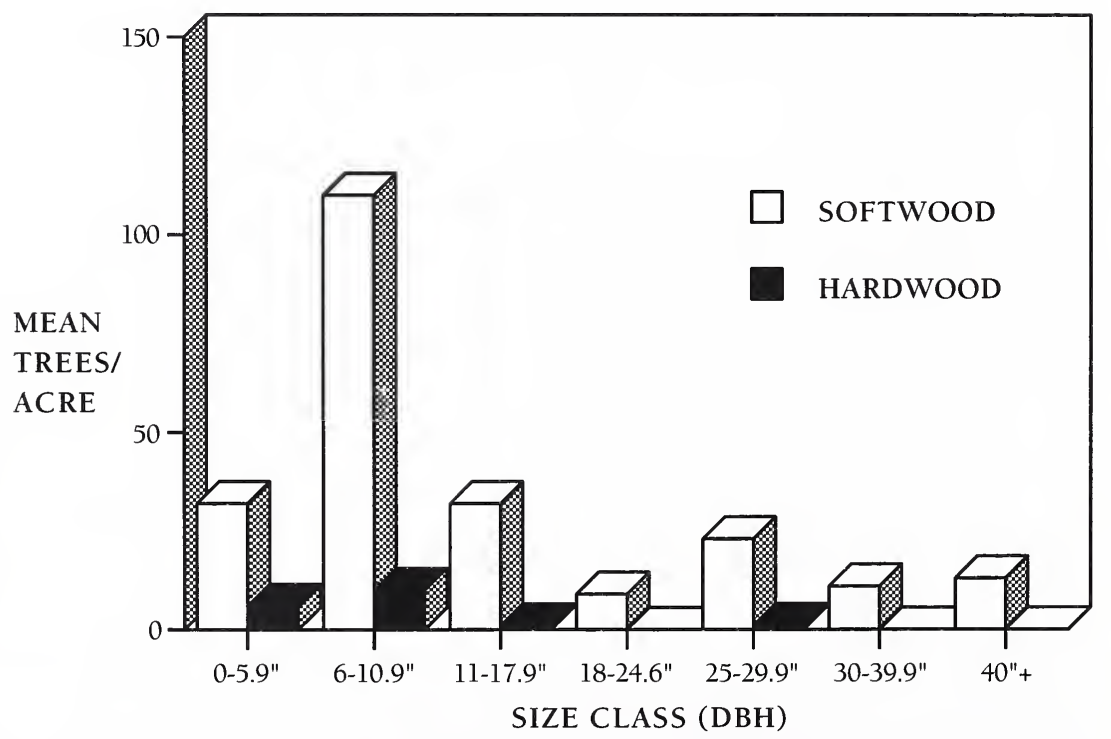

Figure 4. Mean trees/acre by size class, for softwoods and hardwoods in the Port Orford cedar series. 
Large snags and logs were a common feature of this sub-series and tended to persist for long periods of time due to the resistance of Port Orford cedar to decay. The density of snags $>20$ inches diameter and $>15$ feet tall was 6 snags/acre. They averaged 31 inches in diameter and 73 feet tall, and were found primarily in decay classes 1 through 3 (84\%). Logs $>20$ inches diameter and > 10 feet long had a mean density of 27 logs/acre and a mean volume of $3644 \mathrm{ft} 3$ and were included mainly in decay classes 1 through 3 .

Vegetation cover in the Port Orford cedar series was characterized as dense (95\%). The tree layer averaged 77 percent cover. It was dominated by conifer species in the overstory averaging 75 percent and occasionally hardwoods in the mid layer averaging 6 percent. The shrub layer was moderate, averaging 40 percent, as well as the herb layer, 16 percent. The grass layer is sparse ( $1 \%$ cover) due to the cool, moist environment in the streamside positions.

The Port Orford cedar series was dominated by the conifer species Port-Orford cedar along with Douglas-fir, white fir (Abies concolor), sugar pine, incense cedar (Libocedrus decurrens), western white pine (Pinus monticola), red fir (Abies magnifica var. shastensis), and occasionally Brewer's spruce (Picea breweriana) and Pacific yew. Hardwoods were found on selected sites; they were represented by giant chinquapin, tanoak, and Pacific madrone. Which associate tree species dominated was dependent on elevation, moisture, or parent material. The dominance of various shrub species was also determined by the same variables. Prominent shrub species included red huckleberry, huckleberry oak (Quercus vaccinifolia), trailing blackberry, Sadler oak (Quercus sadleriana), wild rose, dwarf Oregon grape, western azalea, salal, Pacific rhododendron, serviceberry (Amelanchier alnifolia), slender salal (Gaultheria ovatifolia), hazelnut, thimbleberry (Rubus parviflorum), Oregon boxwood (Paxistima myrsinites), pinemat manzanita (Arctostaphylos nevadensis), and thinleaf huckleberry (Vaccinium membranaceum). The herb layer was diverse due to its position in wet areas, it contained prince's pine, rattlesnake plantain, twinflower, beargrass, starflower, white flowered trillium, Hooker's fairybells, vanillaleaf, wintergreen (Pyrola picta), queens cup (Clintonia uniflora), western modesty, wild iris (Iris spp.), swordfern (Polystichum munitum), bracken fern, three-leaf anemone (Anemone deltoidea), one sided wintergreen (Pyrola secunda), small inside-out flower (Vancouveria hexandra), false Solomen's seal (Smilacina racemosa var. amplexicaulis), little prince's pine (Chimaphila menziesii), toothleaf pyrola (Pyrola picta var. dentata), white flowered hawkweed (Hieracium albiflorum), and trailplant (Adenocaulon bicolor). The grass layer was dominated by sedges.

Twelve plant associations were identified within the Port Orford cedar series (Table 2). These plant associations differed significantly from those found in the tanoak-Port Orford cedar sub-series. Of particular note was the high frequency of plant associations found on serpentine or peridotite parent materials in the Port Orford cedar series. 
Mean elevation by plant association was higher than those plant associations found in the tanoak-Port Orford cedar sub-series. It ranged from 2964 to 4756 feet. The low elevation plant associations in the Port-orford cedar series included the Port Orford cedar-western white pine/huckleberry oak (2964 ft.), Port Orford cedar/western azalea (3143 ft.), and Port Orford cedar-incense cedar-white alder types (3295 ft.). The high elevation plant associations were the Port Orford cedar-white fir-western white pine/huckleberry oak (4756 ft.) and Port Orford cedar-red Fir/Sadler oak-thinleaf huckleberry (4719ft.) types.

Mean slope in the Port Orford cedar series was generally less than that found in the tanoak-Port Orford cedar sub-series. It ranged from a mean of 18 to 38 percent. Plant associations with gentle slopes included the Port Orford cedar//herb (18\%) and Port Orford cedar/western azalea (21\%). Plant associations with moderate slopes included the Port Orford cedar-white fir/ huckleberry oak (38\%), Port Orford cedar-red fir/Sadler oak-thinleaf huckleberry (38\%), and Port Orford cedar-incense cedar-white alder (38\%) types.

Mean radiation index was somewhat higher in the Port Orford cedar series than in the tanoak-Port Orford cedar sub-series. It ranged from a low of .371 in the Port Orford cedar-red fir/Sadler oak-thinleaf huckleberry type to a high of .542 in the Port Orford cedar-incense cedar-white alder type. Because of slope position, the higher radiation indices were often moderated by topographic shading.

Surface rock was generally higher in the Port Orford cedar series than the tanoak-Port Orford cedar sub-series. The Port Orford cedar-western white pine/huckleberry oak type (13\%) and the Port Orford cedar-red fir/ Sadler oak-thinleaf huckleberry type (12\%) had the highest values.

Due to the low density of hardwoods and the high frequency of serpentine soils found in the Port Orford cedar series, stand structure was very different from that in tanoak-Port Orford cedar sub-series. Sites on serpentine soils had much lower productivity and tended to be open with high horizontal diversity. Sites on better soils had much higher vertical diversity composed almost entirely of conifer species. This was reflected in the range of stand density indices, from low (404) in the Port Orford cedar-western white pine/huckleberry oak type to a high of (592) in the Port Orford cedar/ salal type. Mean softwood volume ranged from low $(6,374 \mathrm{ft} .3)$ in the Portorford cedar-western white pine/huckleberry oak type to very high $(15,044$ ft.3) in the Port Orford cedar-white fir//herb type. Hardwood volume was very low. It ranged from ( $0 \mathrm{ft} .3$ ) in the Port Orford cedar-white fir/huckleberry oak, Port Orford cedar-white fir-western white pine/ huckleberry oak, Port Orford cedar-white fir/western azalea, Port Orford cedar-white fir//herb, and Port Orford cedar-red fir/Sadler oak-thinleaf huckleberry types to low (442 ft.3) in the Port Orford cedar-incense cedar-white alder type. Dunning site class (base age 300 years) mode also reflected this variation in productivity and was generally lower than that found in the tanoak-Port Orford cedar sub-series. The Port Orford cedar/salal, Port Orford cedar/Pacific rhododen- 
dron-salal, Port Orford cedar-white fir//herb, and Port Orford cedar-white fir/ Sadler oak all had site class modes of 1 . The Port Orford cedar-western white pine/huckleberry oak occupied the low end of the site class range with a mode of 5 .

Four of the Port Orford cedar series plant associations were found almost entirely in riparian positions. They included the Port Orford cedarwhite fir/western azalea, Port Orford cedar/western azalea, Port Orford cedarwhite fir//herb, and Port Orford cedar-incense cedar-white alder types. The other eight types were found in upslope positions.

Table 2. Plant associations found in the Port Orford cedar series.

\begin{tabular}{|c|c|}
\hline EDP CODE & PLANT ASSOCIATION NAME \\
\hline CHLA/GASH & Port Orford cedar/Salal \\
\hline CHLA/RHMA-GASH & $\begin{array}{l}\text { Port Orford cedar/Pacific } \\
\text { Rhododendron-Salal }\end{array}$ \\
\hline CHLA/RHOC & Port Orford cedar/Western Azalea \\
\hline CHLA-ABCO/QUVA & $\begin{array}{l}\text { Port Orford cedar-White Fir/ } \\
\text { Huckleberry Oak }\end{array}$ \\
\hline CHLA-ABCO-PIMO3/QUVA & $\begin{array}{l}\text { Port Orford cedar-White Fir-Western } \\
\text { White Pine/Huckleberry Oak }\end{array}$ \\
\hline CHLA-ABCO/RHOC & $\begin{array}{l}\text { Port Orford cedar-White Fir/Western } \\
\text { Azalea }\end{array}$ \\
\hline CHLA-ABCO//Herb & Port Orford cedar-White Fir//Herb \\
\hline CHLA-ABCO/QUSA & Port Orford cedar-White Fir/Sadler Oak \\
\hline CHLA-ABMAS/QUSA-VAME & $\begin{array}{l}\text { Port Orford cedar-Red Fir/Sadler } \\
\text { Oak-Thinleaf Huckleberry }\end{array}$ \\
\hline CHLA-PSME/QUVA & $\begin{array}{l}\text { Port Orford cedar-Douglas-fir/ } \\
\text { Huckleberry Oak }\end{array}$ \\
\hline CHLA-PIMO3/QUVA & $\begin{array}{l}\text { Port Orford cedar-Western White } \\
\text { Pine/Huckleberry Oak }\end{array}$ \\
\hline CHLA-LIDE3-ALRH & $\begin{array}{l}\text { Port Orford cedar-Incense cedar- } \\
\text { White Alder }\end{array}$ \\
\hline
\end{tabular}




\section{CHLA/GASH Association, EcoCode CCOCCO11 Port Orford Cedar/Salal}

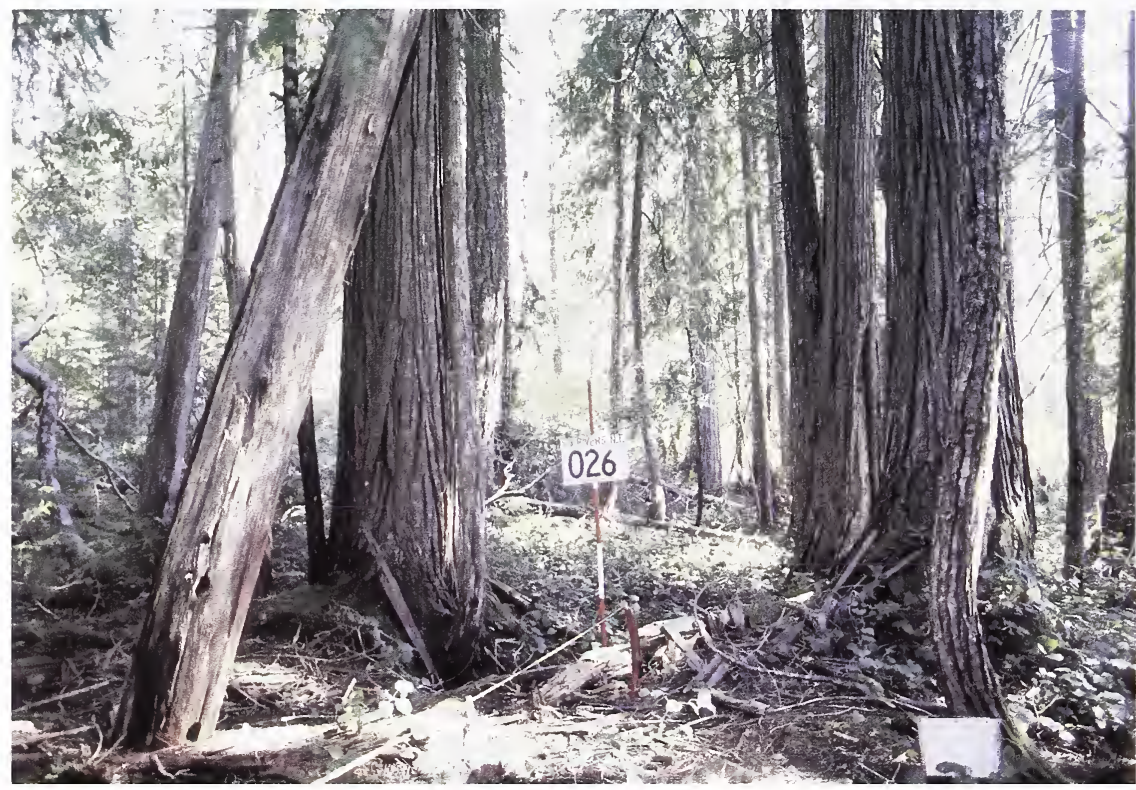

ENVIRONMENT: Elevation: 2800-3740 ft.; Aspect: N.; Slope: 10-62\%; Slope Position: lower and middle 1/3; Surface Rock: 0-5\%;

\section{SUMMARY TABLE}

(Sample size: 12)

COVER

CON

Tree Overstory Layer

CHLA Port Orford Cedar $53 \quad 100$

$\begin{array}{lll}\text { PSME } & \text { Douglas-fir } & 31\end{array}$

\section{Tree Understory Layer}

LIDE2 Tanoak 5

CHLA Port Orford Cedar 6

PSME Douglas-fir

66

100

50

Shrubs

$\begin{array}{llr}\text { GASH } & \text { Salal } & 50 \\ \text { BENEl } & \text { Dwarf Oregon Grape } & 3 \\ \text { RHMA } & \text { Pacific Rhododendron } & 3 \\ \text { VAPA } & \text { Red Huckleberry } & 3\end{array}$

100

58

58

75

Herbs \& Grasses

$\begin{array}{ll}\text { CHUMO } & \text { Prince's Pine } \\ \text { LIBOL } & \text { Twinflower } \\ \text { GOOB } & \text { Rattlesnake Plantain } \\ \text { POMUI } & \text { Sword Fern } \\ \text { XETE } & \text { Beargrass }\end{array}$

58

58

58

58

50
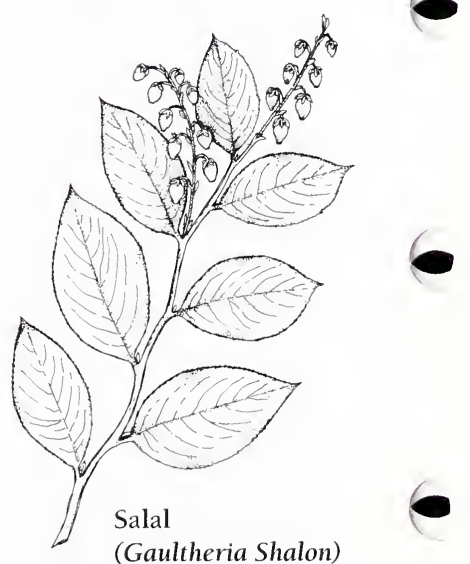

SOILS Pit Depth: 23->40 in.; Coarse Fragments: 10-40\%; Textures: 1, gl, vgl; Parent Material: phyllite, schist, sandstone. 
DISTRIBUTION/ENVIRONMENT: This type was found on the Gasquet, Orleans, and Ukonom ranger districts in lower and middle one-third slope positions with concave, undulating micro-relief. Elevation averaged 3342 feet and ranged from 2800 to 3740 feet, on gentle (34\%) slopes with north facing aspects. Radiation index was low (.381) as a result of north aspects. This type tends to be drier than, and occurs uplsope from wetter Port Orford cedar types.

VEGETATION SUMMARY: Total vegetation cover is very dense (97\%), and overstory cover of 87 percent was second highest in the Port Orford cedar series. Overstory conifer species include Port Orford cedar (53\%), which was codominant with Douglas-fir (31\%) cover. Hardwood cover values in the mid layer are among the highest in the Port Orford cedar series. Tanoak (5\%) cover was present on 33 percent of the plots, chinquapin (2\%) was found on 33 percent of the plots, while Pacific dogwood (2\%) was present on 25 percent of the plots. The tree regeneration layer was dominated by Port Orford cedar (6\%), with tanoak (5\%), and Douglas-fir (1\%) as occasional associates. The shrub layer averaged 61 percent cover, which is among the highest in the Port Orford cedar series. Salal (50\%) dominated here followed by dwarf Oregon-grape (3\%), Pacific rhododendron (3\%), and red huckleberry (3\%). Total forb cover $(11 \%)$ was moderate; it contained a variety of mesic species including prince's pine $(1 \%)$, twinflower $(2 \%)$, vanillaleaf $(2 \%)$, ladyfern $(2 \%)$, rattlesnake plantain ( $1 \%)$, swordfern (1\%), white trillium (1\%), and beargrass (1\%). The grass layer was dominated by sedges (1\%).

SOIL SUMMARY: Soils in this type were well drained, derived from a combination of coarse and fine textured parent materials. The coarse textured soils were derived from sandstone, with the fine textured materials derived from phyllite and schist. They are primarily deep and moderately deep, loamy to very gravelly loams, with high AWC (4.9"), moderately thick A horizons (5"), and low A horizon coarse fragments $(28 \%)$. They were found in the mesic and frigid soil temperature regimes and are highly productive for conifer growth. They present few major limitations for management except for susceptibility to compaction when soils are moist. The dominant soil groups were Hugo deep (35\%); Clallam deep (30\%); and Clallam moderately deep (20\%); with about 15 percent other soils (poorly drained soils, shallow soils).

STAND STRUCTURE SUMMARY: Mean stand age in this type was 349 years, it ranged from 145 to 575 years. The highest frequency of stands (42\%) were greater than 375 years of age. The frequency of stands above 300 years was 58 percent; the frequency of stands below 200 years was 25 percent.

Stands in this type contained a mixture of tolerant and somewhat intolerant conifer and hardwood trees, in a variety of diameter classes and age groups which contributed to uneven-aged stands, often resulting in multiple layers. The overstory was usually composed of at least two layers of different aged conifers, averaging 186 feet tall in the top layer and 146 feet tall in the second layer. The density of large conifers was high, with an average of 27 trees/acre greater than 30 inches diameter. The mid layers were dominated by hardwood species; they ranged from 25 to 70 feet tall. Most hardwood species were found in the smaller diameter classes with an average of 16 trees/acre in the 6 to 10.9 inch diameter class and an average of 8 trees/ acre greater than 11 inches diameter. The regeneration layer was moderate, and was limited by the dense cover of conifers and hardwoods.

Softwood cubic volume was second highest of all Port Orford cedar types with an average of $14,697 \mathrm{ft}^{3} /$ acre. Hardwood cubic volume of $339 \mathrm{ft}^{3} /$ acre was the second highest in the Port Orford cedar series. Dunning site class was 1, with site index of 175 at 300 years. Stand density index was the highest of all Port Orford cedar types with an average of 592 . 


\section{CHLA/RHMA-GASH Association, EcoCode CCOCCO12}

\section{Port Orford Cedar/ Pacific Rhododendron-Salal}

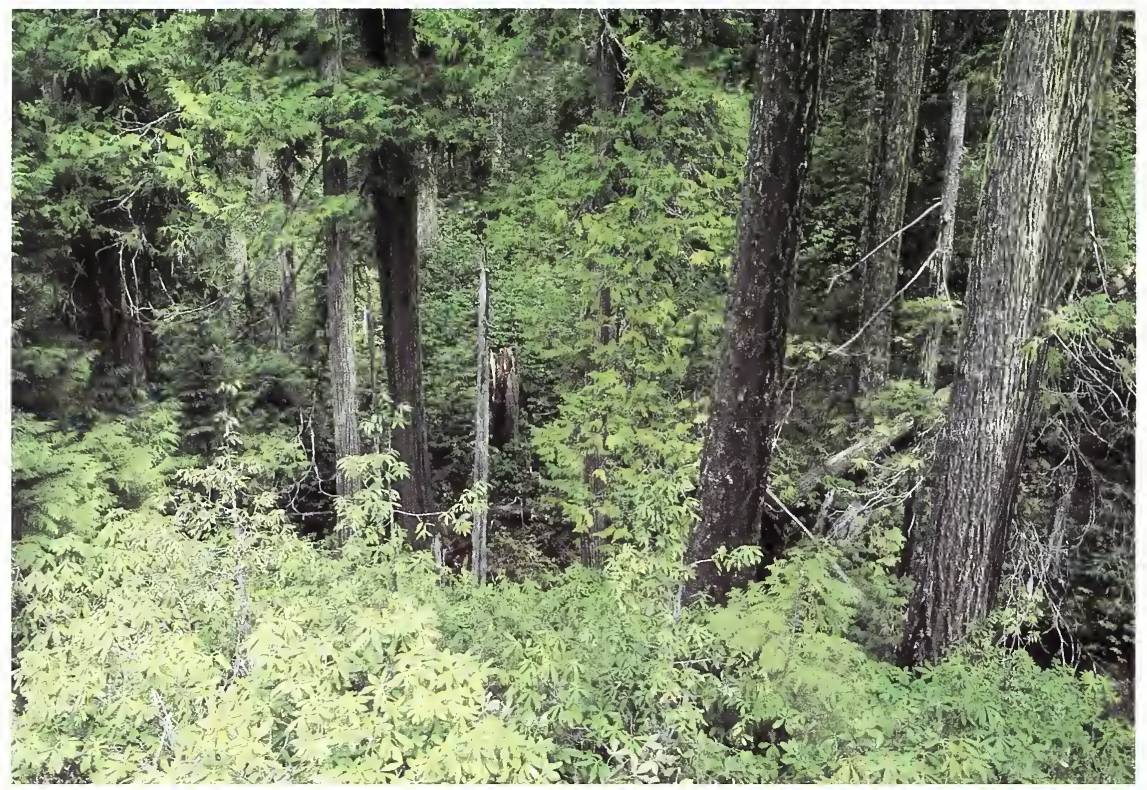

ENVIRONMENT: Elevation: 2700-3600; Aspect: N.W., N.E.; Slope: 10-60\%; Slope Position: lower and middle 1/3; Surface Rock: 0-7\%

\section{SUMMARY TABLE}
(Sample size: 18)
COVER
CON

Tree Overstory Layer

$\begin{array}{llrr}\text { CHLA } & \text { Port Orford Cedar } & 44 & 100 \\ \text { PSME } & \text { Douglas-fir } & 32 & 100 \\ \text { CACH2 } & \text { Chinquapin } & 8 & 66\end{array}$

Tree Understory Layer

$\begin{array}{lllr}\text { CHLA } & \text { Port Orford Cedar } & 4 & 100 \\ \text { LIDE2 } & \text { Tanoak } & 2 & 55 \\ \text { CACH2 } & \text { Chinquapin } & 3 & 50\end{array}$

Shrubs

$\begin{array}{llrr}\text { RHMA } & \text { Pacific Rhododendron } & 35 & 100 \\ \text { GASH } & \text { Salal } & 36 & 94 \\ \text { VAPA } & \text { Red Huckleberry } & 2 & 100\end{array}$

\section{Herbs \& Grasses}

$\begin{array}{ll}\text { XETE } & \text { Beargrass } \\ \text { GOOB } & \text { Rattlesnake Plantain } \\ \text { LIBOL } & \text { Twinflower }\end{array}$

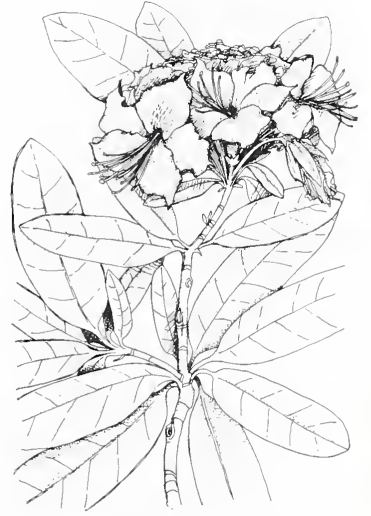

Pacific Rhododendron

(Rhododendron macrophylla)

SOILS Pit Depth: 22->40 in.; Coarse Fragments: 15-45\%; Textures: gl,vgl,vgcl; Parent Material: phyllite, mafic, greenstone, serpentine. 
DISTRIBUTION/ENVIRONMENT: This type was found on the Gasquet and Orleans ranger districts in lower and middle one-third slope positions with undulating, concave and linear micro-relief. Elevation averaged 3269 feet and ranged from 2700 to 3600 feet, on gentle (32\%) slopes with northwest and northeast facing aspects. Radiation index was the second lowest in the Port Orford cedar series (.376) as a result of north aspects.

VEGETATION SUMMARY: Total vegetation cover was very dense (98\%), while overstory cover of 79 percent was moderate. Overstory conifer species included Port Orford cedar (44\%), which was codominant with Douglas-fir (32\%). Hardwood cover values in the mid layer were low with chinquapin $(8 \%)$ as the prominent species. The tree regeneration layer was dominated by Port Orford cedar (4\%), with chinquapin (3\%), tanoak (2\%), and Douglas-fir (1\%) as occasional associates. The shrub layer averaged 70 percent cover, which was the highest in the Port-Orford cedar series. Pacific rhododendron (35\%) and salal (36\%) share dominance, with red huckleberry (2\%), and dwarf Oregon-grape (3\%) as associates. Total forb cover (8\%) was moderate; it included beargrass (3\%), twinflower (3\%), prince's pine (3\%), rattlesnake plantain (1\%), and white trillium (1\%).

SOIL SUMMARY: Soils in this type were well drained, primarily derived from the fine textured metamorphic parent materials phyllite, mafic, greenstone, and serpentine. They were primarily deep and moderately deep, gravelly to very gravelly loams, with moderate to high AWC (3.9"), moderately thick A horizons (5"), and low A horizon coarse fragments (32\%). They were found in the mesic and frigid soil temperature regimes and were highly productive for conifer growth. The major management limitation for these soils is susceptibility to compaction when soils are moist. The dominant soil groups were Goldridge deep (50\%); Hugo moderately deep $(20 \%)$; and Clallam moderately deep (20\%); with about 10 percent other soils (Weitchpec, poorly drained soils).

STAND STRUCTURE SUMMARY: Mean stand age in this type was 394 years, third highest of all Port Orford cedar types. It ranged from 235 to 570 years of age. The highest frequency of stands $(56 \%)$ were found in stands greater than 376 years of age. The frequency of stands above 300 years was 56 percent; the frequency of stands below 200 years was 11 percent.

Stands in this type had a mixture of tolerant and moderately intolerant conifers in the dense overstory; occasional high cover of hardwoods was found in the mid layer, along with a variety of diameter classes which resulted in multiple layered stands. The overstory was usually composed of at least two layers of different aged conifers, averaging 160 feet tall in the top layer and 118 feet tall in the second layer. It had a high density of large conifers greater than 30 inches diameter, with an average of 25 trees/acre. The mid layers were often dominated by hardwood species, they ranged from 25 to 70 feet tall. Most hardwood species were found in the smaller diameter classes with an average of 15 trees/acre in the 6 to 10.9 inch diameter class. The regeneration layer had a high density of conifers.

Softwood cubic volumes were high with an average of $12,498 \mathrm{ft}^{3} / \mathrm{acre}$. Hardwood cubic volume of $156 \mathrm{ft}^{3} /$ acre was low. Dunning site class was 1 , with site index of 175 at 300 years. Stand density index was moderate with an average of 490. 


\section{CHLA/RHOC Association, EcoCode CCOCCO13 \\ Port Orford Cedar/Western Azalea}

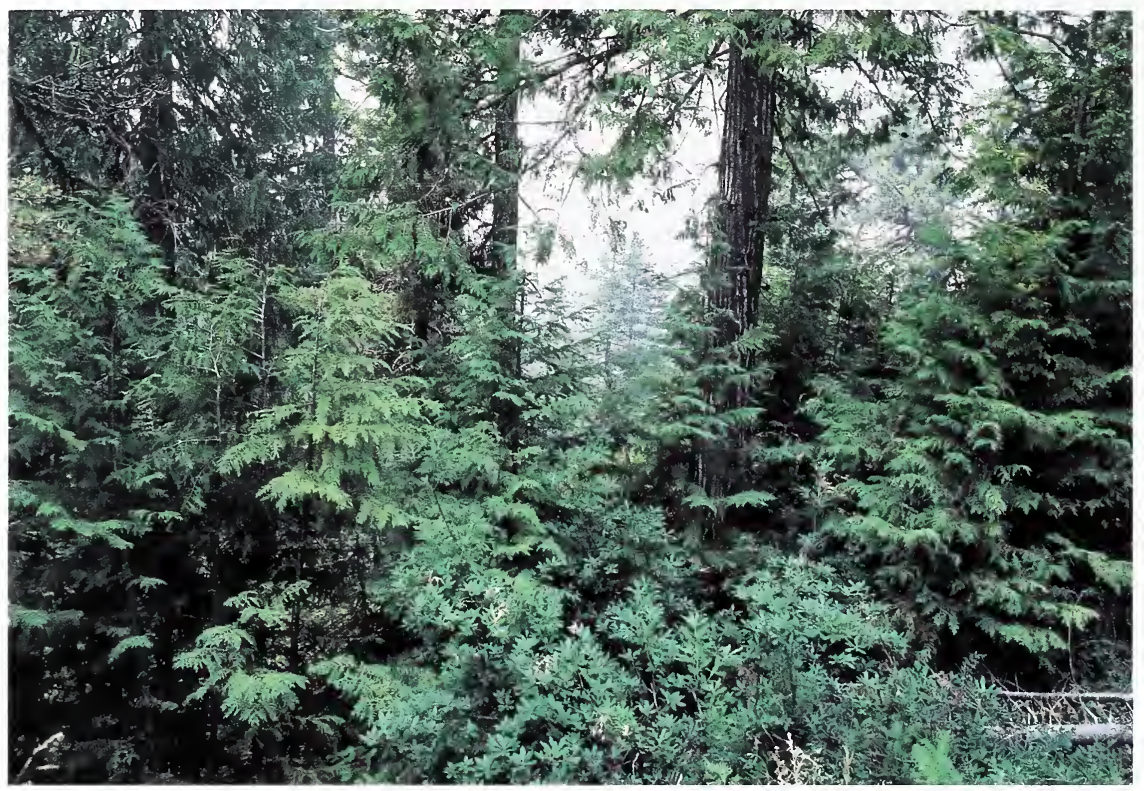

ENVIRONMENT: Elevation: 2500-3940 ft.; Aspect: N.E.; Slope: 5-45\%;

Slope Position: lower and middle 1/3; Surface Rock: 0-6\%;

\section{SUMMARY TABLE}

(Sample size: 12)

COVER

CON

\section{Tree Overstory Layer}

CHLA Port Orford Cedar

PSME Douglas-fir 24

PILA Sugar Pine 4

100
100
61

Tree Understory Layer

CHLA Port Orford Cedar

$\begin{array}{rr}9 & 100 \\ 2 & 69 \\ 2 & 53\end{array}$

$\begin{array}{llll}\text { LIDE2 } & \text { Tanoak } & 2 & 69 \\ \text { PSME } & \text { Douglas-fir } & 2 & 53\end{array}$

Shrubs

$\begin{array}{llrr}\text { RHOC } & \text { Western Azalea } & 24 & 100 \\ \text { VAPA } & \text { Red Huckleberry } & 2 & 76 \\ \text { RUUR } & \text { Trailing Blackberry } & 1 & 76\end{array}$

Herbs \& Grasses

$\begin{array}{lllll}\text { XETE } & \text { Beargrass } & 2 & 76 & \\ \text { GOOB } & \text { Rattlesnake Plantain } & 1 & 69 & \text { Western Azalea } \\ \text { CAR1 } & \text { Sedge } & 2 & 61 & \text { (Rhodendron occidentale) }\end{array}$

SOILS Pit Depth: 33->40 in.; Coarse Fragments: 10-35\%; Textures: 1, gl, vgl; Parent Material: serpentine, peridotite, gneiss, sandstone 
DISTRIBUTION/ENVIRONMENT: This type was found on the Orleans, Ukonom, and Happy Camp ranger districts in the lower and middle one-third slope positions with undulating, linear micro-relief. Elevation averaged 3143 feet and ranged from 2500 to 3940 feet, on gentle (21\%) slopes with northeast facing aspects. Radiation index was moderate (.453), but was partially offset by a high water table and topographic shading.

VEGETATION SUMMARY: Total vegetation cover was dense (95\%), and overstory cover of 77 percent was moderate. Overstory conifer species included Port Orford cedar (42\%), with Douglas-fir (24\%) and sugar pine (4\%) as associate species. Hardwood cover values in the mid layer were low, with tanoak ( $9 \%)$ as an occasional member. The tree regeneration layer was dominated by Port Orford cedar (9\%) with tanoak (2\%) as an occasional associate. The shrub layer averaged 38 percent cover, which was moderate for the Port Orford cedar series. Western azalea (24\%) dominated here followed by salal (12\%), huckleberry oak (4\%), red huckleberry $(2 \%)$, and trailing blackberry (1\%). Total forb cover $(6 \%)$ was moderate; it included beargrass $(2 \%)$, rattlesnake plantain $(1 \%)$, twinflower $(1 \%)$, and prince's pine (1\%). Sedges $(2 \%)$ were the dominant species in the grass layer.

SOIL SUMMARY: Soils in this type were primarily well drained, derived from fine textured metamorphic parent materials including peridotite, gneiss, and serpentine, with occasional coarse textures derived from sandstone.

They were primarily deep and moderately deep, loamy to very gravelly loams, with high AWC (5.4"), moderately thick A horizons (5"), and low A horizon coarse fragments (25\%). They were found in the mesic and frigid soil temperature regimes and were of low to moderate productivity for conifer growth. Limitations for management are mainly associated with fertility imbalances due to the ultramafic parent material. The dominant soil groups were Weitchpec deep (30\%); Clallam deep (25\%); and Weitchpec moderately deep (20\%); with about 20 percent other soils (poorly drained soils, Goldridge deep, Hugo deep).

STAND STRUCTURE SUMMARY: Mean stand age in this type was 420 years average age, second highest of all Port Orford cedar types. It ranged from 300 to 575 years stand age. The highest frequency of stands (66\%) were found between 300 and 425 years of age. The frequency of stands above 300 years was 100 percent; the frequency of stands below 200 years was 0 percent.

Stands in this type had a mixture of tolerant and moderately intolerant conifers in the moderately dense overstory, occasional high cover of hardwoods were found in the mid layer. A variety of diameter classes were present, which resulted in multiple layers. The overstory was usually composed of at least two layers of different aged conifers, averaging 136 feet tall in the top layer and 109 feet tall in the second layer. It had a high density of large conifers, with an average of 22 trees/acre greater than 30 inches diameter. The mid layers were often dominated by hardwood species; they ranged from 25 to 70 feet tall. Most hardwood species were found in the smaller diameter classes with an average of 19 trees/acre in the 6 to 10.9 inch diameter class. The regeneration layer was low due to a high density of small and intermediate conifers and hardwoods.

Softwood cubic volumes ranged from low to moderate with an average of $10,751 \mathrm{ft}^{3} /$ acre. Hardwood cubic volume of $56 \mathrm{ft}^{3} /$ acre was low. Dunning site class was 3 , with site index of 125 at 300 years. Stand density index was moderate with an average of 498 . 


\section{CHLA-ABCO/QUVA Association, EcoCode CCOCFW11 Port Orford Cedar-White Fir/Huckleberry Oak}

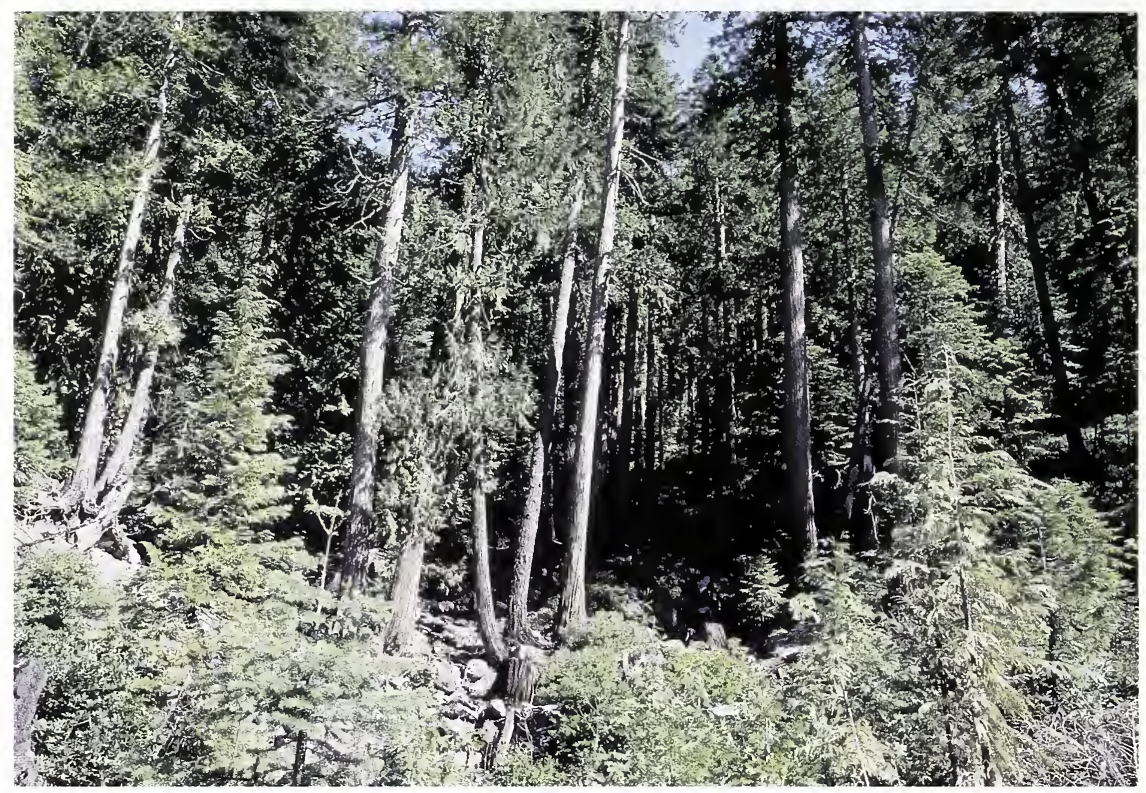

ENVIRONMENT: Elevation: 2980-4620 ft.; Aspect: N.E., W.; Slope: 18-68\%; Slope Position: lower and middle 1/3; Surface Rock: 0-7\%;

\section{SUMMARY TABLE}

(Sample size: 10)

\section{Tree Overstory Layer}

$\begin{array}{llrr}\text { CHLA } & \text { Port Orford Cedar } & 29 & 100 \\ \text { PSME } & \text { Douglas-fir } & 30 & 100 \\ \text { ABCO } & \text { White Fir } & 15 & 100 \\ \text { PILA } & \text { Sugar Pine } & 10 & 60\end{array}$

Tree Understory Layer

ABCO White Fir

CHLA Port Orford Cedar

PSME Douglas-fir

Shrubs

QUVA Huckleberry Oak

VAPA Red Huckleberry

Herbs \& Grasses

$\begin{array}{ll}\text { XETE } & \text { Beargrass } \\ \text { CHUMO } & \text { Prince's Pine } \\ \text { TRLA3 } & \text { Starflower }\end{array}$

100

70

3

2

2

100

100

70

Huckleberry Oak

(Quercus vaccinifolia)

70

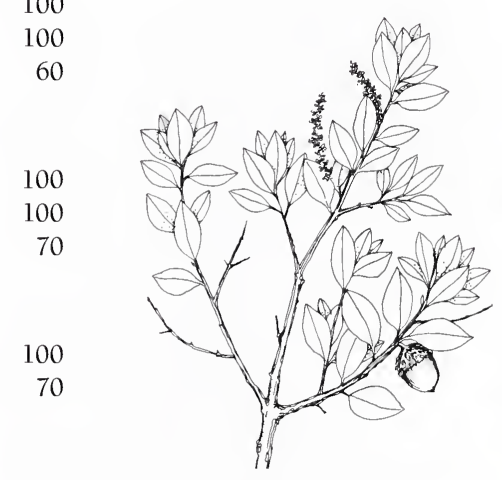
70

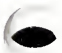

SOILS Pit Depth: 9->40 in.; Coarse Fragments: 25-52\%; Textures: gl, vgl; Parent Material: serpentine, peridotite, greenstone 
DISTRIBUTION/ENVIRONMENT: This type was widespread and found on the Gasquet, Orleans, Ukonom, and Happy Camp ranger districts in the lower and middle one-third slope positions with concave and linear micro-relief. Elevation averaged 3913 feet and ranged from 2980 to 4620 feet, on moderate (38\%) slopes with northeast and west facing aspects. Radiation index was moderate (.451) as a result of west aspects. This type tended to occur on exposed sites where conditions are drier than most Port Orford cedar types. Surface rock was moderate, with an average of 5 percent cover.

VEGETATION SUMMARY: Total vegetation cover (93\%) and overstory cover of 80 percent were moderate. Overstory conifer species included Douglas-fir (30\%), which was codominant with Port-Orford cedar (29\%). White fir $(15 \%)$, sugar pine $(10 \%)$, and incense cedar $(8 \%)$ were associate species. The tree regeneration layer was dominated by white fir (3\%), Port Orford cedar (2\%), Douglas-fir (2\%), and sugar pine $(1 \%)$. The shrub layer averaged $19 \%$ cover, which was among the lowest in the Port-Orford cedar series. Huckleberry oak (11\%) dominated here followed by red huckleberry (6\%), dwarf Oregon-grape (2\%), and Sadler oak (1\%). Total forb cover $(14 \%)$ was moderate; it included twinflower $(7 \%)$, beargrass $(3 \%)$, prince's pine $(2 \%)$, western modesty $(2 \%)$, starflower $(1 \%)$, iris ( $1 \%)$, Hooker's fairybells, and rattlesnake plantain $(1 \%)$.

SOIL SUMMARY: Soils in this type were primarily well drained and derived from the fine textured metamorphic parent materials peridotite, greenstone, and serpentine. They were primarily moderately deep, deep, and occasionally shallow, gravelly to very gravelly loams, with low to moderate AWC (2.6"), moderately thick A horizons (6"), and moderate A horizon coarse fragments (42\%). They were found mainly in the frigid soil temperature regime and were moderately productive for conifer growth. The major limitations for these soils are fertility imbalances and susceptibility to burning damage in areas of ultramafic parent material, along with cold soil temperatures in the frigid soil temperature regime which could inhibit regeneration. The dominant soil groups were Weitchpec deep (40\%); Weitchpec moderately deep (20\%); and Althouse moderately deep (20\%); with about 20 percent other soils (shallow soils, Althouse deep, frigid ultramafic soils).

STAND STRUCTURE SUMMARY: Mean stand age in this type was 344 years; it ranged from 265 to 445 years stand age. The highest frequency of stands (40\%) were found between 326 and 375 years of age. The frequency of stands above 300 years was 80 percent; the frequency of stands below 200 years was 0 percent.

Stands in this type had a mixture of tolerant and moderately intolerant conifers in the moderately dense overstory, along with a variety of diameter classes, which resulted in multiple layers. The overstory was usually composed of at least two layers of different aged conifers, averaging 149 feet tall in the top layer and 119 feet tall in the second layer. It had a high density of large conifers, with an average of 25 trees/ acre greater than 30 inches diameter. The mid layers were dominated by conifer species, they ranged from 25 to 70 feet tall. The regeneration layer was moderately dense.

Softwood cubic volumes ranged from low to moderate with an average of 11,867 $\mathrm{ft}^{3} /$ acre. Dunning site class was 2 , with site index of 150 at 300 years. Stand density index was high with an average of 508. 


\section{CHLA-ABCO-PIMO3/QUVA Association, EcoCode CCOCFW12}

Port Orford Cedar-White Fir-Western White Pine/Huckleberry Oak

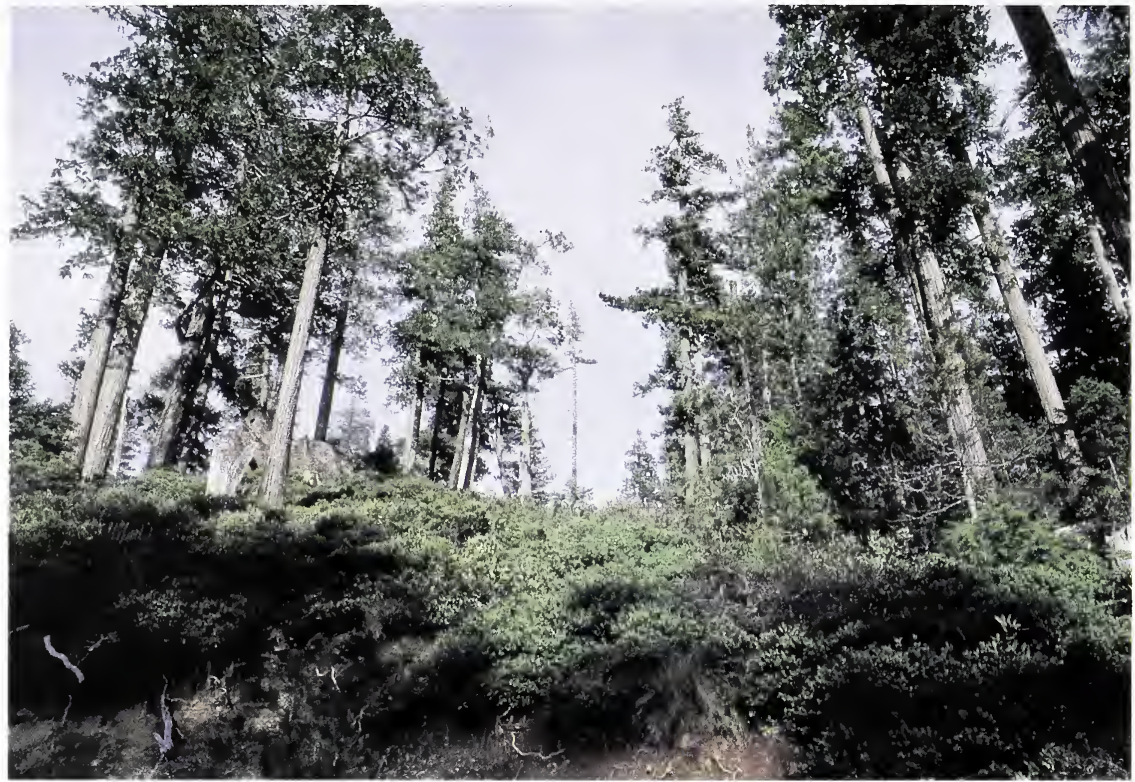

ENVIRONMENT: Elevation: 4360-5180 ft.; Aspect: N.W.; Slope: 10-45\%; Slope Position: middle and upper 1/3; Surface Rock: 2-10\%

\section{SUMMARY TABLE}

(Sample size: 10)

COVER

CON

Tree Overstory Layer

CHLA Port Orford Cedar 34

PSME Douglas-fir 18

ABCO White Fir 11

PIMO3 Western White Pine 11

100

100

100

100

Tree Understory Layer

$\begin{array}{llrr}\text { CHLA } & \text { Port Orford Cedar } & 3 & 100 \\ \text { ABCO } & \text { White Fir } & 2 & 90\end{array}$

Shrubs

QUVA Huckleberry Oak

ARNE2 Pinemat Manzanita 10

100

QUSA Sadler Oak

80

ROGY Wild Rose

80

80

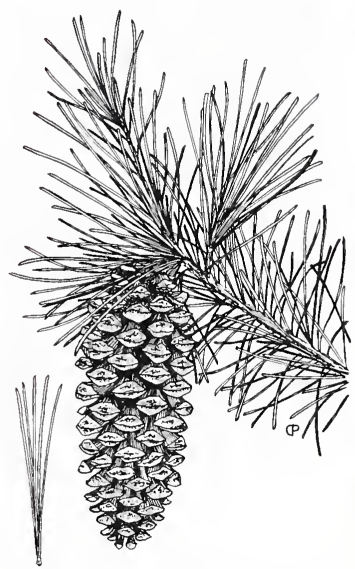

Herbs \& Grasses

$\begin{array}{llrrl}\text { CHUMO } & \text { Prince's Pine } & 2 & 100 & \text { Western White Pine } \\ \text { XETE } & \text { Beargrass } & 3 & 90 & \text { (Pinus monticola) } \\ \text { DIHO2 } & \text { Hooker's Fairybells } & 1 & 60 & \end{array}$

SOILS Pit Depth: 14->40 in.; Coarse Fragments: 30-85\%; Textures: gl, vgcl, xgl; Parent Material: serpentine, peridotite 
DISTRIBUTION/ENVIRONMENT: This type was found on the Gasquet, Ukonom, and Happy Camp ranger districts in the middle and lower one-third slope positions with undulating, linear micro-relief. Elevation averaged 4756 feet, highest of all Port Orford cedar types. It ranged from 4360 to 5180 feet on gentle (27\%) slopes with northwest facing aspects. Radiation index was low (.412) as a result of northwest aspects. This type tended to be found on cold sites that were exposed to heavy winter snow packs. Surface rock was moderate with an average of 7 percent cover.

VEGETATION SUMMARY: Total vegetation cover was moderate (91\%), and overstory cover of 74 percent was among the lowest in the Port-Orford cedar series. Overstory dominance was held by Port Orford cedar (34\%); associate species included Douglas-fir (18\%), white fir (11\%), western white pine $(11 \%)$, and incense cedar $(4 \%)$. The tree regeneration layer was dominated by Port Orford cedar $(3 \%)$, white fir $(2 \%)$, and western white pine $(1 \%)$. The shrub layer averaged $43 \%$ cover, which was moderate for the Port-Orford cedar series. Huckleberry oak (17\%) dominated here, followed by pinemat manzanita (10\%), Sadler oak (4\%), wild rose $(2 \%)$, and trailing blackberry (2\%). Total forb cover ( $8 \%$ ) was moderate; it included beargrass (3\%), prince's pine (2\%), Hooker's fairybells (1\%), queens cup (1\%), and iris (1\%).

SOIL SUMMARY: Soils in this type were well drained and derived from the fine textured ultramafic parent materials peridotite and serpentine. They were primarily moderately deep, deep, and shallow, very gravelly to extremely gravelly loams, with low AWC (2.5"), moderately thick A horizons (6"), and moderate to very high A horizon coarse fragments $(43 \%)$. They were found entirely in the frigid soil temperature regime and were moderately productive for conifer growth. The major limitations for management on these soils are numerous. They include fertility imbalances due to ultramafic parent material, susceptibility to burning damage, high coarse fragments, low AWC, and cold soil temperatures in the frigid soil temperature regime which may inhibit regeneration. The dominant soil groups were Hungry shallow (30\%); Hungry moderately deep (20\%); and Hungry deep (20\%); with about 20 percent other soils (non ultramafic soils).

STAND STRUCTURE SUMMARY: Mean stand age in this type was 356 years average age; it ranged from 310 to 450 years stand age. The highest frequency of stands (50\%) were found between 326 and 375 years of age. The frequency of stands above 300 years was 100 percent; the frequency of stands below 200 years was 0 percent.

Stands in this type had a mixture of tolerant, moderately intolerant, and intolerant conifers in the relatively open overstory, along with a variety of diameter classes which resulted in multiple layers. The overstory was usually composed of at least two layers of different aged conifers, averaging 110 feet tall in the top layer and 85 feet tall in the second layer. It had a high density of large conifers, with an average of 34 trees/ acre greater than 30 inches diameter. The mid layers were dominated by conifer species; they ranged from 20 to 50 feet tall. The regeneration layer was dense due to the open canopy.

Softwood cubic volumes ranged from low to moderate with an average of 11,043 $\mathrm{ft}^{3} /$ acre. Dunning site class was 2 , with site index of 150 at 300 years. Stand density index was high; second highest of all Port Orford cedar types, it averaged 540. 


\section{CHLA-ABCO/RHOC Association, EcoCode CCOCFW13 Port Orford Cedar-White Fir/Western Azalea}

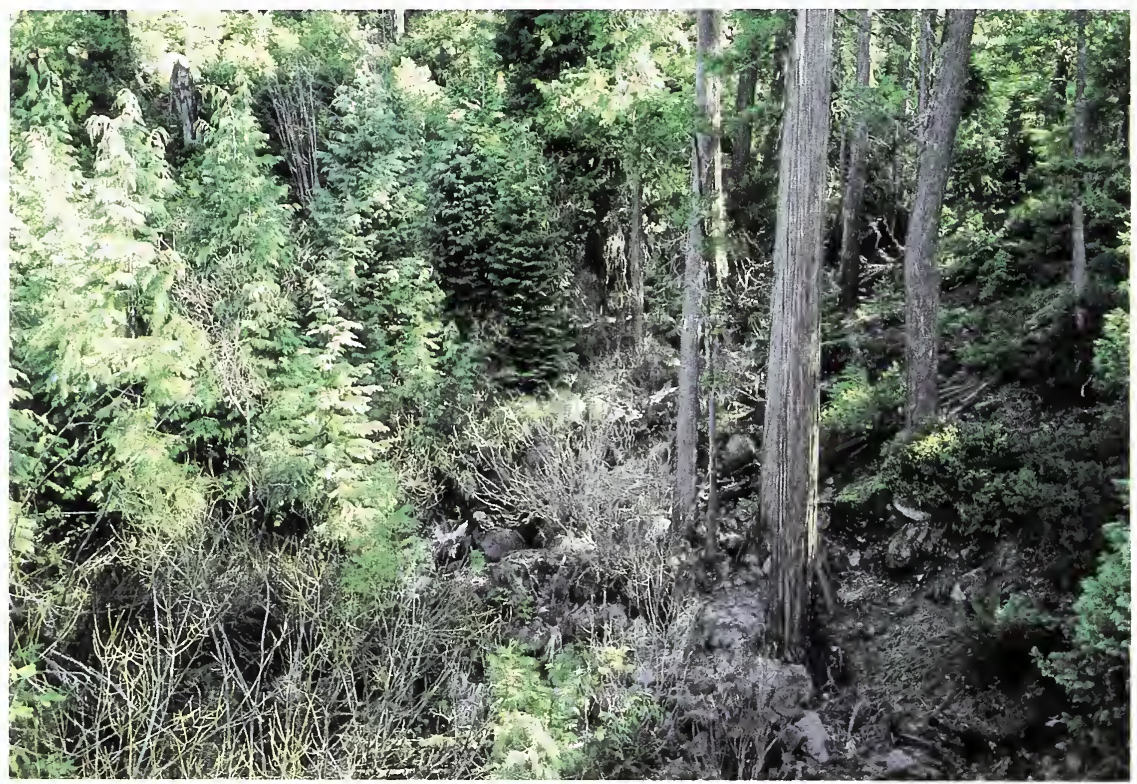

ENVIRONMENT: Elevation: 3740-4320 ft.; Aspect: N.E., S.; Slope: 10-53\%;

Slope Position: lower and middle1/3; Surface Rock: 2-9\%

\section{SUMMARY TABLE}

(Sample size: 10)

COVER

CON

\section{Tree Overstory Layer}

CHLA Port Orford Cedar

$\begin{array}{rr}49 & 100 \\ 13 & 100 \\ 10 & 100 \\ 9 & 70\end{array}$

PSME Douglas-fir

ABCO White Fir

PILA Sugar Pine

70

\section{Tree Understory Layer}

\section{ABCO White Fir}

CHLA Port Orford Cedar

100

100

Shrubs

$\begin{array}{llrr}\text { RHOC } & \text { Western Azalea } & 32 & 100 \\ \text { QUVA } & \text { Huckleberry Oak } & 4 & 80 \\ \text { RUUR } & \text { Trailing Blackberry } & 2 & 70\end{array}$

Herbs \& Grasses

$\begin{array}{llll}\text { CHUMO } & \text { Prince's Pine } & 1 & 70 \\ \text { TRLA3 } & \text { Starflower } & 1 & 70 \\ \text { GOOB } & \text { Rattlesnake Plantain } & 1 & 60\end{array}$
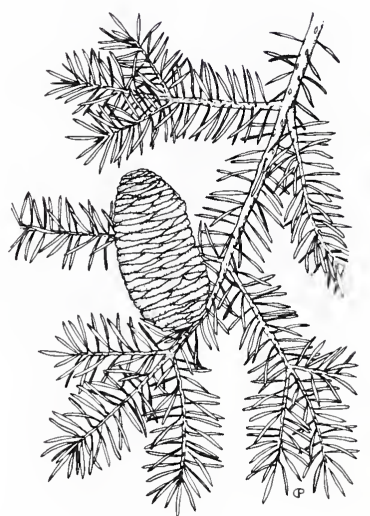

White fir

(Abies concolor)

SOILS Pit Depth: 25->40 in.; Coarse Fragments: 10-46\%; Textures: gl, vgl; Parent Material: serpentine, peridotite. 
DISTRIBUTION/ENVIRONMENT: This type was most common on inland sites found on the Orleans, Ukonom, and Happy Camp ranger districts in the middle and lower one-third slope positions with undulating, concave, and linear micro-relief. Elevation averaged 4040 feet and ranged from 3740 to 4320 feet, on gentle (31\%) slopes with northeast and south facing aspects. Radiation index was high (.461) as a result of south aspects. Surface rock was low here with an average of 4 percent surface cover.

VEGETATION SUMMARY: Total vegetation cover was dense (95\%), and overstory cover of 77 percent was moderate. The overstory was dominated by Port Orford cedar (49\%), with Douglas-fir (13\%), white fir (10\%), and sugar pine (9\%) as - associate species. The tree regeneration layer was dominated by white fir (2\%) and Port Orford cedar (1\%). The shrub layer averaged 45 percent cover, which was moderate for the Port-Orford cedar series. Western azalea (32\%) dominated here with huckleberry oak (4\%), trailing blackberry (2\%), and red huckleberry (2\%) as associates. Total forb cover $(6 \%)$ was moderate; it included beargrass (3\%), twinflower $(2 \%)$, prince's pine $(1 \%)$, starflower $(1 \%)$, rattlesnake plantain $(1 \%)$, wintergreen (1\%), queens cup (1\%), and bracken fern (1\%). Sedge species (1\%) dominated the grass layer.

SOIL SUMMARY: Soils in this type were well drained, derived from the fine textured ultramafic parent materials peridotite and serpentine. They were primarily deep and moderately deep, gravelly to very gravelly loams, with high AWC (4.2"), moderately thick A horizons (6"), and low A horizon coarse fragments (28\%). They were found in the frigid soil temperature regime and were moderately productive for conifer growth. The major limitations for these soils are fertility imbalances in areas of ultramafic parent material, susceptibility to burning damage, and areas of seeps or poorly drained soils. The dominant soil groups were Weitchpec deep (60\%); Weitchpec moderately deep (20\%); with about 20 percent other soils (poorly drained soils, frigid soils, Clallam moderately deep).

STAND STRUCTURE SUMMARY: Mean stand age in this type was 354 years, it ranged from 220 to 465 years stand age. The highest frequency of stands ( $22 \%$ ) were found between 226 and 275 years of age. The frequency of stands above 300 years was 56 percent; the frequency of stands below 200 years was 0 percent.

Stands in this type had a mixture of tolerant and moderately intolerant conifers in the moderately dense overstory, along with a variety of diameter classes which resulted in multiple layers. The overstory was usually composed of at least two layers of different aged conifers, averaging 124 feet tall in the top layer and 97 feet tall in the second layer. It had a high density of large conifers, with an average of 24 trees/acre greater than 30 inches diameter. The mid layers were dominated by conifer species; they ranged from 25 to 70 feet tall. The regeneration layer was low due to a dense shrub layer and high number of intermediate conifers.

Softwood cubic volumes ranged from low to moderate with an average of 11,173 $\mathrm{ft}^{3} / \mathrm{acre}$. Dunning site class was 3 , with site index of 125 at 300 years. Stand density index was moderate with an average of 496. 


\section{CHLA-ABCO//HERB Association, EcoCode CCOCFW14}

\section{Port Orford Cedar-White Fir//Herb}

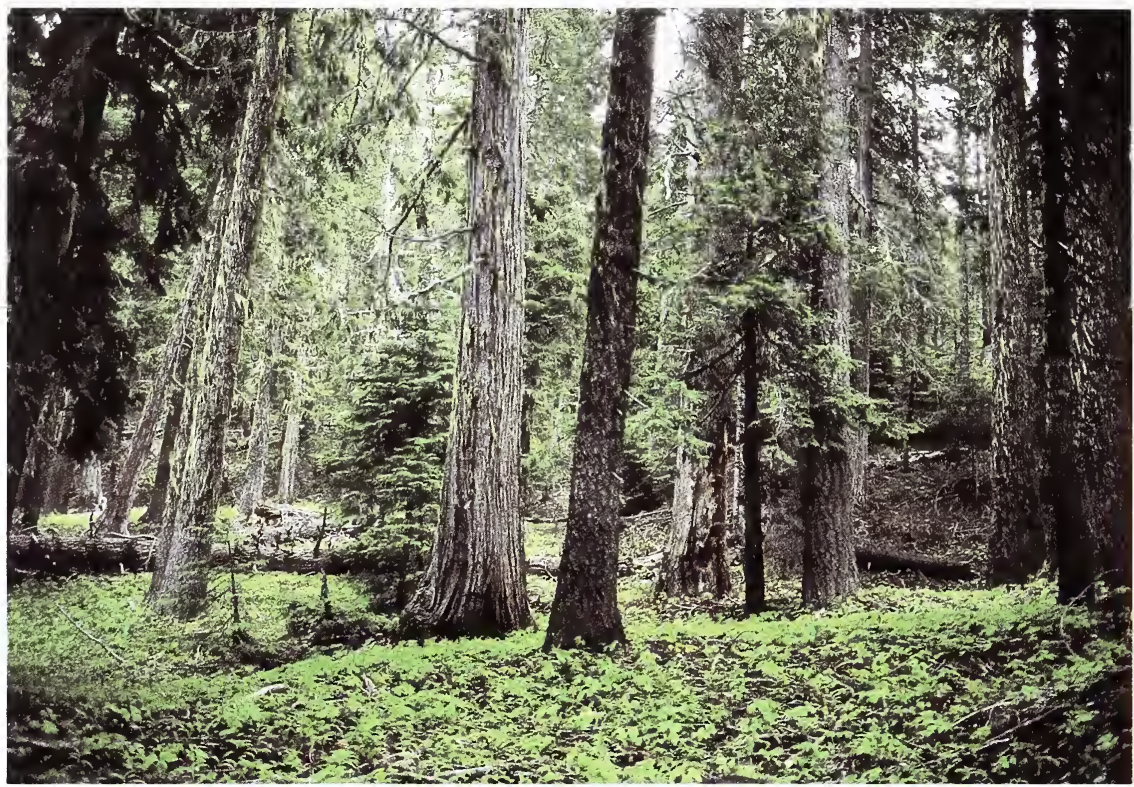

ENVIRONMENT: Elevation: 3600-4540 ft.; Aspect: N.W., N.E., S.W.; Slope: 3-30\%;

Slope Position: lower and middle 1/3; Surface Rock: 0-7\%

\section{SUMMARY TABLE}

(Sample size: 21 )

COVER

CON

\section{Tree Overstory Layer}

CHLA Port Orford Cedar $\quad 44 \quad 100$

ABCO White Fir $\quad 16 \quad 95$

PSME Douglas-fir $\quad 30 \quad 90$

\section{Tree Understory Layer}

CHLA Port Orford Cedar

ABCO White Fir 2

Shrubs

$\begin{array}{llll}\text { RUUR } & \text { Trailing Blackberry } & 2 & 80 \\ \text { ROGY } & \text { Wild Rose } & 1 & 76 \\ \text { COCOC } & \text { Hazelnut } & 5 & 71 \\ \text { QUSA } & \text { Sadler Oak } & 3 & 71\end{array}$

\section{Herbs \& Grasses}

DIHO2 Hooker's Fairybells

TRLA3 Starflower 1

ACTR Vanillaleaf 9

LIBOL Twinflower 13

85

85

80

66

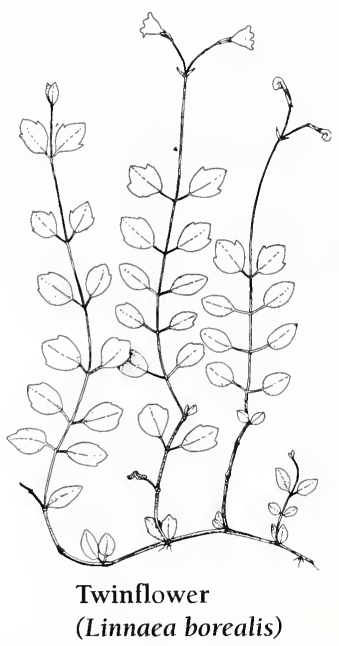

(Linnaea borealis)

SOILS Pit Depth: 16->40 in.; Coarse Fragments: 10-68\%; Textures: gl, vgl, vgsl; Parent Material: granite, mafic, schist, phyllite. 
DISTRIBUTION/ENVIRONMENT: This type was often found on alluvial fans and small basins on the Gasquet, Orleans, Ukonom, and Happy Camp ranger districts in the middle and lower one-third slope positions with linear, undulating, and concave micro-relief. Elevation averaged 4066 feet and ranged from 3600 to 4540 feet, on gentle (18\%) slopes with northwest, northeast, and southwest facing aspects. Radiation index was high (.456) as a result of southwest aspects, but was moderated by topographic shading. This type often has the highest plant species diversity of all forest types in Northwest California.

VEGETATION SUMMARY: Total vegetation cover was dense (96\%), and overstory cover of 82 percent was moderate. Overstory conifer dominance was shared by Port Orford cedar (44\%) and Douglas-fir (30\%), with white fir (16\%) as an associate. The tree regeneration layer was dominated by Port Orford cedar (3\%) and Douglas-fir (2\%), with white fir (2\%) and Pacific dogwood (3\%) as occasional associates. The shrub layer averaged 13 percent cover, which was the second lowest in the Port-Orford cedar series. It included hazel (5\%), sadler oak (3\%), thimbleberry (3\%), trailing blackberry (2\%), and wild rose (1\%). Total forb cover (13\%) was moderate and dominated by a host of mesic species. They included twinflower (13\%), vanillaleaf ( $9 \%)$, inside-out flower (8\%), queens cup (6\%), prince's pine $(3 \%)$, Hooker's fairybells (2\%), starflower (1\%), white trillium (1\%), wintergreen (1\%), and three-leaved anemone (1\%).

SOIL SUMMARY: Soils in this type were equally divided between well drained and poorly drained due to their alluvial origin. They were derived from coarse and fine textured parent materials, including mafic, granite, schist, and phyllite. They were primarily moderately deep and deep, gravelly to very gravelly loams, with low to high AWC (3.5"), thick A horizons (8"), and moderate A horizon coarse fragments $(37 \%)$. They were found in the frigid soil temperature regime and were highly productive for conifer growth. The major limitations for these soils are areas of seeps or poorly drained soils; and cold soil temperatures in the frigid soil temperature regime which may inhibit regeneration. The dominant soil groups were Nanny moderately deep (40\%); Althouse deep (20\%); and Skymor (15\%); with about 25 percent other soils (poorly drained soils, Kistirn, Clallam).

STAND STRUCTURE SUMMARY: Mean stand age in this type was 361 years; it ranged from 170 to 500 years stand age. The highest frequency of stands $(47 \%)$ were found between 326 and 425 years of age. The frequency of stands above 300 years was 76 percent; the frequency of stands below 200 years was 19 percent.

Stands in this type had a mixture of tolerant and moderately intolerant conifers in the moderately dense overstory, along with a variety of diameter classes which resulted in multiple layers. The overstory was usually composed of at least two layers of different aged conifers, averaging 170 feet tall in the top layer and 133 feet tall in the second layer. It had a high density of large conifers, with an average of 31 trees/acre greater than 30 inches diameter, among the highest of all Port Orford cedar types. The mid layers were dominated by conifer species; they ranged from 35 to 70 feet tall. The regeneration layer was moderately dense.

Softwood cubic volumes were the highest of all Port Orford cedar types with an average of $15,044 \mathrm{ft}^{3} /$ acre. Dunning site class was 1 , with site index of 175 at 300 years. Stand density index was high with an average of 521. 


\section{CHLA-ABCO/QUSA Association, EcoCode CCOCFW15}

\section{Port Orford Cedar-White Fir/Sadler Oak}

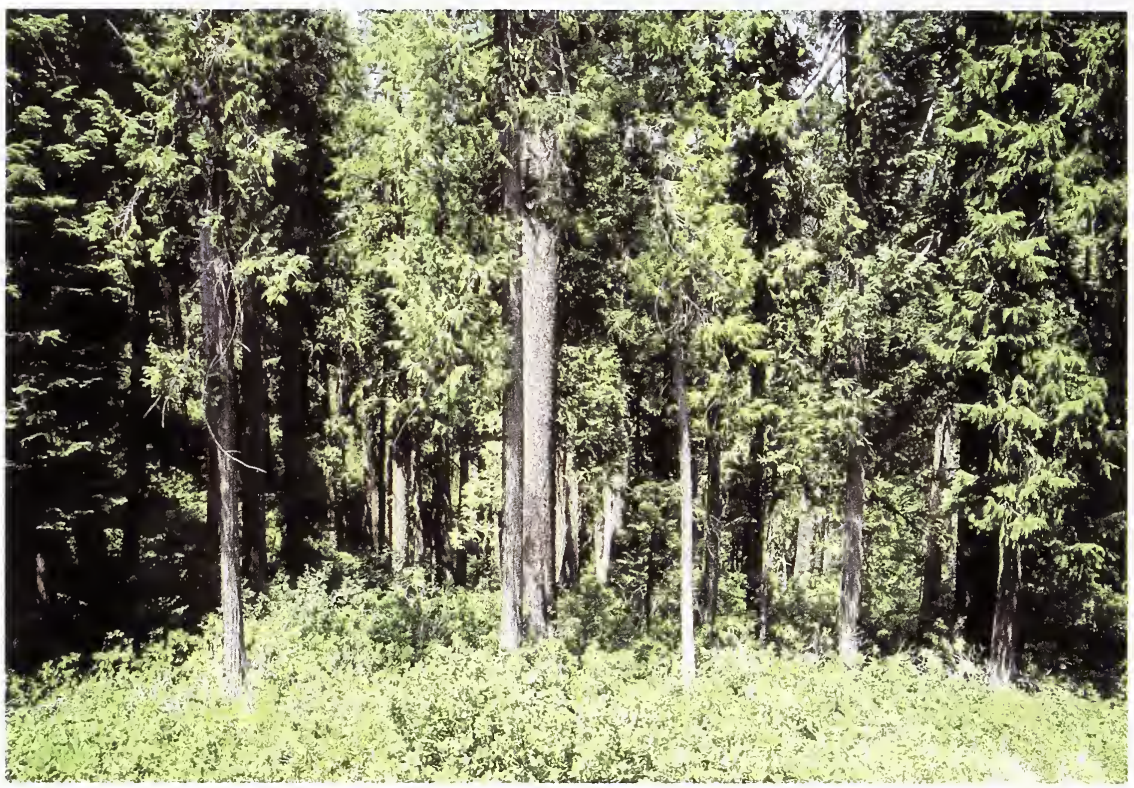

ENVIRONMENT: Elevation: 3220-4360 ft.; Aspect: N.W., N.E.; Slope: 5-50\%;

Slope Position: lower and middle1/3; Surface Rock: 0-12\%

\section{SUMMARY TABLE}

(Sample size: 17)

COVER

CON

Tree Overstory Layer

CHLA Port Orford Cedar

PSME Douglas-fir

ABCO White Fir

26

30

18

Tree Understory Layer

CHLA Port Orford Cedar

ABCO White Fir

PSME Douglas-fir

Shrubs

QUSA Sadler Oak

VAPA Red Huckleberry

BENE1

Dwarf Oregon Grape

Oregon Boxwood

Herbs \& Grasses

CHUMO Prince's Pine

LIBOL Twinflower

ACTR Vanillaleaf

PYPI White-veined

Wintergreen

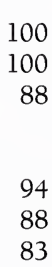

100

61

61

61

94

83

66

61

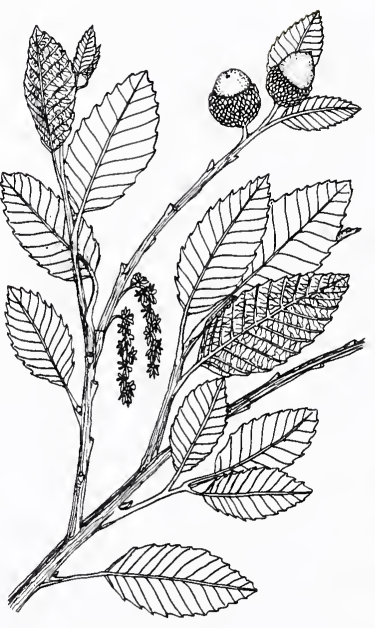

Sadler Oak

(Quercus sadleriana)

SOILS Pit Depth: 22->40 in.; Coarse Fragments: 25-60\%; Textures: gl, vgcl, vgl, gsl; Parent Material: granite, mafic, greenstone. 
DISTRIBUTION/ENVIRONMENT: This type was found on the Gasquet, Orleans, Ukonom, and Happy Camp ranger districts in the middle and lower one-third slope positions with undulating, linear micro-relief. Elevation averaged 3770 feet and ranged from 3220 to 4360 feet, on gentle (31\%) slopes with northeast and northwest facing aspects. Radiation index was moderate (.428) as a result of northeast aspects.

VEGETATION SUMMARY: Total vegetation cover was dense (95\%) and overstory cover of 78 percent was moderate. Overstory conifer dominance was shared by Douglas-fir (30\%) and Port-Orford cedar (26\%), with white fir (18\%) as an associate species. Chinquapin (11\%) was an occasional member of the hardwood layer. The tree regeneration layer was dominated by Port Orford cedar (3\%), white fir (3\%), and Douglas-fir (1\%), with chinquapin $(8 \%)$ as the primary hardwood species. The shrub layer averaged 40 percent cover, which was moderate for the Port-Orford cedar series. Sadler oak (22\%) was the dominant shrub followed by red huckleberry (6\%), dwarf Oregon-grape (5\%), huckleberry oak (3\%), wild rose (2\%), and Oregon boxwood $(1 \%)$. Total forb cover $(22 \%)$ was among the highest in this series. It included twinflower $(10 \%)$, vanillaleaf $(5 \%)$, beargrass $(4 \%)$, prince's pine $(2 \%)$, queens cup $(2 \%)$, wintergreen (1\%), and white trillium (1\%).

SOIL SUMMARY: Soils in this type were well drained, derived from the coarse textured igneous intrusive parent materials, granite and mafic rocks. They were primarily deep and moderately deep, gravelly to very gravelly loams, with low to high AWC (2.9"), thick A horizons ( $\left.8^{\prime \prime}\right)$, and low to high A horizon coarse fragments $(42 \%)$. They were found in the frigid soil temperature regime and were highly productive to moderately productive for conifer growth. The major limitations for these soils include cold soil temperature; areas of high coarse fragments; low AWC and their effects on regeneration success; and susceptibility to compaction when soils are moist. The dominant soil groups were Clallam moderately deep (25\%); Hugo deep (25\%); and Kistirn moderately deep (25\%); with about 25 percent other soils (ultramafic soils, Kistirn deep, Clallam deep, Hugo moderately deep).

STAND STRUCTURE SUMMARY: Mean stand age in this type was 353 years; it ranged from 210 to 500 years stand age. The highest frequency of stands (35\%) were found between 326 and 475 years of age. The frequency of stands above 300 years was 65 percent; the frequency of stands below 200 years was $12 \%$.

Stands in this type had a mixture of tolerant and moderately intolerant conifers in the moderately dense overstory, along with a variety of diameter classes which resulted in multiple layers. The overstory was usually composed of at least two layers of different aged conifers, averaging 160 feet tall in the top layer, and 111 feet tall in the second layer. It had a high density of large conifers, with an average of 20 trees/acre greater than 30 inches diameter. The mid layers were dominated by conifer species; they ranged from 25 to 70 feet tall. The regeneration layer was moderately dense.

Softwood cubic volumes were moderate with an average of $11,425 \mathrm{ft}^{3} /$ acre.

Dunning site class was 1 , with site index of 175 at 300 years. Stand density index was moderate with an average of 457 . 
DISTRIBUTION/ENVIRONMENT: This type was found on the Gasquet, Orleans, Ukonom, and Happy Camp ranger districts in the middle and lower one-third slope positions with linear, undulating, and concave micro-relief. Elevation averaged 4719 feet, the highest of all Port Orford cedar types. Elevation ranged from 4400 to 5270 feet, on gentle (38\%) slopes with north facing aspects. Radiation index was the lowest in the Port Orford cedar series (.371) as a result of north aspects. This type tends to occur on cold sites where it had the second highest cover of surface rock (12\%) in the Port Orford cedar series.

VEGETATION SUMMARY: Total vegetation cover was dense (94\%), and overstory cover of 79 percent was moderate. Overstory dominance was shared by white fir (25\%) and Port Orford cedar (24\%), with Douglas-fir (19\%) and red fir $(16 \%)$ as associate species. The regeneration layer included white fir (3\%), red fir (3\%), and Port Orford cedar (2\%). The shrub layer averaged 35\% cover, which was moderate for the Port-Orford cedar series. Sadler oak (19\%) dominated here, followed by thinleaf huckleberry (8\%), dwarf Oregon-grape (5\%), huckleberry oak (4\%), wild rose $(2 \%)$, and trailing blackberry (1\%). Total forb cover $(23 \%)$ was moderate; it included vanillaleaf ( $9 \%)$, twinflower (9\%), queens cup (5\%), prince's pine $(3 \%)$, starflower $(2 \%)$, three-leaved anemone $(2 \%)$, one-sided wintergreen $(1 \%)$, Hooker's fairybells (1\%), rattlesnake plantain (1\%), and white trillium (1\%).

SOIL SUMMARY: Soils in this type were well drained, derived from coarse and fine textured parent materials including diorite, gabbro, peridotite, and greenstone. They were primarily moderately deep, deep, and shallow, gravelly to very gravelly loams, with low to high AWC (2.5"), thick A horizons (9"), and low to high A horizon coarse fragments $(42 \%)$. They were found in the frigid soil temperature regime and are of low to moderate productivity for conifer growth. Limitations to management include low regeneration potential due to low AWC, high coarse fragments, high surface rock, fertility imbalance on serpentine soils, and reduced soil temperature in the frigid soil temperature regime. The dominant soil groups were Tallac deep (30\%); Althouse moderately deep (30\%); and Skymor (20\%); with about 20 percent other soils (ultramafic soils, soils with less than 35 percent coarse fragments in the subsoil).

STAND STRUCTURE SUMMARY: Mean stand age in this type was 349 years; it ranged from 260 to 485 years stand age. The highest frequency of stands (59\%) were found between 226 and 375 years of age. The frequency of stands above 300 years was 71 percent; the frequency of stands below 200 years was $6 \%$.

Stands in this type had a mixture of tolerant and moderately intolerant conifers in the moderately dense overstory, along with a variety of diameter classes which resulted in multiple layers. The overstory is usually composed of at least two layers of different aged conifers, averaging 145 feet tall in the top layer and 113 feet tall in the second layer. It had a high density of large conifers, with an average of 19 trees/acre greater than 30 inches diameter. The mid layers were dominated by conifer species; they ranged from 25 to 70 feet tall. The regeneration layer was dense due to the open nature of this type.

Softwood cubic volumes ranged from low to moderate with an average of 9,766 $\mathrm{ft}^{3} /$ acre. Dunning site class was 3, with site index of 125 at 300 years. Stand density index was moderate with an average of 454 . 


\section{CHLA-PSME/QUVA Association, EcoCode CCOCFW17}

\section{Port Orford Cedar-Douglas-fir/Huckleberry Oak}

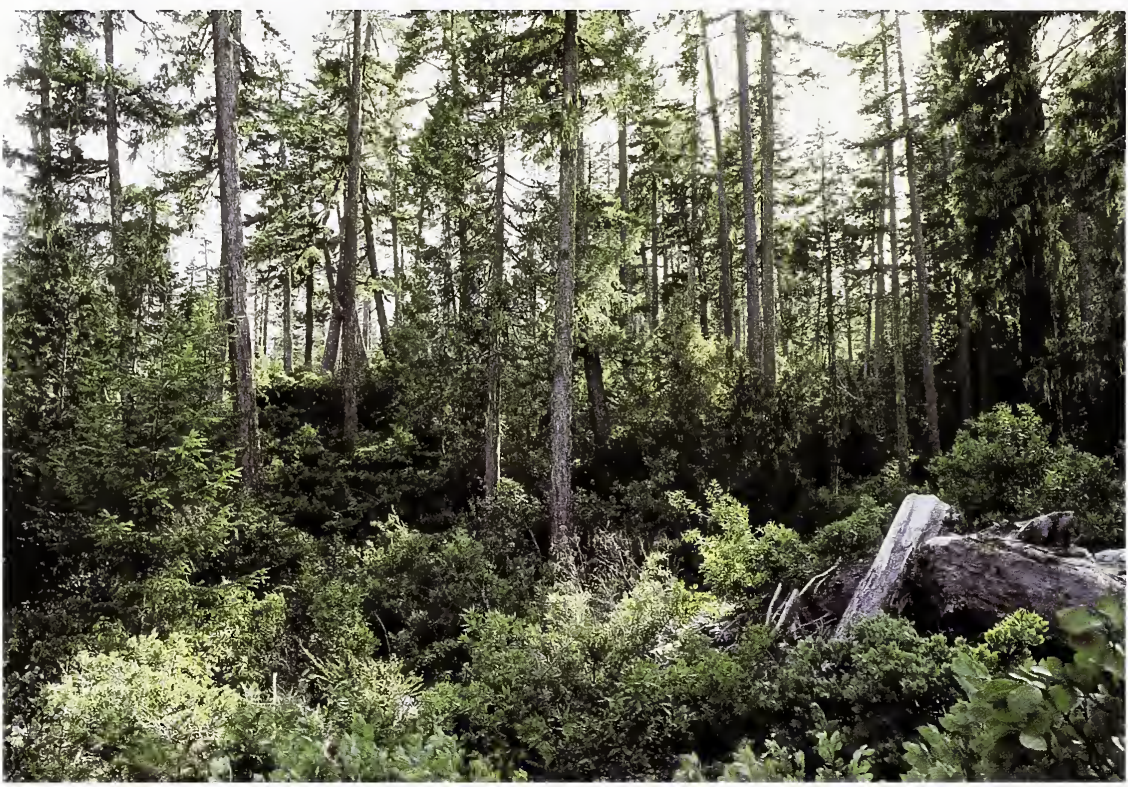

ENVIRONMENT: Elevation: 2520-3720 ft.; Aspect: N.W., E.; Slope: 0-70\%;

Slope Position: lower thru upper 1/3; Surface Rock: 1-10\%

\section{SUMMARY TABLE}

(Sample size: 22)

COVER

CON

\section{Tree Overstory Layer}

CHLA Port Orford Cedar 28

PSME Douglas-fir 26

PILA Sugar Pine 7

100

100

86

Tree Understory Layer

CHLA Port Orford Cedar

PSME Douglas-fir

100

72

Shrubs

QUVA Huckleberry Oak

VAPA Red Huckleberry

Herbs \& Grasses

$\begin{array}{llll}\text { XETE } & \text { Beargrass } & 3 & 77 \\ \text { GOOB } & \text { Rattlesnake Plantain } & 1 & 72 \\ \text { IRI } & \text { Iris } & 1 & 63 \\ \text { WHMO } & \text { Western Modesty } & 2 & 54\end{array}$
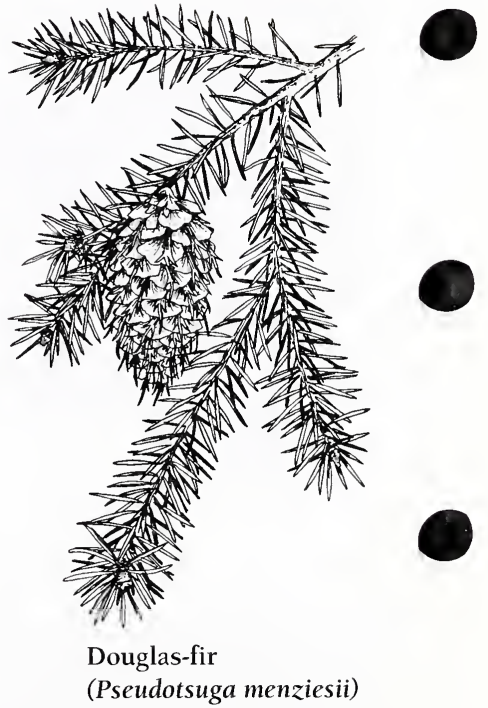
DISTRIBUTION/ENVIRONMENT: This type was found on the Gasquet, Orleans, Ukonom, and Happy Camp ranger districts in the upper, middle, and lower one-third slope positions with concave, undulating, and linear micro-relief. Elevation averaged 3425 feet and ranged from 2520 to 3720 feet, on gentle (30\%) slopes with northwest and east facing aspects. Radiation index was moderate (.431) as a result of east aspects. This type appears to be the driest plant association in the Port Orford cedar series, with a surface rock average of 9 percent.

VEGETATION SUMMARY: Total vegetation cover was moderate (91\%), and overstory cover of 70 percent was second lowest in the Port-Orford cedar series. Overstory conifer dominance was shared between Port Orford cedar (28\%) and Douglas-fir (26\%), with sugar pine (7\%) as an associate species. The tree regeneration layer was dominated by Port Orford cedar (3\%), Douglas-fir (1\%), and tanoak (5\%) in shrub form. The shrub layer averaged 33 percent cover, which was moderate for the Port-Orford cedar series. Huckleberry oak (23\%) dominated here, followed by red huckleberry $(5 \%)$, and wild rose $(1 \%)$. Total forb cover $(9 \%)$ was moderate; it included beargrass (3\%), western modesty $(2 \%)$, rattlesnake plantain $(1 \%)$, iris (1\%), prince's pine (1\%), and starflower (1\%).

SOIL SUMMARY: Soils in this type were well drained, derived from the fine textured ultramafic parent materials peridotite and serpentine. They were primarily deep and moderately deep, gravelly to very gravelly loams, with low to high AWC (3.3"), moderately thick A horizons ( $5^{\prime \prime}$, and low to high A horizon coarse fragments (31\%). They were found in the mesic and frigid soil temperature regimes and were of low to moderately productivity for conifer growth. The major limitations for these soils are fertility imbalances due to the ultramafic parent material, low plantability in areas with high surface rock, areas of high soil coarse fragments, areas of steep slopes, potentially high erodibility, susceptibility to burning damage, and susceptibility to compaction when soils are moist. The dominant soil groups were Weitchpec moderately deep (30\%); Walnett deep (25\%); and Walnett moderately deep (20\%); with about 20 percent other soils (Weitchpec deep, Clallam moderately deep, shallow soils).

STAND STRUCTURE SUMMARY: Mean stand age in this type was 391 years; it ranged from 180 to 660 years stand age. The highest frequency of stands (41\%) were found between 326 and 425 years of age. The frequency of stands above 300 years was 73 percent; the frequency of stands below 200 years was 9 percent.

Stands in this type had a mixture of tolerant and moderately intolerant conifers in the moderate overstory, along with a variety of diameter classes which resulted in multiple layers. The overstory was usually composed of at least two layers of different aged conifers, averaging 136 feet tall in the top layer and 106 feet tall in the second layer. It had a high density of large conifers, with an average of 22 trees/acre greater than 30 inches diameter. The mid layers were dominated by conifer species, they ranged from 25 to 50 feet tall. The regeneration layer was sparse due to a dense shrub layer.

Softwood cubic volumes ranged from low to moderate with an average of 9,821 $\mathrm{ft}^{3} /$ acre. Dunning site class was 2, with site index of 150 at 300 years. Stand density index was moderate with an average of 454. 


\section{CHLA-PIMO3/QUVA Association, EcoCode CCOCCO14}

\section{Port Orford Cedar-Western White Pine/Huckleberry Oak}

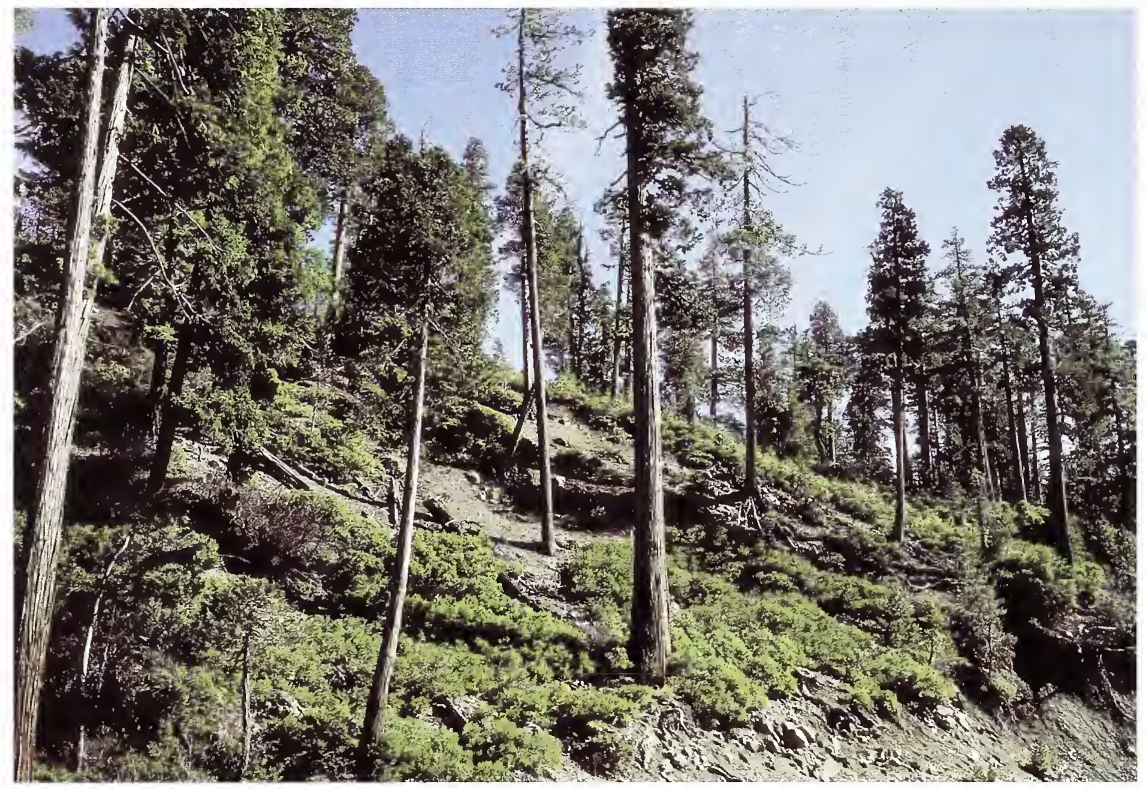

ENVIRONMENT: Elevation: 1500-3840 ft.; Aspect: E.,W.; Slope: 10-50\%;

Slope Position: lower and middle 1/3; Surface Rock: 4-25\%

\section{SUMMARY TABLE}

(Sample size: 10)

COVER

CON

Tree Overstory Layer

CHLA Port Orford Cedar

PSME Douglas-fir

PIMO3 Western White Pine 6

ARME3 Pacific Madrone 2

100

100

100

250

Tree Understory Layer

PIMO3 Western White Pine 1

100

CHLA Port Orford Cedar 3

PSME Douglas-fir 2

Shrubs

QUVA Huckleberry Oak 38

100

VAPA Red Huckleberry

6

LIDEE Dwarf Tanbark

13

GABU2 Boxleaf Maple

Herbs \& Grasses

IRI Iris

XETE Beargrass

WHMO Western Modesty

POMUl Sword Fern

$\begin{array}{rr}2 & 100 \\ 3 & 80 \\ 5 & 70 \\ 2 & 60\end{array}$

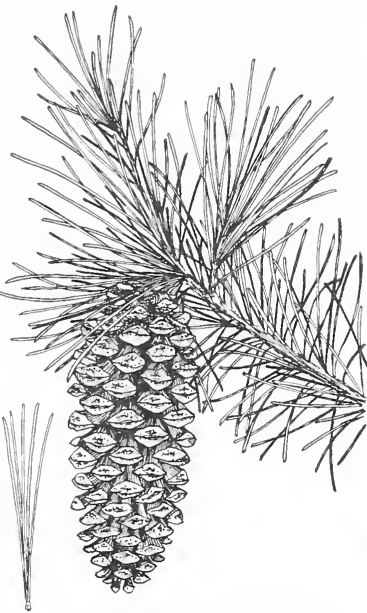

Western White Pine (Pinus monticola)

SOILS Pit Depth: 15->40 in.; Coarse Fragments: 30-90\%; Textures: xgl, vgl, gsl; Parent Material: serpentine, peridotite 
DISTRIBUTION/ENVIRONMENT: This type was found only on the Gasquet Ranger District on cool, coastal sites subject to heavy winter snow packs. It was most often found in the middle and lower one-third slope positions with linear, undulating, and concave micro-relief. Elevation was the lowest in the Port Orford cedar series, with an average of 2884 feet. Elevation ranged from 1500 to 3840 feet, on gentle (33\%) slopes with east and west facing aspects. Radiation index was the highest in the Port Orford cedar series (.441) as a result of west aspects. Surface rock here was the highest in the series with an average of 14 percent cover.

VEGETATION SUMMARY: Total vegetation cover was dense (93\%), and overstory cover of 51 percent was the lowest of all Port-Orford cedar plant associations due to the high frequency of surface and subsurface rock. Port Orford cedar (28\%) was the dominant overstory species, with Douglas-fir (14\%) and western white pine $(6 \%)$ as associates. The tree regeneration layer was dominated by Port Orford cedar (3\%), Douglas-fir (2\%), and western white pine (1\%), with California bay (7\%) in shrub form. The shrub layer averaged 67 percent cover, highest in the Port-Orford cedar series. Huckleberry oak (38\%) dominated here followed by dwarf tanbark (13\%), and red huckleberry (6\%). Total forb cover (14\%) was moderate; it included western modesty $(5 \%)$, twinflower $(3 \%)$, beargrass (3\%), swordfern $(2 \%)$, Prince's pine $(2 \%)$, and iris (2\%). Sedges (4\%) dominated the grass layer.

SOIL SUMMARY: Soils in this type were well drained, derived from the fine textured ultramafic parent materials, peridotite and serpentine. They were moderately deep, and shallow, very gravelly to extremely gravelly loams, with low AWC (1.8"), moderately thick A horizons ( $\left.5^{\prime \prime}\right)$, and high A horizon coarse fragments (62\%). They were found in the mesic and frigid soil temperature regimes and were of low productivity for conifer growth. The major limitations for these soils are fertility imbalances due to the ultramafic parent material, low AWC, areas of shallow soils, areas of high surface coarse fragments, areas of steep slopes, potentially high erodibility, susceptibility to burning damage, and susceptibility to compaction when soils are moist. The dominant soil groups were Weitchpec moderately deep (35\%); Goulding Variant (35\%); and Walnett moderately deep (20\%); with about 10 percent other soils (deep soils).

STAND STRUCTURE SUMMARY: Mean stand age in this type was 421 years; it ranged from 290 to 550 years stand age. The highest frequency of stands (56\%) were found between 276 and 375 years of age. The frequency of stands above 300 years was 95 percent; the frequency of stands below 200 years was 0 percent.

Stands in this type had a mixture of tolerant, moderately intolerant, and intolerant conifers in the open overstory, along with a variety of diameter classes which resulted in multiple layers. The overstory was usually composed of at least two layers of different aged conifers, averaging 90 feet tall in the top layer and 67 feet tall in the second layer. It had a low density of large conifers, with an average of 7 trees/acre greater than 30 inches diameter. The mid layers were dominated by conifer species; they ranged from 15 to 35 feet tall. The regeneration layer was moderate due to a dense shrub layer.

Softwood cubic volumes were the lowest of all Port Orford cedar types with an average of $6,374 \mathrm{ft}^{3} /$ acre. Dunning site class was 5, with site index of 75 at 300 years. Stand density index was the lowest of all Port Orford cedar types with an average of 404 . 


\section{CHLA-LIDE3-ALRH Association, EcoCode CCOCFW18 Port Orford Cedar-Incense Cedar-White Alder}

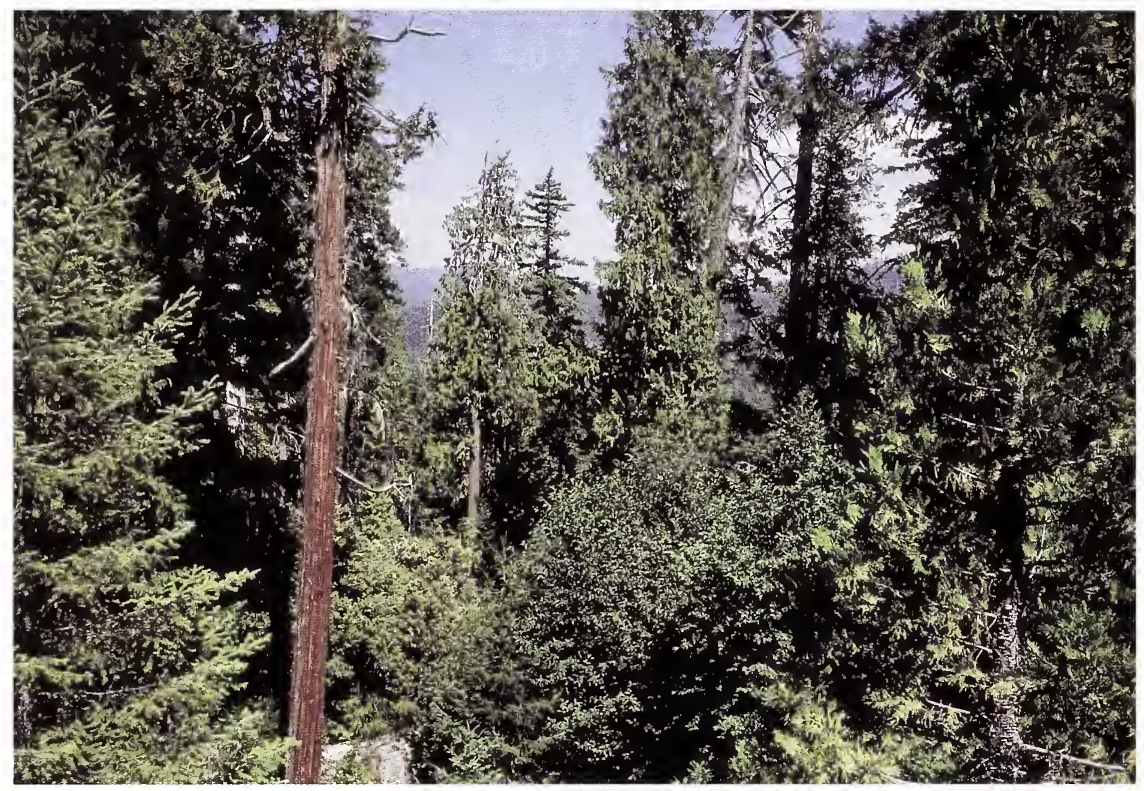

ENVIRONMENT: Elevation: 3220-3390 ft.; Aspect: S.E..; Slope: 25-50\%; Slope Position: lower and middle 1/3; Surface Rock: 2-5\%

SUMMARY TABLE
(Sample size: 2)
COVER
$\mathrm{CON}$

Tree Overstory Layer

$\begin{array}{llrr}\text { CHLA } & \text { Port Orford Cedar } & 37 & 100 \\ \text { PSME } & \text { Douglas-fir } & 8 & 100 \\ \text { ALRH } & \text { White Alder } & 3 & 100 \\ \text { ACMA } & \text { Big Leaf Maple } & 4 & 50\end{array}$

Tree Understory Layer

$\begin{array}{ll}\text { CHLA } & \text { Port Orford Cedar } \\ \text { LIDE3 } & \text { Incense Cedar } \\ \text { ALRH } & \text { White Alder }\end{array}$
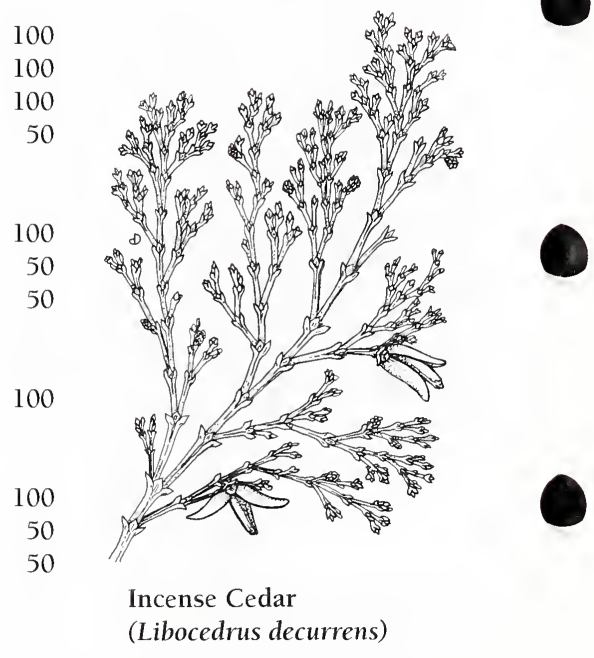

Shrubs

RUUR Trailing Blackberry $\quad 1$

Herbs \& Grasses

$\begin{array}{ll}\text { ACTR } & \text { Vanilla Leaf } \\ \text { LIBOL } & \text { Twinflower }\end{array}$

1
1
1

SOILS Pit Depth: 35->40 in.; Coarse Fragments: 35-45\%; Textures: vgl; Parent Material: schist, mixed 
DISTRIBUTION/ENVIRONMENT: This type was found only on the Ukonom Ranger District in the middle and lower one-third slope positions with undulating, convex micro-relief. Elevation averaged 3295 feet and ranged from 3220 to 3390 feet, on gentle (38\%) slopes with southeast facing aspects. Radiation index was the highest in the Port Orford cedar series (.542) as a result of southeast aspects. This type tends to be dry as a result of aspect and convex micro-relief. The presence of incense cedar substantiates this drier environment.

VEGETATION SUMMARY: Total vegetation cover was very dense (98\%), while the overstory cover of 98 percent was the highest in the Port-Orford cedar series. Overstory dominance was shared between Port Orford cedar (37\%) and Pouglas-fir $(30 \%)$, with incense cedar $(8 \%)$ and white alder $(3 \%)$ as associate species. The tree regeneration layer was dominated by Port Orford cedar (1\%), Douglas-fir (5\%), white fir $(1 \%)$, and white alder (1\%). The shrub layer averaged 2 percent cover, which was the lowest in the Port-Orford cedar series. Dwarf Oregon-grape (2\%), along with trailing blackberry (1\%) and red huckleberry, were among the few shrubs present. Total forb cover (3\%) was also the lowest value in the series. Forb species included vanillaleaf $(1 \%)$, prince's pine $(1 \%)$, twinflower $(1 \%)$, starflower $(1 \%)$, Hooker's fairybells (1\%), western modesty (1\%), sword fern (1\%), inside-out flower (1\%), and hawkweed (1\%).

SOIL SUMMARY: Soils in this type were well drained, derived from the fine textured metamorphic parent materials schist and mixed. They were primarily deep and moderately deep, very gravelly loams, with moderate AWC (3.3"), moderately thick A horizons (6"), and moderate A horizon coarse fragments (40\%). They were found in the frigid soil temperature regime and were moderately productive for conifer growth. They present few major limitations for management. They are occasionally susceptible to compaction when soils are moist. The dominant soil groups were Forgay deep and Forgay moderately deep.

STAND STRUCTURE SUMMARY: Mean stand age in this type was 215 years; lowest of all Prrt Orford cedar types. It ranged from 200 to 225 years stand age. The highest freque 1 cy of stands (100\%) were found between 176 and 225 years of age.

The frequency of stands above 300 years was 0 percent; the frequency of stands below 200 years was also 0 percent.

Stands in this type had a mixture of tolerant and moderately intolerant conifers in the moderately dense overstory, along with a variety of diameter classes which resulted in multiple layers. The overstory was usually composed of at least two layers of different aged conifers, averaging 122 feet tall in the top layer and 105 feet tall in the second layer. It had a moderate density of large conifers, with an average of 18 trees/ acre greater than 30 inches diameter. The mid layers were dominated by conifer species; they ranged from 25 to 70 feet tall. The regeneration layer was low as a result of the dense overstory of trees.

Softwood cubic volumes were generally low with an average of $8,280 \mathrm{ft}^{3} /$ acre. Dunning site class was 3, with site index of 125 at 300 years. Stand density index was moderate with an average of 459 . 
-

-

-

-

-

.

- 
New Port-Orford-cedar Plant Associations 


\section{CHLA-ABCO/ALSI2 Association, EcoCode: CCOCFW19 Port-Orford-cedar-White Fir/ Sitka Alder}
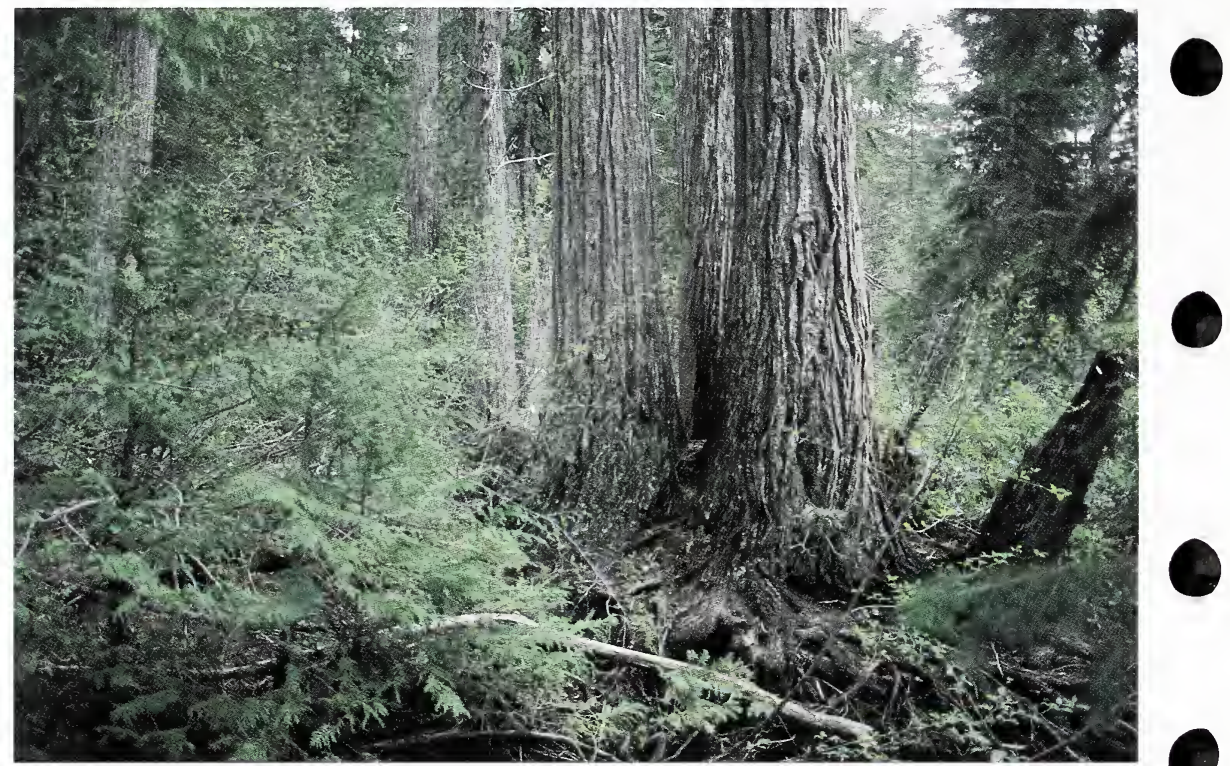

SUMMARY TABLE

(Sample size: 19)

COVER CON

\section{Tree Overstory Layer}

CHLA Port-Orford-cedar $48 \quad 100$

$\begin{array}{lll}\text { ABCO White Fir } & 12 & 100\end{array}$

$\begin{array}{lll}\text { PSME } & \text { Douglas-fir } & 18\end{array}$

Tree Understory Layer

$\begin{array}{llll}\text { CHLA } & \text { Port-Orford-cedar } & 5 & 89 \\ \text { ABCO } & \text { White Fir } & 4 & 84 \\ \text { PSME } & \text { Douglas-fir } & 1 & 42\end{array}$

Shrubs

$\begin{array}{llrr}\text { ALSI2 } & \text { Sitka Alder } & 23 & 100 \\ \text { QUSA } & \text { Sadler Oak } & 2 & 68 \\ \text { ROGY } & \text { Wood Rose } & 2 & 68\end{array}$

\section{Herbs \& Grasses}

$\begin{array}{llll}\text { TRLA3 } & \text { Starflower } & 3 & 68 \\ \text { ACTR } & \text { Vanilla leaf } & 5 & 53 \\ \text { ATFIC3 } & \text { Common Lady Fern } & 4 & 47 \\ \text { CLUN2 } & \text { Queens Cup } & 4 & 47\end{array}$

\section{ENVIRONMENT:}

Elevation: 3920-5050 ft.;

Aspect: W., E.;

Slope: $5-45 \%$;

Slope Position: lower 1/3, bottom;

Surface Rock: 2-18\%;

Distance to the Ocean: 13.4-31.6 miles

SOILS:

Pit Depth: 22-32 in.;

AWC: $1.0-10.0$ in.;

Parent Material: granitic, mafic, ultramafic, mixed

A Horizon:

Coarse Fragments: 20-66\%;

Textures: vgl;

Thickness: 1.0-16.0 in.;

Surface PH: 5.0-6.7 


\section{DISTRIBUTION/ENVIRONMENT:}

This plant association was among the most extensive in the western portion of the range of Port-Orford-cedar. It covered 1064 acres. It was found on the Gasquet and Orleans Ranger Districts, Six Rivers National Forest and the Happy Camp and Ukonom Ranger Districts of the Klamath National Forest. Sites were lower one-third, streamside positions with concave and undulating slope shapes. Mean distance to the Pacific Ocean was 22.4 miles and ranged from 13.4 to 31.6 miles. Elevation averaged 4458 feet and ranged from 3920 to 5050 feet. Slopes were moderately steep averaging $23 \%$ and ranged from 5\% to $45 \%$. Radiation index was a warm .460 as a result of mainly west and east aspects, but was moderated by topographic shading.

\section{VEGETATION SUMMARY:}

Total vegetation cover was dense (94\%) and was composed of trees $(76 \%)$, shrubs (39\%) and forbs (33\%). Port-Orford-cedar (48\%), white fir (12\%) and Douglas-fir (18\%) dominated the tree layer. The shrub layer included Sitka alder (23\%), Sadler oak $(2 \%)$, wood rose $(2 \%)$ and red huckleberry $(8 \%)$. Total forb cover was high (33\%) and included vanillaleaf, common lady fern, western prince's pine, Hooker's fairybell, braken fern, queens cup, white trillium and starflower. The grass layer was of low cover $(5 \%)$ and included a mixture of grass and sedge species.

\section{SOIL SUMMARY:}

Soils in this type were frigid, moderately deep and poorly drained to well drained. They formed in bedrock, colluvium and alluvium from mafic and granitic parent material. The litter layer thickness averaged 1.1" at 79\% cover. Surface rock and gravel averaged 13\% cover. The average surface horizon thickness was 6", texture was very gravelly loams, coarse fragment content averaged $39 \%$ and $\mathrm{pH}$ averaged 6.0 .

Subsoil textures were very gravelly loam, coarse fragment content averaged $34 \%$ and $\mathrm{pH}$ averaged 6.5 . The soils were $80 \%$ skeletal.

\section{STAND STRUCTURE SUMMARY:}

Late seral stands in this type often had 3 or more layers of trees, while early mature and mid mature stands usually had 2 layers. Large sized conifers dominated the top two layers with an average of 79 trees/acre $>21$ inches $\mathrm{dbh}, 30$ trees/acre $>30$ inches $\mathrm{dbh}$, and 11 trees/acre $>40$ inches $\mathrm{dbh}$. Very few hardwoods were present in this type.

The stand structure characteristics by layer were as follows. The top layer averaged 317 years old with an average diameter of 49.2 inches and average height of 148 feet. It was made up of dominant white fir, Douglas-fir and Port-Orford-cedar. The second layer had an average age of 278 years with a mean diameter of 34.8 inches and a mean height of 106 feet. It included codominant Port-Orford-cedar and white fir. The third layer had an average age of 87 years with a mean diameter of 15.2 inches and a mean height of 43 feet. The third layer included intermediate PortOrford-cedar and white fir.

Overall biomass production (conifer + hardwoods + shrubs) was generally high. Modal Dunning site class was 1 with site index of 175 at 300 years. Conifer productivity was generally high with an average volume of $15,527 \mathrm{ft}^{3}{ }^{3}$, it ranged from 13,574 to $18,067 \mathrm{ft}^{3}$ Softwood basal area averaged $440 \mathrm{ft}^{2}$ and ranged from 400 to $467 \mathrm{ft}^{2}{ }^{2}$ Stand density index was 632 and fell in the middle of the Port-Orford-cedar series. Quadratic mean diameter was 19.8 inches and fell in the high end of the PortOrford-cedar series. 


\section{CHLA-ABCO/ACCI Association, EcoCode: CCOCFW20 Port-Orford-cedar-White Fir/Vine Maple}
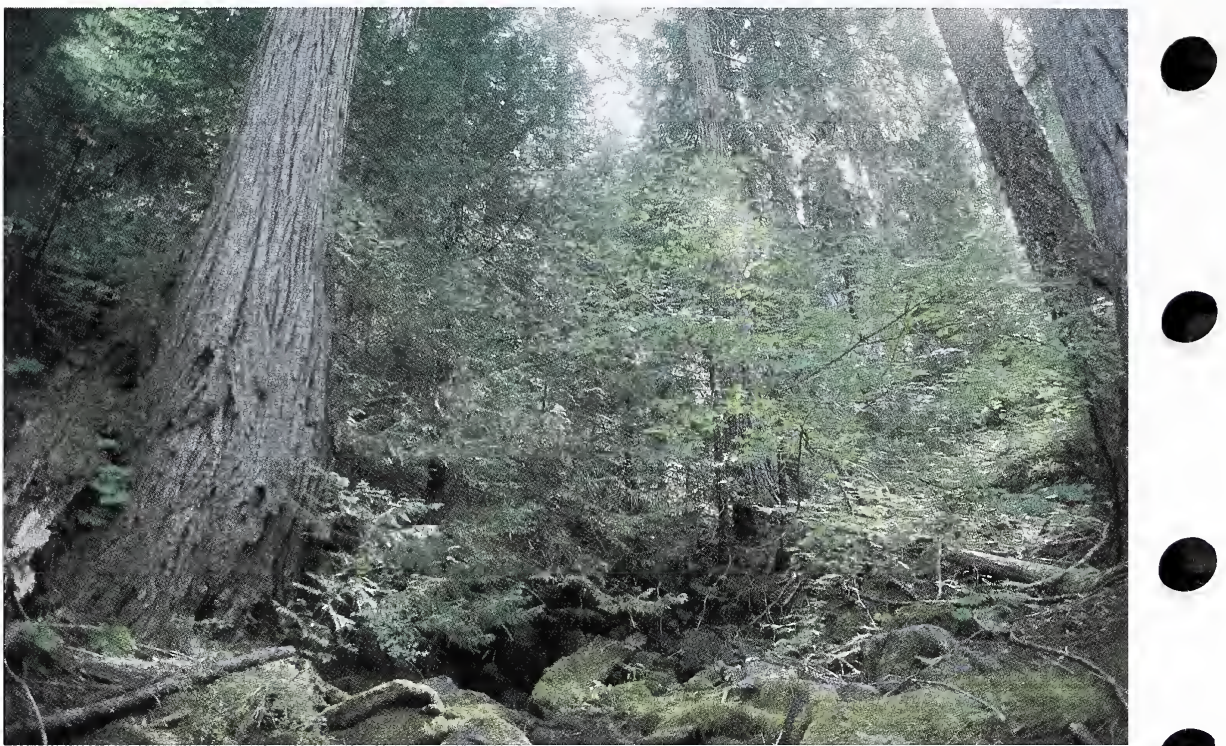

\section{SUMMARY TABLE}

(Sample size: 8)

COVER CON

\section{Tree Overstory Layer}

CHLA Port-Orford-cedar $44 \quad 100$

ABCO White Fir $15 \quad 100$

$\begin{array}{lll}\text { PSME } & \text { Douglas-fir } & 100\end{array}$

\section{Tree Understory Layer}

$\begin{array}{llrr}\text { CHLA } & \text { Port-Orford-cedar } & 4 & 100 \\ \text { ABCO } & \text { White Fir } & 2 & 50 \\ \text { PSME } & \text { Douglas-fir } & 1 & 63\end{array}$

Shrubs

$\begin{array}{llrr}\text { ACCI } & \text { Vine Maple } & 24 & 100 \\ \text { BENEl } & \text { Dwarf Oregon-grape } & 8 & 88\end{array}$

\section{Herbs \& Grasses}

$\begin{array}{llrr}\text { ACTR } & \text { Vanilla Leaf } & 14 & 100 \\ \text { TRLA3 } & \text { Starflower } & 3 & 75 \\ \text { LIBOL } & \text { Twinflower } & 15 & 63 \\ \text { DIHO2 } & \text { Hooker's fairybell } & 3 & 63\end{array}$

\section{ENVIRONMENT:}

Elevation: $2750-4420 \mathrm{ft}$.;

Aspect: N.E., N.W.;

Slope: $15-60 \%$;

Slope Position: lower 1/3, middle 1/3, draw;

Surface Rock: 1-15\%;

Distance to the Ocean: 14.0-34.3 miles.

SOILS:

Pit Depth: 31-39 in.;

AWC: 3.5-4.6 in.;

Parent Material: granitic, mixed

A Horizon:

Coarse Fragments: 37-51\%;

Textures: vgl;

Thickness: 1-4 in.;

Surface PH: 5.7-6.3 


\section{DISTRIBUTION/ENVIRONMENT:}

This plant association was a minor component in the western portion of the range of Port-Orford-cedar. It covered 291 acres. It was found on the Gasquet Ranger District, Six Rivers National Forest and the Happy Camp Ranger District of the Klamath National Forest. Sites were lower one-third, streamside positions with concave and linear slope shapes. Mean distance to the Pacific Ocean was 22.7 miles and ranged from 14.0 to 34.3 miles. Elevation averaged 3653 feet and ranged from 2750 to 4420 feet. Slopes were moderately steep averaging $36 \%$ and ranged from $15 \%$ to $60 \%$. Radiation index was a cool .389 as a result of mainly north aspects with topographic shading.

\section{VEGETATION SUMMARY:}

Total vegetation cover was a very dense $(98 \%)$ and was composed of trees $(85 \%)$, shrubs (39\%) and forbs (36\%). Port-Orford-cedar (44\%), white fir (15\%) and Douglas-fir (29\%) dominated the tree layer. The shrub layer was dominated by vine maple (24\%), dwarf Oregon-grape $(8 \%)$, hazelnut $(6 \%)$, wood rose $(2 \%)$ and red huckleberry $(4 \%)$. Total forb cover was high $(36 \%)$ and included vanillaleaf, western prince's pine, three-leaf anemone, Hooker's fairybell, twinflower, white trillium and starflower. The grass layer was of low cover (1\%) and included a mixture of grass species.

\section{SOIL SUMMARY:}

Soils in this type were frigid, moderately deep and poorly drained to well drained. They formed in bedrock and alluvium from mixed and granitic parent material. The litter layer thickness averaged $0.5^{\prime \prime}$ at $77 \%$ cover. Surface rock and gravel averaged $14 \%$ cover. The average surface horizon thickness was $2 "$, texture was very gravelly loams, coarse fragment content averaged $45 \%$ and $\mathrm{pH}$ averaged 6.0 .

Subsoil textures were extremely gravelly loam, coarse fragment content averaged $54 \%$ and $\mathrm{pH}$ averaged 6.1 . The soils were $80 \%$ skeletal.

\section{STAND STRUCTURE SUMMARY:}

Late seral stands in this type often had 4 or more layers of trees, while early mature and mid mature stands usually had 3 layers. Large sized conifers dominated the top two layers with an average of 57 trees/acre $>21$ inches dbh, 26 trees/acre $>30$ inches dbh, and 16 trees/acre $>40$ inches dbh. Scattered hardwoods were present in the lower layers and included 63 trees/acre $>5$ inches $\mathrm{dbh}$ and 3 trees/acre $>11$ inches dbh.

The stand structure characteristics by layer were as follows. The top layer averaged 300 years old with an average diameter of 49.5 inches and average height of 156 feet. It was made up of dominant Douglas-fir, white fir and Port-Orford-cedar. The second layer had an average age of 340 years with a mean diameter of 41.0 inches and a mean height of 117 feet. It included codominant Port-Orford-cedar and white fir. The third layer had an average age of 195 years with a mean diameter of 26.0 inches and a mean height of 80 feet. The third layer included intermediate PortOrford-cedar and white fir. The fourth layer was dominated by intermediate PortOrford-cedar and hardwoods.

Overall biomass production (conifer + hardwoods + shrubs) was generally high Modal Dunning site class was 1 with site index of 175 at 300 years. Conifer productivity was generally high with an average volume of $13,422 \mathrm{ft}^{3}$, it ranged from 8932 to $17,500 \mathrm{ft}^{3}$ Softwood basal area averaged $367 \mathrm{ft}^{2}$ and ranged from 227 to 475 $\mathrm{ft}^{2}{ }^{2}$ Hardwood volume averaged $76 \mathrm{ft}^{3}$ and ranged from 9 to $276 \mathrm{ft}{ }^{3}$ Hardwood basal area averaged $4 \mathrm{ft}^{2}$ and ranged from 1 to $13 \mathrm{ft}^{2}{ }^{2}$ Stand density index was 534 and fell in the middle of the Port-Orford-cedar series. Quadratic mean diameter was 23.2 inches and fell in the high end of the Port-Orford-cedar series. 


\section{CHLA-ABMAS-PIBR/QUSA-QUVA Association, EcoCode: CCOCFR01 \\ Port-Orford-cedar-Shasta Red fir-Brewer's Spruce/Sadler Oak- Huckleberry Oak}
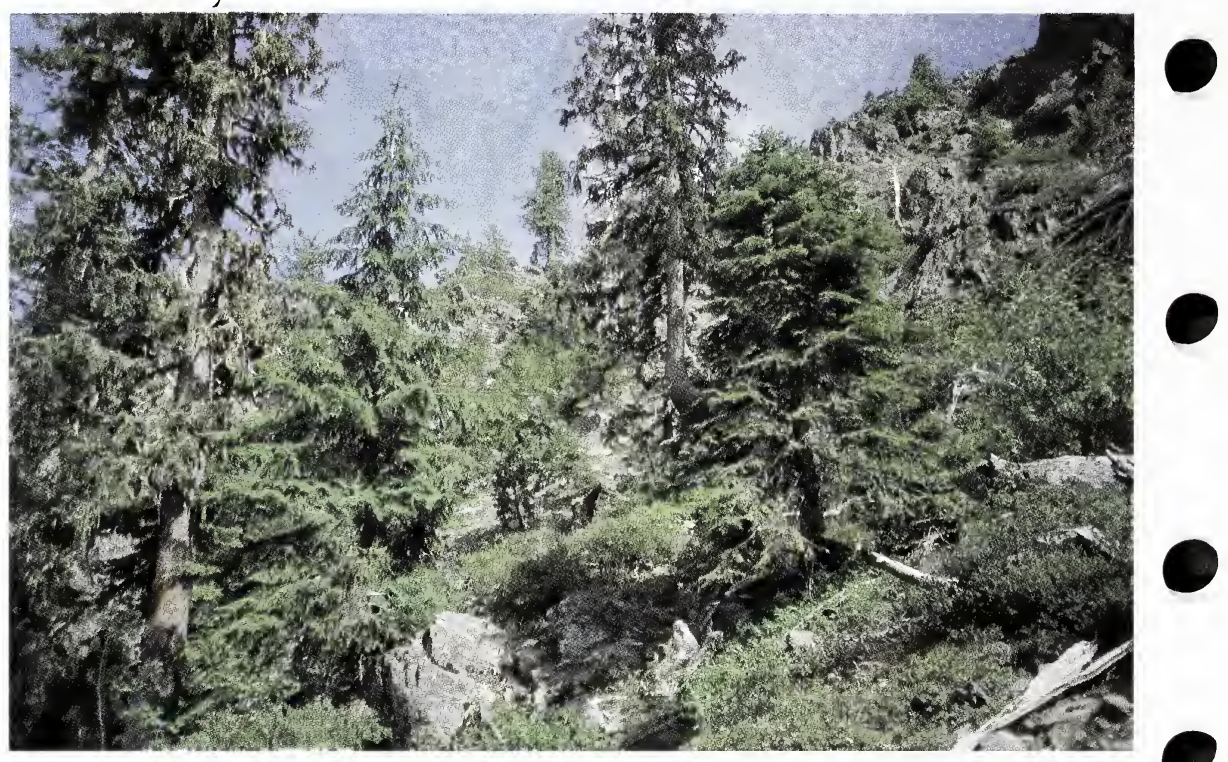

\section{SUMMARY TABLE}

COVER CON

\section{Tree Overstory Layer}

$\begin{array}{llrr}\text { CHLA } & \text { Port-Orford-cedar } & 26 & 100 \\ \text { ABMAS } & \text { Shasta Red Fir } & 8 & 100 \\ \text { PIBR } & \text { Brewer's Spruce } & 7 & 95\end{array}$

Tree Understory Layer

$\begin{array}{llll}\text { CHLA } & \text { Port-Orford-cedar } & 4 & 90 \\ \text { ABMAS } & \text { Shasta Red Fir } & 2 & 90 \\ \text { PIBR } & \text { Brewer's Spruce } & 2 & 70\end{array}$

Shrubs

QUVA Huckleberry Oak $26 \quad 80$

$\begin{array}{lll}\text { QUSA } & \text { Sadler Oak } & 12\end{array}$

VAME Thinleaf Huckleberry 998

Herbs \& Grasses

CHUMO Western Prince's pine 270

XETE Beargrass
ENVIRONMENT:

Elevation: 4710-5500 ft.;

Aspect: N., W., E.;

Slope: 0-65\%;

Slope Position: upper 1/3, lower 1/3, bottom;

Surface Rock: 5-20\%

Distance to the Ocean: 19.8-30.3 miles

SOILS:

Pit Depth: 16-18 in.;

AWC: 0.9-2.5 in.;

Parent Material: ultramafic, mixed A Horizon:

Coarse Fragments: $8-57 \%$; Textures: gl, gscl; Thickness: 1-6 in.; Surface PH: 5.7-6.5 


\section{DISTRIBUTION/ENVIRONMENT:}

This plant association was a minor component in the western portion of the range of Port-Orford-cedar. It covered 197 acres and was found on the Gasquet Ranger District, Six Rivers National Forest and the Happy Camp and Ukonom Ranger Districts of the Klamath National Forest. Sites were found in upper and lower onethird slope positions with concave and undulating slope shapes. Mean distance to the Pacific Ocean was 24.2 miles and ranged from 19.8 to 30.3 miles. Elevation averaged 5082 feet and ranged from 4850 to 5500 feet. Slopes were moderately steep averaging $29 \%$ and ranged from $0 \%$ to $65 \%$. Radiation index was a cool .424 as a result of mainly northwest and northeast aspects.

\section{VEGETATION SUMMARY:}

Total vegetation cover was dense $(91 \%)$ and was composed of primarily trees $(55 \%)$ and shrubs (60\%). Port-Orford-cedar (25\%), red fir (8\%), Brewer's spruce $(7 \%)$, white fir $(8 \%)$ and western white pine $(7 \%)$ dominated the tree layer. The shrub layer included Sadler oak (12\%), huckleberry oak (26\%), thinleaf huckleberry (9\%) and pinemat manzanita (15\%). Total forb cover was moderate (12\%) and included western prince's pine, beargrass, white-veined wintergreen, rattlesnake plantain, queens cup, and white trillium. The grass layer was of low cover (1\%) and included grass and sedge.

\section{SOIL SUMMARY:}

Soils in this type were frigid, shallow and well drained. They formed in bedrock from fine textured ultramafic parent material. The litter layer thickness averaged 2.0" at $86 \%$ cover. Surface rock and gravel averaged $11 \%$ cover. The average surface horizon thickness was 6", texture was gravelly loam and gravelly sandy clay loam, coarse fragment content averaged $32 \%$ and $\mathrm{pH}$ averaged 6.0 .

Subsoil textures were very gravelly clay loam, coarse fragment content averaged $52 \%$ and $\mathrm{pH}$ averaged 6.1 . The soils were $100 \%$ skeletal.

\section{STAND STRUCTURE SUMMARY:}

Late seral stands in this type often had 3 or more layers of trees, while early mature and mid mature stands usually had 2 layers. Large sized conifers dominated the top two layers with an average of 43 trees/acre $>21$ inches dbh, 14 trees/acre $>30$ inches $\mathrm{dbh}$, and 2.5 trees/acre $>40$ inches $\mathrm{dbh}$. Hardwoods were practically absent from the lower layers.

The stand structure characteristics by layer were as follows. The top layer averaged 265 years old with an average diameter of 35.4 inches and average height of 94 feet. It was made up of dominant Douglas-fir, white fir and Port-Orford-cedar. The second layer had an average age of 182 years with a mean diameter of 35.6 inches and a mean height of 79 feet. It included codominant Port-Orford-cedar, red fir and Brewer spruce. The third layer had an average age of 105 years with a mean diameter of 24.5 inches and a mean height of 53 feet. The third layer included intermediate Port-Orford-cedar and Brewer spruce.

Overall biomass production (conifer + hardwoods + shrubs) was generally low. Modal Dunning site class was 4 with site index of 100 at 300 years. Conifer productivity was generally low with an average volume of $6784 \mathrm{ft}^{3}{ }^{3}$, it ranged from 3040 to $10,528 \mathrm{ft}^{3}{ }^{3}$ Softwood basal area averaged $263 \mathrm{ft}^{2}$ and ranged from 180 to 347 $\mathrm{ft}^{2}$ Stand density index was 472 and fell in the low end of the Port-Orford-cedar series. Quadratic mean diameter was 21.3 inches and fell in the high end of the PortOrford-cedar series. 


\section{CHLA-ABMAS/ALSI2-QUSA Association, EcoCode: CCOCFR02 \\ Port-Orford-cedar-Shasta Red Fir/Sitka Alder-Sadler Oak}
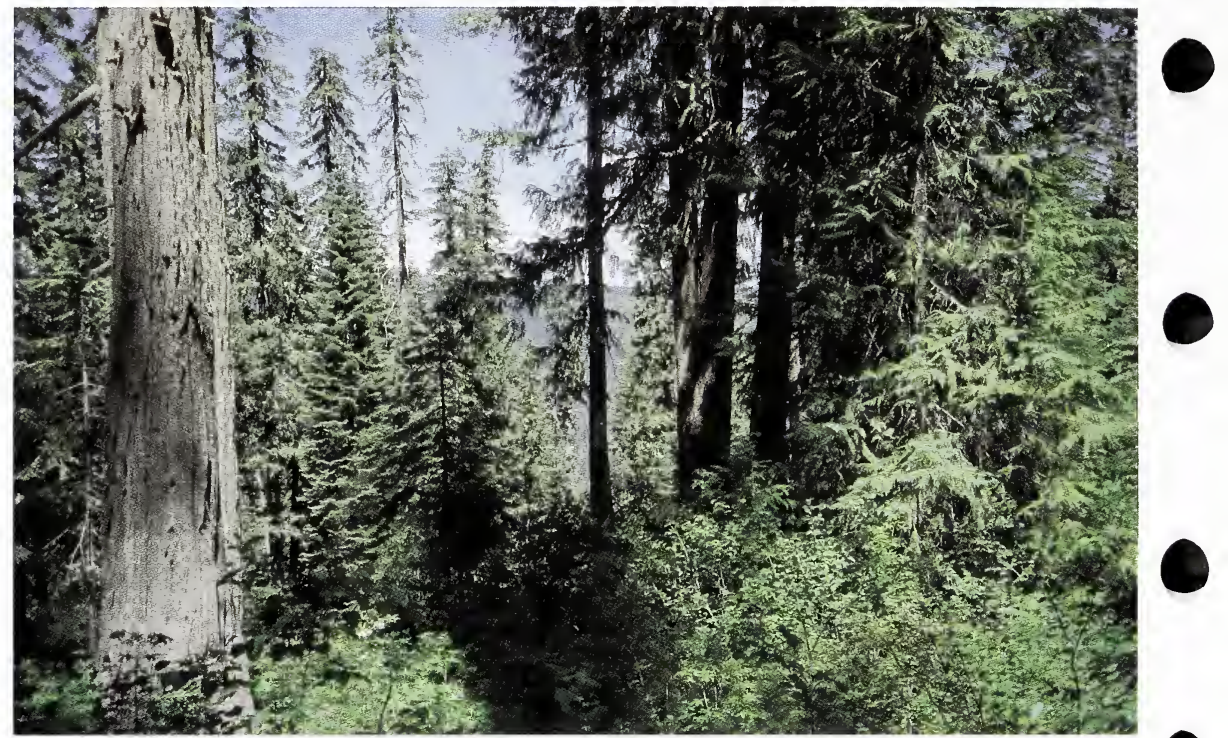

\section{SUMMARY TABLE}

(Sample size: 11)

COVER CON

\section{Tree Overstory Layer}

CHLA Port-Orford-cedar $\quad 36 \quad 100$

$\begin{array}{lll}\text { ABMAS Shasta Red Fir } & 7 & 91\end{array}$

$\begin{array}{lll}\text { PSME } & \text { Douglas-fir } & 11\end{array}$

Tree Understory Layer

$\begin{array}{llll}\text { CHLA Port-Orford-cedar } & 4 & 100\end{array}$

ABMAS Shasta Red Fir $\quad 2 \quad 82$

$\begin{array}{lll}\text { PSME } & \text { Douglas-fir } & 1\end{array}$

Shrubs

ALSI2 Sitka Alder

QUSA Sadler Oak

VAME Thinleaf Huckleberry $16 \quad 82$

Herbs \& Grasses

CLUN2 Queens cup $\quad 5 \quad 55$

CHUMO Western Prince's Pine $3 \quad 55$

DACA2 California Pitcher Plant $15 \quad 9$
ENVIRONMENT:

Elevation: 4520-5300 ft.;

Aspect: N., N.E., S.E.;

Slope: $5-55 \%$;

Slope Position: lower 1/3,

bottom, middle $1 / 3$,

Surface Rock: $0-10 \%$

Distance to the Ocean: 19.1-31.4 miles

SOILS:

Pit Depth: $30-38$ in.;

AWC: 3.3-4.4 in.;

Parent Material: mixed

A Horizon:

Coarse Fragments: 25-50\%;

Textures: vgl, xgl;

Thickness: 1-4 in.;

Surface PH: 5.7-6.3 


\section{DISTRIBUTION/ENVIRONMENT:}

This plant association was a minor component in the western portion of the range of Port-Orford-cedar. It covered 119 acres. It was found on the Gasquet Ranger District, Six Rivers National Forest and the Happy Camp Ranger District of the Klamath National Forest. Sites were lower one-third, streamside positions with concave and undulating slope shapes. Mean distance to the Pacific Ocean was 25.6 miles and ranged from 19.1 to 31.4 miles. Elevation averaged 4995 feet and ranged from 4520 to 5300 feet. Slopes were moderately steep averaging $26 \%$ and ranged from $5 \%$ to $55 \%$. Radiation index was a cool .427 as a result of mainly north and northeast aspects.

\section{VEGETATION SUMMARY:}

Total vegetation cover was dense (96\%). It was composed of primarily trees $(68 \%)$ and shrubs (57\%). Port-Orford-cedar (36\%), red fir $(7 \%)$ and white fir $(9 \%)$ dominated the tree layer. Sadler oak (12\%), Sitka alder (29\%) and thinleaf huckleberry (16\%) dominated the shrub layer. Total forb cover was high $(25 \%)$ and included western prince's pine, Hooker's fairybell, braken fern, white-veined wintergreen, queens cup, and white trillium. The grass layer was of low cover $(4 \%)$ and included grass and sedge.

\section{SOIL SUMMARY:}

Soils in this type were frigid, moderately deep and well drained. They formed in alluvium from mixed parent material. The litter layer thickness averaged 0.2 " at $75 \%$ cover. Surface rock and gravel averaged $15 \%$ cover. The average surface horizon thickness was 2", texture was very gravelly and extremely gravelly loams, coarse fragment content averaged $43 \%$ and $\mathrm{pH}$ averaged 6.0 .

Subsoil textures were extremely gravelly loam, coarse fragment content averaged $55 \%$ and $\mathrm{pH}$ averaged 6.1 . The soils were $100 \%$ skeletal.

\section{STAND STRUCTURE SUMMARY:}

Late seral stands in this type often had 3 or more layers of trees, while early mature and mid mature stands usually had 2 layers. Medium sized conifers dominated the top two layers with an average of 13 trees/acre $>21$ inches dbh, 6 trees/ acre $>30$ inches $\mathrm{dbh}$, and 4 trees/acre $>40$ inches $\mathrm{dbh}$. Hardwoods were absent in this type.

The stand structure characteristics by layer were as follows. The top layer averaged 345 years old with an average diameter of 34.9 inches and average height of 110 feet. It was made up of dominant red fir, white fir, Douglas-fir and Port-Orfordcedar. The second layer had an average age of 205 years with a mean diameter of 24.5 inches and a mean height of 85 feet. It included codominant Port-Orford-cedar, white fir and red fir. The third layer had an average age of 125 years with a mean diameter of 20.1 inches and a mean height of 50 feet. The third layer included intermediate Port-Orford-cedar and white fir.

Overall biomass production (conifer + hardwoods + shrubs) was generally high. Modal Dunning site class was 3 with site index of 125 at 300 years. Conifer productivity was generally high with an average volume of $13,798 \mathrm{ft}^{3}$, it ranged from 6085 to $17,252 \mathrm{ft}^{3}$ Softwood basal area averaged $370 \mathrm{ft}^{2}{ }^{2}$ and ranged from 240 to 440 $\mathrm{ft}^{2}$ Stand density index was 547 and fell in the middle of the Port-Orford-cedar series. Quadratic mean diameter was 18.8 inches and fell in the high end of the PortOrford-cedar series. 


\section{CHLA-ABMAS/ALSI2/DACA2 Association, EcoCode: CCOCFR03}

\section{Port-Orford-cedar-Shasta Red Fir/Sitka Alder/California}

\section{Pitcher Plant}
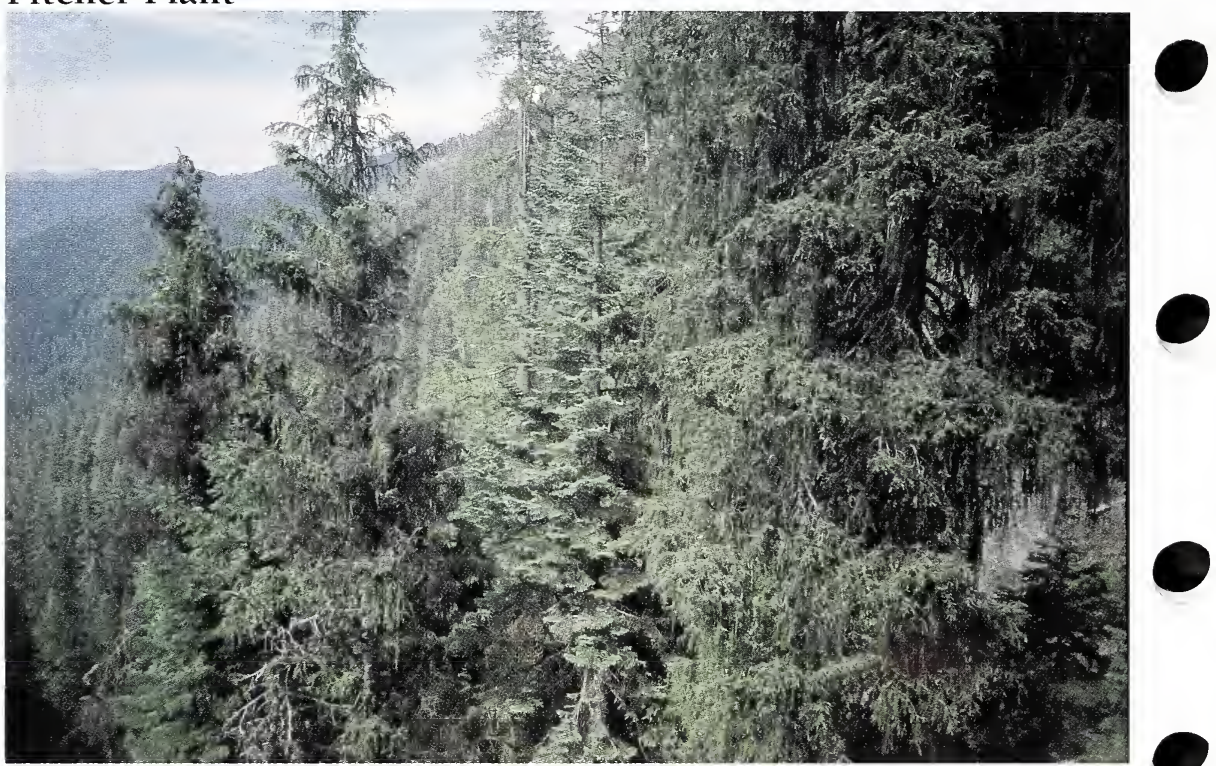

SUMMARY TABLE

(Sample size: 3)

COVER CON

Tree Overstory Layer

CHLA Port-Orford-cedar

ABMAS Shasta Red Fir

TSME Mountain Hemlock

$\begin{array}{rr}26 & 100 \\ 3 & 100 \\ 11 & 67\end{array}$

Tree Understory Layer

CHLA Port-Orford-cedar

ABMAS Shasta Red Fir

TSME Mountain Hemlock

\section{ENVIRONMENT:}

Elevation: 5250-5480 ft;

Aspect: N.W, S.E.;

Slope: $10-15 \%$;

Slope Position: lower 1/3, basin edge, wetland, bottom

Surface Rock: $10 \%$

Distance to the Ocean: 21.6-23.2miles

\section{Shrubs}

$\begin{array}{ll}\text { ALSI2 } & \text { Sitka Alder } \\ \text { RHOC } & \text { Western Azalea }\end{array}$

GAOV Slender Salal

Herbs \& Grasses

$\begin{array}{llrr}\text { GRAM } & \text { Grass species } & 48 & 100 \\ \text { DACA2 } & \text { California Pitcher Plant } & 35 & 100 \\ \text { ALVA } & \text { Pacific Onion } & 3 & 100 \\ \text { SETR } & \text { Woolly Ragwort } & 2 & 100\end{array}$

100

100

100

SOILS:

Pit Depth: 26-35 in;

AWC: 2.8-3.4 in;

Parent Material: mafic

A Horizon:

Coarse Fragments: 10-22\%,

Textures: 1 ;

Thickness: 5-8 in;

Surface PH: 5.5-6.4 


\section{DISTRIBUTION/ENVIRONMENT:}

This plant association was a minor component in the western portion of the range of Port-Orford-cedar. It covered 23 acres. It was found on the Orleans Ranger District, Six Rivers National Forest and the Happy Camp Ranger District of the Klamath National Forest. It was found in draws and along intermittent streams with linear, concave and undulating slope shapes. Mean distance to the Pacific Ocean was 29.5 miles and ranged from 20.2 to 37.2 miles. Elevation averaged 3577 feet and ranged from 2740 to 4320 feet. Slopes were gentle averaging $11 \%$ and ranged from $2 \%$ to $20 \%$. Radiation index was a warm .469 as a result of mainly east aspects, but was moderated by topographic shading.

\section{VEGETATION SUMMARY:}

Total vegetation cover was high ( $89 \%)$ and was composed of trees $(66 \%)$, shrubs (35\%) and forbs (49\%). Port-Orford-cedar (46\%) and Douglas-fir (12\%) dominated the tree layer. Pacific yew was often found here in the lower layers as a small tree. Hazelnut (26\%), western azalea (5\%), wood rose (2\%), trailing blackberry (3\%) and red huckleberry $(1 \%)$ dominated the shrub layer. Total forb cover was very high (49\%) and included vanillaleaf, inside-out flower, Hooker's fairybell, rattlesnake plantain, twinflower and starflower. The grass layer was of low cover (1\%) and included grass and sedge.

\section{SOIL SUMMARY:}

Soils in this type were mesic, moderately deep and well drained. They formed in colluvium from fine textured metamorphic parent material. The litter layer thickness averaged $1.7 \mathrm{l}$ at $76 \%$ cover. Surface rock and gravel averaged $18 \%$ cover. The average surface horizon thickness was 6", texture was extremely gravelly loam, coarse fragment content averaged $63 \%$ and $\mathrm{pH}$ averaged 6.5 .

Subsoil textures were extremely gravelly loam, coarse fragment content averaged $81 \%$ and $\mathrm{pH}$ averaged 6.8 . The soils were $100 \%$ skeletal.

\section{STAND STRUCTURE SUMMARY:}

Late seral stands in this type often had 3 or more layers of trees, while early mature and mid mature stands usually had 2 layers. Large sized conifers dominated the top two layers with an average of 36 trees/acre $>21$ inches $\mathrm{dbh}, 16$ trees/acre $>30$ inches $\mathrm{dbh}$, and 9 trees/acre $>40$ inches dbh. Hardwoods dominated the lower layers and included 30 trees/acre $>5$ inches $\mathrm{dbh}$ and 2 trees/acre $>11$ inches $\mathrm{dbh}$.

The stand structure characteristics by layer were as follows. The top layer averaged 390 years old with an average diameter of 74.7 inches and average height of 215 feet. It was made up of predominant Douglas-fir and Port-Orford-cedar. The second layer had an average age of 262 years with a mean diameter of 29.3 inches and a mean height of 152 feet. It included dominant Port-Orford-cedar and Douglas-fir. The third layer had an average age of 202 years with a mean diameter of 29.1 inches and a mean height of 105 feet. The third layer included intermediate sized PortOrford-cedar.

Overall biomass production (conifer + hardwoods + shrubs) was generally high. Modal Dunning site class was 3 with site index of 125 at 300 years. Conifer productivity was generally moderate with an average volume of $8251 \mathrm{ft}^{3}$, it ranged from 3668 to $14,356 \mathrm{ft}^{3}$ Softwood basal area averaged $240 \mathrm{ft}^{2}$ and ranged from 129 to $387 \mathrm{ft}^{2}$ Hardwood volume averaged $183 \mathrm{ft}^{3}$ and ranged from 0 to $616 \mathrm{ft}^{3}$ Hardwood basal area averaged $13 \mathrm{ft}^{2}$ and ranged from 0 to $32 \mathrm{ft}^{2}$ Stand density index was 426 and fell in the low end of the Port-Orford-cedar series. Quadratic mean diameter was 18.7 inches and fell in the high end of the Port-Orford-cedar series. 
CHLA-PSME-ALRU2/ACCI-BENE1 Association, EcoCode: CCOCD003

Port-Orford-cedar-Douglas-fir-Red Alder/Vine Maple-

Oregon-grape

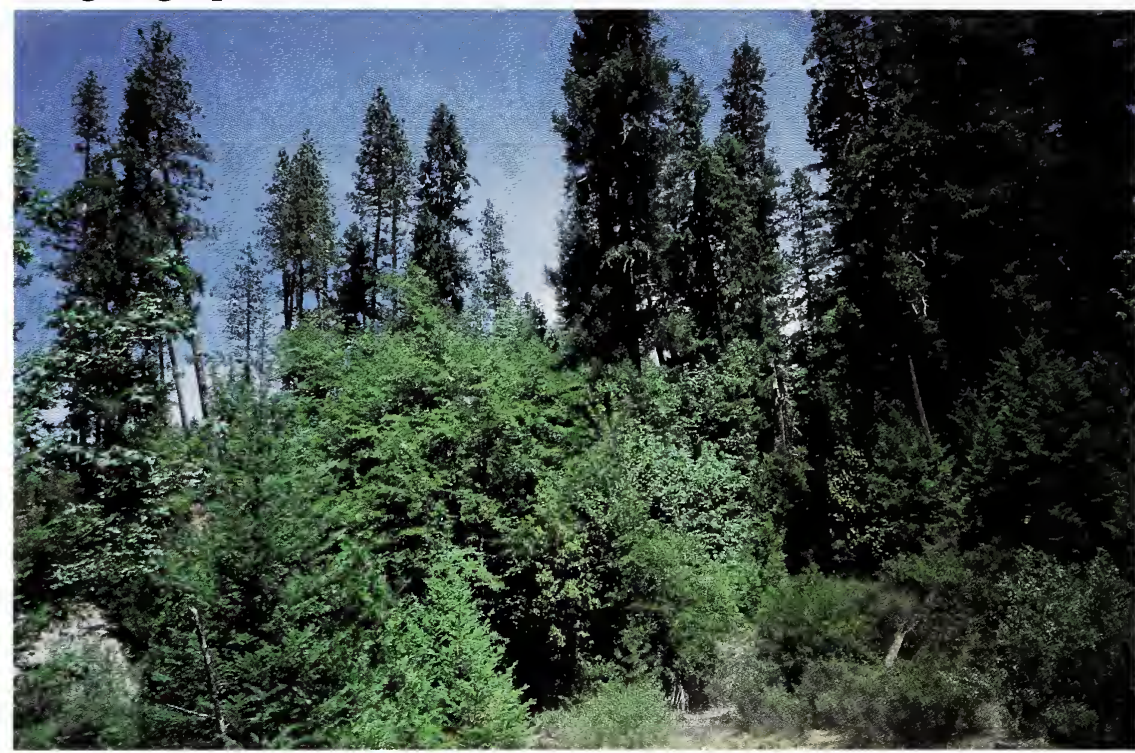

SUMMARY TABLE

(Sample size: 8)

COVER CON

Tree Overstory Layer

CHLA Port-Orford-cedar

PSME Douglas-fir

ALRU2 Red Alder

Tree Understory Layer

CHLA Port-Orford-cedar

PSME Douglas-fir

ALRU2 Red Alder

Shrubs

ACCI Vine Maple $12 \quad 100$

BENE1 Dwarf Oregon-grape $10 \quad 75$

COCOC California Hazelnut $6 \quad 75$

Herbs \& Grasses

POMUl Swordferm

WHMO Western Modesty

TRLA3 Starflower
ENVIRONMENT:

Elevation: 1890-3140 ft.;

Aspect: N., N.E., N.W.;

Slope: 1-30\%;

Slope Position: lower 1/3, draw;

Surface Rock: 25\%

Distance to the Ocean: 18.5-37.6 miles

SOILS:

Pit Depth: 22-34 in.;

AWC: 1.4-2.3 in.;

Parent Material: metamorphic

A Horizon:

Coarse Fragments: $38-57 \%$;

Textures: xgl;

Thickness: 1-4 in.;

Surface PH: 5.3-5.9 


\section{DISTRIBUTION/ENVIRONMENT:}

This plant association was a minor component in the western portion of the range of Port-Orford-cedar. It covered 91 acres. It was found on the Orleans Ranger District, Six Rivers National Forest and the Happy Camp Ranger District of the Klamath National Forest. Sites were in streamside positions with linear, concave and undulating slope shapes. Mean distance to the Pacific Ocean was 32.7 miles and ranged from 18.5 to 37.6 miles. Elevation averaged 2424 feet and ranged from 1890 to 3140 feet. Slopes were gentle averaging $19 \%$ and ranged from $1 \%$ to $30 \%$. Radiation index was a cool .440 as a result of mainly north aspects with topographic shading.

\section{VEGETATION SUMMARY:}

Total vegetation cover was dense (95\%) and was composed of trees (78\%), shrubs $(43 \%)$ and forbs (32\%). Port-Orford-cedar $(21 \%)$, red alder $(33 \%)$ and Douglas-fir $(32 \%)$ dominated the tree layer. Pacific yew was often present here as an understory tree. The shrub layer was dominated by vine maple (12\%), hazelnut $(6 \%)$, dwarf Oregon-grape (10\%), western azalea (10\%) and red huckleberry $(4 \%)$. Total forb cover was high $(32 \%)$ and included vanillaleaf, Hooker's fairybell, swordfern, western modesty and starflower. The grass layer was of low cover $(2 \%)$ and included grass and sedge.

\section{SOIL SUMMARY:}

Soils in this type were mesic, moderately deep and well drained. They formed in alluvium from fine textured metamorphic parent material. The litter layer thickness averaged $0.5^{\prime \prime}$ at $76 \%$ cover. Surface rock and gravel averaged $25 \%$ cover. The average surface horizon thickness was $2 "$, texture was extremely gravelly loam, coarse fragment content averaged $48 \%$ and $\mathrm{pH}$ averaged 5.5 .

Subsoil textures were extremely gravelly loam, coarse fragment content averaged $52 \%$ and $\mathrm{pH}$ averaged 5.7 . The soils were $100 \%$ skeletal

\section{STAND STRUCTURE SUMMARY:}

Late seral stands in this type often had 3 or more layers of trees, while early mature and mid mature stands usually had 2 layers. Small sized conifers dominated the top two layers with an average of 4 trees/acre $>21$ inches dbh and 2 trees/acre $>30$ inches dbh. Hardwoods dominated the lower layers and included 76 trees/acre $>5$ inches $\mathrm{dbh}$ and 22 trees/acre $>11$ inches $\mathrm{dbh}$.

The stand structure characteristics by layer were as follows. The top layer averaged 275 years old with an average diameter of 35.3 inches and average height of 152 feet. It was made up of dominant Douglas-fir and Port-Orford-cedar. The second layer had an average age of 225 years with a mean diameter of 30.1 inches and a mean height of 110 feet. It included codominant Port-Orford-cedar and Douglas-fir. The third layer had an average age of 40 years with a mean diameter of 15.5 inches and a mean height of 71 feet. The third layer included primarily red alder.

Overall biomass production (conifer + hardwoods + shrubs) was generally low. Modal Dunning site class was 2 with site index of 150 at 300 years. Conifer productivity was generally very low with an average volume of $1201 \mathrm{ft}^{3}$, it ranged from 800 to $1534 \mathrm{ft}^{3}$ Softwood basal area averaged $80 \mathrm{ft}^{2}$ and ranged from 50 to 95 $\mathrm{ft}^{2}$ Hardwood volume averaged $320 \mathrm{ft}^{3}$ and ranged from 270 to $360 \mathrm{ft}^{3}$ Hardwood basal area averaged $46 \mathrm{ft}^{2}$ and ranged from 28 to $96 \mathrm{ft}^{2}{ }^{2}$ Stand density index was 425 and fell in the low end of the Port-Orford-cedar series. Quadratic mean diameter was 11.2 inches and fell in the low end of the Port-Orford-cedar series. 


\section{CHLA-PIMO3/RHOC-LIDEE-LEGLl Association,}

EcoCode: COCPW01

Port-Orford-cedar-Western White Pine/Western Azalea-Dwarf Tanbark-Labrador Tea

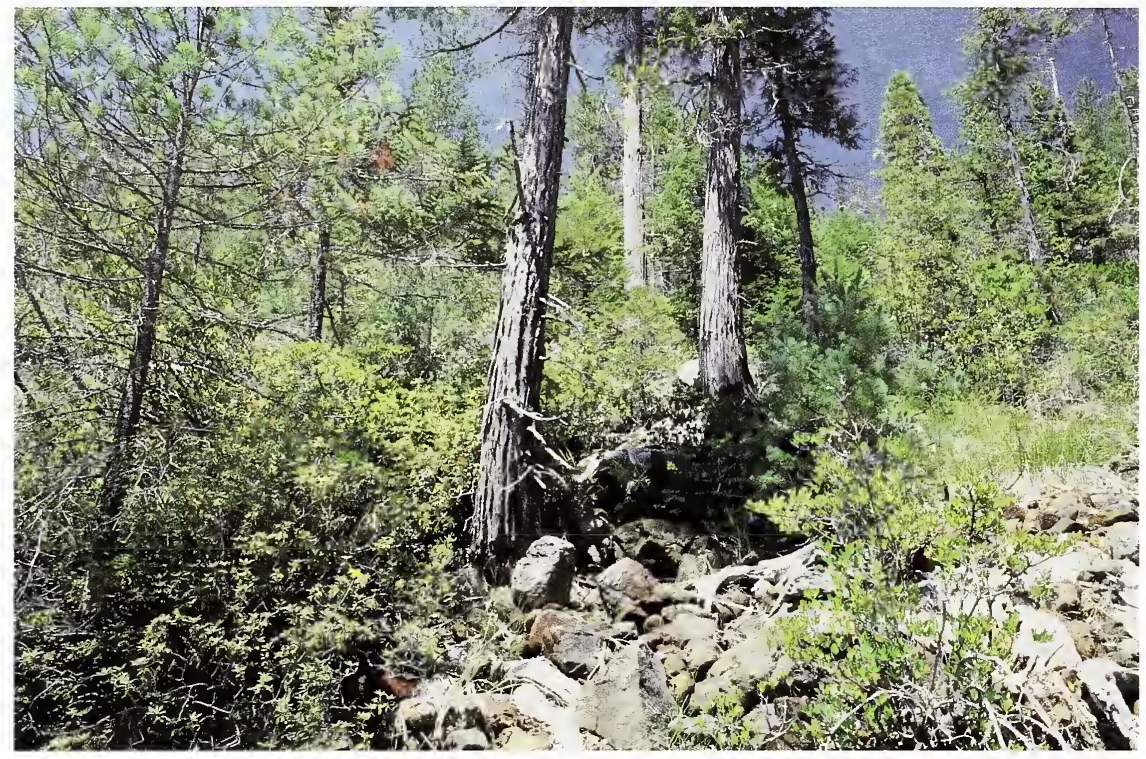

SUMMARY TABLE

(Sample size: 9) COVER CON

\section{Tree Overstory Layer}

CHLA Port-Orford-cedar

PIMO3 Western White Pine

PSME Douglas-fir

Tree Understory Layer

CHLA Port-Orford-cedar

PIMO3 Western White Pine

PSME Douglas-fir

Shrubs

RHOC Western Azalea

LIDEE Dwarf Tanbark

LEGL1 Western Labrador Tea

$\begin{array}{rr}26 & 100 \\ 5 & 100 \\ 22 & 67\end{array}$

Herbs \& Grasses

CARl Sedge

GRAM Grass

ADPEA Five-Finger Fern

TRRI Oregon Trillium

$\begin{array}{rr}33 & 100 \\ 8 & 100 \\ 4 & 78\end{array}$

3100

2100

$1 \quad 22$

\section{ENVIRONMENT:}

Elevation: 1320-3750 ft.;

Aspect: S.E., W., N.;

Slope: $5-27 \%$;

Slope Position: lower $1 / 3$, bottom, draw;

Surface Rock: 2-80\%;

Distance to the Ocean: 8.6-16.5 miles

\section{-

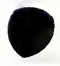

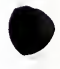

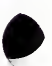




\section{DISTRIBUTION/ENVIRONMENT:}

This plant association was one of the more extensive types in the western portion of the range of Port-Orford-cedar. It covered 706 acres. It was found on the coastal portion of the Gasquet Ranger District, Six Rivers National Forest. Sites were lower one-third slope and stream bottom positions with concave slope shapes. Mean distance to the Pacific Ocean was 12.9 miles and ranged from 8.6 to 16.5 miles. Elevation averaged 2408 feet and ranged from 1320 to 3480 feet. Slopes were gentle averaging $16 \%$ and ranged from $5 \%$ to $27 \%$. Radiation index was a warm .476 as a result of mainly southeast and west aspects.

\section{VEGETATION SUMMARY:}

Total vegetation cover was ( $82 \%)$ and was composed of primarily trees (46\%) and shrubs (58\%). Port-Orford-cedar (33\%), Douglas-fir (4\%) and western white pine $(8 \%)$ dominated the tree layer. The shrub layer was dominated by dwarf tanbark ( $5 \%$ ), labrador-tea (22\%), huckleberry oak (10\%), coffeeberry $(3 \%)$, western azalea (26\%) and red huckleberry (2\%). Total forb cover was low (4\%) and included fivefinger fern, Oregon trillium, inside-out flower and beargrass. The grass layer was of low cover $(11 \%)$ and included a variety of grass and sedge species.

\section{SOIL SUMMARY:}

Soils in this type were mesic, moderately deep and poorly drained. They formed in alluvium from fine textured ultramafic parent material. The litter layer thickness averaged $0.8 "$ at $40 \%$ cover. Surface rock and gravel averaged $56 \%$ cover. The average surface horizon thickness was $2 "$, texture was very gravelly to extremely gravelly loam, coarse fragment content averaged $55 \%$ and $\mathrm{pH}$ averaged 6.3.

Subsoil texture was extremely gravelly loam, coarse fragment content averaged $60 \%$ and $\mathrm{pH}$ averaged 6.5 . The soils were $100 \%$ skeletal.

\section{STAND STRUCTURE SUMMARY:}

Late seral stands in this type often had 3 or more layers of trees, while early mature and mid mature stands usually had 2 layers. Small sized conifers dominated the top two layers with an average of 12 trees/acre $>21$ inches $\mathrm{dbh}$ and 1 trees/acre $>30$ inches dbh. Hardwoods were absent in this type.

The stand structure characteristics by layer were as follows. The top layer averaged 357 years old with an average diameter of 36.1 inches and average height of 125 feet. It was made up of western white pine, Douglas-fir and Port-Orford-cedar. The second layer had an average age of 323 years with a mean diameter of 30.2 inches and a mean height of 83 feet. It included codominant Port-Orford-cedar and western white pine. The third layer had an average age of 218 years with a mean diameter of 17.7 inches and a mean height of 58 feet. The third layer included intermediate sized Port-Orford-cedar.

Overall biomass production (conifer + hardwoods + shrubs) moderate. Modal Dunning site class was 5 with site index of 75 at 300 years. Conifer productivity was generally low with an average volume of $6169 \mathrm{ft}^{3}$, it ranged from 2860 to $11090 \mathrm{ft}$. $^{3}$ Softwood basal area averaged $318 \mathrm{ft}^{2}$ and ranged from 160 to $480 \mathrm{ft}^{2}$ Stand density index was 482 and quadratic mean diameter was 16.6 inches. They both fell at the low end of the Port-Orford-cedar series. 


\section{CHLA-PIMO3/LEGL1/DACA2//COASTAL Association, EcoCode: CCOCPW02 \\ Port-Orford-cedar-Western White Pine/Labrador-Tea/ California Pitcher Plant//Coastal}

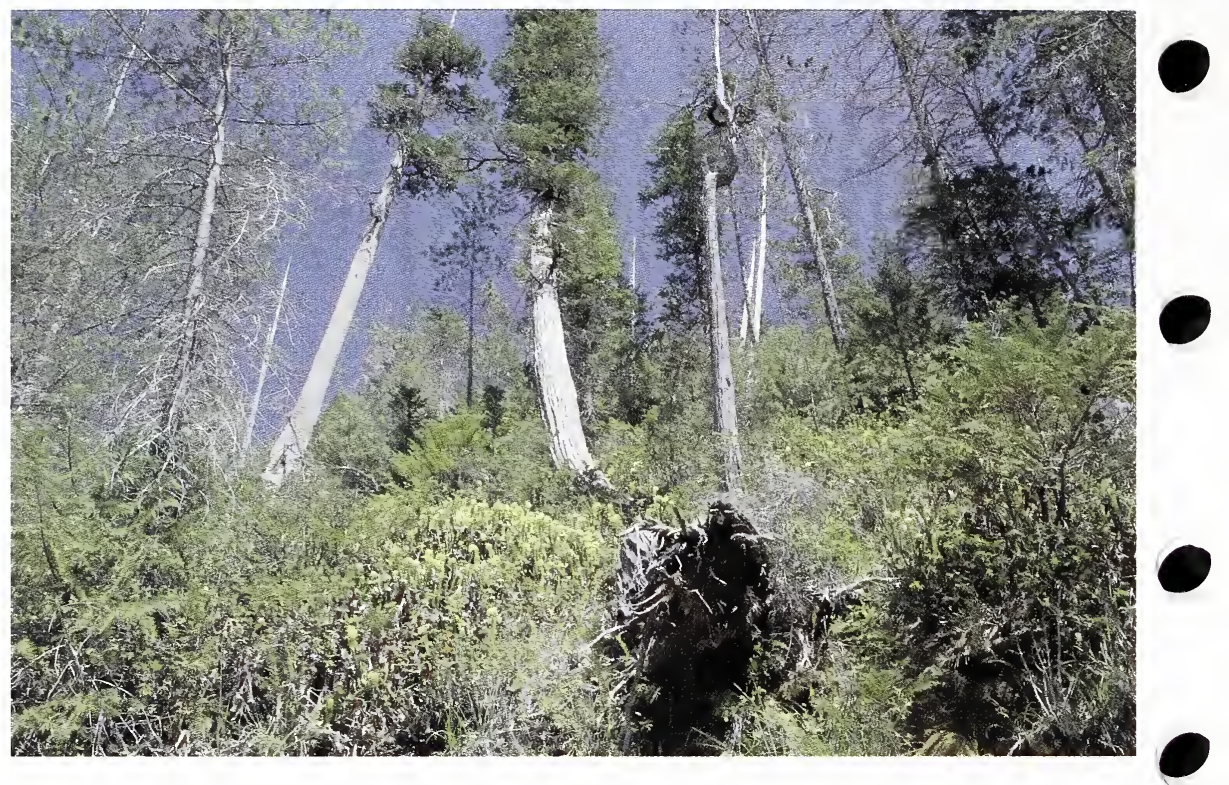

\section{SUMMARY TABLE}

(Sample size: 23)

COVER CON

\section{Tree Overstory Layer}

CHLA Port-Orford-cedar

PIMO3 Western White Pine

$39 \quad 100$

$8 \quad 100$

Tree Understory Layer

CHLA

Port-Orford-cedar

$4 \quad 100$

PIMO3

$\begin{array}{rr}4 & 96\end{array}$

\section{Shrubs}

$\begin{array}{llrr}\text { LEGL1 } & \text { Western Labrador Tea } & 29 & 100 \\ \text { RHOC } & \text { Western Azalea } & 15 & 100 \\ \text { LIDEE } & \text { Dwarf Tanbark } & 8 & 91\end{array}$

Herbs \& Grasses

DACA2 California Pitcher Plant. $11 \quad 91$

$\begin{array}{lll}\text { CARl Sedge } & 23 & 87\end{array}$

GRAM Grass species

ENVIRONMENT:

Elevation: 550-3660 ft.;

Aspect: S.W., N.W., N.E.;

Slope: 1-35\%;

Slope Position: bottom, lower 1/3 draw;

Surface Rock: 1-75\%;

Distance to the Ocean: 8.4-20.2 miles.

SOILS:

Pit Depth: 16-25 in.;

AWC: 1.7-2.6 in.;

Parent Material: ultramafic A Horizon:

Coarse Fragments: 8-17\%;

Textures: 1;

Thickness: $3-5$ in.;

Surface PH: 5.8-6.4 


\section{DISTRIBUTION/ENVIRONMENT:}

This plant association was one of the more extensive types in the western portion of the range of Port-Orford-cedar. It covered 620 acres. It was found on the coastal portion of the Gasquet Ranger District, Six Rivers National Forest. Sites were boggy, lower one-third slope and stream bottom positions, with concave slope shapes. Mean distance to the Pacific Ocean was 13.8 miles and ranged from 8.4 to 20.2 miles. Elevation averaged 2213 feet and ranged from 550 to 3660 feet. Slopes were gentle averaging $18 \%$ and ranged from $1 \%$ to $35 \%$. Radiation index was a warm .481 as a result of mainly southwest aspects.

\section{VEGETATION SUMMARY:}

Total vegetation cover was (87\%) and was composed of trees $(54 \%)$, shrubs $(56 \%)$, grass $(25 \%)$ and forbs (15\%). Port-Orford-cedar (39\%), Douglas-fir $(6 \%)$ and western white pine $(8 \%)$ dominated the tree layer. The shrub layer included dwarf tanbark (8\%), labrador-tea (29\%), huckleberry oak (4\%), coffeeberry (3\%), western azalea (15\%), California bay (4\%) and red huckleberry (2\%). Total forb cover was low $(15 \%)$ and included California pitcher plant, Oregon trillium and beargrass. The grass layer was of high cover $(25 \%)$ and included primarily sedge species.

\section{SOIL SUMMARY:}

Soils in this type were mesic, shallow to moderately deep and poorly drained. They formed in peat or muck from fine textured ultramafic parent material. The litter layer thickness averaged $0.6 "$ at $69 \%$ cover. Surface rock and gravel averaged $27 \%$ cover. The average surface horizon thickness was $4 "$, texture was loam, coarse fragment content averaged $12 \%$ and $\mathrm{pH}$ averaged 6.1 .

Subsoil texture was loam, coarse fragment content averaged 20\% and pH averaged 6.2. The soils were $100 \%$ non-skeletal.

\section{STAND STRUCTURE SUMMARY:}

Late seral stands in this type often had 3 or more layers of trees, while early mature and mid mature stands usually had 2 layers. Small sized conifers dominated the top two layers with an average of 10 trees/acre $>21$ inches dbh and 2 trees/acre $>30$ inches $\mathrm{dbh}$. Hardwoods dominated the lower layers and included 12 trees/acre $>5$ inches dbh.

The stand structure characteristics by layer were as follows. The top layer averaged 299 years old with an average diameter of 35.3 inches and average height of 117 feet. It was made up of western white pine and Port-Orford-cedar. The second layer had an average age of 294 years with a mean diameter of 23.0 inches and a mean height of 83 feet. It included codominant Port-Orford-cedar and western white pine. The third layer had an average age of 207 years with a mean diameter of 15.5 inches and a mean height of 58 feet. The third layer included intermediate sized PortOrford-cedar.

Overall biomass production (conifer + hardwoods + shrubs) was generally low. Modal Dunning site class was 4 with site index of 100 at 300 years. Conifer productivity was generally low with an average volume of $4837 \mathrm{ft}^{3}{ }^{3}$, it ranged from 2430 to $7500 \mathrm{ft}^{3}{ }^{3}$ Softwood basal area averaged $204 \mathrm{ft}^{2}$ and ranged from 120 to 260 $\mathrm{ft}^{2}$ Hardwood volume averaged $73 \mathrm{ft}^{3}$ and ranged from 0 to $100 \mathrm{ft}^{3}$. Hardwood basal area averaged $8 \mathrm{ft}^{2}$ and ranged from 0 to $20 \mathrm{ft}^{2}{ }^{2}$ Stand density index was 404 and fell in the low end of the Port-Orford-cedar series. Quadratic mean diameter was 12.9 inches and fell in the low end of the Port-Orford-cedar series. 


\section{PIJE-CHLA/QUVA Association, EcoCode: CPJCCO001 Jeffrey Pine-Port-Orford-cedar/Huckleberry Oak}
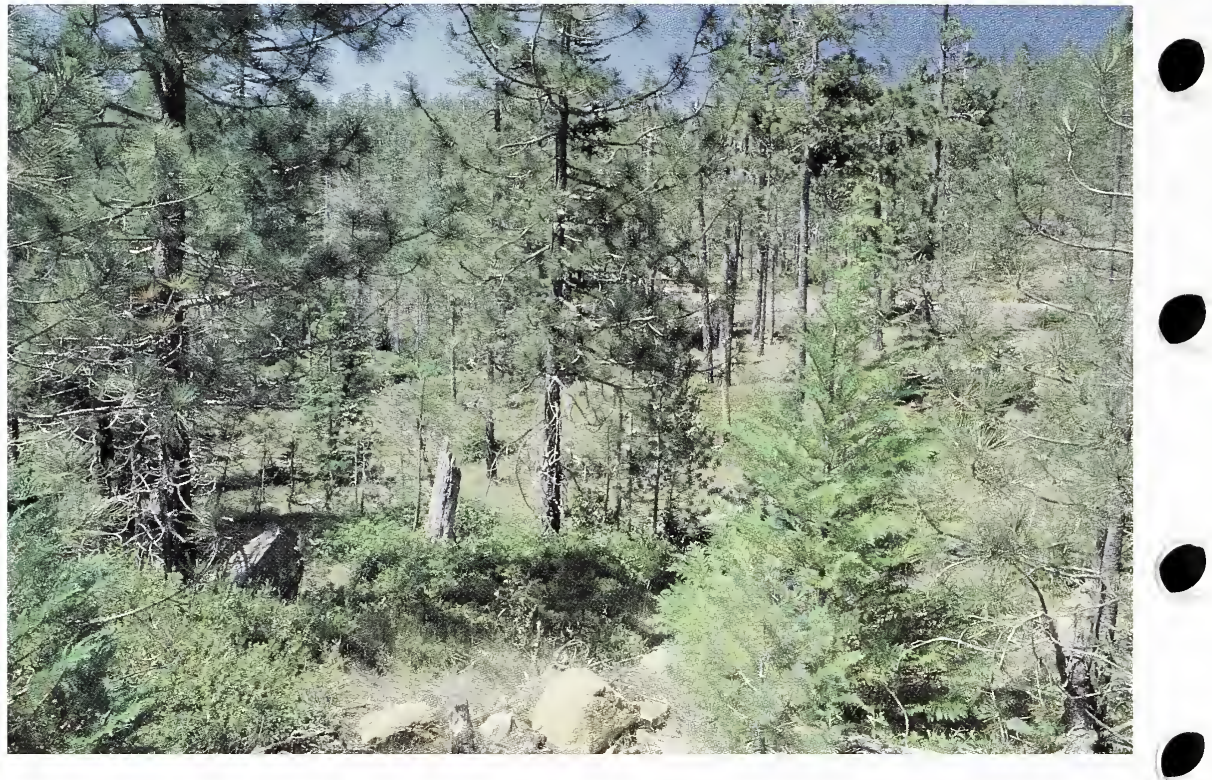

\section{SUMMARY TABLE}

(Sample size: 8)

COVER CON

Tree Overstory Layer

$\begin{array}{lll}\text { PIJE Jeffrey Pine } & 14 & 100\end{array}$

CHLA Port-Orford-cedar $8 \quad 100$

PILA Sugar Pine $\quad 6 \quad 88$

CADE3 Incense Cedar $\quad 3 \quad 88$

Tree Understory Layer

$\begin{array}{llll}\text { PIJE } & \text { Jeffrey Pine } & 88\end{array}$

CHLA Port-Orford-cedar $2 \quad 100$

PILA Sugar Pine $\quad 1 \quad 38$

CADE3 Incense Cedar $\quad 1 \quad 88$

Shrubs

QUVA Huckleberry Oak $27 \quad 100$

ARNE2 Pinemat Manzanita $7 \quad 75$

$\begin{array}{lll}\text { RHCA2 Coffeebery } & 2 & 75\end{array}$

Herbs \& Grasses

$\begin{array}{llll}\text { XETE } & \text { Beargrass } & 7 & 75 \\ \text { IRI } & \text { Iris } & 1 & 50\end{array}$

ENVIRONMENT:

Elevation: 4180-5230 ft.;

Aspect: S.E, S.W., N.W.;

Slope: 5-60\%;

Slope Position: upper 1/3, middle 1/3;

Surface Rock: 1-18\%

Distance to the Ocean: 16.3-31.0 miles
SOILS:

Pit Depth: 15-40+ in.;

AWC: 1.0-6.0 in.;

Parent Material: ultramafic

A Horizon:

Coarse Fragments: $25-35 \%$;

Textures: vgl, gl;

Thickness: $4-5$ in.;

Surface PH: 6.5-7.5 


\section{DISTRIBUTION/ENVIRONMENT:}

This plant association was a minor component in the western portion of the range of Port-Orford-cedar. It covered 210 acres. It was found on the Orleans Ranger District, Six Rivers National Forest and the Ukonom and Happy Camp Ranger Districts of the Klamath National Forest. Sites were in upper and middle one-third slope positions with linear and undulating slope shapes. Mean distance to the Pacific Ocean was 23.2 miles and ranged from 16.3 to 31.0 miles. Elevation averaged 4689 feet and ranged from 4180 to 5230 feet. Slopes were typically moderately steep averaging $34 \%$ and ranged from 5\% to $60 \%$. Radiation index was a warm .512 as a result of mainly south aspects.

\section{VEGETATION SUMMARY:}

Total vegetation cover was moderate $(76 \%)$ and was composed of a sparse tree layer $(38 \%)$ and moderate shrub layer $(41 \%)$. The tree layer was dominated by Jeffrey pine $(14 \%)$ and Port-Orford-cedar ( $8 \%)$. The shrub layer was dominated by huckleberry oak (27\%) and pinemat manzanita (7\%). Total forb cover was low (8\%) and included beargrass, iris and white-veined wintergreen. The grass layer was of low cover $(1 \%)$ and included grass and sedge.

\section{SOIL SUMMARY:}

Soils in this type were frigid, shallow to deep and well drained. They formed in bedrock from fine textured ultramafic parent material. The litter layer thickness averaged $1.3 "$ at $90 \%$ cover. Surface rock and gravel averaged $9 \%$ cover. The average surface horizon thickness was 4", texture was gravelly and very gravelly loams, coarse fragment content averaged $30 \%$ and $\mathrm{pH}$ averaged 7.2.

Subsoil textures were gravelly and extremely gravelly clay loams, coarse fragment content averaged $43 \%$ and $\mathrm{pH}$ averaged 7.6. The soils were $65 \%$ skeletal.

\section{STAND STRUCTURE SUMMARY:}

Late seral stands in this type often had 3 or more layers of trees, while early mature and mid mature stands usually had 2 layers. Medium sized conifers dominated the top two layers with an average of 28 trees/acre $>21$ inches $\mathrm{dbh}$ and 7 trees/acre $>30$ inches dbh. Hardwoods were absent in this type.

The stand structure characteristics by layer were as follows. The top layer averaged 404 years old with an average diameter of 45.3 inches and average height of 121 feet. It was made up of dominant Jeffrey pine and Port-Orford-cedar. The second layer had an average age of 208 years with a mean diameter of 21.6 inches and a mean height of 69 feet. It included codominant Port-Orford-cedar and Jeffrey pine. The third layer had an average age of 55 years with a mean diameter of 8.4 inches and a mean height of 30 feet. The third layer included small sized Port-Orford-cedar.

Overall biomass production (conifer + hardwoods + shrubs) was generally low.

Modal Dunning site class was 4 with site index of 100 at 300 years. Conifer productivity was generally low with an average volume of $5214 \mathrm{ft}^{3}$, it ranged from 3216 to $7188 \mathrm{ft}^{3}{ }^{3}$ Softwood basal area averaged $182 \mathrm{ft}^{2}$ and ranged from 133 to 227 $\mathrm{ft}^{2}$ Stand density index was 325 and fell in the low end of all types containing PortOrford-cedar. Quadratic mean diameter was 11.2 inches and fell in the low end of all Port-Orford-cedar types. 
0

0

0

-

.

.

- 


\section{LITERATURE CITED}

○

○

○

-

○

○ 


\section{LITERATURE CITED}

Abrams, L. 1968. Illustrated flora of the Pacific States: Washington, Oregon, and California. Stanford University Press. Stanford, CA. Vols 1-4.

Allen, Barbara H. 1987. Ecological type classification for California: the Forest Service approach. Gen. Tech. Rep. PSW-98. Berkeley, CA: Pacific Southwest Forest and Range Experiment Station, Forest Service, U.S. Department of Agriculture; 8 p.

Atzet, T. and D.L. Wheeler. 1984. Preliminary plant associations of the Siskiyou Mountain province. Portland, OR: Pacific Northwest Regional Office, Forest Service, U.S. Department of Agriculture; 315 p.

Dunning, D. 1942. A site classification for the mixed-conifer selection forests of the Sierra Nevada. USDA Forest Service California Forest and Range Experiment Station. Res. Note 28. Berkeley, CA. 21 p.

Edwards, S.W. 1983. Cenozoic history of Alaskan and Port-Orford Chamaecyparis cedars. Ph.D. dissertation. University of California, Berkeley, CA. 271 p.

Frank, E.C. and R. Lee. 1966. Potential solar beam irradiation on slopes: Tables for 30 to 50 latitude. Res. Paper RM-18. Ft. Collins, Colorado: Rocky Mountain Forest and Range Experiment Station, Forest Service, U.S. Department of Agriculture; 102 p.

Hunter, M.L. 1991. Coping with ignorance: the coarse-filter strategy for maintaining biodiversity. pp. 292-317. In: W.C. Clark and R.E. Munn (eds). Sustainable Development of the Biosphere. Cambridge University Press, Cambridge, U.K. 491 p.

Jimerson, T.M. 1989. Snag densities in old-growth stands on the Gasquet Ranger District, Six Rivers National Forest, California. Res. Paper PSW-196. Berkeley, CA: Pacific Southwest Forest and Range Experiment Station, Forest Service, U.S. Department of Agriculture; 12 p.

Jimerson, T.M. and M. Creasy. 1990. A preliminary vegetation classification for Port-Orford cedar in Northwest California. USDA Forest Service, Six Rivers National Forest, Eureka, CA. 145 p. 
Jimerson, T.M. and M. Creasy. 1991. Variation in Port-Orford cedar plant communities along primary environmental gradients in Northwest California. pp 122-133, In: Proceedings of the Symposium on Biodiversity of Northwestern California. R.R. Harris, D.C. Erman, and H.M. Kerner, Tech. Coords. University of California, Berkeley, CA. 308 p.

Jimerson, T.M. In Press. Vegetation series of Northwest California.

McClellan, R. 1986. Learning to Care. Unpublished manuscript. McKinleyville, CA.

Munz, P.A. and D.D. Keck. 1973. A California flora. University of California Press, Berkeley, CA. 1681 p.

Noss, R.F. 1987. From plant communities to landscapes in conservation inventories: a look at the Nature Conservancy (USA). Biological Conservation 41 (1): 11-37.

Reed, M.J., W.R. Powell, and B.S. Bal. 1963. Electronic data processing codes for California wildland plants. Research Note PSW-N20. Berkeley, CA: Pacific Southwest Forest and Range Experiment Station, Forest Service, U.S. Department of Agriculture; 314 p.

Roth, L.F., R.D. Harvey, Jr., and J.T. Kliejunas. 1987. Port-Orford cedar root disease. R6 Forest Pest Management. PR 010 91. Portland: U.S. Department of Agriculture, Forest Service, Pacific Northwest Region; 11p.

USDA, 1992. Strategy for implementing ecosystem management. Pacific Southwest Region, Forest Service, U.S. Department of Agriculture. 17 p.

Zobel, D.B. L.F. Roth, and G.L. Hawk. 1985. Ecology, pathology and management of Port-Orford cedar (Chamaecyparis lawsoniana). USDA Forest Service Gen. Tech. Rep. PNW-184. Pacific Northwest Forest and Range Experiment Station Portland, OR. 161 p. 
-

○

-

-

.

-

- 
APPENDIX I: PLANT SPECIES LIST

$\bullet$

○

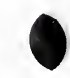

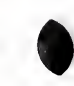

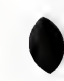




\section{Plant Species List}

Tree Species

Species

Abies concolor

Abies magnifica var. shastensis

Acer macrophyllum

Alnus oregona

Alnus rubra

Alnus rhombifolia

Arbutus menziesii

Castanopsis chrsophylla

Chamaecyparis lawsoniana

Chamaecyparis nootkatensis

Cornus nuttallii

Libocedrus decurrens

Calocedrus decurrens

Lithocarpus densiflora

Picea breweriana

Pinus attenuata

Pinus contorta

Pinus jeffreyi

Pinus lambertiana

Pinus monticola

Pinus ponderosa

Pseudotsuga menziesii

Quercus chrysolepis

Quercus kelloggii

Rhamnus purshiana

Sequoia sempervirens

Taxus brevifolia

Thuja plicata

Tsuga mertensiana

Tsuga heterophylla

Umbellularia californica
EDPcode CommonName

ABCO White fir

ABMAS Shasta red fir

ACMA Bigleaf maple

ALOR Red alder

ALRU2 Red alder

ALRH White alder

ARME3 Madrone

$\mathrm{CACH} 2$ Chinquapin

CHLA Port-Orford-cedar

CHNO Alaska Yellow cedar

CONU2 Pacific dogwood

LIDE3 Incense cedar

CADE3 Incense cedar

LIDE2 Tanoak

PIBR Brewer's spruce

PIAT1 Knobcone pine

PICOl Lodgepole pine

PIJE Jeffrey pine

PILA Sugar pine

PIMO3 Western white pine

PIPO Ponderosa pine

PSME Douglas-fir

QUCH2 Canyon live oak

QUKE Black oak

RHPU Cascara

SESE2 Redwood

TABR Pacific yew

THPL Western Red Cedar

TSME Mountain hemlock

TSHE Western hemlock

UMCA California bay (laurel)
Shrub Species

\author{
Acer circinatum \\ Acer glabrum var. torreyi \\ Alnus sinuata \\ Amelanchier alnifolia \\ Amelanchier spp.
}

$\begin{array}{ll}\text { ACCI } & \text { Vine maple } \\ \text { ACGLT } & \text { Rocky Mtn. maple } \\ \text { ALSI2 } & \text { Sitka alder } \\ \text { AMAL } & \text { Saskatoon Serviceberry } \\ \text { AME } & \text { Serviceberry }\end{array}$

$70-\mathrm{g}$ 
Arctostaphylos nevadensis

Arctostaphylos patula

Arctostaphylos viscida

Berberis nervosa

Berberis pumila

Berberis repens

Ceanothus integerrimus

Ceanothus prostratus

Ceanothus velutinus

Corylus cornuta var. californica

Cornus stolonifera

Euonymus occidentalis

Garrya buxifolia

Garrya fremontia

Gaultheria ovatifolia

Gaultheria shallon

Holodiscus discolor

Juniperus communis

Ledum glandulosum

Ledum glandulosum var. californicum

Lithocarpus densiflorus var. echinoides

Lonicera hispidula var. vacillans

Myrica californica

Osmaronia cerasiformis

Paxistima myrsinites

Phyllodoce emperiformis

Physocarpus capitatus

Prunus emarginata

Quercus sadleriana

Quercus vaccinifolia

Rhamnus californica

Rhododendron macrophyllum

Rhododendron occidentalis

Rhus (Toxicodendron) diversiloba

Ribes bracteosum

Ribes cereum

Ribes lobbii

Ribes sanguineum

Ribes velutinum var. glanduliferum

Ribes viscosissimum var. hallii

Ribes spp.

Rosa gymnocarpa

Rosa pisocarpa

Rosa spp.

Rubus glaucifolius
ARNE2

ARPA9

ARVI3

BENE1

BEPU

BERE

CEIN3

CEPR

CEVE3

COCOC

cost 3

EUOC3

GABU2

GAFR

GAOV

GASH

HODI

JUCO

LEGL1

LEGLC

LIDEE

LOHIV

MYCA

OSCE

PAMY

PHEM

PHCA8

PREM

QUSA

QUVA

RHCA

RHMA

RHOC

RHDI

RIBR

RICE

RILO

RISA

RIVEG

RIVIH

RIB

ROGY

ROPI

ROS

RUGL
Pinemat manzanita

Greenleaf manzanita

Whiteleaf manzanita

Dwarf Oregon-grape

Pygmy Oregon-grape

Creeping Oregon-grape

Deer brush

Squaw carpet

Snow brush

Hazel/Calfornia Hazelnut

Creek dogwood

Western burningbush

Box-leaved silktassel

Fremont's silktassel

Slender salal

Salal

Ocean spray

Common juniper

Western Labrador tea

Labrador tea

Dwarf tanbark oak

Hairy honeysuckle

Wax-myrtle

Oso berry

Oregon boxwod

Pink Mountain heath

Pacific ninebark

Bitter cherry

Sadler oak

Huckleberry-oak

Coffeeberry

Pacific rhododendron

Western azalea

Poison oak

Stink currant

Squaw currant

Lobb's gooseberry

Red-flowering currant

Desert gooseberry

Sticky currant

Gooseberry

Baldhip/wood rose

Cluster rose

Rose

Smoothleaf raspberry 
Rubus lasiococcus

Rubus leucodermis

Rubus parviflorus

Rubus ursinus

Salix scouleriana

Salix sp.

Smilax californica

Sorbus californica

Sorbus cascadensis

Spirea densiflora

Spirea douglasii

Symphoricarpos mollis

Symphoricarpos rivularis

Umbellaria californica

Vaccinium ovatum

Vaccinium membranaceum

Vaccinium parvifolium

Vaccinium scoparium
RULA Dwarf blackberry

RULE Whitebark raspberry

RUPA2 Thimbleberry

RUUR Trailing blackberry

SASC Scouler's willow

SAL13 Willow species

SMCA Greenbrier

SOCA8 California mountain-ash

SOCA3 Cascade mountain-ash

SPDE Spirea

SPDO Douglas' spirea

SYMO Creeping snowberry

SYRI Streamside snowberry

UMCAl California bay (shrub)

VAOV Evergreen huckleberry

VAME Thin-leaf huckleberry

VAPA Red huckleberry

VASC Little-leaf/Grouse huckleberry

Herb and Fern Species

Actea rubra var. arguta

Achlys triphylla

Adenocaulon bicolor

Adiatum pedatum var. aleuticum

Agasta cheurticifolia

Allium validum

Anemone deltoidea

Anemone quiquefolia var. oregana

Angelica arguta

Apocynum androsaemifolium

Apocynum pumilum

Aquilegia formosa

Aralia californica

Arnica discoidea

Asarum caudatum

Aster ledophyllus

Athyrium felix-femina

Blechnum spicant

Boykinia major

Boschniakia strobilacea

Calypso bulbosa

Campanula prenanthoides

Campanula scouleri

Chimaphilla menziesii

$\begin{array}{ll}\text { ACRUA } & \text { Baneberry } \\ \text { ACTR } & \text { Vanillaleaf } \\ \text { ADBI } & \text { Trailplant } \\ \text { ADPEA } & \text { Five-finger fern } \\ \text { AGUR } & \text { Nettle-leaf giant-hyssop } \\ \text { ALVA } & \text { Bog/Pacific onion } \\ \text { ANDE } & \text { Three-leaf anemone } \\ \text { ANQUO } & \text { Oregon windflower } \\ \text { ANAR3 } & \text { Sharptooth angelica } \\ \text { APAN } & \text { Spreading dogbane } \\ \text { APPU } & \text { Dogbane } \\ \text { AQFO } & \text { Red columbine } \\ \text { ARCA2 } & \text { California spikenard } \\ \text { ARDI3 } & \text { Discoid arnica } \\ \text { ASCA2 } & \text { Wild ginger } \\ \text { ASLE7 } & \text { Aster } \\ \text { ATFIC } & \text { Lady fern } \\ \text { BLSP } & \text { Deer fern } \\ \text { BOMA2 } & \text { Mountain boykinia } \\ \text { BOST2 } & \text { Ground-cone } \\ \text { CABU2 } & \text { Calypso orchid } \\ \text { CAPR6 } & \text { California harebell } \\ \text { CASC4 } & \text { Scouler's harebell } \\ \text { CHME2 } & \text { Little prince's-pine }\end{array}$


Chimaphilla umbellata v. occidentalis CHUMO Clintonia uniflora

Convolvulus polymorpha

Corallorhiza spp.

Corallorhiza maculata

Corallorhiza mertensiana

Corallo rhizastriata

Cynoglossum grande

Cypripedium californicum

Darlingtonia californica

Dentaria californica

Dicentra formosa

Disporum hookeri

Disporum smithii

Eburophyton austinae

Epilobium angustifolium

Equisetum arvense

Equisetum telmateia var. braunii

Erythronium californicum

Erythronium grandiflorum v. pallidum ERGRP

Frasera albicaulis var. nitida

Fragaria californica

Fritillaria lanceolata

Galium ambiguum

Galium aparine

Galium triflorum

Goodyera oblongifolia

Habenaria spp.

Habenaria unalascensis

Hemitomes congestum

Heuchera micrantha var. erubescens HEMIE

Hiericium albiflorum

Iris spp.

Iris chrysophylla

Iris innominata

Iris tenuissima

Kelloggia galioides

Lathyrus spp.

Linnea borealis

Lilium spp.

Lilium bolanderi

Lilium columbianum

Lilium volmeri

Lilium washingtonianum v. purpurascens LIWAP

Lilium wigginsii
CLUN2

$\mathrm{COPO}$

COR2

COMA4

COME

COST 1

CYGR

CYCA2

DACA2

DECA4

DIFO

$\mathrm{DIHO} 2$

DISM

EBAU

EPAN2

EQAR

EQTEB

ERCA4

FRALN

FRCA1

FRLA1

GAAM

GAAP

GATR2

GOOB

$\mathrm{HAB}$

HAUN 1

HECO1

HIAL

IRI

IRCH

IRIN

IRTE

KEGA

LAT 1

LIBOL

LIL2

LIBO1

LICO 1

LIVO

LIWI
Western prince's pine

Queens cup

Morning glory

Coral-root

Spotted coral-root

Western coral-root

Striped coral-root

Hound's-tongue

California lady-slipper

California pitcher-plant

Toothwort

Bleeding-heart

Hooker's fairy-bell

Smith's fairy-bell

Phantom-orchid

Fireweed

Common horsetail

Giant horsetail

California fawn-lily

Large-flowered fawn-lily

White-margin green-gentian

Wild strawberry

Checker-lily

Bedstraw

Bedstraw

Bedstraw

Rattlesnake-plantain

Bog/Rein Orchid

Green bog/rein-orchid

Gnome plant

Alum-root

White hawk-weed

Iris species

Slender-tubed iris

Iris

Iris

Kelloggia

Pea

Twinflower

Lily

Bolander's lily

Columbia lily

Volmer's lily

Washington lily

Wiggin's lily 


\begin{tabular}{|c|c|c|}
\hline Listera caurina & LICA4 & Twayblade \\
\hline Listera convallarioides & $\mathrm{LICO} 4$ & Twayblade \\
\hline Lotus spp. & LOT3 & Lotus \\
\hline Lupinus spp. & LUP3 & Lupine \\
\hline Mitella spp. & MIT3 & Bishop's-cap \\
\hline Mitella ovalis & MIOV & Bishop's-cap \\
\hline Mitella trifida & MITR3 & Bishop's-cap \\
\hline Monardella odoratissima & MOOD & Mountain pennyroyal \\
\hline Onychium densum & ONDE & Cliff-brake \\
\hline Osmorhiza chilensis & $\mathrm{OSCH}$ & Sweet-cicely \\
\hline Oxalis oregana & OXOR & Redwood sorrel \\
\hline Pedicularis racemosa & PERAl & Leafy pedicularis \\
\hline Penstemon anquineus & PEAN2 & Tongue-leaved penstemon \\
\hline Penstemon deustus & PEDE2 & Hot-rock penstemon \\
\hline Penstemon newberryi & PENEl & Newberry's penstemon \\
\hline Petasites palmatus & PEPA6 & Coltsfoot \\
\hline Phlox adsurgens & PHAD2 & Woodland phlox \\
\hline Pleuricosporam fimbriolata & PLFI & Pinesap \\
\hline Polygala californica & POCA8 & California milkwort \\
\hline Polygala cornuta & POCO6 & Milkwort \\
\hline Polygonum phytolaccaefolium & POPH & Alpine knotweed \\
\hline Polypodium glycerrhiza & POGL1 & Licorice fern \\
\hline Polystichum munitum & POMU1 & Sword fern \\
\hline Polystichum munitum var. imbricans & POMUI & Imbricated swordfern \\
\hline Prunella vulgaris & PRVU & Self-heal \\
\hline Psoralea physodes & PSPH & California tea \\
\hline Pteridium aquilinum v. lanuginosum & PTAQL & Bracken fern \\
\hline Pyrola assarifolia v. purpurea & PYASP & Liverleaf pyrola \\
\hline Pyrola picta & PYPI & White-veined wintergreen \\
\hline Pyrola picta var. aphylla & PYPIA & Leafless pyrola \\
\hline Pyrola picta var. dentata & PYPID & Toothleaf pyrola \\
\hline Pyrola secunda & PYSE & One-sided wintergreen \\
\hline Sarcodes sanquinea & SASA3 & Snow plant \\
\hline Sedum spp. & SED & Stonecrop \\
\hline Sedum laxum var. flavidum & SELAF & Pale Trinity stonecrop \\
\hline Sedum pathulifolium & SESP2 & Spatula-leaf stonecrop \\
\hline Senecio triangularis & SETR & Woolly ragwort \\
\hline Sidalcea malvaeflora & SIMA1 & Mallow-leafed checker \\
\hline Silene californica & SICA2 & California campion \\
\hline Smilacena racemosa v. amplexicaulis & SMRAA & Western Solomon-seal \\
\hline Smilacena stellata & SMST & Starry Solomon-seal \\
\hline Streptopus amplexifolius denticulatus & STAMD & Twisted stalk \\
\hline Stachys rigida var. lanata & STRIL & Hedge-nettle \\
\hline Synthyris reniformis var. cordata & SYREC & Snow-queen \\
\hline
\end{tabular}

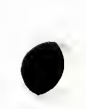




$\begin{array}{lll}\text { Thermopsis macrophylla } & \text { THMA } & \text { False-lupine } \\ \text { Tiarella trifoliata } & \text { TITR } & \text { Coolwort foamflower } \\ \text { Tiarella unifoliata } & \text { TIUN } & \text { Foamflower } \\ \text { Tolmiea menziesii } & \text { TOME } & \text { Tolmiea } \\ \text { Trifolium howellii } & \text { TRHO } & \text { Howell's clover } \\ \text { Trifolium longipes } & \text { TRLO } & \text { Long-stalked clover } \\ \text { Trientalis latifolia } & \text { TRLA3 } & \text { Starflower } \\ \text { Trillium ovatum } & \text { TROV2 } & \text { White trillium } \\ \text { Trillium rivale } & \text { TRRI } & \text { Oregon trillium } \\ \text { Valerianella carinata } & \text { VACA4 } & \text { European cornsalad } \\ \text { Vancouveria chrysantha } & \text { VACH } & \text { Yellow inside-out flower } \\ \text { Vancouveria hexandra } & \text { VAHE } & \text { Inside-out flower } \\ \text { Vancouveria planipetala } & \text { VAPL } & \text { Coast inside-out flower } \\ \text { Veratrum californicum } & \text { VECA1 } & \text { California false-hellebore } \\ \text { Veratrum viride } & \text { VEVIl } & \text { Green false-hellebore } \\ \text { Vicia americana var. occidentalis } & \text { VIAMO } & \text { American vetch } \\ \text { Viola glabella } & \text { VIGL } & \text { Stream violet } \\ \text { Viola lobata } & \text { VILO } & \text { Palmately lobed violet } \\ \text { Viola sempervirens } & \text { VISE } & \text { Redwood violet } \\ \text { Viola sheltonii } & \text { VISH } & \text { Shelton's violet } \\ \text { Whipplea modesta } & \text { WHMO } & \text { Western modesty } \\ \text { Woodwordia fimbriata } & \text { WOFI } & \text { Woodwardia fern } \\ \text { Xerophyllum tenax } & \text { XETE } & \text { Beargrass } \\ & & \end{array}$

Grass, Sedge, and Rush Species

Bromus spp.

Bromus carinatus var.californica

Bromus marginatus

Bromus pacificus

Bromus vulgaris

Calamagrostis koelerioides

Carex sp.

Carex echinata

Elymus glaucus

Festuca species

Festuca californica

Festuca idahoensis

Festuca occidentalis

Festuca subulata

Graminoid species

Hierochloe occidentalis

Juncus spp.

Luzula spp.
BRO3 Brome grass

BRCA1 California brome

BRMA3 Brome

BRPA Pacific brome

BRVU Columbia brome

CAKO Reed grass

CAR1 Sedge

CAOR Prickly Sedge

ELGL Wild-rye

FES2 Fescue

FECA California fescue

FEID Idaho fescue

FEOCl Western fescue

FESU1 Bearded fescue

GRAM Grass species

HIOC California sweet grass

JUN2 Rush species

LUZ Wood rush 
Grass, Sedge and Rush Species (cont'd)

Luzula comosa

Melica aristata

Melica subulata

Poa pratensis
LUCO1 Hairy wood rush

MEAR1 Bearded onion grass

MESU Alaska onion grass

POPRl Kentucky blue grass 


\section{APPENDIX II: ENVIRONMENT SUMMARY}




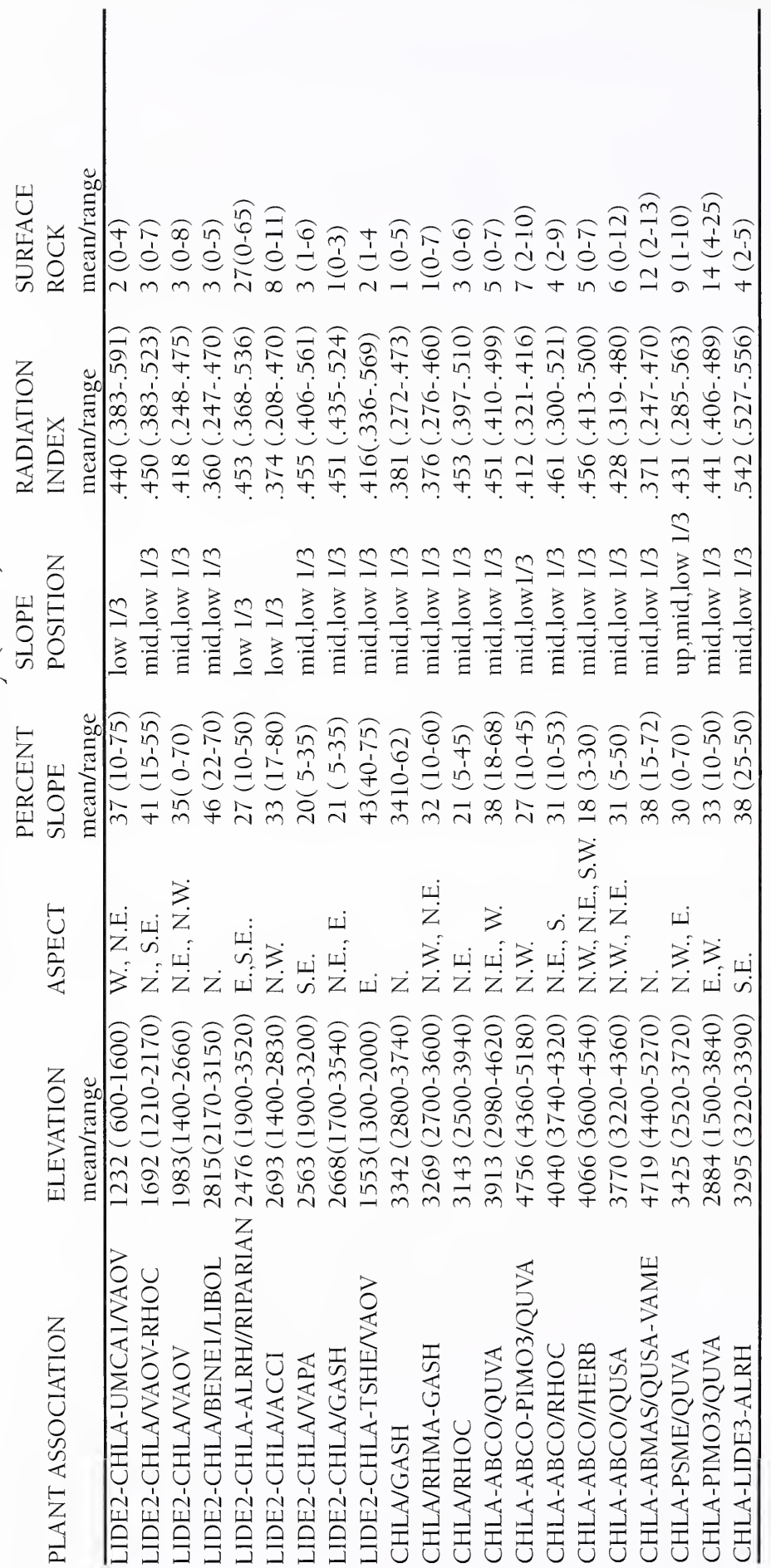




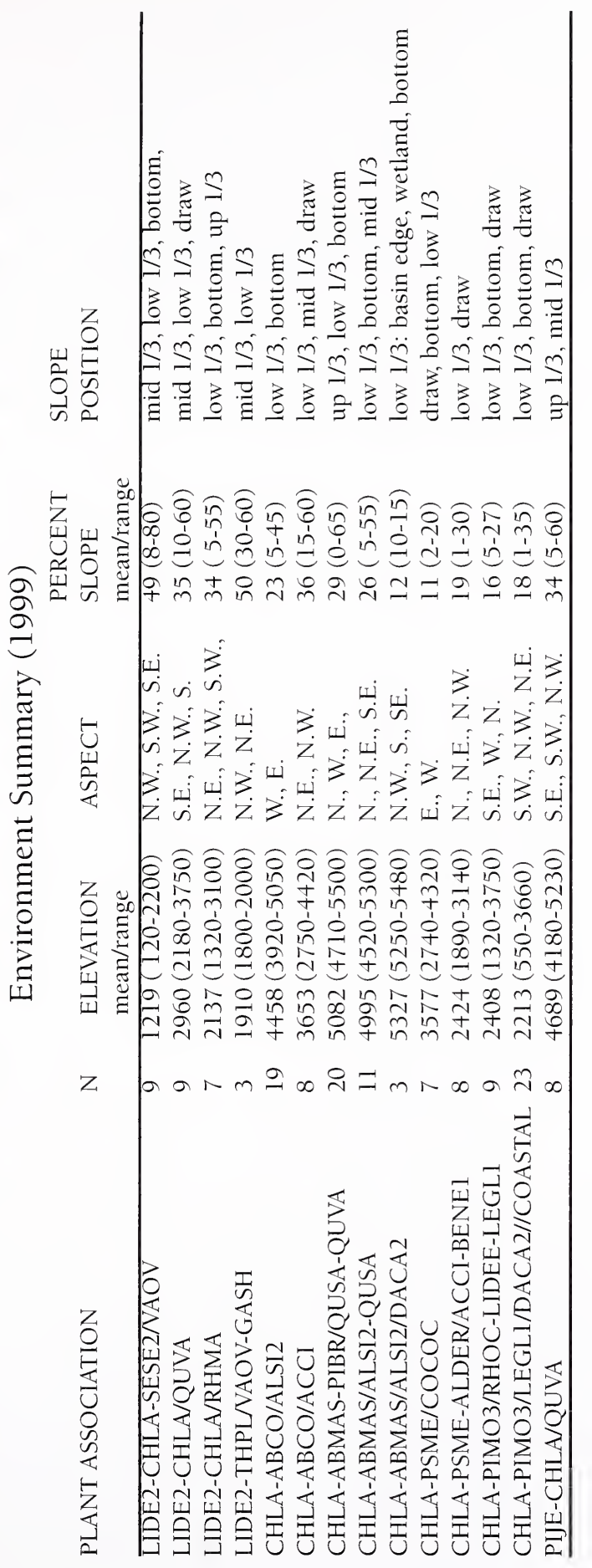




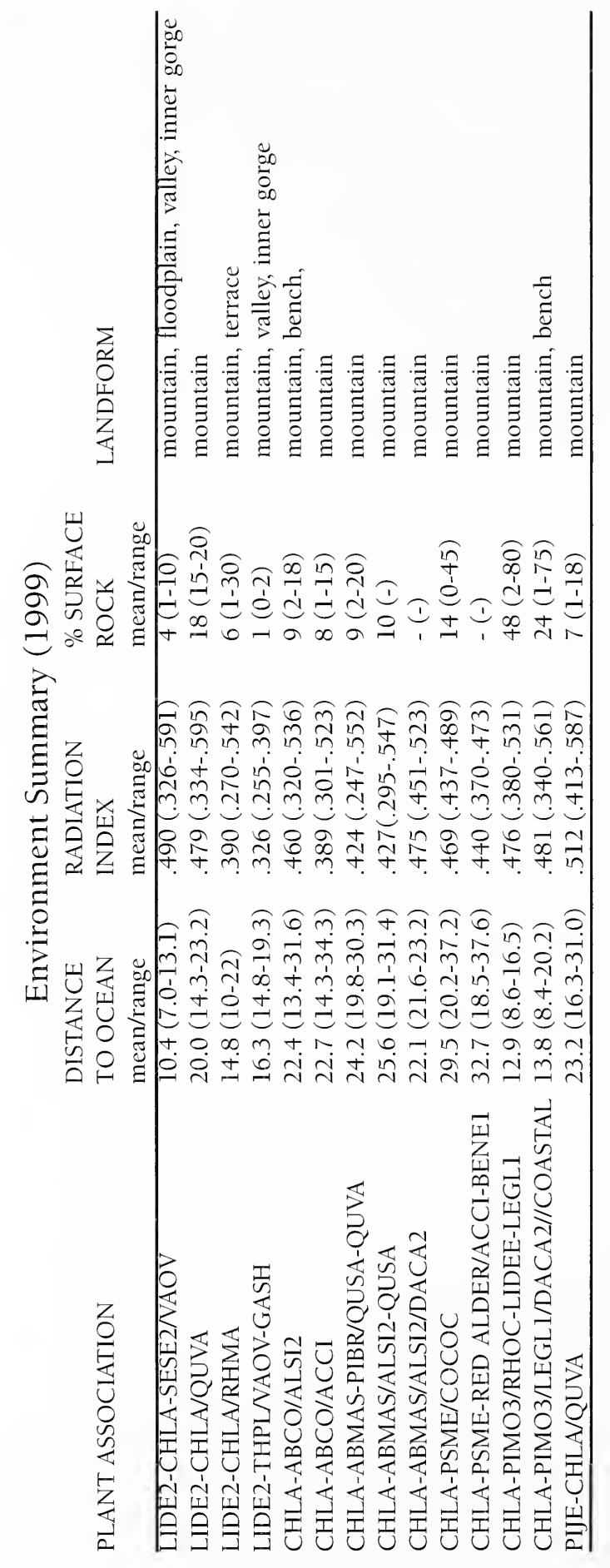




\section{APPENDIX III: SOIL SUMMARY}




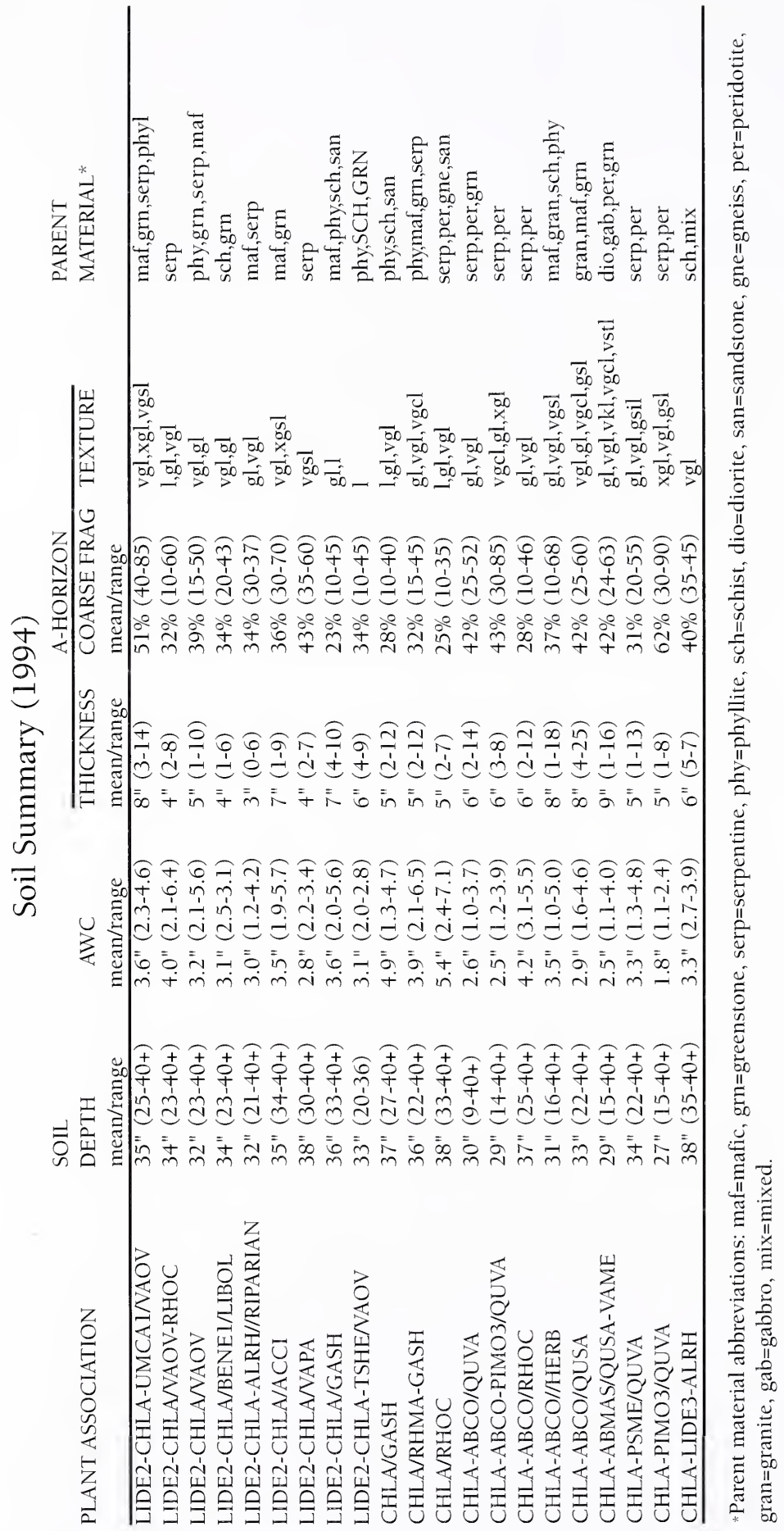




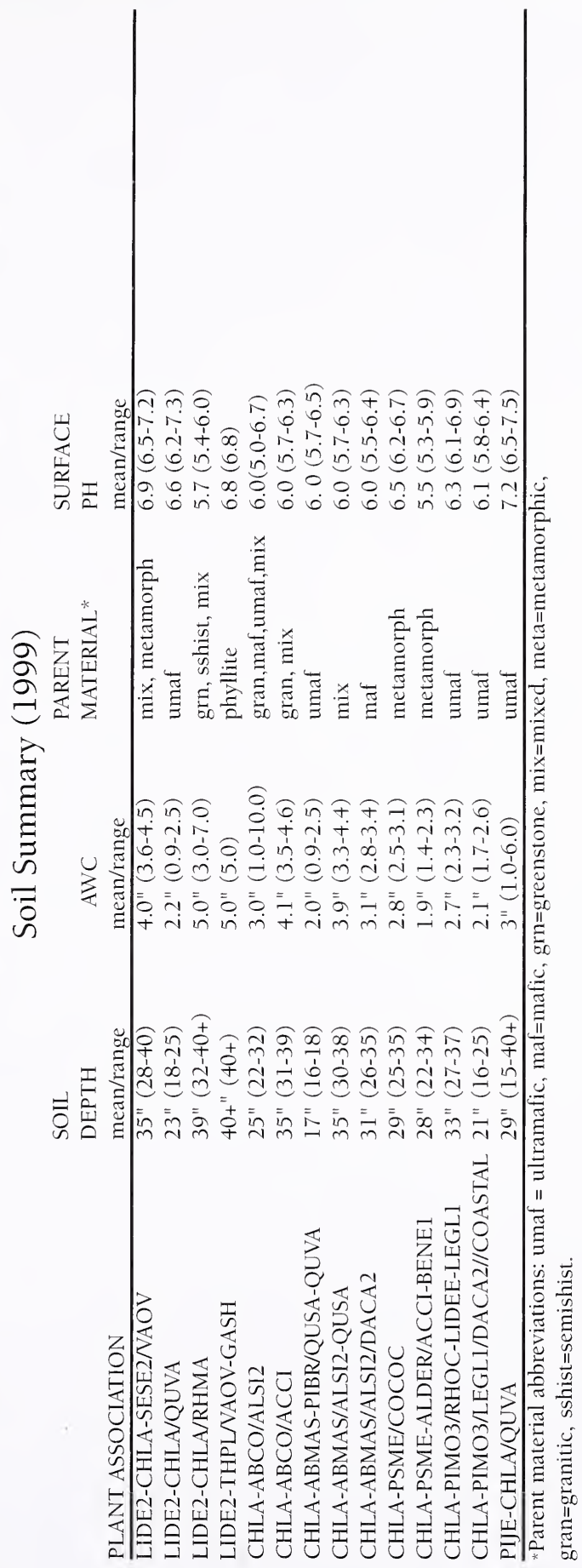




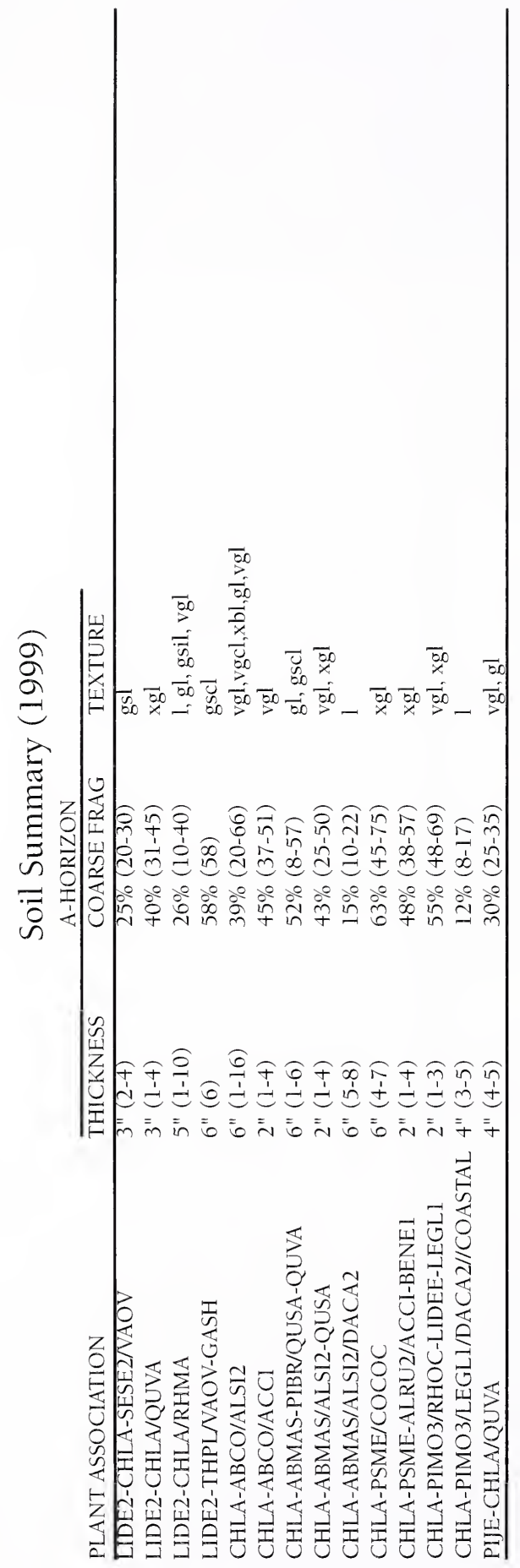




\section{APPENDIX IV: STAND STRUCTURE SUMMARY}




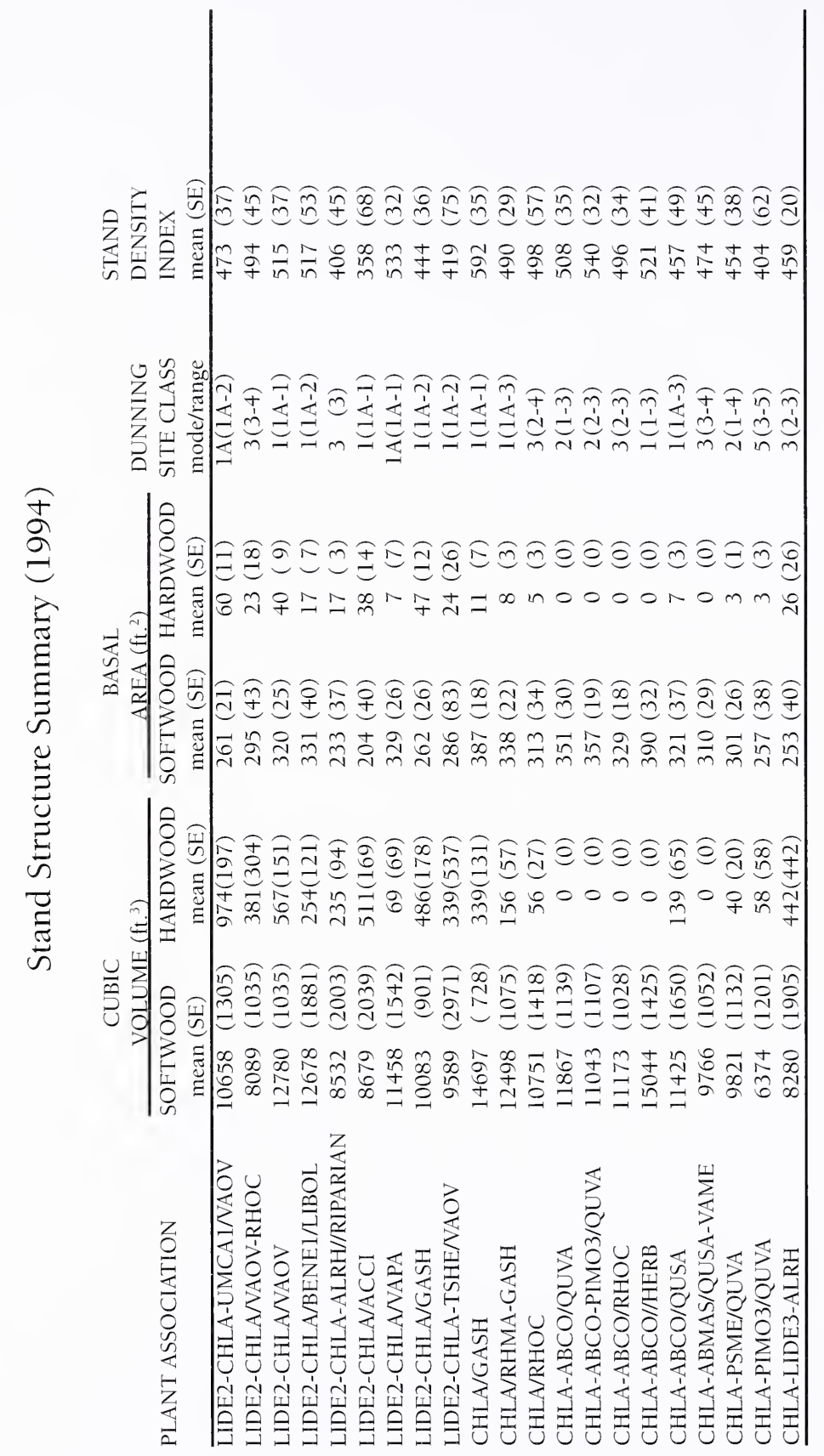




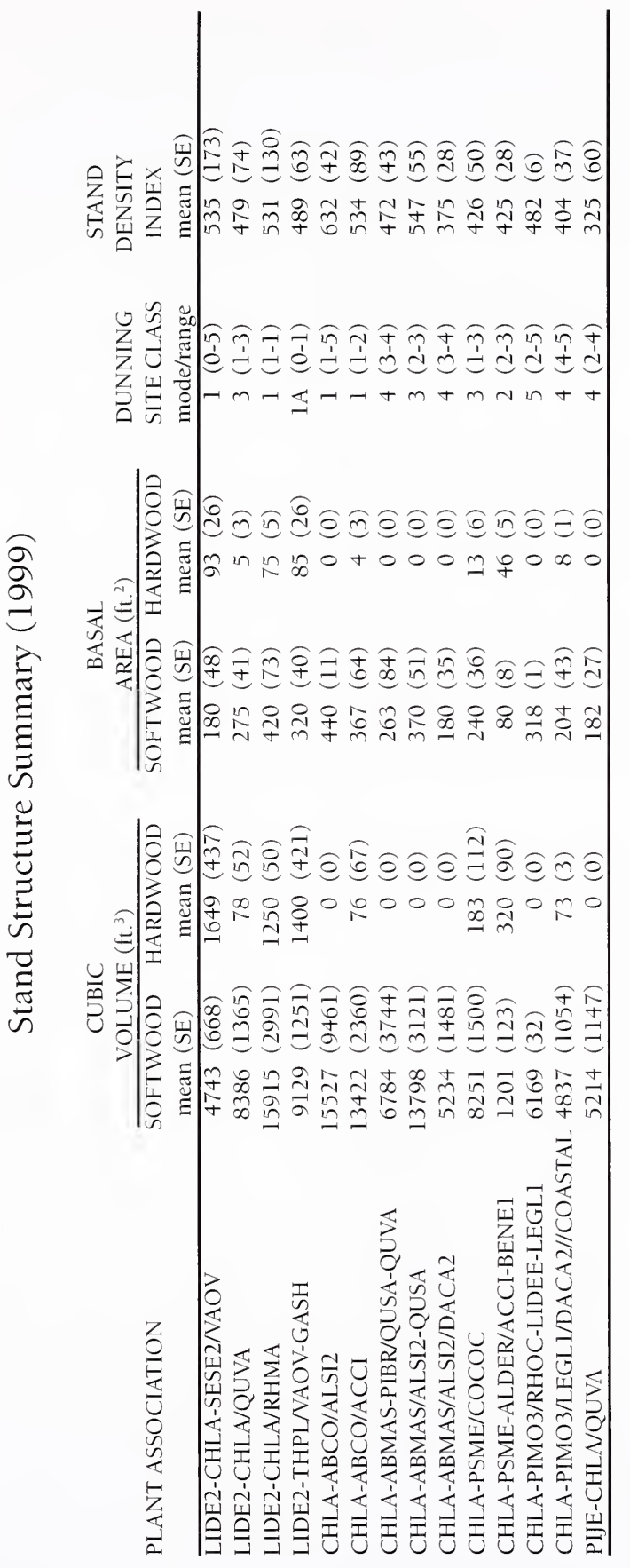




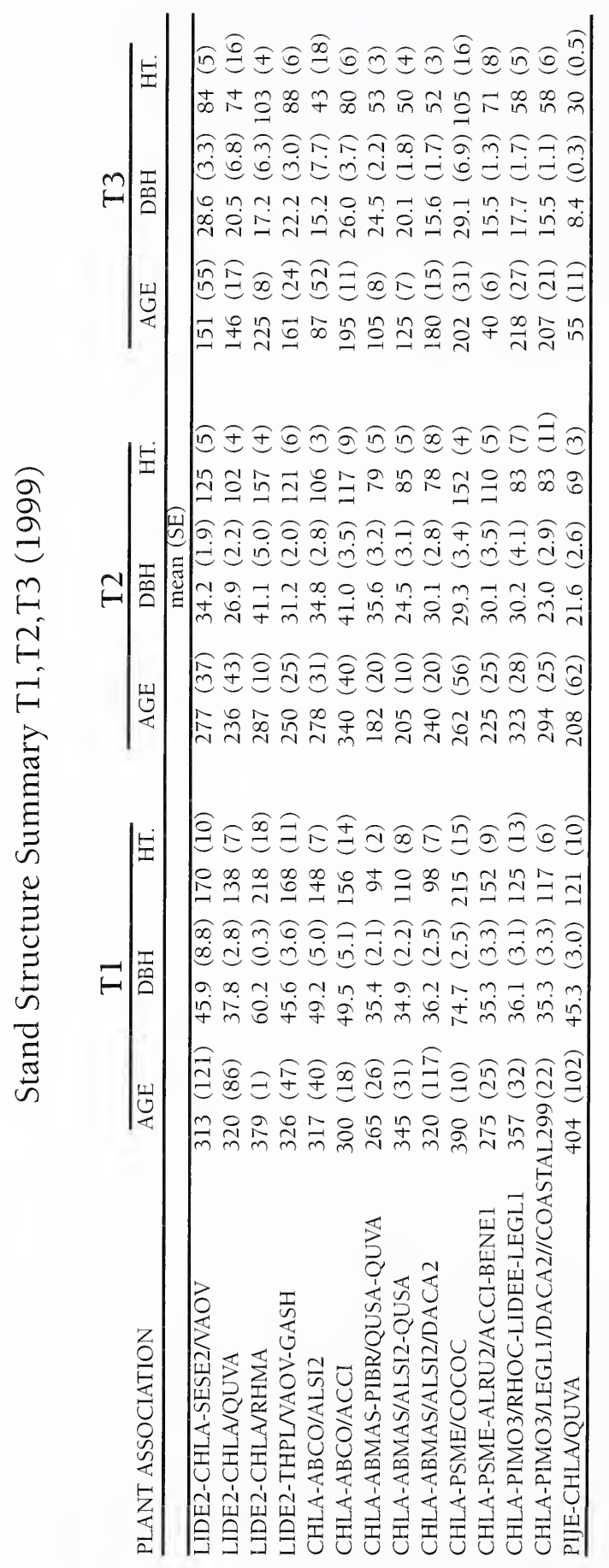




\section{- APPENDIX V: VEGETATION SUMMARY}
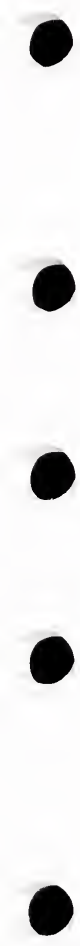


\section{VEGETATION SUMMARY}

\begin{tabular}{|c|c|c|c|}
\hline PLANT ASSOCIATION: & \multicolumn{3}{|c|}{$\%$ COVER } \\
\hline \multirow[b]{2}{*}{ VEGETATION LAYER: } & LIDE2-CHLA- & LIDE2-CHLA/ & \multirow{2}{*}{$\begin{array}{c}\text { LIDE2-CHLA/ } \\
\text { VAOV }\end{array}$} \\
\hline & UMCA1/VAOV & VAOV-RHOC & \\
\hline TOTAL COVER & 99 & 99 & 98 \\
\hline GRASS COVER & 1 & 2 & $<1$ \\
\hline FORB COVER & 21 & 13 & 14 \\
\hline SHRUB COVER & 53 & 58 & 53 \\
\hline TREE COVER & 92 & 85 & 88 \\
\hline TREE OVERSTORY: & \multicolumn{3}{|c|}{ \% COVER (CONSTANCY) } \\
\hline DOUGLAS-FIR & $39(100)$ & $36(100)$ & $35(100)$ \\
\hline TANOAK & $30(100)$ & $24 \quad(100)$ & $26(100)$ \\
\hline PACIFIC MADRONE & $1(7)$ & $3(50)$ & $5(42)$ \\
\hline CHINQUAPIN & & $7 \quad(20)$ & $4(23)$ \\
\hline CANYON LIVE OAK & & $2(10)$ & $2(4)$ \\
\hline SUGAR PINE & $1(7)$ & $4 \quad(40)$ & $3(23)$ \\
\hline PACIFIC DOGWOOD & $3(64)$ & $3(30)$ & $4(14)$ \\
\hline BIGLEAF MAPLE & $8(57)$ & & $5(38)$ \\
\hline PACIFIC YEW & $5(35)$ & $3(40)$ & $6(19)$ \\
\hline INCENSE CEDAR & $2(7)$ & $10 \quad(10)$ & \\
\hline CALIFORNIA BAY & $12(71)$ & $5(30)$ & $1(4)$ \\
\hline PORT-ORFORD-CEDAR & $33(100)$ & $34 \quad(100)$ & $36(100)$ \\
\hline \multicolumn{4}{|l|}{ WHITE FIR } \\
\hline ALDER & $9(21)$ & $4 \quad(20)$ & $12(9)$ \\
\hline TREE UNDERSTORY: & \multicolumn{3}{|c|}{ \% COVER (CONSTANCY) } \\
\hline TANOAK & $8(100)$ & $9(100)$ & $10(100)$ \\
\hline DOUGLAS-FIR & $1(64)$ & $2(50)$ & $1(52)$ \\
\hline CANYON LIVE OAK & & $1 \quad(10)$ & $1(19)$ \\
\hline CHINQUAPIN & & $2(20)$ & $1(28)$ \\
\hline PACIFIC DOGWOOD & $2(50)$ & $2(20)$ & $3(4)$ \\
\hline PACIFIC YEW & $2(21)$ & $1 \quad(60)$ & $1(23)$ \\
\hline CALIFORNIA BAY & $3(100)$ & $2(50)$ & $2(14)$ \\
\hline PACIFIC MADRONE & $1(14)$ & $1 \quad(10)$ & $1(4)$ \\
\hline WHITE FIR & & & \\
\hline BIGLEAF MAPLE & $1(14)$ & & $1(4)$ \\
\hline PORT ORFORD CEDAR & $3(92)$ & $2(80)$ & $3(95)$ \\
\hline ALDER & $2(14)$ & $1 \quad(10)$ & $3(9)$ \\
\hline
\end{tabular}


PLANT ASSOCIATION:

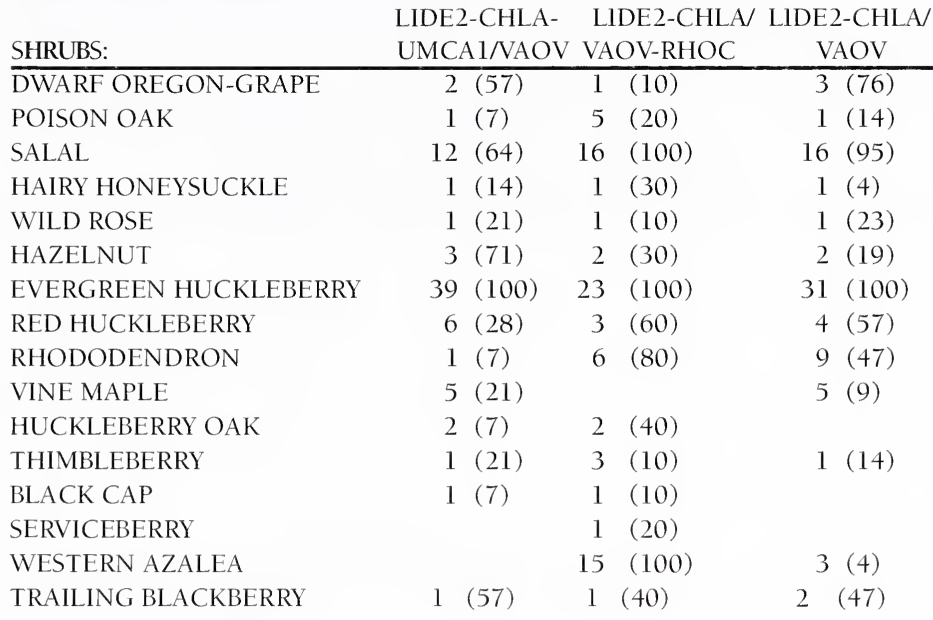

HERBS \& GRASSES:

\% COVER (CONSTANCY)

\begin{tabular}{|c|c|c|c|}
\hline$\overline{\text { BRACKEN FERN }}$ & 2(14) & $1 \quad(10)$ & $1(42)$ \\
\hline LITTLE PRINCE'S PINE & & $1 \quad(10)$ & $1(9)$ \\
\hline SWORDFERN & $8(92)$ & $5(80)$ & $4(85)$ \\
\hline RATTLESNAKE PLANTAIN & $1(42)$ & $1 \quad(60)$ & $1(85)$ \\
\hline PRINCE'S PINE & $1(7)$ & $3(30)$ & $1(19)$ \\
\hline VANILLA LEAF & $1(14)$ & & $2(28)$ \\
\hline WHITE-VEINED WINTERGREEN & $1(14)$ & 1 (I0) & $1(4)$ \\
\hline HOOKER'S FAIRYBELL & $1(35)$ & $1 \quad(10)$ & $1(33)$ \\
\hline STARFLOWER & $1(50)$ & $1(40)$ & $1(38)$ \\
\hline WHITE INSIDE-OUT FLOWER & $2(42)$ & $4 \quad(30)$ & $2(38)$ \\
\hline IRIS & $1(7)$ & $1 \quad(30)$ & $1(4)$ \\
\hline BEARGRASS & $2(7)$ & $2(50)$ & $2(28)$ \\
\hline \multicolumn{4}{|l|}{ RAYLESS ARNICA } \\
\hline REDWOOD VIOLET & $2(21)$ & & \\
\hline TWINFLOWER & $3(42)$ & $3(30)$ & $11(23)$ \\
\hline TRAILPLANT & $2(14)$ & & $1(14)$ \\
\hline SMALL INSIDE-OUT FLOWE & & $(30)$ & $1(28)$ \\
\hline FALSE SOLOMON'S SEAL & $1(21)$ & & $1(14)$ \\
\hline WHITE TRILLIUM & $1(85)$ & $1 \quad(10)$ & $1(33)$ \\
\hline \multicolumn{4}{|l|}{ LEAFLESS WINTERGREEN } \\
\hline REDWOOD SORREL & $7(50)$ & $3(70)$ & $8(42)$ \\
\hline CALIFORNIA TOOTHWORT & $2(14)$ & $1 \quad(10)$ & $2(4$ \\
\hline OREGON TRILLIUM & $1(21)$ & $1 \quad(30)$ & $2(19)$ \\
\hline FAIRY SLIPPER & & $1 \quad(30)$ & $1(4)$ \\
\hline MARBLED WILD GINGER & $2(57)$ & & \\
\hline WESTERN MODESTY & $4(42)$ & $(60)$ & $2(38)$ \\
\hline WESTERN FESCUE & $2(7)$ & & $1(9)$ \\
\hline FESCUE & $1(3)$ & $1 \quad(20)$ & $2(14)$ \\
\hline CALIFORNIA SWEETGRASS & $2(35)$ & $2(40)$ & $2(4)$ \\
\hline SEDGE & $1 \quad(21)$ & $2(40)$ & $2(9)$ \\
\hline
\end{tabular}




\section{VEGETATION SUMMARY}

PLANT ASSOCIATION:

LIDE2-CHLA/ LIDE2-CHLA LIDE2-CHLA/

VEGETATION LAYER:

TOTAL COVER

GRASS COVER

FORB COVER

SHRUB COVER

TREE COVER

TREE OVERSTORY:

DOUGLAS-FIR

TANOAK

PACIFIC MADRONE

CHINQUAPIN

CANYON LIVE OAK

SUGAR PINE

PACIFIC DOGWOOD

BIGLEAF MAPLE

PACIFIC YEW

INCENSE CEDAR

CALIFORNIA BAY

PORT-ORFORD-CEDAR

WHITE FIR

ALDER \begin{tabular}{ccc} 
BENE1/LIBOL & ALRH/RIPARIAN & ACCI \\
\hline 95 & 97 & 96
\end{tabular}

$<1$

14

13

18

34

90

85
12

67

73

3

(3)

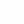

$39(100) \quad 20(100) \quad 35(100)$

$13(27) \quad 5 \quad(10) \quad 5(10)$

5 (18) $1 \quad(10) \quad 2(40)$

5 (18)

3 (18) $1 \quad(10)$

$2(27) \quad 6 \quad(20) \quad 3(50)$

$7(27) \quad 4 \quad(50) \quad 11(30)$

2 (36) $10 \quad 30) \quad 3(30)$

$39(100) \quad 33(100) \quad 32(100)$

3 (18) $5(10) \quad 3(10)$

2 (18) $41 \quad(100) \quad 25(10)$

$8(100) \quad 11 \quad(90) \quad 14(100)$

TREE UNDERSTORY:

\begin{tabular}{lcrrr}
\hline TANOAK & $12(100)$ & 10 & $(90)$ & $11(100)$ \\
DOUGLAS-FIR & $1(72)$ & 2 & $(50)$ & $2(40)$ \\
CANYON LIVE OAK & $2(36)$ & 1 & $(30)$ & $1(10)$ \\
CHINQUAPIN & $1(9)$ & 1 & $(10)$ & $2(40)$ \\
PACIFIC DOGWOOD & $1(9)$ & 1 & $(20)$ & $2(50)$ \\
PACIFIC YEW & $1(36)$ & 1 & $(50)$ & \\
CALIFORNIA BAY & $1(9)$ & 1 & $(10)$ & $2(20)$ \\
PACIFIC MADRONE & $1(9)$ & & & $1(10)$ \\
WHITE FIR & $1(45)$ & 1 & $(20)$ & $4(10)$ \\
BIGLEAF MAPLE & & $3(30)$ & $1(10)$ \\
PORT ORFORD CEDAR & $3(100)$ & $4(90)$ & $4(100)$ \\
ALDER & & & & $5(10)$
\end{tabular}


PLANT ASSOCIATION:

$\%$ COVER (CONSTANCY)

LIDE2-CHLA/ LIDE2-CHLA LIDE2-CHLA/

SHRUBS:

BENE1/LIBOL ALRH//RIPARIAN ACCI

DWARF OREGON-GRAPE

$11(100) \quad 2$ (20)

POISON OAK

SALAL

HAIRY HONEYSUCKLE

WILD ROSE

4 (63)

$12(10)$

$10(90)$

HAZELNUT

$1(63) \quad 1 \quad(10)$

$39(60)$

EVERGREEN HUCKLEBERRY

2 (54) $4 \quad(10)$

$3(50)$

2 (9)

$5(50)$

RED HUCKLEBERRY

RHODODENDRON

VINE MAPLE

HUCKLEBERRY OAK

2 (72) 1 (30)

1 (30)

5 (18) $2(20)$

2 (40)

1 (27) $43 \quad(50)$

$8(40)$

2 (9)

THIMBLEBERRY

4 (50)

$50(100)$

BLACK CAP

SERVICEBERRY

WESTERN AZALEA

TRAILING BLACKBERRY

8 (9) $1 \quad(10)$

4 (18) $12 \quad(20)$

1 (36) 2 (50)

$5(10)$

1 (10)

HERBS \& GRASSES:

$\%$ COVER (CONSTANCY)

BRACKEN FERN
LITTLE PRINCE'S PINE
SWORDFERN
RATTLESNAKE PLANTAIN
PRINCE'S PINE
VANILLA LEAF
WHITE-VEINED WINTERGREEN
HOOKER'S FAIRYBELL
STARFLOWER
WHITE INSIDE-OUT FLOWER
IRIS
BEARGRASS
RAYLESS ARNICA
REDWOOD VIOLET
TWINFLOWER
TRAILPLANT
SMALL INSIDE-OUT FLOWER
FALSE SOLOMON'S SEAL
WHITE TRILLIUM
REDWOOD SORREL
CALIFORNIA TOOTHWORT
OREGON TRILLIUM
BEDSTRAW
FAIRY SLIPPER
MARBLED WILD GINGER
WESTERN MODESTY
WESTERN FESCUE
FESCUE
CALIFORNIA SWEETGRASS
SEDGE

l (27)

$1(20) \quad 1(50)$

1 (18) 1 (20)

$3(72) \quad 6 \quad(90) \quad 4(80)$

1 (54) 1 (30)

1 (36) $1 \quad(10) \quad 2(40)$

$2(81) \quad 2(40) \quad 3(40)$

I (27) 1 (10) 1 (10)

1 (63) $1(10) \quad 1 \quad(30)$

$1(81) \quad 2 \quad(20) \quad 1$ (10)

$2(36)$

1 (45) $1 \quad(30)$

1 (18)

1 (20)

1 (18)

$1(27)$

1 (20)

6 (81) 3 (30)

$10(30)$

1 (9)

1 (20)

2 (9) 1 (20)

2 (20)

l (27) 1 (10)

1 (10)

1 (9)

1 (40)

1 (50)

3 (18)

4 (10)

1 (20)

$1(30)$

1 (50)

$3(72) \quad 2(20)$

7 (50)

1 (9)

SEDGE

$2(50)$

$1(40)$ 


\section{VEGETATION SUMMARY}

PLANT ASSOCIATION:

$\%$ COVER

LIDE2-CHLA/ LIDE2-CHLAV LIDE2-CHLA-

VEGETATION LAYER:

VAPA

GASH

TSHE/NAOV

\begin{tabular}{lccc}
\hline TOTAL COVER & 95 & 97 & 97 \\
GRASS COVER & 1 & 0 & $<1$ \\
FORB COVER & 9 & 4 & 13 \\
SHRUB COVER & 17 & 70 & 64 \\
TREE COVER & 89 & 89 & 92
\end{tabular}

TREE OVERSTORY: \% COVER (CONSTANCY)

DOUGLAS-FIR

TANOAK

PACIFIC MADRONE

CHINQUAPIN

CANYON LIVE OAK

SUGAR PINE

PACIFIC DOGWOOD

BIGLEAF MAPLE

PACIFIC YEW

INCENSE CEDAR

CALIFORNIA BAY

PORT-ORFORD-CEDAR

WHITE FIR

ALDER

WESTERN HEMLOCK
$<1$

13

64

92

$\begin{aligned} 32 & (100) & 47 & (100) & 28 & (100) \\ 13 & (100) & 18 & (100) & 21 & (100) \\ 7 & (60) & 3 & (20) & & \\ 8 & (10 & 18 & (70) & & \end{aligned}$

$12(80) \quad 5 \quad(40)$

$3(10) \quad 5(10)$

$3(10) \quad 8(30)$

$5(30) \quad 6(50)$

$11(30)$

1 (10)

$33(100) \quad 31 \quad(100) \quad 34(100)$

5 (10)

15 (10)

24 (100)

TREE UNDERSTORY:

TANOAK
DOUGLAS-FIR
CANYON LIVE OAK
CHINQUAPIN
PACIFIC DOGWOOD
PACIFIC YEW
CALIFORNIA BAY
PACIFIC MADRONE
WHITE FIR
BIGLEAF MAPLE
PORT ORFORD CEDAR
ALDER
WESTERN HEMLOCK

\% COVER (CONSTANCY)

$30(90) \quad 6(100) \quad 7(100)$

$1(60) \quad 1 \quad(50) \quad 2(20)$

8 (20)

$1(50) \quad 2(40)$

$1(10) \quad 1(10)$

$1(40) \quad 1 \quad(10)$

1 (30)

2 (20) 1 (10)

1 (30)

1 (10)

$5(90) \quad 2(100) \quad 3(70)$

$3(100)$ 
PLANT ASSOCIATION:

$\%$ COVER (CONSTANCY)

LIDE2-CHLA/ LIDE2-CHLA/ LIDE2-CHLA-

SHRUBS:

VAPA

GASH

TSHE/VAOV

\begin{tabular}{lcccc}
\hline DWARF OREGON-GRAPE & $1(10)$ & $6(60)$ & $1(40)$ \\
POISON OAK & $1(10)$ & 1 & $(10)$ & \\
SALAL & $5(50)$ & $70(100)$ & $4(40)$ \\
HAIRY HONEYSUCKLE & $1(50)$ & $1(20)$ & \\
WILD ROSE & & 1 & $(10)$ & \\
HAZELNUT & $3(50)$ & $3(40)$ & $57(100)$ \\
EVERGREEN HUCKLEBERRY & $9(100)$ & $3(50)$ & $1(20)$ \\
RED HUCKLEBERRY & $2(20)$ & $8(70)$ & $11(80)$ \\
RHODODENDRON & $2(30)$ & & & \\
VINE MAPLE & $1(10)$ & $1(10)$ & $1(20)$ \\
HUCKLEBERRY OAK & $1(10)$ & $1(10)$ & $1(10)$ \\
THIMBLEBERRY & $15(10)$ & & \\
TRAILING BLACKBERRY & $5(10)$ & & \\
BLACK CAP & $2(10)$ & $2(20)$ & \\
SERVICEBERRY & & &
\end{tabular}

HERBS \& GRASSES:

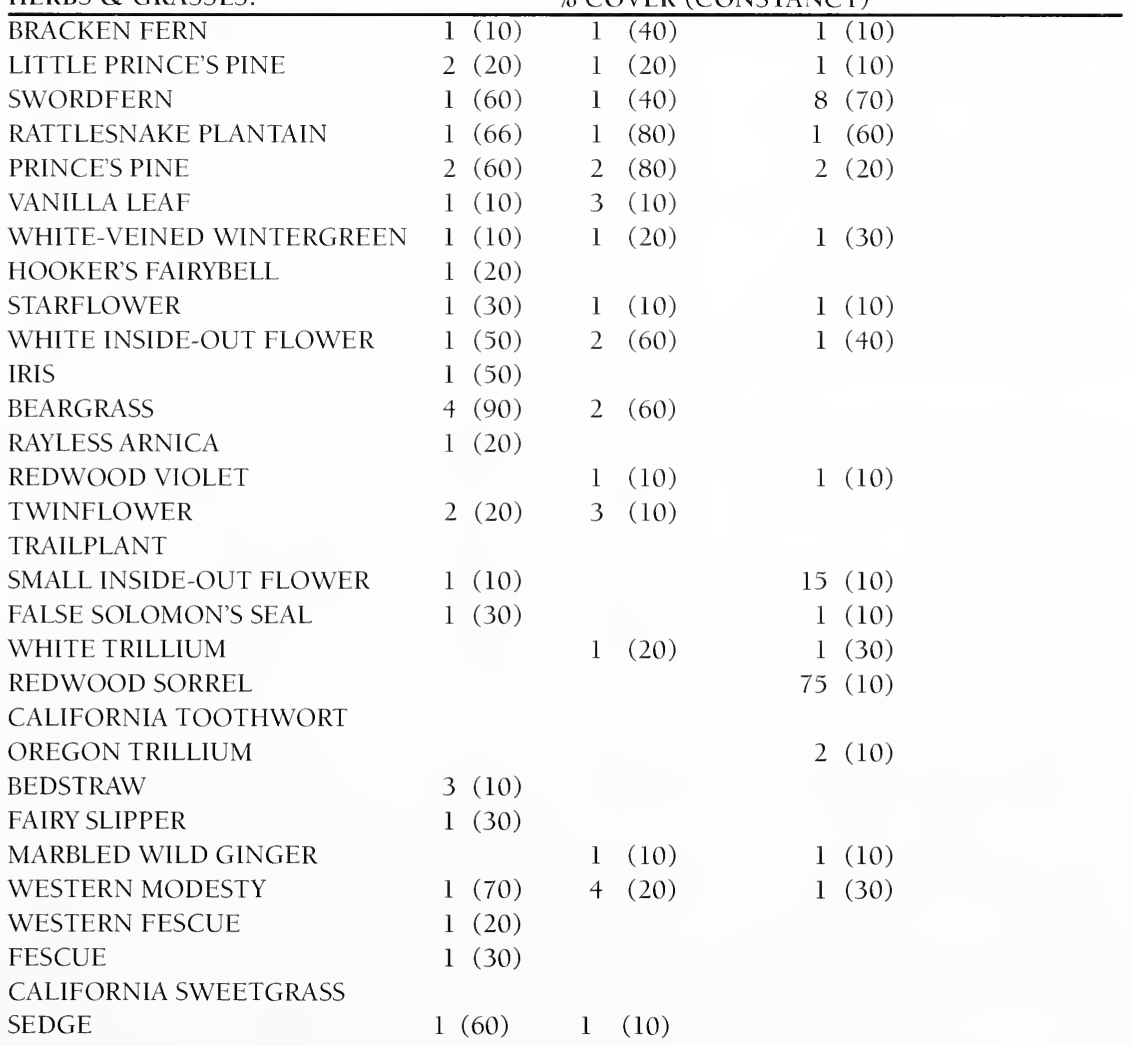




\section{VEGETATION SUMMARY}

PLANT ASSOCIATION:

\% COVER

\begin{tabular}{lcccc} 
VEGETATION LAYER: & $\begin{array}{c}\text { CHLA/ } \\
\text { GASH }\end{array}$ & $\begin{array}{c}\text { CHLA/ } \\
\text { RHMA-GASH }\end{array}$ & $\begin{array}{c}\text { CHLA/ } \\
\text { RHOC }\end{array}$ & $\begin{array}{c}\text { CHLA-ABCO/ } \\
\text { QUVA }\end{array}$ \\
\hline TOTAL COVER & 97 & 98 & 95 & 93 \\
GRASS COVER & 1 & $<1$ & 1 & 1 \\
FORB COVER & 11 & 8 & 6 & 13 \\
SHRUB COVER & 61 & 70 & 38 & 22 \\
TREE COVER & 87 & 79 & 77 & 79
\end{tabular}

TREE OVERSTORY:

\% COVER (CONSTANCY)

\begin{tabular}{lrrlrl}
\hline PORT-ORFORD-CEDAR & $53(100)$ & 44 & $(100)$ & $42(100)$ & $28(100)$ \\
DOUGLAS-FIR & $31(100)$ & 32 & $(100)$ & $24(100)$ & $29(100)$ \\
WHITE FIR & $2(8)$ & 9 & $(11)$ & $5(7)$ & $16(100)$ \\
SUGAR PINE & $10(16)$ & 6 & $(33)$ & $4(61)$ & $10(60)$ \\
CHINQUAPIN & $2(33)$ & 8 & $(66)$ & $1(30)$ & $3(20$ \\
INCENSE CEDAR & & & & $1(7)$ & $8(60)$ \\
TANOAK & $5(33)$ & 6 & $(22)$ & $9(61)$ & \\
WESTERN WHITE PINE & $4(16)$ & 4 & $(11)$ & $2(7)$ & $1(20)$ \\
PACIFIC MADRONE & & & & & \\
RED FIR & & 1 & $(5)$ & $1(7)$ & $3(20)$ \\
BREWER'S SPRUCE & $2(25)$ & $3(22)$ & $5(15)$ & \\
PACIFIC YEW & $2(25)$ & $2(5)$ & $3(7)$ & \\
ALDER & $2(25)$ & $5(22)$ & & \\
PACIFIC DOGWOOD & $2(8)$ & & & & \\
BIGLEAF MAPLE & $4(8)$ & & & \\
CANYON LIVE OAK & & & & & \\
JEFFREY PINE & & & & &
\end{tabular}

TREE UNDERSTORY:

\% COVER (CONSTANCY)

\begin{tabular}{llllll}
\hline PORT ORFORD CEDAR & $6(100)$ & 4 & $(100)$ & $9(100)$ & $2(100)$ \\
WHITE FIR & $3(25)$ & 1 & $(11)$ & $2(15)$ & $3(100)$ \\
DOUGLAS-FIR & $1(50)$ & $3(44)$ & $2(53)$ & $2(70)$ \\
TANOAK & $5(66)$ & $2(55)$ & $2(69)$ & $2(20)$ \\
CHINQUAPIN & $1(41)$ & $3(50)$ & $1(30)$ & $1(20)$ \\
PACIFIC YEW & $1(25)$ & $2(16)$ & $1(30)$ & $3(40)$ \\
SUGAR PINE & & $1(11)$ & $1(30)$ & $1(60)$ \\
RED FIR & & & & & $1(10)$ \\
INCENSE CEDAR & & & $1(5)$ & & $1(7)$ \\
WESTERN WHITE PINE & & $1(5)$ & & \\
PACIFIC DOGWOOD & & $2(5)$ & & $1(10)$ \\
BREWER'S SPRUCE & & $3(5)$ & & $1(10)$ \\
CALIFORNIA BAY & & & & \\
ALDER & & & & \\
CANYON LIVE OAK & & & & & \\
JEFFREY PINE & & & & &
\end{tabular}


PLANT ASSOCIATION:

\% COVER (CONSTANCY)

\begin{tabular}{|c|c|c|c|c|}
\hline SHRUBS: & $\begin{array}{l}\text { CHLA/ } \\
\text { GASH }\end{array}$ & $\begin{array}{c}\text { CHLA/ } \\
\text { RHMA-GASH }\end{array}$ & $\begin{array}{l}\text { CHLA/ } \\
\text { RHOC }\end{array}$ & $\begin{array}{c}\text { CHLA-ABCO } \\
\text { QUVA }\end{array}$ \\
\hline RED HUCKLEBERRY & $3(75)$ & $2(100)$ & $2(76)$ & $5(70)$ \\
\hline HUCKLEBERRY OAK & $2(25)$ & $2(16)$ & $4(53)$ & $11(100)$ \\
\hline TRAILING BLACKBERRY & $1(66)$ & $1 \quad(27)$ & $1(76)$ & $1(60)$ \\
\hline SADLER OAK & $2(16)$ & $7 \quad(44)$ & $1(7)$ & $1(70)$ \\
\hline WILD ROSE & $1(25)$ & $1 \quad(38)$ & $1(38)$ & $1(40)$ \\
\hline DWARF OREGON-GRAPE & $3(58)$ & $3(55)$ & $3(38)$ & $2(50)$ \\
\hline WESTERN AZALEA & $9(33)$ & $(33)$ & $24(100)$ & $2(10)$ \\
\hline SALAL & $50(100)$ & $36 \quad(94)$ & $12(46)$ & $2(10)$ \\
\hline PACIFIC RHODODENDRON & $3(58)$ & $35(100)$ & $2(30)$ & \\
\hline SLENDER SALAL & $2(16)$ & $4(11)$ & $1(38)$ & $1(10)$ \\
\hline HAZELNUT & $1(8)$ & & $1(7)$ & $1(10)$ \\
\hline THIMBLEBERRY & $1(33)$ & & $1(7)$ & $1(10)$ \\
\hline THIN-LEAVED HUCKLEBERRY & & & & $2(10)$ \\
\hline PINEMAT MANZANITA & & & $1(7)$ & $1(40)$ \\
\hline OREGON BOXWOOD & $1(8)$ & $2(5)$ & & $1(20)$ \\
\hline VINE MAPLE & $2(8)$ & & & \\
\hline DWARF TANBARK & & $2(16)$ & & \\
\hline
\end{tabular}

HERBS \& GRASSES:

\begin{tabular}{|c|c|c|c|c|}
\hline PRINCE'S PINE & $1(58)$ & $3(55)$ & $1(53)$ & $2(70)$ \\
\hline RATTLESNAKE PLANTAIN & $1(58)$ & $1 \quad(77)$ & $1(69)$ & $1(50)$ \\
\hline TWINFLOWER & $2(58)$ & $3(66)$ & $1(38)$ & $6(70)$ \\
\hline BEARGRASS & $1(50)$ & $3(83)$ & $2(76)$ & $3(70)$ \\
\hline STARFLOWER & $1(42)$ & $1 \quad(33)$ & $1(38)$ & $1(70)$ \\
\hline WHITE TRILLIUM & $1(58)$ & $1 \quad(50)$ & $1(38)$ & $1(40)$ \\
\hline HOOKER'S FAIRYBELLS & $1(25)$ & $1 \quad(11)$ & $1(7)$ & \\
\hline VANILLALEAF & $2(50)$ & $1 \quad(5)$ & $2(7)$ & $2(20)$ \\
\hline WHITE-VEINED WINTERGREEN & $1(25)$ & $1 \quad(11)$ & $1(7)$ & $1(30)$ \\
\hline QUEENS CUP & $2(8)$ & $1 \quad(5)$ & $2(7)$ & $2(30)$ \\
\hline WESTERN MODESTY & $1(50)$ & $1 \quad(16)$ & $1(23)$ & $2(50)$ \\
\hline IRIS & $1(25)$ & & & $1(60)$ \\
\hline SWORDFERN & $1(58)$ & $1 \quad(33)$ & $1(23)$ & $1(20)$ \\
\hline BRACKEN FERN & $1(25)$ & $1 \quad(27)$ & $1(7)$ & $1(30)$ \\
\hline \multicolumn{5}{|l|}{ THREE-LEAVED ANEMONE } \\
\hline ONE-SIDED WINTERGREEN & $1(8)$ & & & \\
\hline WHITE INSIDE-OUT FLOWER & $2(25)$ & $1 \quad(22)$ & $1(23)$ & $1(40)$ \\
\hline FALSE SOLOMON'S SEAL & $1(16)$ & $1 \quad(5)$ & $1(15)$ & $1(20)$ \\
\hline LITTLE PRINCE'S PINE & $1(33)$ & $1 \quad(16)$ & $1(7)$ & $1(10)$ \\
\hline HAWKWEED & & & & $1(50)$ \\
\hline TRAILPLANT & & & & $1(10)$ \\
\hline TOOTHED WINTERGREEN & $1(8)$ & $1 \quad(5)$ & $1(15)$ & $1(40)$ \\
\hline REDWOOD VIOLET & $1(25)$ & $1 \quad(11)$ & $1(7)$ & $1(20)$ \\
\hline LADYFERN & $2(50)$ & & $1(7)$ & \\
\hline REDWOOD IVY & $2(37)$ & $1 \quad(22)$ & $1(23)$ & \\
\hline SEDGE & $2(42)$ & $4 \quad(11)$ & $2(61)$ & $1(20)$ \\
\hline WESTERN FESCUE & $1(8)$ & & & $1(30)$ \\
\hline
\end{tabular}




\section{VEGETATION SUMMARY}

\begin{tabular}{lcccc} 
PLANT ASSOCIATION: & \multicolumn{5}{c}{$\begin{array}{c}\text { \% COVER } \\
\text { CHLA-ABCO } \\
\text { VEGETATION LAYER: }\end{array}$} & $\begin{array}{c}\text { CHLA-ABCO/ } \\
\text { PIMO3/QUVA }\end{array}$ & $\begin{array}{c}\text { CHLA-ABCO// CHLA-ABCO/ } \\
\text { RERB }\end{array}$ & $\begin{array}{c}\text { QUSA } \\
\text { TOTAL COVER }\end{array}$ & 92 & 93 & 96 & 94 \\
GRASS COVER & $<1$ & $<1$ & 2 & $<1$ \\
FORB COVER & 8 & 6 & 43 & 21 \\
SHRUB COVER & 52 & 41 & 13 & 38 \\
TREE COVER & 68 & 75 & 82 & 77
\end{tabular}

TREE OVERSTORY: $\%$ COVER (CONSTANCY)

\begin{tabular}{|c|c|c|c|c|c|}
\hline PORT-ORFORD-CEDAR & $31(100)$ & 49 & $(100)$ & $44(100)$ & $26(100)$ \\
\hline DOUGLAS-FIR & $17(100)$ & 13 & $(100)$ & $30(90)$ & $30(100)$ \\
\hline WHITE FIR & $11(100)$ & 10 & $(100)$ & $16(95)$ & $18(88)$ \\
\hline SUGAR PINE & $4(30)$ & 9 & $(70)$ & $4(33)$ & 7 (38) \\
\hline CHINQUAPIN & & & & & $11(33)$ \\
\hline INCENSE CEDAR & $4(50)$ & 10 & (10) & $3(14)$ & \\
\hline TANOAK & & & & $1(64)$ & $2(11)$ \\
\hline $\begin{array}{l}\text { WESTERN WHITE PINE } \\
\text { PACIFIC MADRONE }\end{array}$ & $11(100)$ & & & $2(4)$ & $3(11)$ \\
\hline RED FIR & $2(10)$ & 5 & (20) & & $6(11)$ \\
\hline BREWER'S SPRUCE & $2(30)$ & 1 & (10) & $1(9)$ & $6(16)$ \\
\hline PACIFIC YEW & & 3 & (10) & & $2(16)$ \\
\hline
\end{tabular}

ALDER

PACIFIC DOGWOOD

3 (23)

2 (4) 5(5)

CANYON LIVE OAK

JEFFREY PINE

$1(30)$

TREE UNDERSTORY:

$\%$ COVER (CONSTANCY)

\begin{tabular}{|c|c|c|c|c|}
\hline PORT ORFORD CEDAR & $2(100)$ & $1(100)$ & $3(95)$ & $3(94)$ \\
\hline WHITE FIR & $2(90)$ & $2(100)$ & $2(95)$ & $3(88)$ \\
\hline DOUGLAS-FIR & $1(30)$ & $1 \quad(30)$ & $2(42)$ & $1(83)$ \\
\hline TANOAK & & & $1(9)$ & $2(33)$ \\
\hline CHINQUAPIN & & $2(30)$ & $1(14)$ & $8(50)$ \\
\hline PACIFIC YEW & $1(10)$ & $1 \quad(10)$ & $1(14)$ & $2(22)$ \\
\hline SUGAR PINE & $1(10)$ & $1 \quad(20)$ & & $1(16)$ \\
\hline RED FIR & $1(30)$ & & $1(4)$ & $1(5)$ \\
\hline INCENSE CEDAR & $1(10)$ & & $1(9)$ & $1(5)$ \\
\hline WESTERN WHITE PINE & $1(70)$ & & & $1(5)$ \\
\hline PACIFIC DOGWOOD & & & $3(42)$ & \\
\hline BREWER'S SPRUCE & $1(10)$ & & & $1(22)$ \\
\hline CALIFORNIA BAY & & & $2(4)$ & \\
\hline \multicolumn{5}{|l|}{ ALDER } \\
\hline CANYON LIVE OAK & & & & \\
\hline JEFFREY PINE & & $1 \quad(10)$ & & \\
\hline
\end{tabular}


PLANT ASSOCIATION:

\% COVER (CONSTANCY)

\begin{tabular}{lccccc} 
& $\begin{array}{c}\text { CHLA-ABCO } \\
\text { SHRUBS: }\end{array}$ & CHLA-ABCO/ & CHLA-ABCO// CHLA-ABCO/ \\
\hline RED HUCKLEBERRY & $16(20)$ & 2 & $(50)$ & $1(28)$ & $6(61)$ \\
HUCKLEBERRY OAK & $29(100)$ & 4 & $(80)$ & $1(33)$ & $3(50)$ \\
TRAILING BLACKBERRY & $2(40)$ & 2 & $(70)$ & $2(80)$ & $1(5)$ \\
SADLER OAK & $4(60)$ & 1 & $(50)$ & $3(71)$ & $22(100)$ \\
WILD ROSE & $2(60)$ & 1 & $(10)$ & $1(76)$ & $2(50)$ \\
DWARF OREGON-GRAPE & $2(20)$ & 1 & $(10)$ & $3(28)$ & $5(61)$ \\
WESTERN AZALEA & $7(50)$ & $32(100)$ & $1(14)$ & $11(11)$ \\
SALAL & $50(10)$ & & & & $31(11)$ \\
PACIFIC RHODODENDRON & & & & & $3(11)$ \\
SLENDER SALAL & $2(10)$ & $5(30)$ & $2(23)$ & $4(33)$ \\
HAZELNUT & $3(10)$ & $3(30)$ & $5(71)$ & $5(27)$ \\
THIMBLEBERRY & $1(10)$ & & $3(66)$ & $1(16)$ \\
THIN-LEAVED HUCKLEBERRY & $13(30)$ & & $1(4)$ & $1(38)$ \\
PINEMAT MANZANITA & $8(80)$ & $2(20)$ & & $1(11)$ \\
OREGON BOXWOOD & & & & $3(4)$ & $3(11)$ \\
VINE MAPLE & $5(20)$ & & &
\end{tabular}

HERBS \& GRASSES:

\% COVER (CONSTANCY)

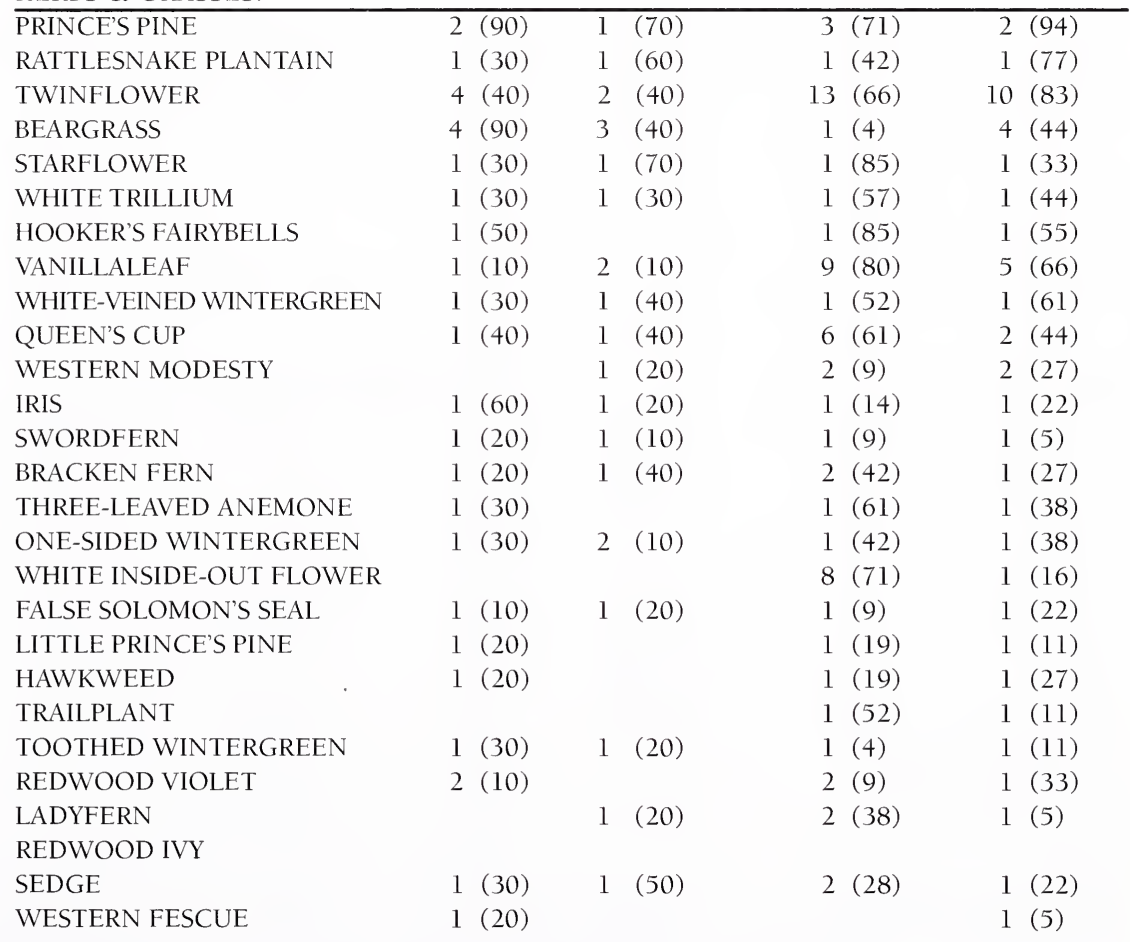




\section{VEGETATION SUMMARY}

\begin{tabular}{lcccc} 
PLANT ASSOCIATION: & \multicolumn{5}{c}{$\begin{array}{c}\text { COVER } \\
\text { CHLA-ABMAS/ }\end{array}$} \\
$\begin{array}{lccl}\text { CHLA-PSME/ } \\
\text { VEGETATION LAYER : }\end{array}$ & $\begin{array}{l}\text { CHLA-PIMO3/ } \\
\text { QUVA }\end{array}$ & $\begin{array}{c}\text { CHLA- } \\
\text { LIDE3-ALRH }\end{array}$ \\
\hline TOTAL COVER & 94 & 91 & 93 & 98 \\
GRASS COVER & $<1$ & 1 & 5 & 1 \\
FORB COVER & 23 & 9 & 14 & 3 \\
SHRUB COVER & 35 & 33 & 67 & 2 \\
TREE COVER & 79 & 70 & 54 & 98
\end{tabular}

TREE OVERSTORY:

$\%$ COVER (CONSTANCY)

PORT-ORFORD-CEDAR

DOUGLAS-FIR

WHITE FIR

SUGAR PINE

CHINQUAPIN

$\begin{array}{llll}24 & (100) & 28 & (100) \\ 19 & (82) & 26 & (100)\end{array}$

$28(100)$

14 (100)

$37(100)$

$30(100)$

$25(100) \quad 5 \quad(4)$

3 (35) 7 (86)

$12(10)$

INCENSE CEDAR

11 (17)

4 (9)

TANOAK

7 (40)

14 (22)

WESTERN WHITE PINE

$5(35)$

$10(20)$

$8(100)$

PACIFIC MADRONE

RED FIR

5 (31)

$16(94) \quad 2$ (4)

3 (23) 1 (9)

3 (5) 4 (9)

PACIFIC YEW

ALDER

1 (4)

3 (4)

$6(100)$

$2(50)$

PACIFIC DOGWOOD

BIGLEAF MAPLE

CANYON LIVE OAK

JEFFREY PINE

$13(27)$

3 (100)

1 (50)

$5(100)$

TREE UNDERSTORY: $\%$ COVER (CONSTANCY)

PORT ORFORD CEDAR

2 (94)

3 (100)

$3(90)$

l (100)

WHITE FIR

$3(88)$

1 (31)

1 (40)

1 (50)

DOUGLAS-FIR

1 (17)

1 (72)

2 (80)

$5(50)$

TANOAK

5 (54)

9 (20)

1 (50)

CHINQUAPIN

2(5)

1 (9)

PACIFIC YEW

1 (17)

2 (36)

2(20)

1 (11)

1 (45)

1 (10)

RED FIR

$3(88)$

1 (5)

1 (45)

1 (10)

l(50)

WESTERN WHITE PINE

1 (11)

1 (100)

PACIFIC DOGWOOD

BREWER'S SPRUCE

1 (17)

1 (4)

CALIFORNIA BAY

ALDER

l(50)

CANYON LIVE OAK

JEFFREY PINE

$1 \quad(12$ 
PLANT ASSOCIATION:

$\%$ COVER (CONSTANCY)

\begin{tabular}{|c|c|c|c|c|}
\hline SHRUBS: & $\begin{array}{l}\text { CHLA-ABMAS } \\
\text { QUSA-VAME }\end{array}$ & $\begin{array}{l}\text { CHLA-PSME/ } \\
\text { QUVA }\end{array}$ & $\begin{array}{l}\text { CHLA-PIMO3/ } \\
\text { QUVA }\end{array}$ & $\begin{array}{c}\text { CHLA- } \\
\text { LIDE3-ALRH }\end{array}$ \\
\hline RED HUCKLEBERRY & $2(17)$ & $5(81)$ & $6(80)$ & l $(50)$ \\
\hline HUCKLEBERRY OAK & $4(58)$ & $(100)$ & $38(100)$ & \\
\hline TRAILING BLACKBERRY & $1(64)$ & $(31)$ & $1(10)$ & $1(100)$ \\
\hline SADLER OAK & $19(100)$ & 2 (18) & $2(10)$ & \\
\hline WILD ROSE & $2(64)$ & $1 \quad(45)$ & $1(30)$ & \\
\hline DWARF OREGON-GRAPE & $5(64)$ & $2(27)$ & $4(30)$ & $2(50)$ \\
\hline WESTERN AZALEA & $4(11)$ & (9) & $12(60)$ & \\
\hline SALAL & & & $2(10)$ & \\
\hline PACIFIC RHODODENDRON & & $1 \quad(4)$ & $16(30)$ & \\
\hline SLENDER SALAL & $12(17)$ & $1 \quad(18)$ & $4(10)$ & \\
\hline HAZELNUT & $2(5)$ & $1 \quad(4)$ & & \\
\hline THIMBLEBERRY & $2(11)$ & (4) & & \\
\hline THIN-LEAVED HUCKLEBERRY & $8(82)$ & & & \\
\hline PINEMAT MANZANITA & $6(11)$ & $(22)$ & $3(10)$ & \\
\hline OREGON BOXWOOD & $9(\mathrm{I} 7)$ & (4) & & \\
\hline VINE MAPLE & & & & \\
\hline DWARF TANBARK & & (4) & $13(60)$ & \\
\hline
\end{tabular}

HERBS \& GRASSES:

$\%$ COVER (CONSTANCY)

\begin{tabular}{|c|c|c|c|c|c|c|c|c|}
\hline PRINCE'S PINE & 3 & $(94)$ & 1 & (54) & & $(50)$ & 1 & (50) \\
\hline RATTLESNAKE PLANTAIN & 1 & $(88)$ & I & $(72)$ & 1 & $(20)$ & & \\
\hline TWINFLOWER & 9 & $(35)$ & 2 & $(36)$ & 3 & $(60)$ & 1 & (50) \\
\hline BEARGRASS & 1 & $(17)$ & 3 & $(77)$ & 3 & $(80)$ & & \\
\hline STARFLOWER & 2 & $(47)$ & 1 & $(45)$ & 1 & $(20)$ & 1 & (50) \\
\hline WHITE TRILLIUM & 1 & $(76)$ & 1 & (4) & & & & \\
\hline HOOKER'S FAIRYBELLS & 1 & $(76)$ & 1 & (18) & 1 & $(20)$ & 1 & (50) \\
\hline VANILLALEAF & 9 & $(52)$ & 2 & (18) & & & 1 & $(100)$ \\
\hline WHITE-VEINED WINTERGREEN & 1 & $(35)$ & I & $(22)$ & 1 & (10) & & \\
\hline QUEENS CUP & 5 & $(70)$ & & & & & & \\
\hline WESTERN MODESTY & & & 2 & (54) & 5 & $(70)$ & 1 & (50) \\
\hline IRIS & 1 & (5) & 1 & $(63)$ & 2 & $(100)$ & & \\
\hline SWORDFERN & 1 & $(29)$ & 1 & (31) & 2 & $(60)$ & 1 & (50) \\
\hline BRACKEN FERN & 2 & $(17)$ & 1 & (4) & 1 & (10) & & \\
\hline THREE-LEAVED ANEMONE & 2 & $(52)$ & & & & & & \\
\hline ONE-SIDED WINTERGREEN & 1 & $(70)$ & & & 1 & (10) & & \\
\hline WHITE INSIDE-OUT FLOWER & 1 & (11) & 1 & $(27)$ & 1 & (20) & 1 & $(50)$ \\
\hline FALSE SOLOMON'S SEAL & 1 & (29) & 1 & (36) & 1 & $(20)$ & & \\
\hline LITTLE PRINCE'S PINE & 1 & (23) & 1 & (18) & 1 & (10) & & \\
\hline HAWKWEED & 1 & $(11)$ & 1 & (4) & 1 & $(10)$ & 1 & $(50)$ \\
\hline TRAILPLANT & 1 & (29) & & & & & 1 & $(50)$ \\
\hline TOOTHED WINTERGREEN & 1 & $(5)$ & & & 1 & $(30)$ & & \\
\hline REDWOOD VIOLET & 1 & (11) & & & & & & \\
\hline LADYFERN & 15 & $(5)$ & & & & & & \\
\hline REDWOOD IVY & & & 1 & (13) & 1 & (20) & & \\
\hline SEDGE & & (5) & 2 & (18) & 4 & (30) & & \\
\hline WESTERN FESCUE & & & 1 & (9) & 1 & (10) & 1 & (50) \\
\hline
\end{tabular}




\section{VEGETATION SUMMARY}

PLANT ASSOCIATION:

\% COVER

\begin{tabular}{lcccc} 
VEGETATION LAYER : & $\begin{array}{l}\text { LIDE2-CHLA- } \\
\text { SESE2/NAOV }\end{array}$ & $\begin{array}{l}\text { LIDE2-CHLA/ } \\
\text { QUVA }\end{array}$ & $\begin{array}{l}\text { LIDE2-CHLA/ LIDE2-THPL/ } \\
\text { RHMA }\end{array}$ & $\begin{array}{c}\text { VAOV-GASH } \\
\text { VAOV }\end{array}$ \\
\hline TOTAL COVER & 9 & 9 & 7 & 3 \\
GRASS COVER & 95 & 92 & 98 & 99 \\
FORB COVER & 1 & 2 & 1 & 0 \\
SHRUB COVER & 26 & 14 & 21 & 33 \\
TREE COVER & 45 & 38 & 62 & 26
\end{tabular}

TREE OVERSTORY:

\% COVER (CONSTANCY)

\begin{tabular}{lcrrr}
\hline BIG LEAF MAPLE (ACMA) & $6(44)$ & $-(-)$ & $5(14)$ & $5(33)$ \\
BREWER'S SPRUCE (PIBR) & $-(-)$ & $-(-)$ & $-(-)$ & $-(-)$ \\
DOUGLAS-FIR (PSME) & $26(100)$ & $29(100)$ & $30(100)$ & $32(100)$ \\
INCENSE CEDAR (CADE3) & $1(11)$ & $8(69)$ & $-(-)$ & $6(33)$ \\
JEFFREY PINE (PIJE) & $-(-)$ & $6(10)$ & $-(-)$ & $-(-)$ \\
MADRONE (ARME3) & $5(33)$ & $8(56)$ & $-(-)$ & $12(33)$ \\
MOUNTAIN HEMLOCK (TSME) & $-(-)$ & $-(-)$ & $-(-)$ & $-(-)$ \\
PONDEROSA PINE (PIPO) & $-(-)$ & $7(44)$ & $-(-)$ & $-(-)$ \\
PORT-ORFORD-CEDAR (CHLA) & $13(89)$ & $27(100)$ & $33(100)$ & $10(33)$ \\
RED ALDER (ALRU2) & $16(33)$ & $6(22)$ & $20(14)$ & $-(-)$ \\
REDWOOD (SESE2) & $12(100)$ & $-(-)$ & $-(-)$ & $-(-)$ \\
SHASTA RED FIR (ABMAS) & $-(-)$ & $2(6)$ & $-(-)$ & $-(-)$ \\
SUGAR PINE (PILA) & $5(11)$ & $6(22)$ & $4(57)$ & $4(33)$ \\
TANOAK (LIDE2) & $35(100)$ & $13(100)$ & $30(100)$ & $48(100)$ \\
WESTERN RED CEDAR (THPL) & $-(-)$ & $-(-)$ & $-(-)$ & $21(100)$ \\
WESTERN WHITE PINE (PIMO3) & $-(-)$ & $-(-)$ & $-(-)$ & $-(-)$ \\
WHITE FIR (ABCO) & $-(-)$ & $1(11)$ & $3(14)$ & $-(-)$
\end{tabular}

TREE UNDERSTORY:

\% COVER (CONSTANCY)

\begin{tabular}{|c|c|c|c|c|}
\hline$\overline{\text { BIG LEAF MAPLE (ACMA) }}$ & $-(-)$ & $-(-)$ & $-(-)$ & $2(33)$ \\
\hline BREWER'S SPRUCE (PIBR) & $-(-)$ & $-(-)$ & $-(-)$ & $-(-)$ \\
\hline DOUGLAS-FIR (PSME) & $2(56)$ & $4 \quad(78)$ & $2(29)$ & $2(100)$ \\
\hline INCENSE CEDAR (CADE3) & $-(-)$ & $6 \quad(22)$ & $-(-)$ & $1(33)$ \\
\hline JEFFREY PINE (PIJE) & $-(-)$ & $-(-)$ & $-(-)$ & $-(-)$ \\
\hline MADRONE (ARME3) & $-(-)$ & $1 \quad(11)$ & $-(-)$ & $1(33)$ \\
\hline MOUNTAIN HEMLOCK (TSME) & $-(-)$ & $-(-)$ & $-(-)$ & $-(-)$ \\
\hline PONDEROSA PINE (PIPO) & $-(-)$ & $-(-)$ & $-(-)$ & $-(-)$ \\
\hline PORT-ORFORD-CEDAR (CHLA) & $2(89)$ & $5 \quad(89)$ & $4(86)$ & $1(33)$ \\
\hline RED ALDER (ALRU2) & $2(11)$ & (11) & $-(-)$ & $-(-)$ \\
\hline REDWOOD (SESE2) & $2(56)$ & $-(-)$ & $-(-)$ & $-(-)$ \\
\hline SHASTA RED FIR (ABMAS) & $-(-)$ & $-(-)$ & $-(-)$ & $-(-)$ \\
\hline SUGAR PINE (PILA) & $10(20)$ & $(-)$ & $1(14)$ & $1(33)$ \\
\hline TANOAK (LIDE2) & $7(100)$ & $18(100)$ & $11(100)$ & $8(100)$ \\
\hline WESTERN RED CEDAR (THPL) & $-(-)$ & $-(-)$ & $-(-)$ & $2(67)$ \\
\hline WESTERN WHITE PINE (PIMO3) & $-(-)$ & $-(-)$ & $-(-)$ & $-(-)$ \\
\hline WHITE FIR (ABCO) & $-(-)$ & $1 \quad(11)$ & $-(-)$ & $-(-)$ \\
\hline
\end{tabular}




\begin{tabular}{|c|c|c|c|c|}
\hline \multirow[b]{2}{*}{ SHRUBS:: } & LIDE2-CHLA- & \multirow{2}{*}{$\begin{array}{l}\text { LIDE2-CHLAV } \\
\text { QUVA }\end{array}$} & \multicolumn{2}{|c|}{ LIDE2-CHLA/ LIDE2-THPL } \\
\hline & ESE2/NAOV & & RHMA & VAOV-GASH \\
\hline CALIFORNIA HAZELNUT (COCOC) & C) $4(67)$ & $-(-)$ & $5(29)$ & $-(-)$ \\
\hline COFFEEBERRY (RHCA) & $-(-)$ & $8(22)$ & $2(55)$ & $-(-)$ \\
\hline DWARF OREGON-GRAPE (BENE1) & $2(33)$ & $5(44)$ & $2(71)$ & $1(33)$ \\
\hline DWARF TANBARK (LIDEE) & $-(-)$ & $-(-)$ & $-(-)$ & $-(-)$ \\
\hline EVERGREEN HUCKLEBERRY (VAO) & OV)24 (100) & $-(-)$ & $28(86)$ & $15(100)$ \\
\hline HUCKLEBERRY OAK (QUVA) & $-(-)$ & $18(100)$ & $-(-)$ & $-(-)$ \\
\hline PACIFIC RHODODENDRON (RHMA & AA) 2 (11) & $-(-)$ & $24(100)$ & $5(33)$ \\
\hline PINEMAT MANZANITA (ARNE2) & $-(-)$ & $-(-)$ & $-(-)$ & $-(-)$ \\
\hline POISON OAK (RHDI) & $6(56)$ & $-(-)$ & $-(-)$ & $1(33)$ \\
\hline RED HUCKLEBERRY (VAPA) & $2(44)$ & $5(56)$ & $6(57)$ & $1(67)$ \\
\hline SADLER OAK (QUSA) & $-(-)$ & $-(-)$ & $5(14)$ & $-(-)$ \\
\hline SALAL (GASH) & $12(100)$ & $13(44)$ & $17(100)$ & $10(100)$ \\
\hline SITKA ALDER (ALSI2) & $-(-)$ & $-(-)$ & $-(-)$ & - (-) \\
\hline SLENDER SALAL (GAOV) & $-(-)$ & $-(-)$ & $-(-)$ & $-(-)$ \\
\hline THIN-LEAF HUCKLEBERRY (VAME) & $-(-)$ & $-(-)$ & $-(-)$ & $-(-)$ \\
\hline TRAILING BLACKBERRY (RUUR) & $3(44)$ & $1(11)$ & $2(43)$ & $1(33)$ \\
\hline VINE MAPLE (ACCI) & $25(11)$ & $-(-)$ & $-(-)$ & $5(33)$ \\
\hline WESTERN AZALEA (RHOC) & $3(22)$ & $23(67)$ & $3(14)$ & $-(-)$ \\
\hline WOOD ROSE (ROGY) & $2(22)$ & 1 (11) & $2(29)$ & $1(33)$ \\
\hline WESTERN LABRADOR TEA (LEGL1) & L1) - (-) & $-(-)$ & $-(-)$ & $-(-)$ \\
\hline
\end{tabular}

HERBS \& GRASSES:

BEARGRASS (XETE)
BRACKEN FERN (PTAQL)
CALIF. PITCHER PLANT (DACA2)
COMMON LADY FERN (ATFIC)
DEER FERN (BLSP)
FIVE-FINGER FERN (ADPEA)
HOOKER'S FAIRYBELL (DIHO2)
INSIDE-OUT FLOWER (VAPL)
IRIS (IRI)
LILY (LIL2)
LITTLE PRINCE'S PINE (CHME)
OREGON TRILLIUM (TRRI)
PACIFIC ONION (ALVA)
QUEENS CUP (CLUN2)
RATTLESNAKE PLANTAIN (GOOB)
REDWOOD SORREL (OXOR)
STARFLOWER (TRLA3)
SWORDFERN (POMU1)
TWINFLOWER (LIBOL)
VANILLA LEAF (ACTR)

WESTERN MODESTY (WHMO)

WESTERN PRINCE'S PINE (CHUMO) - (-)

WHITE HAWKWEED (HIAL)

WHITE TRILLIUM (TROV2)

$2(11)$

WHITE-VEIN WINTERGREEN (PYPI) - (-)

WOOLLY RAGWORT (SETR)

SEDGE (CAR1)

GRASS SPECIES (GRAM)

RUSH (JUN2)
\% COVER (CONSTANCY)

$\begin{array}{lll}10(11) & 10(14) & -(-) \\ -(-) & 10(29) & -(-) \\ -(-) & -(-) & -(-) \\ -(-) & -(-) & -(-) \\ -(-) & -(-) & 20(33) \\ 4(44) & -(-) & 3(33) \\ 1(11) & -(-) & -(-) \\ 1(11) & 2(57) & -(-) \\ 1(22) & 1(14) & 3(33) \\ 1(11) & -(-) & -(-) \\ -(-) & 1 & (14) \\ -(-) & 1(29) & -(-) \\ -(-) & -(-) & -(-) \\ -(-) & -(-) & -(-) \\ 1(11) & 1(57) & -(-) \\ -(-) & 4(57) & 15(33) \\ 1(33) & 2(71) & -(-) \\ 9(67) & 12(71) & 40(33) \\ 1(11) & 3(43) & -(-) \\ -(-) & 6(43) & -(-) \\ 5(44) & 6(25) & -(-) \\ 3(22) & 2(29) & -(-) \\ -(-) & -(-) & -(-) \\ 1(11) & 1(43) & 1(33) \\ 1(22) & 1(14) & -(-) \\ -(-) & -(-) & -(-) \\ 5(11) & 1(29) & -(-) \\ 3(22) & 1(29) & -(-) \\ -(-) & -(-) & -(-)\end{array}$




\section{VEGETATION SUMMARY}

\begin{tabular}{|c|c|c|c|c|}
\hline \multirow{3}{*}{$\begin{array}{l}\text { PLANT ASSOCIATION: } \\
\text { VEGETATION LAYER : }\end{array}$} & \multicolumn{4}{|c|}{$\%$ COVER } \\
\hline & \multirow{2}{*}{$\begin{array}{l}\text { CHLA-ABCO/ } \\
\text { ALSI } 2\end{array}$} & \multirow{2}{*}{$\begin{array}{l}\text { CHLA-ABCO/ } \\
\text { ACCI }\end{array}$} & \multirow{2}{*}{$\begin{array}{l}\text { CHLA-ABMAS- } \\
\text { PIBR/QUSA-QUVA }\end{array}$} & \multirow{2}{*}{$\begin{array}{l}\text { CHLA-ABMAS/ } \\
\text { ALSI2-QUSA }\end{array}$} \\
\hline & & & & \\
\hline $\mathrm{N}$ & 19 & 8 & 20 & 11 \\
\hline TOTAL COVER & 94 & 98 & 91 & 96 \\
\hline GRASS COVER & 5 & 1 & 1 & 4 \\
\hline FORB COVER & 33 & 36 & 12 & 25 \\
\hline SHRUB COVER & 39 & 39 & 60 & 57 \\
\hline TREE COVER & 76 & 85 & 55 & 68 \\
\hline TREE OVERSTORY: & & $\%$ COVER & (CONSTANCY) & \\
\hline$\overline{\mathrm{BIG} \text { LEAF MAPLE (ACMA) }}$ & $2(11)$ & $9(63)$ & $-(-)$ & $-(-)$ \\
\hline BREWER'S SPRUCE (PIBR) & $1(5)$ & $-(-)$ & $7(95)$ & $2(55)$ \\
\hline DOUGLAS-FIR (PSME) & $18(89)$ & $29(100)$ & $6(65)$ & $11(64)$ \\
\hline INCENSE CEDAR (CADE3) & $3(26)$ & $1(13)$ & $2(40)$ & $5(45)$ \\
\hline JEFFREY PINE (PIJE) & $-(-)$ & $-(-)$ & $6(10)$ & $-(-)$ \\
\hline MADRONE (ARME3) & $-(-)$ & $-(-)$ & $-(-)$ & $-(-)$ \\
\hline MOUNTAIN HEMLOCK (TSME) & $-(-)$ & $-(-)$ & $4(25)$ & $11(18)$ \\
\hline PONDEROSA PINE (PIPO) & $-(-)$ & $-(-)$ & $8(10)$ & $4(18)$ \\
\hline PORT-ORFORD-CEDAR (CHLA) & $48(100)$ & $44(100)$ & $26(100)$ & $36(100)$ \\
\hline RED ALDER (ALRU2) & - (-) & $2(25)$ & $-(-)$ & $-(-)$ \\
\hline REDWOOD (SESE2) & $-(-)$ & $-(-)$ & $-(-)$ & $-(-)$ \\
\hline SHASTA RED FIR (ABMAS) & $4(26)$ & $-(-)$ & $8(100)$ & $7(91)$ \\
\hline SUGAR PINE (PILA) & $5(26)$ & $-(-)$ & $5(30)$ & $5(27)$ \\
\hline TANOAK (LIDE2) & $5(3)$ & $2(13)$ & $-(-)$ & $-(-)$ \\
\hline WESTERN RED CEDAR (THPL) & $-(-)$ & $-(-)$ & $-(-)$ & $-(-)$ \\
\hline WESTERN WHITE PINE (PIMO3) & $4(21)$ & $-(-)$ & $7(100)$ & $5(36)$ \\
\hline WHITE FIR (ABCO) & $12(100)$ & $15(100)$ & $8(85)$ & $9(82)$ \\
\hline TREE UNDERSTORY: & & $\%$ COVER & (CONSTANCY) & \\
\hline$\overline{\mathrm{BIG} \text { LEAF MAPLE (ACMA) }}$ & $-(-)$ & $1 \quad(13)$ & $-(-)$ & $-(-)$ \\
\hline BREWER'S SPRUCE (PIBR) & $-(-)$ & $-(-)$ & $2(70)$ & $1(18)$ \\
\hline DOUGLAS-FIR (PSME) & $1(42)$ & $1 \quad(63)$ & $1(10)$ & $1(9)$ \\
\hline INCENSE CEDAR (CADE3) & $1(11)$ & $1 \quad(13)$ & $1(30)$ & $2(18)$ \\
\hline JEFFREY PINE (PIJE) & $-(-)$ & $-(-)$ & $3(5)$ & $-(-)$ \\
\hline MADRONE (ARME3) & $-(-)$ & $-(-)$ & $-(-)$ & $-(-)$ \\
\hline MOUNTAIN HEMLOCK (TSME) & $-(-)$ & $-(-)$ & $1(15)$ & $3(18)$ \\
\hline PONDEROSA PINE (PIPO) & $-(-)$ & $-(-)$ & $-(-)$ & $-(-)$ \\
\hline PORT-ORFORD-CEDAR (CHLA) & $5(89)$ & $4 \quad(100)$ & $4(90)$ & $4(100)$ \\
\hline RED ALDER (ALRU2) & $-(-)$ & $-(-)$ & $-(-)$ & $-(-)$ \\
\hline REDWOOD (SESE2) & $-(-)$ & $-(-)$ & $-(-)$ & $-(-)$ \\
\hline SHASTA RED FIR (ABMAS) & $6(11)$ & $-(-)$ & $2(90)$ & $2(82)$ \\
\hline SUGAR PINE (PILA) & $2(11)$ & $-(-)$ & $2(10)$ & $1(9)$ \\
\hline TANOAK (LIDE2) & $-(-)$ & $3(50)$ & $-(-)$ & $-(-)$ \\
\hline WESTERN RED CEDAR (THPL) & $-(-)$ & $-(-)$ & $-(-)$ & $-(-)$ \\
\hline WESTERN WHITE PINE (PIMO3) & $-(-)$ & $-(-)$ & $3(60)$ & $1(36)$ \\
\hline WHITE FIR (ABCO) & $4(84)$ & $2(50)$ & $2(85)$ & $2(82)$ \\
\hline
\end{tabular}




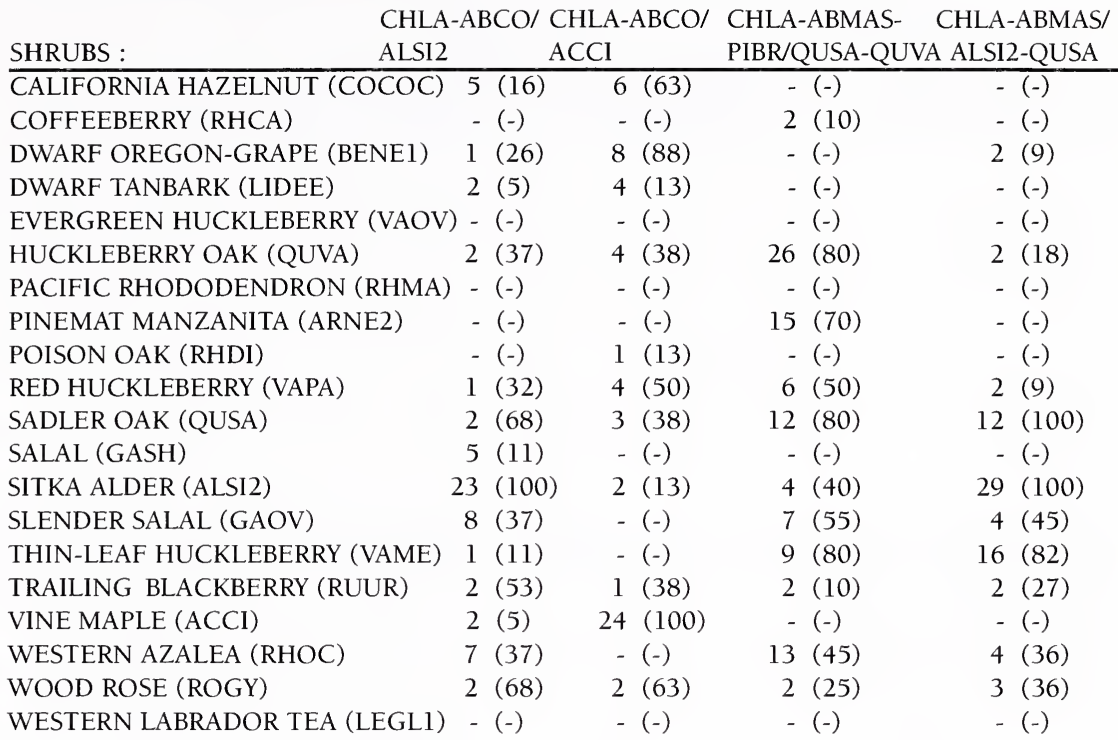

HERBS \& GRASSES:

\% COVER (CONSTANCY)

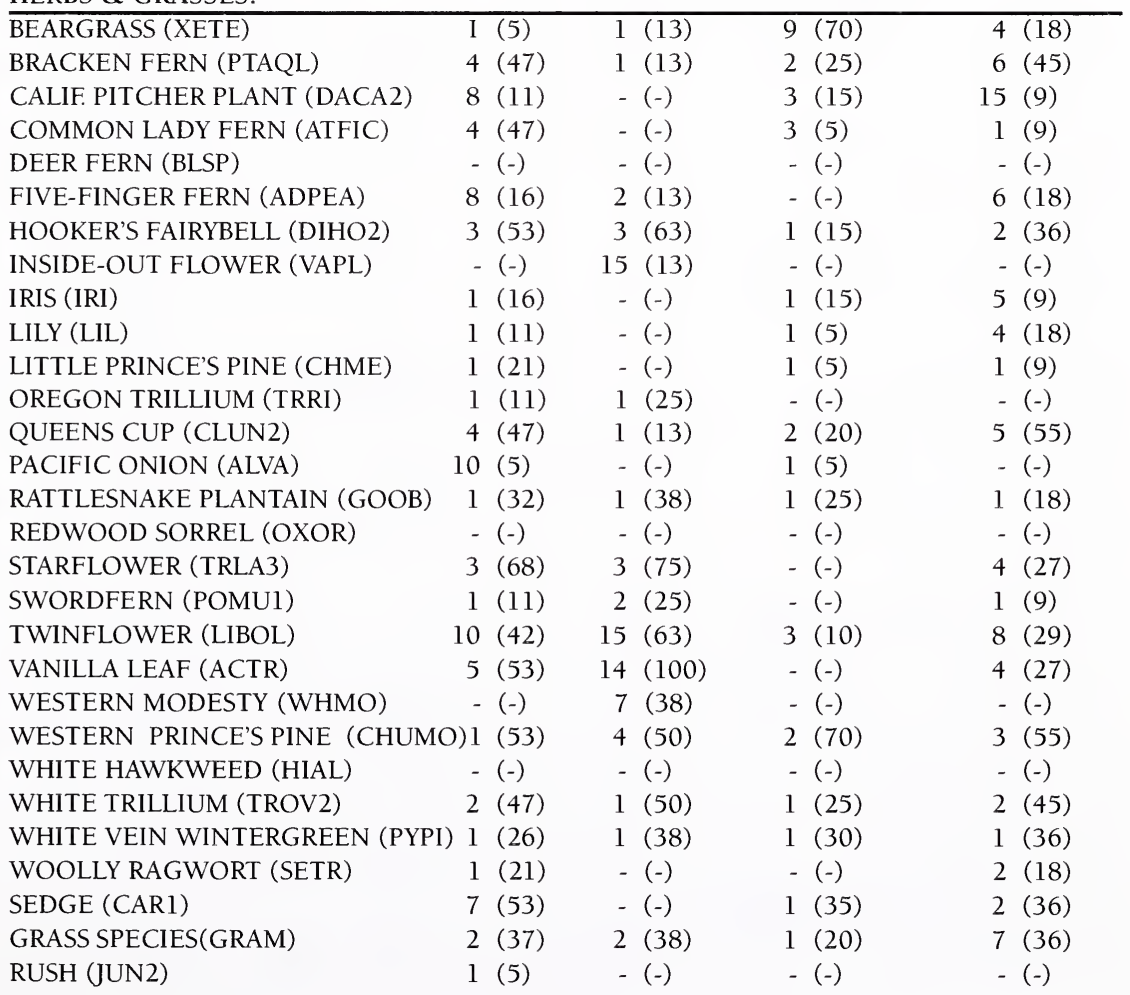




\section{VEGETATION SUMMARY}

\begin{tabular}{lccc} 
PLANT ASSOCIATION: & $\begin{array}{c}\text { \% COVER } \\
\text { CHLA-ABMAS/ } \\
\text { VEGETATION LAYER : }\end{array}$ & $\begin{array}{c}\text { CHLASI2/DACA2 } \\
\text { COCOC }\end{array}$ & $\begin{array}{c}\text { CHLA-PSME- } \\
\text { ALDER/ACCI-BENE1 }\end{array}$ \\
\hline $\mathrm{N}$ & 3 & 7 & 8 \\
TOTAL COVER & 97 & 89 & 95 \\
GRASS COVER & 48 & 1 & 2 \\
FORB COVER & 53 & 49 & 32 \\
SHRUB COVER & 37 & 35 & 43 \\
TREE COVER & 38 & 66 & 78
\end{tabular}

TREE OVERSTORY:

\% COVER (CONSTANCY)

\begin{tabular}{|c|c|c|c|}
\hline$\overline{\mathrm{BIG} \text { LEAF MAPLE (ACMA) }}$ & $-(-)$ & $20(43)$ & $10(50)$ \\
\hline BREWER'S SPRUCE (PIBR) & $1(67)$ & $-(-)$ & $-(-)$ \\
\hline DOUGLAS-FIR (PSME) & $1(33)$ & $12(100)$ & $32(100)$ \\
\hline INCENSE CEDAR (CADE3) & $-(-)$ & $-(-)$ & $7(50)$ \\
\hline JEFFREY PINE (PIJE) & $-(-)$ & $-(-)$ & $-(-)$ \\
\hline MADRONE (ARME3) & $-(-)$ & $5(14)$ & $5(25)$ \\
\hline MOUNTAIN HEMLOCK (TSME) & $11(67)$ & $-(-)$ & $-(-)$ \\
\hline PONDEROSA PINE (PIPO) & $-(-)$ & $-(-)$ & $-(-)$ \\
\hline PORT-ORFORD-CEDAR (CHLA) & $26(100)$ & $46(100)$ & $21(100)$ \\
\hline RED ALDER (ALRU2) & $-(-)$ & $20(14)$ & $33(100)$ \\
\hline REDWOOD (SESE2) & $12(100)$ & $-(-)$ & $-(-)$ \\
\hline SHASTA RED FIR (ABMAS) & $3(100)$ & $2(6)$ & $-(-)$ \\
\hline SUGAR PINE (PILA) & $-(-)$ & $-(-)$ & $-(-)$ \\
\hline TANOAK (LIDE2) & $-(-)$ & $-(-)$ & $3(83)$ \\
\hline WESTERN RED CEDAR (THPL) & $-(-)$ & $-(-)$ & $-(-)$ \\
\hline WESTERN WHITE PINE (PIMO3) & $4(100)$ & $-(-)$ & $-(-)$ \\
\hline WHITE FIR (ABCO) & $11(67)$ & $3(43)$ & $4(38)$ \\
\hline TREE UNDERSTORY: & \multicolumn{3}{|c|}{ \% COVER (CONSTANCY) } \\
\hline$\overline{\text { BIG LEAF MAPLE (ACMA) }}$ & $-(-)$ & $2(14)$ & $2(13)$ \\
\hline BREWER'S SPRUCE (PIBR) & $1(100)$ & $-(-)$ & $-(-)$ \\
\hline DOUGLAS-FIR (PSME) & $1(33)$ & $2(71)$ & $5(63)$ \\
\hline INCENSE CEDAR (CADE3) & $-(-)$ & $-(-)$ & $1(13)$ \\
\hline JEFFREY PINE (PIJE) & $-(-)$ & $-(-)$ & $-(-)$ \\
\hline MADRONE (ARME3) & $-(-)$ & $-(-)$ & $-(-)$ \\
\hline MOUNTAIN HEMLOCK (TSME) & $3(67)$ & $-(-)$ & $-(-)$ \\
\hline PONDEROSA PINE (PIPO) & $-(-)$ & $-(-)$ & $-(-)$ \\
\hline PORT-ORFORD-CEDAR (CHLA) & $6(100)$ & $3(86)$ & $3(88)$ \\
\hline RED ALDER (ALRU2) & $-(-)$ & $4(14)$ & $2(63)$ \\
\hline REDWOOD (SESE2) & $-(-)$ & $-(-)$ & $-(-)$ \\
\hline SHASTA RED FIR (ABMAS) & $2(100)$ & $-(-)$ & $-(-)$ \\
\hline SUGAR PINE (PILA) & $-(-)$ & $-(-)$ & $-(-)$ \\
\hline TANOAK (LIDE2) & $-(-)$ & $-(-)$ & $3(38)$ \\
\hline WESTERN RED CEDAR (THPL) & $-(-)$ & $-(-)$ & $-(-)$ \\
\hline WESTERN WHITE PINE (PIMO3) & $3(100)$ & $-(-)$ & $-(-)$ \\
\hline WHITE FIR (ABCO) & $1(67)$ & $1(57)$ & $3(25)$ \\
\hline
\end{tabular}




\begin{tabular}{llcc} 
& CHLA-ABMAS/ & CHLA-PSME/ & CHLA-PSME- \\
SHRUBS : & ALSI2/DACA2 & COCOC & ALDERACCI-BENEl \\
\hline CALIFORNIA HAZELNUT (COCOC) & $-(-)$ & $26(100)$ & $6(75)$ \\
COFFEEBERRY (RHCA) & $-(-)$ & $1(14)$ & $3(13)$ \\
DWARF OREGON-GRAPE (BENE1) & $-(-)$ & $3(43)$ & $10(75)$ \\
DWARF TANBARK (LIDEE) & $-(-)$ & $-(-)$ & $-(-)$ \\
EVERGREEN HUCKLEBERRY (VAOV) & $-(-)$ & $-(-)$ & $-(-)$ \\
HUCKLEBERRY OAK (QUVA) & $1-(67)$ & $1(43)$ & $3(38)$ \\
PACIFIC RHODODENDRON (RHMA) & $-(-)$ & $-(-)$ & $-(-)$ \\
PINEMAT MANZANITA (ARNE2) & $-(-)$ & $-(-)$ & $-(-)$ \\
POISON OAK (RHDI) & $-(-)$ & $10(14)$ & $10(25)$ \\
RED HUCKLEBERRY (VAPA) & $-(-)$ & $-(-)$ & $4(50)$ \\
SADLER OAK (QUSA) & $2(100)$ & $1(14)$ & $-(-)$ \\
SALAL (GASH) & $-(-)$ & $-(-)$ & $-(-)$ \\
SITKA ALDER (ALSI2) & $20(100)$ & $-(-)$ & $-(-)$ \\
SLENDER SALAL (GAOV) & $3(100)$ & $-(-)$ & $9(25)$ \\
THIN-LEAF HUCKLEBERRY (VAME) & $4(100)$ & $-(-)$ & $-(-)$ \\
TRAILING BLACKBERRY (RUUR) & $-(-)$ & $3(71)$ & $2(38)$ \\
VINE MAPLE (ACCI) & $-(-)$ & $-(-)$ & $12(100)$ \\
WESTERN AZALEA (RHOC) & $5(100)$ & $5(57)$ & $10(63)$ \\
WOOD ROSE (ROGY) & $-(-)$ & $2(57)$ & $2(38)$ \\
WESTERN LABRADOR TEA (LEGL1) & $-(-)$ & $-(-)$ & $-(-)$
\end{tabular}

HERBS \& GRASSES:

\% COVER (CONSTANCY)

\begin{tabular}{|c|c|c|c|c|}
\hline BEARGRASS (XETE) & 1 & $(67)$ & $-(-)$ & $-(-)$ \\
\hline BRACKEN FERN (PTAQL) & - & $(-)$ & $2(29)$ & $5(13)$ \\
\hline CALIF. PITCHER PLANT (DACA2) & 35 & $(100)$ & $-(-)$ & $-(-)$ \\
\hline COMMON LADY FERN (ATFIC) & - & $(-)$ & $-(-)$ & $-(-)$ \\
\hline DEER FERN (BLSP) & - & $(-)$ & $-(-)$ & $-(-)$ \\
\hline FIVE-FINGER FERN (ADPEA) & - & $(-)$ & $1(14)$ & $4(25)$ \\
\hline HOOKER'S FAIRYBELL (DIHO2) & - & $(-)$ & $8(71)$ & $1(50)$ \\
\hline INSIDE-OUT FLOWER (VAPL) & - & $(-)$ & $4(43)$ & $-(-)$ \\
\hline IRIS (IRI) & - & $(-)$ & $1(29)$ & $-(-)$ \\
\hline LILY (LIL2) & 1 & $(100)$ & $8(29)$ & $1(13)$ \\
\hline LITTLE PRINCE'S PINE (CHME) & - & $(-)$ & $2(14)$ & $1(13)$ \\
\hline OREGON TRILLIUM (TRRI) & - & $(-)$ & $-(-)$ & $-(-)$ \\
\hline QUEENS CUP (CLUN2) & 1 & (33) & $-(-)$ & $-(-)$ \\
\hline PACIFIC ONION (ALVA) & 3 & $(100)$ & $-(-)$ & $-(-)$ \\
\hline RATTLESNAKE PLANTAIN (GOOB) & 1 & $(33)$ & $1(71)$ & $1(13)$ \\
\hline REDWOOD SORREL (OXOR) & - & $(-)$ & $-(-)$ & $-(-)$ \\
\hline STARFLOWER (TRLA3) & - & $(-)$ & $3(71)$ & $3(63)$ \\
\hline SWORDFERN (POMU1) & - & $(-)$ & $1(14)$ & $10(75)$ \\
\hline TWINFLOWER (LIBOL) & - & $(-)$ & $12(57)$ & $13(38)$ \\
\hline VANILLA LEAF (ACTR) & - & $(-)$ & $18(86)$ & $5(50)$ \\
\hline WESTERN MODESTY (WHMO) & - & $(-)$ & $5(43)$ & $9(63)$ \\
\hline WESTERN PRINCE'S PINE (CHUMO) & - & $(-)$ & $2(14)$ & $2(13)$ \\
\hline WHITE HAWKWEED & - & $(-)$ & $-(-)$ & l (13) \\
\hline WHITE TRILLIUM (TROV2) & - & $(-)$ & $1(29)$ & $1(25)$ \\
\hline WHITE VEIN WINTERGREEN (PYPI) & - & $(-)$ & $-(-)$ & $-(-)$ \\
\hline WOOLLY RAGWORT (SETR) & 2 & $(100)$ & $-(-)$ & $-(-)$ \\
\hline SEDGE (CARl) & - & $(-)$ & $13(14)$ & $5(13)$ \\
\hline GRASS SPECIES (GRAM) & 48 & $(100)$ & $2(14)$ & $2(38)$ \\
\hline RUSH (JUN2) & - & $(-)$ & $-(-)$ & $-(-)$ \\
\hline new $7 / 99$ & & $107-g$ & & \\
\hline
\end{tabular}




\section{VEGETATION SUMMARY}

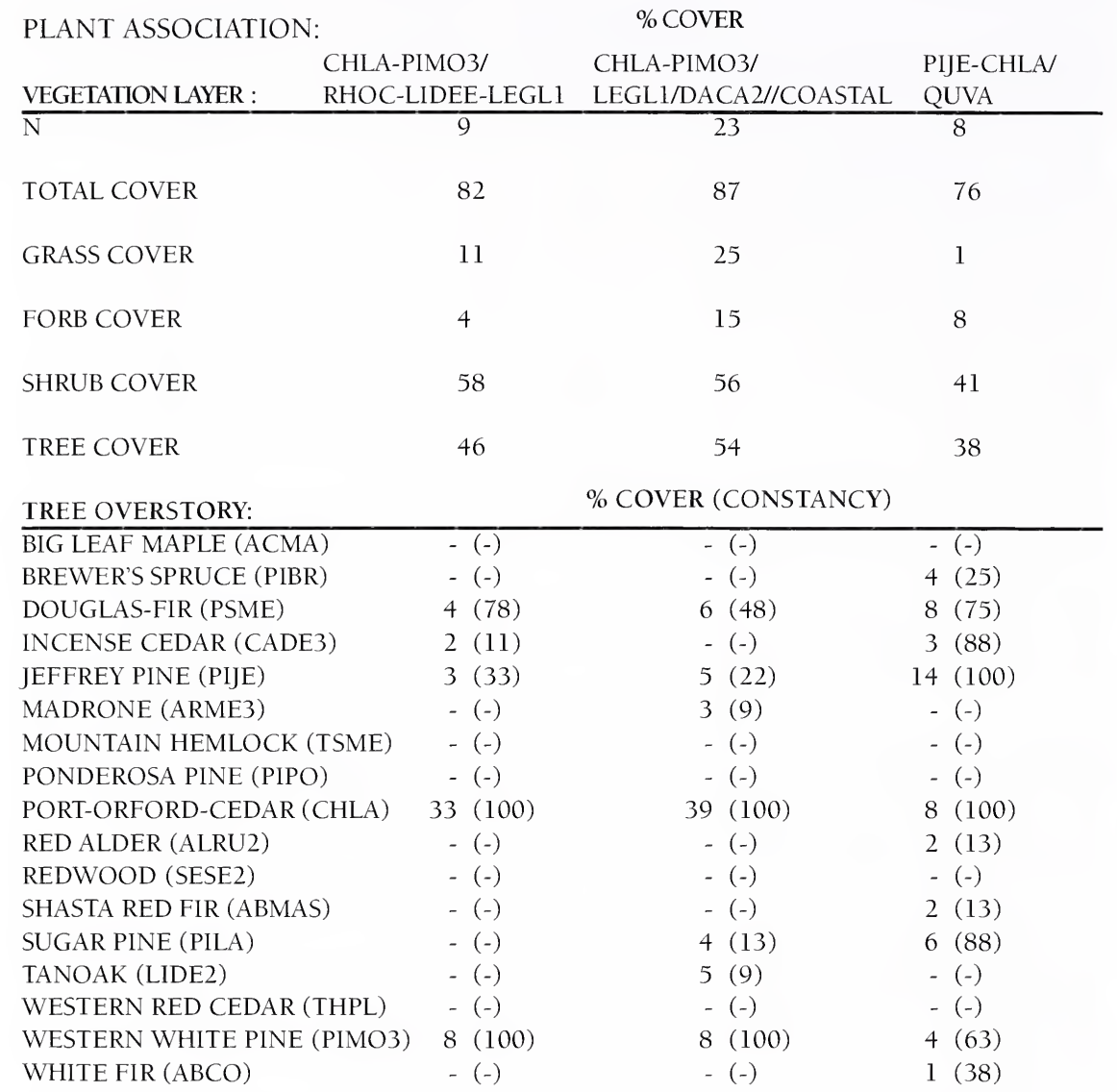

TREE UNDERSTORY:

\% COVER (CONSTANCY)

\begin{tabular}{llll}
\hline BIG LEAF MAPLE (ACMA) & $-(-)$ & $-(-)$ & $-(-)$ \\
BREWER'S SPRUCE (PIBR) & $-(-)$ & $-(-)$ & $2(25)$ \\
DOUGLAS-FIR (PSME) & $1(22)$ & $1(26)$ & $1(63)$ \\
INCENSE CEDAR (CADE3) & $-(-)$ & $-(-)$ & $1(88)$ \\
JEFFREY PINE (PIJE) & $1(11)$ & $1(13)$ & $2(88)$ \\
MADRONE (ARME3) & $-(-)$ & $-(-)$ & $-(-)$ \\
MOUNTAIN HEMLOCK (TSME) & $-(-)$ & $-(-)$ & $-(-)$ \\
PONDEROSA PINE (PIPO) & $-(-)$ & $-(-)$ & $-(-)$ \\
PORT-ORFORD-CEDAR (CHLA) & $3(100)$ & $4(100)$ & $2(100)$ \\
RED ALDER (ALRU2) & $-(-)$ & $-(-)$ & $-(-)$ \\
REDWOOD (SESE2) & $-(-)$ & $-(-)$ & $-(-)$ \\
SHASTA RED FIR (ABMAS) & $-(-)$ & $-(-)$ & $1(13)$ \\
SUGAR PINE (PILA) & $-(-)$ & $2(13)$ & $1(38)$ \\
TANOAK (LIDE2) & $-(-)$ & $2(9)$ & $-(-)$ \\
WESTERN RED CEDAR (THPL) & $-(-)$ & $-(-)$ & $-(-)$ \\
WESTERN WHITE PINE (PIMO3) & $2(100)$ & $3(96)$ & $2(50)$ \\
WHITE FIR (ABCO) & $-(-)$ & $-(-)$ & $1(13)$
\end{tabular}


RHOC-LIDEE-LEGL1 LEGL1/DACA2//COASTAL QUVA

CALIFORNIA HAZELNUT (COCOC)
COFFEEBERRY (RHCA)
DWARF OREGON-GRAPE (BENEI)
DWARF TANBARK (LIDEE)
EVERGREEN HUCKLEBERRY (VAOV)
HUCKLEBERRY OAK (QUVA)
PACIFIC RHODODENDRON (RHMA)
PINEMAT MANZANITA (ARNE2)
POISON OAK (RHDI)
RED HUCKLEBERRY (VAPA)
SADLER OAK (QUSA)
SALAL (GASH)
SITKA ALDER (ALSI2)
SLENDER SALAL (GAOV)
THIN-LEAF HUCKLEBERRY (VAME)
TRAILING BLACKBERRY (RUUR)
VINE MAPLE (ACCI)
WESTLRN AZALEA (RHOC)
WOOD ROSE (ROGY)
WESTERN

$\begin{array}{rlr}3(78) & 3(57) & 2(75) \\ -(-) & -(-) & -(-) \\ 5(100) & 8(91) & -(-) \\ 1(22) & 6(39) & -(-) \\ 10(89) & 4(83) & 27(100) \\ 1(11) & 3(17) & -(-) \\ 1(11) & 5(4) & 7(75) \\ -(-) & -(-) & -(-) \\ 2(78) & 2(52) & 6(63) \\ -(-) & -(-) & -(-) \\ -(-) & 9(35) & -(-) \\ -(-) & -(-) & -(-) \\ -(-) & -(-) & -(-) \\ 1(11) & -(-) & -(-) \\ -(-) & 1(4) & 1(13) \\ -(-) & -(-) & -(-) \\ 26(100) & 15(100) & -(-) \\ -(-) & 1(4) & 1(25) \\ 22(67) & 29(100) & -(-)\end{array}$

HERBS \& GRASSES:

\% COVER (CONSTANCY)

\begin{tabular}{|c|c|c|c|}
\hline$\overline{\text { BEARGRASS (XETE) }}$ & $5(33)$ & $4(43)$ & $7(75)$ \\
\hline BRACKEN FERN (PTAQL) & $-(-)$ & $-(-)$ & $-(-)$ \\
\hline CALIF. PITCHER PLANT (DACA2) & $1(11)$ & $11(91)$ & $-(-)$ \\
\hline COMMON LADY FERN (ATFIC) & $-(-)$ & $-(-)$ & $-(-)$ \\
\hline DEER FERN (BLSP) & $-(-)$ & $-(-)$ & $-(-)$ \\
\hline FIVE-FINGER FERN (ADPEA) & $2(44)$ & $3(13)$ & $-(-)$ \\
\hline HOOKER'S FAIRYBELL (DIHO2) & $-(-)$ & $-(-)$ & $-(-)$ \\
\hline INSIDE-OUT FLOWER (VAPL) & $1(33)$ & $-(-)$ & $-(-)$ \\
\hline IRIS (IRI) & $1(11)$ & $2(26)$ & $1(50)$ \\
\hline LILY (LIL2) & $-(-)$ & $1(9)$ & $1(13)$ \\
\hline LITTLE PRINCE'S PINE (CHME) & $-(-)$ & $-(-)$ & $-(-)$ \\
\hline OREGON TRILLIUM (TRRI) & $-(-)$ & $1(39)$ & $-(-)$ \\
\hline QUEENS CUP (CLUN2) & $-(-)$ & $-(-)$ & $-(-)$ \\
\hline PACIFIC ONION (ALVA) & $-(-)$ & $-(-)$ & $-(-)$ \\
\hline RATTLESNAKE PLANTAIN (GOOB) & $1(22)$ & $1(4)$ & $1(13)$ \\
\hline REDWOOD SORREL (OXOR) & $-(-)$ & $-(-)$ & $-(-)$ \\
\hline STARFLOWER (TRLA3) & $-(-)$ & $-(-)$ & $-(-)$ \\
\hline SWORDFERN (POMU1) & $-(-)$ & $2(17)$ & $-(-)$ \\
\hline TWINFLOWER (LIBOL) & $-(-)$ & $-(-)$ & $-(-)$ \\
\hline VANILLA LEAF (ACTR) & $-(-)$ & $-(-)$ & $-(-)$ \\
\hline WESTERN MODESTY (WHMO) & $1(22)$ & $3(4)$ & $2(13)$ \\
\hline WESTERN PRINCE'S PINE (CHUMO) & $-(-)$ & $1(4)$ & $-(-)$ \\
\hline WHITE HAWKWEED (HIAL) & $-(-)$ & $-(-)$ & $-(-)$ \\
\hline WHITE TRILLIUM (TROV2) & $-(-)$ & $-(-)$ & $-(-)$ \\
\hline WHITE VEIN WINTERGREEN (PYPI) & $-(-)$ & $1(4)$ & $1(25)$ \\
\hline WOOLLY RAGWORT (SETR) & $-(-)$ & $-(-)$ & $-(-)$ \\
\hline SEDGE (CAR1) & $7(89)$ & $23(87)$ & $2(25)$ \\
\hline GRASS SPECIES (GRAM) & $4(89)$ & $4(78)$ & $1(25)$ \\
\hline RUSH (JUN2) & $-(-)$ & $10(4)$ & $-(-)$ \\
\hline new $7 / 99$ & 109 & & \\
\hline
\end{tabular}





\section{APPENDIX VI: GLOSSARY}




\section{GLOSSARY}

Definitions. The following definitions are used throughout the Pacific Southwest Region of the Forest Service to standardize the approach to its hierarchical vegetation classification. At the top of the vegetation hierarchy is the series. Series are identified by the presence of the dominant species in all or most of the structural layers present in late seral stage stands. Series are followed in the hierarchy by the sub-series. Here the series name is modified by the addition of a second species that has indicator value across multiple plant associations. At the bottom of the classification hierarchy the finest vegetation units described are plant associations. They are the potential natural community with uniform appearance and definite floristic composition.

SERIES: A vegetation series is an aggregation of taxonomically related plant associations which take the name of the (climatic) climax species that dominate (or have the potential to dominate) the principal vegetation layer in a time frame appropriate to the vegetation or taxonomic group under consideration.

SUB-SERIES: A vegetation sub-series is an aggregation of taxonomically related plant associations within a series that takes the name of that series followed by related species that are dominant, or have indicator value across multiple plant associations.

PLANT ASSOCIATION: A potential natural plant community of definite floristic composition and uniform appearance that repeats itself across the landscape and takes the name of the projected climax type.

INDICATOR SPECIES: A species which is sensitive to important environment features of a site such that its constancy or abundance reflect significant changes in environment.

ECOLOGICAL TYPE: A category of land having a unique combination of potential natural community, soil, landscape features, climate, and differing from other ecological types in its ability to produce vegetation and respond to management.

CHARACTERISTIC COVER: The percent cover one could expect to find in a plant association if a species were present. It is calculated by summing percent cover and dividing by the number of plots containing the species. 
CONSTANCY: The percent of times a species was found to occur in a plant association.

REPRODUCING SUCCESSFULLY: The species is present throughout the structural layers which are represented in the late seral stand.

PRIMARY REGENERATING SPECIES: The species which is higher in cover, or in number of individual stems, than any other species of the principle vegetative layer. 



\section{APPENDIX VII: ECOCLASS CODES}




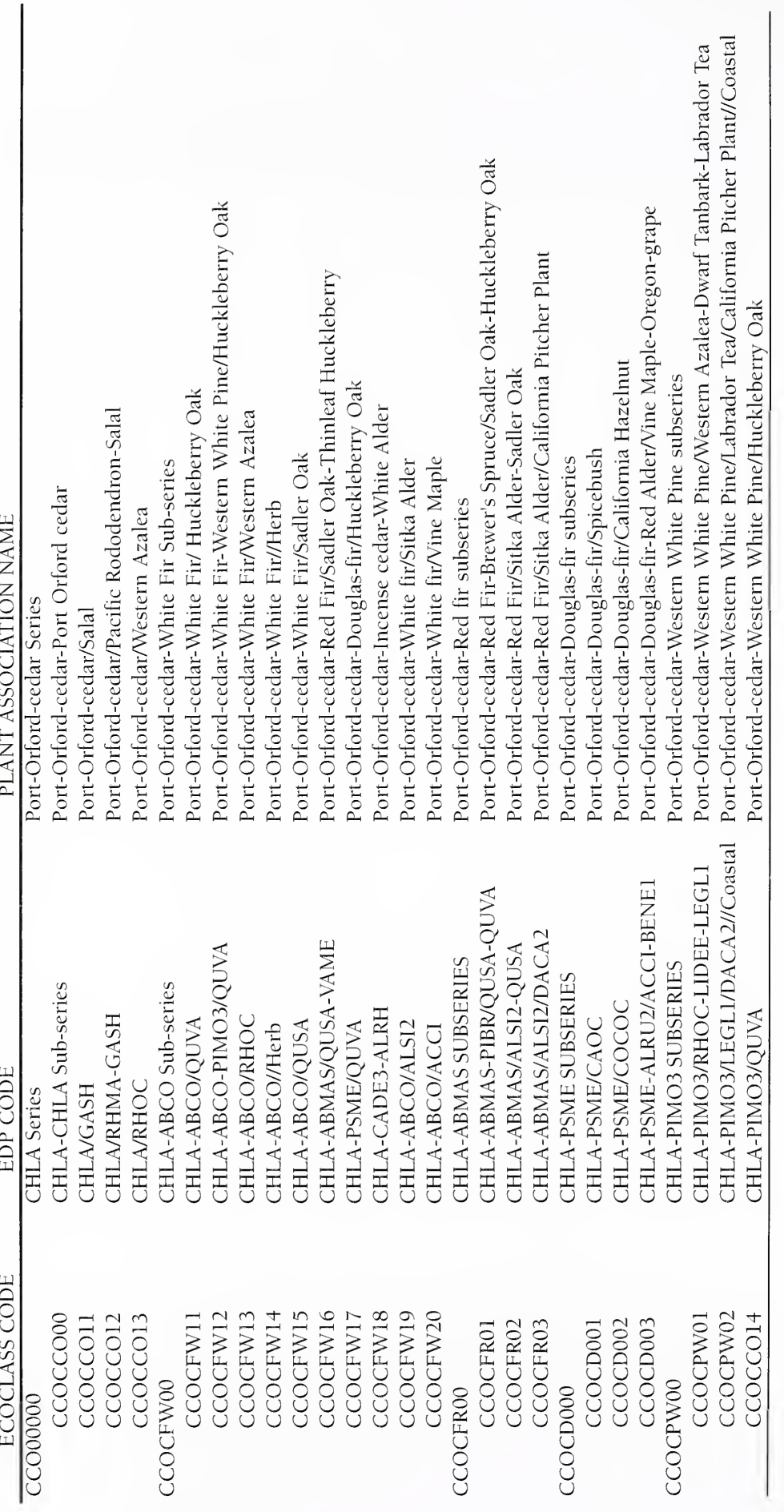



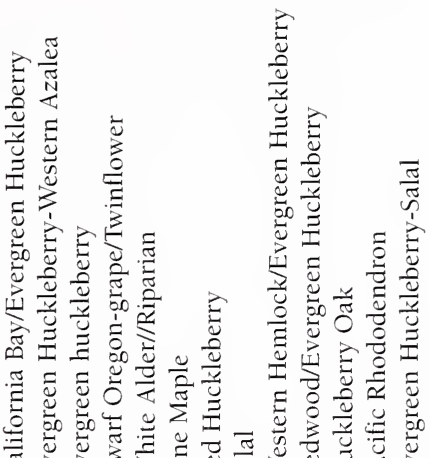

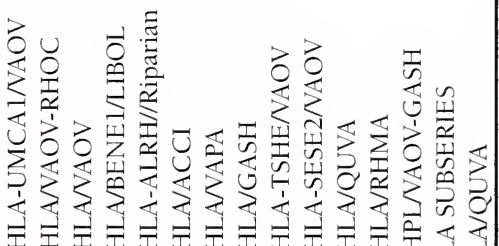

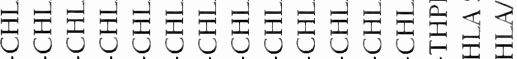
ஸ்่

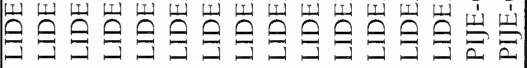

تี

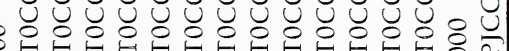

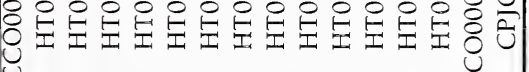
点 



\section{Port-Orford-cedar Plant Associations In the Trinity \& Sacramento River Drainages}



A Supplement to:

\author{
A Field Guide To Port-Orford-cedar \\ Plant Associations in Northwest California
}

Thomas M. Jimerson

Elizabeth A. McGee

Gregg DeNitto

Drawings By:

Christina Ericksen

Photographs By:

Thomas M. Jimerson

Jeffrey K. Jones 


\section{ACKNOWLEDGMENTS}

The USDA Forest Service, Forest Pest Management Program funded this supplement to the Port-Orford-cedar field guide. We thank the following individuals for their assistance in the development of this field guide: Jeff Jones, Bruce Bryan, Edward Biery, Richard Dwerlkotle, Peter Figura, Laura Andrews, Philip Purcell and Bud Adamson for ecology plot data collection; Tom Laurent, Tim Hagen ,Patricia Caswell, Theresa Kunch, and Mike Vollmer for soils data collection; and Peggi Lawrence, David Jones, Pete Angwin and Frank Betlejewski for manuscript review and Jerry Boberg for assistance with graphics. 


\section{Table of Contents}

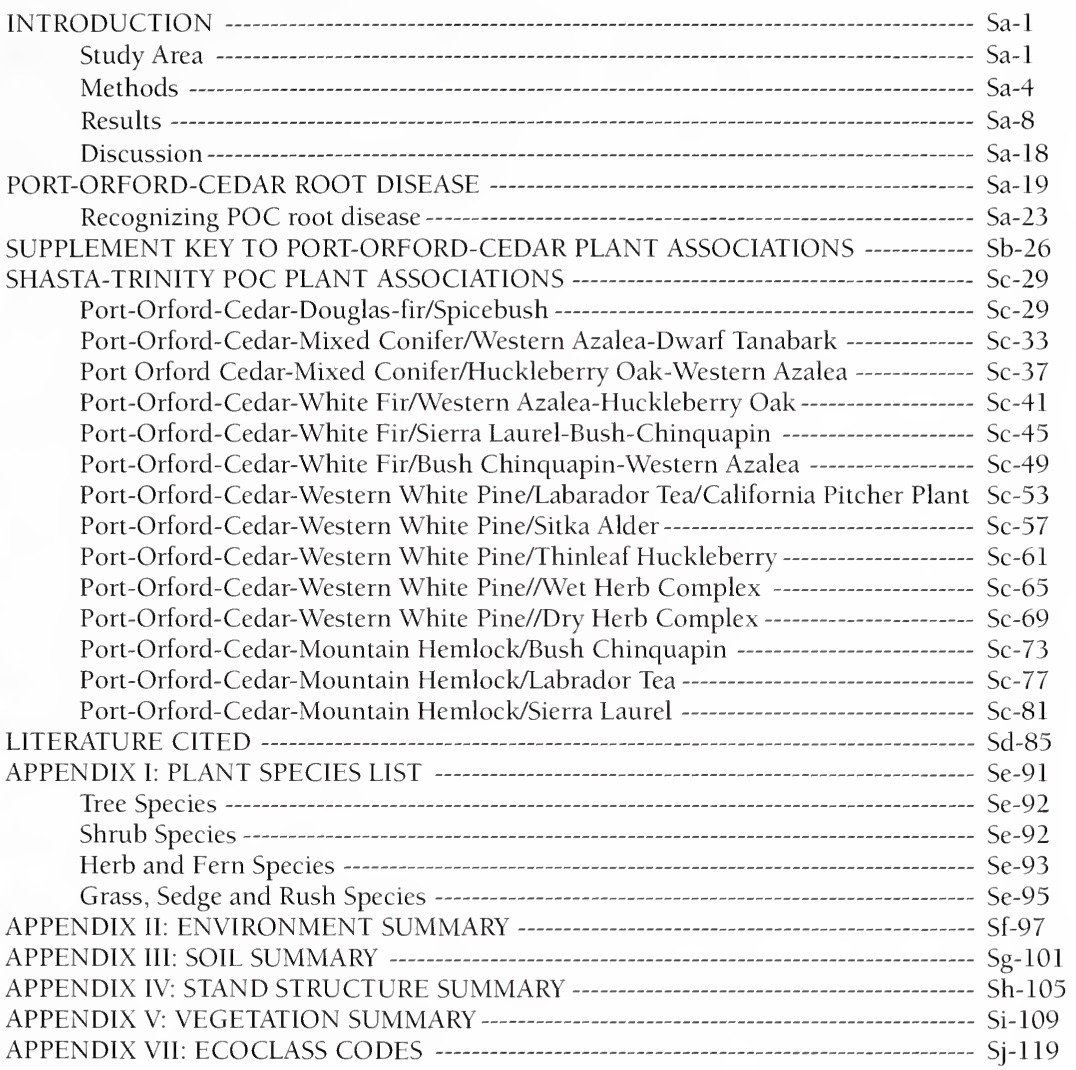





\section{INTRODUCTION}

This document is a supplement to "A Field Guide To PortOrford-cedar Plant Associations In Northwest California" (Jimerson 1994). It is based on the expansion of Port-Orford-cedar sampling into the Sacramento and Trinity River drainages in the vicinity of Mt. Shasta on the Shasta-Trinity National Forest (fig. 1). It describes the expanded study area, methodology and classification and includes descriptions of the newly identified Port-Orford-cedar plant associations. In addition, a second section describes the root disease affecting the species (Phytophthora lateralis) and ways to limit the disease spread. The addition of this supplement to the original field guide will result in a complete ecological classification of Port-Orford-cedar plant associations on National Forest System lands throughout northern California.

The information included in this field guide will be used in the development of the USDA Forest Service/Bureau of Land Management strategy for the conservation of Port-Orford-cedar. Together with the mapped polygons of Port-Orford-cedar, it will allow managers to identify opportunities to reduce human-related spread of Port-Orfordcedar root disease, especially into uninfected watersheds. In addition, the biological diversity of Port-Orford-cedar plant associations and their extent in California can be examined. This will allow for the identification of potential refugia sites for Port-Orford-cedar plant associations that capture the variability of Port-Orford-cedar plant communities throughout California.

\section{STUDY AREA}

The ecological subsections of California (USDA 1997) were used to stratify the study area. Samples were collected in the Eastern Klamath Mountains, Upper Scott Mountains and Lower Scott Mountains (USDA 1997) (fig. 2). These three subsections are disjunct from the main body of Port-Orford-cedar found in the western part of the range and are collectively known as the east subsections. These relatively uniform ecological units were mapped based on associations of their biotic and environmental factors that directly affect ecosystem function (McNab and Avers 1994). As such they can serve as a key component of a conservation strategy for Port-Orford-cedar. Under- 


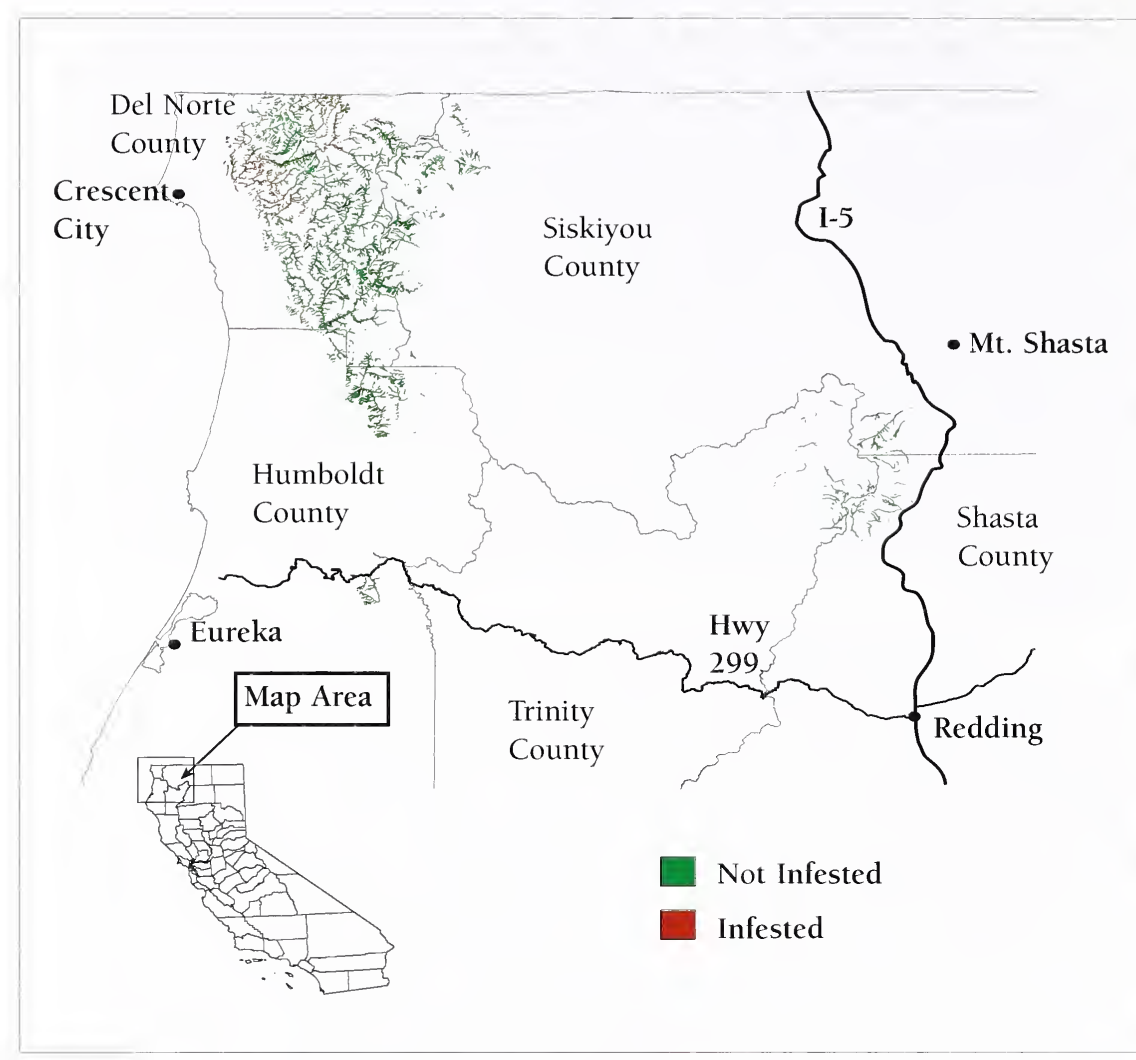

Figure 1. The distribution of infested and non-infested Port-Orfordcedar plant associations in Northern California. 


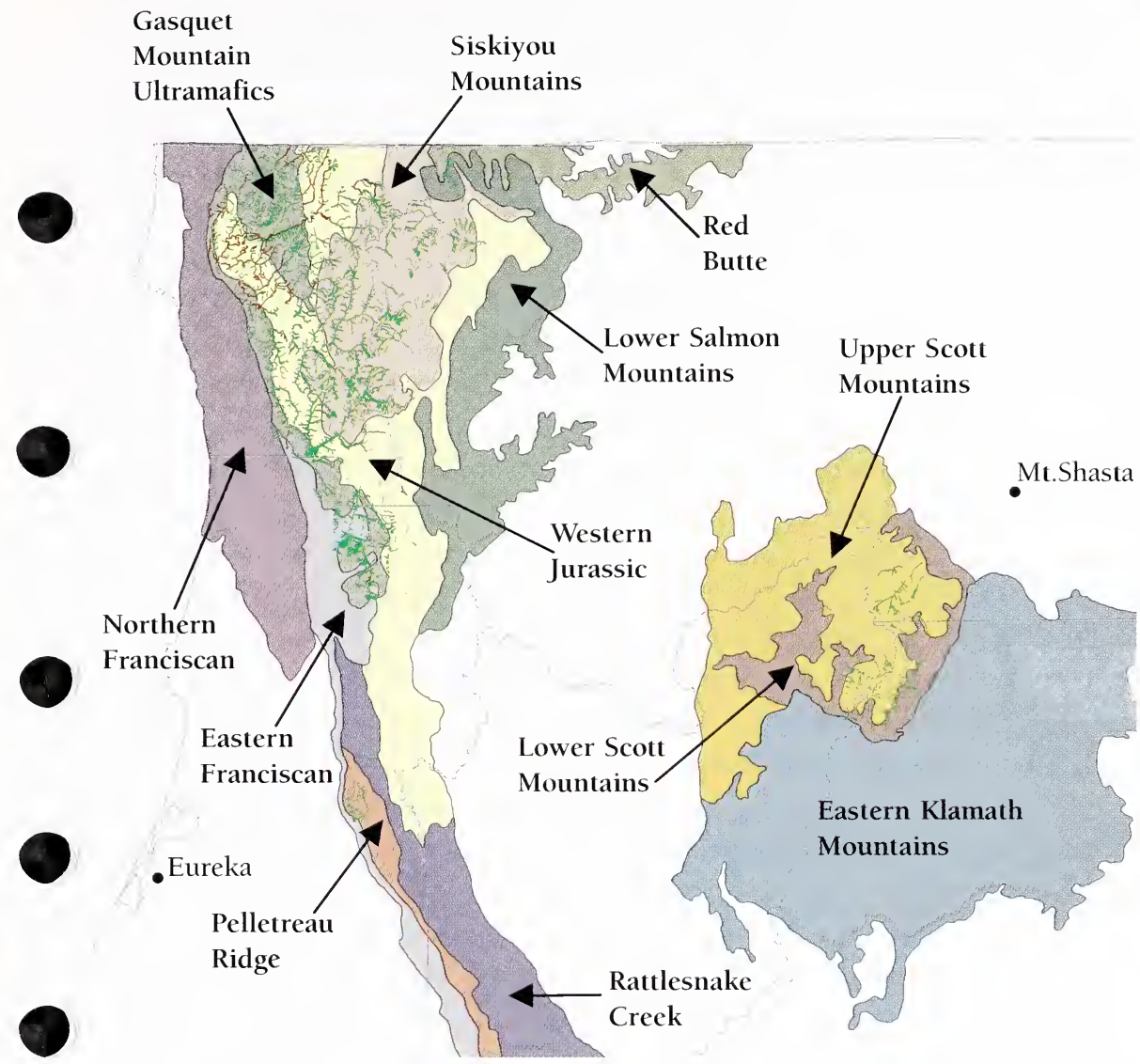

Figure 2. The distribution of Port-Orford-cedar plant associations by Ecological subsection in Northern California. 
standing the key functional components operating in each subsection will help us better manage for the continued existence of Port-Orfordcedar.

The east subsections are distinguished from the other populations of Port-Orford-cedar mapped in Northern California, based on several environmental factors. They have the highest mean elevation compared to the other subsection areas. The mean elevation for PortOrford-cedar stands in this area is 4,872 feet. Port-Orford-cedar is found more consistently at higher elevations in this eastern portion than in the other subsection areas. They are farthest from the coast with an average distance of 84 miles. Mean annual temperature (45 degrees F) and mean annual precipitation (56 inches) were the lowest of all the subsection areas. The low mean temperature is probably related to the number of high elevation sites in this area. The low mean precipitation may have to do with winter storm paths or the distance from the coast and changes in topography. The range of precipitation is from 30 to 80 inches. Most of these plant associations are in the Headwaters of the Sacramento River followed by the East Fork Trinity River and Shotgun-Slate Creeks. Although no infection was found in these eastern polygons there are infected Port-Orfordcedar stands on private land in the Upper Sacramento River drainage (DeNitto 1996).

\section{METHODS}

\section{Field Sampling}

Field work for this supplement was conducted in conjunction with the ecosystem classification program on the Six Rivers, Klamath, Shasta-Trinity and Mendocino National Forests in northern California. Plot data was collected in late-seral stage stands (old-growth) and mid-seral stands (mature). Plots were stratified by environment and selected as study sites. Sampling methods generally followed those described earlier by Hall 1970; Moir and Ludwig 1983; and Allen and Diaz 1986. Sample plot locations were restricted to forested stands with homogeneous vegetation, seral stage, soils, geology, and landform (Pfister and Arno, 1980). Sample sites were selected after a review of previous studies, the information on the factors described above and an extensive aerial photo and ground reconnaissance of the area. Plot size was 0.1 acre for herbs, graminoids and understory trees and of variable radius for shrubs and overstory trees (Bitterlich 1947). 
For each plot the following descriptive information were recorded: plot number, national forest, ranger district, forest map number, forest timber compartment, township, range, section, latitude and longitude (derived from ARC/INFO). Other variables are described below.

\section{Environment variables}

The physical environment was defined by elevation, aspect, percent slope, landform (general topographic characterization), micro-position (position of the plot on the slope), horizontal micro-relief (slope shape parallel to the contours), vertical micro-relief (slope shape across the contours), bare ground percent, surface gravel percent, surface rock percent, potential annual radiation (total annual radiation received for a given aspect, slope and latitude) (Frank and Lee 1966), transformed aspect (aspect transformed to a linear variable from 1-8) (Lewis 1982), and radiation index (ratio of total annual radiation on a given aspect and slope to total annual radiation received on a flat surface for a given latitude) (Frank and Lee 1966). In addition, annual precipitation, distance (miles) to the Pacific Ocean ( $\mathrm{X}$ coordinate) and position on the north/south gradient (Y coordinate) (UTM) were determined from the ARC/INFO plot locations.

At selected sites, a soil pit was dug to a maximum depth of 40 inches or to bedrock. For each pit, data were recorded on: percent surface litter cover, litter thickness, parent material, parent material origin, total soil depth (to a maximum of 40 inches), rootability (whether the soil can be penetrated by roots), A horizon thickness, A horizon texture (using texture by feel), percent A horizon coarse fragments (using $2 \mathrm{~mm}$ sieved soil samples), A horizon color (hue, value, and chroma using Munsell color charts) (Munsell 1975), sub-surface texture, percent sub-surface coarse fragments, sub-surface color, soil drainage class, available water holding capacity (AWC) for the top 20 inches of soil, soil name (classified to family), $\mathrm{pH}$ of the surface horizon (using a Hellige-Truog Soil Reaction Tester), and pH of the sub-surface horizon.

\section{Vegetation variables}

At each plot, total percent cover was ocularly estimated and recorded for moss, forbs, graminoids, shrubs and trees. All plants were identified to species where possible (nomenclature follows Munz 1973 and Hickman 1993). Abundance was recorded for the herbaceous and 
graminoid layers only (Allen and Diaz 1986). Estimates of tree height and standing basal area (basal area factor 20 or 40) were recorded at three points per plot using a Speigel relaskop. In addition, diameter at breast height (dbh), total tree age, 10 and 20 year radial growth were recorded for a minimum of one dominant tree per point.

\section{Prism data}

Prism variables are computer generated climate data that were added to the plot data set to help explain the variability of Port-Orfordcedar communities over their range. The climate data was derived from precipitation and temperature map surfaces generated by the Precipitation-elevation Regression on Independent Slopes Model (PRISM) (Daly et al. 1994, Daly et al. 1997). This model uses digital elevation models (DEMs) to account for topographic effects in interloping weather measurements from an irregular network of weather stations to a uniform grid. Thirteen precipitation and thirteen temperature map surfaces (mean annual and 12 mean monthlies) were generated at 4 $\mathrm{km}$ resolution from 1961-1990 weather data. The precipitation data was specifically for California and Oregon respectively and the temperature data was for the conterminous United States. These map surfaces were imported as Arcinfo grids. Indices developed by Ohmann and Spies (1998) were computed from the mean monthly precipitation and temperature values for each grid for both the California and Oregon data. The temperature indices used were Mean annual temperature (ANNTMP), Mean August maximum (AUGMAXT), Mean December minimum (DECMINT), Mean Summer temperature (SMRTMP), and the difference between the mean August maximum and the mean December minimum (DIFTMP). Some of the precipitation values were log-transformed because vegetation does not respond linearly to amount of precipitation. A $1.0 \mathrm{~cm}$ difference in precipitation is more important at low than at high levels (Ohmann and Spies 1998). The precipitation indices used were as follows, the log of Mean Annual Precipitation (ANNPRE), Mean Annual Precipitation (PRISMPPT), and the log of Mean Summer Precipitation (SMRPRE). Seasonal variability and continentality indices for the precipitation layer were also computed. Continental climates experience less seasonal variability in precipitation because of increased prevalence of rainfall from summer convective storms. This is reflected in the CVPRE and CONTPRE indices. The Precipitation and temperature indices developed from the grid layers were assigned to each Port- 
Orford-cedar plot location using bilinear interpolation (LATTICSPOT function, ESRI 1991).

\section{Data analysis}

The vegetation and environment data were analyzed using the following programs and statistical packages.

\section{Vegetation classification}

Initial classification was accomplished through the use of the polythetic divisive classification technique Two-way Indicator Species Analysis, [TWINSPAN] (Hill 1979). TWINSPAN groups the plots based on similarity of species cover values. The classification was refined using the ordination technique, detrended correspondence analysis [DECORANA] (Hill 1979) and canonical correspondence analysis [CANOCO] (Ter Braak 1988, Jongman et al. 1995). The vegetation classification was constructed from the results of these analyses.

\section{Direct gradient analysis}

Direct gradient analysis was performed using canonical correspondence analysis [CANOCO] (Ter Braak 1988, Jongman et al. 1995). This technique constrains the ordination of the main matrix (species cover) by a multiple regression on environment variables contained in the secondary matrix. CANOCO was used as the primary tool to define the environment gradients that best explained the variability of Port-Orford-cedar communities (McCune and Mefford 1995). The analysis was done in a stepwise manner beginning with the full data set. This initial ordination helped to identify the primary gradients influencing species composition within Port-Orford-cedar stands. The final partitioning involved a separate analysis of each subseries (dependent on sufficient plot numbers) to identify the environment gradients affecting Port-Orford-cedar plant associations. In situations where the identified gradients were so long that they masked other important environment gradients a second iteration of the analysis was run. The results of the direct ordination are presented both descriptively and in graphic form. First, key correlated variables are described in relation to Port-Orford-cedar plant associations. Second, the position of each plant association by quadrant, a graphic representation (centered X Y) of Port-Orford-cedar plots coded by plant association is presented. The center point of the graphic is the 
point of origin of biplot scores for the key environment variables. The longer the environmental line, the stronger the relationship of the variable with the plant association (McCune and Mefford, 1995). Last, these environmental lines are used to help describe plant association relationships. For example, plant association $\mathrm{X}$ was found in the outer edge of the upper right quadrant where elevation was positively correlated. This position indicates that plant association $\mathrm{X}$ was found in the highest elevation positions of the group analyzed.

\section{RESULTS}

The vegetation classification developed for Port-Orford-cedar stands in the east subsections identified fourteen plant associations, included in five sub-series and one series (Table 1). The forest series was the Port-Orford-cedar series. By definition here a forest series requires at least $10 \%$ tree cover and is determined by the dominant tolerant tree species that will most fully occupy the site over time barring human disturbance and major disturbance events. For further ease of comparison, the fourteen plant associations were aggregated into five sub-series Port-Orford-cedar-Douglas-fir, Port-Orford-cedarMixed Conifer, Port-Orford-cedar-White Fir, Port-Orfordcedar-Western White Pine and Port-Orford-cedar-Mountain Hemlock. These vegetation sub-series are defined first by the series designation (Port-Orford-cedar) and second by the indicator species (white fir, western white pine and mountain hemlock). These indicator species are usually highly correlated with the primary environment gradients and establish the sub-series position along them. Sub-series are closely analogous to plant communities and both terms are used here to mean the same thing. 
Table 1. Port-Orford-cedar plant associations described from the Sacramento and Trinity River drainages.

SUB-SERIES/

EDP CODE

PLANT ASSOCIATION NAME

Port-Orford-cedar-Douglas-fir Sub-series

CHLA-PSME/CAOC

Port-Orford-cedar-Douglas-fir/

Spicebush

Port-Orford-cedar-Mixed Conifer Sub-series

CHLA-MCON/RHOC-LIDEE

Port-Orford-cedar-Mixed Conifer/

Western Azalea-Dwarf Tanbark

CHLA-MCON/QUVA-RHOC

Port-Orford-cedar-Mixed Conifer/

Huckleberry Oak-Western Azalea

Port-Orford-cedar-White Fir Sub-series

CHLA-ABCO/RHOC-QUVA

Port-Orford-cedar-White Fir/

Western Azalea-Huckleberry Oak

CHLA-ABCO/LEDA-CASE3

Port-Orford-cedar-White Fir/

Sierra Laurel-Bush Chinquapin

CHLA-ABCO/CASE3-RHOC

Port-Orford-cedar-White Fir/Bush

Chinquapin-Western Azalea

Port-Orford-cedar-Western White Pine Sub-series

CHLA-PIMO3/LEGL1/DACA2

CHLA-PIMO3/ALSI2

CHLA-PIMO3/VAME

CHLA-PIMO3//NET HERB COMP.

CHLA-PIMO3//DRY HERB COMP.
Port-Orford-cedar-Western White

Pine/Labrador-Tea/California Pitcher Plant

Port-Orford-cedar-Western White Pine/ Sitka Alder

Port-Orford-cedar-Western White Pine/

Thinleaf Huckleberry

Port-Orford-cedar-Western

White Pine//Wet Herb Complex

Port-Orford-cedar-Western

White Pine//Dry Herb

Complex 
CHLA-TSME/CASE3

CHLA-TSME/LEGL1

CHLA-TSME/LEDA
Port-Orford-cedar-Mountain Hemlock/ Bush Chinquapin

Port-Orford-cedar-Mountain Hemlock/ Labrador-Tea

Port-Orford-cedar-Mountain

Hemlock/Sierra Laurel

\section{Sub-series Gradient Analysis}

A direct gradient analysis (CANOCO) of Port-Orford-cedar sub-series (plots and species) are contained in figures 3-5. The plot ordination in figure 3 identified elevation as the highest correlated variable with axis $1(r=.95)$, followed by moisture stress $(r=-.84)$, mean annual temperature $(r=-.78)$, macro-position $(r=-.70)$, granite parent rock $(r=.48)$, ultramafic parent rock $(r=-.56)$, A horizon coarse fragments $(r=-.47)$ and $Y$ coordinate $(r=.50)$. The left side of the graph includes the Port-Orford-cedar-Douglas-fir and Port-Orfordcedar-Mixed Conifer sub-series. These sub-series are found on low elevation sites, with high moisture stress, high mean annual temperature, warm southerly aspects, in lower slope macro-positions on ultramafic parent rock. These factors contribute to the tendency of these sub-series to be dominated by species such as canyon live oak, huckleberry oak, dwarf tanbark, coffeeberry, Ponderosa pine and sugar pine that are considered to be dry or mesic in their moisture requirements or tend to occur on soils derived from ultramafic parent rock (fig. 4). In contrast, the Port-Orford-cedar-White Fir, Port-Orfordcedar-Western White Pine and Port-Orford-cedar-Mountain Hemlock sub-series displayed on the right side of figure 6 are found on high elevation sites, dominated by soils derived from granite parent material in the northern portion of the east subsections. Here cooler conditions with lower moisture stress favor species such as western white pine, lodgepole pine, labrador tea, sierra laurel and California pitcher-plant (fig. 4).

Other examples of indicator species and environment interactions are displayed in figure 5. In this graph, axis 3 displays its highest correlation with soil drainage $(r=-.70)$, parent material origin $(r=-$ $.56)$, indirect solar radiation $(r=-.44)$, slope $(r=-.41)$ and micro- 


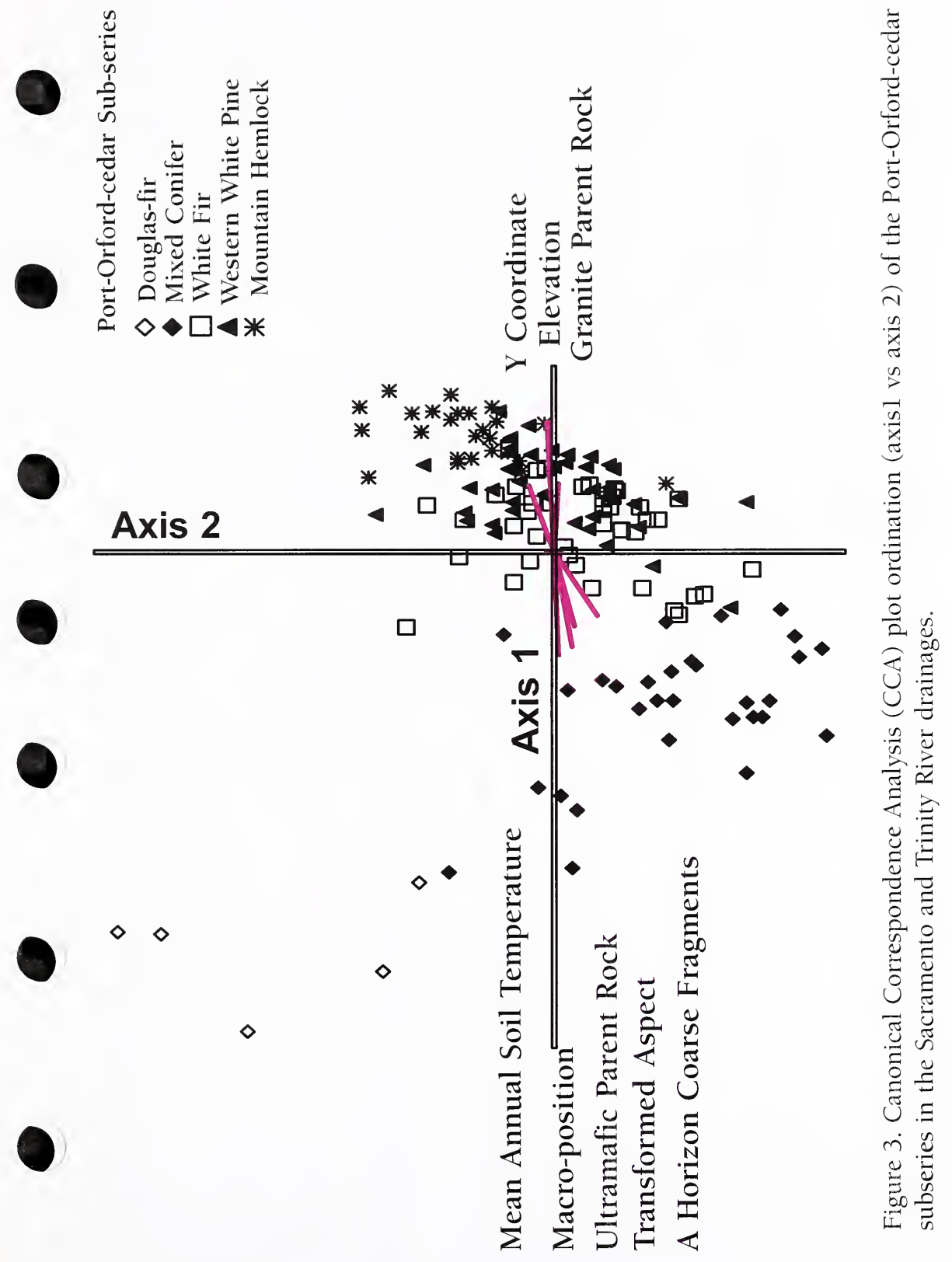




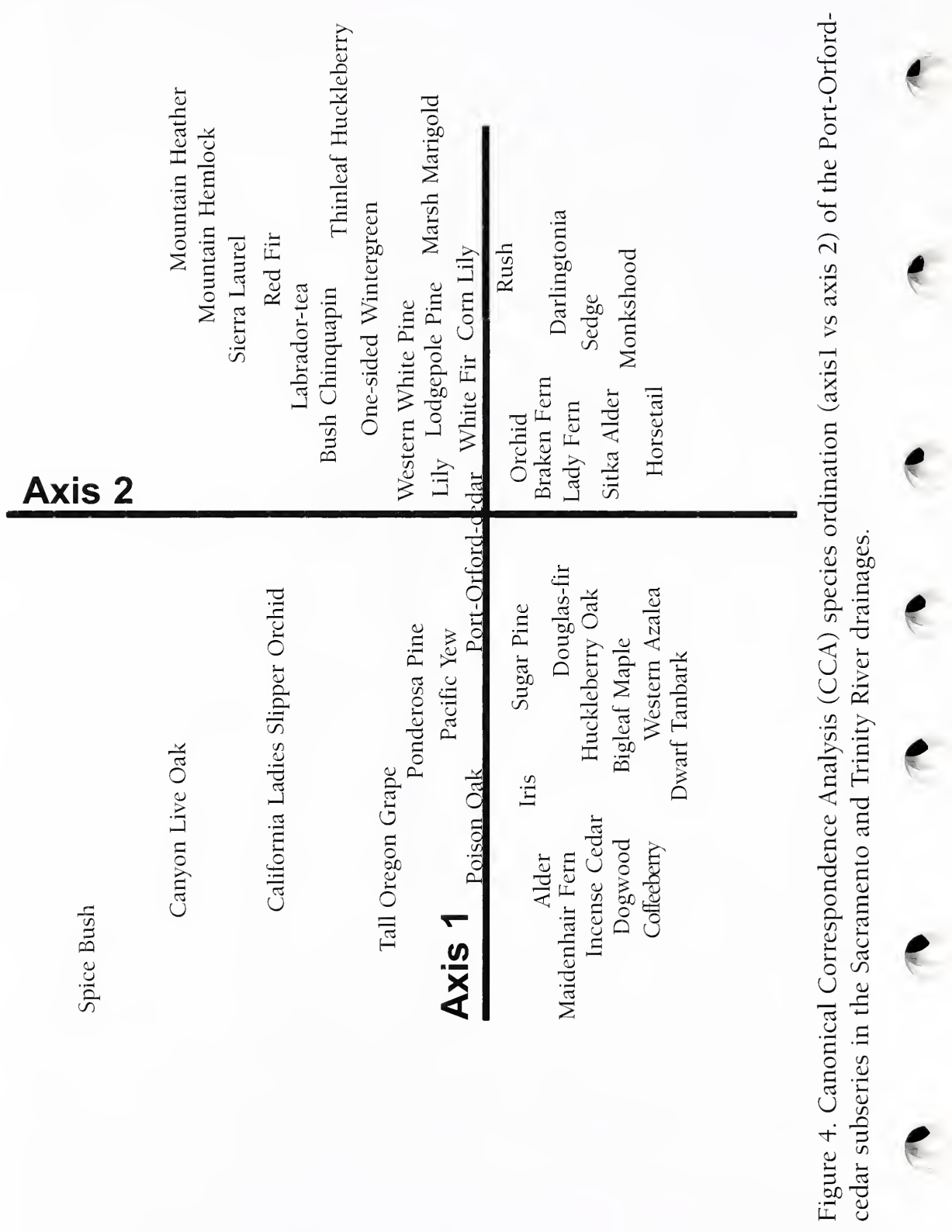




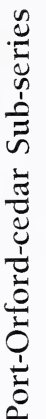

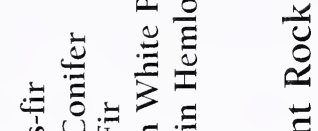

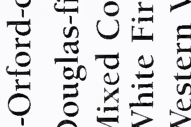

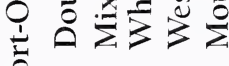

$\therefore \diamond \diamond \square<$ 米

米吅橉米

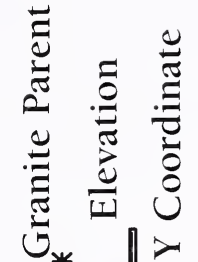

$\frac{\Xi}{010}$

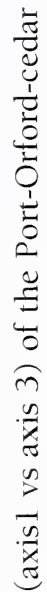

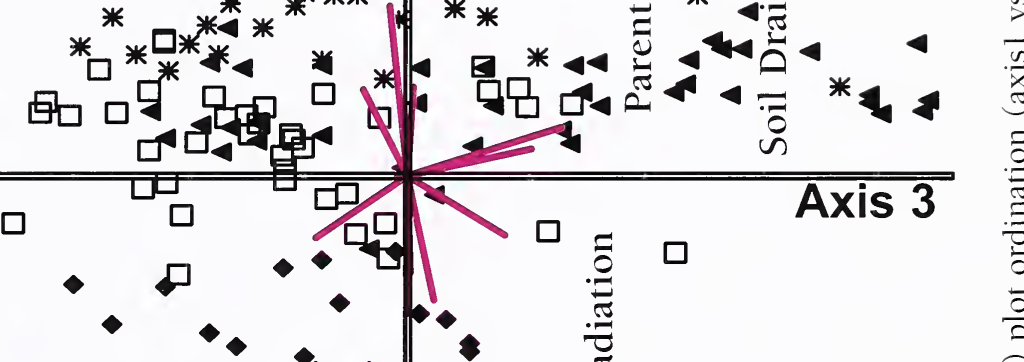

$\frac{0}{0}$

0

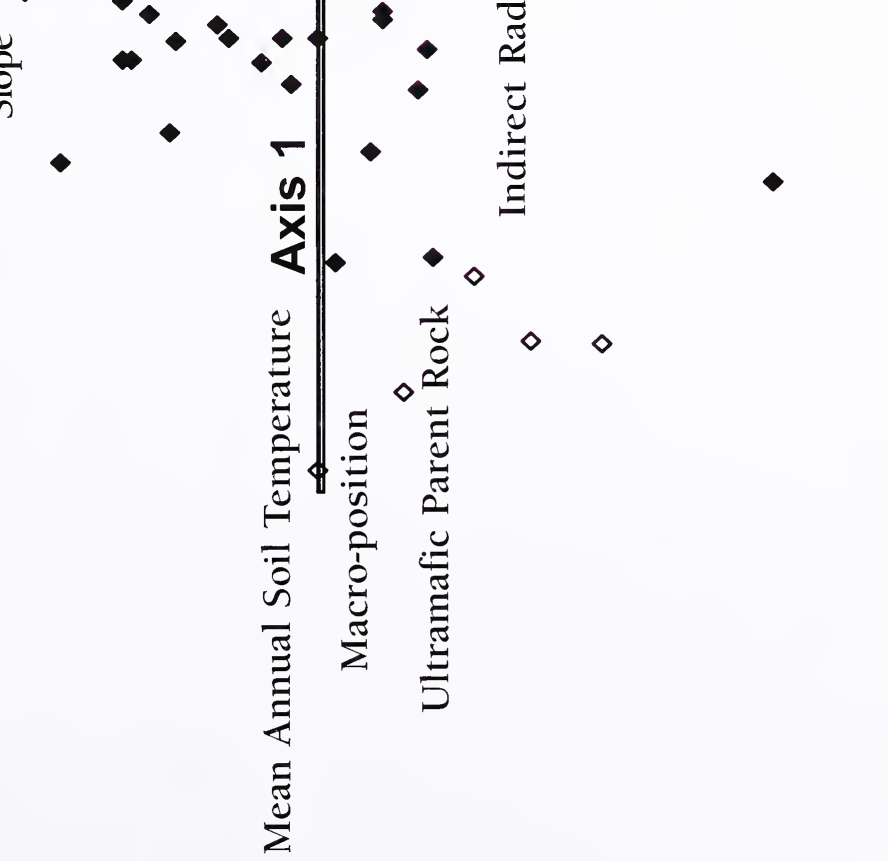

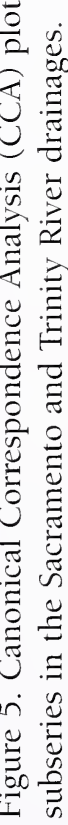


position $(r=-.40)$. Most of the plots in the Port-Orford-cedar-Western White Pine sub-series were found here on these wet, glacial basin sites. Species found along this axis include Darlingtonia, sedge, monkshood, horsetail, labrador-tea and ladyfern.

\section{Plant Association gradient Analysis}

Plant associations are analyzed below by sub-series in an attempt to identify both the primary and secondary gradients that define them.

The Port-Orford-cedar-Douglas-fir sub-series contained only one plant association the Port-Orford-cedar-Douglas-fir/Spicebush type. It was found on the lowest elevation sites in the eastern subsections on floodplain and terrace landforms derived from ultramafic parent rock. Climate is warm here as a result of east and southeast aspects. Moisture stress is also high as a result of the above factors and the high percentage of soil coarse fragments.

The indicator species, Spicebush is indicative of warm, moist places. Within the Port-Orford-cedar-Douglas-fir/Spicebush type, it appears to follow ephemeral stream courses that likely contain available subsurface water.

The Port-Orford-cedar-Mixed Conifer sub-series contained 2 plant associations; Port-Orford-cedar-Mixed Conifer/Western AzaleaDwarf Tanbark and Port-Orford-cedar-Mixed Conifer/Huckleberry Oak-Western Azalea. These plant associations were found on warm, mid elevation terraces, floodplains and mountain sideslopes. Soils were derived from ultramafic parent material on these moderate to highly rocky sites. Micro-relief was linear and undulating. The 2 plant associations differ by aspect, total vegetation, elevation and surface rock. Indirect gradient analysis identified elevation $(r=-.44)$, direct solar radiation $(r=-.42)$, hours of sunlight $(r=.37)$ and transformed aspect as correlated with axis 1 . In axis 2 mean annual precipitation $(r=.43), Y$ coordinate $(r=-.40)$, macro-position $(r=-.37)$ and surface rock $(r=.28)$ were identified as correlated variables. Axis 3 was correlated with micro-position $(\mathrm{r}=-.53)$, transformed aspect $(\mathrm{r}$ $=.52)$, mean annual precipitation $(r=-.43)$ and slope $(r=.33)$.

The Port-Orford-cedar-Mixed Conifer/Western Azalea-Dwarf Tanbark type was found on terraces, floodplains and mountain sideslopes derived from ultramafic parent material. Indirect solar radiation was high as a result of topographic shading on these bottom and lower one-third slopes. Micro-relief was linear and undulating on these moderately rocky east, south, west and north aspects. 
The Port-Orford-cedar-Mixed Conifer/Huckleberry OakWestern Azalea was found on warm floodplains and mountain sideslopes derived from ultramafic parent rock. Surface rock was high and direct solar radiation was high as a result of the south and southeast facing aspects.

Indicator species reflect the subtle differences between these 2 types. The Port-Orford-cedar-Mixed Conifer/Western Azalea-Dwarf Tanbark type was slightly cooler due to aspect and topographic shading. These factors combined with soils derived from ultramafic parent rock allow for the combination of a wet indicator species, western azalea and a mesic indicator species dwarf tanbark. In the Port-

Orford-cedar-Mixed Conifer/Huckleberry Oak-Western Azalea type site conditions are warmer and drier. Huckleberry oak was the dominant shrub while western azalea is found on micro-sites where water can be reached through sub-surface cracking in the ultramafic parent rock.

The Port-Orford-cedar-White Fir sub-series contained 3 plant associations; Port-Orford-cedar-White Fir/Western Azalea-Huckleberry Oak, Port-Orford-cedar-White Fir/Sierra Laurel-Bush Chinquapin and Port-Orford-cedar-White Fir/Bush Chinquapin -Western Azalea. These plant associations were found primarily on high elevation mountain sideslopes and streamsides with northwest, northeast and west aspects. Soils were derived from granite or ultramafic parent material, which together with landform determined which indicator species dominated. Direct gradient analysis identified granite parent rock $(r=.63)$, ultramafic parent rock $(r=-.60)$, slope $(r=.41)$, indirect solar radiation $(r=-.41)$ and indirect solar radiation $(r=-.39)$ as correlated with axis 1 . Axis 2 included micro-position $(r=.45), X$ coordinate $(r=.41)$, macro-position $(r=.40)$ and transformed aspect $(r=.27)$ as correlated variables. Axis 3 included the following variables; elevation $(r=-.52)$, hours sunlight $(r=-.40)$ and direct solar radiation $(r=-.39)$.

The Port-Orford-cedar-White Fir/Western Azalea-Huckleberry Oak type was found on rocky floodplains, mountain sideslopes and streamsides derived from ultramafic parent rocks. Direct solar radiation was high as a result of west aspects.

The Port-Orford-cedar-White Fir/Sierra Laurel-Bush Chinquapin type was found on linear and undulating middle and lower one third slope positions of mountain sideslopes. Parent rock was mainly granitic on these moderately steep, cool, northwest facing aspects.

The Port-Orford-cedar-White Fir/Bush Chinquapin-Western Azalea type was found on rocky mountain sideslopes in lower one- 
third slope positions. Parent rock was mainly granite on these cool north, northeast and west facing sites.

Indicator species varied in response to the factors described above. Western azalea had its highest cover on ultramafic soils in streamside positions. Huckleberry oak was present in the Port-Orfordcedar-White Fir/Western Azalea-Huckleberry Oak type due to the ultramafic parent material but of low cover due to the close proximity to water. Sierra laurel had its highest cover on cool, mesic sites derived from granitic parent material. Bush chinquapin cover varied with surface rock percent. The combination of bush chinquapin and western azalea was likely related to the undulating topography on these cool, moderately rocky sites. These conditions tend to create irregular available moisture conditions that favor these two species.

The Port-Orford-cedar-Western White Pine sub-series contained 5 plant associations; Port-Orford-cedar-Western White Pine/ Labrador-Tea/California Pitcher Plant, Port-Orford-cedar-Western White Pine/Sitka Alder, Port-Orford-cedar-Western White Pine/ Thinleaf Huckleberry, Port-Orford-cedar-Western White Pine//Wet Herb complex and Port-Orford-cedar-Western White Pine//Dry Herb complex. These plant associations were identified on high elevation sites with northeast and northwest aspects. Soils were derived from granite or ultramafic parent rock, landforms included streamsides, basins, terraces, mountain sideslopes and glacial moraines. Changes in plant association and species composition were mainly due to these factors and those identified in the direct gradient analysis. CANOCO identified soil drainage $(r=.58)$, hours of sunlight $(r=.49)$, microposition $(r=.31)$, indirect solar radiation $(r=.28)$ and slope $(r=-.26)$ as the variables most highly correlated with axis 1 . Axis 2 included macro-position $(r=.75)$, elevation $(r=-.53)$ and $X$ coordinate $(r=$ $.46)$ as the most highly correlated variables. Axis 3 was correlated with ultramafic parent rock $(r=.42)$ and slope $(r=.31)$.

The Port-Orford-cedar-Western White Pine/Labrador-Tea/ California Pitcher Plant type was found mainly in gently sloping, poorly drained, basin micro-positions derived from granite or ultramafic parent rocks. Hours of sunlight were higher here than in all other Port-Orford-cedar-Western White Pine plant associations. The indicator species labrador-tea and California pitcher plant exemplified the wet nature of these sites.

The Port-Orford-cedar-Western White Pine /Sitka Alder type was found in rocky, streamside positions derived from granite and mafic parent rocks. Indirect solar radiation was high here. The wet 
area indicator species Sitka Alder dominated on these sites due to its close proximity to perennial streams.

The Port-Orford-cedar-Western White Pine/Thinleaf Huckleberry type was found on streamside terraces and mountain sideslopes where soils were derived from granite parent rock. Thinleaf huckleberry a mesic indicator species, dominated on these sites.

The Port-Orford-cedar-Western White Pine//Wet Herb complex was found in poorly drained, wet basin micro-positions derived from ultramafic and granite parent rocks. A variety of wet indicator forb species were found here including tiger lily, ragwort, corn lily, loveage, bleeding heart, monkshood, lady fern, marsh-marigold, and anemone.

The Port-Orford-cedar-Western White Pine//Dry Herb complex was found on rocky sites that resulted from glacial moraine deposits. These sites were derived from granite or ultramafic parent rocks and were often found adjacent to the Port-Orford-cedar-Western White Pine//Wet Herb type. They contained low cover of shrubs most notably huckleberry oak and high cover of dry and mesic herbs such as hawkweed, brakenfern, wild pea, clover, one-sided wintergreen and a variety of grass species.

\section{The Port-Orford-cedar-Mountain Hemlock sub-series con-} tained 3 plant associations; Port-Orford-cedar-Mountain Hemlock/ Bush Chinquapin, Port-Orford-cedar-Mountain Hemlock/Labrador-tea and Port-Orford-cedar-Mountain Hemlock/Sierra Laurel. These plant associations were identified on high elevation sites with north or west facing aspects. They were dominated by granite rock and influenced by glacial landforms. For instance, the bush chinquapin type is found on glacial moraines, while the Labrador-tea type is found along the edges of cirque basins and the Sierra laurel type was found on mountain sideslopes. These factors, in combination with the results of direct gradient analysis (CANOCO), help explain species composition. CANOCO identified transformed aspect $(r=-.56)$, surface rock $(r=.53)$ and direct solar radiation $(r=-.43)$ as the highest correlated variables with axis 1 . Axis 2 had its highest correlation with vertical micro-relief ( $\mathrm{r}=$ - .60) and micro-position $(r=-.54)$. These factors in combination have an influence on available water, which is reflected in the indicator species composition found in these communities. One of these indicators, bush chinquapin, has a high tolerance for somewhat dry sites such as those found in the rocky surface layers of glacial moraines. Labrador-tea, a wet area indicator species, was found on west facing, wet sites such as those associated with concave shaped glacial cirques. 
Sierra laurel is considered a mesic species; hence its location on mountain side slopes above the Labrador-tea type.

\section{DISCUSSION}

As we can see from the descriptions of the sub-series in which Port-Orford-cedar was found, the potential effects of Port-Orfordcedar root disease on biological diversity in northern California are many. Foremost, is the loss or significant decline of a major shade tolerant tree species found in many plant communities. In northern California alone, Port-Orford-cedar has been noted as a major component of forty-eight plant associations and as a minor tree component $(<10 \%)$ in other associations (Jimerson and Creasy 1990). The loss of Port-Orford-cedar will also lead to changes in species composition as other tree species fill the vacant niches. This could alter not only the compositional features of the stand, but also structural and functional features. Port-Orford-cedar, because of its limited height growth compared to Douglas-fir, white fir and red fir and because of its tolerance to shade often forms a distinctive second and third layer. This has implications for wildlife species that benefit from multiple layers, whether for foraging and roosting habitat or for thermal and hiding cover. It is apparent from the growth data collected during the development of this classification that Port-Orford-cedar is often the oldest tree species in a stand, thus, providing long term habitat values. If Port-Orford-cedar root disease continues to spread, snags and logs would also decline over time, leading to a loss of what is one of the most enduring snag and log features in northwest California (Jimerson 1989). 
-

0

.

0

0

0

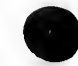


0

-

○

-

○

○

○ 


\section{PORT-ORFORD-CEDAR ROOT DISEASE}

Phytophthora lateralis Tucker \& Milbrath, is an organism that causes a root disease of Port-Orford-cedar and Pacific yew (Taxus brevifolia Nutt.). It is a member of a group of organisms called Oomycetes, which are similar to fungi, but possess enough differences to be considered distinct. The disease was first reported in a nursery in Seattle in 1923, but the cause was not identified until 1942 when $P$. lateralis was isolated from nursery material in Oregon (Tucker and Milbrath 1942; Zobel et al. 1985). By this time, it had been spread widely in Washington and Oregon through transport of infected nursery stock. In 1952, Port-Orford-cedar root disease was first identified in the native range of Port-Orford-cedar at Coos Bay, Oregon (Roth et al. 1957). A survey in 1964 found new centers of infection that were mainly in areas that had been harvested or associated with pasturing domestic stock (Nelson 1964). Port-Orford-cedar root disease was confirmed in California in 1979 (Kliejunas and Adams 1980), but was originally observed by 1960 along the Middle Fork of the Smith River (Zobel et al. 1985). In 1979 it was reported in eight locations in California: seven in the Smith River basin and one in an ornamental planting in Eureka (Kliejunas and Adams 1980). The disease was not observed in the Klamath, Trinity, or Sacramento River basins. This was a survey of selected sites, not of the entire population and other areas of infestation within the Smith River basin were likely present. A more complete inventory of Port-Orford-cedar on National Forest System lands was performed in 1992 and 1993. Using standardized stream buffers, this inventory identified Port-Orfordcedar on about 160,000 acres with an estimated 9,000 acres to have root disease. The only known infested drainage in California at that time was the Smith River basin. In 1995 and 1996 two new areas of infestation were identified on tributaries of the Klamath River. Also in 1996 an infested area was observed on the main stem of the Sacramento River (DeNitto 1996). In 1998 intensive mapping of PortOrford-cedar plant associations was completed on National Forest lands in California (Jimerson et al. 1999). This study identified PortOrford-cedar plant associations covering a total of 37,734 acres. PortOrford-cedar root disease was present in 3,267 acres. The plant association mapping only included stands of with $10 \%$ or greater PortOrford-cedar. 
Phytophthora lateralis has four spore forms that have different functions in survival and transport (Trione 1959, 1974). The oospore is rarely observed and constitutes the sexual stage. It may play a role in long-term survival and overland movement, but that is probably secondary to the chlamydospores. The chlamydospore is an asexual structure commonly referred to as the "resting spore". It is thick-walled and is commonly found in rootlets killed by $P$. lateralis (Ostrofsky et al. 1977). It is probably the main structure that enables $P$. lateralis disease to survive on a site during adverse conditions or in the absence of a host (Trione 1974). It is also believed to be the primary means of spread to new areas in infested organic matter. When induced to germinate by the presence of water, the chlamydospores form sac-like structures called sporangia. This sporangium subsequently germinates and produces zoospores, which are commonly called "motile spores" because of their capability to propel themselves with their flagella. The zoospores are likely attracted by exudates produced by Port-Orford-cedar rootlets, similar to other Phytophthora spp. (Carlile 1983). Once in contact with unsuberized growing root tips, zoospores can germinate and infect the rootlet. Subsequent spread within the plant occurs by growth of the mycelium through the inner bark and cambium of the root system to the root collar with eventual mortality of the host.

Following root and tree mortality many saprophytic organisms begin to invade the woody tissues. This displaces and replaces the mycelium of $P$. lateralis. The chlamydospores that had developed within the woody tissue, however, are more resistant to microbial attack and provide the survival capability in the absence of a host. Oospores may have a similar, but lesser, role in survival. It appears that survival on a site occurs within the decaying roots of infected trees when living hosts are absent (Ostrofsky et al. 1977; Tsao 1993). Measuring and quantifying the amount of $P$. lateralis disease in the soil is difficult, but it appears that the amount is low even beneath dead and dying trees (Tsao 1993).

The longevity of $P$. lateralis on a site in the absence of live hosts has been examined in two studies. One in Coos County, Oregon has found it surviving for up to 7 years (Hansen and Hamm 1996). The second study, in Del Norte County, California, reported the nonrecovery of $P$. lateralis after 4 years (Kliejunas 1992). Differences between these two studies are attributed to sampling variability, difficulties in recovering $P$. lateralis disease from soil, and to different environmental conditions between the two sites. Survival in the 
absence of the host may depend on soil moisture and temperature conditions, with survival being longer further north.

Two types of movement occur with $P$. lateralis. Long distance spread between drainages and watersheds occurs when infested organic matter is transported (Roth et al. 1972). Humans have been the main vectors of Port-Orford-cedar root disease. Long distance spread has resulted from moving infected seedlings and, especially, infested soil into disease-free sites (Hadfield et al 1986; Harvey et al. 1985; Kliejunas and Adams 1980; Roth et al. 1972; Roth et al. 1987).

Major spread of the disease has occurred through earth movement in road construction, road maintenance, logging and traffic flow on forest roads. In general, the spread of the disease is limited in areas where physical barriers or lack of access have prevented human vector activity, especially during wet periods. Seasonal road and harvest closures have been used as effective prevention techniques. Movement of $P$. lateralis in soil clinging to the feet of cattle and elk is suspected to occur and may have resulted in new infestations in a few instances (Hansen et al. 1994; Roth et al. 1987; Zobel et al. 1985).

The second type of movement is the short-distance "swimming" of motile zoospores. When chlamydospores germinate, sporangia and zoospores are produced. The zoospores can move short distances, up to a few centimeters, with the use of their flagella until they contact a host rootlet where they will attach themselves and germinate (Carlile 1983). If they do not contact a susceptible rootlet, they will encyst. Encysted spores may be transported in water or perish. After a tree is infected, sporangia develop from the roots when conditions are conducive and produce zoospores. These can then invade nearby rootlets, either of the same tree or a neighboring tree.

Once brought into a new area, $P$. lateralis spreads in water downslope from roads and trails. The inoculum often builds to high levels in dense stands of Port-Orford-cedar growing on disturbed areas, close to road edges, thus increasing the likelihood of downhill spread. In almost all cases, infection of Port-Orford-cedar by the pathogen occurs in areas where obvious avenues for waterborne chlamydospore and zoospore dispersal exists. Infection is also dependent on the presence of free water in the immediate vicinity of susceptible tree roots. Spread rates are quite variable, but can be great in favorable wet years. Topography has a considerable influence on spread (Hadfield et al 1986). Steep slopes dissected by drainages quickly channel zoospore-infested water into streams. Cross slope spread is restricted. On broad slopes or flat areas infested water may 
spread out over larger areas and move more slowly. Concave areas with Port-Orford-cedar are very vulnerable to damage because they are easily flooded. Convex slopes have very limited vulnerability. PortOrford-cedar growing on sites or microsites that are unfavorable for spread of the pathogen often escape infection, even in areas where infected trees are nearby.

The spread of infested material and subsequent infection of Port-Orford-cedar in a new area requires a number of events to occur. First, the material must land in an area where Port-Orford-cedar is present. Second, P. lateralis must be able to survive until temperature and moisture conditions occur that permits spore germination. Conditions on road surfaces, for example, probably are not conducive to P. lateralis survival, except during wet conditions. Third, zoospores must reach the root tips of Port-Orford-cedar or Pacific yew. This means chlamydospores, oospores, or sporangia must be transported near or within the dripline of a Port-Orford-cedar and be within a few centimeters of susceptible rootlets for infection to occur. Then zoospores must be produced and travel to the rootlets, followed by germination and penetration. The length of time of motility of $P$. lateralis zoospores has not been measured, but zoospores of other Phytophthora spp. have remained motile under ideal conditions for up to 84 hours (Carlile 1983). Observations indicate that zoospores of Port-Orford-cedar root disease encyst readily when agitated. Each of the steps described above requires precise conditions of cool soil temperatures and saturated to near-saturated soil moisture over a period of time in order for infection to occur (Trione 1959, 1974; Tucker and Milbrath 1942).

The length of time between infection and tree mortality likely varies by tree size because of the amount of root system available to support the tree. Most observations are based on the estimated time when $P$. lateralis was introduced into an area and when mortality occurred. Seedling mortality occurs rapidly and is dependent on weather conditions. It may be a few weeks to 2 to 3 months (Tucker and Milbrath 1942). Larger trees may survive for several years following infection (Roth et al. 1972; Zobel et al. 1985). During this period, infected roots develop sporangia and zoospores under proper conditions, which can intensify the disease in an area and result in further downhill spread (Trione 1974). 


\section{Recognizing Port-Orford-cedar Root Disease}

Recognizing new areas with Port-Orford-cedar root disease is critical to managing the disease and limiting its spread. The presence of the disease can be determined with some reliability in the field. However, confirmation of new areas should be done by a plant pathologist who has the capability to identify the P. lateralis in the laboratory. include:

Suggestions that Port-Orford-cedar root disease may be present

1 Port-Orford-cedar that have died over a period of several years and includes trees in various stages of decline

1 More severely affected Port-Orford-cedar nearer to areas with standing or slowly moving water

1 Stringers of dead and dying Port-Orford-cedar running downslope along water courses

1 An association of dead and dying Port-Orford-cedar with actively used roads and trails, especially in ditches and drainages

The foliage of trees affected by Port-Orford-cedar root disease fades from green to yellow to brown from the time of infection. This fading pattern is expressed throughout the crown, not just portions of the crown or individual branches. There are no fruiting bodies or other structures present on the tree to help identify the presence of the disease. The disease affects all sizes of trees.

When the presence of Port-Orford-cedar root disease is suspected based on dead and dying trees, closer observations need to be made. Trees selected for these observations should not be dead. They should still have some live phloem remaining which means some green to yellow foliage will be present. It is necessary to slice or chop into the base of the tree to make this determination. Care needs to be taken not to slice into the wood, which does not discolor and could confuse observations. The only symptom that is present in diseased trees is dead phloem. This displays itself as a golden-brown discoloration of 
the phloem in the roots or near the base of the tree. There is a sharp demarcation between the discoloration and the unaffected, creamy white phloem higher on the stem. The discoloration extends down into the roots without any patches of white phloem. Other agents can cause a similar brown coloring of the phloem, but does not extend into and down the roots. Observations need to be made as close to ground level as possible to reduce the chances for confusion with other agents. If this pattern of tree mortality and phloem discoloration is observed, a pathologist needs to be consulted for confirmation.

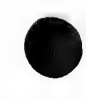




\section{SUPPLEMENT KEY TO PORT-ORFORD-CEDAR PLANT ASSOCIATIONS IN THE SACRAMENTO AND TRINITY RIVER HEADWATERS}

1a. Spicebush present and greater than $10 \%$ cover CHLA-PSME/CAOC (p.Sc-28)

1b. Spicebush absent or not as above

2a. Mountain hemlock present and greater than $5 \%$ cover ...... 3

3a. Bush chinquapin present and greater than 5\% cover ... CHLA-TSME/CASE3(p.Sc-71)

3b. Bush chinquapin absent or not as above

4a. Labrador-tea present and greater than 5\% cover ...... CHLA-TSME/LEGL1(p.Sc-75)

4b. Labrador-tea absent or not as above

5a. Sierra laurel present and greater than 5\% cover .. CHLA-TSME/LEDA (p.Sc-79)

5b. Sierra laurel absent or not as above

2b. Mountain hemlock absent or not as above 6

6a. Douglas-fir present and greater than $10 \%$ cover, white fir usually less than $10 \%$ cover

7a. Western azalea and huckleberry oak usually present

and greater than $10 \%$ cover CHLA-MCON/QUVA-RHOC (p.Sc-35)

7b. Western azalea and huckleberry oak absent or not as above. 8

8a. Western azalea and dwarf tanbark usually present

CHLA-MCON/RHOC-LIDEE (p.Sc-31)

8b. Western azalea and dwarf tanbark absent or not as above 9

6b. Douglas-fir absent or not as above 9

9a. White fir overstory cover exceeds western white pine 10

10a. Sierra laurel present and greater than $10 \%$ cover,

bush chinquapin present CHLA-ABCO/LEDA-CASE3 (p.Sc-43)

10b. Sierra laurel or bush chinquapin absent or not as above

11a. Bush chinquapin present and greater than $5 \%$ cover, western azalea usually present CHLA-ABCO/CASE3-RHOC (p.Sc-47)

$11 \mathrm{~b}$. Bush chinquapin and western azalea absent or not as above..... 12

12a. Western azalea present and greater than 5\% cover,

huckleberry oak usually present .... CHLA-ABCO/RHOC-QUVA (p.Sc-39)

12b. Western azalea and huckleberry oak absent or not as above

9b. Western white pine overstory cover exceeds white fir

13a. Labrador-tea present and greater than 5\% cover CHLA-PIMO3/LEGL1/DACA2 (p.Sc-51)

13b. Labrador-tea absent or not as above 
○

-

-

-

○

-

Sb-26 
14a. Sitka alder present and greater than $10 \%$ cover

CHLA-PIMO3/ALSI2 (p.Sc-55)

14b. Sitka alder absent or not as above

15a. Thinleaf huckleberry present and greater than $5 \%$ cover

CHLA-PIMO3/VAME (p.Sc-59)

15b. Thinleaf huckleberry absent or not as above

16a. Wet species such as lily, California false hellebore, woolly ragwort, lady fern and bleeding heart, dominate the forb layer

CHLA-PIMO3//Wet Herb complex (p.Sc-63)

16a. Mesic species such as braken fern, white hawkweed, Gray's licorice root, one-sided pyrola, and white-vein wintergreen dominate the forb layer CHLA-PIMO3//Dry Herb complex (Sc-67) 
0

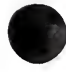

0

.

0

?

0 
Port-Orford-cedar Plant Associations In the Trinity \& Sacramento River Drainages 
-

-

-

0

0

0

○ 


\title{
A Supplement to:
}

\section{A Field Guide To Port-Orford-cedar}

Plant Associations in Northwest California

\author{
Thomas M. Jimerson
}

Gregg DeNitto

Drawings By:

Christina Ericksen

Photographs By:

Thomas M. Jimerson

Jeffrey K. Jones 


\section{ACKNOWLEDGMENTS}

The USDA Forest Service, Forest Pest Management Program funded this supplement to the Port-Orford-cedar field guide. We thank the following individuals for their assistance in the development of this field guide: Jeff Jones, Bruce Bryan, Edward Biery, Richard Dwerlkotle, Peter Figura, Laura Andrews, Philip Purcell and Bud Adamson for ecology plot data collection; Tom Laurent, Tim Hagen ,Patricia Caswell, Theresa Kunch, and Mike Vollmer for soils data collection; and Peggi Lawrence, David Jones, Pete Angwin and Frank Betlejewski for manuscript review and Jerry Boberg for assistance with graphics.

$\bullet$
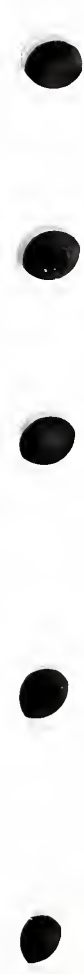


\section{Table of Contents}

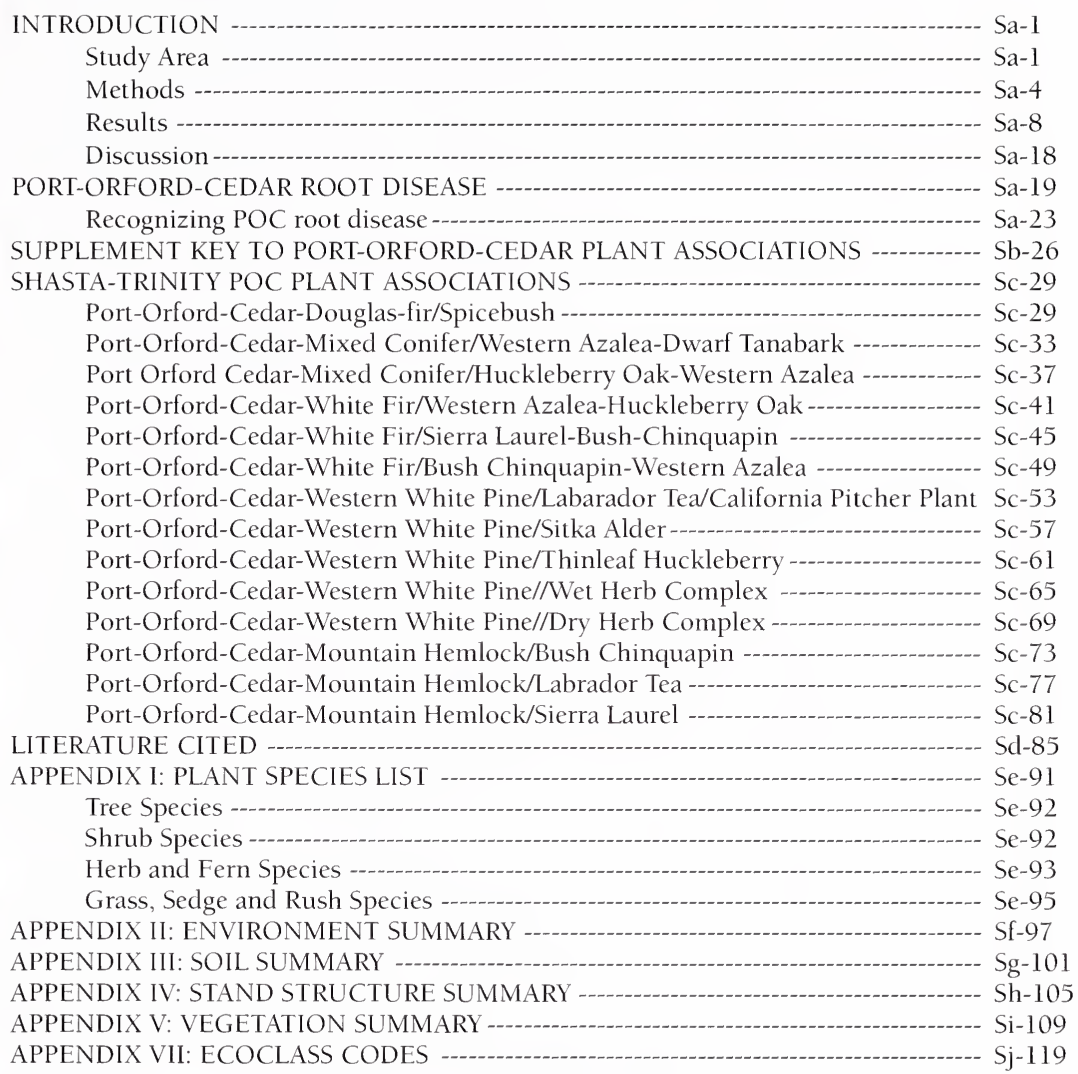




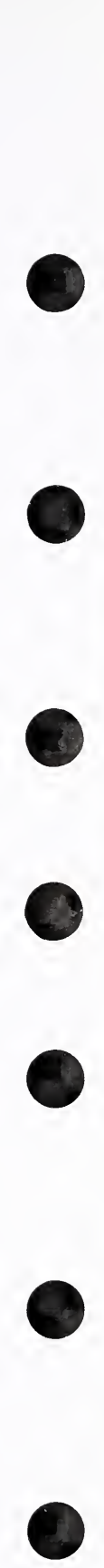




\section{INTRODUCTION}

This document is a supplement to "A Field Guide To PortOrford-cedar Plant Associations In Northwest California" (Jimerson 1994). It is based on the expansion of Port-Orford-cedar sampling into the Sacramento and Trinity River drainages in the vicinity of Mt. Shasta on the Shasta-Trinity National Forest (fig. 1). It describes the expanded study area, methodology and classification and includes descriptions of the newly identified Port-Orford-cedar plant associations. In addition, a second section describes the root disease affecting the species (Phytophthora lateralis) and ways to limit the disease spread. The addition of this supplement to the original field guide will result in a complete ecological classification of Port-Orford-cedar plant associations on National Forest System lands throughout northern California.

The information included in this field guide will be used in the development of the USDA Forest Service/Bureau of Land Management strategy for the conservation of Port-Orford-cedar. Together with the mapped polygons of Port-Orford-cedar, it will allow managers to identify opportunities to reduce human-related spread of Port-Orfordcedar root disease, especially into uninfected watersheds. In addition, the biological diversity of Port-Orford-cedar plant associations and their extent in California can be examined. This will allow for the identification of potential refugia sites for Port-Orford-cedar plant associations that capture the variability of Port-Orford-cedar plant communities throughout California.

\section{STUDY AREA}

The ecological subsections of California (USDA 1997) were used to stratify the study area. Samples were collected in the Eastern Klamath Mountains, Upper Scott Mountains and Lower Scott Mountains (USDA 1997) (fig. 2). These three subsections are disjunct from the main body of Port-Orford-cedar found in the western part of the range and are collectively known as the east subsections. These relatively uniform ecological units were mapped based on associations of their biotic and environmental factors that directly affect ecosystem function (McNab and Avers 1994). As such they can serve as a key component of a conservation strategy for Port-Orford-cedar. Under- 


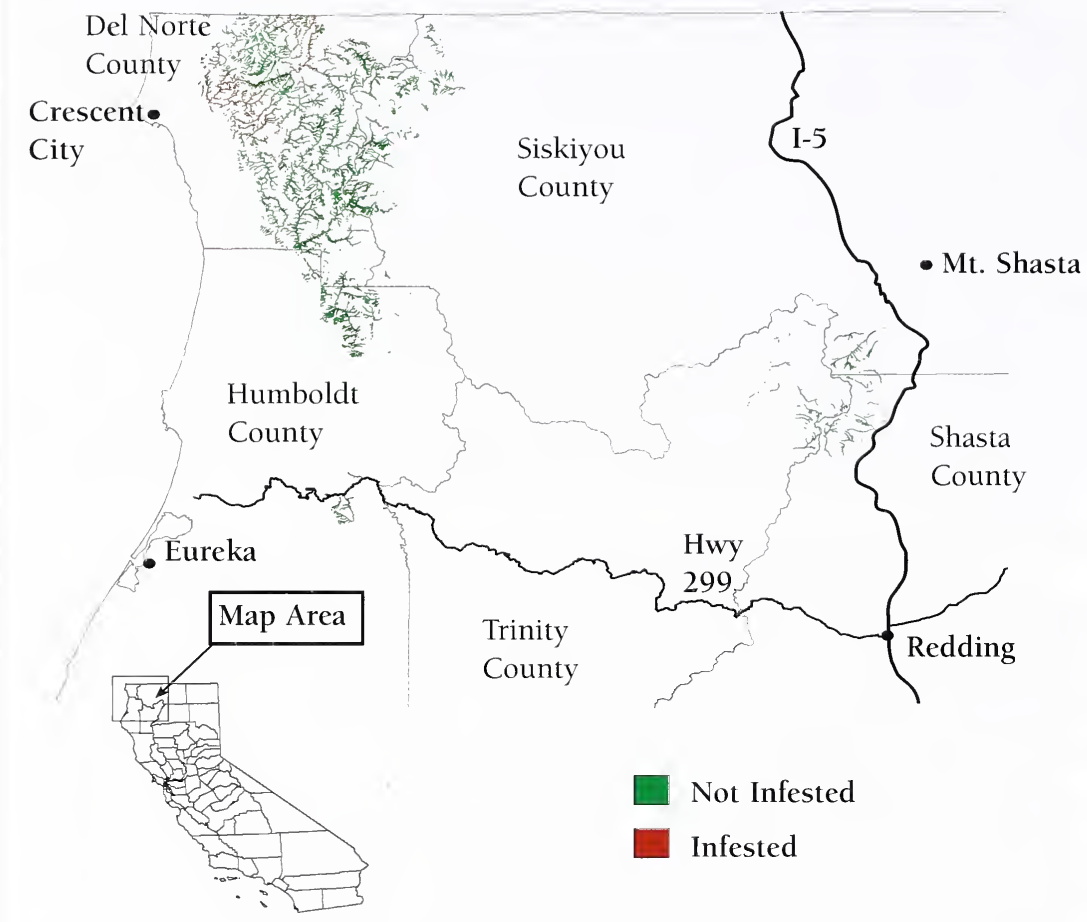

Figure 1. The distribution of infested and non-infested Port-Orfordcedar plant associations in Northern California. 


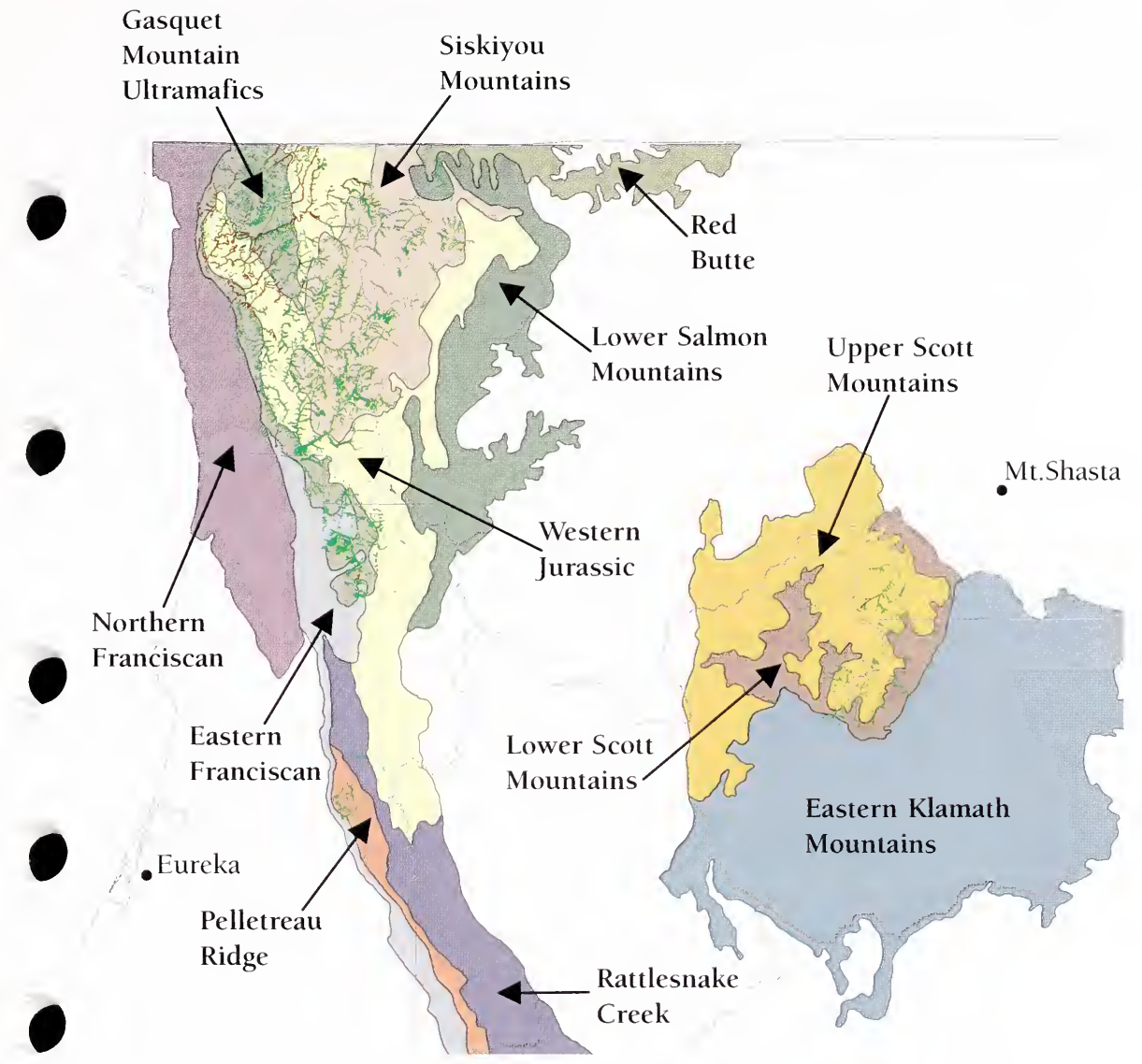

Figure 2. The distribution of Port-Orford-cedar plant associations by Ecological subsection in Northern California. 
standing the key functional components operating in each subsection will help us better manage for the continued existence of Port-Orfordcedar.

The east subsections are distinguished from the other populations of Port-Orford-cedar mapped in Northern California, based on several environmental factors. They have the highest mean elevation compared to the other subsection areas. The mean elevation for PortOrford-cedar stands in this area is 4,872 feet. Port-Orford-cedar is found more consistently at higher elevations in this eastern portion than in the other subsection areas. They are farthest from the coast with an average distance of 84 miles. Mean annual temperature (45 degrees F) and mean annual precipitation (56 inches) were the lowest of all the subsection areas. The low mean temperature is probably related to the number of high elevation sites in this area. The low mean precipitation may have to do with winter storm paths or the distance from the coast and changes in topography. The range of precipitation is from 30 to 80 inches. Most of these plant associations are in the Headwaters of the Sacramento River followed by the East Fork Trinity River and Shotgun-Slate Creeks. Although no infection was found in these eastern polygons there are infected Port-Orfordcedar stands on private land in the Upper Sacramento River drainage (DeNitto 1996).

\section{METHODS}

\section{Field Sampling}

Field work for this supplement was conducted in conjunction with the ecosystem classification program on the Six Rivers, Klamath, Shasta-Trinity and Mendocino National Forests in northern California. Plot data was collected in late-seral stage stands (old-growth) and mid-seral stands (mature). Plots were stratified by environment and selected as study sites. Sampling methods generally followed those described earlier by Hall 1970; Moir and Ludwig 1983; and Allen and Diaz 1986. Sample plot locations were restricted to forested stands with homogeneous vegetation, seral stage, soils, geology, and landform (Pfister and Arno, 1980). Sample sites were selected after a review of previous studies, the information on the factors described above and an extensive aerial photo and ground reconnaissance of the area. Plot size was 0.1 acre for herbs, graminoids and understory trees and of variable radius for shrubs and overstory trees (Bitterlich 1947). 
For each plot the following descriptive information were recorded: plot number, national forest, ranger district, forest map number, forest timber compartment, township, range, section, latitude and longitude (derived from ARC/INFO). Other variables are described below.

\section{Environment variables}

The physical environment was defined by elevation, aspect, percent slope, landform (general topographic characterization), micro-position (position of the plot on the slope), horizontal micro-relief (slope shape parallel to the contours), vertical micro-relief (slope shape across the contours), bare ground percent, surface gravel percent, surface rock percent, potential annual radiation (total annual radiation received for a given aspect, slope and latitude) (Frank and Lee 1966), transformed aspect (aspect transformed to a linear variable from 1-8) (Lewis 1982), and radiation index (ratio of total annual radiation on a given aspect and slope to total annual radiation received on a flat surface for a given latitude) (Frank and Lee 1966). In addition, annual precipitation, distance (miles) to the Pacific Ocean (X coordinate) and position on the north/south gradient (Y coordinate) (UTM) were determined from the ARC/INFO plot locations.

At selected sites, a soil pit was dug to a maximum depth of 40 inches or to bedrock. For each pit, data were recorded on: percent surface litter cover, litter thickness, parent material, parent material origin, total soil depth (to a maximum of 40 inches), rootability (whether the soil can be penetrated by roots), A horizon thickness, A horizon texture (using texture by feel), percent A horizon coarse fragments (using $2 \mathrm{~mm}$ sieved soil samples), A horizon color (hue, value, and chroma using Munsell color charts) (Munsell 1975), sub-surface texture, percent sub-surface coarse fragments, sub-surface color, soil drainage class, available water holding capacity (AWC) for the top 20 inches of soil, soil name (classified to family), $\mathrm{pH}$ of the surface horizon (using a Hellige-Truog Soil Reaction Tester), and pH of the sub-surface horizon.

\section{Vegetation variables}

At each plot, total percent cover was ocularly estimated and recorded for moss, forbs, graminoids, shrubs and trees. All plants were identified to species where possible (nomenclature follows Munz 1973 and Hickman 1993). Abundance was recorded for the herbaceous and 
graminoid layers only (Allen and Diaz 1986). Estimates of tree height and standing basal area (basal area factor 20 or 40) were recorded at three points per plot using a Speigel relaskop. In addition, diameter at breast height (dbh), total tree age, 10 and 20 year radial growth were recorded for a minimum of one dominant tree per point.

\section{Prism data}

Prism variables are computer generated climate data that were added to the plot data set to help explain the variability of Port-Orfordcedar communities over their range. The climate data was derived from precipitation and temperature map surfaces generated by the Precipitation-elevation Regression on Independent Slopes Model (PRISM) (Daly et al. 1994, Daly et al. 1997). This model uses digital elevation models (DEMs) to account for topographic effects in interloping weather measurements from an irregular network of weather stations to a uniform grid. Thirteen precipitation and thirteen temperature map surfaces (mean annual and 12 mean monthlies) were generated at 4 $\mathrm{km}$ resolution from 1961-1990 weather data. The precipitation data was specifically for California and Oregon respectively and the temperature data was for the conterminous United States. These map surfaces were imported as Arcinfo grids. Indices developed by Ohmann and Spies (1998) were computed from the mean monthly precipitation and temperature values for each grid for both the California and Oregon data. The temperature indices used were Mean annual temperature (ANNTMP), Mean August maximum (AUGMAXT), Mean December minimum (DECMINT), Mean Summer temperature (SMRTMP), and the difference between the mean August maximum and the mean December minimum (DIFTMP). Some of the precipitation values were log-transformed because vegetation does not respond linearly to amount of precipitation. A $1.0 \mathrm{~cm}$ difference in precipitation is more important at low than at high levels (Ohmann and Spies 1998). The precipitation indices used were as follows, the log of Mean Annual Precipitation (ANNPRE), Mean Annual Precipitation (PRISMPPT), and the log of Mean Summer Precipitation (SMRPRE). Seasonal variability and continentality indices for the precipitation layer were also computed. Continental climates experience less seasonal variability in precipitation because of increased prevalence of rainfall from summer convective storms. This is reflected in the CVPRE and CONTPRE indices. The Precipitation and temperature indices developed from the grid layers were assigned to each Port- 
Orford-cedar plot location using bilinear interpolation (LATTICSPOT function, ESRI 1991).

\section{Data analysis}

The vegetation and environment data were analyzed using the following programs and statistical packages.

\section{Vegetation classification}

Initial classification was accomplished through the use of the polythetic divisive classification technique Two-way Indicator Species Analysis, [TWINSPAN] (Hill 1979). TWINSPAN groups the plots based on similarity of species cover values. The classification was refined using the ordination technique, detrended correspondence analysis [DECORANA] (Hill 1979) and canonical correspondence analysis [CANOCO] (Ter Braak 1988, Jongman et al. 1995). The vegetation classification was constructed from the results of these analyses.

\section{Direct gradient analysis}

Direct gradient analysis was performed using canonical correspondence analysis [CANOCO] (Ter Braak 1988, Jongman et al. 1995). This technique constrains the ordination of the main matrix (species cover) by a multiple regression on environment variables contained in the secondary matrix. CANOCO was used as the primary tool to define the environment gradients that best explained the variability of Port-Orford-cedar communities (McCune and Mefford 1995). The analysis was done in a stepwise manner beginning with the full data set. This initial ordination helped to identify the primary gradients influencing species composition within Port-Orford-cedar stands. The final partitioning involved a separate analysis of each subseries (dependent on sufficient plot numbers) to identify the environment gradients affecting Port-Orford-cedar plant associations. In situations where the identified gradients were so long that they masked other important environment gradients a second iteration of the analysis was run. The results of the direct ordination are presented both descriptively and in graphic form. First, key correlated variables are described in relation to Port-Orford-cedar plant associations. Second, the position of each plant association by quadrant, a graphic representation (centered X Y) of Port-Orford-cedar plots coded by plant association is presented. The center point of the graphic is the 
point of origin of biplot scores for the key environment variables. The longer the environmental line, the stronger the relationship of the variable with the plant association (McCune and Mefford, 1995). Last, these environmental lines are used to help describe plant association relationships. For example, plant association $\mathrm{X}$ was found in the outer edge of the upper right quadrant where elevation was positively correlated. This position indicates that plant association $\mathrm{X}$ was found in the highest elevation positions of the group analyzed.

\section{RESULTS}

The vegetation classification developed for Port-Orford-cedar stands in the east subsections identified fourteen plant associations, included in five sub-series and one series (Table 1). The forest series was the Port-Orford-cedar series. By definition here a forest series requires at least $10 \%$ tree cover and is determined by the dominant tolerant tree species that will most fully occupy the site over time barring human disturbance and major disturbance events. For further ease of comparison, the fourteen plant associations were aggregated into five sub-series Port-Orford-cedar-Douglas-fir, Port-Orford-cedarMixed Conifer, Port-Orford-cedar-White Fir, Port-Orfordcedar-Western White Pine and Port-Orford-cedar-Mountain Hemlock. These vegetation sub-series are defined first by the series designation (Port-Orford-cedar) and second by the indicator species (white fir, western white pine and mountain hemlock). These indicator species are usually highly correlated with the primary environment gradients and establish the sub-series position along them. Sub-series are closely analogous to plant communities and both terms are used here to mean the same thing. 
Table 1. Port-Orford-cedar plant associations described from the Sacramento and Trinity River drainages.

SUB-SERIES/

EDP CODE

PLANT ASSOCIATION NAME

Port-Orford-cedar-Douglas-fir Sub-series

CHLA-PSME/CAOC

Port-Orford-cedar-Douglas-fir/ Spicebush

Port-Orford-cedar-Mixed Conifer Sub-series

CHLA-MCON/RHOC-LIDEE

Port-Orford-cedar-Mixed Conifer/

Western Azalea-Dwarf Tanbark

CHLA-MCON/QUVA-RHOC

Port-Orford-cedar-Mixed Conifer/

Huckleberry Oak-Western Azalea

Port-Orford-cedar-White Fir Sub-series

CHLA-ABCO/RHOC-QUVA

Port-Orford-cedar-White Fir/

Western Azalea-Huckleberry Oak

CHLA-ABCO/LEDA-CASE3

Port-Orford-cedar-White Fir/

Sierra Laurel-Bush Chinquapin

CHLA-ABCO/CASE3-RHOC

Port-Orford-cedar-White Fir/Bush

Chinquapin-Western Azalea

Port-Orford-cedar-Western White Pine Sub-series

CHLA-PIMO3/LEGL1/DACA2

Port-Orford-cedar-Western White

Pine/Labrador-Tea/California Pitcher

Plant

CHLA-PIMO3/ALSI2

Port-Orford-cedar-Western White Pine/ Sitka Alder

CHLA-PIMO3/VAME

Port-Orford-cedar-Western White Pine/ Thinleaf Huckleberry

CHLA-PIMO3//WET HERB COMP.

Port-Orford-cedar-Western

White Pine//Wet Herb Complex

CHLA-PIMO3//DRY HERB COMP.

Port-Orford-cedar-Western

White Pine//Dry Herb

Complex 
Port-Orford-cedar-Mountain Hemlock Sub-series

CHLA-TSME/CASE3

CHLA-TSME/LEGL1

CHLA-TSME/LEDA
Port-Orford-cedar-Mountain Hemlock/ Bush Chinquapin

Port-Orford-cedar-Mountain Hemlock/ Labrador-Tea

Port-Orford-cedar-Mountain

Hemlock/Sierra Laurel

\section{Sub-series Gradient Analysis}

A direct gradient analysis (CANOCO) of Port-Orford-cedar sub-series (plots and species) are contained in figures 3-5. The plot ordination in figure 3 identified elevation as the highest correlated variable with axis $1(r=.95)$, followed by moisture stress $(r=-.84)$, mean annual temperature $(r=-.78)$, macro-position $(r=-.70)$, granite parent rock $(r=.48)$, ultramafic parent rock $(r=-.56)$, A horizon coarse fragments $(r=-.47)$ and $Y$ coordinate $(r=.50)$. The left side of the graph includes the Port-Orford-cedar-Douglas-fir and Port-Orfordcedar-Mixed Conifer sub-series. These sub-series are found on low elevation sites, with high moisture stress, high mean annual temperature, warm southerly aspects, in lower slope macro-positions on ultramafic parent rock. These factors contribute to the tendency of these sub-series to be dominated by species such as canyon live oak, huckleberry oak, dwarf tanbark, coffeeberry, Ponderosa pine and sugar pine that are considered to be dry or mesic in their moisture requirements or tend to occur on soils derived from ultramafic parent rock (fig. 4). In contrast, the Port-Orford-cedar-White Fir, Port-Orfordcedar-Western White Pine and Port-Orford-cedar-Mountain Hemlock sub-series displayed on the right side of figure 6 are found on high elevation sites, dominated by soils derived from granite parent material in the northern portion of the east subsections. Here cooler conditions with lower moisture stress favor species such as western white pine, lodgepole pine, labrador tea, sierra laurel and California pitcher-plant (fig. 4).

Other examples of indicator species and environment interactions are displayed in figure 5. In this graph, axis 3 displays its highest correlation with soil drainage $(r=-.70)$, parent material origin $(r=-$ $.56)$, indirect solar radiation $(r=-.44)$, slope $(r=-.41)$ and micro- 


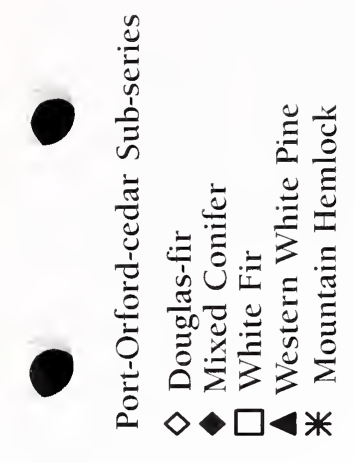

○

○

Axis 2
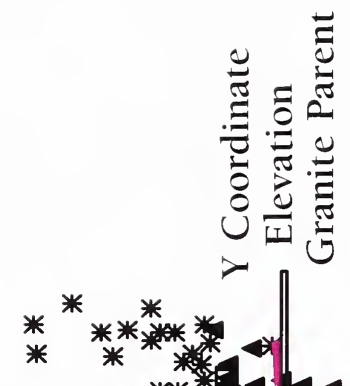

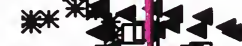

*

ב气

C

$0 \diamond \diamond$

-

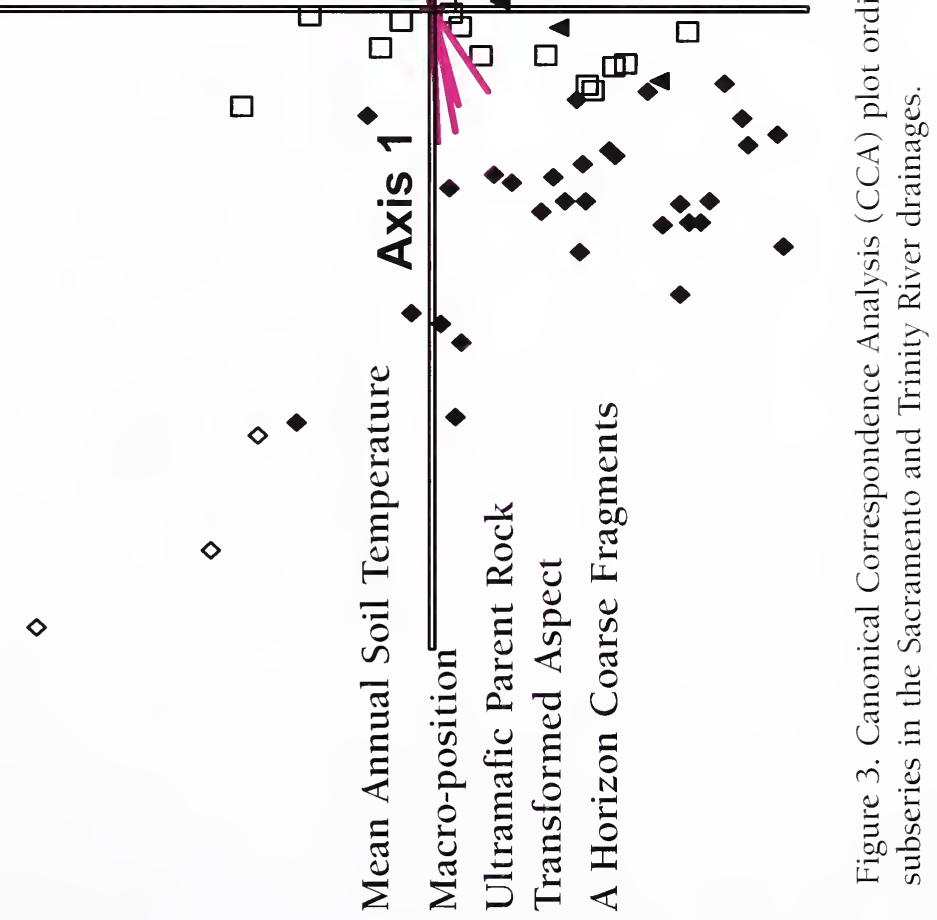




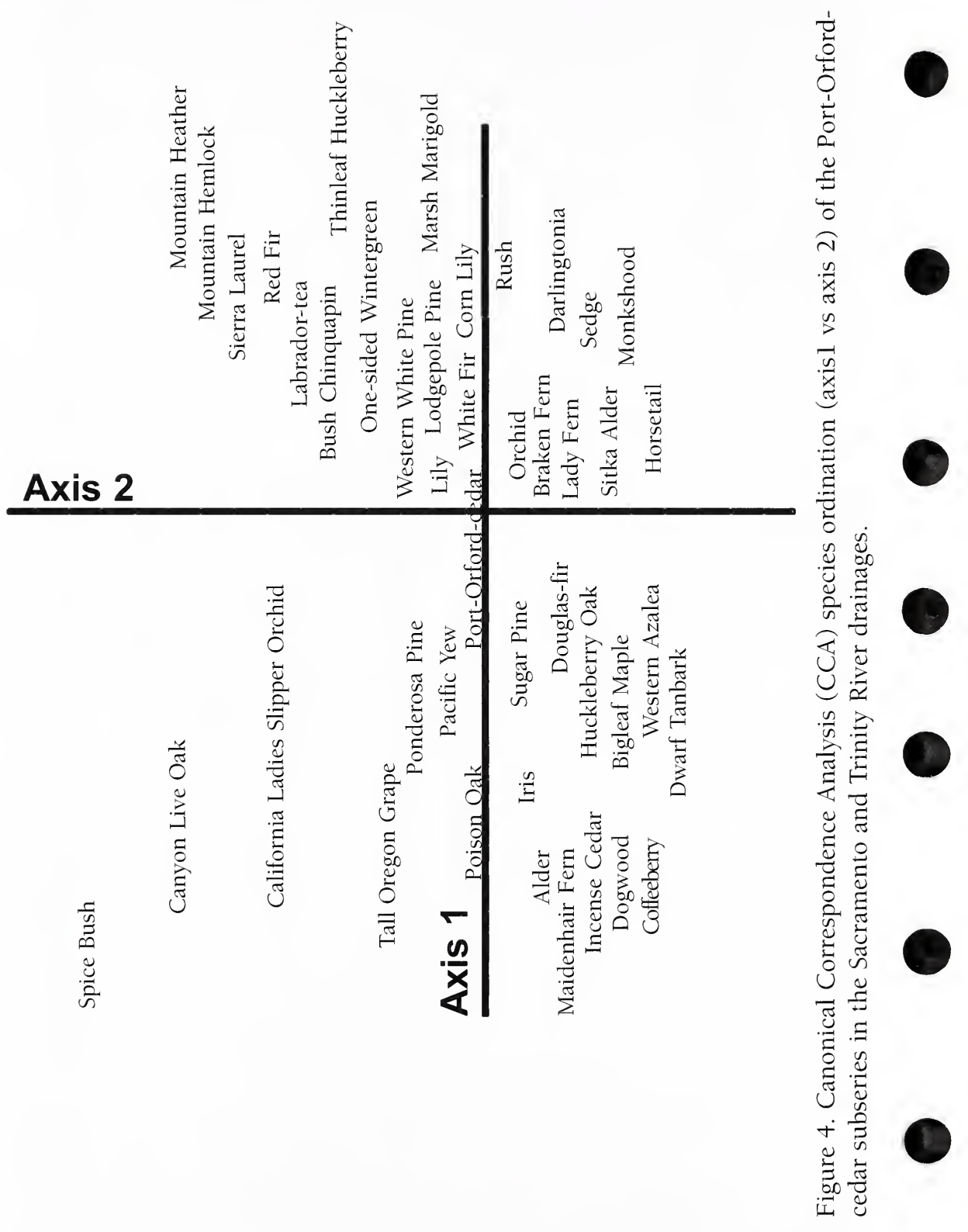


-

-

0

-

-

-

- 
-

-

-

-

.

-

. 


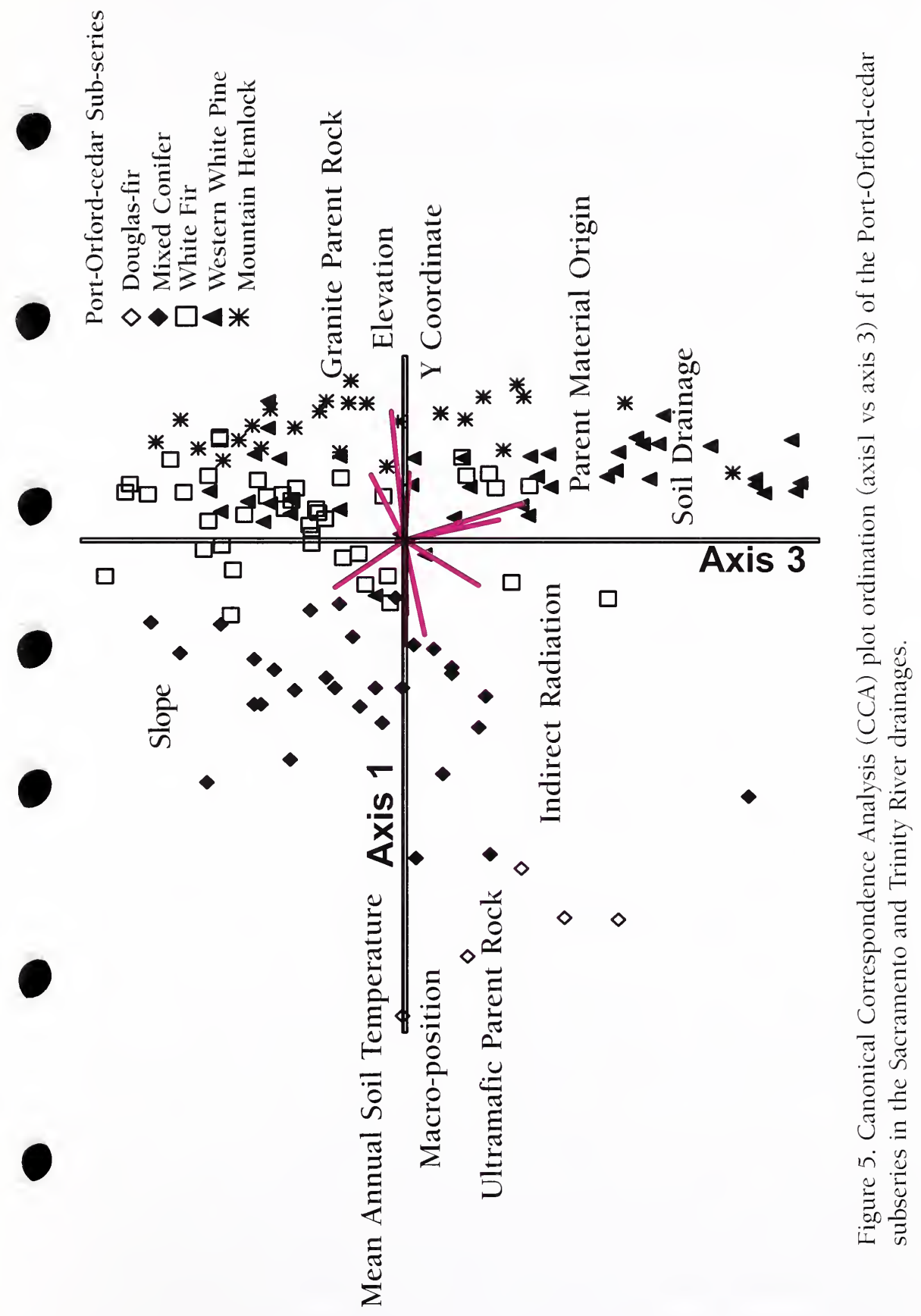


position $(r=-.40)$. Most of the plots in the Port-Orford-cedar-Western White Pine sub-series were found here on these wet, glacial basin sites. Species found along this axis include Darlingtonia, sedge, monkshood, horsetail, labrador-tea and ladyfern.

\section{Plant Association gradient Analysis}

Plant associations are analyzed below by sub-series in an attempt to identify both the primary and secondary gradients that define them.

The Port-Orford-cedar-Douglas-fir sub-series contained only one plant association the Port-Orford-cedar-Douglas-fir/Spicebush type. It was found on the lowest elevation sites in the eastern subsections on floodplain and terrace landforms derived from ultramafic parent rock. Climate is warm here as a result of east and southeast aspects. Moisture stress is also high as a result of the above factors and the high percentage of soil coarse fragments.

The indicator species, Spicebush is indicative of warm, moist places. Within the Port-Orford-cedar-Douglas-fir/Spicebush type, it appears to follow ephemeral stream courses that likely contain available subsurface water.

The Port-Orford-cedar-Mixed Conifer sub-series contained 2 plant associations; Port-Orford-cedar-Mixed Conifer/Western AzaleaDwarf Tanbark and Port-Orford-cedar-Mixed Conifer/Huckleberry Oak-Western Azalea. These plant associations were found on warm, mid elevation terraces, floodplains and mountain sideslopes. Soils were derived from ultramafic parent material on these moderate to highly rocky sites. Micro-relief was linear and undulating. The 2 plant associations differ by aspect, total vegetation, elevation and surface rock. Indirect gradient analysis identified elevation $(r=-.44)$, direct solar radiation $(r=-.42)$, hours of sunlight $(r=.37)$ and transformed aspect as correlated with axis 1 . In axis 2 mean annual precipitation $(r=.43), Y$ coordinate $(r=-.40)$, macro-position $(r=-.37)$ and surface rock $(r=.28)$ were identified as correlated variables. Axis 3 was correlated with micro-position $(\mathrm{r}=-.53)$, transformed aspect $(\mathrm{r}$ $=.52)$, mean annual precipitation $(r=-.43)$ and slope $(r=.33)$.

The Port-Orford-cedar-Mixed Conifer/Western Azalea-Dwarf Tanbark type was found on terraces, floodplains and mountain sideslopes derived from ultramafic parent material. Indirect solar radiation was high as a result of topographic shading on these bottom and lower one-third slopes. Micro-relief was linear and undulating on these moderately rocky east, south, west and north aspects. 
The Port-Orford-cedar-Mixed Conifer/Huckleberry OakWestern Azalea was found on warm floodplains and mountain sideslopes derived from ultramafic parent rock. Surface rock was high and direct solar radiation was high as a result of the south and southeast facing aspects.

Indicator species reflect the subtle differences between these 2 types. The Port-Orford-cedar-Mixed Conifer/Western Azalea-Dwarf Tanbark type was slightly cooler due to aspect and topographic shading. These factors combined with soils derived from ultramafic parent rock allow for the combination of a wet indicator species, western azalea and a mesic indicator species dwarf tanbark. In the PortOrford-cedar-Mixed Conifer/Huckleberry Oak-Western Azalea type site conditions are warmer and drier. Huckleberry oak was the dominant shrub while western azalea is found on micro-sites where water can be reached through sub-surface cracking in the ultramafic parent rock.

The Port-Orford-cedar-White Fir sub-series contained 3 plant associations; Port-Orford-cedar-White Fir/Western Azalea-Huckleberry Oak, Port-Orford-cedar-White Fir/Sierra Laurel-Bush Chinquapin and Port-Orford-cedar-White Fir/Bush Chinquapin -Western Azalea. These plant associations were found primarily on high elevation mountain sideslopes and streamsides with northwest, northeast and west aspects. Soils were derived from granite or ultramafic parent material, which together with landform determined which indicator species dominated. Direct gradient analysis identified granite parent rock $(r=.63)$, ultramafic parent rock $(r=-.60)$, slope $(r=.41)$, indirect solar radiation $(r=-.41)$ and indirect solar radiation $(r=-.39)$ as correlated with axis 1 . Axis 2 included micro-position $(r=.45), X$ coordinate $(\mathrm{r}=.41)$, macro-position $(\mathrm{r}=.40)$ and transformed aspect $(\mathrm{r}=.27)$ as correlated variables. Axis 3 included the following variables; elevation $(r=-.52)$, hours sunlight $(r=-.40)$ and direct solar radiation $(r=-.39)$.

The Port-Orford-cedar-White Fir/Western Azalea-Huckleberry Oak type was found on rocky floodplains, mountain sideslopes and streamsides derived from ultramafic parent rocks. Direct solar radiation was high as a result of west aspects.

The Port-Orford-cedar-White Fir/Sierra Laurel-Bush Chinquapin type was found on linear and undulating middle and lower one third slope positions of mountain sideslopes. Parent rock was mainly granitic on these moderately steep, cool, northwest facing aspects.

The Port-Orford-cedar-White Fir/Bush Chinquapin-Western Azalea type was found on rocky mountain sideslopes in lower one- 
third slope positions. Parent rock was mainly granite on these cool north, northeast and west facing sites.

Indicator species varied in response to the factors described above. Western azalea had its highest cover on ultramafic soils in streamside positions. Huckleberry oak was present in the Port-Orfordcedar-White Fir/Western Azalea-Huckleberry Oak type due to the ultramafic parent material but of low cover due to the close proximity to water. Sierra laurel had its highest cover on cool, mesic sites derived from granitic parent material. Bush chinquapin cover varied with surface rock percent. The combination of bush chinquapin and western azalea was likely related to the undulating topography on these cool, moderately rocky sites. These conditions tend to create irregular available moisture conditions that favor these two species.

The Port-Orford-cedar-Western White Pine sub-series contained 5 plant associations; Port-Orford-cedar-Western White Pine/ Labrador-Tea/California Pitcher Plant, Port-Orford-cedar-Western White Pine/Sitka Alder, Port-Orford-cedar-Western White Pine/ Thinleaf Huckleberry, Port-Orford-cedar-Western White Pine//Wet Herb complex and Port-Orford-cedar-Western White Pine//Dry Herb complex. These plant associations were identified on high elevation sites with northeast and northwest aspects. Soils were derived from granite or ultramafic parent rock, landforms included streamsides, basins, terraces, mountain sideslopes and glacial moraines. Changes in plant association and species composition were mainly due to these factors and those identified in the direct gradient analysis. CANOCO identified soil drainage $(r=.58)$, hours of sunlight $(r=.49)$, microposition $(r=.31)$, indirect solar radiation $(r=.28)$ and slope $(r=-.26)$ as the variables most highly correlated with axis 1 . Axis 2 included macro-position $(r=.75)$, elevation $(r=-.53)$ and $X$ coordinate $(r=$ $.46)$ as the most highly correlated variables. Axis 3 was correlated with ultramafic parent rock $(r=.42)$ and slope $(r=.31)$.

The Port-Orford-cedar-Western White Pine/Labrador-Tea/ California Pitcher Plant type was found mainly in gently sloping, poorly drained, basin micro-positions derived from granite or ultramafic parent rocks. Hours of sunlight were higher here than in all other Port-Orford-cedar-Western White Pine plant associations. The indicator species labrador-tea and California pitcher plant exemplified the wet nature of these sites.

The Port-Orford-cedar-Western White Pine /Sitka Alder type was found in rocky, streamside positions derived from granite and mafic parent rocks. Indirect solar radiation was high here. The wet 
area indicator species Sitka Alder dominated on these sites due to its close proximity to perennial streams.

The Port-Orford-cedar-Western White Pine/Thinleaf Huckleberry type was found on streamside terraces and mountain sideslopes where soils were derived from granite parent rock. Thinleaf huckleberry a mesic indicator species, dominated on these sites.

The Port-Orford-cedar-Western White Pine//Wet Herb complex was found in poorly drained, wet basin micro-positions derived from ultramafic and granite parent rocks. A variety of wet indicator forb species were found here including tiger lily, ragwort, corn lily, loveage, bleeding heart, monkshood, lady fern, marsh-marigold, and anemone.

The Port-Orford-cedar-Western White Pine//Dry Herb complex was found on rocky sites that resulted from glacial moraine deposits. These sites were derived from granite or ultramafic parent rocks and were often found adjacent to the Port-Orford-cedar-Western White Pine//Wet Herb type. They contained low cover of shrubs most notably huckleberry oak and high cover of dry and mesic herbs such as hawkweed, brakenfern, wild pea, clover, one-sided wintergreen and a variety of grass species.

The Port-Orford-cedar-Mountain Hemlock sub-series contained 3 plant associations; Port-Orford-cedar-Mountain Hemlock/ Bush Chinquapin, Port-Orford-cedar-Mountain Hemlock/Labrador-tea and Port-Orford-cedar-Mountain Hemlock/Sierra Laurel. These plant associations were identified on high elevation sites with north or west facing aspects. They were dominated by granite rock and influenced by glacial landforms. For instance, the bush chinquapin type is found on glacial moraines, while the Labrador-tea type is found along the edges of cirque basins and the Sierra laurel type was found on mountain sideslopes. These factors, in combination with the results of direct gradient analysis (CANOCO), help explain species composition. CANOCO identified transformed aspect $(r=-.56)$, surface rock $(r=.53)$ and direct solar radiation $(r=-.43)$ as the highest correlated variables with axis 1. Axis 2 had its highest correlation with vertical micro-relief $(r=$ $-.60)$ and micro-position $(r=-.54)$. These factors in combination have an influence on available water, which is reflected in the indicator species composition found in these communities. One of these indicators, bush chinquapin, has a high tolerance for somewhat dry sites such as those found in the rocky surface layers of glacial moraines. Labrador-tea, a wet area indicator species, was found on west facing, wet sites such as those associated with concave shaped glacial cirques. 
Sierra laurel is considered a mesic species; hence its location on mountain side slopes above the Labrador-tea type.

\section{DISCUSSION}

As we can see from the descriptions of the sub-series in which Port-Orford-cedar was found, the potential effects of Port-Orfordcedar root disease on biological diversity in northern California are many. Foremost, is the loss or significant decline of a major shade tolerant tree species found in many plant communities. In northern California alone, Port-Orford-cedar has been noted as a major component of forty-eight plant associations and as a minor tree component $(<10 \%)$ in other associations (Jimerson and Creasy 1990). The loss of Port-Orford-cedar will also lead to changes in species composition as other tree species fill the vacant niches. This could alter not only the compositional features of the stand, but also structural and functional features. Port-Orford-cedar, because of its limited height growth compared to Douglas-fir, white fir and red fir and because of its tolerance to shade often forms a distinctive second and third layer. This has implications for wildlife species that benefit from multiple layers, whether for foraging and roosting habitat or for thermal and hiding cover. It is apparent from the growth data collected during the development of this classification that Port-Orford-cedar is often the oldest tree species in a stand, thus, providing long term habitat values. If Port-Orford-cedar root disease continues to spread, snags and logs would also decline over time, leading to a loss of what is one of the most enduring snag and log features in northwest California (Jimerson 1989). 


\section{PORT-ORFORD-CEDAR ROOT DISEASE}

Phytophthora lateralis Tucker \& Milbrath, is an organism that causes a root disease of Port-Orford-cedar and Pacific yew (Taxus brevifolia Nutt.). It is a member of a group of organisms called Oomycetes, which are similar to fungi, but possess enough differences to be considered distinct. The disease was first reported in a nursery in Seattle in 1923, but the cause was not identified until 1942 when $P$. lateralis was isolated from nursery material in Oregon (Tucker and Milbrath 1942; Zobel et al. 1985). By this time, it had been spread widely in Washington and Oregon through transport of infected nursery stock. In 1952, Port-Orford-cedar root disease was first identified in the native range of Port-Orford-cedar at Coos Bay, Oregon (Roth et al. 1957). A survey in 1964 found new centers of infection that were mainly in areas that had been harvested or associated with pasturing domestic stock (Nelson 1964). Port-Orford-cedar root disease was confirmed in California in 1979 (Kliejunas and Adams 1980), but was originally observed by 1960 along the Middle Fork of the Smith River (Zobel et al. 1985). In 1979 it was reported in eight locations in California: seven in the Smith River basin and one in an ornamental planting in Eureka (Kliejunas and Adams 1980). The disease was not observed in the Klamath, Trinity, or Sacramento River basins. This was a survey of selected sites, not of the entire population and other areas of infestation within the Smith River basin were likely present. A more complete inventory of Port-Orford-cedar on National Forest System lands was performed in 1992 and 1993. Using standardized stream buffers, this inventory identified Port-Orfordcedar on about 160,000 acres with an estimated 9,000 acres to have root disease. The only known infested drainage in California at that time was the Smith River basin. In 1995 and 1996 two new areas of infestation were identified on tributaries of the Klamath River. Also in 1996 an infested area was observed on the main stem of the Sacramento River (DeNitto 1996). In 1998 intensive mapping of PortOrford-cedar plant associations was completed on National Forest lands in California (Jimerson et al. 1999). This study identified PortOrford-cedar plant associations covering a total of 37,734 acres. PortOrford-cedar root disease was present in 3,267 acres. The plant association mapping only included stands of with $10 \%$ or greater PortOrford-cedar. 
Phytophthora lateralis has four spore forms that have different functions in survival and transport (Trione 1959, 1974). The oospore is rarely observed and constitutes the sexual stage. It may play a role in long-term survival and overland movement, but that is probably secondary to the chlamydospores. The chlamydospore is an asexual structure commonly referred to as the "resting spore". It is thick-walled and is commonly found in rootlets killed by P. lateralis (Ostrofsky et al. 1977). It is probably the main structure that enables $P$. lateralis disease to survive on a site during adverse conditions or in the absence of a host (Trione 1974). It is also believed to be the primary means of spread to new areas in infested organic matter. When induced to germinate by the presence of water, the chlamydospores form sac-like structures called sporangia. This sporangium subsequently germinates and produces zoospores, which are commonly called "motile spores" because of their capability to propel themselves with their flagella. The zoospores are likely attracted by exudates produced by Port-Orford-cedar rootlets, similar to other Phytophthora spp. (Carlile 1983). Once in contact with unsuberized growing root tips, zoospores can germinate and infect the rootlet. Subsequent spread within the plant occurs by growth of the mycelium through the inner bark and cambium of the root system to the root collar with eventual mortality of the host.

Following root and tree mortality many saprophytic organisms begin to invade the woody tissues. This displaces and replaces the mycelium of P. lateralis. The chlamydospores that had developed within the woody tissue, however, are more resistant to microbial attack and provide the survival capability in the absence of a host. Oospores may have a similar, but lesser, role in survival. It appears that survival on a site occurs within the decaying roots of infected trees when living hosts are absent (Ostrofsky et al. 1977; Tsao 1993). Measuring and quantifying the amount of $P$. lateralis disease in the soil is difficult, but it appears that the amount is low even beneath dead and dying trees (Tsao 1993).

The longevity of $P$. lateralis on a site in the absence of live hosts has been examined in two studies. One in Coos County, Oregon has found it surviving for up to 7 years (Hansen and Hamm 1996). The second study, in Del Norte County, California, reported the nonrecovery of $P$. lateralis after 4 years (Kliejunas 1992). Differences between these two studies are attributed to sampling variability, difficulties in recovering P. lateralis disease from soil, and to different environmental conditions between the two sites. Survival in the 
absence of the host may depend on soil moisture and temperature conditions, with survival being longer further north.

Two types of movement occur with P. lateralis. Long distance spread between drainages and watersheds occurs when infested organic matter is transported (Roth et al. 1972). Humans have been the main vectors of Port-Orford-cedar root disease. Long distance spread has resulted from moving infected seedlings and, especially, infested soil into disease-free sites (Hadfield et al 1986; Harvey et al. 1985; Kliejunas and Adams 1980; Roth et al. 1972; Roth et al. 1987).

Major spread of the disease has occurred through earth movement in road construction, road maintenance, logging and traffic flow on forest roads. In general, the spread of the disease is limited in areas where physical barriers or lack of access have prevented human vector activity, especially during wet periods. Seasonal road and harvest closures have been used as effective prevention techniques. Movement of $P$. lateralis in soil clinging to the feet of cattle and elk is suspected to occur and may have resulted in new infestations in a few instances (Hansen et al. 1994; Roth et al. 1987; Zobel et al. 1985).

The second type of movement is the short-distance "swimming" of motile zoospores. When chlamydospores germinate, sporangia and zoospores are produced. The zoospores can move short distances, up to a few centimeters, with the use of their flagella until they contact a host rootlet where they will attach themselves and germinate (Carlile 1983). If they do not contact a susceptible rootlet, they will encyst. Encysted spores may be transported in water or perish. After a tree is infected, sporangia develop from the roots when conditions are conducive and produce zoospores. These can then invade nearby rootlets, either of the same tree or a neighboring tree.

Once brought into a new area, $P$. lateralis spreads in water downslope from roads and trails. The inoculum often builds to high levels in dense stands of Port-Orford-cedar growing on disturbed areas, close to road edges, thus increasing the likelihood of downhill spread. In almost all cases, infection of Port-Orford-cedar by the pathogen occurs in areas where obvious avenues for waterborne chlamydospore and zoospore dispersal exists. Infection is also dependent on the presence of free water in the immediate vicinity of susceptible tree roots. Spread rates are quite variable, but can be great in favorable wet years. Topography has a considerable influence on spread (Hadfield et al 1986). Steep slopes dissected by drainages quickly channel zoospore-infested water into streams. Cross slope spread is restricted. On broad slopes or flat areas infested water may 
spread out over larger areas and move more slowly. Concave areas with Port-Orford-cedar are very vulnerable to damage because they are easily flooded. Convex slopes have very limited vulnerability. PortOrford-cedar growing on sites or microsites that are unfavorable for spread of the pathogen often escape infection, even in areas where infected trees are nearby.

The spread of infested material and subsequent infection of Port-Orford-cedar in a new area requires a number of events to occur. First, the material must land in an area where Port-Orford-cedar is present. Second, P. lateralis must be able to survive until temperature and moisture conditions occur that permits spore germination. Conditions on road surfaces, for example, probably are not conducive to $\mathrm{P}$. lateralis survival, except during wet conditions. Third, zoospores must reach the root tips of Port-Orford-cedar or Pacific yew. This means chlamydospores, oospores, or sporangia must be transported near or within the dripline of a Port-Orford-cedar and be within a few centimeters of susceptible rootlets for infection to occur. Then zoospores must be produced and travel to the rootlets, followed by germination and penetration. The length of time of motility of $P$. lateralis zoospores has not been measured, but zoospores of other Phytophthora spp. have remained motile under ideal conditions for up to 84 hours (Carlile 1983). Observations indicate that zoospores of Port-Orford-cedar root disease encyst readily when agitated. Each of the steps described above requires precise conditions of cool soil temperatures and saturated to near-saturated soil moisture over a period of time in order for infection to occur (Trione 1959, 1974; Tucker and Milbrath 1942).

The length of time between infection and tree mortality likely varies by tree size because of the amount of root system available to support the tree. Most observations are based on the estimated time when $P$. lateralis was introduced into an area and when mortality occurred. Seedling mortality occurs rapidly and is dependent on weather conditions. It may be a few weeks to 2 to 3 months (Tucker and Milbrath 1942). Larger trees may survive for several years following infection (Roth et al. 1972; Zobel et al. 1985). During this period, infected roots develop sporangia and zoospores under proper conditions, which can intensify the disease in an area and result in further downhill spread (Trione 1974). 


\section{Recognizing Port-Orford-cedar Root Disease}

Recognizing new areas with Port-Orford-cedar root disease is critical to managing the disease and limiting its spread. The presence of the disease can be determined with some reliability in the field. However, confirmation of new areas should be done by a plant pathologist who has the capability to identify the $P$. lateralis in the laboratory. include:

Suggestions that Port-Orford-cedar root disease may be present

1 Port-Orford-cedar that have died over a period of several years and includes trees in various stages of decline

1 More severely affected Port-Orford-cedar nearer to areas with standing or slowly moving water

1 Stringers of dead and dying Port-Orford-cedar running downslope along water courses

1 An association of dead and dying Port-Orford-cedar with actively used roads and trails, especially in ditches and drainages

The foliage of trees affected by Port-Orford-cedar root disease fades from green to yellow to brown from the time of infection. This fading pattern is expressed throughout the crown, not just portions of the crown or individual branches. There are no fruiting bodies or other structures present on the tree to help identify the presence of the disease. The disease affects all sizes of trees.

When the presence of Port-Orford-cedar root disease is suspected based on dead and dying trees, closer observations need to be made. Trees selected for these observations should not be dead. They should still have some live phloem remaining which means some green to yellow foliage will be present. It is necessary to slice or chop into the base of the tree to make this determination. Care needs to be taken not to slice into the wood, which does not discolor and could confuse observations. The only symptom that is present in diseased trees is dead phloem. This displays itself as a golden-brown discoloration of 
the phloem in the roots or near the base of the tree. There is a sharp demarcation between the discoloration and the unaffected, creamy white phloem higher on the stem. The discoloration extends down into the roots without any patches of white phloem. Other agents can cause a similar brown coloring of the phloem, but does not extend into and down the roots. Observations need to be made as close to ground level as possible to reduce the chances for confusion with other agents. If this pattern of tree mortality and phloem discoloration is observed, a pathologist needs to be consulted for confirmation.

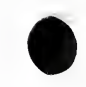




\section{SUPPLEMENT KEY TO PORT-ORFORD-CEDAR PLANT ASSOCIATIONS IN THE SACRAMENTO AND TRINITY RIVER HEADWATERS}

la. Spicebush present and greater than $10 \%$ cover CHLA-PSME/CAOC (p.Sc-28)

lb. Spicebush absent or not as above

2a. Mountain hemlock present and greater than $5 \%$ cover 3

3a. Bush chinquapin present and greater than 5\% cover ... CHLA-TSME/CASE3(p.Sc-71)

3b. Bush chinquapin absent or not as above 4

4a. Labrador-tea present and greater than 5\% cover ...... CHLA-TSME/LEGLl(p.Sc-75) 4b. Labrador-tea absent or not as above

5a. Sierra laurel present and greater than 5\% cover .. CHLA-TSME/LEDA (p.Sc-79)

5b. Sierra laurel absent or not as above

2b. Mountain hemlock absent or not as above 6

6a. Douglas-fir present and greater than $10 \%$ cover, white fir usually less than $10 \%$ cover

7a. Western azalea and huckleberry oak usually present and greater than $10 \%$ cover CHLA-MCON/QUVA-RHOC (p.Sc-35)

7b. Western azalea and huckleberry oak absent or not as above

8a. Western azalea and dwarf tanbark usually present

CHLA-MCON/RHOC-LIDEE (p.Sc-31)

8b. Western azalea and dwarf tanbark absent or not as above 9

6b. Douglas-fir absent or not as above

9a. White fir overstory cover exceeds western white pine

10a. Sierra laurel present and greater than $10 \%$ cover,

bush chinquapin present CHLA-ABCO/LEDA-CASE3 (p.Sc-43)

10b. Sierra laurel or bush chinquapin absent or not as above

11a. Bush chinquapin present and greater than 5\% cover, western azalea usually present .......... CHLA-ABCO/CASE3-RHOC (p.Sc-47)

$1 \mathrm{lb}$. Bush chinquapin and western azalea absent or not as above.....

12a. Western azalea present and greater than $5 \%$ cover, huckleberry oak usually present .... CHLA-ABCO/RHOC-QUVA (p.Sc-39)

12b. Western azalea and huckleberry oak absent or not as above ................. 13

9b. Western white pine overstory cover exceeds white fir

13a. Labrador-tea present and greater than $5 \%$ cover

CHLA-PIMO3/LEGL1/DACA2 (p.Sc-51)

13b. Labrador-tea absent or not as above 
-

-

-

-

-

-

-

Sb-26 
14a. Sitka alder present and greater than $10 \%$ cover

CHLA-PIMO3/ALSI2 (p.Sc-55)

14b. Sitka alder absent or not as above

15a. Thinleaf huckleberry present and greater than $5 \%$ cover

CHLA-PIMO3/VAME (p.Sc-59)

15b. Thinleaf huckleberry absent or not as above

16

16a. Wet species such as lily, California false hellebore, woolly ragwort, lady fern and bleeding heart, dominate the forb layer CHLA-PIMO3//Wet Herb complex (p.Sc-63)

16a. Mesic species such as braken fern, white hawkweed, Gray's licorice root, one-sided pyrola, and white-vein wintergreen dominate the forb layer CHLA-PIMO3//Dry Herb complex (Sc-67) 
-

-

-

-

-

-

- 
-

-

0

-

○

-

- 

A Supplement to:

\author{
A Field Guide To Port-Orford-cedar \\ Plant Associations in Northwest California
}

Thomas M. Jimerson

Elizabeth A. McGee

Gregg DeNitto

Drawings By:

Christina Ericksen

Photographs By:

Thomas M. Jimerson

Jeffrey $\mathrm{K}$. Jones 


\section{ACKNOWLEDGMENTS}

The USDA Forest Service, Forest Pest Management Program funded this supplement to the Port-Orford-cedar field guide. We thank the following individuals for their assistance in the development of this field guide: Jeff Jones, Bruce Bryan, Edward Biery, Richard Dwerlkotle, Peter Figura, Laura Andrews, Philip Purcell and Bud Adamson for ecology plot data collection; Tom Laurent, Tim Hagen ,Patricia Caswell, Theresa Kunch, and Mike Vollmer for soils data collection; and Peggi Lawrence, David Jones, Pete Angwin and Frank Betlejewski for manuscript review and Jerry Boberg for assistance with graphics.
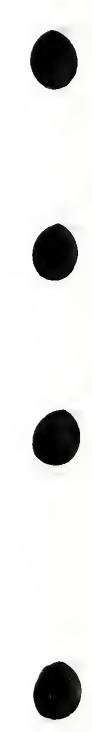
Plant Association: Port-Orford-cedar-Douglas-fir/Spicebush EDP Code Name: CHLA-PSME/CAOC5

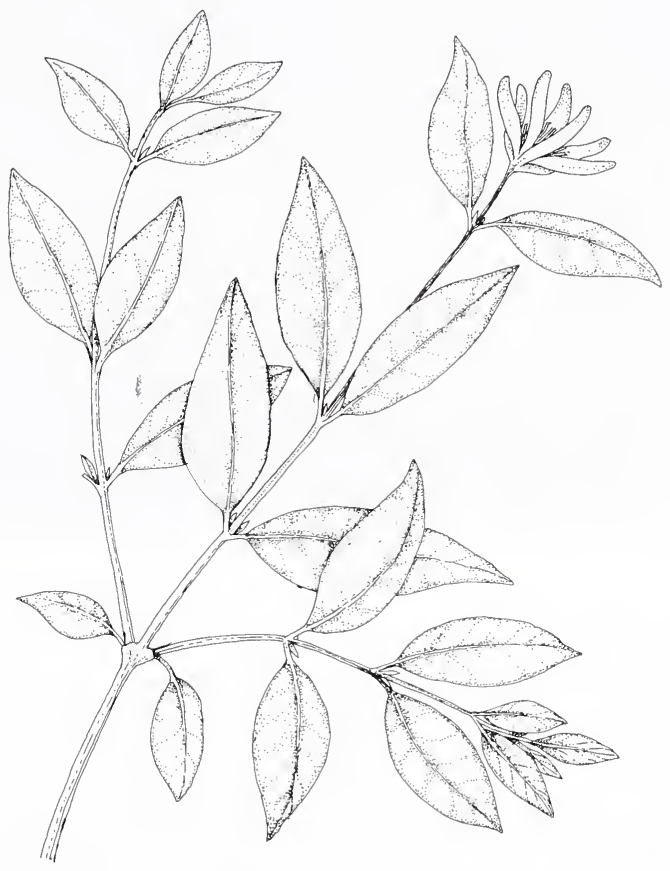

Indicator species:

Spicebush (Calycanthus occidentalis-CAOC5) was found on low elevation, moist, lower $1 / 3$, mountain slopes. 


\section{CHLA-PSME/CAOC5 Association, Port-Orford-cedar-Douglas-fir/Spicebush,}

EcoCode: CCOCD001

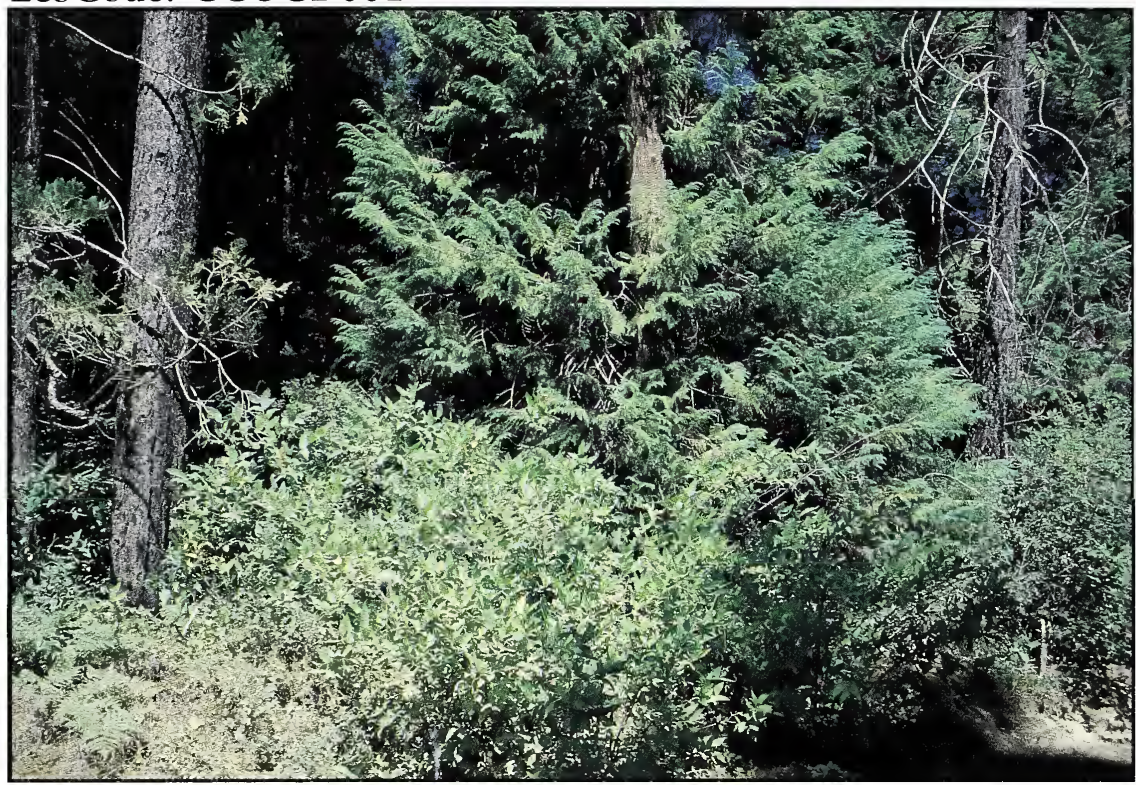

\section{SUMMARY TABLE}

(Sample size: 5)

COVER CON

\section{Tree Overstory Layer}

CHLA Port-Orford-cedar

$\begin{array}{rr}51 & 100 \\ 24 & 100 \\ 16 & 80\end{array}$

$\begin{array}{ll}\text { PSME } & \text { Douglas-fir } \\ \text { QUCH2 } & \text { Canyon Live Oak }\end{array}$

$16 \quad 80$

Tree Understory Layer

$\begin{array}{lll}\text { CHLA Port-Orford-cedar } & 1 & 100\end{array}$

PSME Douglas-fir $\quad 1 \quad 40$

QUCH2 Canyon Live Oak 1100

\section{ENVIRONMENT:}

Elevation: 1940-2550 ft.;

Aspect: E.;

Slope: $10-60 \%$;

Slope Position: lower $1 / 3$,

Draw;

Surface Rock: 3-40\%;

Distance to Ocean: 83.6-89.9 miles

\section{Shrubs}

$\begin{array}{llrr}\text { CAOC5 } & \text { Spicebush } & 45 & 100 \\ \text { RHOC } & \text { Western Azalea } & 4 & 80 \\ \text { RHCA } & \text { Coffeeberry } & 1 & 80\end{array}$

Herbs \& Grasses

$\begin{array}{llll}\text { CAR1 } & \text { Sedge } & 3 & 80 \\ \text { ADPEA } & \text { Five-Finger Fern } & 2 & 80 \\ \text { POCO } & \text { Milkwort } & 1 & 60 \\ \text { CYCA } & \text { California Lady's Slipper } & 1 & 60 \\ \text { PTAQL } & \text { Bracken Fern } & 1 & 60\end{array}$

SOILS:

Pit Depth: $40+$ in.;

AWC: 4.8 in.;

Parent Material: ultramafic;

A Horizon:

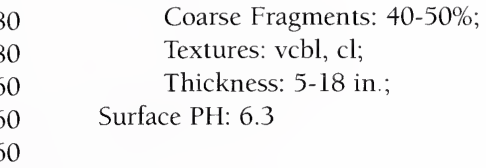




\section{DISTRIBUTION/SETTING:}

This type was a minor component that covered only 18 acres. It was found on inland sites on the Mt. Shasta Ranger District of the Shasta-Trinity National Forest where mean distance to the Pacific Ocean was 87.1 miles. Elevation was the lowest of all inland sites and averaged 2124 feet. Landforms were flood plains and terraces with undulating horizontal micro-relief and undulating/linear vertical micro-relief. Slopes were gentle to steep (10-60\%) in lower one-third slope micro-positions. Radiation index was a warm .449 as a result of east facing aspects but was moderated by topographic shading.

\section{VEGETATION SUMMARY:}

Total vegetation cover was very dense $(97 \%)$ and was composed of primarily trees (88\%) and shrubs (49\%). Port-Orford-cedar (51\%), Douglas-fir (24\%) and canyon live oak $(16 \%)$ dominated the tree layer. The shrub layer was dominated by spicebush $(45 \%)$ and included western azalea (4\%), coffeeberry (1\%) and trailing blackberry. Total forb cover was low (4\%) and included five-finger fern, California lady-slipper, milkwort and braken fern. The grass layer was also of low cover (5\%) and dominated by sedge.

\section{SOIL SUMMARY:}

Soils in this type were mesic, deep and moderately well drained. They formed in alluvium from the fine textured ultramafic parent material peridotite. The litter layer thickness averaged $1.4 "$ at $84 \%$ cover. Surface rock and gravel averaged $17 \%$ cover. The average surface horizon thickness was 9". Texture was very cobbly loam, coarse fragment content averaged $47 \%$ and $\mathrm{pH}$ averaged 6.3 .

Subsoil texture was predominately extremely cobbly loam. Subsoil coarse fragment content averaged 63\%. Subsurface $\mathrm{pH}$ averaged 7.0. The soils were $100 \%$ skeletal.

\section{STAND STRUCTURE SUMMARY:}

Late seral stands in this type often had 3 or more layers of trees, while early mature and mid mature stands usually had 2 layers. Medium sized conifers dominated the top two layers with an average of 41 trees/acre $>21$ inches $\mathrm{dbh}, 11$ trees/acre $>30$ inches $\mathrm{dbh}$, and 3 trees/acre $>40$ inches $\mathrm{dbh}$. Hardwoods were found in the lower layers and included 29 trees/acre $>5$ inches $\mathrm{dbh}$ and 6 trees/acre $>11$ inches $\mathrm{dbh}$.

The stand structure characteristics by layer were as follows. The top layer averaged 254 years old with an average diameter of 41.9 inches and average height of 140 feet. It was made up of predominant Douglas-fir and dominant Port-Orford-cedar. The second layer had an average age of 177 years with a mean diameter of 24.4 inches and a mean height of 87 feet. It included codominant Port-Orford-cedar. The third layer had an average age of 109 years with a mean diameter of 15.4 inches and a mean height of 70 feet. The third layer included intermediate sized Port-Orford-cedar and canyon live oak.

Overall biomass production (conifer + hardwoods + shrubs) was generally moderate. Modal Dunning site class was 4 with site index of 100 at 300 years. Conifer productivity was generally low with an average volume of $7217 \mathrm{ft}^{3}$, it ranged from 6980 to $7480 \mathrm{ft}$. Softwood basal area averaged $404 \mathrm{ft}^{2}$ and ranged from 333 to $460 \mathrm{ft}^{2}{ }^{2}$ Hardwood volume averaged $107 \mathrm{ft}^{3}$ and ranged from 0 to $220 \mathrm{ft}^{3}$. Hardwood basal area averaged $11 \mathrm{ft}^{2}$ and ranged from 0 to $20 \mathrm{ft}^{2}{ }^{2}$ Stand density index was 713 and fell in the high end of the PortOrford-cedar series. Quadratic mean diameter was 12.7 inches and fell in the low end of the Port-Orford-cedar series. 


\section{CLOSELY RELATED TYPES:}

The CHLA-PSME/CAOC5 type is unlike all other types based on the fact that spicebush (CAOC5) the indicator species was only found here. This type is replaced on higher elevation, streamside, serpentine sites by the CHLA-MCN/RHOC-LIDEE and on rocky, serpentine sites by the CHLA-MCN/QUVA-RHOC type. 
Plant Association: Port-Orford-cedar-Mixed Conifer/Western AzaleaDwarf Tanbark

EDP Code Name: CHLA-MCON/RHOC-LIDEE

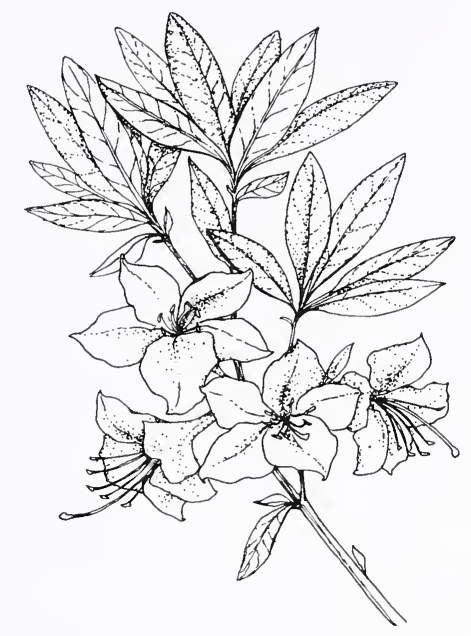

Indicator species:

Western azalea (Rhododendron occidentalis-RHOC) was found on cool, wet sites in lower $1 / 3$ slope positions.

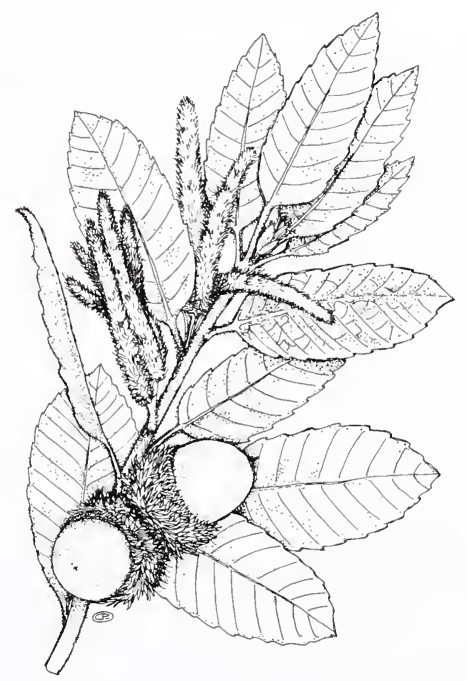

Indicator species:

Dwarf tanbark (Lithocarpus densiflorus var. echinoides-LIDEE) was found on rocky, moist, high elevation sites on serpentine soils. 


\section{CHLA-MCN/RHOC-LIDEE Association,}

\section{Port-Orford-cedar-Mixed Conifer/Western Azalea-}

Dwarf tanbark, EcoCode: CCOCD004

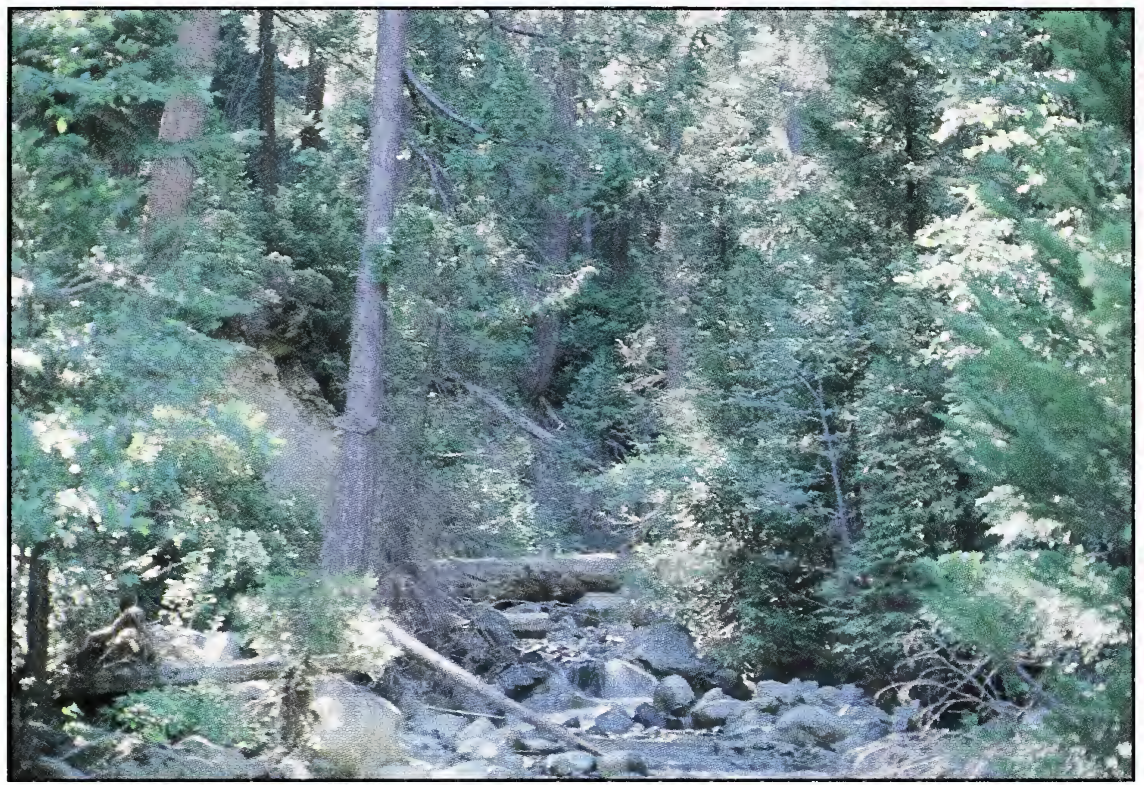

\section{SUMMARY TABLE}

\section{Tree Overstory Layer}

CHLA Port-Orford-cedar

PSME Douglas-fir

ABCO White Fir

CADE3 Incense Cedar

Tree Understory Layer

CHLA Port-Orford-cedar

PSME Douglas-fir

ABCO White Fir

CADE3 Incense Cedar

\section{Shrubs}

RHOC Western Azalea

LIDEE Dwarf Tanbark

QUVA Huckleberry Oak
$47 \quad 100$

19100

$5 \quad 75$

$8 \quad 69$

Slope: 1-35\%;

Slope Position: lower $1 / 3$, bottom, basin edge;

Surface Rock: 0-42\%

Distance to Ocean: 73.2-89.5 miles

SOILS:

Pit Depth: 37-40+ in.;

AWC: 1.3-9.1 in.;

Parent Material: Ultramafic, mixed; A Horizon:

Coarse Fragments: 10-85\%;

Textures: xksl, sl, vgl;

Thickness: 3-23 in.;

Surface PH: 6.3-7.5

$\begin{array}{llll}\text { GOOB } & \text { Rattlesnake Plantain } & 1 & 44 \\ \text { TRLA3 } & \text { Starflower } & 1 & 44 \\ \text { CAR1 } & \text { Sedge } & 1 & 44\end{array}$
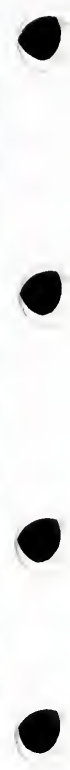


\section{DISTRIBUTION/SETTING:}

This type was one of the more extensive Port-Orford-cedar plant associations; it covered 195 acres and was found on inland sites on the Weaverville and Mt. Shasta Ranger Districts of the Shasta-Trinity National Forest. Mean distance to the Pacific Ocean was 82.2 miles, elevation was the second lowest of all inland sites, averaging 3566 feet. Landforms were flood plains and terraces with concave, undulating and linear horizontal micro-relief and linear/concave vertical micro-relief. Slopes were level to moderate (1$35 \%$ ) in mainly streamside micro-positions. Radiation index was a warm .480 as a result of east, south and west facing aspects but was moderated by topographic shading.

\section{VEGETATION SUMMARY:}

Total vegetation cover was dense (93\%) and was composed of primarily trees $(80 \%)$ and shrubs (23\%). The tree layer was dominated by Port-Orford-cedar (47\%), Douglasfir $(19 \%)$ and incense cedar $(8 \%)$. The shrub layer was dominated by western azalea (17\%), dwarf tanbark (4\%) and huckleberry oak (3\%). Total forb cover was low (6\%) and included rattlesnake plantain, starflower and braken fern. The grass layer was also of low cover (4\%) and dominated by sedge.

\section{SOIL SUMMARY:}

Soils in this type were mesic, deep and moderately well drained to somewhat poorly drained. They formed in alluvium from the fine textured ultramafic parent material peridotite. The litter layer thickness averaged $3.0 "$ at $77 \%$ cover. Surface rock and gravel averaged $14 \%$ cover. The average surface horizon thickness was $11 "$, texture varied from loams to extremely cobbly loam, coarse fragment content averaged $44 \%$ and $\mathrm{pH}$ averaged 7.3 .

Subsoil texture was predominately extremely cobbly loam, but also included clay loams and gravelly loams. Subsoil coarse fragment content averaged $41 \%$. Subsurface $\mathrm{pH}$ averaged 7.3. The soils were $65 \%$ skeletal.

\section{STAND STRUCTURE SUMMARY:}

Late seral stands in this type often had 4 or more layers of trees, while early mature and mid mature stands usually had 2 layers. Medium sized conifers dominated the top two layers with an average of 52 trees/acre $>21$ inches $\mathrm{dbh}, 18$ trees/acre $>30$ inches $\mathrm{dbh}$, and 3 trees/acre $>40$ inches dbh. Hardwoods were found in the lower layers and included 41 trees/acre $>5$ inches $\mathrm{dbh}$ and 5 trees/acre $>11$ inches $\mathrm{dbh}$.

The stand structure characteristics by layer were as follows. The top layer averaged 235 years old with an average diameter of 32.3 inches and average height of 118 feet. It was made up of dominant Douglas-fir, Port-Orford-cedar and incense cedar. The second layer had an average age of 185 years with a mean diameter of 24.4 inches and a mean height of 81 feet. It included codominant Port-Orford-cedar, Douglas-fir and occasional white fir. The third layer had an average age of 105 years with a mean diameter of 17.4 inches and a mean height of 62 feet. The third layer included intermediate sized PortOrford-cedar.

Overall biomass production (conifer + hardwoods + shrubs) was generally moderate. Modal Dunning site class was 4 with site index of 100 at 300 years. Conifer productivity was generally moderate with an average volume of $8055 \mathrm{ft}^{3}$, it ranged from 7340 to 9580 $\mathrm{ft}$. Softwood basal area averaged $359 \mathrm{ft}^{2}$ and ranged from 300 to $480 \mathrm{ft}^{2}$ Hardwood volume averaged $153 \mathrm{ft}^{3}$ and ranged from 0 to $1070 \mathrm{ft}^{3}{ }^{3}$ Hardwood basal area averaged $19 \mathrm{ft}^{2}{ }^{2}$ and ranged from 0 to $60 \mathrm{ft}^{2}{ }^{2}$ Stand density index was 587 and fell in the middle of the Port-Orford-cedar series. Quadratic mean diameter was 17.3 inches and fell in the middle of the Port-Orford-cedar series. 


\section{CLOSELY RELATED TYPES:}

The CHLA-MCN/RHOC-LIDEE type is replaced on lower elevation serpentine sites by the CHLA-PSME/CAOC5 type and on rocky, serpentine sites by the CHLA-MCN/ QUVA-RHOC type. 
Plant Association: Port-Orford-cedar-Mixed Conifer/Huckleberry OakWestern Azalea

EDP Code Name: CHLA-MCON/QUVA-RHOC

Indicator species:

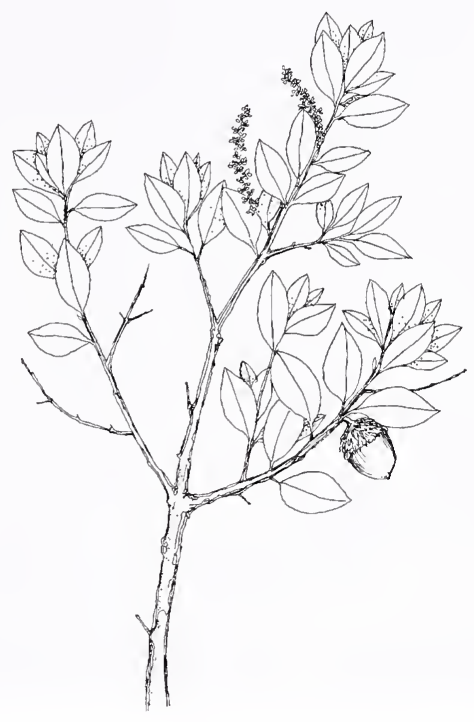

Huckleberry Oak (Quercus vaccinifolia-QUVA) was found on rocky, dry, high elevation sites on serpentine soils.

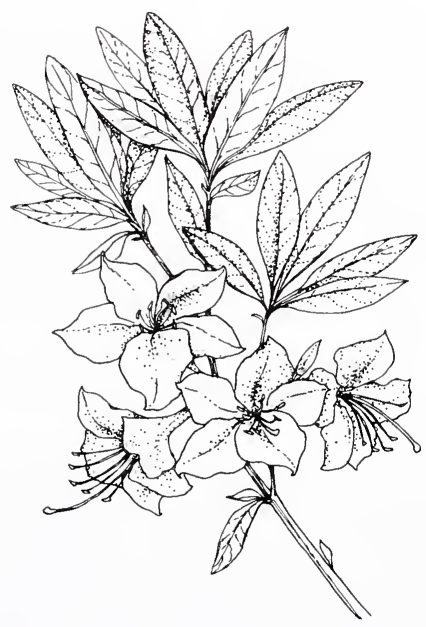

Indicator species:

Western azalea (Rhododendron occidentalis-RHOC) was found on cool, wet sites in lower $1 / 3$ slope positions. 
CHLA-MCN/QUVA-RHOC Association, Port-Orford-cedar-Mixed Conifer/Huckleberry OakWestern Azalea EcoCode: CCOCD005

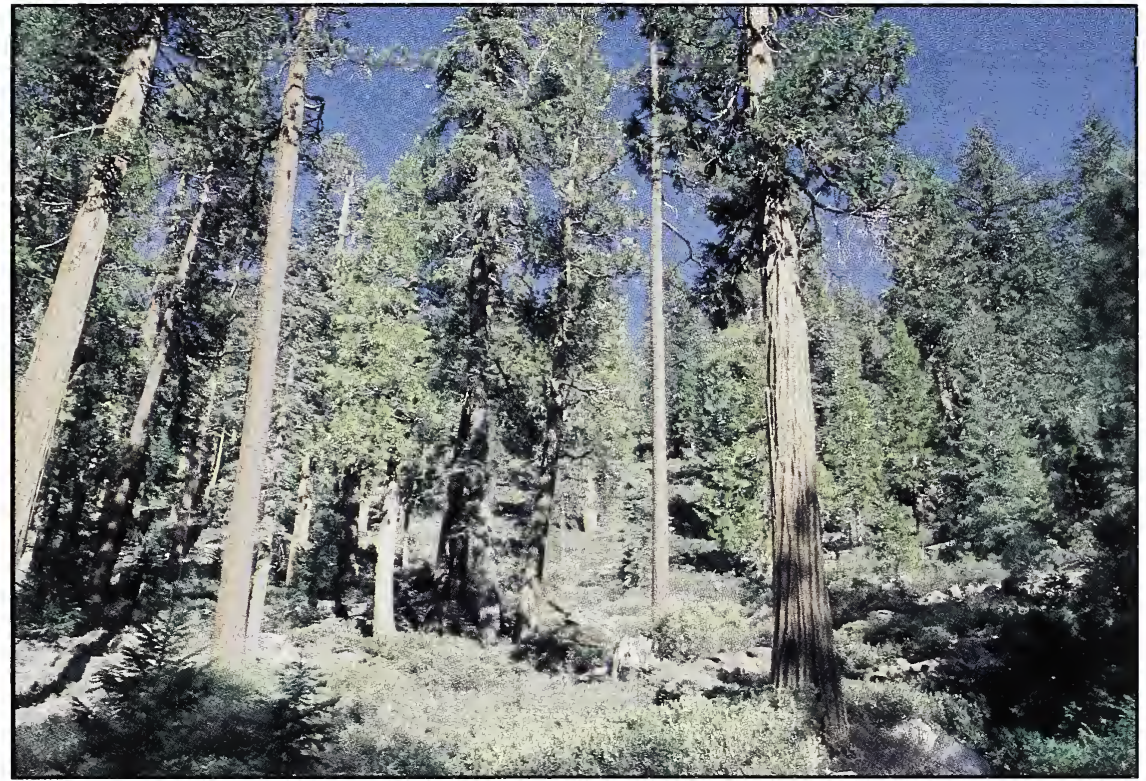

SUMMARY TABLE

(Sample size: 14)

COVER CON

Tree Overstory Layer

\begin{tabular}{|c|c|c|c|c|}
\hline CHLA & Port-Orford-cedar & 34 & 100 & ENVIRONMENT: \\
\hline PSME & Douglas-fir & 22 & 100 & Elevation: $2480-5180 \mathrm{ft}$; \\
\hline $\mathrm{ABCO}$ & White Fir & 7 & 64 & Aspect: S, SE.; \\
\hline PILA & Sugar Pine & 4 & 57 & Slope: $3-40 \%$ \\
\hline \multicolumn{4}{|c|}{ e Understory Layer } & $\begin{array}{l}\text { Slope Position: lower } 1 / 3 \text {, bottom, } \\
\text { draw; }\end{array}$ \\
\hline CHLA & Port-Orford-cedar & 3 & 100 & Surface Rock: 1-50\%; \\
\hline PSME & Douglas-fir & 1 & 100 & Distance to Ocean: $73.4-87.8$ miles \\
\hline $\mathrm{ABCO}$ & White Fir & 2 & 64 & \\
\hline PILA & Sugar Pine & 1 & 57 & \\
\hline
\end{tabular}

Shrubs

$\begin{array}{llrr}\text { RHOC } & \text { Western Azalea } & 17 & 93 \\ \text { QUVA } & \text { Huckleberry Oak } & 11 & 86 \\ \text { AME } & \text { Serviceberry } & 1 & 43 \\ \text { RHCA } & \text { Coffeeberry } & 2 & 57\end{array}$

Herbs \& Grasses

$\begin{array}{llll}\text { CAR1 } & \text { Sedge } & 8 & 64 \\ \text { CHME } & \text { Little Prince's Pine } & 1 & 36 \\ \text { GAL } & \text { Bedstraw } & 1 & 36 \\ \text { SCAL } & \text { White Rush lily } & 1 & 36\end{array}$

\section{SOILS}

Pit Depth: 20-40+ in.;

AWC: 0.2-5.3 in.;

Parent Material: ultramafic;

A Horizon:

Coarse Fragments: 10-95\%; Textures: vgsl, xgsl; Thickness: 2-14 in.;

Surface PH: 6. 5-7.5 


\section{DISTRIBUTION/SETTING:}

This type was the second most extensive Port-Orford-cedar type in the study area; it covered 249 acres and was found on inland sites on the Weaverville and Mt. Shasta Ranger Districts of the Shasta-Trinity National Forest. Mean distance to the Pacific Ocean was 81.9 miles; elevation was the third lowest of all inland sites, averaging 3992 feet. Landforms were flood plains and mountain slopes with concave and undulating horizontal micro-relief and linear/undulating vertical micro-relief. Slopes were level to moderate (3-40\%) in lower one-third slope micro-positions. Radiation index was the warmest of all inland sites at .522 due to south and southeast facing aspects.

\section{VEGETATION SUMMARY:}

Total vegetation cover was a moderate $(82 \%)$ and was composed of primarily trees $(65 \%)$ and shrubs (27\%). The tree layer was dominated by Port-Orford-cedar $(34 \%)$, Douglas-fir $(22 \%)$, incense cedar $(6 \%)$ and sugar pine $(4 \%)$. The shrub layer was dominated by western azalea (17\%), huckleberry oak (11\%), coffeeberry (2\%) and serviceberry (1\%). Total forb cover was low (4\%) and included little prince's pine, bedstraw, milkwort, white rush lily and braken fern. The grass layer was also of low cover $(6 \%)$ and dominated by sedge.

\section{SOIL SUMMARY:}

Soils in this type were mesic, moderately deep and well drained. They formed in alluvium from the fine textured ultramafic parent material peridotite. The litter layer thickness averaged $0.8 "$ at $62 \%$ cover. Surface rock and gravel averaged $30 \%$ cover. The average surface horizon thickness was 7", texture varied from clay loams to gravelly sandy clay and very gravelly sandy loam, coarse fragment content averaged $54 \%$ and $\mathrm{pH}$ averaged 6.7 .

Subsoil texture was predominately extremely stoney loam but also included clay loams and sandy clay loams. Subsoil coarse fragment content averaged 61\%. Subsurface $\mathrm{pH}$ averaged 6.8. The soils were $89 \%$ skeletal.

\section{STAND STRUCTURE SUMMARY:}

Late seral stands in this type often had 4 or more layers of trees, while early mature and mid mature stands usually had 2 layers. Medium sized conifers dominated the top two layers with an average of 40 trees/acre $>21$ inches $\mathrm{dbh}, 10$ trees/acre $>30$ inches $\mathrm{dbh}$, and 2 trees/acre $>40$ inches $\mathrm{dbh}$. Hardwoods were found infrequently in the lower layers.

The stand structure characteristics by layer were as follows. The top layer averaged 357 years old with an average diameter of 36.1 inches and average height of 125 feet. It was made up of dominant Port-Orford-cedar, Douglas-fir and sugar pine. The second layer had an average age of 323 years with a mean diameter of 30.2 inches and a mean height of 83 feet. It included codominant Port-Orford-cedar, Douglas-fir, incense cedar and white fir. The third layer had an average age of 218 years with a mean diameter of 17.7 inches and a mean height of 58 feet. The third layer included intermediate sized Port-Orford-cedar.

Overall biomass production (conifer + hardwoods + shrubs) was generally low. Modal Dunning site class was 4 with site index of 100 at 300 years. Conifer productivity was generally low with an average volume of $6169 \mathrm{ft}^{3}$, it ranged from 2860 to $11090 \mathrm{ft}$. Softwood basal area averaged $318 \mathrm{ft}^{2}$ and ranged from 160 to $480 \mathrm{ft}^{2}{ }^{2}$ Hardwood volume averaged $6 \mathrm{ft}^{3}$ and ranged from 0 to $9 \mathrm{ft}^{3}{ }^{3}$ Hardwood basal area averaged $1 \mathrm{ft} .{ }^{2}$ and ranged from 0 to $9 \mathrm{ft}^{2}{ }^{2}$ Stand density index was 482 and fell in the low end of the Port-Orfordcedar series. Quadratic mean diameter was 16.6 inches and fell in the middle of the Port-Orford-cedar series. 


\section{CLOSELY RELATED TYPES:}

The CHLA-MCN/QUVA-RHOC type is replaced on lower elevation serpentine sites by the CHLA-PSME/CAOC5 type and on streamside, serpentine sites by the CHLAMCN/RHOC-LIDEE type. 
Plant Association: Port-Orford-cedar-White Fir/Western AzaleaHuckleberry Oak

EDP Code Name: CHLA-ABCO/RHOC-QUVA

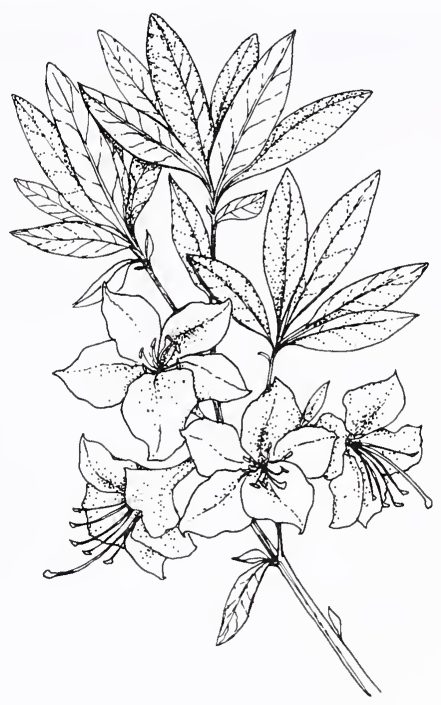

Indicator species.

Western azalea (Rhododendron occidentalis-RHOC) was found on cool, wet sites in lower $1 / 3$ slope positions.

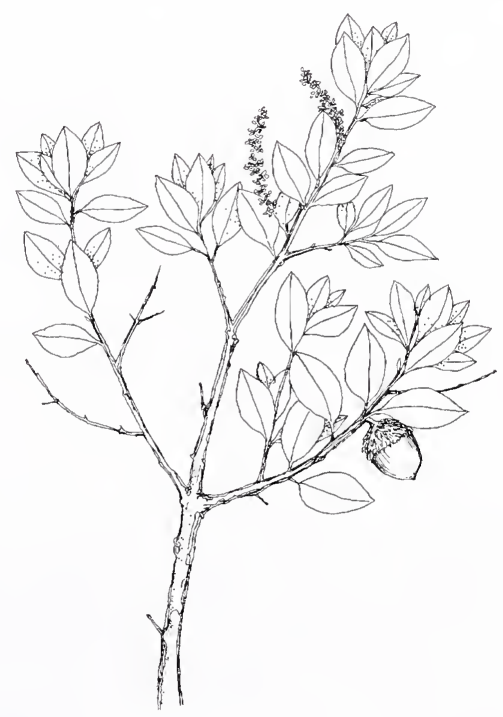

Indicator species:

Huckleberry Oak (Quercus vaccinifolia-QUVA) was found on rocky, dry, high elevation sites on serpentine soils. 


\section{CHLA-ABCO/RHOC-QUVA Association,}

\section{Port-Orford-cedar-White Fir/Western Azalea-Huckleberry Oak}

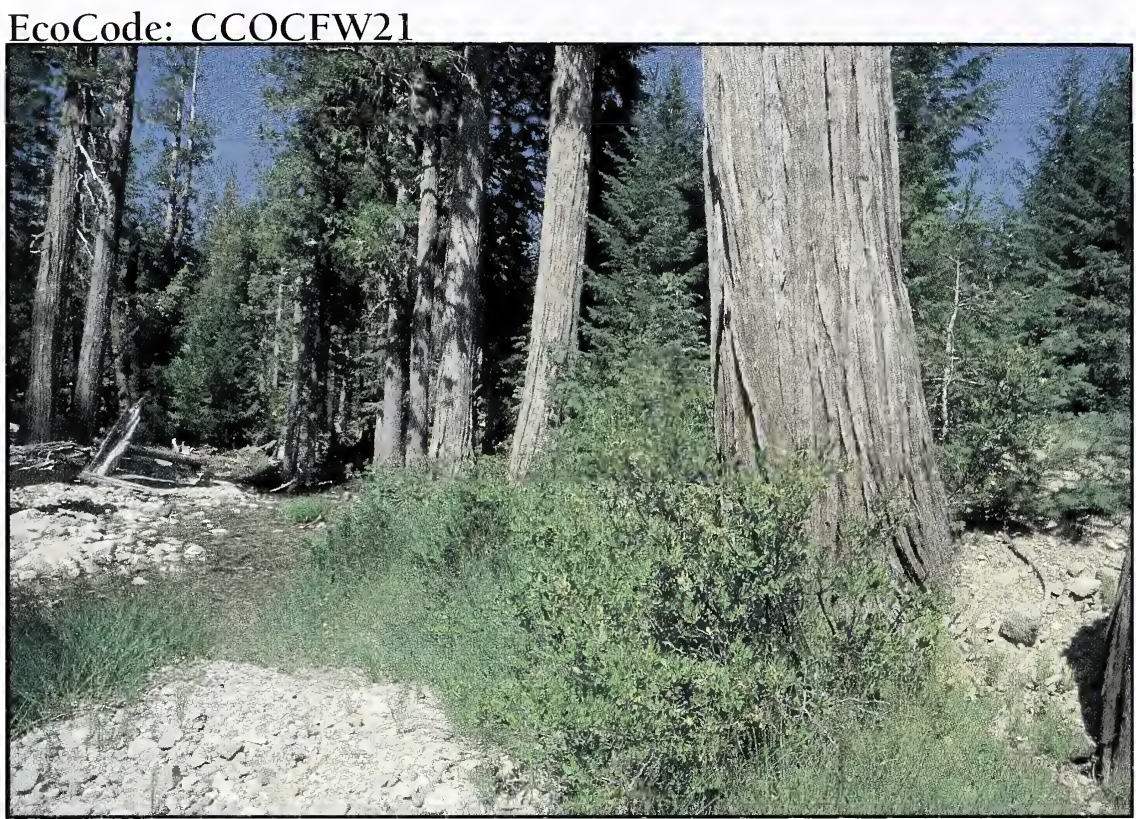

\section{SUMMARY TABLE}

(Sample size: 23)

COVER CON

Tree Overstory Layer

CHLA Port-Orford-cedar

ABCO White Fir

PSME Douglas-fir

PIMO3 Western White Pine

\section{Tree Understory Layer}

CHLA Port-Orford-cedar

ABCO White Fir

PSME Douglas-fir

PIMO3 Western White Pine
$48 \quad 100$

$10 \quad 100$

$8 \quad 74$

$7 \quad 78$

$4 \quad 100$

378

$1 \quad 30$

$1 \quad 65$

\section{Shrubs}

RHOC Western Azalea

QUVA Huckleberry Oak

AME Serviceberry

\section{Herbs \& Grasses}

CARl Sedge

CHUMO Western Prince's Pine

GOOB Rattlesnake plantain

XETE Beargrass

$\begin{array}{rr}18 & 100 \\ 3 & 70 \\ 1 & 70\end{array}$

SOILS:

Pit Depth: $8-40+$ in.;

AWC: 0.6-6.4 in.;

Parent Material: ultramafic, mafic, granite;

A Horizon:

Coarse Fragments: 10-90\%; Textures: vgl, xkl, xgl, xstl; Thickness: 1-14 in.;

Surface PH: 5.4-7.5

$\begin{array}{ll}2 & 70 \\ 1 & 52 \\ 1 & 35 \\ 7 & 43\end{array}$
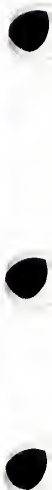

Elevation: 4810-5920 ft.;

Slope: $5-30 \%$;

Slope Position: intermittent stream, basin edge, bottom; Surface Rock: 1-70\%;

Distance to Ocean: 77.9-87.3 miles

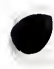




\section{DISTRIBUTION/SETTING:}

This type was one of the most extensive Port-Orford-cedar plant association in the study area and covered 485 acres. It was found on inland sites on the Weaverville and Mt. Shasta Ranger Districts of the Shasta-Trinity National Forest. Mean distance to the Pacific Ocean was 83.2 miles and elevation averaged 5340 feet. Landforms were mountain slopes and floodplains with concave, undulating, and linear horizontal micro-relief and undulating/linear vertical micro-relief. Slopes were gentle to moderate (5-30\%) in mainly streamside micro-positions. Radiation index was a cool .437 as a result of northeast, north and west facing aspects.

\section{VEGETATION SUMMARY:}

Total vegetation cover was a moderately dense (87\%) and was composed of primarily trees $(74 \%)$ and shrubs $(24 \%)$. The tree layer was dominated by Port-Orford-cedar (48\%), white fir (10\%), Douglas-fir (8\%) and western white pine (7\%). The shrub layer was dominated by western azalea (18\%) and huckleberry oak (3\%). Total forb cover was low $(9 \%)$ and included western prince's pine, white-veined wintergreen and beargrass. The grass layer was also of low cover (3\%) and dominated by sedge.

\section{SOIL SUMMARY:}

Soils in this type were frigid, shallow to deep and well drained. They formed in colluvium and alluvium from coarse textured mafic and granitic parent material. The litter layer thickness averaged $1.2 "$ at $62 \%$ cover. Surface rock and gravel averaged $25 \%$ cover. The average surface horizon thickness was 6", texture varied from very gravelly loam to extremely stoney loam, coarse fragment content averaged $58 \%$ and $\mathrm{pH}$ averaged 6.2 .

Subsoil texture was very gravelly loam to extremely stoney loam. Subsoil coarse fragment content averaged $52 \%$. Subsurface $\mathrm{pH}$ averaged 6.6 . The soils were $82 \%$ skeletal.

\section{STAND STRUCTURE SUMMARY:}

Late seral stands in this type often had 4 or more layers of trees, while early mature and mid mature stands usually had 2 layers. Medium sized conifers dominated the top two layers with an average of 64 trees/acre $>21$ inches $\mathrm{dbh}, 15$ trees/acre $>30$ inches $\mathrm{dbh}$, and 5 trees/acre $>40$ inches dbh. Hardwoods were absent in this type.

The stand structure characteristics by layer were as follows. The top layer averaged 422 years old with an average diameter of 47.5 inches and average height of 126 feet. It was made up of predominant Douglas-fir and dominant Port-Orford-cedar. The second layer had an average age of 286 years with a mean diameter of 31.5 inches and a mean height of 82 feet. It included codominant Port-Orford-cedar, Douglas-fir, incense cedar and white fir. The third layer had an average age of 217 years with a mean diameter of 15.5 inches and a mean height of 57 feet. The third layer included intermediate sized Port-Orford-cedar and white fir.

Overall biomass production (conifer + hardwoods + shrubs) was generally moderate. Modal Dunning site class was 4 with site index of 100 at 300 years. Conifer productivity was generally moderate with an average volume of $8353 \mathrm{ft}^{3}$, it ranged from 4290 to $11850 \mathrm{ft}$. Softwood basal area averaged $445 \mathrm{ft}^{2}$ and ranged from 170 to $773 \mathrm{ft}^{2}$ No hardwoods were present on these plots. Stand density index was 697 and fell in the high end of the Port-Orford-cedar series. Quadratic mean diameter was 15.5 inches and fell in the middle of the Port-Orford-cedar series. 


\section{CLOSELY RELATED TYPES:}

The CHLA-ABCO/RHOC-QUVA type is replaced on rocky moist sites by the CHLAABCO/CASE3-RHOC type and on moist mountain sideslopes by the CHLA-ABCO/LEDACASE3 type. 
Plant Association: Port-Orford-cedar-White Fir/Sierra LaurelBush Chinquapin

EDP Code Name: CHLA-ABCO/LEDA-CASE3

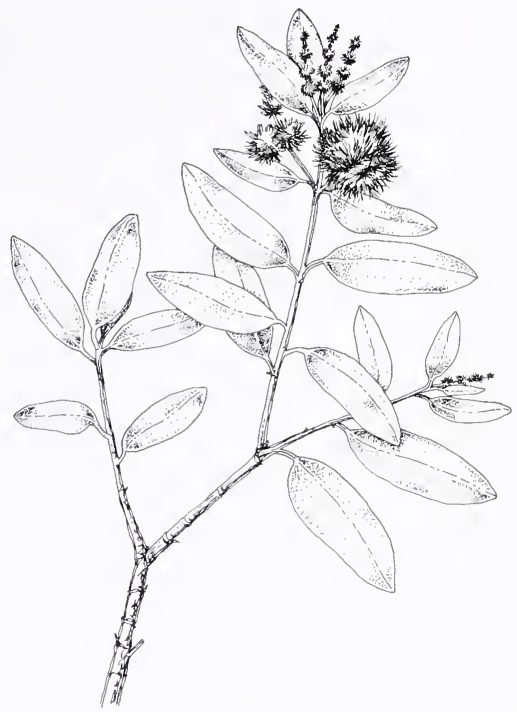

Indicator species:

Bush chinquapin (Castanopsis sempervirens-CASE3) was found on rocky, dry, high elevation sites on soils derived from granite parent rock.

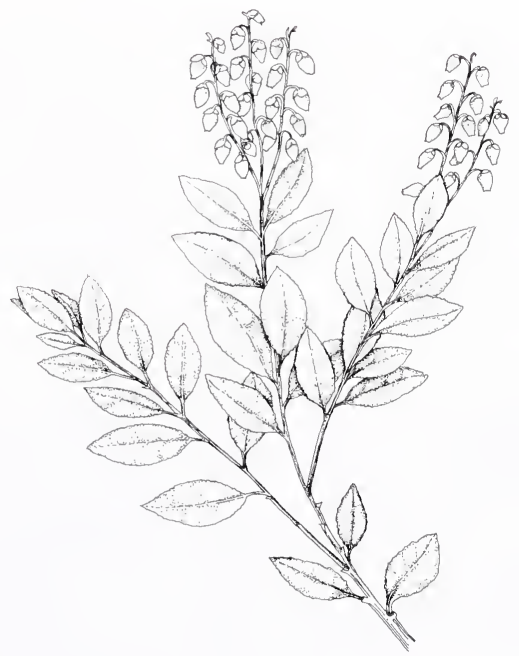

Indicator species:

Sierra laurel (Leucothoe davisiae-LEDA) was found on cool, moist, high elevation mountain slopes. 
CHLA-ABCO/LEDA-CASE3 Association, Port-Orford-cedar-White Fir/ Sierra Laurel-Bush Chinquapin

EcoCode: CCOCFW22

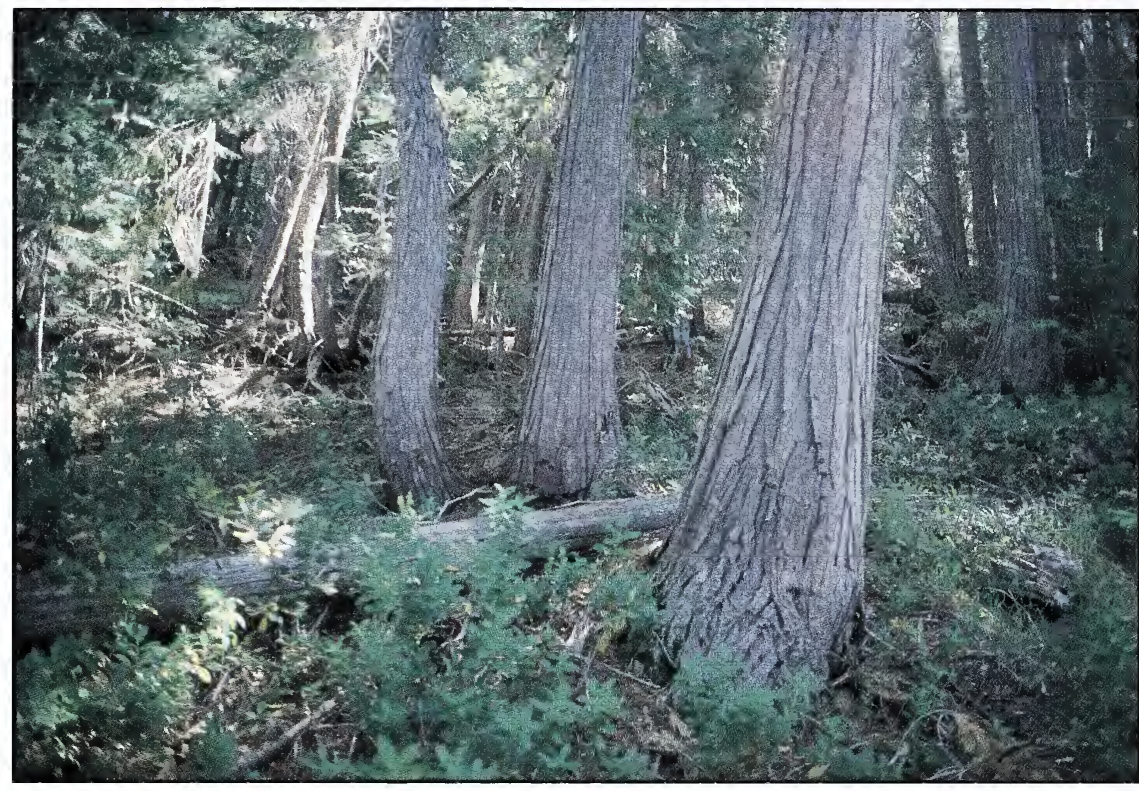

\section{SUMMARY TABLE}

(Sample size: 8)

COVER CON

Tree Overstory Layer

$\begin{array}{lllll}\text { CHLA } & \text { Port-Orford-cedar } & 46 & 100 & \text { ENVIRONMENT: } \\ \text { ABCO } & \text { White Fir } & 16 & 100 & \text { Elevation: 4980-56 }\end{array}$

PIMO3 Western White Pine 963

Tree Understory Layer

$\begin{array}{llrr}\text { CHLA } & \text { Port-Orford-cedar } & 4 & 100 \\ \text { ABCO } & \text { White Fir } & 2 & 88 \\ \text { PIMO3 } & \text { Western White Pine } & 1 & 38\end{array}$

Elevation: 4980-5660 ft.;

Aspect: N.W;

Slope: $18-45 \%$;

Slope Position: lower 1/3, middle 1/3:

Surface Rock: 1-20\%;

Distance to Ocean: 83.9-87.6 miles

\section{Shrubs}

$\begin{array}{llrr}\text { LEDA } & \text { Sierra Laurel } & 30 & 100 \\ \text { CASE3 } & \text { Bush Chinquapin } & 6 & 88 \\ \text { RHOC } & \text { Western Azalea } & 6 & 63\end{array}$

\section{Herbs \& Grasses}

$\begin{array}{llll}\text { PTAQL } & \text { Bracken Fern } & 2 & 75 \\ \text { PYPI } & \text { White-veined Wintergreen } & 1 & 63 \\ \text { LIBOL } & \text { Twinflower } & 7 & 63\end{array}$

SOILS

Pit Depth: 30-35 in.;

AWC: 1.2-2.0 in.;

Parent Material: granite;

A Horizon:

Coarse Fragments: 20-53\%;

Textures: gl, vgsl;

Thickness: 3 in.;

Surface PH: 5.5-5.6 


\section{DISTRIBUTION/SETTING:}

This type was a minor component in the study area; it covered 72 acres and was found on inland sites on the Mt. Shasta Ranger District of the Shasta-Trinity National Forest. Mean distance to the Pacific Ocean was 85.3 miles and elevation averaged 5315 feet. Landforms were mountain slopes with linear, undulating and concave horizontal micro-relief and linear/undulating vertical micro-relief. Slopes were moderate to steep (18-45\%) in lower and middle one-third micro-positions. Radiation index was a cool .405 as a result of northwest facing aspects.

\section{VEGETATION SUMMARY:}

Total vegetation cover was dense (92\%) and was composed of trees (71\%) and shrubs (42\%). The tree layer was dominated by Port-Orford-cedar (46\%), white fir $(16 \%)$ and western white pine $(9 \%)$. The shrub layer was dominated by Sierra laurel (30\%), bush chinquapin (6\%) and western azalea (6\%). Total forb cover was low $(9 \%)$ and included western prince's pine, little prince's pine, rattlesnake plantain, twinflower, white-veined wintergreen and braken fern. The grass layer was also of low cover (3\%) and dominated by sedge.

\section{SOIL SUMMARY:}

Soils in this type were frigid, moderately deep and well drained. They formed in colluvium from coarse textured granite parent material. The litter layer thickness averaged $1.4^{\prime \prime}$ at $83 \%$ cover. Surface rock and gravel averaged $12 \%$ cover. The average surface horizon thickness was 3", texture varied from gravelly loam to very gravelly loam, coarse fragment content averaged 33\%, and pH averaged 5.5 .

Subsoil texture was very gravelly loam and extremely cobbly loam. Subsoil coarse fragment content averaged $45 \%$. Subsurface pH averaged 5.4. The soils were $100 \%$ skeletal.

\section{STAND STRUCTURE SUMMARY:}

Late seral stands in this type often had 4 or more layers of trees, while early mature and mid mature stands usually had 2 layers. Medium sized conifers dominated the top two layers with an average of 60 trees/acre $>21$ inches $\mathrm{dbh}, 10$ trees/acre $>30$ inches $\mathrm{dbh}$, and 1 trees/acre $>40$ inches $\mathrm{dbh}$. Hardwoods were absent in this type.

The stand structure characteristics by layer were as follows. The top layer averaged 135 years old with an average diameter of 34.0 inches and average height of 136 feet. It was made up of dominant Port-Orford-cedar and sugar pine. The second layer had an average age of 448 years with a mean diameter of 40.0 inches and a mean height of 97 feet. It included codominant Port-Orford-cedar and white fir. The third layer had an average age of 118 years with a mean diameter of 14.3 inches and a mean height of 54 feet. The third layer included intermediate sized Port-Orford-cedars.

Overall biomass production (conifer + hardwoods + shrubs) was generally high. Modal Dunning site class was 2 with site index of 150 at 300 years. Conifer productivity was generally high with an average volume of 10,017 ft. ${ }^{3}$, it ranged from 8640 to 10,830 ft. Softwood basal area averaged $422 \mathrm{ft}^{2}{ }^{2}$ and ranged from 360 to $507 \mathrm{ft}^{2}{ }^{2}$ No hardwoods were found in this type. Stand density index was 639 and fell in the middle of the PortOrford-cedar series. Quadratic mean diameter was 17.7 inches and fell in the middle of the Port-Orford-cedar series. 


\section{CLOSELY RELATED TYPES:}

The CHLA-ABCO/LEDA-CASE3 type is replaced on rocky floodplains by the CHLAABCO/RHOC-QUVA type and on moist rocky sideslopes by the CHLA-ABCO/CASE3RHOC type.
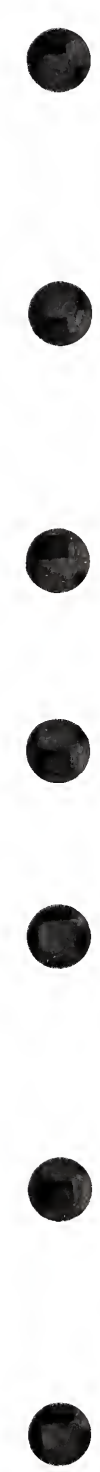
Plant Association: Port-Orford-cedar-White Fir/Bush ChinquapinWestern Azalea

EDP Code Name: CHLA-ABCO/CASE3-RHOC

Indicator species:

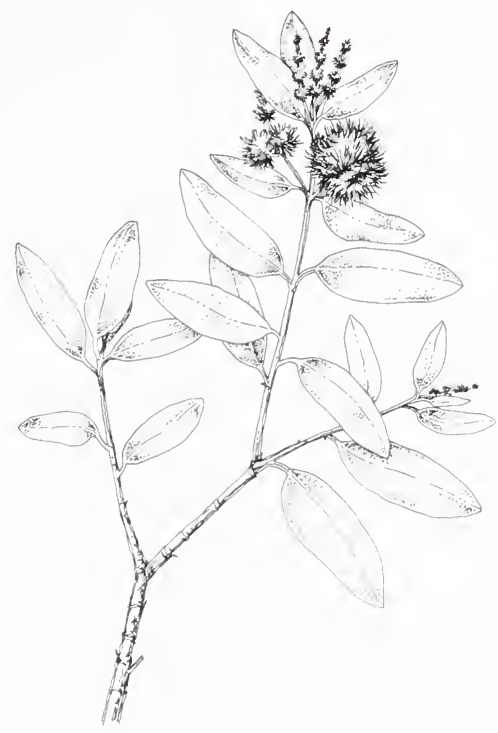

- Bush chinquapin (Castanopsis sempervirens-CASE3) was found on rocky, dry, high elevation sites on soils derived from granite parent rock.

Indicator species:

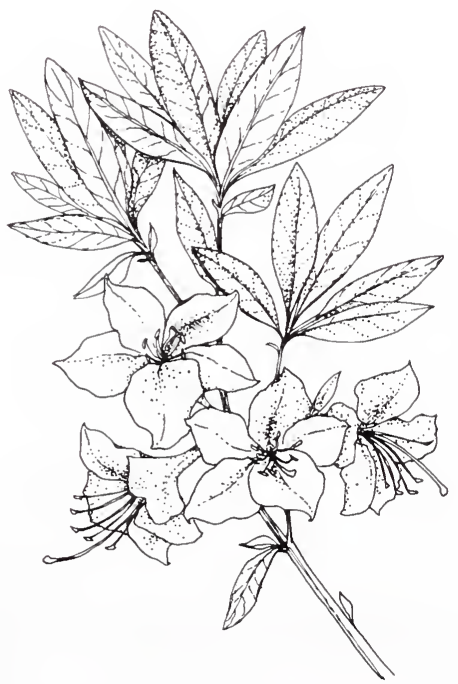

Western azalea (Rhododendron occidentalis-RHOC) was found on cool, wet sites in lower $1 / 3$ slope positions. 


\section{CHLA-ABCO/CASE3-RHOC Association,}

\section{Port-Orford-cedar-White Fir/Bush Chinquapin-Western Azalea}

EcoCode: CCOCFW23
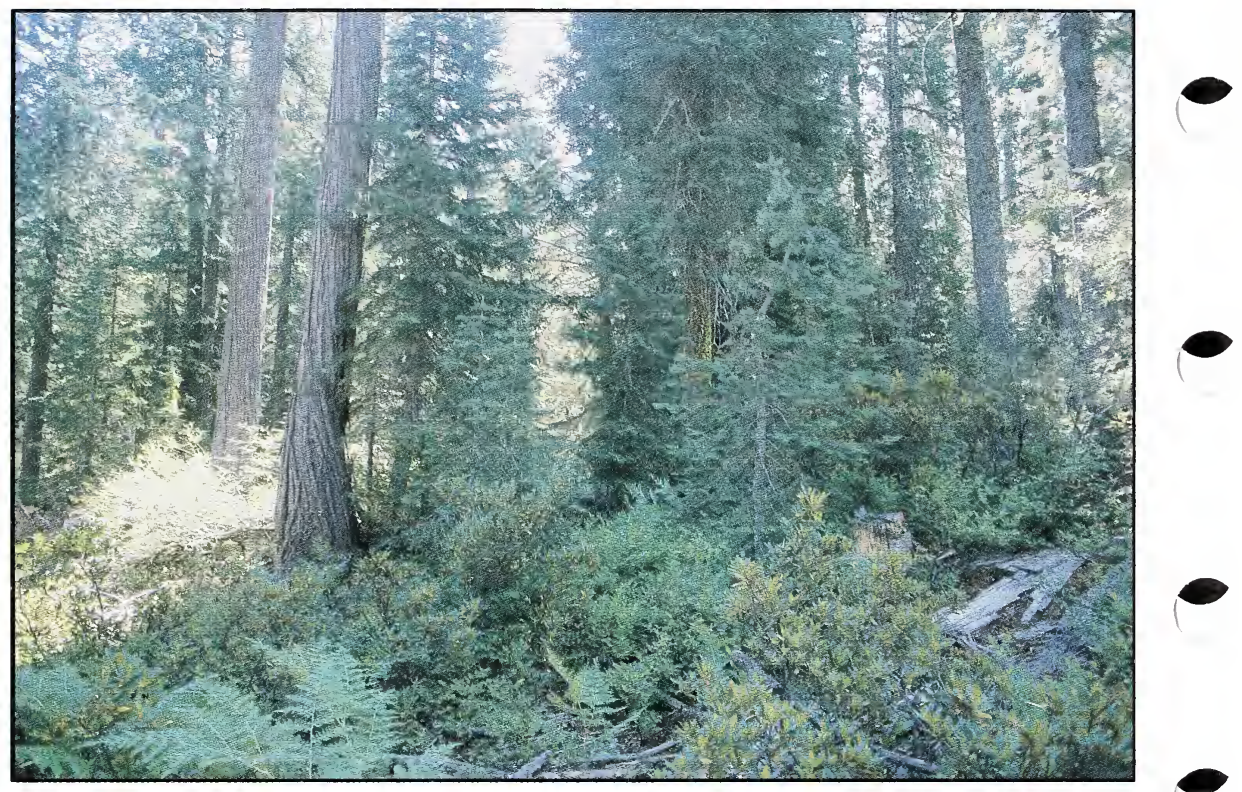

\section{SUMMARY TABLE}

\section{Tree Overstory Layer}

$\begin{array}{llrr}\text { CHLA } & \text { Port-Orford-cedar } & 45 & 100 \\ \text { ABCO } & \text { White Fir } & 17 & 100 \\ \text { PSME } & \text { Douglas-fir } & 16 & 90 \\ \text { PIMO3 } & \text { Western White Pine } & 8 & 60\end{array}$

Tree Understory Layer

$\begin{array}{llrr}\text { CHLA } & \text { Port-Orford-cedar } & 4 & 100 \\ \text { ABCO } & \text { White Fir } & 2 & 100 \\ \text { PSME } & \text { Douglas-fir } & 1 & 40 \\ \text { PIMO3 } & \text { Western White Pine } & 1 & 20\end{array}$

\section{ENVIRONMENT:}

Elevation: 4950-5750 ft.;

Aspect: N.E.,W;

Slope: $30-65 \%$;

Slope Position: lower 1/3, basin edge, wetland;

Surface Rock: 1-50\%;

Distance to Ocean: 82.2-87.7 miles.

\section{Shrubs}

$\begin{array}{llrr}\text { CASE3 } & \text { Bush Chinquapin } & 7 & 100 \\ \text { RHOC } & \text { Western Azalea } & 7 & 80 \\ & & & \\ \text { bs \& Grasses } & & \\ \text { PYPI } & \text { White-veined Wintergreen } & 1 & 80 \\ \text { CHUMO } & \text { Western Prince's Pine } & 2 & 80 \\ \text { PTAQL } & \text { Bracken Fern } & 3 & 70 \\ \text { GOOB } & \text { Rattlesnake Plantain } & 1 & 50\end{array}$

SOILS:

Pit Depth: 20-40+ in.;

AWC: 0.6-1.1 in.;

Parent Material: granite

A Horizon:

Coarse Fragments: 15-65\%;

Textures: gsl,xcsl;

Thickness: 4-12 in.

Surface PH: 5.4-6.2 


\section{DISTRIBUTION/SETTING:}

This type was a minor component; it covered only 67 acres and was found on inland sites on the Mt. Shasta Ranger District of the Shasta-Trinity National Forest. Mean distance to the Pacific Ocean was 85.0 miles and elevation averaged 5426 feet. Landforms were mountain slopes with undulating, concave, and linear horizontal micro-relief and linear vertical micro-relief. Slopes were moderate to steep (30-65\%) in mainly lower one-third micro-positions. Radiation index was a cool .406 as a result of northeast and west facing aspects.

\section{VEGETATION SUMMARY:}

Total vegetation cover was dense (94\%) and was composed of primarily trees (81\%), shrubs (19\%) and forbs (12\%). The tree layer was dominated by Port-Orford-cedar (45\%), white fir (17\%) and Douglas-fir (16\%). The shrub layer was dominated by bush chinquapin (7\%), western azalea (7\%) and huckleberry oak (3\%). The forb layer included western prince's pine, rattlesnake plantain, white-veined wintergreen and braken fern. The grass layer was also of low cover (3\%) and dominated by sedge.

\section{SOIL SUMMARY:}

Soils in this type were frigid, moderately deep to deep and well drained. They formed in alluvium from coarse textured granite parent material. The litter layer thickness averaged 0.8 " at $86 \%$ cover. Surface rock and gravel averaged $16 \%$ cover. The average surface horizon thickness was $8 "$ ", texture varied from gravelly loamy sand to extremely cobbly loamy sand, coarse fragment content averaged $40 \%$ and $\mathrm{pH}$ averaged 5.8 .

Subsoil texture was very gravelly sand and very cobbly loamy sand. Subsoil coarse fragment content averaged 54\%. Subsurface pH averaged 5.7. The soils were 100\% skeletal.

\section{STAND STRUCTURE SUMMARY:}

Late seral stands in this type often had 3 or more layers of trees, while early mature and mid mature stands usually had 2 layers. Medium sized conifers dominated the top two layers with an average of 43 trees/acre $>21$ inches $\mathrm{dbh}, 16$ trees/acre $>30$ inches $\mathrm{dbh}$, and 2 trees/acre $>40$ inches dbh. Hardwoods were absent in this type.

The stand structure characteristics by layer were as follows. The top layer averaged 268 years old with an average diameter of 30.3 inches and average height of 107 feet. It was made up of dominant Port-Orford-cedar and white fir. The second layer had an average age of 228 years with a mean diameter of 22.2 inches and a mean height of 76 feet. It included codominant Port-Orford-cedar and white fir.

Overall biomass production (conifer + hardwoods + shrubs) was generally moderate. Modal Dunning site class was 3 with site index of 125 at 300 years. Conifer productivity was generally low with an average volume of $7045 \mathrm{ft}^{3}$, it ranged from 6760 to $7330 \mathrm{ft}$. Softwood basal area averaged $300 \mathrm{ft}^{2}$ and ranged from 280 to $320 \mathrm{ft}^{2}$ No hardwoods were identified on these plots. Stand density index was 432 and fell in the low end of the Port-Orford-cedar series. Quadratic mean diameter was 19.0 inches and fell in the high end of the Port-Orford-cedar series.

\section{CLOSELY RELATED TYPES:}

The CHLA-ABCO/CASE3-RHOC type is replaced on rocky floodplains by the CHLAABCO/RHOC-QUVA type and on moist mountain sideslopes by the CHLA-ABCO/LEDACASE3 type. 
-

-

-

-

-

-

- 
Plant Association: Port-Orford-cedar-Western White Pine/ Labrador-tea/California Pitcher Plant

EDP Code Name: CHLA-PIMO3/LEGL1/DACA2

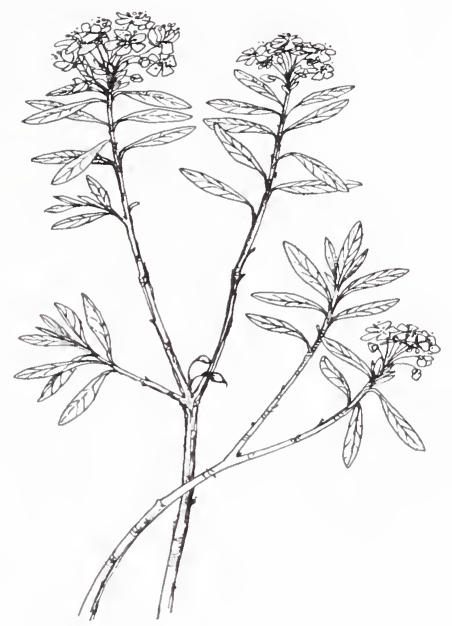

Indicator species:

Labrador-tea (Ledum glandulosum-LEGL1) was found on boggy, wet, mainly high elevation sites on soils derived from ultramafic or granite parent material.

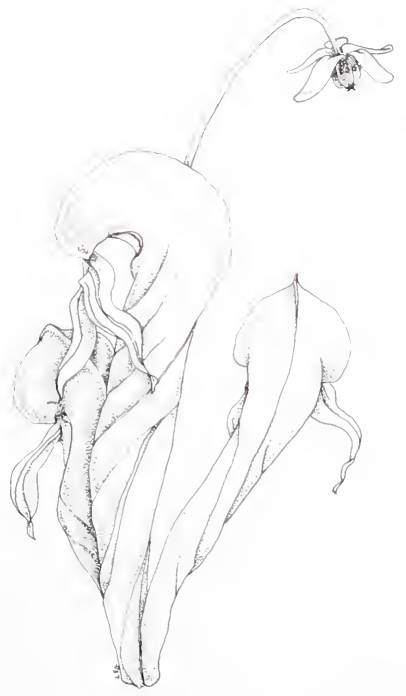

Indicator species:

California pitcher plant (Darlingtonia californica-DACA2) was found on boggy, wet sites on soils derived from ultramafic or granite parent material. 


\section{CHLA-PIMO3/LEGL1/DACA2 Association,}

Port-Orford-cedar-Western White Pine/Labrador Tea/ California Pitcher Plant EcoCode: CCOCPW03

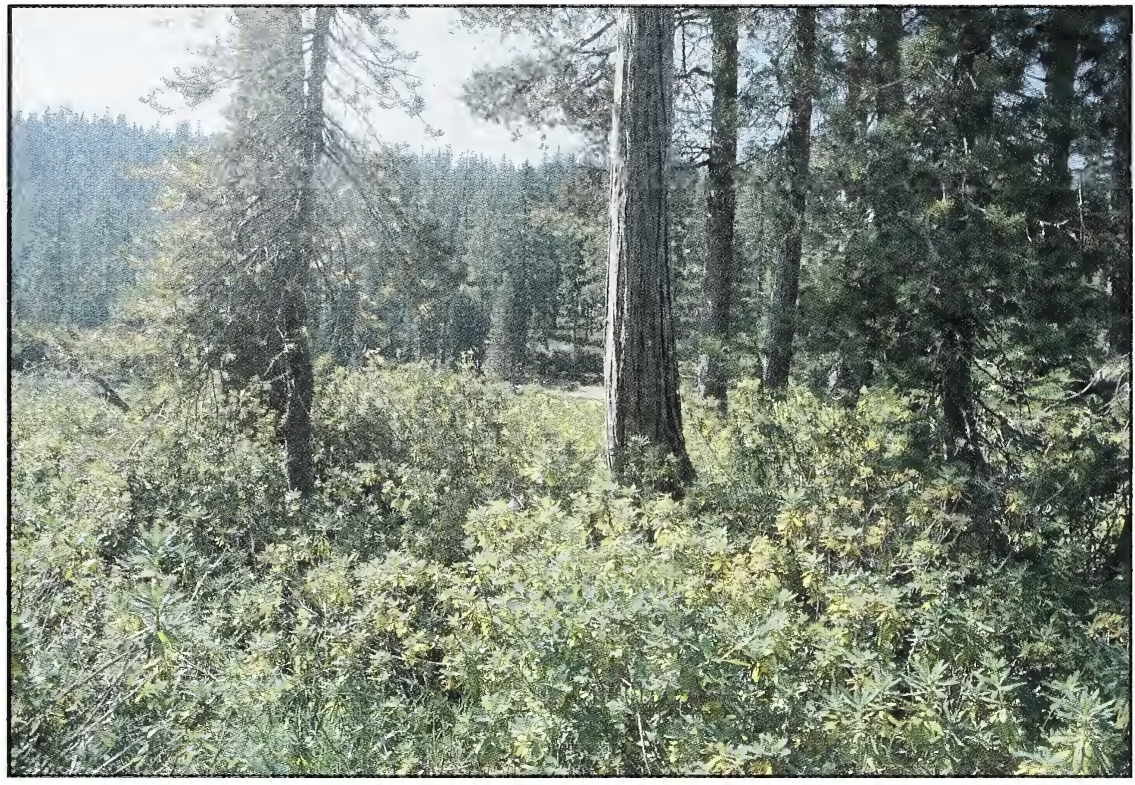

\section{SUMMARY TABLE}

(Sample size: 15)

COVER CON

Tree Overstory Layer

$\begin{array}{llrr}\text { CHLA } & \text { Port-Orford-cedar } & 53 & 100 \\ \text { PIMO3 } & \text { Western White Pine } & 10 & 93 \\ \text { ABCO } & \text { White Fir } & 8 & 87 \\ \text { ABMAS } & \text { Shasta Red Fir } & 5 & 80 \\ & & & \\ \text { Understory Layer } & & \\ \text { CHLA } & \text { Port-Orford-cedar } & 10 & 100 \\ \text { PIMO3 } & \text { Western White Pine } & 1 & 80 \\ \text { ABCO } & \text { White Fir } & 3 & 93 \\ \text { ABMAS } & \text { Shasta Red Fir } & 1 & 47\end{array}$

Shrubs

LEGL1 Western Labrador Tea $28 \quad 100$

$\begin{array}{lll}\text { RHOC Western Azalea } & 8 & 60\end{array}$

\section{Herbs \& Grasses}

DACA2 California Pitcher Plant $4 \quad 67$

$\begin{array}{lll}\text { LIL Lily } & 1 & 60\end{array}$

VECA California False Hellebore 160

$\begin{array}{llll}\text { GOOB } & \text { Rattlesnake Plantain } & 1 & 47\end{array}$
ENVIRONMENT:

Elevation: 4300-5950 ft.;

Aspect: N.W., E.;

Slope: $1-25 \%$;

Slope Position: bottom,

basin edge;

Surface Rock: 0-30\%

Distance to Ocean: 81.4-87.2 miles

SOILS:

Pit Depth: 15-40+ in.;

AWC: 0.9-8.8 in.;

Parent Material: granite, mafic,

ultramafic, quartzite;

A Horizon:

Coarse Fragments: 0-55\%;

Textures: 1, gls;

Thickness: 4-25 in.;

Surface PH: 5.4-6.6 


\section{DISTRIBUTION/SETTING:}

This type was small in extent, 100 acres, but high in species diversity. It was found on inland sites on the Mt. Shasta Ranger District of the Shasta-Trinity National Forest. Mean distance to the Pacific Ocean was 78.8 miles and elevation averaged 5581 feet. Landforms were mountain basins with linear, concave, and undulating horizontal microrelief and linear/undulating vertical micro-relief. Slopes were level to moderate (1-25\%) on mainly slope bottom micro-positions. Radiation index was a cool .442 as a result of northwest and east facing aspects.

\section{VEGETATION SUMMARY:}

Total vegetation cover was dense (97\%) and was composed of primarily trees (73\%) and shrubs (42\%). The tree layer was dominated by Port-Orford-cedar (53\%), western white pine (10\%), white fir ( $8 \%$ ) and red fir $(5 \%)$. The shrub layer was dominated by western labrador-tea (28\%) and western azalea (8\%). Total forb cover was low (9\%) and included California pitcher plant, common lady fern, rattlesnake plantain, bog orchid, twinflower, lily, California false hellebore and braken fern. The grass layer was also of low cover $(11 \%)$ and dominated by sedge.

\section{SOIL SUMMARY:}

Soils in this type were frigid, moderately deep to deep and very poorly drained. They formed in glacial till and alluvium from coarse textured granite parent material and fine textured ultramafic parent material. The litter layer thickness averaged $2.5 \mathrm{n}$ at $61 \%$ cover. Surface rock and gravel averaged $6 \%$ cover. The average surface horizon thickness was 12 ", texture varied from loam to peaty muck, coarse fragment content averaged $28 \%$ and $\mathrm{pH}$ averaged 5.9 .

Subsoil texture was silty loam to peaty muck. Subsoil coarse fragment content averaged $40 \%$. Subsurface $\mathrm{pH}$ averaged 5.9. The soils were $44 \%$ skeletal.

\section{STAND STRUCTURE SUMMARY:}

Late seral stands in this type often had 4 or more layers of trees, while early mature and mid mature stands usually had 2 layers. Large sized conifers dominated the top two layers with an average of 72 trees/acre $>21$ inches $\mathrm{dbh}, 23$ trees/acre $>30$ inches $\mathrm{dbh}$, and 4 trees/acre $>40$ inches $\mathrm{dbh}$. Hardwoods were absent in this type.

The stand structure characteristics by layer were as follows. The top layer averaged 299 years old with an average diameter of 35.3 inches and average height of 117 feet. It was made up of dominant Port-Orford-cedar, white fir, red fir, Douglas-fir and western white pine. The second layer had an average age of 294 years with a mean diameter of 23.0 inches and a mean height of 83 feet. It included codominant Port-Orford-cedar, lodgepole pine, western white pine and white fir. The third layer had an average age of 207 years with a mean diameter of 15.5 inches and a mean height of 58 feet. The third layer included intermediate sized Port-Orford-cedar and white fir.

Overall biomass production (conifer + hardwoods + shrubs) was generally high. Modal Dunning site class was 4 with site index of 100 at 300 years. Conifer productivity was generally high with an average volume of $9971 \mathrm{ft}^{3}{ }^{3}$, it ranged from 5210 to $14,250 \mathrm{ft}$. Softwood basal area averaged $505 \mathrm{ft}^{2}$ and ranged from 320 to $667 \mathrm{ft}^{2}$ No hardwoods were found on this type. Stand density index was 772 and fell in the high end of the Port-Orford-cedar series. Quadratic mean diameter was 16.1 inches and fell in the middle of the Port-Orford-cedar series. 


\section{CLOSELY RELATED TYPES:}

The CHLA-PIMO3/LEGL1/DACA2 type is replaced on rocky streamsides by the CHLA-PIMO3/ALSI2 type, on moist mountain sideslopes by the CHLA-PIMO3/VAME type, in wet glacial basins by the CHLA-PIMO3//Wet Herb Complex and on glacial moraines by the CHLA-PIMO3//Dry Herb complex. 
Plant Association: Port-Orford-cedar-Western White Pine/Sitka Alder EDP Code Name: CHLA-PIMO3/ALSI2

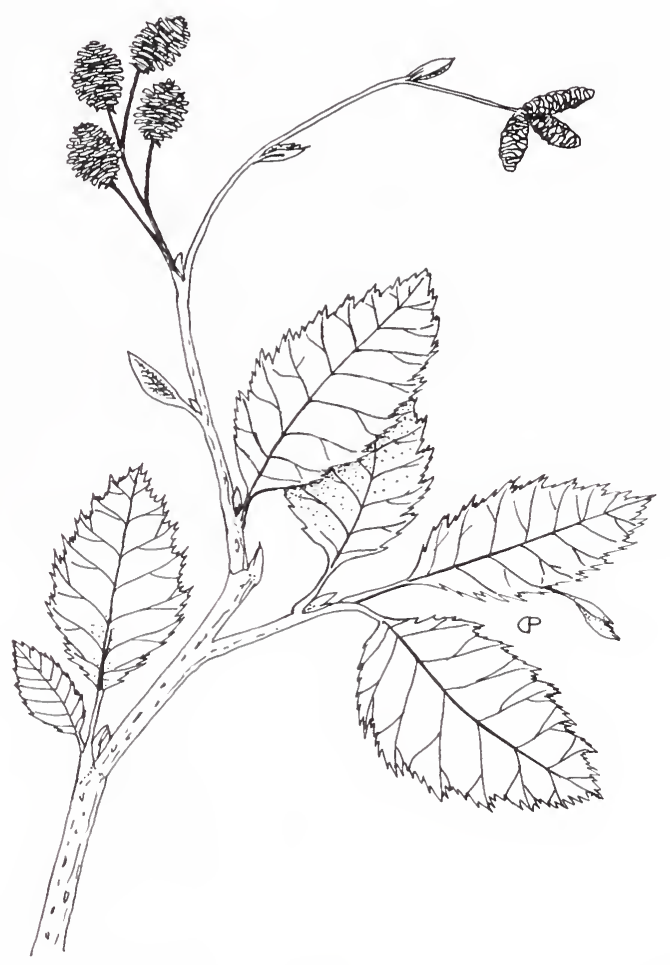

Indicator species:

Sitka alder (Alnus sinuata-ALSI2) was found on, wet, streamsides, mainly on high elevation sites on soils derived from granite parent material. 
CHLA-PIMO3/ALSI2 Association, Port-Orford-cedar-Western White Pine/Sitka Alder, EcoCode: CCOCPW04

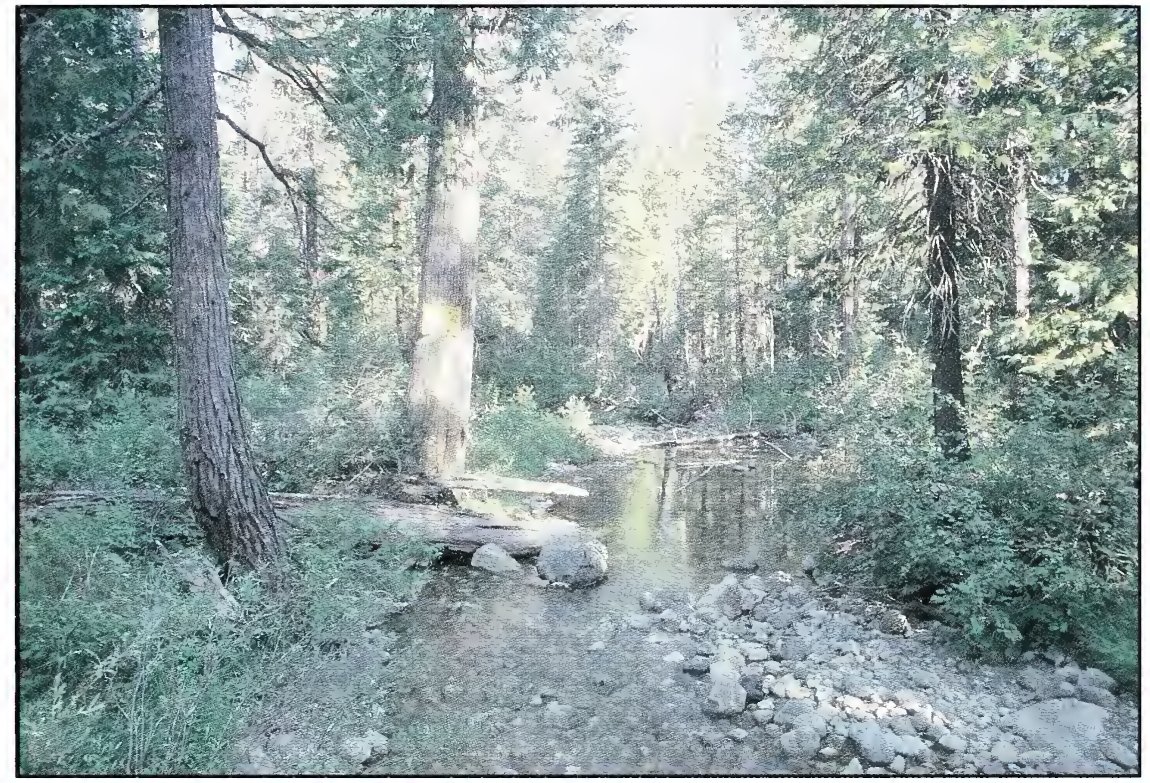

SUMMARY TABLE

(Sample size: 6)

COVER CON

Tree Overstory Layer

CHLA Port-Orford-cedar

ABCO White Fir

PIMO3 Western White Pine

$45 \quad 100$

ENVIRONMENT:

PSME Douglas-fir

$9 \quad 100$

Elevation: 4640-5700 ft.;

$8100 \quad$ Aspect: N.W., N.E.;

$6 \quad 83$ Slope: $5-35 \%$;

Slope Position: basin edge, bottom draw;

Tree Understory Layer

CHLA Port-Orford-cedar

100

ABCO White Fir

50

$\begin{array}{lll}\text { PIMO3 Western White Pine } & 2 & 17\end{array}$

PSME Douglas-fir

$\begin{array}{ll}1 & 17\end{array}$

Shrubs

$\begin{array}{llrrl}\text { ALSI2 } & \text { Sitka Alder } & 31 & 100 & \text { SOILS: } \\ \text { RHOC } & \text { Western Azalea } & 4 & 50 & \text { Pit Depth: 12-35 in.; } \\ & & & & \text { AWC: } 0.3-1.2 \text { in.; }\end{array}$

Herbs \& Grasses

PTAQL Bracken Fern $\quad 2 \quad 83$

Parent Material: mixed, ultramafic;

$\begin{array}{lll}\text { LIL Lily } & 1 & 83\end{array}$

$\begin{array}{lll}\mathrm{HAB} & \text { Bog Orchid } & 2\end{array}$

A Horizon:

Coarse Fragments: 2-80\%; Textures: xkl;

Thickness:1-20 in.;

Surface PH:6.3-6.5 


\section{DISTRIBUTION/SETTING:}

This type was of minor extent; it covered only 84 acres and was found on inland sites on the Mt. Shasta Ranger District of the Shasta-Trinity National Forest. Mean distance to the Pacific Ocean was 85.9 miles and elevation averaged 5067 feet. Landforms were mountain basins and streamsides with concave/horizontal micro-relief and concave/ undulating vertical micro-relief. Slopes were gentle to moderate (5-35\%). Radiation index was a cool .448 as a result of northwest and northeast facing aspects.

\section{VEGETATION SUMMARY:}

Total vegetation cover was dense (93\%) and was composed of trees $(67 \%)$ and shrubs $(45 \%)$. The tree layer was dominated by Port-Orford-cedar $(45 \%)$, western white pine $(8 \%)$, white fir (9\%) and Douglas-fir (6\%). The shrub layer was dominated by Sitka alder $(31 \%)$ and western azalea (4\%). Total forb cover was moderate (16\%) and included bride's bonnet, common lady fern, common horsetail, bog orchid, lily and braken fern. The grass layer was also of moderate cover (25\%) and dominated by sedge.

\section{SOIL SUMMARY:}

Soils in this type were frigid, shallow to moderately deep and moderately well drained. They formed in alluvium and glacial till from coarse textured granite parent material. The litter layer thickness averaged $1.8 "$ at $81 \%$ cover. Surface rock and gravel averaged $15 \%$ cover. The average surface horizon thickness was $11 "$. Texture was extremely cobbly loam, coarse fragment content averaged $41 \%$ and $\mathrm{pH}$ averaged 6.4 .

Subsoil texture was extremely cobbly loam and sandy loam. Subsoil coarse fragment content averaged 45\%. Subsurface pH averaged 6.1. The soils were 50\% skeletal.

\section{STAND STRUCTURE SUMMARY:}

Late seral stands in this type often had 3 or more layers of trees, while early mature and mid mature stands usually had 2 layers. Medium sized conifers dominated the top two layers with an average of 49 trees/acre $>21$ inches dbh, 21 trees/acre $>30$ inches dbh, and 1 trees/acre $>40$ inches dbh. Hardwoods were absent in this type.

The stand structure characteristics by layer were as follows. The top layer averaged 233 years old with an average diameter of 35.9 inches and average height of 126 feet. It was made up of dominant Port-Orford-cedar, western white pine and white fir. The second layer had an average age of 294 years with a mean diameter of 31.0 inches and a mean height of 91 feet. It included codominant Port-Orford-cedar and western white pine.

Overall biomass production (conifer + hardwoods + shrubs) was generally moderate. Modal Dunning site class was 4 with site index of 100 at 300 years. Conifer productivity was generally moderate with an average volume of $7885 \mathrm{ft}^{3}$, it ranged from 5720 to $10050 \mathrm{ft}$. Softwood basal area averaged $393 \mathrm{ft}^{2}$ and ranged from 320 to $467 \mathrm{ft}^{2}$ No hardwoods were found in this type. Stand density index was 592 and fell in the middle of the Port-Orford-cedar series. Quadratic mean diameter was 16.5 inches and fell in the middle of the Port-Orford-cedar series.

\section{CLOSELY RELATED TYPES:}

The CHLA-PIMO3/ALSI2 type is replaced on wet glacial basins by the CHLA-PIMO3/ LEGL1/DACA2 type, on moist mountain sideslopes by the CHLA-PIMO3/VAME type, in wet glacial basins by the CHLA-PIMO3//Wet Herb Complex and on glacial moraines by the CHLA-PIMO3//Dry Herb complex. 
Plant Association: Port-Orford-cedar-Western White Pine/ Thinleaf Huckleberry

EDP Code Name: CHLA-PIMO3/VAME

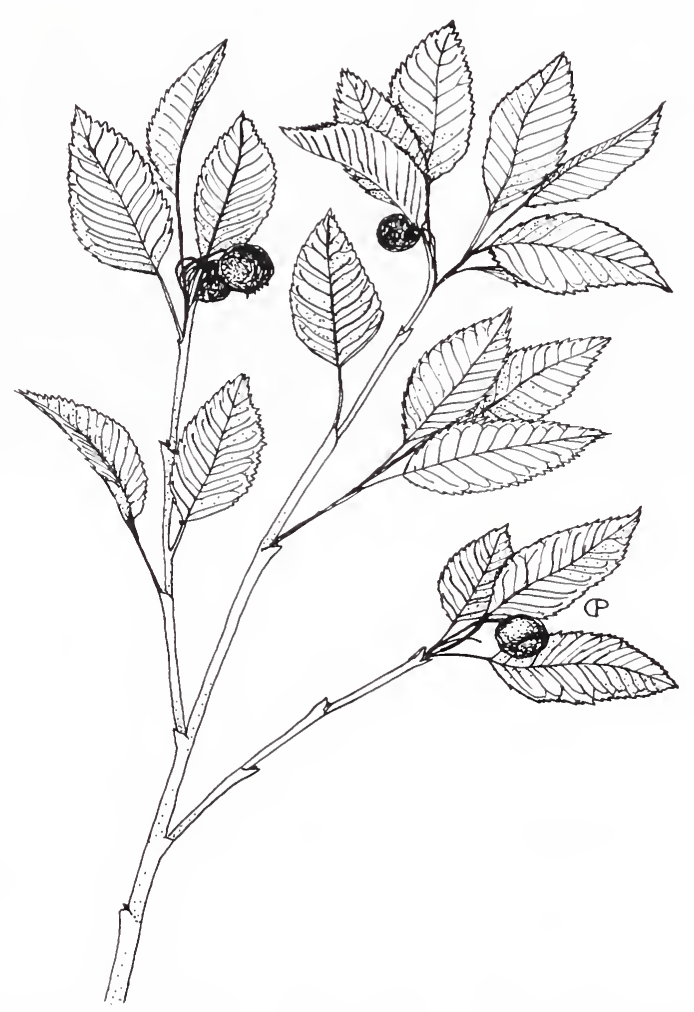

Indicator species:

Thinleaf huckleberry (Vaccinium membranaceum-VAME) was found on cool, shaded, high elevation sites on soils derived from granite parent material. 


\section{CHLA-PIMO3/VAME Association,}

\section{Port-Orford-cedar-Western White Pine/Thinleaf Huckleberry,}

\section{EcoCode: CCOCPW05}

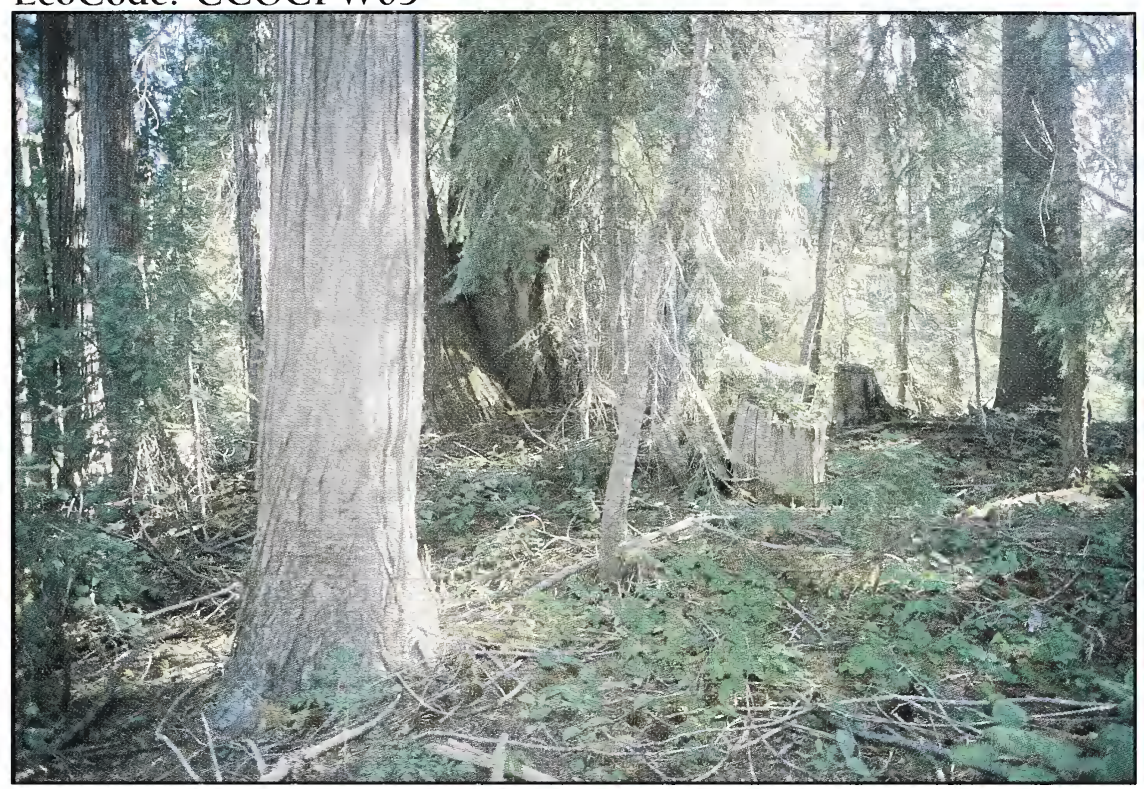

SUMMARY TABLE

(Sample size: 6)

COVER CON

Tree Overstory Layer

$\begin{array}{llrr}\text { CHLA } & \text { Port-Orford-cedar } & 52 & 100 \\ \text { PIMO3 } & \text { Western White Pine } & 15 & 100 \\ \text { ABCO } & \text { White Fir } & 13 & 67 \\ \text { TSME } & \text { Mountain Hemlock } & 3 & 67\end{array}$

\section{ENVIRONMENT:}

Elevation: 4920-6000 ft.;

TSME Mountain Hemlock

Aspect: N.E;

Slope: $2-30 \%$;

Slope Position: lower $1 / 3$, bottom;

Tree Understory Layer

$\begin{array}{llll}\text { CHLA } & \text { Port-Orford-cedar } & 6 & 100\end{array}$

PIMO3 Western White Pine 1183

Rock: 1-10\%

ABCO White Fir $\quad 5 \quad 67$

TSME Mountain Hemlock 150

Distance to Ocean: 84.0-86.9 miles

\section{Shrubs}

$\begin{array}{llrr}\text { VAME } & \text { Thinleaf Huckleberry } & 44 & 100 \\ \text { RUPA } & \text { Thimbleberry } & 1 & 67 \\ \text { LEDA } & \text { Sierra Laurel } & 7 & 67\end{array}$

\section{Herbs \& Grasses}

PTAQL Bracken Fern $\quad 1 \quad 83$

GOOB Rattlesnake Plantain 1167

CLUN2 Bride's Bonnet $\quad 950$

$\begin{array}{lll}\text { CARl Sedge } & 1 & 50\end{array}$

SOILS:

Pit Depth: $30-40+$ in.;

AWC: 0.5-3.6 in.;

Parent Material: granite, mixed;

A Horizon:

Coarse Fragments: 16-35\%;

Textures: vgls, gl;

Thickness: 6-8 in.;

Surface PH: 5.2-6.8 


\section{DISTRIBUTION/SETTING:}

This type was very limited in extent; it covered only 25 acres and was found on inland sites on the Mt. Shasta Ranger District of the Shasta-Trinity National Forest. Mean distance to the Pacific Ocean was 86.0 miles and elevation averaged 5492 feet. Landforms were mountain slopes and basins with linear and concave horizontal micro-relief and linear vertical micro-relief. Slopes were level to moderate (2-30\%) in mainly lower onethird slope micro-positions. Radiation index was a cool .439 as a result of northeast facing aspects.

\section{VEGETATION SUMMARY:}

Total vegetation cover was dense (94\%) and was composed of primarily trees $(77 \%)$ and shrubs (54\%). The tree layer was dominated by Port-Orford-cedar (52\%), western white pine (15\%), white fir (13\%) and mountain hemlock $(3 \%)$. The shrub layer was dominated by thinleaf huckleberry (44\%), Sierra laurel (7\%) and serviceberry (5\%). Total forb cover was moderate (15\%) and included western prince's pine, bride's bonnet, rattlesnake plantain and braken fern. The grass layer was also of low cover (2\%) and dominated by sedge.

\section{SOIL SUMMARY:}

Soils in this type were frigid, moderately deep to deep and well drained. They formed in glacial till, alluvium and colluvium from coarse textured granite parent material. The litter layer thickness averaged 1.2" at 93\% cover. Surface rock and gravel averaged $5 \%$ cover. The average surface horizon thickness was $7 "$, texture included fine loamy sand, very gravelly loamy sand and gravelly loam, coarse fragment content averaged $22 \%$ and $\mathrm{pH}$ averaged 6.0 .

Subsoil texture was extremely gravelly sand and loamy sand. Subsoil coarse fragment content averaged 54\%. Subsurface pH averaged 6.0. The soils were $75 \%$ skeletal.

\section{STAND STRUCTURE SUMMARY:}

Late seral stands in this type often had 4 or more layers of trees, while early mature and mid mature stands usually had 2 layers. Large sized conifers dominated the top two layers with an average of 100 trees/acre $>21$ inches $\mathrm{dbh}, 44$ trees/acre $>30$ inches $\mathrm{dbh}$, and 6 trees/acre $>40$ inches dbh. Hardwoods were absent in this type.

The stand structure characteristics by layer were as follows. The top layer averaged 306 years old with an average diameter of 39.7 inches and average height of 142 feet. It was made up of dominant Port-Orford-cedar, western white pine and white fir. The second layer had an average age of 323 years with a mean diameter of 36.8 inches and a mean height of 118 feet. It included codominant Port-Orford-cedar and western white pine. The third layer had an average age of 133 years with a mean diameter of 18.7 inches and a mean height of 66 feet. The third layer included intermediate sized PortOrford-cedars.

Overall biomass production (conifer + hardwoods + shrubs) was generally high. Modal Dunning site class was 3 with site index of 125 at 300 years. Conifer productivity was generally high with an average volume of $14,832 \mathrm{ft}^{3}{ }^{3}$, it ranged from 5450 to 22,860 ft. Softwood basal area averaged $578 \mathrm{ft}^{2}$ and ranged from 267 to $900 \mathrm{ft}^{2}$ No hardwoods were identified in this type. Stand density index was 758 and fell in the high end of the Port-Orford-cedar series. Quadratic mean diameter was 22.5 inches and fell in the high end of the Port-Orford-cedar series.

\section{CLOSELY RELATED TYPES:}

The CHLA-PIMO3/VAME type is replaced on rocky streamsides by the CHLAPIMO3/ALSI2 type, on wet glacial basins by the CHLA-PIMO3/LEGLI/DACA2 type, in wet glacial basins by the CHLA-PIMO3//Wet Herb Complex and on glacial moraines by the CHLA-PIMO3//Dry Herb complex. 
Plant Association: Port-Orford-cedar-Western White Pine// Wet Herb Complex

EDP Code Name: CHLA-PIMO3//Wet Herb Complex

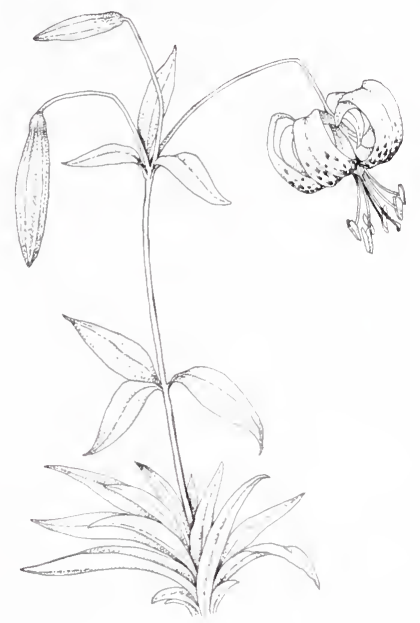

Indicator species:

Lily (Lilium sp.-LIL) was found on wet, mainly high elevation sites.

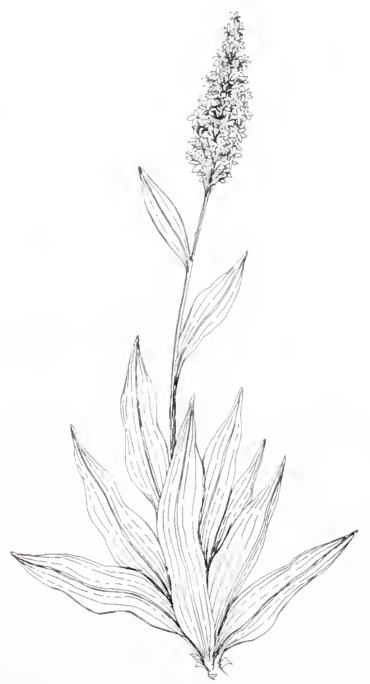

Indicator species:

California false hellebore (Veratrum Californicum-VECA) was found on wet, mainly high elevation sites. 
CHLA-PIMO3//wet herb complex Association, Port-Orford-cedar-Western White Pine//Wet Herb Complex, EcoCode: CCOCPW06

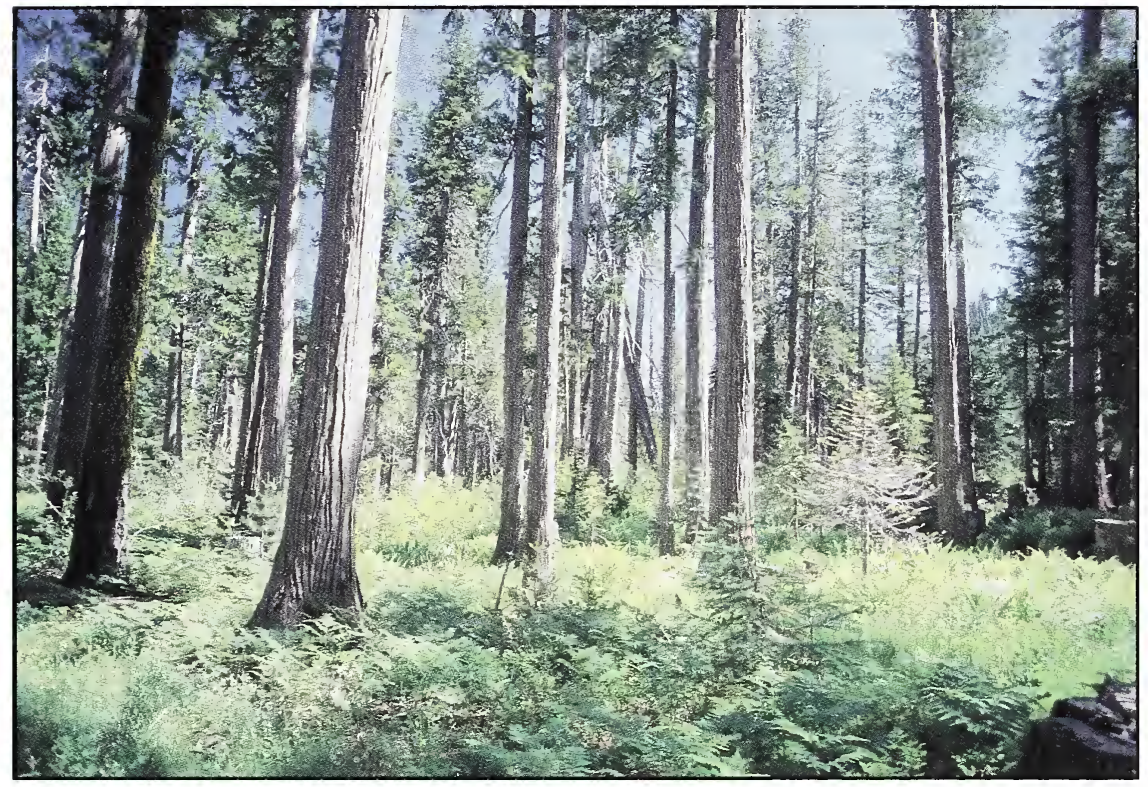

SUMMARY TABLE

(Sample size: 10)

COVER CON

Tree Overstory Layer

CHLA Port-Orford-cedar

$\mathrm{ABCO}$ White Fir

$59 \quad 100$

PIMO3 Western White Pine

790

690

Tree Understory Layer

$\begin{array}{llrr}\text { CHLA } & \text { Port-Orford-cedar } & 8 & 100 \\ \text { ABCO } & \text { White Fir } & 2 & 90 \\ \text { PIMO3 } & \text { Western White Pine } & 1 & 60\end{array}$

ENVIRONMENT:

Elevation 4860-6000 ft.;

Aspect: N.E;

Slope: 4-15\%;

Slope Position: bottom, lower 1/3 basin edge;

Surface Rock: 0-5\%

Distance to Ocean: 83.3-87.6 miles

Shrubs

$\begin{array}{llll}\text { VAME } & \text { Thinleaf Huckleberry } & 3 & 40 \\ \text { ALSI2 } & \text { Sitka Alder } & 7 & 30\end{array}$

SOILS:

Pit Depth: $30-40+$ in.;

AWC: 1.4-7.3 in.;

Herbs \& Grasses

$\begin{array}{llll}\text { LIL } & \text { Lily } & 2 & 90 \\ \text { VECA } & \text { California False Hellebore } & 1 & 90 \\ \text { SETR } & \text { Woolly Ragwort } & 1 & 80 \\ \text { AQFO } & \text { Red Columbine } & 1 & 60\end{array}$

Parent Material granite, ultramafic;

A Horizon:

Coarse Fragments: 5-25\%;

Textures: mp, gsl;

Thickness: 7-24 in.;

Surface PH: 5.4-6.8 


\section{DISTRIBUTION/SETTING:}

This type was of limited extent, but high importance due to its high species diversity; it covered 85 acres and was found on inland sites on the Mt. Shasta Ranger District of the Shasta-Trinity National Forest. Mean distance to the Pacific Ocean was 85.4 miles and elevation averaged 5349 feet. Landforms were mountain basins and depressions caused by glaciers. Horizontal micro-relief was undulating and linear, while vertical microrelief was linear and undulating. Slopes were level to gentle (4-15\%) in mainly lower slope depression micro-positions. Radiation index was a cool .435 as a result of north and east facing aspects.

\section{VEGETATION SUMMARY:}

Total vegetation cover was dense (93\%) and was composed of primarily trees (73\%) and forbs (37\%). The tree layer was dominated by Port-Orford-cedar (59\%), western white pine (6\%) and white fir (7\%). The shrub layer was of low cover (10\%) and included thinleaf huckleberry and serviceberry. Total forb cover was high (37\%) and included Gray's licorice root, lily, California false hellebore, woolly ragwort,monkshood, bleeding heart and marsh marigold. The grass layer was also of moderate cover (14\%) and dominated by grasses and sedges.

\section{SOIL SUMMARY:}

Soils in this type were frigid, shallow to deep and poorly drained. They formed in alluvium and organic muck from coarse textured granite parent material and fine textured ultramafic parent material. The litter layer thickness averaged 2.2 " at $95 \%$ cover. Surface rock and gravel averaged 2\% cover. The average surface horizon thickness was 12". Texture was primarily peaty muck, coarse fragment content averaged $16 \%$ and $\mathrm{pH}$ averaged 6.3 .

Subsoil texture was peaty muck, very gravelly sand and very gravelly loamy sand. Subsoil coarse fragment content averaged 33\%. Subsurface pH averaged 6.7. The soils were $35 \%$ skeletal.

\section{STAND STRUCTURE SUMMARY:}

Late seral stands in this type often had 4 or more layers of trees, while early mature and mid mature stands usually had 2 layers. Large sized conifers dominated the top two layers with an average of 70 trees/acre $>21$ inches $\mathrm{dbh}, 26$ trees/acre $>30$ inches $\mathrm{dbh}$, and 4 trees/acre $>40$ inches $\mathrm{dbh}$. Hardwoods were absent in this type.

The stand structure characteristics by layer were as follows. The top layer averaged 254 years old with an average diameter of 34.4 inches and average height of 119 feet. It was made up of dominant Port-Orford-cedar, Douglas-fir and lodgepole pine. The second layer had an average age of 200 years with a mean diameter of 29.6 inches and a mean height of 99 feet. It included codominant Port-Orford-cedar, western white pine and white fir. The third layer had an average age of 140 years with a mean diameter of 20.4 inches and a mean height of 69 feet. The third layer included intermediate sized PortOrford-cedar, Douglas-fir and white fir.

Overall biomass production (conifer + hardwoods + shrubs) was generally high. Modal Dunning site class was 4 with site index of 100 at 300 years. Conifer productivity was generally high with an average volume of $10,389 \mathrm{ft}^{3}{ }^{3}$, it ranged from 6750 to 14,230 $\mathrm{ft}$. Softwood basal area averaged $503 \mathrm{ft}^{2}$ and ranged from 360 to $627 \mathrm{ft}^{2}{ }^{2}$ No hardwoods were identified in this type. Stand density index was 734 and fell in the high end of the Port-Orford-cedar series. Quadratic mean diameter was 18.5 inches and fell in the high end of the Port-Orford-cedar series. 


\section{CLOSELY RELATED TYPES:}

The CHLA-PIMO3//Wet Herb Complex type is replaced on rocky streamsides by the CHLA-PIMO3/ALSI2 type, on moist mountain sideslopes by the CHLA-PIMO3/VAME type, in wet glacial basins by the CHLA-PIMO3/LEGL1/DACA2 and on glacial moraines by the CHLA-PIMO3//Dry Herb complex. 
Plant Association: Port-Orford-cedar-Western White Pine//

Dry Herb Complex

EDP Code Name: CHLA-PIMO3//Dry Herb Complex

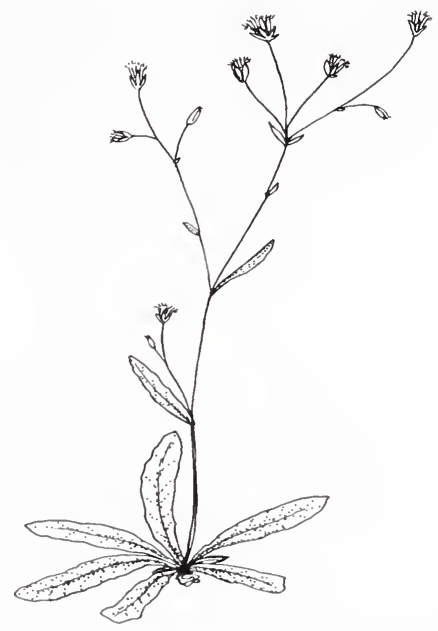

Indicator species:

White Hawkweed (Hieraceum albiflorum-HIAL) was found on warm, moist/dry, high elevation sites.

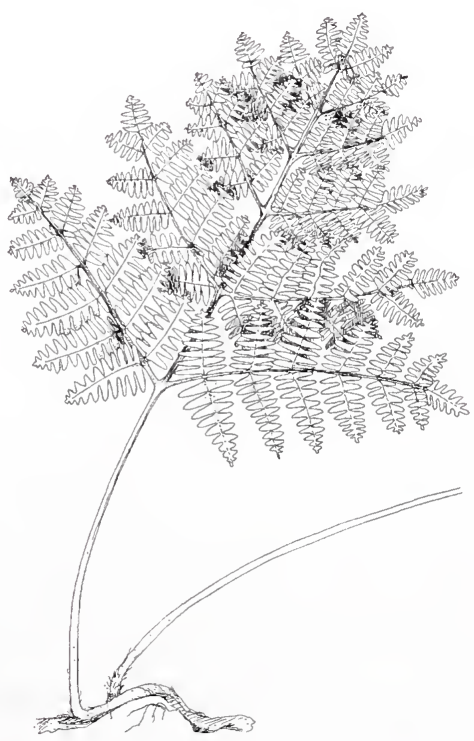

Indicator species:

Bracken fern (Pteridium aquilinum var. langulosum-PTAQL) was found on warm, moist/dry, high elevation sites. 


\section{CHLA-PIMO3//dry herb complex Association, Port-Orford-cedar-Western White Pine//Dry Herb Complex, EcoCode: CCOCPW07}

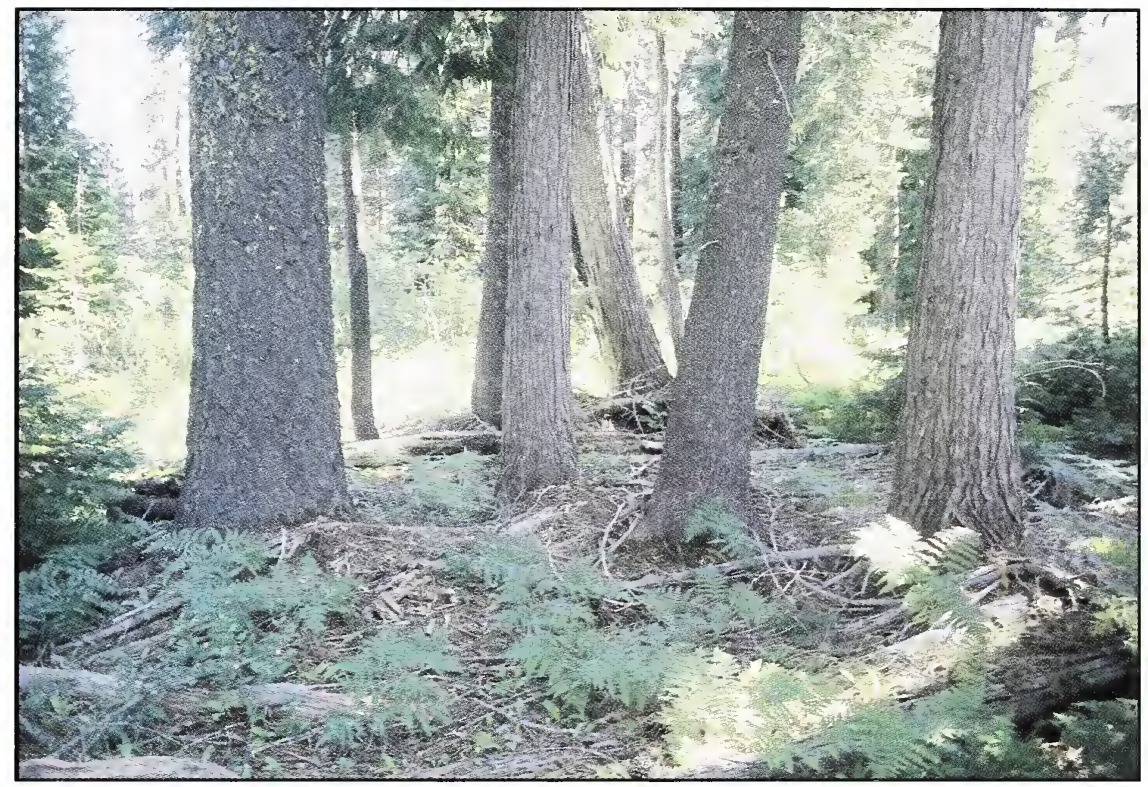

\section{SUMMARY TABLE}

(Sample size: 4) COVER CON

\section{Tree Overstory Layer}

CHLA Port-Orford-cedar

PIMO3 Western White Pine

ABCO White Fir

\section{Tree Understory Layer}

$\begin{array}{llrr}\text { CHLA } & \text { Port-Orford-cedar } & 3 & 100 \\ \text { PIMO3 } & \text { Western White Pine } & 2 & 100 \\ \text { ABCO } & \text { White Fir } & 4 & 75\end{array}$

Shrubs

QUVA Huckleberry Oak

AME Serviceberry

SPDO Douglas' Spirea

Herbs \& Grasses

$\begin{array}{llrr}\text { GRAM } & \text { Grass } & 1 & 100 \\ \text { PTAQL } & \text { Bracken Fern } & 29 & 75 \\ \text { LIGR } & \text { Gray's Licorice Root } & 2 & 75 \\ \text { HIAL } & \text { White Hawkweed } & 1 & 75 \\ \text { TRKIP } & \text { King's Clover } & 2 & 50 \\ \text { AQFO } & \text { Red Columbine } & 1 & 50 \\ \text { SILE } & \text { Lemmon's Catchfly } & 1 & 50 \\ & & \text { Sc-70 }\end{array}$

\section{ENVIRONMENT:}

Elevation: 4860-6000 ft.;

Aspect: $\mathrm{N}$;

Slope: $5-28 \%$;

Slope Position: lower 1/3, basin edge; Surface Rock: 1-20\%;

Distance to Ocean: 83.4-87.8 miles
SOILS:

Pit Depth: $40+$ in.;

AWC: $5.0-5.5$ in.;

Parent Material: ultramafic, granite; A Horizon:

Coarse Fragments: 29-45\%;

Textures: xksl, vgsl;

Thickness: 6-7 in.;

Surface PH: 5.8-6.5 


\section{DISTRIBUTION/SETTING:}

This type was one of the most limited Port-Orford-cedar plant associations; it covered only 18 acres and was found on inland sites on the Mt. Shasta Ranger District of the Shasta-Trinity National Forest. Mean distance to the Pacific Ocean was 85.8 miles and elevation averaged 5355 feet. Landforms were glacial moraines with linear and undulating horizontal micro-relief and linear vertical micro-relief. Slopes were gentle to moderate (5-28\%) in mainly lower one-third slope micro-positions. Radiation index was a cool .423 as a result of north facing aspects.

\section{VEGETATION SUMMARY:}

Total vegetation cover was dense (92\%) and was composed of primarily trees (70\%) and forbs (34\%). The tree layer was dominated by Port-Orford-cedar (49\%), western white pine (13\%) and white fir (9\%). The shrub layer was of low cover (6\%) and included serviceberry, huckleberry oak, willow, red huckleberry and Douglas' spirea. Total forb cover was high (34\%) and included three-leaf anemone, red columbine, western prince's pine, white hawkweed, Gray's licorice root, white-veined wintergreen, one-sided pyrola, Lemmons catchfly, clover and braken fern. The grass layer was also of low cover (3\%) and dominated by grass.

\section{SOIL SUMMARY:}

Soils in this type were frigid, deep and well drained. They formed in glacial till from coarse textured granite parent material and fine textured ultramafic parent material. The litter layer thickness averaged $1.4^{\prime \prime}$ at $83 \%$ cover. Surface rock and gravel averaged 13\% cover. The average surface horizon thickness was 5", texture varied from gravelly loam to extremely cobbly loam, coarse fragment content averaged $45 \%$ and $\mathrm{pH}$ averaged 6.2 .

Subsoil texture was very gravelly sandy loam and extremely cobbly sandy loam. Subsoil coarse fragment content averaged 64\%. Subsurface pH averaged 6.5. The soils were $100 \%$ skeletal.

\section{STAND STRUCTURE SUMMARY:}

Late seral stands in this type often had 4 or more layers of trees, while early mature and mid mature stands usually had 2 layers. Medium sized conifers dominated the top two layers with an average of 53 trees/acre $>21$ inches $\mathrm{dbh}, 17$ trees/acre $>30$ inches $\mathrm{dbh}$, and 6 trees/acre $>40$ inches dbh. Hardwoods were absent in this type.

The stand structure characteristics by layer were as follows. The top layer averaged 322 years old with an average diameter of 42.0 inches and average height of 125 feet. It was made up of dominant Port-Orford-cedar and western white pine. The second layer had an average age of 256 years with a mean diameter of 27.4 inches and a mean height of 106 feet. It included codominant Port-Orford-cedar and western white pine. The third layer had an average age of 225 years with a mean diameter of 19.8 inches and a mean height of 85 feet. The third layer included intermediate sized Port-Orford-cedars.

Overall biomass production (conifer + hardwoods + shrubs) was generally moderate. Modal Dunning site class was 4 with site index of 100 at 300 years. Conifer productivity was generally moderate with an average volume of $8380 \mathrm{ft}^{3}$, it ranged from 6260 to $10,500 \mathrm{ft}$. Softwood basal area averaged $362 \mathrm{ft}^{2}$ and ranged from 300 to $427 \mathrm{ft}^{2}{ }^{2}$ No hardwoods were identified in this type. Stand density index was 501 and fell in the middle of the Port-Orford-cedar series. Quadratic mean diameter was 22.0 inches and fell in the high end of the Port-Orford-cedar series. 


\section{CLOSELY RELATED TYPES:}

The CHLA-PIMO3//Dry Herb Complex type is replaced on rocky streamsides by the CHLA-PIMO3/ALSI2 type, on moist mountain sideslopes by the CHLA-PIMO3/VAME type, in wet glacial basins by the CHLA-PIMO3//Wet Herb Complex and the CHLAPIMO3/LEGL1/DACA2 type. 
Plant Association: Port-Orford-cedar-Mountain Hemlock/ Bush Chinquapin

EDP Code Name: CHLA-TSME/CASE3

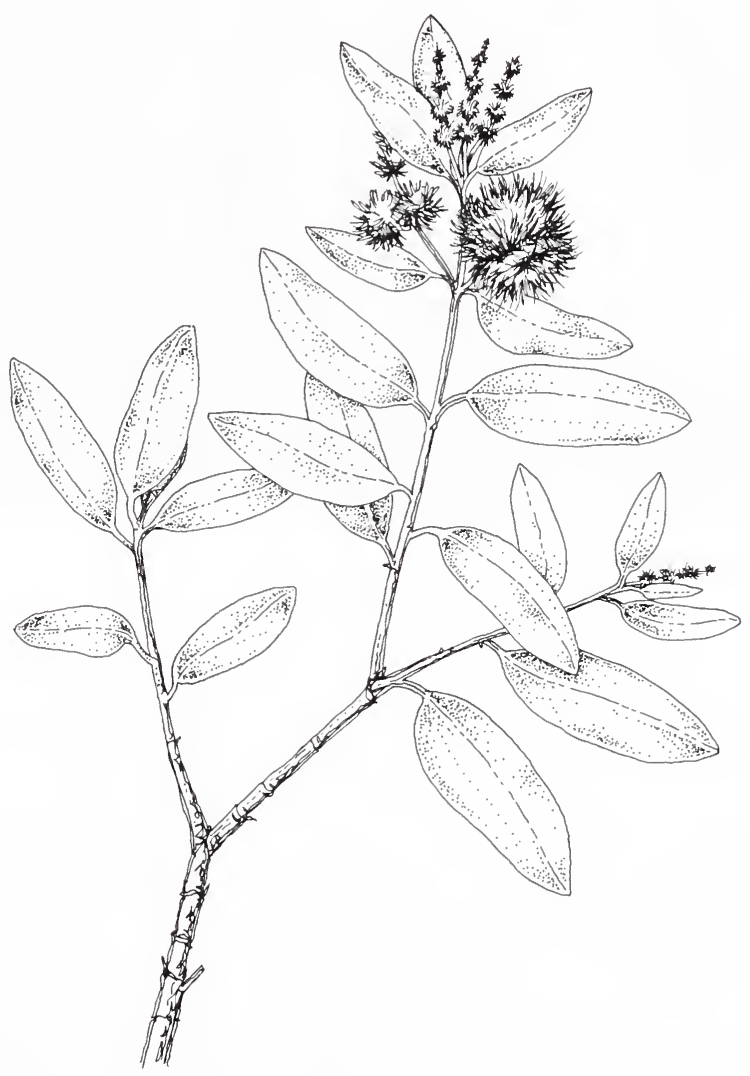

Indicator species:

Bush chinquapin (Castanopsis sempervirens-CASE3) was found on rocky, dry, high elevation sites on soils derived from granite parent rock. 


\section{CHLA-TSME/CASE3 Association,}

\section{Port-Orford-cedar-Mountain Hemlock/Bush Chinquapin,}

\section{EcoCode: CCOCHMO1}

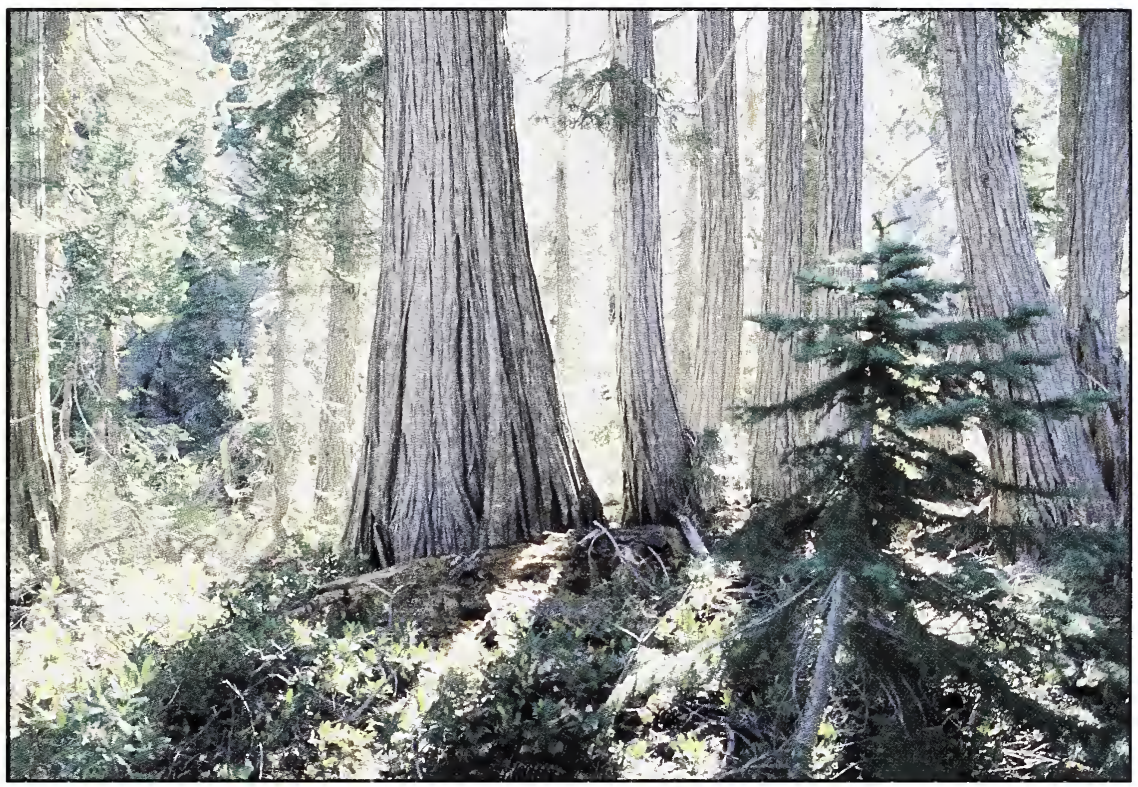

\section{SUMMARY TABLE}

(Sample size: 4)

COVER CON

\section{Tree Overstory Layer}

CHLA Port-Orford-cedar

PIMO3 Western White Pine

TSME Mountain Hemlock

ABMAS Red Fir

$\begin{array}{rr}63 & 100 \\ 10 & 100 \\ 6 & 100 \\ 5 & 100\end{array}$

Tree Understory Layer

$\begin{array}{ll}\text { CHLA } & \text { Port-Orford-cedar } \\ \text { PIMO3 } & \text { Western White Pine } \\ \text { TSME } & \text { Mountain Hemlock } \\ \text { ABMAS } & \text { Red Fir }\end{array}$

$9 \quad 100$

$1 \quad 75$

1100

1100

Shrubs

$\begin{array}{llrr}\text { CASE3 } & \text { Bush Chinquapin } & 16 & 100 \\ \text { QUVA } & \text { Huckleberry Oak } & 3 & 100 \\ \text { ARNE2 } & \text { Pinemat Manzanita } & 2 & 100 \\ \text { VASC } & \text { Littleleaf Huckleberry } & 3 & 100\end{array}$

\section{Herbs \& Grasses}

PYPI White-veined Wintergreen $2 \quad 100$

$\begin{array}{lll}\text { PYSE } & \text { One-sided Pyrola } & 100\end{array}$

CHUMO Western Prince's pine 1100

CARl Sedge 1100

\section{ENVIRONMENT:}

Elevation: 6080-6310 ft.;

Aspect: N.E..;

Slope: $5-20 \%$;

Slope Position: basin edge, draw;

Surface Rock: 5-20\%;

Distance to Ocean: 84.8-86.5 miles

SOILS:

Pit Depth: 25-29 in.;

AWC: 2.3-2.8 in.;

Parent Material: granite, quartzite;

A Horizon:

Coarse Fragments: 0-20\%;

Textures: 1, gl;

Thickness: 9-20 in.;

Surface PH: 5.5-5.6 


\section{DISTRIBUTION/SETTING:}

This type was the most limited Port-Orford-cedar plant association in the study area; it covered only 5 acres and was found on inland sites on the Mt. Shasta Ranger District of the Shasta-Trinity National Forest. Mean distance to the Pacific Ocean was 85.3 miles. Elevation averaged 6248 feet, highest of all Port-Orford-cedar plant associations. Landforms were glacial moraines with hummocky horizontal micro-relief and hummocky and undulating vertical micro-relief. Slopes were level to moderate (5$20 \%$ ) in mainly edge of basin micro-positions. Radiation index was a cool .439 as a result of north east facing aspects.

\section{VEGETATION SUMMARY:}

Total vegetation cover was dense (94\%) and was composed of primarily trees (84\%) and shrubs (28\%). The tree layer was dominated by Port-Orford-cedar (63\%), western white pine $(10 \%)$, red fir $(5 \%)$ and mountain hemlock $(6 \%)$. The shrub layer was dominated by bush chinquapin (16\%), pinemat manzanita (2\%), pink mountain heather (1\%), huckleberry oak (3\%), thinleaf huckleberry (4\%) and littleleaf huckleberry (3\%). Total forb cover was low (5\%) and included common yarrow, western prince's pine, little prince's pine, penstemon, white-veined wintergreen, one-sided pyrola, saxifrage and stonecrop. The grass layer was also of low cover (1\%) and dominated by sedge.

\section{SOIL SUMMARY:}

Soils in this type were frigid, moderately deep and moderately well drained. They formed in glacial till from coarse textured granite and quartzite parent material. The litter layer thickness averaged $0.6 "$ at $43 \%$ cover. Surface rock and gravel averaged 16\% cover. The average surface horizon thickness was 12", texture included loams and gravelly loams, coarse fragment content averaged $18 \%$ and $\mathrm{pH}$ averaged 5.5.

Subsoil texture was cobbly loam. Subsoil coarse fragment content averaged 53\%. Subsurface pH averaged 5.5. The soils were 100\% skeletal.

\section{STAND STRUCTURE SUMMARY:}

Late seral stands in this type often had 3 or more layers of trees, while early mature and mid mature stands usually had 2 layers. Large sized conifers dominated the top two layers with an average of 56 trees/acre $>21$ inches $\mathrm{dbh}, 36$ trees/acre $>30$ inches $\mathrm{dbh}$, and 6 trees/acre $>40$ inches $\mathrm{dbh}$. Hardwoods were absent in this type.

The stand structure characteristics by layer were as follows. The top layer averaged 360 years old with an average diameter of 38.4 inches and average height of 95 feet. It was made up of dominant Port-Orford-cedars. The second layer had an average age of 324 years with a mean diameter of 35.8 inches and a mean height of 80 feet. It included codominant Port-Orford-cedar and mountain hemlock.

Overall biomass production (conifer + hardwoods + shrubs) was generally high. Modal Dunning site class was 4 with site index of 100 at 300 years. Conifer productivity was generally high with an average volume of $11,063 \mathrm{ft}^{3}{ }^{3}$, it ranged from 6310 to 13,830 $\mathrm{ft}$. Softwood basal area averaged $640 \mathrm{ft}^{2}$ and ranged from 400 to $800 \mathrm{ft}^{2}{ }^{2}$ No hardwoods were identified in this type. Stand density index was 1001 and fell in the high end of the Port-Orford-cedar series. Quadratic mean diameter was 14.3 inches and fell in the low end of the Port-Orford-cedar series.

\section{CLOSELY RELATED TYPES:}

The CHLA-TSME/CASE3 type is replaced on basin landforms by the CHLA-TSME/ LEGLl type and on moist slightly upslope sites by the CHLA-TSME/LEDA type. 
Plant Association: Port-Orford-cedar-Mountain Hemlock/Labrador-tea EDP Code Name: CHLA-TSME/LEGLl

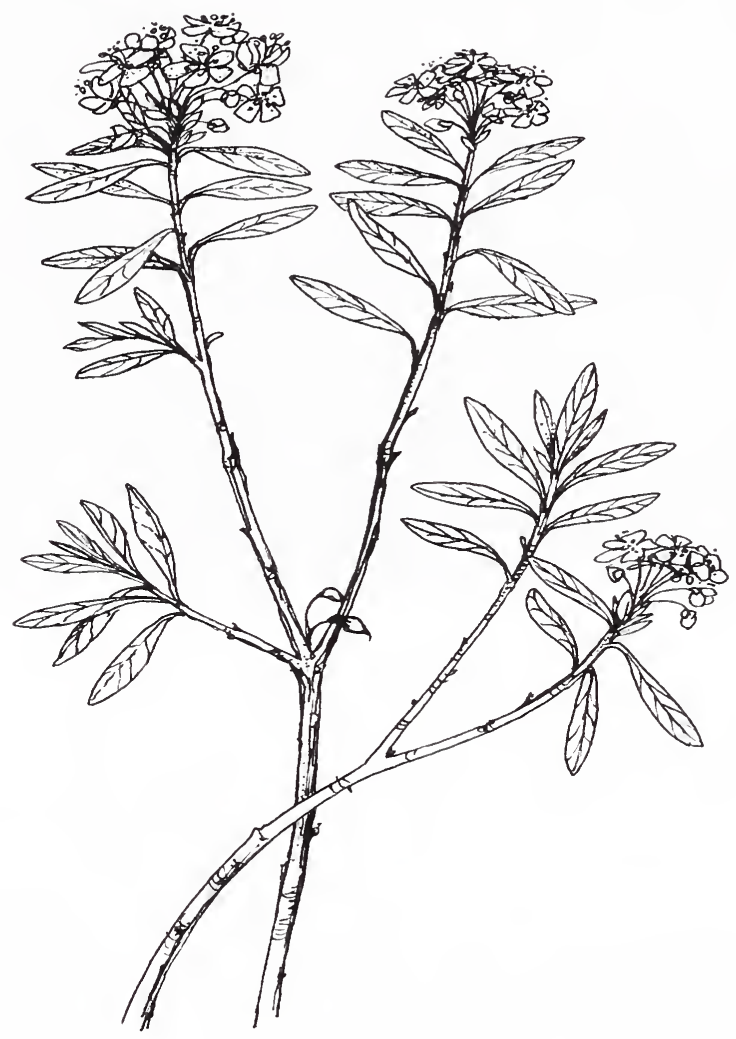

Indicator species:

Labrador-tea (Ledum glandulosum-LEGLl) was found on boggy, wet, mainly high elevation sites on soils derived from ultramafic or granite parent material. 


\section{CHLA-TSME/LEGL1 Association,}

\section{Port-Orford-cedar-Mountain Hemlock/Labrador-Tea,}

\section{EcoCode: CCOCHMO2}

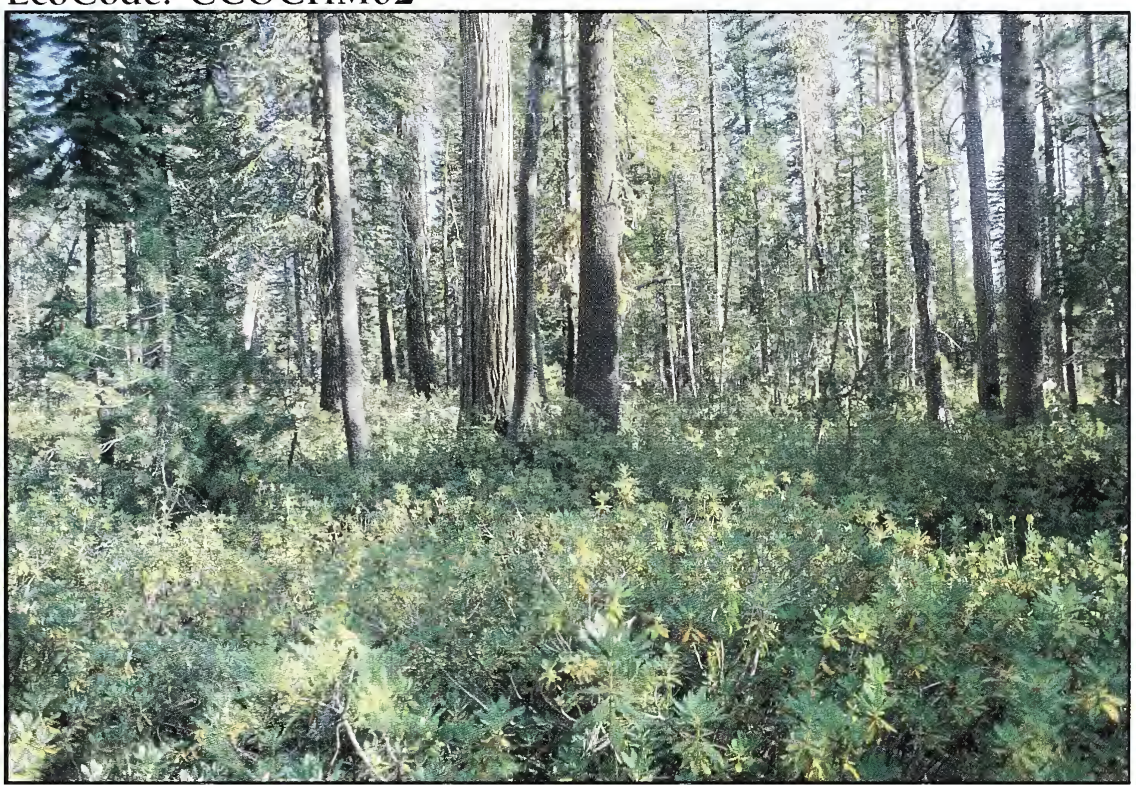

SUMMARY TABLE

(Sample size: 8)

COVER CON

\section{Tree Overstory Layer}

$\begin{array}{llrr}\text { CHLA } & \text { Port-Orford-cedar } & 37 & 100 \\ \text { TSME } & \text { Mountain Hemlock } & 14 & 100 \\ \text { ABMAS } & \text { Red fir } & 10 & 75 \\ \text { PICO1 } & \text { Lodgepole Pine } & 8 & 63\end{array}$

\section{Tree Understory Layer}

CHLA Port-Orford-cedar

$\begin{array}{rr}6 & 88 \\ 14 & 100 \\ 5 & 75 \\ 1 & 38\end{array}$

Shrubs

$\begin{array}{llrr}\text { LEGLl } & \text { Western Labrador Tea } & 29 & 100 \\ \text { VAME } & \text { Thinleaf Huckleberry } & 3 & 63\end{array}$

Herbs \& Grasses

$\begin{array}{llll}\text { LIL } & \text { Lily } & 2 & 50 \\ \text { BOMA2 } & \text { Mountain Boykinia } & 1 & 50\end{array}$

SOILS:

Pit Depth: $40+$ in.;

AWC: 3.3-5.8 in.;

Parent Material: granite, mafic;

A Horizon:

Coarse Fragments: 0-45\%;

Textures: sl, l;

Thickness: 4-40 in.;

Surface PH: 5.9-6.0 


\section{DISTRIBUTION/SETTING:}

This type was one of the least extensive Port-Orford-cedar plant associations; it covered 25 acres and was found on inland sites on the Mt. Shasta Ranger District of the Shasta-Trinity National Forest. Mean distance to the Pacific Ocean was 85.4 miles and elevation averaged 6032 feet, second highest of all types. Landforms were glacial cirques with linear, concave and undulating horizontal micro-relief and linear/undulating vertical micro-relief. Slopes were near level (2-9\%) in mainly basin micro-positions. Radiation index was .468 as a result of west and northeast facing aspects.

\section{VEGETATION SUMMARY:}

Total vegetation cover was dense (94\%) and was composed of primarily trees (71\%) and shrubs (53\%). The tree layer was dominated by Port-Orford-cedar (37\%), western white pine (7\%), red fir (10\%), white fir (8\%), lodgepole pine (8\%) and mountain hemlock (14\%). The shrub layer was dominated by western labrador-tea (29\%), Sierra laurel (39\%) and thinleaf huckleberry (3\%). Total forb cover was low (9\%) and included mountain boykinia, lily and California false hellebore. The grass layer cover was low (3\%), it included occasional grasses and sedges.

\section{SOIL SUMMARY:}

Soils in this type were frigid, deep, well drained and somewhat poorly drained. They formed in alluvium and lacustrine deposits from coarse textured granite parent material. The litter layer thickness averaged $2.8 "$ at $95 \%$ cover. Surface rock and gravel averaged $2 \%$ cover. The average surface horizon thickness was $20 "$, texture included loams, silt loams and sandy loams, coarse fragment content averaged $16 \%$ and $\mathrm{pH}$ averaged 6.0 .

Subsoil textures were silt loams and extremely cobbly sand. Subsoil coarse fragment content averaged 39\%. Subsurface pH averaged 6.1. The soils were 65\% skeletal.

\section{STAND STRUCTURE SUMMARY:}

Late seral stands in this type often had 4 or more layers of trees, while early mature and mid mature stands usually had 2 layers. Large sized conifers dominated the top two layers with an average of 55 trees/acre $>21$ inches dbh, 23 trees/acre $>30$ inches dbh, and 9 trees/acre $>40$ inches dbh. Hardwoods were absent in this type.

The stand structure characteristics by layer were as follows. The top layer averaged 460 years old with an average diameter of 38.6 inches and average height of 112 feet. It was made up of dominant Port-Orford-cedars. The second layer had an average age of 337 years with a mean diameter of 37.6 inches and a mean height of 86 feet. It included codominant Port-Orford-cedar and mountain hemlock. The third layer had an average age of 328 years with a mean diameter of 19.2 inches and a mean height of 63 feet. The third layer included intermediate sized Port-Orford-cedar and mountain hemlock.

Overall biomass production (conifer + hardwoods + shrubs) was generally low. Modal Dunning site class was 5 with site index of 75 at 300 years. Conifer productivity was generally low with an average volume of $7110 \mathrm{ft}^{3}{ }^{3}$, it ranged from 6060 to $8610 \mathrm{ft}$. Softwood basal area averaged $391 \mathrm{ft}^{2}$ and ranged from 280 to $467 \mathrm{ft}^{2}{ }^{2}$ No hardwoods were identified in this type. Stand density index was 655 and fell in the middle of the Port-Orford-cedar series. Quadratic mean diameter was 13.3 inches and fell in the low end of the Port-Orford-cedar series.

\section{CLOSELY RELATED TYPES:}

The CHLA-TSME/LEGLl type is replaced on terminal and lateral moraines by the CHLA-TSME/CASE3 type and on moist slightly upslope sites by the CHLA-TSME/LEDA type. 
Plant Association: Port-Orford-cedar-Mountain Hemlock/Sierra Laurel EDP Code Name: CHLA-TSME/LEDA

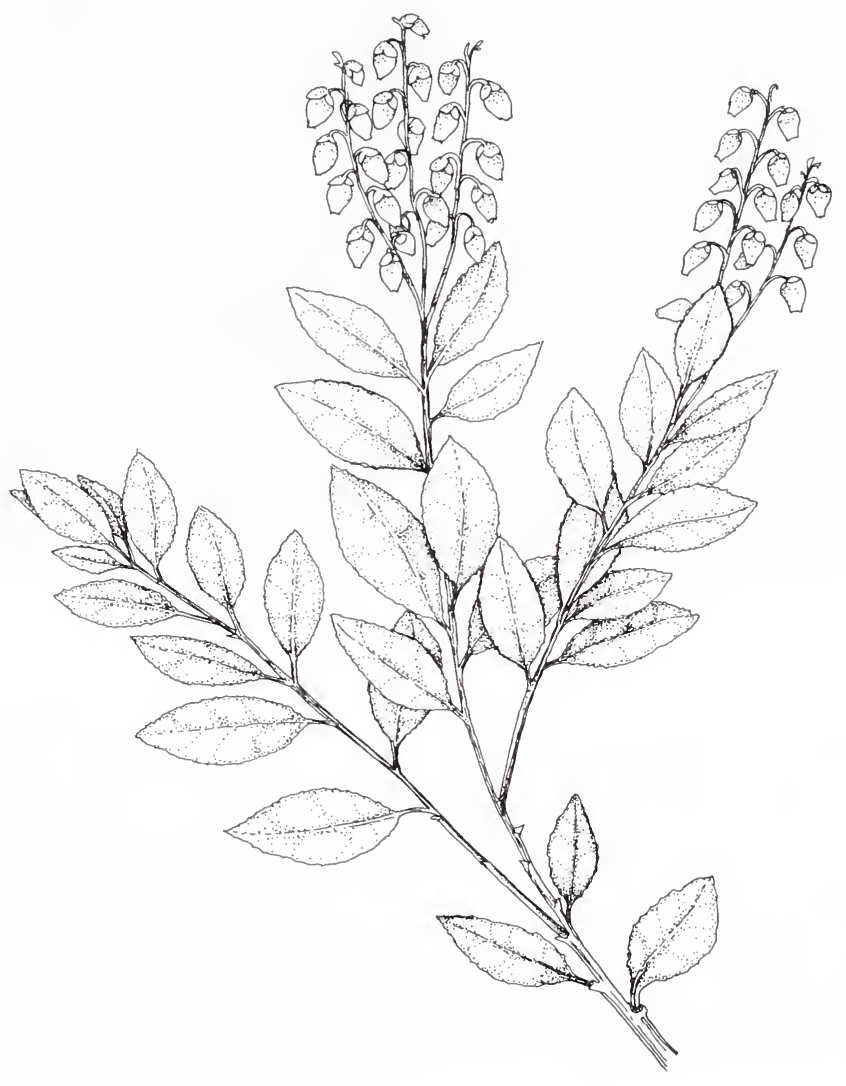

Indicator species:

Sierra laurel (Leucothoe davisiae-LEDA) was found on cool, moist, high elevation mountain slopes. 


\section{CHLA-TSME/LEDA Association,}

Port-Orford-cedar-Mountain Hemlock/Sierra Laurel,

EcoCode: CCOCHM03

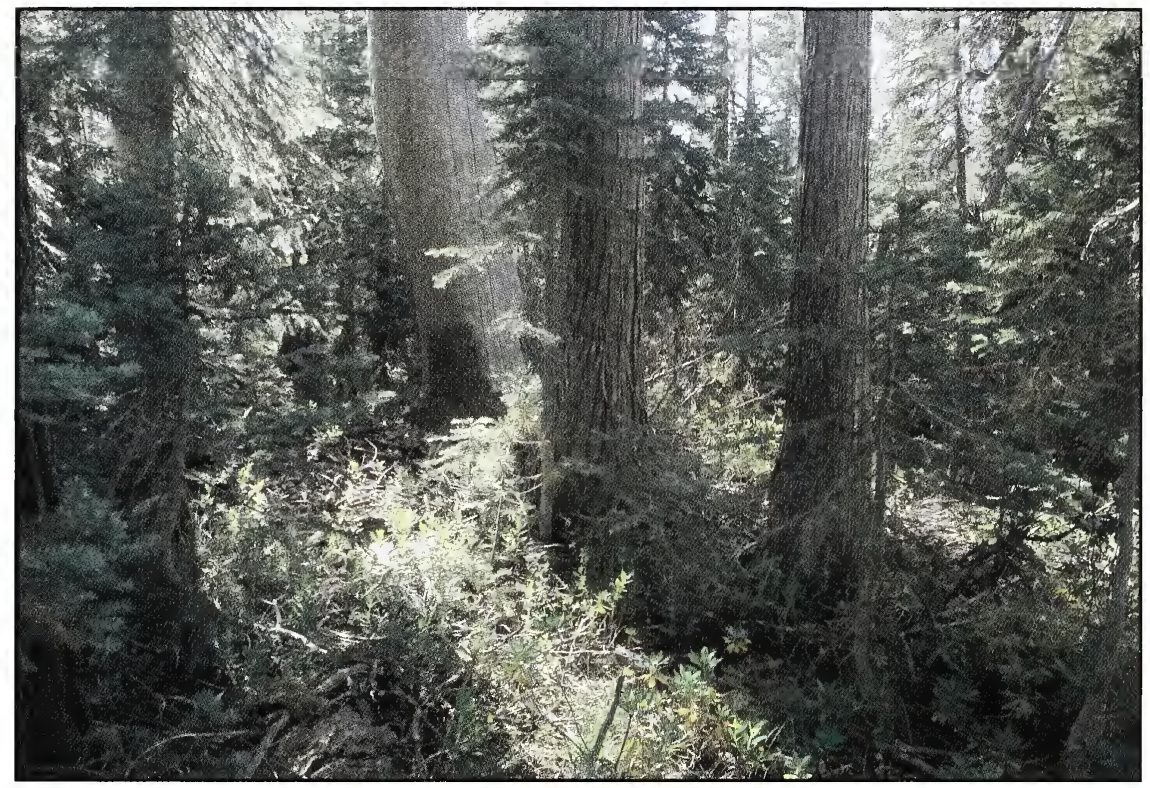

SUMMARY TABLE

(Sample size: 12)

COVER CON

Tree Overstory Layer

CHLA Port-Orford-cedar $40 \quad 100$

PIMO3 Western White Pine $13 \quad 92$

ABMAS Shasta Red Fir $\quad 10 \quad 92$

TSME Mountain Hemlock $13 \quad 75$

Tree Understory Layer

$\begin{array}{llll}\text { CHLA Port-Orford-cedar } & 6 & 100\end{array}$

PIMO3 Western White Pine 142

ABMAS Shasta Red Fir $\quad 1 \quad 58$

TSME Mountain Hemlock 267

Shrubs

$\begin{array}{llrr}\text { LEDA } & \text { Sierra Laurel } & 28 & 100 \\ \text { VAME } & \text { Thinleaf Huckleberry } & 5 & 33 \\ \text { RHOC } & \text { Western Azalea } & 4 & 33\end{array}$

Herbs \& Grasses

$\begin{array}{llrr}\text { CARl } & \text { Sedge } & 3 & 67 \\ \text { PTAQL } & \text { Bracken Fern } & 14 & 42 \\ \text { CHUMO } & \text { Western Prince's pine } & 2 & 42 \\ \text { JUN1 } & \text { Rush } & 2 & 42 \\ \text { PYSE } & \text { One-sided ptrola } & 1 & 42\end{array}$

SOILS:

Pit Depth: $18-40+$ in.;

AWC: 1.2-4.9 in.;

Parent Material: granite, mafic;

A Horizon:

Elevation: 4360-5180 ft.;

Aspect: N., N.E..;

Slope: 1-20\%;

Slope Position: basin edge, lower 1/3; Surface Rock: 0-30\%

Distance to Ocean: 81.9-87.5 miles

Coarse Fragments: 0-63\%; Textures: gl vgsl, l; Thickness: 4-12 in.;

Surface PH: 5.2-6.6 


\section{DISTRIBUTION/SETTING:}

This type was one of the least extensive Port-Orford-cedar plant associations; it covered 35 acres and was found on inland sites on the Mt. Shasta Ranger District of the Shasta-Trinity National Forest. Mean distance to the Pacific Ocean was 84.3 miles and elevation averaged 5895 feet. Landforms were mountain slopes, glacial moraines and basins with concave and undulating horizontal micro-relief and linear and concave vertical micro-relief. Slopes were level to moderate (1-20\%) in mainly edge of basin and lower one-third slope micro-positions. Radiation index was a cool .412 as a result of north and northeast facing aspects.

\section{VEGETATION SUMMARY:}

Total vegetation cover was dense (89\%) and was composed of primarily trees ( $72 \%)$ and shrubs (32\%). The tree layer was dominated by Port-Orford-cedar (40\%), western white pine $(13 \%)$, red fir $(10 \%)$, white fir $(5 \%)$ and mountain hemlock $(13 \%)$. The shrub layer was dominated by Sierra laurel (28\%). Total forb cover was low (10\%) and included western prince's pine, rattlesnake plantain, one-sided pyrola and braken fern. The grass layer was also of low cover (3\%) and dominated by sedge.

\section{SOIL SUMMARY:}

Soils in this type were frigid, moderately deep to deep, well drained and moderately well drained. They formed in glacial till and alluvium from coarse textured granite parent material. The litter layer thickness averaged 2.2 " at $93 \%$ cover. Surface rock and gravel averaged $7 \%$ cover. The average surface horizon thickness was $9 "$, texture included loams, gravelly loams and very gravelly sandy loams, coarse fragment content averaged $45 \%$ and $\mathrm{pH}$ averaged 6.0 .

Subsoil texture was gravelly loam, very gravelly sandy loam and gravelly clay loam. Subsoil coarse fragment content averaged $45 \%$. Subsurface $\mathrm{pH}$ averaged 6.0. The soils were $80 \%$ skeletal.

\section{STAND STRUCTURE SUMMARY:}

Late seral stands in this type often had 4 or more layers of trees, while early mature and mid mature stands usually had 2 layers. Large sized conifers dominated the top two layers with an average of 57 trees/acre $>21$ inches $\mathrm{dbh}, 24$ trees/acre $>30$ ir ches dbh, and 5 trees/acre $>40$ inches $\mathrm{dbh}$. Hardwoods were absent in this type.

The stand structure characteristics by layer were as follows. The top layer averaged 358 years old with an average diameter of 42.6 inches and average height of 132 feet. It was made up of dominant Port-Orford-cedar, Douglas-fir and western white pine. The second layer had an average age of 271 years with a mean diameter of 26.2 inches and a mean height of 85 feet. It included codominant Port-Orford-cedar, red fir and mountain hemlock. The third layer had an average age of 166 years with a mean diameter of 16.6 inches and a mean height of 63 feet. The third layer included intermediate sized PortOrford-cedar and mountain hemlock .

Overall biomass production (conifer + hardwoods + shrubs) was generally moderate. Modal Dunning site class was 4 with site index of 100 at 300 years. Conifer productivity was generally moderate with an average volume of $9161 \mathrm{ft}^{3}$, it ranged from 5940 to $13,790 \mathrm{ft}$. Softwood basal area averaged $443 \mathrm{ft}^{2}{ }^{2}$ and ranged from 333 to $560 \mathrm{ft}^{2}{ }^{2}$ No hardwoods were identified in this type. Stand density index was 652 and fell in the middle of the Port-Orford-cedar series. Quadratic mean diameter was 18.8 inches and fell in the upper end of the Port-Orford-cedar series.

\section{CLOSELY RELATED TYPES:}

The CHLA-TSME/LEDA type is replaced on basin landforms by the CHLA-TSME/ LEGLl type and on terminal and lateral moraines by the CHLA-TSME/CASE3 type. 


\section{LITERATURE CITED}

Abrams, L. 1968. Illustrated flora of the Pacific States: Washington, Oregon and California. Stanford University Press. Stanford, CA. Vols 1-4.

Allen, B.H. and D.V. Diaz. 1986. R-5 Ecosystem Classification Handbook. USDA For. Serv.Pacific Southwest Region, San Francisco, California. $98 \mathrm{p}$.

Atzet, T.A., D.E. White, L.A. McCrimmon, P.A. Martinez, P.R. Fong, and V.D. Randall. 1996. Field guide to the forested plant associations of Southwestern Oregon. Tech. Paper R6-NRECOL-TP-17-96. USDA Forest Service, Pacific Northwest Region, Portland OR. 353 p.

Bitterlich, W. 1947. Measurements of basal area per hectare by means of angle measurement. Allg. Forst. Holzwirts. Ztg. 58:94-96.

Carlile, M.J. 1983. Motility, taxis, and tropism in Phytophthora. Pages 95-107. In D.C. Erwin, S. Bartnicki-Garcia, and P. Tsao, eds. Phytophthora: Its Biology, Taxonomy, Ecology, and Pathology. The American Phytopathological Society, St. Paul, MN. 392 pp.

DeNitto, G. 1996. The occurrence of Port-Orford-cedar root disease in the Klamath River basin. Pages 15-16 Appendix. In D.H. Adams and J.E. Rios, eds. Proceedings, 45th Annual Meeting of the California Forest Pest Council, November 13 and 14, 1996. Sacramento, CA. California Department of Forestry and Fire Protection, Sacramento, CA.

Dunning, D. 1942. A site classification for the mixed-conifer forests of the Sierra Nevada. USDA Forest Service California Forest and Range Experiment Station. Res. Note 28. Berkeley, CA 21 p.

Edwards, S.W. 1983. Cenozoic history of Alaskan and Port Orford Chamaecyparis cedars. University of California. Ph.D. dissertation, $271 \mathrm{p}$. 
Frank, E.C., and R. Lee. 1966. Potential solar beam irradiation on slopes: Tables for 30 to 50 latitude USDA For. Serv. Res. Paper RM-18. Rocky Mountain For. and Rng. Exp. Sta. Ft. Collins, Colorado.

Hadfield, J.S., Goheen,D.J., Filip, G.M., Schmitt, C.L., and Harvey, R.D. 1986. Root diseases in Oregon and Washington conifers. USDA Forest Service, Pacific Northwest Region, Forest Pest Management. Technical Report R6-FPM-250-86. 27p.

Hall, F.C. 1970. An ecological classification proposal and its importance in land measurement. In Range and Wildlife Habitat Evaluation. A Research Symposium. USDA Misc. Pub. 1147. 210-217.

Hansen, E.M., and Hamm, P.B. 1996. Survival of Phytophthora lateralis in infected roots of Port Orford cedar. Plant Dis. 80: 1075-1078.

Hansen, E.M., Wilson, M., and Zobel, D. 1994. Roadside surveys for Port-Orford-cedar root disease on the Powers Ranger District, Siskiyou National Forest. Oregon State University Project Report to the USDA Forest Service, February 14, 1994. 21p.

Harvey, R.D., Jr., Hadfield, J.S., and Greenup, M. 1985.

Port-Orford-cedar root rot on the Siskiyou National Forest in Oregon. USDA Forest Service, Pacific Northwest Region, Forest Pest Management. Technical Report Unnumbered. 18p.

Hickman, J.C. 1993. The Jepson Manual: higher plants of California. University of California Press, Berkeley, CA. 1400 p.

Hill, M.O. 1979. TWINSPAN-A FORTRAN program for arranging multivariate data in an ordered two-way table by classification of the individuals and attributes. Cornell University, Ithaca, NY.

Hill, M.O. 1979. DECORANA-A FORTRAN program for detrended correspondence analysis and reciprocal averaging. Cornell University, Ithaca, NY. 
Jimerson, T.M. 1989. Snag densities in old-growth stands on the Gasquet Ranger District, Six Rivers National Forest, California. USDA For. Serv. Res. Paper PSW-196. Berkeley, California. $12 \mathrm{p}$.

Jimerson, T.M. and R.M. Creasy. 1990. A preliminary vegetation classification for Port-orford-cedar in Northwest California. USDA Forest Service, Six Rivers National Forest, Eureka, CA. $145 \mathrm{p}$.

Jimerson, T.M. and R.M. Creasy. 1991. Variation in Port-Orford-cedar plant communities along environmental gradients in Northwest California. pp 122-133, In: Proceedings of the Symposium on Biodiversity of Northwestern California. R.R. Harris, D.C. Erman, H.M. Kerner, Tech. Coords. University of California, Berkeley, CA. 308 p.

Jongman, R.H.G.; C.J.F. Ter Braak, and O.F.R. Van Tongeren. 1995. Data Analysis in Community and Landscape Ecology. Cambridge University Press, New York. 299 p.

Kliejunas, J., and Adams, D. 1980. An evaluation of Phytophthora root rot of Port-Orford-cedar in California. USDA Forest Service Forest Pest Mgmt. Report No. 80-1. 16p.

Kliejunas, J.T.; D.H. Adams. 1981. Phytophthora root rot of Port-Orford-cedar in California. Plant Disease 65:446-447.

Kliejunas, J. 1992. Soil monitoring for Phytophthora lateralis at Cedar Rustic Campground, Gasquet Ranger District, Six Rivers National Forest. USDA Forest Service, Pacific Southwest Region. Technical Report No. R92-3. 4p.

Lewis, J. 1982. Soil moisture and temperature regimes in the Mad River District of Six Rivers National Forest, Humboldt State University, Arcata, California. MS thesis, 187 p.

McClellan, R. 1986. Learning to care. Unpublished manuscript. McKinleyville, CA. 
McCune, B., and M.J. Mefford. 1995. PC-ORD. Multivariate Analysis of Ecological Data, Version 2.0. MjM Software Design. Gleneden Beach, Oregon, USA.

Moir, W.H., and J.A. Ludwig. 1983. Methods of forest habitat type classification. Workshop on Southwestern Habitat Types, Albuquerque, NM. 6 p.

Munsell Color Corporation. 1975. Munsell soil color charts. Kollmongen Corp. Baltimore Maryland. 20 p.

Munz, P.A. 1973. A California flora. University of California Press. Berkeley, California. 1905 p.

Nelson, E.E. 1964. Phytophthora root disease of Port-Orford-cedar. 1964 Survey Findings. Office Report, File Designation 4600, June 12, 1964. Pacific Northwest Forest and Range Experiment Station. Portland, OR. 4p.

Noss, R.F.1987. From plant communities to landscapes in conservation inventories; a look at the Nature Conservancy (USA). Biological Conservation 41 (1): 11-37.

Ostrofsky, W.D., Pratt, R.G., and Roth, L.F. 1977. Detection of Phytophthora lateralis in soil organic matter and factors that affect its survival. Phytopathology 67:79-84.

Pfister, R.D. and S.F. Arno. 1980. Classifying forest habitat types based on potential climax vegetation. For. Sci., 26(1), 52-70.

Reed, M.J., W.R. Powell, and B.S. Bal. 1963. Electronic data processing codes for California wildland plants. Research Note PSW-N20. Berkeley, CA: Pacific Southwest Forest and Range Experiment Station, Forest Service, U.S. Department of Agriculture; 314 p.

Roth, L.F., Bynum, H.H., and Nelson, E.E. 1972. Phytophthora root rot of Port-Orford-cedar. USDA Forest Service Forest Pest Leafl. 131. $7 \mathrm{pp}$. 
Roth, L.F., Harvey, Jr., R.D. and Kliejunas, J.T. 1987. Port-Orford-cedar root disease. USDA Forest Service, Pacific Northwest Region. Forest Pest Management Report No. R6-FPM-PR-010-91. 11p.

Roth, L.F., Trione, E.J., and Ruhmann, W.H. 1957. Phytophthora induced root rot of native Port-Orford-cedar. J. Forestry 55:294-298.

Ter Braak, C.J.F. 1988. CANOCO - a FORTRAN program for Canonical Community Ordination. Microcomputer Power, Ithaca, New York, USA.

Trione, E.J. 1959. The pathology of Phytophthora lateralis on native Chamaecyparis lawsoniana. Phytopathology 49:306-310.

Trione, E.J. 1974. Sporulation and germination of Phytophthora lateralis. Phytopathology 64:1531-1533.

Tsao, P.H. 1993. Detection of Port-Orford-cedar pathogen in soil. University of California-Riverside Project Report to the USDA Forest Service.

Tucker, C.M., and Milbrath, J.A. 1942. Root rot of Chamaecyparis caused by a species of Phytophthora. Mycologia 34: 94-103.

USDA, 1992. Strategy for implementing ecosystem management Pacific Southwest Region, Forest Service, U.S. Department of Agriculture. 17 p.

USDA, 1997. Ecological Subregions of California, Section and Subsection Descriptions. United States Department of Agriculture,Forest Service, Pacific Southwest Region, R5-EMTP-005.

Zobel, D.B. L.F. Roth, and G.L. Hawk. 1985. Ecology, pathology and management of Port-Orford-Cedar (Chamaecyparis lawsoniana). USDA For. Serv. Gen. Tech. Rep. PNW-184. Pac. Northwest For. and Range Expt. Stn. Portland, OR. 161 p. 
t

t

t

c

e

c

c 
APPENDIX I: PLANT SPECIES LIST 


\section{Plant Species List}

\section{Tree Species}

Species

Abies concolor

Abies magnifica var. shastensis

Acer macrophyllum

Alnus rhombifolia

Alnus spp.

Calocedrus decurrens

Chamaecyparis lawsoniana

Cornus nuttallii

Pinus contorta var. contorta

Pinus jeffreyi

Pinus lambertiana

Pinus monticola

Pinus ponderosa

Pseudotsuga menziesii

Quercus chrysolepis

Taxus brevifolia

Tsuga mertensiana
EDPcode CommonName

ABCO White fir

ABMAS Shasta red fir

ACMA Bigleaf maple

ALRH2 White Alder

ALN Alder

CADE3 Incense Cedar

CHLA Port-Orford-cedar

CONU2 Pacific dogwood

PICO1 Lodgepole pine

PIJE Jeffrey pine

PILA Sugar pine

PIMO3 Western white pine

PIPO Ponderosa pine

PSME Douglas-fir

QUCH2 Canyon live oak

TABR Pacific yew

TSME Mountain hemlock

\section{Shrub Species}

Acer glabrum var. torreyi

Alnus sinuata

Amelanchier spp.

Arctostaphylos nevadensis

Berberis aquifolium

Berberis nervosa

Calycanthus occidentalis

Castinopsis sempivirens

Ceanothus prostratus

Ledum glandulosum

Leucothoe davisiae

Lithocarpus densiflorus var. echinoides

Paxistima myrsinites

Phyllodoce empetriformis

Physocarpus capitatus

Quercus vaccinifolia
ACGLT Rocky Mtn. maple

ALSI2 Sitka alder

AME Serviceberry

ARNE2 Pinemat manzanita

BEAQ Tall Oregon-grape

BENEl Dwarf Oregon-grape

CAOC5 Spicebush

CASE3 Bush chinquapin

CEPR Squaw carpet

LEGLl Western Labrador tea

LEDA Sierra laurel

LIDEE Dwarf tanbark

PAMY Oregon boxwod

PHEM Pink mountainheather

PHCA8 Pacific ninebark

QUVA Huckleberry oak 
Rhamnus californica

Rhamnus purshiana

Rhododendron occidentale

Rhus (Toxicodendron) diversiloba

Ribes spp.

Rosa spp.

Rubus leucodermis

Rubus parviflorus

Rubus ursinus

Rubus spp.

Salix sp.

Spirea douglasii

Symphoricarpos mollis

Vaccinium membranaceum

Vaccinium scoparium

$\begin{array}{ll}\text { RHCA } & \text { Coffeeberry } \\ \text { RHPU } & \text { Cascara } \\ \text { RHOC } & \text { Western azalea } \\ \text { RHDI } & \text { Poison oak } \\ \text { RIB } & \text { Gooseberry species } \\ \text { ROS } & \text { Rose species } \\ \text { RULE } & \text { Western raspberry } \\ \text { RUPA } & \text { Thimbleberry } \\ \text { RUUR } & \text { Trailing blackberry } \\ \text { RUB } & \text { Blackberry species } \\ \text { SAL13 } & \text { Willow species } \\ \text { SPDO } & \text { Douglas' spirea } \\ \text { SYMO } & \text { Creeping snowberry } \\ \text { VAME } & \text { Thinleaf huckleberry } \\ \text { VASC } & \text { Littleleaf huckleberry }\end{array}$

Herb and Fern Species

Achillea millefolium

Aconitum columbianum

Adenocaulon bicolor

Adiatum pedatum var. aleuticum

Allium validum

Anemone deltoidea

Anemone drummondii

Anemone quiquefolia var. minor

Anemone spp.

Angelica tomentosa

Aquilegia formosa

Arnica spp.

Athyrium felix-femina

Boykinia major

Caltha howellii

Campanula prenanthoides

Chimaphilla menziesii

Chimaphilla umbellata var. occidentalis

Clintonia uniflora

Cypripedium californicum

Darlingtonia californica

Dicentra formosa

Dodecatheon jeffreyi

Equisetum arvense

Galium spp.

Galium triflorum

$\begin{array}{ll}\text { ACMI } & \text { Common yarrow } \\ \text { ACCO2 } & \text { Monkshood } \\ \text { ADBI } & \text { Trailplant } \\ \text { ADPEA } & \text { Five-finger fern } \\ \text { ALVA } & \text { Pacific onion } \\ \text { ANDE } & \text { Three-leaf anemone } \\ \text { ANDR } & \text { Drummonds anemone } \\ \text { ANQUM } & \text { Nightcaps } \\ \text { ANE1 } & \text { Anemone } \\ \text { ANTO } & \text { Wooly angelica } \\ \text { AQFO } & \text { Red columbine } \\ \text { ARN8 } & \text { Arnica species } \\ \text { ATFIC } & \text { Lady fern } \\ \text { BOMA2 } & \text { Mountain boykinia } \\ \text { CAHO2 } & \text { Marsh marigold } \\ \text { CAPR6 } & \text { California harebell } \\ \text { CHME } & \text { Little prince's pine } \\ \text { CHUMO } & \text { Western prince's pine } \\ \text { CLUN2 } & \text { Bride's Bonnet } \\ \text { CYCA } & \text { California lady-slipper } \\ \text { DACA2 } & \text { California pitcher-plant } \\ \text { DIFO } & \text { Bleeding heart } \\ \text { DOJE } & \text { Mountain shootingstar } \\ \text { EQAR } & \text { Common horsetail } \\ \text { GAL } & \text { Bedstraw } \\ \text { GATR2 } & \text { Bedstraw }\end{array}$


Gentiana spp.

Goodyera oblongifolia

Habenaria sparsiflora

Habenaria spp.

Helenium bigelovii

Hieracium albiflorum

Iris spp.

Lathyrus spp.

Ligusticum grayi

Lilium pardilinum

Lilium spp.

Linnea borealis var. longiflora

Listera caurina

Listera convallarioides

Lotus spp.

Lupinus spp.

Osmorhiza chilensis

Parnassia palustris var. californica

Penstemon spp.

Polygala cornuta

Polystichum munitum

Prunella vulgaris

Pteridium aquilinum var. lanuginosum

Pterospora andromedea

Pyrola assarifolia v. bracteata

Pyrola assarifolia v. purpurea

Pyrola picta

Pyrola picta var. aphylla

Pyrola picta var. dentata

Pyrola secunda

Saxifraga spp.

Schoenolirion album

Sedum spp.

Senecio triangularis

Silene lemmonii

Stachys spp.

Stellaria jamesiana

Stylocline amphibola

Tofieldia glutinosa var. occidentalis

Trientalis latifolia

Trifolium kingii var productum

Trifolium spp.

Trillium ovatum

Veratrum californicum

Veratrum spp.
GEN2 Gentian species

GOOB Rattlesnake plantain

HASP Canyon bog-orchid

$\mathrm{HAB} \quad$ Bog Orchid species

HEBI Bigelow's sneezeweed

HIAL White hawkweed

IRI Iris species

LAT $1 \quad$ Pea species

LIGR Grey's licoriceroot

LIPA1 Leopard Lily

LIL Lily species

LIBOL Twinflower

LICA4 Twayblade

LICO4 Twayblade

LOT3 Lotus species

LUP3 Lupine species

OSCH Sweet-cicely

PAPAC Calif. Grass-of-Parnassus

PEN Penstemon species

POCO Milkwort

POMU1 Sword fern

PRVU Self-heal

PTAQL Bracken fern

PTAN Pinedrops

PYASB2 Pink wintergreen

PYASP Liverleaf pyrola

PYPI White-vein wintergreen

PYPIA Leafless pyrola

PYPID Toothleaf pyrola

PYSE One-sided pyrola

SAX2 Saxifrage species

SCAL White rush lily

SED Stonecrop species

SETR Woolly ragwort

SILE2 Lemmon's catchfly

STA3 Hedgenettle species

STJA Sticky starwort

STAM Cottonweed

TOGLO tofieldia

TRLA3 Starflower

TRKIP King's clover

TRI11 Clover species

TROV2 White trillium

VECA California false hellebore

VER1 Hellebore species 
Viola glabella

Viola lobata

Viola spp.

Xerophyllum tenax
VIGL Stream violet

VILO Palmately lobed violet

VIO3 Violet species

XETE Beargrass

Grass, Sedge and Rush Species

Agrostis thurberiana

Carex spp.

Deschampsia spp.

Festuca californica

Festuca occidentalis

Graminoid spp.

Glyceria striata

Juncus spp.
AGTH2 Thurber's bentgrass

CARl Sedge species

DES1 Hairgrass

FECA California fescue

FEOCl Western fescue

GRAM Grass species

GLST Fowl mannagrass

JUN1 Rush species 
APPENDIX II: ENVIRONMENT SUMMARY 


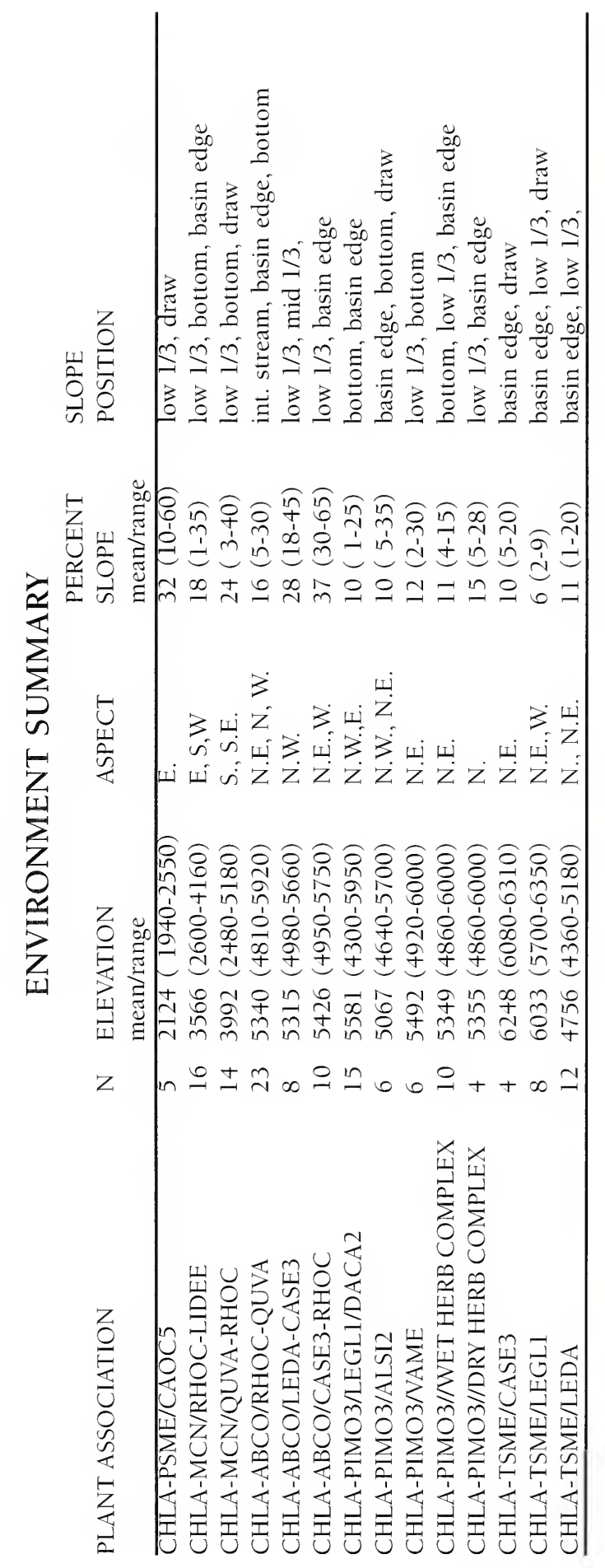




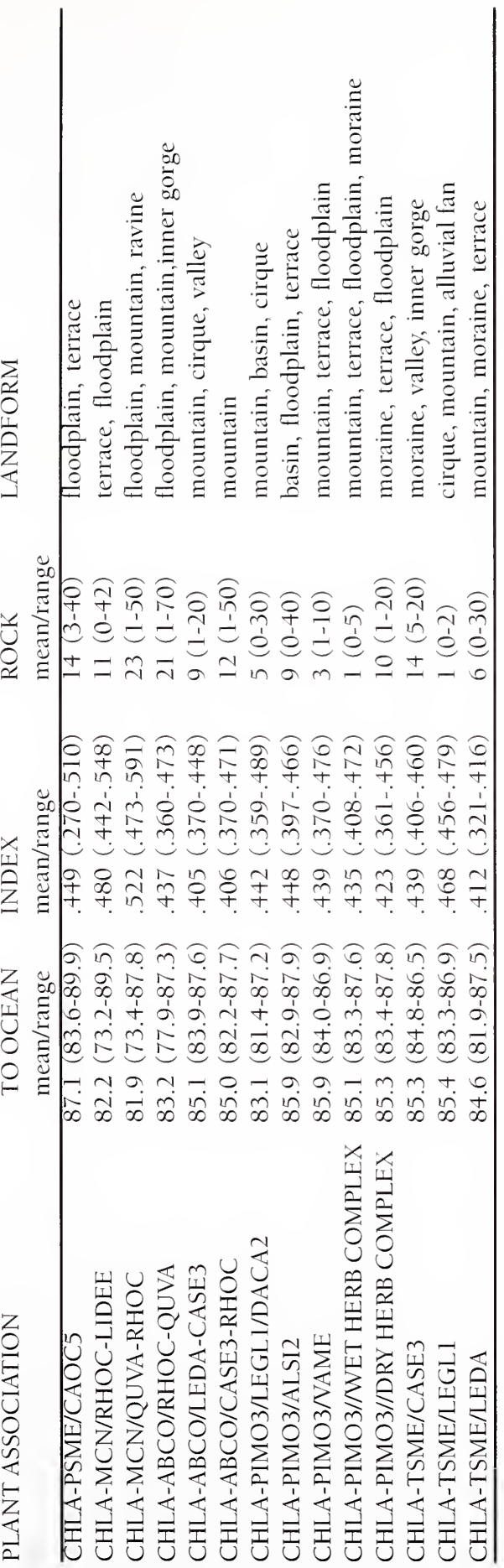


APPENDIX III: SOIL SUMMARY 


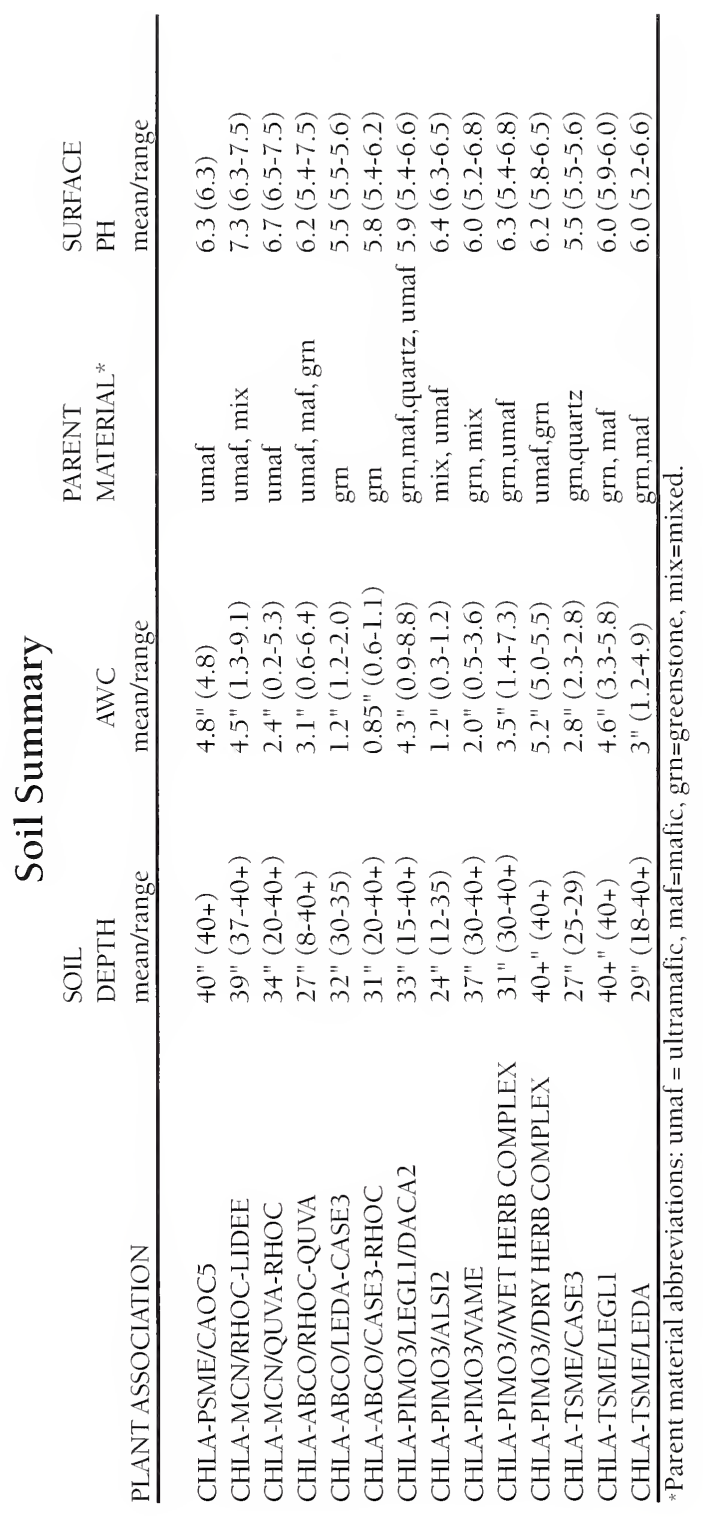




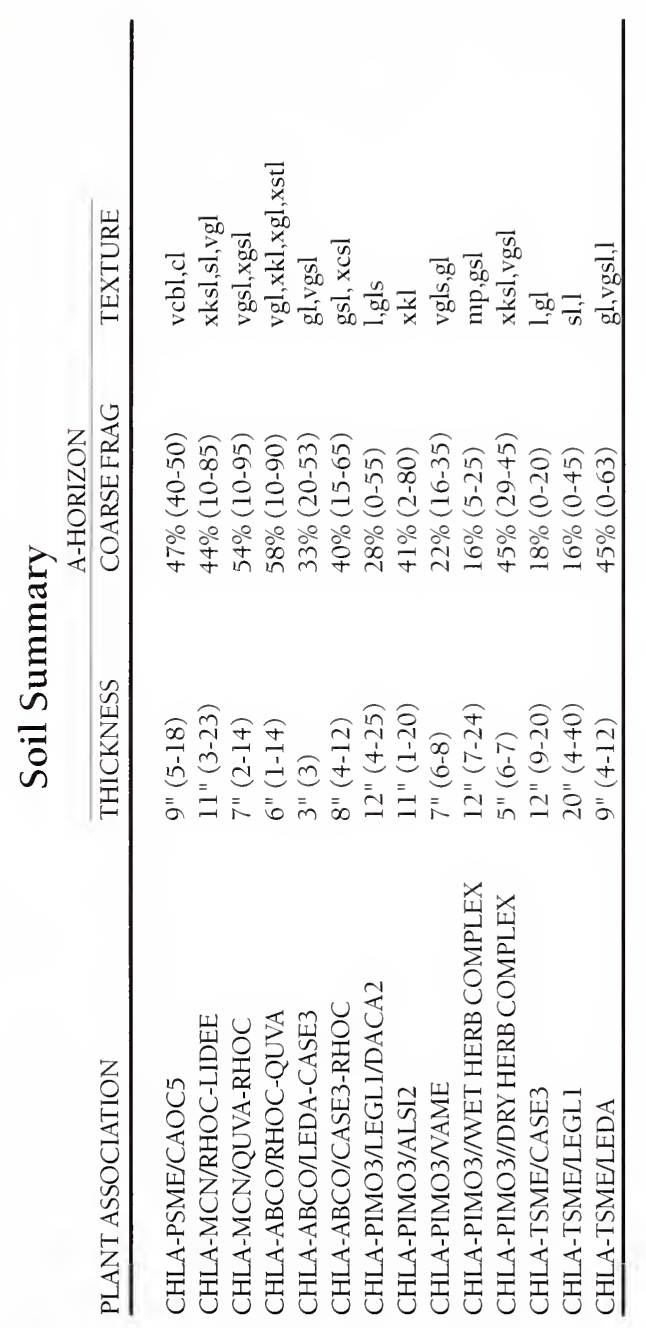





\section{APPENDIX IV: STAND STRUCTURE SUMMARY}




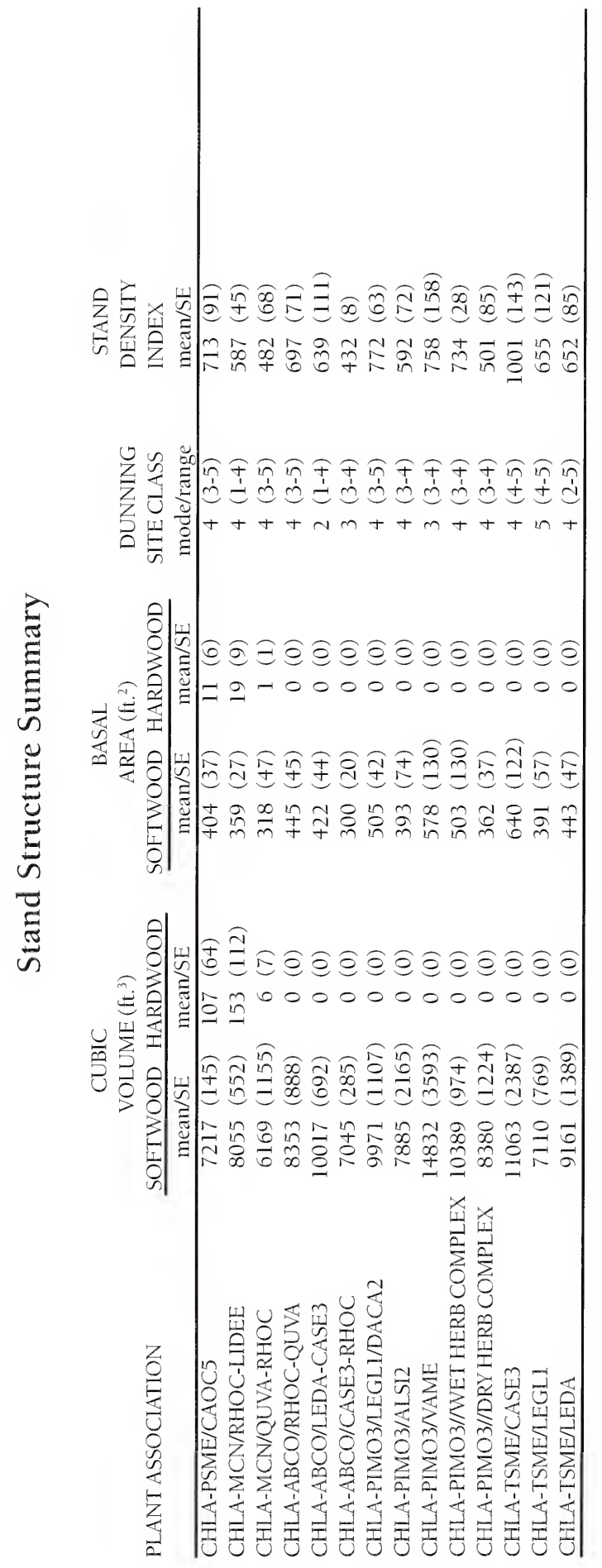

Sh-106 


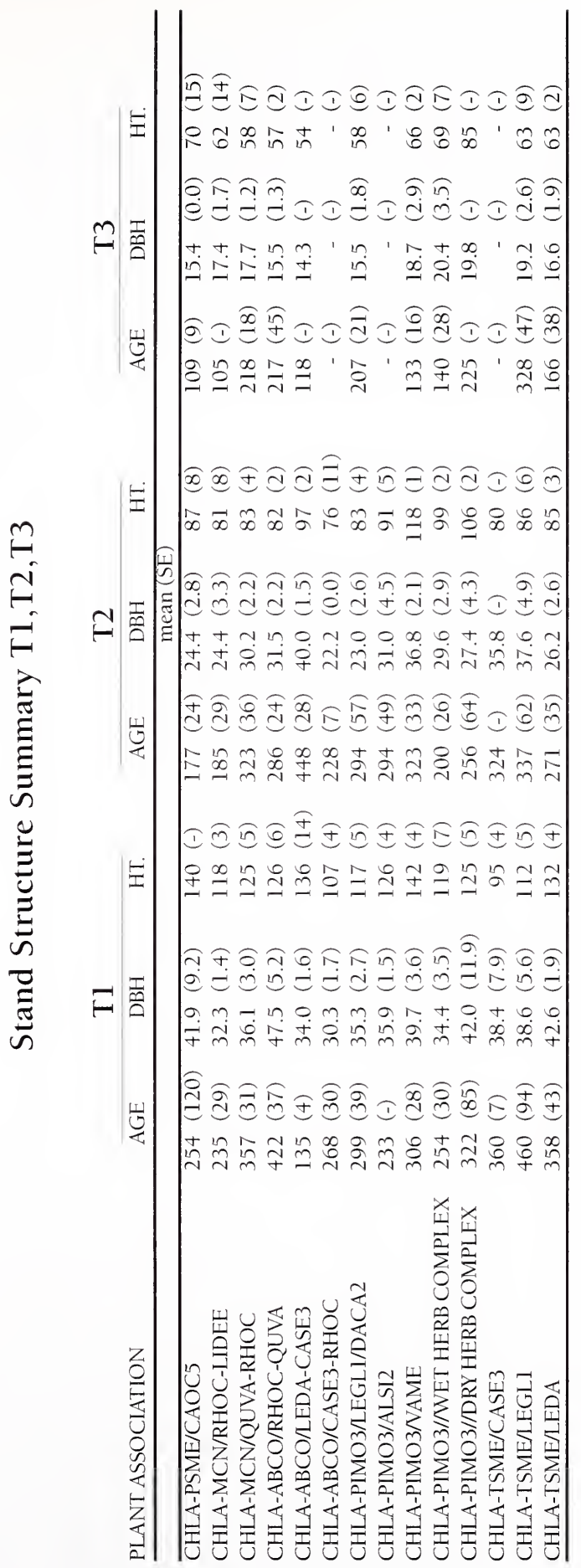

Sh-107 


\section{APPENDIX V: VEGETATION SUMMARY}




\section{VEGETATION SUMMARY}

PLANT ASSOCIATION:

$\%$ COVER

\begin{tabular}{lcccc} 
VEGETATIONLAYER: & $\begin{array}{l}\text { CHLA-PSME/ } \\
\text { CAOC5 }\end{array}$ & $\begin{array}{l}\text { CHLA-MCN/ } \\
\text { RHOC-LIDEE }\end{array}$ & $\begin{array}{c}\text { CHLA-MCN/ } \\
\text { QUVA-RHOC }\end{array}$ & $\begin{array}{c}\text { CHLA-ABCO/ } \\
\text { RHOC-QUVA }\end{array}$ \\
\hline N & 5 & 16 & 14 & 23 \\
TOTAL COVER & 97 & 93 & 82 & 87 \\
GRASS COVER & 5 & 4 & 6 & 3 \\
FORB COVER & 4 & 6 & 4 & 9 \\
SHRUB COVER & 49 & 23 & 27 & 24 \\
TREE COVER & 88 & 80 & 65 & 74
\end{tabular}

TREE OVERSTORY:

\% COVER (CONSTANCY)

\begin{tabular}{|c|c|c|c|c|c|c|c|}
\hline ALDER (ALN) & $-(-)$ & 9 & $(56)$ & & (14) & - & $(-)$ \\
\hline BIGLEAF MAPLE (ACMA) & $-(-)$ & 7 & (31) & 5 & (7) & & $(-)$ \\
\hline CANYON LIVE OAK (QUCH2) & $16(80)$ & 16 & (13) & 8 & (7) & - & $(-)$ \\
\hline DOUGLAS-FIR (PSME) & $24(100)$ & 19 & $(100)$ & 22 & $(100)$ & 8 & $(74)$ \\
\hline INCENSE CEDAR (CADE3) & $12(40)$ & 8 & $(69)$ & 6 & $(57)$ & 2 & (26) \\
\hline JEFFREY PINE (PIJE) & $-(-)$ & 6 & $(10)$ & 10 & (7) & 4 & (30) \\
\hline LODGEPOLE PINE (PICO1) & $-(-)$ & - & $(-)$ & - & $(-)$ & 6 & (30) \\
\hline MOUNTAIN HEMLOCK (TSME) & $-(-)$ & - & $(-)$ & - & $(-)$ & 1 & (4) \\
\hline PACIFIC DOGWOOD (CONU2) & $2(20)$ & 3 & $(44)$ & 5 & (57) & - & $(-)$ \\
\hline PACIFIC YEW (TABR) & $-(-)$ & 4 & $(25)$ & 5 & (7) & 3 & (4) \\
\hline PONDEROSA PINE (PIPO) & $10(40)$ & 7 & $(44)$ & 2 & (50) & - & $(-)$ \\
\hline PORT ORFORD CEDAR (CHLA) & $51(100)$ & 47 & $(100)$ & 34 & $(100)$ & 48 & $(100)$ \\
\hline SHASTA RED FIR (ABMAS) & $-(-)$ & 2 & (6) & - & $(-)$ & 2 & $(17)$ \\
\hline SUGAR PINE (PILA) & $10(20)$ & 3 & $(56)$ & 4 & (57) & 3 & (22) \\
\hline WESTERN WHITE PINE (PIMO3) & $-(-)$ & 2 & (6) & - & $(-)$ & 7 & (78) \\
\hline WHITE FIR (ABCO) & $-(-)$ & 5 & $(75)$ & 7 & (64) & 10 & $(100)$ \\
\hline TREE UNDERSTORY: & \multicolumn{7}{|c|}{$\%$ COVER (CONSTANCY) } \\
\hline BIGLEAF MAPLE (ACMA) & $-(-)$ & 1 & $(19)$ & - & $(-)$ & - & $(-)$ \\
\hline CANYON LIVE OAK (QUCH2) & $1(100)$ & 1 & (19) & 1 & (14) & - & $(-)$ \\
\hline DOUGLAS-FIR (PSME) & $1(40)$ & 1 & $(81)$ & 1 & $(100)$ & 1 & (30) \\
\hline INCENSE CEDAR (CADE3) & $1(40)$ & 1 & $(31)$ & 1 & $(50)$ & 1 & (26) \\
\hline JEFFREY PINE (PIJE) & $-(-)$ & 1 & (6) & 1 & (7) & 1 & (9) \\
\hline LODGEPOLE PINE (PICO1) & $-(-)$ & - & $(-)$ & - & $(-)$ & 1 & (4) \\
\hline MOUNTAIN HEMLOCK (TSME) & $-(-)$ & - & $(-)$ & - & $(-)$ & - & $(-)$ \\
\hline PACIFIC DOGWOOD (CONU2) & $1(20)$ & 2 & $(25)$ & - & $(-)$ & - & $(-)$ \\
\hline PACIFIC YEW (TABR) & $-(-)$ & 1 & (13) & 1 & (14) & 2 & (9) \\
\hline PONDEROSA PINE (PIPO) & $-(-)$ & - & $(-)$ & 1 & (36) & - & $(-)$ \\
\hline PORT ORFORD CEDAR (CHLA) & $1(100)$ & 2 & $(100)$ & 3 & $(100)$ & 4 & (100) \\
\hline SHASTA RED FIR (ABMAS) & $-(-)$ & - & $(-)$ & - & $(-)$ & 2 & (17) \\
\hline SUGAR PINE (PILA) & $1(20)$ & 1 & $(25)$ & 1 & (57) & 1 & (4) \\
\hline WESTERN WHITE PINE (PIMO3) & $-(-)$ & - & $(-)$ & - & $(-)$ & 1 & $(65)$ \\
\hline WHITE FIR (ABCO) & $-(-)$ & 2 & (69) & 2 & (64) & 3 & (78) \\
\hline
\end{tabular}




\begin{tabular}{lcccc} 
& $\begin{array}{c}\text { CHLA-PSME/ } \\
\text { CHRUBS:: }\end{array}$ & $\begin{array}{c}\text { CHLA-MCN/ } \\
\text { RHOC-LIDEE }\end{array}$ & $\begin{array}{c}\text { CHLA-MCN/ } \\
\text { QUVA-RHOC }\end{array}$ & $\begin{array}{c}\text { CHLA-ABCO/ } \\
\text { RHOC-QUVA }\end{array}$ \\
\hline BUSH CHINQUAPIN (CASE3) & $-(-)$ & $-(-)$ & $-(-)$ & $1(4)$ \\
COFFEEBERRY (RHCA) & $1(80)$ & $6(31)$ & $2(57)$ & $-(-)$ \\
DOUGLAS SPIREA (SPDO) & $-(-)$ & $-(-)$ & $1(7)$ & $1(13)$ \\
DWARF TANBARK (LIDEE) & $-(-)$ & $4(75)$ & $-(-)$ & $-(-)$ \\
HUCKLEBERRY OAK (QUVA) & $-(-)$ & $3(56)$ & $11(86)$ & $3(70)$ \\
LITTLELEAF HUCKLEBERRY (VASC) & $-(-)$ & $-(-)$ & $-(-)$ & $-(-)$ \\
PINEMAT MANZANITA (ARNE2) & $-(-)$ & $-(-)$ & $1(7)$ & $2(35)$ \\
PINK MOUNTAIN HEATH (PHEM) & $-(-)$ & $-(-)$ & $-(-)$ & $-(-)$ \\
SERVICEBERRY (AME) & $1-(20)$ & $1-(19)$ & $1-43)$ & $1(70)$ \\
SIERRA LAUREL (LEDA) & $-(-)$ & $-(-)$ & $-(-)$ & $6(17)$ \\
SITKA ALDER (ALSI2) & $-(-)$ & $5(6)$ & $-(-)$ & $1(9)$ \\
SPICEBUSH (CAOC5) & $45(100)$ & $-(-)$ & $-(-)$ & $-(-)$ \\
THIMBLEBERRY (RUPA) & $-(-)$ & $3(13)$ & $-(-)$ & $1(13)$ \\
THINLEAF HUCKLEBERRY (VAME) & $-(-)$ & $-(-)$ & $-(-)$ & $4(13)$ \\
WESTERN AZALEA (RHOC) & $4(80)$ & $17(88)$ & $17(93)$ & $18(100)$ \\
WESTERN LABRADOR TEA (LEGL1) & $-(-)$ & $-(-)$ & $-(-)$ & $3(22)$
\end{tabular}

HERBS \& GRASSES:

$\%$ COVER (CONSTANCY)

\begin{tabular}{|c|c|c|c|c|}
\hline BEARGRASS (XETE) & $-(-)$ & l (13) & $2(14)$ & $7(43)$ \\
\hline BEDSTRAW (GAL) & $-(-)$ & $-(-)$ & $1(36)$ & $1(4)$ \\
\hline BOG ORCHID (HAB) & $-(-)$ & $-(-)$ & $-(-)$ & $1(9)$ \\
\hline BRACKEN FERN (PTAQL) & I $(60)$ & $2(56)$ & $1(36)$ & $3(26)$ \\
\hline BRIDE'S BONNET (CLUN2) & $-(-)$ & $-(-)$ & $-(-)$ & $-(-)$ \\
\hline CALIF FALSE HELLEBORE (VECA) & $-(-)$ & $-(-)$ & $1(11)$ & $2(21)$ \\
\hline CALIF. LADY-SLIPPER (CYCA) & $1(60)$ & $2(26)$ & $-(-)$ & $-(-)$ \\
\hline CALIF PITCHER PLANT (DACA2) & $-(-)$ & $6(8)$ & $7(7)$ & $3(9)$ \\
\hline COLUMBIAN MONKSHOOD (ACCO4) & $-(-)$ & $-(-)$ & $-(-)$ & $8(4)$ \\
\hline FIVE-FINGER FERN (ADPEA) & $2(80)$ & $2(38)$ & l (21) & $2(26)$ \\
\hline GRAY'S LICORICE ROOT (LIGR) & $-(-)$ & $1(6)$ & $1(7)$ & $7(17)$ \\
\hline HOWELLS MARIGOLD (CAHO) & $-(-)$ & $-(-)$ & $-(-)$ & $-(-)$ \\
\hline KING'S CLOVER (TRKIP) & $-(-)$ & $-(-)$ & $-(-)$ & $-(-)$ \\
\hline LEMMON'S CATCHFLY (SILE) & $-(-)$ & $-(-)$ & $-(-)$ & $-(-)$ \\
\hline LILY (LIL) & $1(40)$ & $1(31)$ & $1(21)$ & $1(17)$ \\
\hline LITTLE PRINCE'S PINE (CHME) & $1(33)$ & $1(19)$ & $1(36)$ & $1(39)$ \\
\hline MILKWORT (POCO) & $1(60)$ & $1(19)$ & $1(29)$ & $-(-)$ \\
\hline MOUNTAIN BOYKINIA (BOMA2) & $-(-)$ & $1(6)$ & $-(-)$ & $-(-)$ \\
\hline ONE-SIDED PYROLA (PYSE) & $-(-)$ & $-(-)$ & $-(-)$ & $2(9)$ \\
\hline RATTLESNAKE PLANTAIN (GOOB) & $1(40)$ & $1(44)$ & $1(21)$ & $1(35)$ \\
\hline RED COLUMBINE (AQFO) & $-(-)$ & $-(-)$ & $1(7)$ & $1(13)$ \\
\hline STARFLOWER (TRLA3) & $1(40)$ & $1(44)$ & l (29) & $-(-)$ \\
\hline SWORDFERN (POMU1) & $1(40)$ & $1(13)$ & $1(21)$ & $-(-)$ \\
\hline TWINFLOWER (LIBOL) & $-(-)$ & $1(6)$ & $-(-)$ & $9(22)$ \\
\hline WESTERN PRINCE'S PINE (CHUMO) & $1(20)$ & $1(31)$ & $2(29)$ & $1(52)$ \\
\hline WHITE HAWKWEED (HIAL) & $-(-)$ & $1(6)$ & l (21) & $1(13)$ \\
\hline WHITE RUSH LILY (SCAL) & $1(20)$ & $1(13)$ & $1(36)$ & $1(22)$ \\
\hline WHITE-VEINED WINTERGREEN (PYPI & I) $-(-)$ & $1(6)$ & l (7) & $1(43)$ \\
\hline WOOLLY RAGWORT (SETR) & $-(-)$ & $-(-)$ & $-(-)$ & $1(13)$ \\
\hline GRASS (GRAM) & $1(20)$ & $1(13)$ & $-(-)$ & $-(-)$ \\
\hline RUSH (JUN2) & $-(-)$ & $-(-)$ & $-(-)$ & $-(-)$ \\
\hline SEDGE (CAR1) & $3(80)$ & $1(44)$ & $8(64)$ & $2(70)$ \\
\hline
\end{tabular}




\section{VEGETATION SUMMARY}

\begin{tabular}{|c|c|c|c|c|}
\hline \multirow{2}{*}{ PLANT ASSOCIATION: } & \multicolumn{4}{|c|}{$\%$ COVER } \\
\hline & CHLA-ABCO/ & CHLA-ABCO/ & CHLA-PIMO3/ & CHLA-PIMO3/ \\
\hline VEGETATIONLAYER: & LEDA-CASE3 & CASE3-RHOC & LEGL1/DACA2 & ALSI2 \\
\hline$\overline{\mathrm{N}}$ & 8 & 10 & 15 & 6 \\
\hline TOTAL COVER & 92 & 94 & 97 & 93 \\
\hline GRASS COVER & 3 & 3 & 11 & 25 \\
\hline FORB COVER & 9 & 12 & 9 & 16 \\
\hline SHRUB COVER & 42 & 19 & 42 & 45 \\
\hline TREE COVER & 71 & 81 & 73 & 67 \\
\hline
\end{tabular}

TREE OVERSTORY:

\% COVER (CONSTANCY)

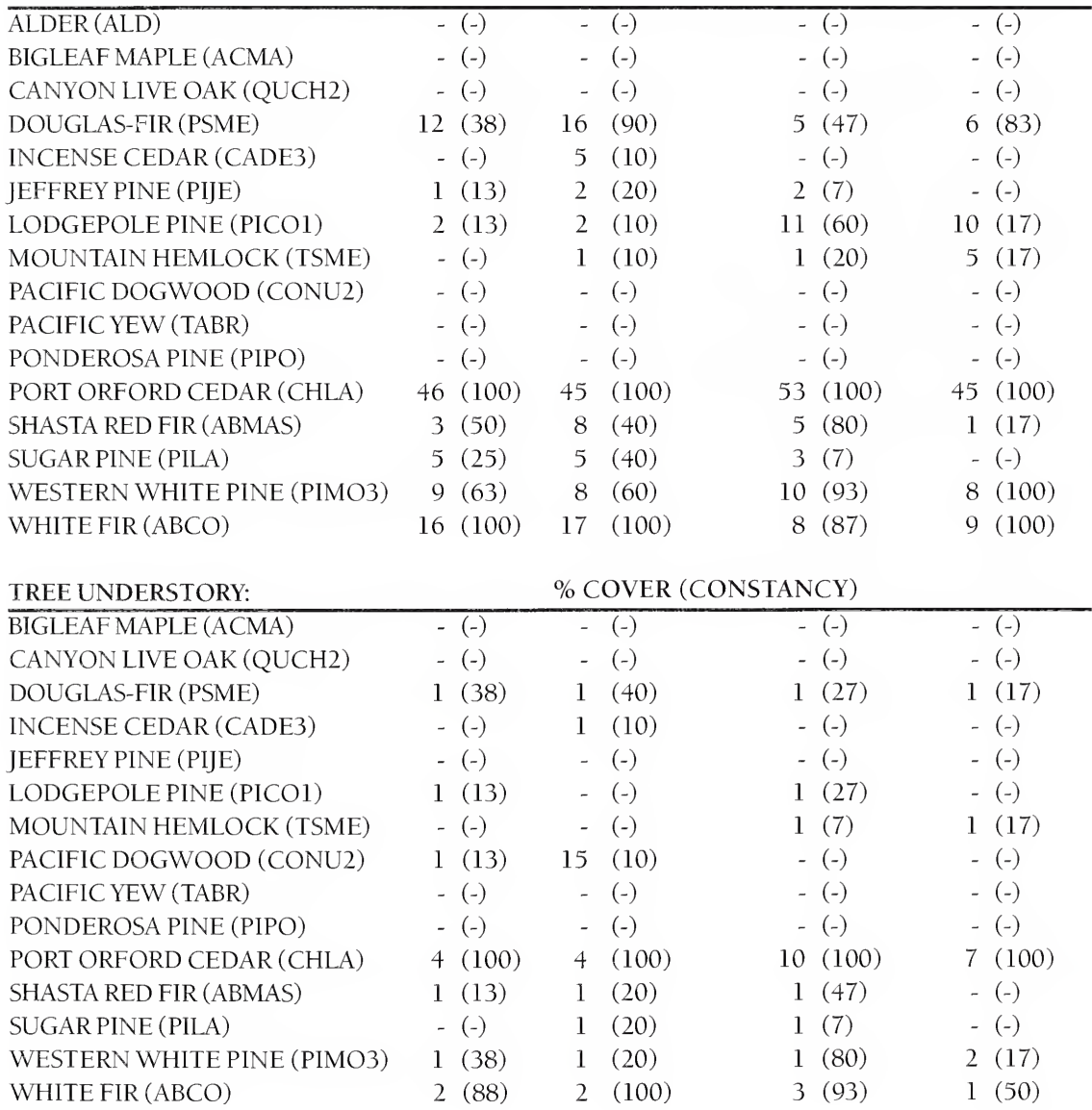




\section{PLANT ASSOCIATION:}

\begin{tabular}{lcccc} 
& CHLA-ABCO/ & CHLA-ABCO/ & CHLA-PIMO3/ & CHLA-PIMO3/ \\
SHRUBS: & LEDA-CASE3 & CASE3-RHOC & LEGL1/DACA2 & ALSI2 \\
\hline BUSH CHINQUAPIN (CASE3) & $6(88)$ & $7(100)$ & $4(33)$ & $-(-)$ \\
COFFEEBERRY (RHCA) & $-(-)$ & $-(-)$ & $-(-)$ & $-(-)$ \\
DOUGLAS' SPIREA (SPDO) & $-(-)$ & $1(10)$ & $1(7)$ & $-(-)$ \\
DWARF TANBARK (LIDEE) & $-(-)$ & $1(10)$ & $15(7)$ & $-(-)$ \\
HUCKLEBERRY OAK (QUVA) & $1-(13)$ & $3(50)$ & $2(13)$ & $-(-)$ \\
LITTLELEAF HUCKLEBERRY (VASC) & $-(-)$ & $-(-)$ & $2(13)$ & $-(-)$ \\
PINEMAT MANZANITA (ARNE2) & $-(-)$ & $-(-)$ & $2(7)$ & $-(-)$ \\
PINK MOUNTAIN HEATH (PHEM) & $-(-)$ & $-(-)$ & $-(-)$ & $-(-)$ \\
SERVICEBERRY (AME) & $2(13)$ & $1(30)$ & $3(13)$ & $5(17)$ \\
SIERRA LAUREL (LEDA) & $30(100)$ & $-(-)$ & $6(33)$ & $-(-)$ \\
SITKA ALDER (ALSI2) & $-(-)$ & $3(30)$ & $6(27)$ & $31(100)$ \\
SPICEBUSH (CAOC5) & $-(-)$ & $-(-)$ & $-(-)$ & $-(-)$ \\
THIMBLEBERRY (RUPA) & $1(25)$ & $1(20)$ & $1(7)$ & $3(33)$ \\
THINLEAF HUCKLEBERRY (VAME) & $35(13)$ & $1(10)$ & $3(33)$ & $-(-)$ \\
WESTERN AZALEA (RHOC) & $6(63)$ & $7(80)$ & $8(60)$ & $4(50)$ \\
WESTERN LABRADOR TEA (LEGL1) & $6(25)$ & $1(10)$ & $28(100)$ & $-(-)$
\end{tabular}

HERBS \& GRASSES:

$\%$ COVER (CONSTANCY)

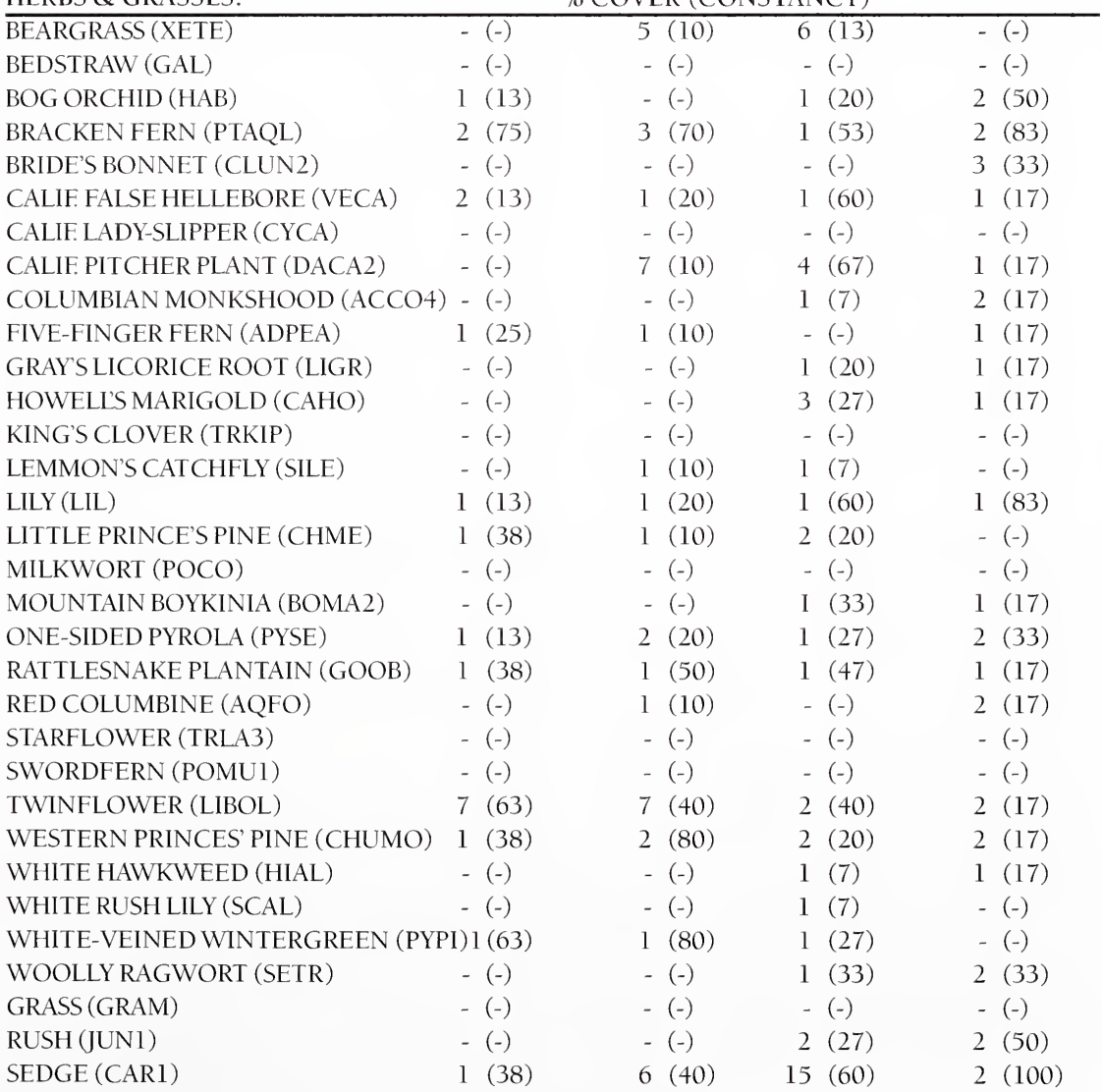




\section{VEGETATION SUMMARY}

\begin{tabular}{lccc} 
PLANT ASSOCIATION: & $\begin{array}{l}\text { \%COVER } \\
\text { CHLA-PIMO3/ } \\
\text { VEGETATIONLAYER: }\end{array}$ & $\begin{array}{l}\text { CHLA-PIMO3// } \\
\text { wet herb complex }\end{array}$ & $\begin{array}{l}\text { CHLA-PIMO3// } \\
\text { dry herb complex }\end{array}$ \\
\hline N & 6 & 10 & 4 \\
TOTAL COVER & 94 & 93 & 92 \\
GRASS COVER & 2 & 14 & 3 \\
FORB COVER & 15 & 37 & 6 \\
SHRUB COVER & 54 & 10 & 70 \\
TREE COVER & 77 & 73 & 70
\end{tabular}

TREE OVERSTORY:

\% COVER (CONSTANCY)

\begin{tabular}{|c|c|c|c|}
\hline ALDER (ALD) & $-(-)$ & $-(-)$ & $-(-)$ \\
\hline BIGLEAF MAPLE (ACMA) & $-(-)$ & $-(-)$ & $-(-)$ \\
\hline CANYON LIVE OAK (QUCH2) & $-(-)$ & $-(-)$ & $-(-)$ \\
\hline DOUGLAS-FIR (PSME) & $6(50)$ & $9(30)$ & $10(25)$ \\
\hline INCENSE CEDAR (CADE3) & $-(-)$ & $-(-)$ & $2(25)$ \\
\hline JEFFREY PINE (PIJE) & $-(-)$ & $3(10)$ & $10(25)$ \\
\hline LODGEPOLE PINE (PICO1) & $5(33)$ & $18(20)$ & $-(-)$ \\
\hline MOUNTAIN HEMLOCK (TSME) & $3(67)$ & $1(10)$ & $-(-)$ \\
\hline PACIFIC DOGWOOD (CONU2) & $2(33)$ & $-(-)$ & $-(-)$ \\
\hline PACIFIC YEW (TABR) & $-(-)$ & $-(-)$ & $-(-)$ \\
\hline PONDEROSA PINE (PIPO) & $1(17)$ & $-(-)$ & $5(25)$ \\
\hline PORT ORFORD CEDAR (CHLA) & $52(100)$ & $59(100)$ & $49(100)$ \\
\hline SHASTARED FIR (ABMAS) & $4(50)$ & $1(20)$ & $-(-)$ \\
\hline SUGAR PINE (PILA) & $3(17)$ & $3(10)$ & $-(-)$ \\
\hline WESTERN WHITE PINE (PIMO3) & $15(100)$ & $6(90)$ & $13(100)$ \\
\hline WHITE FIR (ABCO) & $13(67)$ & $7(90)$ & $9(75)$ \\
\hline TREE UNDERSTORY: & \multicolumn{3}{|c|}{ \% COVER (CONSTANCY) } \\
\hline BIGLEAF MAPLE (ACMA) & $-(-)$ & $-(-)$ & $-(-)$ \\
\hline CANYON LIVE OAK (QUCH2) & $-(-)$ & $-(-)$ & $-(-)$ \\
\hline DOUGLAS-FIR (PSME) & $1(17)$ & $1(30)$ & $1(50)$ \\
\hline INCENSE CEDAR (CADE3) & $-(-)$ & $1(10)$ & $-(-)$ \\
\hline JEFFREY PINE (PIJE) & $-(-)$ & $-(-)$ & $1(25)$ \\
\hline LODGEPOLE PINE (PICOI) & $2(17)$ & $1(10)$ & $-(-)$ \\
\hline MOUNTAIN HEMLOCK (TSME) & $1(50)$ & $1(10)$ & $-(-)$ \\
\hline PACIFIC DOGWOOD (CONU2) & $-(-)$ & $-(-)$ & $-(-)$ \\
\hline PACIFIC YEW (TABR) & $-(-)$ & $-(-)$ & $-(-)$ \\
\hline PONDEROSA PINE (PIPO) & $-(-)$ & $-(-)$ & $-(-)$ \\
\hline PORT ORFORD CEDAR (CHLA) & $6(100)$ & $8(100)$ & $3(100)$ \\
\hline SHASTA RED FIR (ABMAS) & $2(33)$ & $1(20)$ & $-(-)$ \\
\hline SUGAR PINE (PILA) & $-(-)$ & $-(-)$ & $-(-)$ \\
\hline WESTERN WHITE PINE (PIMO3) & $1(83)$ & $1(60)$ & $2(100)$ \\
\hline WHITE FIR (ABCO) & $5(67)$ & $2(90)$ & $4(75)$ \\
\hline
\end{tabular}


PLANT ASSOCIATION:

\begin{tabular}{lccc} 
SHRUBS : & $\begin{array}{l}\text { CHLA-PIMO3/ } \\
\text { VAME }\end{array}$ & $\begin{array}{c}\text { CHLA-PIMO3// } \\
\text { wet herb complex }\end{array}$ & $\begin{array}{l}\text { CHLA-PIMO3// } \\
\text { dry herb complex }\end{array}$ \\
\hline BUSH CHINQUAPIN (CASE3) & $2(33)$ & $1(10)$ & $-(-)$ \\
COFFEEBERRY (RHCA) & $-(-)$ & $-(-)$ & $-(-)$ \\
DOUGLAS' SPIREA (SPDO) & $2(50)$ & $3(30)$ & $1-(50)$ \\
DWARF TANBARK (LIDEE) & $-(-)$ & $-(-)$ & $-(-)$ \\
HUCKLEBERRY OAK (QUVA) & $5(33)$ & $1(20)$ & $1-(75)$ \\
LITTLELEAF HUCKLEBERRY (VASC) & $-(-)$ & $-(-)$ & $-(-)$ \\
PINEMAT MANZANITA (ARNE2) & $1(17)$ & $-(-)$ & $1-(25)$ \\
PINK MOUNTAIN HEATH (PHEM) & $-(-)$ & $-(-)$ & $-(-)$ \\
SERVICEBERRY (AME) & $5(50)$ & $2(30)$ & $-(75)$ \\
SIERRA LAUREL (LEDA) & $7(67)$ & $2(20)$ & $-(-)$ \\
SITKA ALDER (ALSI2) & $5(17)$ & $7(30)$ & $-(-)$ \\
SPICEBUSH (CAOC5) & $-(-)$ & $-(-)$ & $1-(50)$ \\
THIMBLEBERRY (RUPA) & $1(67)$ & $1(20)$ & $-(-)$ \\
THINLEAF HUCKLEBERRY (VAME) & $44(100)$ & $3(40)$ & $-(-)$ \\
WESTERN AZALEA (RHOC) & $7(33)$ & $1(30)$ & $-(-)$ \\
WESTERN LABRADOR TEA (LEGL1) & $-(-)$ & $1(10)$ &
\end{tabular}

HERBS \& GRASSES:

BEARGRASS (XETE)
BEDSTRAW (GAL)
BOG ORCHID (HAB)
BRACKEN FERN (PTAQL)
BRIDE'S BONNET (CLUN2)
CALIF. FALSE HELLEBORE (VECA)
CALIF. LADY-SLIPPER (CYCA)
CALIF. PITCHER PLANT (DACA2)
COLUMBIAN MONKSHOOD (ACCO4)
FIVE-FINGER FERN (ADPEA)
GRAY'SLICORICE ROOT (LIGR)
HOWELLS MARIGOLD (CAHO)
KING'S CLOVER (TRKIP)
LEMMON'S CATCHFLY (SILE)
LILY (LIL)
LITTLE PRINCE'S PINE (CHME)
MILKWORT (POCO)
MOUNTAIN BOYKINIA (BOMA2)
ONE-SIDED PYROLA (PYSE)
RATTLESNAKE PLANTAIN (GOOB)
RED COLUMBINE (AQFO)
STARFLOWER (TRLA3)
SWORDFERN (POMU1)
TWINFLOWER (LIBOL)
WESIERN PRINCES PINE (CHUMO)

WESTERN PRINCES' PINE (CHUMO) WHITE HAWKWEED (HIAL)

WHITE RUSH LILY (SCAL)

WHITE-VEINED WINTERGREEN (PYPI) WOOLLY RAGWORT (SETR)

GRASS (GRAM)

RUSH (JUNI)

SEDGE (CARl)
\% COVER (CONSTANCY)

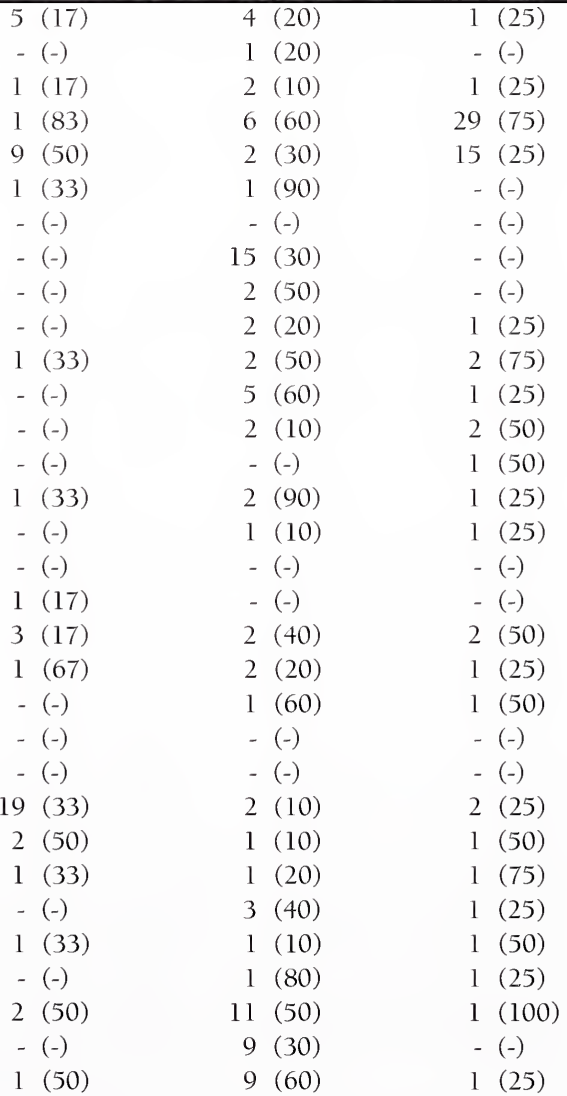




\section{VEGETATION SUMMARY}

\begin{tabular}{|c|c|c|c|}
\hline \multirow{2}{*}{ PLANT ASSOCIATION: } & \multicolumn{3}{|c|}{$\%$ COVER } \\
\hline & CHLA-TSME/ & CHLA-TSME/ & CHLA-TSME/ \\
\hline VEGETATIONLAYER : & CASE3 & LEGLl & LEDA \\
\hline$\overline{\mathrm{N}}$ & 4 & 8 & 12 \\
\hline TOTAL COVER & 94 & 94 & 89 \\
\hline GRASS COVER & 1 & 3 & 3 \\
\hline FORB COVER & 5 & 9 & 10 \\
\hline SHRUB COVER & 28 & 53 & 32 \\
\hline TREE COVER & 84 & 71 & 72 \\
\hline
\end{tabular}

TREE OVERSTORY:

\% COVER (CONSTANCY)

\begin{tabular}{lccc}
\hline ALDER (ALN2) & $-(-)$ & $-(-)$ & $-(-)$ \\
BIGLEAF MAPLE (ACMA) & $-(-)$ & $-(-)$ & $-(-)$ \\
CANYON LIVE OAK (QUCH2) & $-(-)$ & $-(-)$ & $-(-)$ \\
DOUGLAS-FIR (PSME) & $-(-)$ & $4(13)$ & $5(33)$ \\
INCENSE CEDAR (CADE3) & $-(-)$ & $-(-)$ & $-(-)$ \\
JEFFREY PINE (PIJE) & $-(-)$ & $-(-)$ & $-(-)$ \\
LODGEPOLE PINE (PICO1) & $3(75)$ & $8(63)$ & $4(58)$ \\
MOUNTAIN HEMLOCK (TSME) & $6(100)$ & $14(100)$ & $13(75)$ \\
PACIFIC DOGWOOD (CONU2) & $-(-)$ & $-(-)$ & $-(-)$ \\
PACIFIC YEW (TABR) & $-(-)$ & $-(-)$ & $-(-)$ \\
PONDEROSA PINE (PIPO) & $-(-)$ & $-(-)$ & $-(-)$ \\
PORT ORFORD CEDAR (CHLA) & $63(100)$ & $37(100)$ & $40(100)$ \\
SHASTA RED FIR (ABMAS) & $5(100)$ & $10(75)$ & $10(92)$ \\
SUGAR PINE (PILA) & $-(-)$ & $-(-)$ & $-(-)$ \\
WESTERN WHITE PINE (PIMO3) & $10(100)$ & $7(88)$ & $13(92)$ \\
WHITE FIR (ABCO) & $1(50)$ & $8(63)$ & $5(67)$
\end{tabular}

TREE UNDERSTORY:

$\%$ COVER (CONSTANCY)

\begin{tabular}{llcc}
\hline BIGLEAF MAPLE (ACMA) & $-(-)$ & $-(-)$ & $-(-)$ \\
CANYON LIVE OAK (QUCH2) & $-(-)$ & $-(-)$ & $-(-)$ \\
DOUGLAS-FIR (PSME) & $-(-)$ & $2(13)$ & $1(8)$ \\
INCENSE CEDAR (CADE3) & $-(-)$ & $-(-)$ & $-(-)$ \\
JEFFREY PINE (PIJE) & $-(-)$ & $-(-)$ & $-(-)$ \\
LODGEPOLE PINE (PICO1) & $1(50)$ & $1(38)$ & $1(8)$ \\
MOUNTAIN HEMLOCK (TSME) & $1(100)$ & $2(100)$ & $2(67)$ \\
PACIFIC DOGWOOD (CONU2) & $-(-)$ & $-(-)$ & $-(-)$ \\
PACIFIC YEW (TABR) & $-(-)$ & $-(-)$ & $-(-)$ \\
PONDEROSA PINE (PIPO) & $-(-)$ & $-(-)$ & $-(-)$ \\
PORT ORFORD CEDAR (CHLA) & $9(100)$ & $6(88)$ & $6(100)$ \\
SHASTA RED FIR (ABMAS) & $1(100)$ & $5(75)$ & $1(58)$ \\
SUGAR PINE (PILA) & $-(-)$ & $-(-)$ & $-(-)$ \\
WESTERN WHITE PINE (PIMO3) & $1(75)$ & $1(63)$ & $1(42)$ \\
WHITE FIR (ABCO) & $-(-)$ & $3(63)$ & $1(33)$
\end{tabular}




\begin{tabular}{|c|c|c|c|}
\hline SHRUBS: & $\begin{array}{l}\text { CHLA-TSME } \\
\text { CASE3 }\end{array}$ & $\begin{array}{l}\text { CHLA-TSME/ } \\
\text { LEGL1 }\end{array}$ & $\begin{array}{l}\text { CHLA-TSME/ } \\
\text { LEDA }\end{array}$ \\
\hline$\overline{\text { BUSH CHINQUAPIN (CASE3) }}$ & $16(100)$ & $3(25)$ & $10(8)$ \\
\hline COFFEEBERRY (RHCA) & $-(-)$ & $-(-)$ & $-(-)$ \\
\hline DOUGLAS' SPIREA (SPDO) & $-(-)$ & $1(13)$ & $-(-)$ \\
\hline DWARF TANBARK (LIDEE) & $-(-)$ & $-(-)$ & $-(-)$ \\
\hline HUCKLEBERRY OAK (QUVA) & $3(100)$ & $1(25)$ & $-(-)$ \\
\hline LITTLELEAF HUCKLEBERRY (VASC) & $3(100)$ & $2(13)$ & $5(17)$ \\
\hline PINEMAT MANZANITA (ARNE2) & $2(100)$ & $-(-)$ & $1(8)$ \\
\hline PINK MOUNTAIN HEATH (PHEM) & $1(75)$ & $2(13)$ & $2(8)$ \\
\hline SERVICEBERRY (AME) & $-(-)$ & $-(-)$ & $1(8)$ \\
\hline SIERRA LAUREL (LEDA) & $-(-)$ & $39(50)$ & $28(100)$ \\
\hline SITKA ALDER (ALSI2) & $-(-)$ & $-(-)$ & $-(-)$ \\
\hline SPICEBUSH (CAOC5) & $34(100)$ & $-(-)$ & $-(-)$ \\
\hline THIMBLEBERRY (RUPA) & $-(-)$ & $-(-)$ & $-(-)$ \\
\hline THINLEAF HUCKLEBERRY (VAME) & $4(75)$ & $3(63)$ & $5(33)$ \\
\hline WESTERN AZALEA (RHOC) & $-(-)$ & $3(13)$ & $4(33)$ \\
\hline WESTERN LABRADOR TEA (LEGL1) & $5(25)$ & $29(100)$ & $5(8)$ \\
\hline
\end{tabular}

HERBS \& GRASSES:

$\%$ COVER (CONSTANCY)

\begin{tabular}{|c|c|c|c|}
\hline BEARGRASS (XETE) & $-(-)$ & $25(25)$ & $2(17)$ \\
\hline BEDSTRAW (GAL) & $-(-)$ & $1(13)$ & $-(-)$ \\
\hline BOG ORCHID (HAB) & $-(-)$ & $-(-)$ & $1(17)$ \\
\hline BRACKEN FERN (PTAQL) & $-(-)$ & $2(38)$ & $14(42)$ \\
\hline BRIDE'S BONNET (CLUN2) & $-(-)$ & $-(-)$ & $-(-)$ \\
\hline CALIF. FALSE HELLEBORE (VECA) & $-(-)$ & $1(38)$ & $-(-)$ \\
\hline CALIF. LADY-SLIPPER (CYCA) & $-(-)$ & $-(-)$ & $-(-)$ \\
\hline CALIF. PITCHER PLANT (DACA2) & $-(-)$ & $-(-)$ & $1(8)$ \\
\hline COLUMBIAN MONKSHOOD (ACCO4) & $-(-)$ & $-(-)$ & $-(-)$ \\
\hline FIVE-FINGER FERN (ADPEA) & $-(-)$ & $-(-)$ & $1(8)$ \\
\hline GRAY'S LICORICE ROOT (LIGR) & $-(-)$ & $1(13)$ & $-(-)$ \\
\hline HOWELL'S MARIGOLD (CAHO) & $-(-)$ & $-(-)$ & $-(-)$ \\
\hline KING'S CLOVER (TRKIP) & $-(-)$ & $-(-)$ & $-(-)$ \\
\hline LEMMON'S CATCHFLY (SILE) & $-(-)$ & $-(-)$ & $-(-)$ \\
\hline LILY (LIL) & $-(-)$ & $2(50)$ & $1(33)$ \\
\hline LITTLE PRINCE'S PINE (CHME) & $1(50)$ & $1(25)$ & $1(25)$ \\
\hline MILKWORT (POCO) & $-(-)$ & $-(-)$ & $-(-)$ \\
\hline MOUNTAIN BOYKINIA (BOMA2) & $-(-)$ & $1(50)$ & $1(25)$ \\
\hline ONE-SIDED PYROLA (PYSE) & $2(100)$ & $2(25)$ & $1(42)$ \\
\hline RATTLESNAKE PLANTAIN (GOOB) & $-(-)$ & $1(25)$ & $1(42)$ \\
\hline RED COLUMBINE (AQFO) & $-(-)$ & $-(-)$ & $-(-)$ \\
\hline STARFLOWER (TRLA3) & $-(-)$ & $-(-)$ & $-(-)$ \\
\hline SWORDFERN (POMU1) & $-(-)$ & $-(-)$ & $-(-)$ \\
\hline TWINFLOWER (LIBOL) & $-(-)$ & $-(-)$ & $1(8)$ \\
\hline WESTERN PRINCE'S PINE (CHUMO) & $1(100)$ & $2(25)$ & $2(42)$ \\
\hline WHITE HAWKWEED (HIAL) & $-(-)$ & $1(13)$ & $1(8)$ \\
\hline WHITE RUSH LILY (SCAL) & $-(-)$ & $-(-)$ & $1(8)$ \\
\hline WHITE-VEINED WINTERGREEN (PYPI) & $2(100)$ & l (25) & $1(33)$ \\
\hline WOOLLY RAGWORT (SETR) & $-(-)$ & $1(13)$ & l (17) \\
\hline GRASS (GRAM) & $1(25)$ & $1(13)$ & $-(-)$ \\
\hline RUSH (JUN1) & $-(-)$ & $1(25)$ & $2(42)$ \\
\hline SEDGE (CAR1) & $1(100)$ & $1(13)$ & $3(67)$ \\
\hline
\end{tabular}




\section{APPENDIX VII: ECOCLASS CODES}

$\bullet$

$\bullet$

$\bullet$

$\bullet$

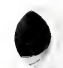

-

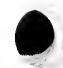




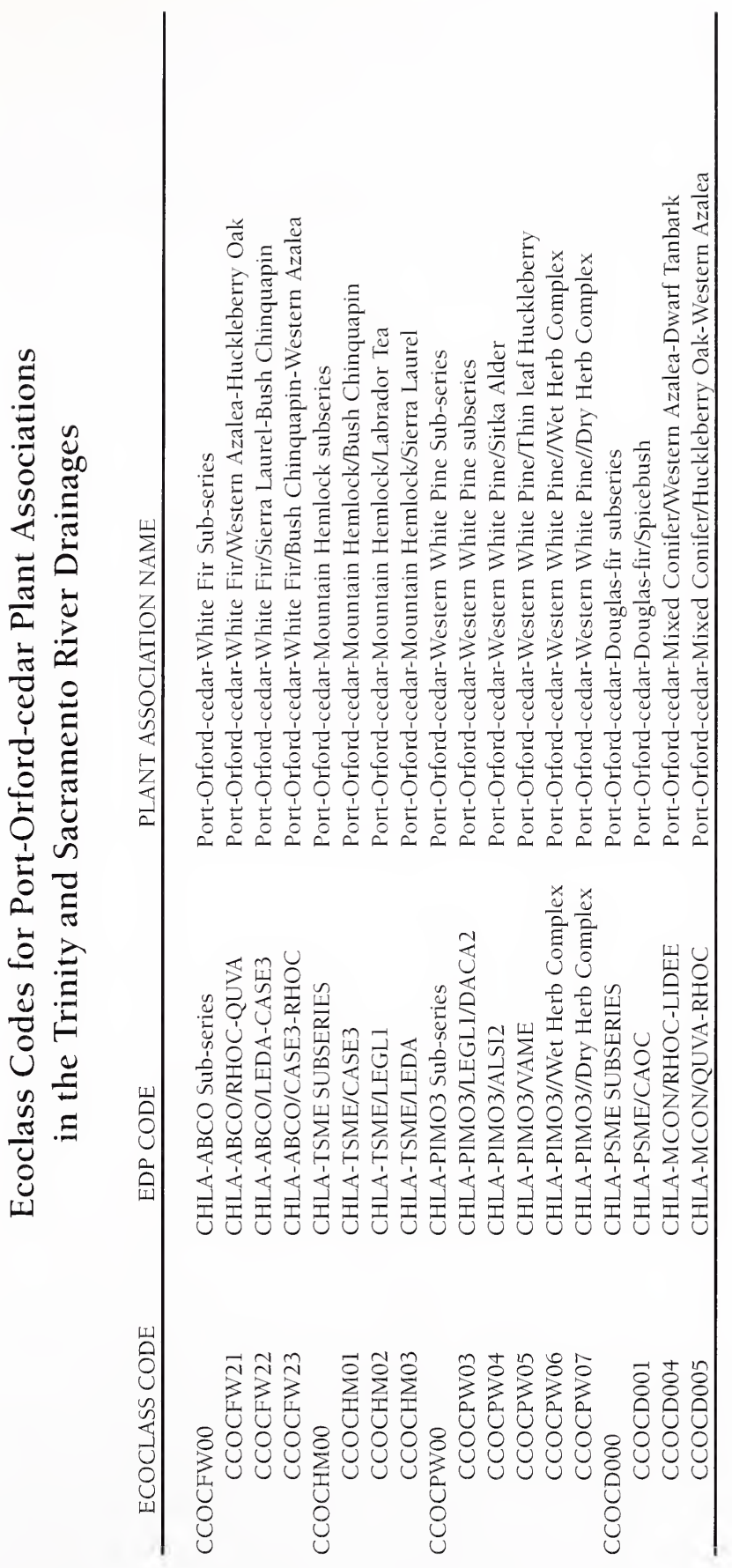


APPENDIX I: PLANT SPECIES LIST

-

$\bullet$

$\bullet$

-

- 


\section{Plant Species List}

Tree Species

Species

Abies concolor

Abies magnifica var. shastensis

Acer macrophyllum

Alnus oregona

Alnus rubra

Alnus rhombifolia

Arbutus menziesii

Castanopsis chrsophylla

Chamaecyparis lawsoniana

Chamaecyparis nootkatensis

Cornus nuttallii

Libocedrus decurrens

Calocedrus decurrens

Lithocarpus densiflora

Picea breweriana

Pinus attenuata

Pinus contorta

Pinus jeffreyi

Pinus lambertiana

Pinus monticola

Pinus ponderosa

Pseudotsuga menziesii

Quercus chrysolepis

Quercus kelloggii

Rhamnus purshiana

Sequoia sempervirens

Taxus brevifolia

Thuja plicata

Tsuga mertensiana

Tsuga heterophylla

Umbellularia californica
EDPcode CommonName

$\begin{array}{ll}\text { ABCO } & \text { White fir } \\ \text { ABMAS } & \text { Shasta red fir } \\ \text { ACMA } & \text { Bigleaf maple } \\ \text { ALOR } & \text { Red alder } \\ \text { ALRU2 } & \text { Red alder } \\ \text { ALRH } & \text { White alder } \\ \text { ARME3 } & \text { Madrone } \\ \text { CACH2 } & \text { Chinquapin } \\ \text { CHLA } & \text { Port-Orford-cedar } \\ \text { CHNO } & \text { Alaska Yellow cedar } \\ \text { CONU2 } & \text { Pacific dogwood } \\ \text { LIDE3 } & \text { Incense cedar } \\ \text { CADE3 } & \text { Incense cedar } \\ \text { LIDE2 } & \text { Tanoak } \\ \text { PIBR } & \text { Brewer's spruce } \\ \text { PIAT1 } & \text { Knobcone pine } \\ \text { PICO1 } & \text { Lodgepole pine } \\ \text { PIJE } & \text { Jeffrey pine } \\ \text { PILA } & \text { Sugar pine } \\ \text { PIMO3 } & \text { Western white pine } \\ \text { PIPO } & \text { Ponderosa pine } \\ \text { PSME } & \text { Douglas-fir } \\ \text { QUCH2 } & \text { Canyon live oak } \\ \text { QUKE } & \text { Black oak } \\ \text { RHPU } & \text { Cascara } \\ \text { SESE2 } & \text { Redwood } \\ \text { TABR } & \text { Pacific yew } \\ \text { THPL } & \text { Western Red Cedar } \\ \text { TSME } & \text { Mountain hemlock } \\ \text { TSHE } & \text { Western hemlock } \\ \text { UMCA } & \text { California bay (laurel) } \\ & \end{array}$

Shrub Species

Acer circinatum

Acer glabrum var. torreyi

Alnus sinuata

Amelanchier alnifolia

Amelanchier spp.
ACCI Vine maple

ACGLT Rocky Mtn. maple

ALSI2 Sitka alder

AMAL Saskatoon Serviceberry

AME Serviceberry 
Arctostaphylos nevadensis

Arctostaphylos patula

Arctostaphylos viscida

Berberis nervosa

Berberis pumila

Berberis repens

Ceanothus integerrimus

Ceanothus prostratus

Ceanothus velutinus

Corylus cornuta var. californica

Cornus stolonifera

Euonymus occidentalis

Garrya buxifolia

Garrya fremontia

Gaultheria ovatifolia

Gaultheria shallon

Holodiscus discolor

Juniperus communis

Ledum glandulosum

Ledum glandulosum var. californicum

Lithocarpus densiflorus var. echinoides

Lonicera hispidula var. vacillans

Myrica californica

Osmaronia cerasiformis

Paxistima myrsinites

Phyllodoce emperiformis

Physocarpus capitatus

Prunus emarginata

Quercus sadleriana

Quercus vaccinifolia

Rhamnus californica

Rhododendron macrophyllum

Rhododendron occidentalis

Rhus (Toxicodendron) diversiloba

Ribes bracteosum

Ribes cereum

Ribes lobbii

Ribes sanguineum

Ribes velutinum var. glanduliferum

Ribes viscosissimum var. hallii

Ribes spp.

Rosa gymnocarpa

Rosa pisocarpa

Rosa spp.

Rubus glaucifolius
ARNE2 Pinemat manzanita

ARPA9 Greenleaf manzanita

ARVI3

BENE1

BEPU

BERE

CEIN3

CEPR

CEVE3

COCOC

cost 3

EUOC3

GABU2

GAFR

GAOV

GASH

HODI

JUCO

LEGL1

LEGLC

LIDEE

LOHIV

MYCA

OSCE

PAMY

PHEM

PHCA8

PREM

QUSA

QUVA

RHCA

RHMA

RHOC

RHDI

RIBR

RICE

RILO

RISA

RIVEG

RIVIH

RIB

ROGY

ROPI

ROS

RUGL
Whiteleaf manzanita

Dwarf Oregon-grape

Pygmy Oregon-grape

Creeping Oregon-grape

Deer brush

Squaw carpet

Snow brush

Hazel/Calfornia Hazelnut

Creek dogwood

Western burningbush

Box-leaved silktassel

Fremont's silktassel

Slender salal

Salal

Ocean spray

Common juniper

Western Labrador tea

Labrador tea

Dwarf tanbark oak

Hairy honeysuckle

Wax-myrtle

Oso berry

Oregon boxwod

Pink Mountain heath

Pacific ninebark

Bitter cherry

Sadler oak

Huckleberry-oak

Coffeeberry

Pacific rhododendron

Western azalea

Poison oak

Stink currant

Squaw currant

Lobb's gooseberry

Red-flowering currant

Desert gooseberry

Sticky currant

Gooseberry

Baldhip/wood rose

Cluster rose

Rose

Smoothleaf raspberry 
Rubus lasiococcus

Rubus leucodermis

Rubus parviflorus

Rubus ursinus

Salix scouleriana

Salix sp.

Smilax californica

Sorbus californica

Sorbus cascadensis

Spirea densiflora

Spirea douglasii

Symphoricarpos mollis

Symphoricarpos rivularis

Umbellaria californica

Vaccinium ovatum

Vaccinium membranaceum

Vaccinium parvifolium

Vaccinium scoparium
RULA Dwarf blackberry

RULE Whitebark raspberry

RUPA2 Thimbleberry

RUUR Trailing blackberry

SASC Scouler's willow

SAL13 Willow species

SMCA Greenbrier

SOCA8 California mountain-ash

SOCA3 Cascade mountain-ash

SPDE Spirea

SPDO Douglas' spirea

SYMO Creeping snowberry

SYRI Streamside snowberry

UMCAl California bay (shrub)

VAOV Evergreen huckleberry

VAME Thin-leaf huckleberry

VAPA Red huckleberry

VASC Little-leaf/Grouse huckleberry

Herb and Fern Species

Actea rubra var. arguta
Achlys triphylla
Adenocaulon bicolor
Adiatum pedatum var. aleuticum
Agasta cheurticifolia
Allium validum
Anemone deltoidea
Anemone quiquefolia var. oregana
Angelica arguta
Apocynum androsaemifolium
Apocynum pumilum
Aquilegia formosa
Aralia californica
Arnica discoidea
Asarum caudatum
Aster ledophyllus
Athyrium felix-femina
Blechnum spicant
Boykinia major
Boschniakia strobilacea
Calypso bulbosa
Campanula prenanthoides
Campanula scouleri
Chimaphilla menziesii

$\begin{array}{ll}\text { ACRUA } & \text { Baneberry } \\ \text { ACTR } & \text { Vanillaleaf } \\ \text { ADBI } & \text { Trailplant } \\ \text { ADPEA } & \text { Five-finger fern } \\ \text { AGUR } & \text { Nettle-leaf giant-hyssop } \\ \text { ALVA } & \text { Bog/Pacific onion } \\ \text { ANDE } & \text { Three-leaf anemone } \\ \text { ANQUO } & \text { Oregon windflower } \\ \text { ANAR3 } & \text { Sharptooth angelica } \\ \text { APAN } & \text { Spreading dogbane } \\ \text { APPU } & \text { Dogbane } \\ \text { AQFO } & \text { Red columbine } \\ \text { ARCA2 } & \text { California spikenard } \\ \text { ARDI3 } & \text { Discoid arnica } \\ \text { ASCA2 } & \text { Wild ginger } \\ \text { ASLE7 } & \text { Aster } \\ \text { ATFIC } & \text { Lady fern } \\ \text { BLSP } & \text { Deer fern } \\ \text { BOMA2 } & \text { Mountain boykinia } \\ \text { BOST2 } & \text { Ground-cone } \\ \text { CABU2 } & \text { Calypso orchid } \\ \text { CAPR6 } & \text { California harebell } \\ \text { CASC4 } & \text { Scouler's harebell } \\ \text { CHME2 } & \text { Little prince's-pine } \\ & \end{array}$


Chimaphilla umbellata v. occidentalis CHUMO

Clintonia uniflora

Convolvulus polymorpha

Corallorhiza spp.

Corallorhiza maculata

Corallorhiza mertensiana

Corallo rhizastriata

Cynoglossum grande

Cypripedium californicum

Darlingtonia californica

Dentaria californica

Dicentra formosa

Disporum hookeri

Disporum smithii

Eburophyton austinae

Epilobium angustifolium

Equisetum arvense

Equisetum telmateia var. braunii

Erythronium californicum

Erythronium grandiflorum v. pallidum ERGRP

Frasera albicaulis var. nitida

Fragaria californica

Fritillaria lanceolata

Galium ambiguum

Galium aparine

Galium triflorum

Goodyera oblongifolia

Habenaria spp.

Habenaria unalascensis

Hemitomes congestum

Heuchera micrantha var. erubescens HEMIE

Hiericium albiflorum

Iris spp.

Iris chrysophylla

Iris innominata

Iris tenuissima

Kelloggia galioides

Lathyrus spp.

Linnea borealis

Lilium spp.

Lilium bolanderi

Lilium columbianum

Lilium volmeri

Lilium washingtonianum v. purpurascens

Lilium wigginsii
CLUN2

$\mathrm{COPO}$

COR2

COMA4

COME

COSTl

CYGR

CYCA2

DACA2

DECA4

DIFO

DIHO2

DISM

EBAU

EPAN2

EQAR

EQTEB

ERCA4

FRALN

FRCAl

FRLAl

GAAM

GAAP

GATR2

GOOB

$\mathrm{HAB}$

HAUN1

HECOl

HIAL

IRI

IRCH

IRIN

IRTE

KEGA

LAT 1

LIBOL

LIL2

LIBO 1

LICO1

LIVO

LIWAP

LIWI
Western prince's pine

Queens cup

Morning glory

Coral-root

Spotted coral-root

Western coral-root

Striped coral-root

Hound's-tongue

California lady-slipper

California pitcher-plant

Toothwort

Bleeding-heart

Hooker's fairy-bell

Smith's fairy-bell

Phantom-orchid

Fireweed

Common horsetail

Giant horsetail

California fawn-lily

Large-flowered fawn-lily

White-margin green-gentian

Wild strawberry

Checker-lily

Bedstraw

Bedstraw

Bedstraw

Rattlesnake-plantain

Bog/Rein Orchid

Green bog/rein-orchid

Gnome plant

Alum-root

White hawk-weed

Iris species

Slender-tubed iris

Iris

Iris

Kelloggia

Pea

Twinflower

Lily

Bolander's lily

Columbia lily

Volmer's lily

Washington lily

Wiggin's lily 
Listera caurina

Listera convallarioides

Lotus spp.

Lupinus spp.

Mitella spp.

Mitella ovalis

Mitella trifida

Monardella odoratissima

Onychium densum

Osmorhiza chilensis

Oxalis oregana

Pedicularis racemosa

Penstemon anquineus

Penstemon deustus

Penstemon newberryi

Petasites palmatus

Phlox adsurgens

Pleuricosporam fimbriolata

Polygala californica

Polygala cornuta

Polygonum phytolaccaefolium

Polypodium glycerrhiza

Polystichum munitum

Polystichum munitum var. imbricans

Prunella vulgaris

Psoralea physodes

Pteridium aquilinum v. lanuginosum PTAQL

Pyrola assarifolia v. purpurea

Pyrola picta

Pyrola picta var. aphylla

Pyrola picta var. dentata

Pyrola secunda

Sarcodes sanquinea

Sedum spp.

Sedum laxum var. flavidum

Sedum pathulifolium

Senecio triangularis

Sidalcea malvaeflora

Silene californica

Smilacena racemosa v. amplexicaulis

Smilacena stellata

Streptopus amplexifolius denticulatus STAMD

Stachys rigida var. lanata

Synthyris reniformis var. cordata
LICA4

$\mathrm{LICO} 4$

LOT3

LUP3

MIT3

MIOV

MITR3

MOOD

ONDE

$\mathrm{OSCH}$

OXOR

PERA 1

PEAN2

PEDE2

PENE1

PEPA6

PHAD2

PLFI

POCA8

POCO6

POPH

POGL1

POMU1

POMUI

PRVU

PSPH

PYASP

PYPI

PYPIA

PYPID

PYSE

SASA3

SED

SELAF

SESP2

SETR

SIMAI

SICA2

SMRAA

SMST

STRIL

SYREC
Twayblade

Twayblade

Lotus

Lupine

Bishop's-cap

Bishop's-cap

Bishop's-cap

Mountain pennyroyal

Cliff-brake

Sweet-cicely

Redwood sorrel

Leafy pedicularis

Tongue-leaved penstemon

Hot-rock penstemon

Newberry's penstemon

Coltsfoot

Woodland phlox

Pinesap

California milkwort

Milkwort

Alpine knotweed

Licorice fern

Sword fern

Imbricated swordfern

Self-heal

California tea

Bracken fern

Liverleaf pyrola

White-veined wintergreen

Leafless pyrola

Toothleaf pyrola

One-sided wintergreen

Snow plant

Stonecrop

Pale Trinity stonecrop

Spatula-leaf stonecrop

Woolly ragwort

Mallow-leafed checker

California campion

Western Solomon-seal

Starry Solomon-seal

Twisted stalk

Hedge-nettle

Snow-queen 
Thermopsis macrophylla

Tiarella trifoliata

Tiarella unifoliata

Tolmiea menziesii

Trifolium howellii

Trifolium longipes

Trientalis latifolia

Trillium ovatum

Trillium rivale

Valerianella carinata

Vancouveria chrysantha

Vancouveria hexandra

Vancouveria planipetala

Veratrum californicum

Veratrum viride

Vicia americana var. occidentalis

Viola glabella

Viola lobata

Viola sempervirens

Viola sheltonii

Whipplea modesta

Woodwordia fimbriata

Xerophyllum tenax

$\begin{array}{ll}\text { THMA } & \text { False-lupine } \\ \text { TITR } & \text { Coolwort foamflower } \\ \text { TIUN } & \text { Foamflower } \\ \text { TOME } & \text { Tolmiea } \\ \text { TRHO } & \text { Howell's clover } \\ \text { TRLO } & \text { Long-stalked clover } \\ \text { TRLA3 } & \text { Starflower } \\ \text { TROV2 } & \text { White trillium } \\ \text { TRRI } & \text { Oregon trillium } \\ \text { VACA4 } & \text { European cornsalad } \\ \text { VACH } & \text { Yellow inside-out flower } \\ \text { VAHE } & \text { Inside-out flower } \\ \text { VAPL } & \text { Coast inside-out flower } \\ \text { VECA1 } & \text { California false-hellebore } \\ \text { VEVI1 } & \text { Green false-hellebore } \\ \text { VIAMO } & \text { American vetch } \\ \text { VIGL } & \text { Stream violet } \\ \text { VILO } & \text { Palmately lobed violet } \\ \text { VISE } & \text { Redwood violet } \\ \text { VISH } & \text { Shelton's violet } \\ \text { WHMO } & \text { Western modesty } \\ \text { WOFI } & \text { Woodwardia fern } \\ \text { XETE } & \text { Beargrass }\end{array}$

Grass, Sedge, and Rush Species

$\begin{array}{lll}\text { Bromus spp. } & \text { BRO3 } & \text { Brome grass } \\ \text { Bromus carinatus var.californica } & \text { BRCA1 } & \text { California brome } \\ \text { Bromus marginatus } & \text { BRMA3 } & \text { Brome } \\ \text { Bromus pacificus } & \text { BRPA } & \text { Pacific brome } \\ \text { Bromus vulgaris } & \text { BRVU } & \text { Columbia brome } \\ \text { Calamagrostis koelerioides } & \text { CAKO } & \text { Reed grass } \\ \text { Carex sp. } & \text { CAR1 } & \text { Sedge } \\ \text { Carex echinata } & \text { CAOR } & \text { Prickly Sedge } \\ \text { Elymus glaucus } & \text { ELGL } & \text { Wild-rye } \\ \text { Festuca species } & \text { FES2 } & \text { Fescue } \\ \text { Festuca californica } & \text { FECA } & \text { California fescue } \\ \text { Festuca idahoensis } & \text { FEID } & \text { Idaho fescue } \\ \text { Festuca occidentalis } & \text { FEOC1 } & \text { Western fescue } \\ \text { Festuca subulata } & \text { FESU1 } & \text { Bearded fescue } \\ \text { Graminoid species } & \text { GRAM } & \text { Grass species } \\ \text { Hierochloe occidentalis } & \text { HIOC } & \text { California sweet grass } \\ \text { Juncus spp. } & \text { JUN2 } & \text { Rush species } \\ \text { Luzula spp. } & \text { LUZ } & \text { Wood rush }\end{array}$


Grass, Sedge and Rush Species (cont'd)

Luzula comosa Melica aristata

Melica subulata

Poa pratensis
LUCO1 Hairy wood rush

MEAR1 Bearded onion grass

MESU Alaska onion grass

POPR1 Kentucky blue grass 
- APPENDIX II: ENVIRONMENT SUMMARY

$\bullet$

$\bullet$

$\bullet$ 


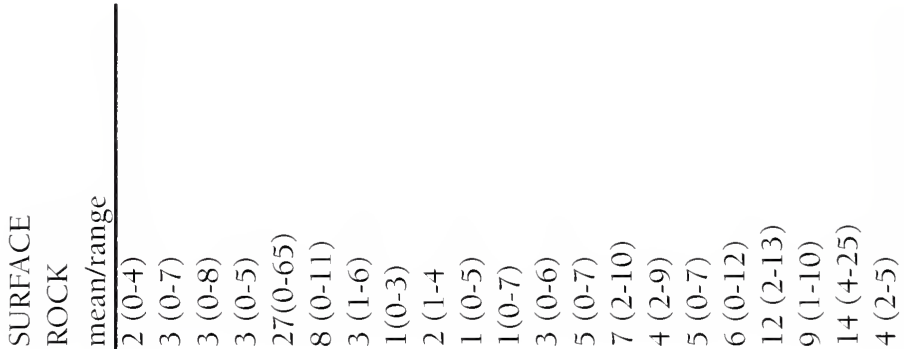

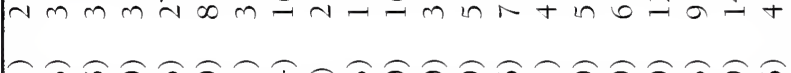

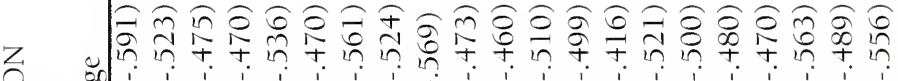

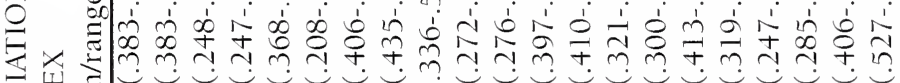

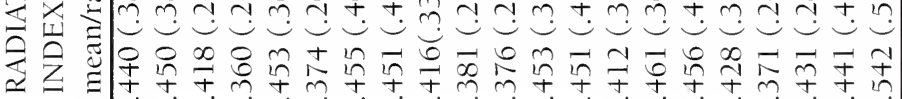

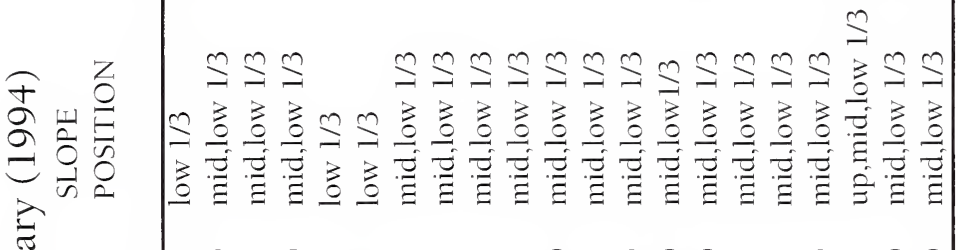

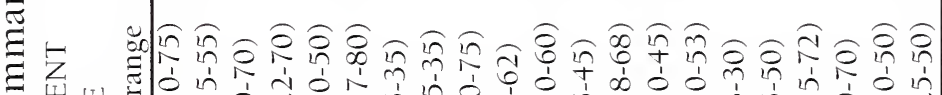

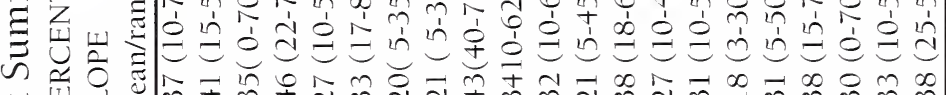

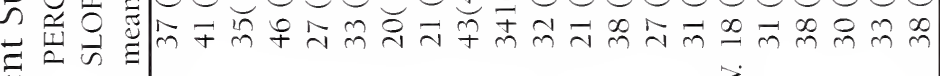

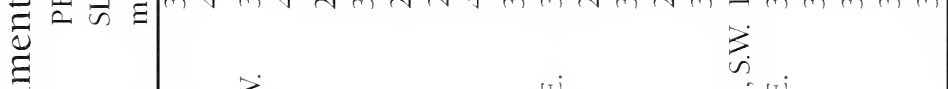

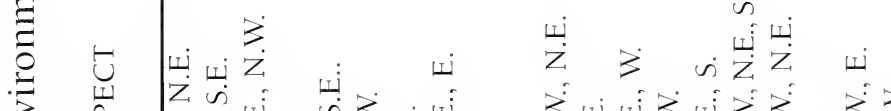

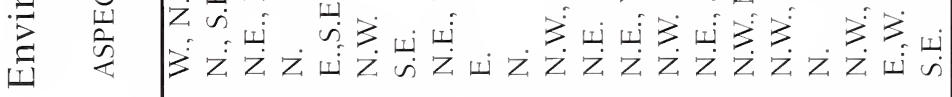

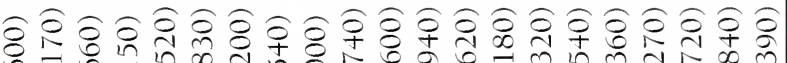
Z Z Z 山ق 壮

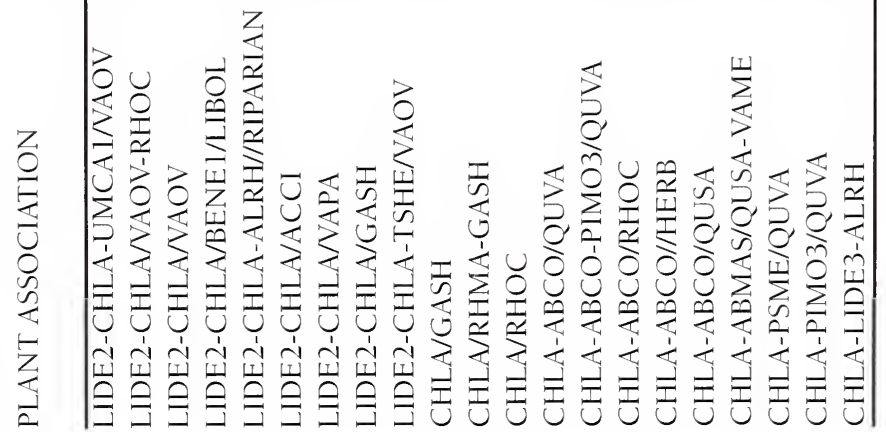




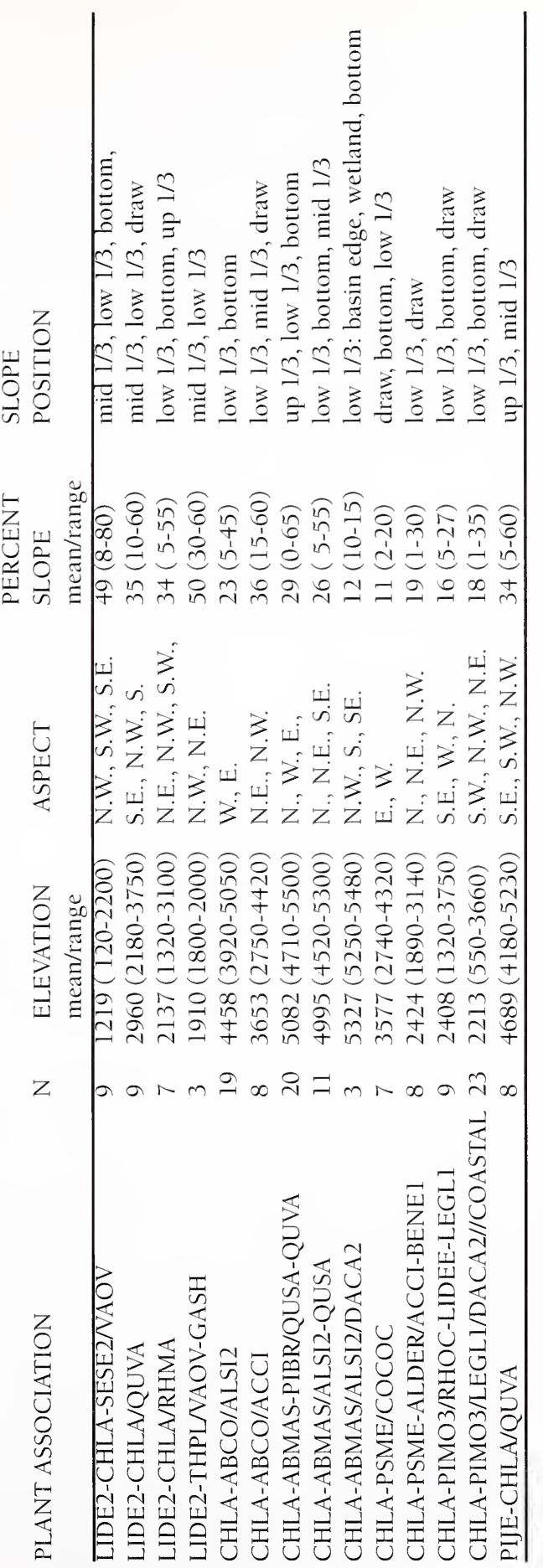




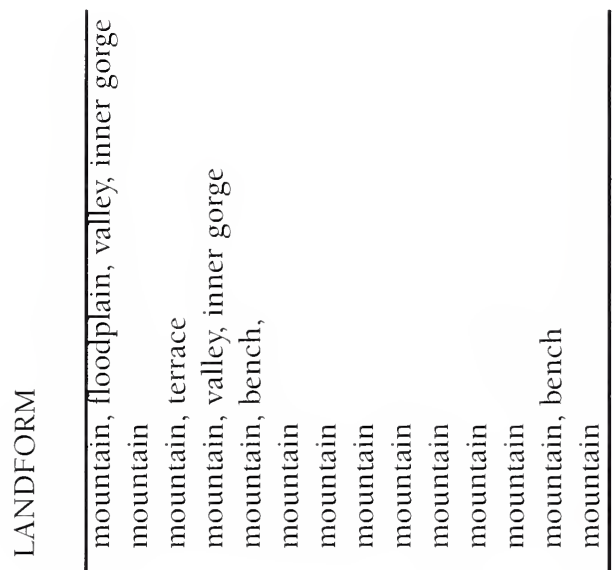

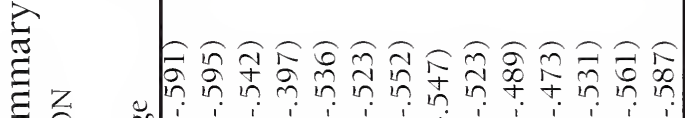

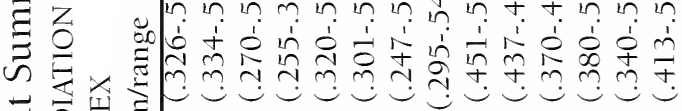

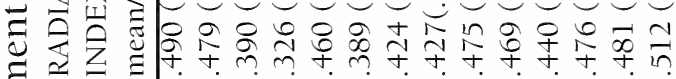
$\Xi \simeq \leq \Xi$.

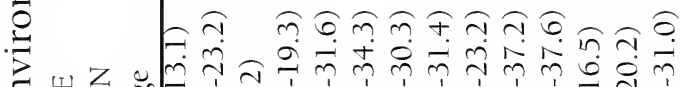

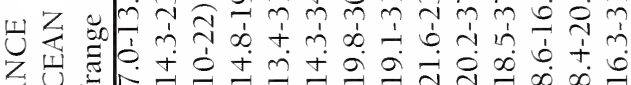

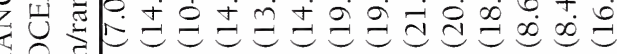

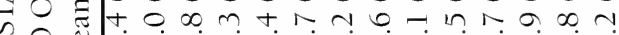
อิ

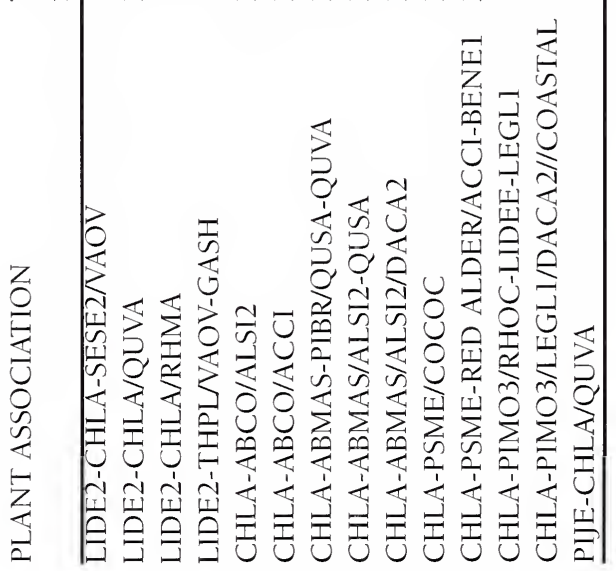




\section{APPENDIX III: SOIL SUMMARY}




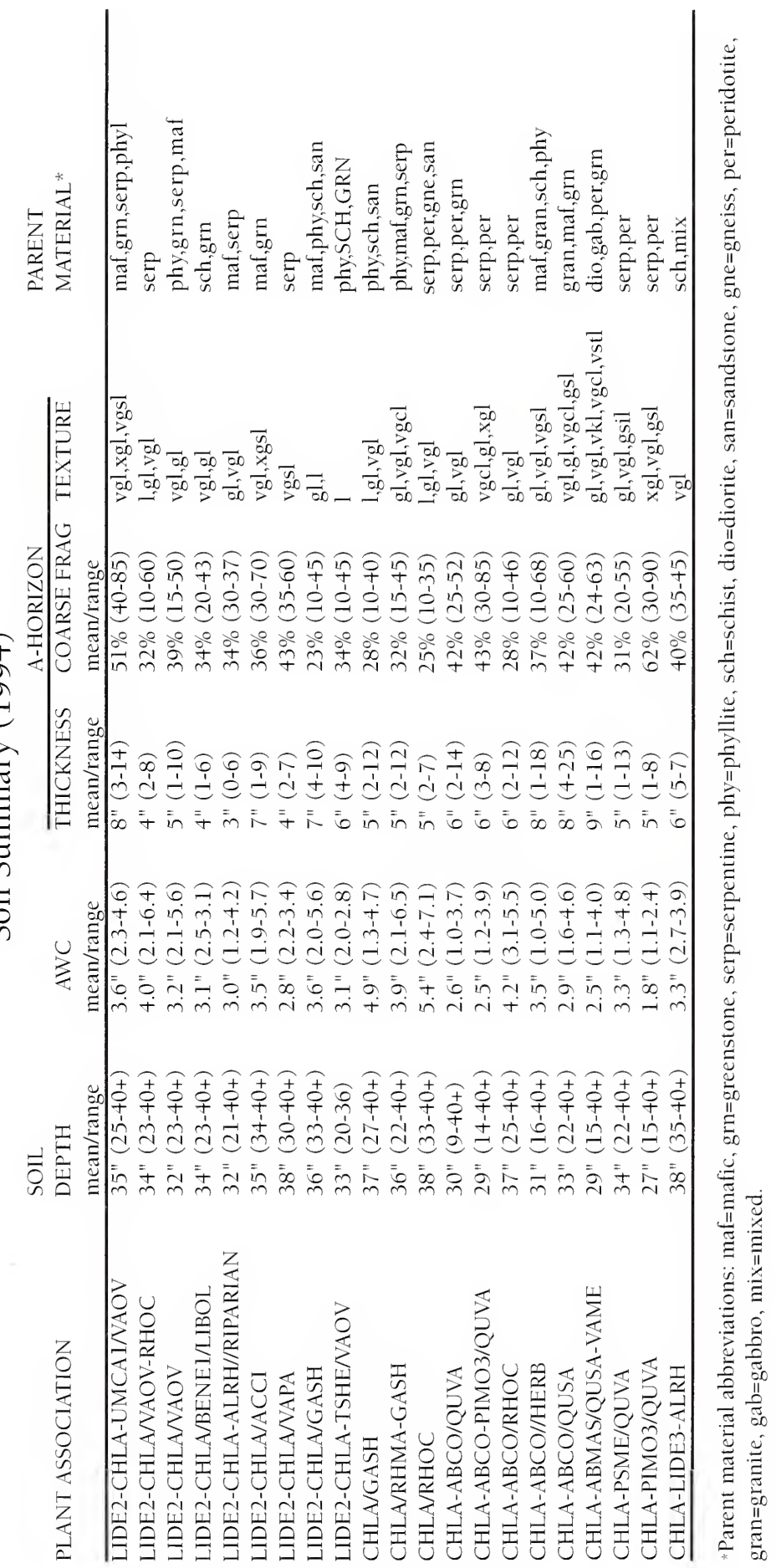




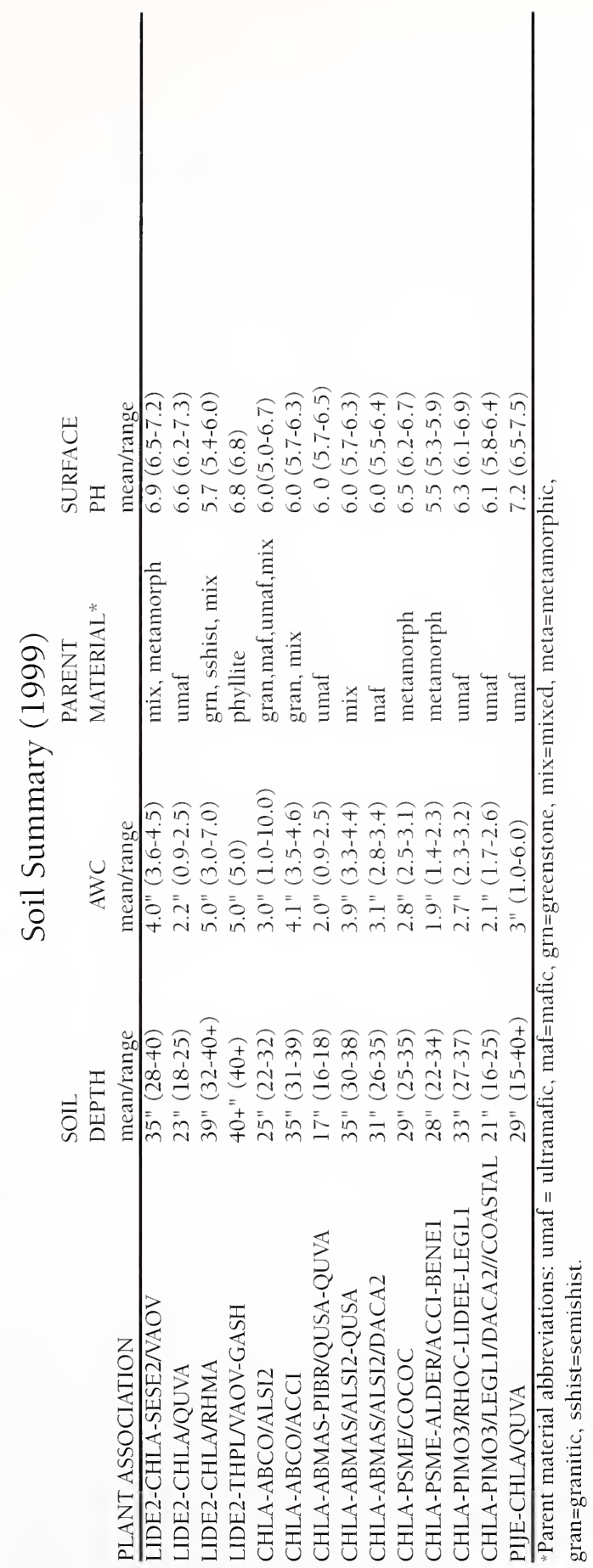




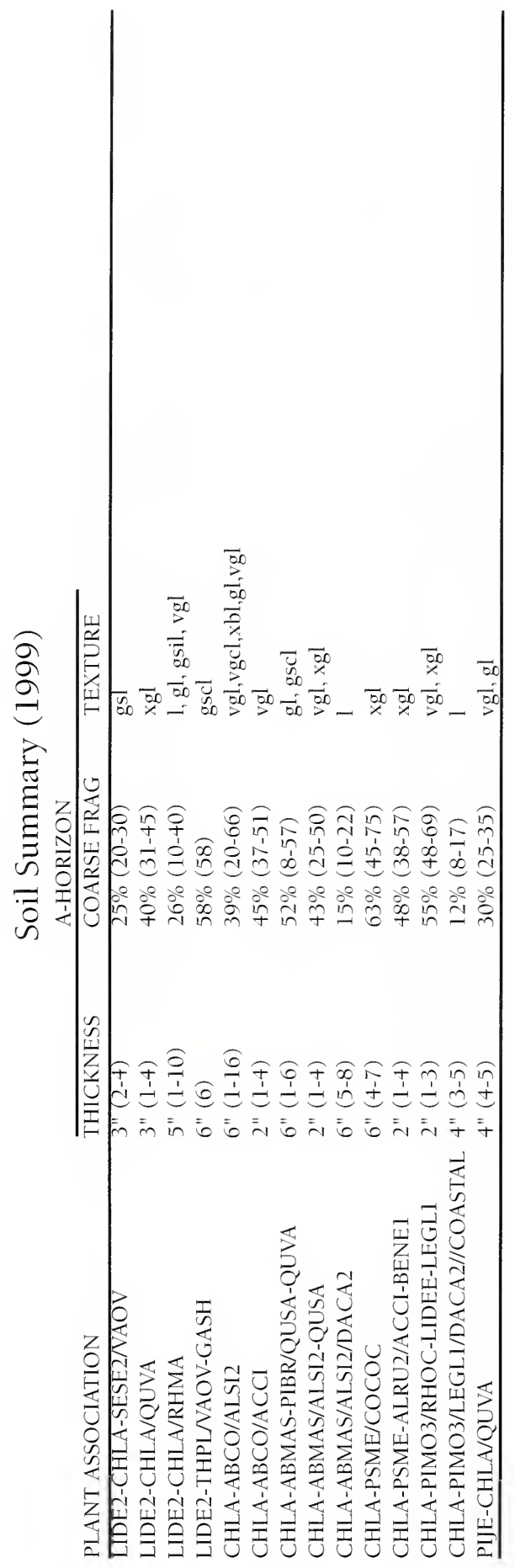




\section{APPENDIX IV: STAND STRUCTURE SUMMARY}




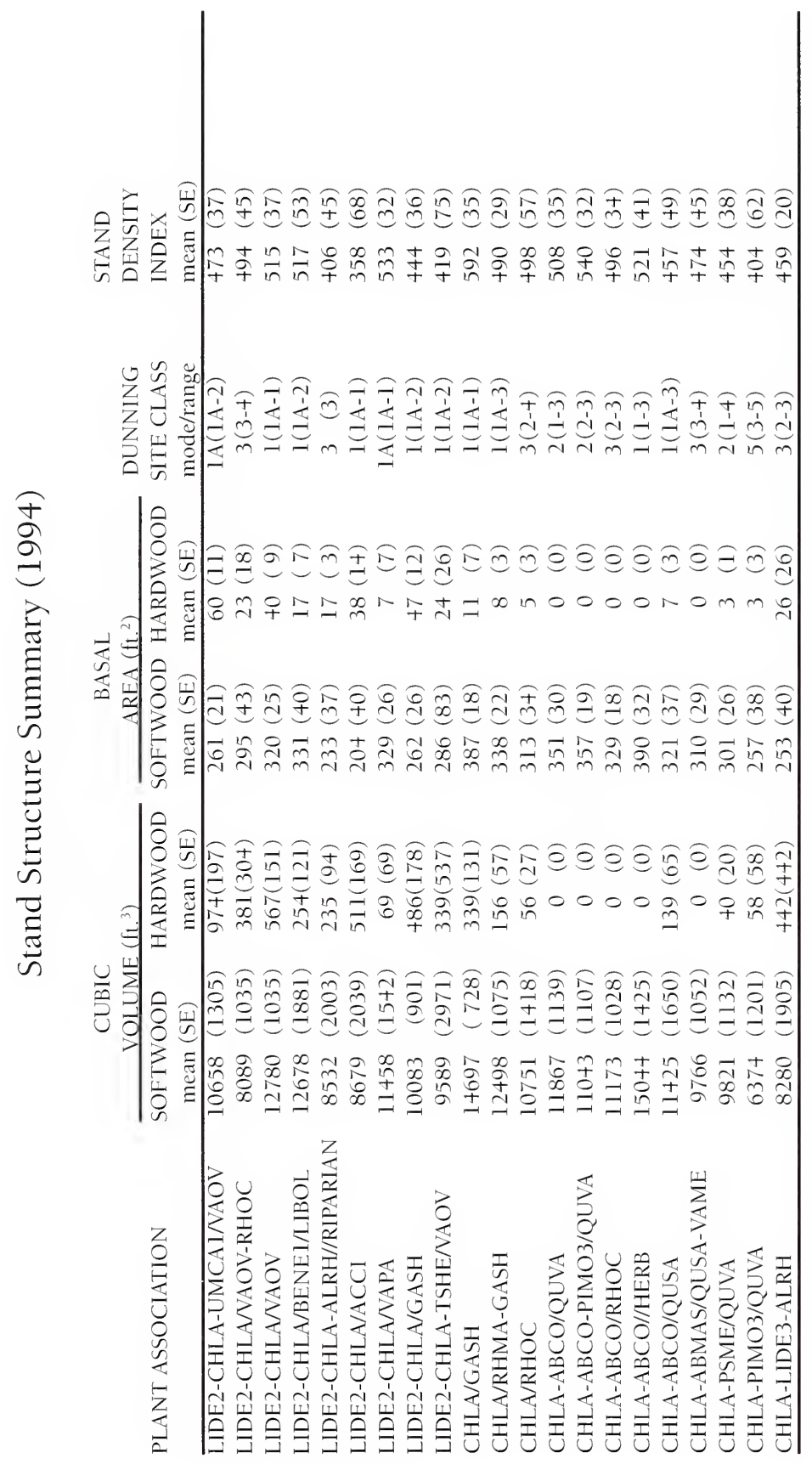




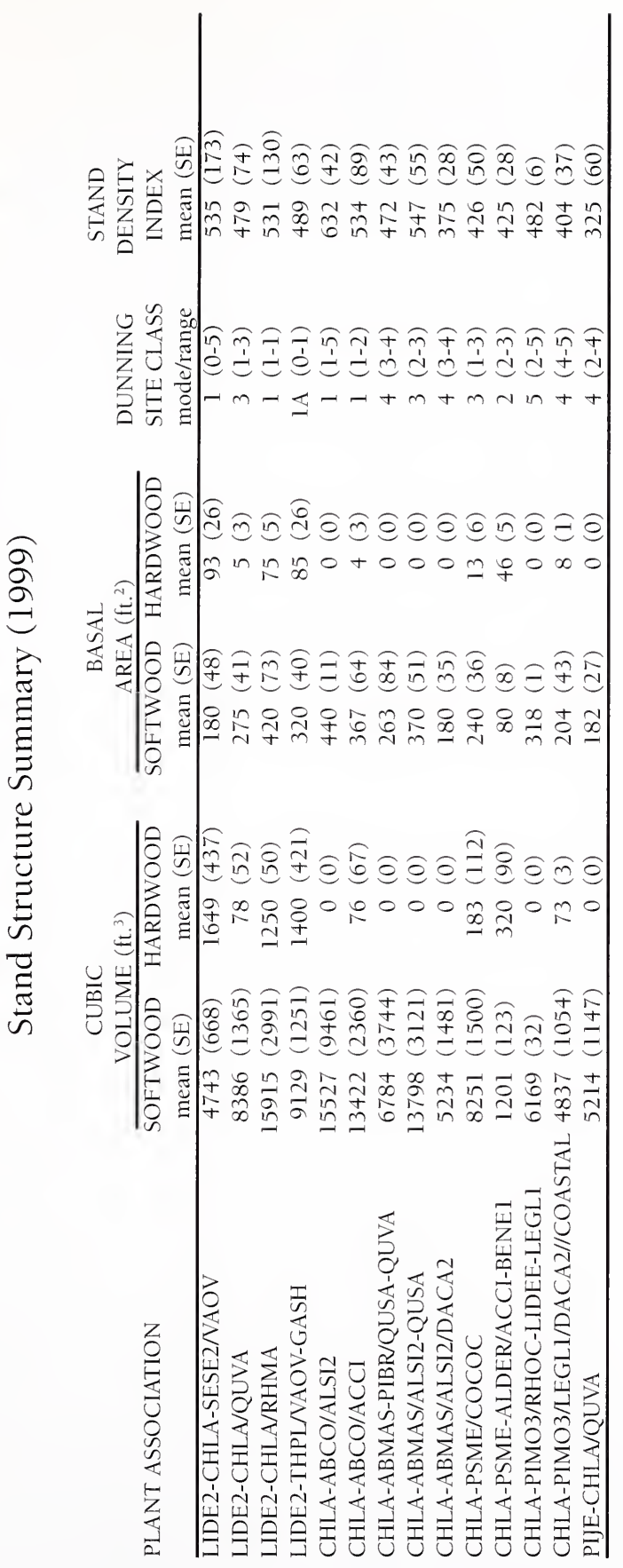




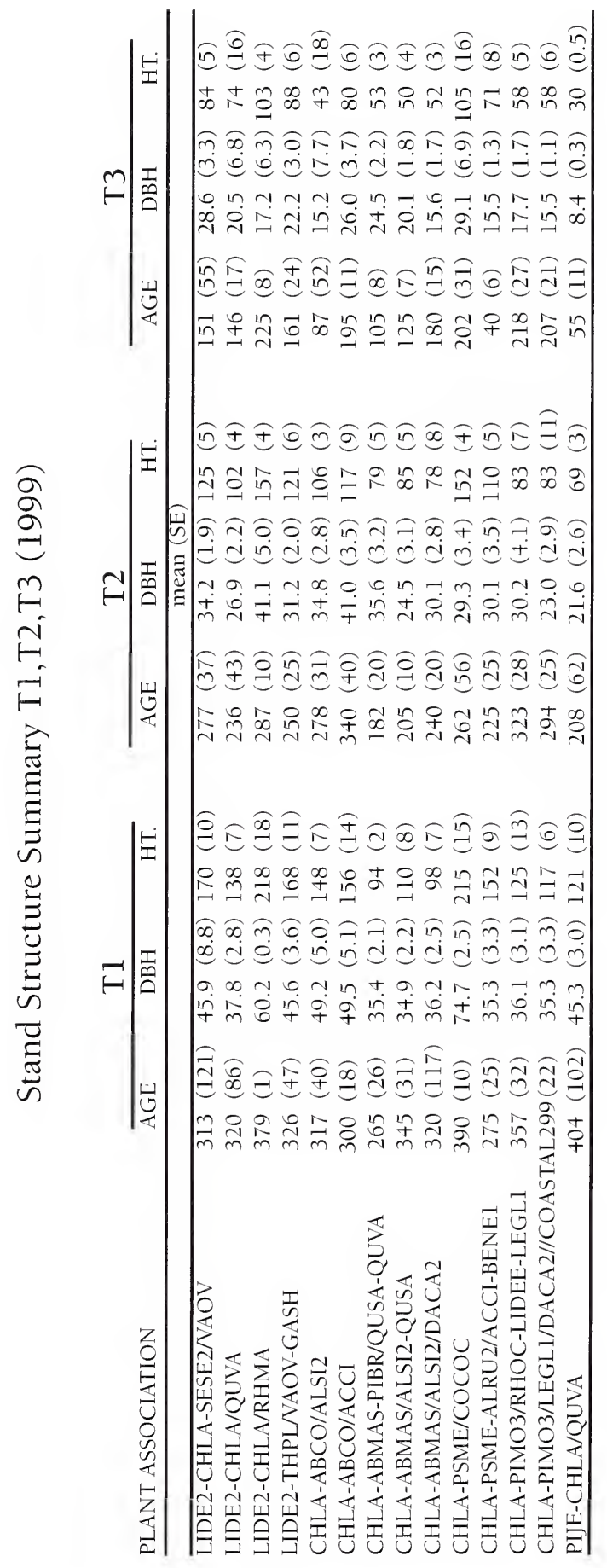


APPENDIX V: VEGETATION SUMMARY 


\section{VEGETATION SUMMARY}

\begin{tabular}{|c|c|c|c|}
\hline PLANT ASSOCIATION: & & $\%$ COVER & \\
\hline & LIDE2-CHLA- & LIDE2-CHLA/ & LIDE2-CHLA/ \\
\hline VEGETATION LAYER: & UMCAI/NAOV & VAOV-RHOC & VAOV \\
\hline TOTAL COVER & 99 & 99 & 98 \\
\hline GRASS COVER & 1 & 2 & $<1$ \\
\hline FORB COVER & 21 & 13 & 14 \\
\hline SHRUB COVER & 53 & 58 & 53 \\
\hline TREE COVER & 92 & 85 & 88 \\
\hline
\end{tabular}

TREE OVERSTORY:

\% COVER (CONSTANCY)

\begin{tabular}{|c|c|c|c|c|c|c|}
\hline DOUGLAS-FIR & 39 & $(100)$ & 36 & $(100)$ & 35 & $(100)$ \\
\hline TANOAK & 30 & $(100)$ & 24 & $(100)$ & 26 & $(100)$ \\
\hline PACIFIC MADRONE & 1 & (7) & 3 & $(50)$ & 5 & $(42)$ \\
\hline CHINQUAPIN & & & 7 & (20) & 4 & (23) \\
\hline CANYON LIVE OAK & & & 2 & (10) & 2 & (4) \\
\hline SUGAR PINE & & $(7)$ & 4 & $(40)$ & 3 & (23) \\
\hline PACIFIC DOGWOOD & 3 & $(64)$ & 3 & $(30)$ & 4 & $(14)$ \\
\hline BIGLEAF MAPLE & 8 & $(57)$ & & & 5 & (38) \\
\hline PACIFIC YEW & 5 & (35) & 3 & $(40)$ & 6 & (19) \\
\hline INCENSE CEDAR & 2 & (7) & 10 & (10) & & \\
\hline CALIFORNIA BAY & 12 & $(71)$ & 5 & $(30)$ & 1 & (4) \\
\hline PORT-ORFORD-CEDAR & 33 & $(100)$ & 34 & $(100)$ & 36 & $(100)$ \\
\hline WHITE FIR & & & & & & \\
\hline ALDER & 9 & $(21)$ & 4 & $(20)$ & 12 & (9) \\
\hline TREE UNDERSTORY: & \multicolumn{6}{|c|}{ \% COVER (CONSTANCY) } \\
\hline TANOAK & 8 & $(100)$ & 9 & $(100)$ & 10 & $(100)$ \\
\hline DOUGLAS-FIR & 1 & $(64)$ & 2 & $(50)$ & 1 & $(52)$ \\
\hline CANYON LIVE OAK & & & 1 & (10) & 1 & (19) \\
\hline CHINQUAPIN & & & 2 & $(20)$ & 1 & (28) \\
\hline PACIFIC DOGWOOD & 2 & $(50)$ & 2 & $(20)$ & 3 & (4) \\
\hline PACIFIC YEW & 2 & $(21)$ & 1 & $(60)$ & 1 & (23) \\
\hline CALIFORNIA BAY & 3 & $(100)$ & 2 & $(50)$ & 2 & $(14)$ \\
\hline PACIFIC MADRONE & 1 & $(14)$ & 1 & $(10)$ & 1 & (4) \\
\hline WHITE FIR & & & & & & \\
\hline BIGLEAF MAPLE & 1 & (14) & & & 1 & (4) \\
\hline PORT ORFORD CEDAR & 3 & $(92)$ & 2 & $(80)$ & 3 & (95) \\
\hline ALDER & 2 & (14) & 1 & $(10)$ & 3 & (9) \\
\hline
\end{tabular}


PLANT ASSOCIATION:

\begin{tabular}{|c|c|c|c|}
\hline SHRUBS: & $\begin{array}{l}\text { LIDE2-CHLA- } \\
\text { UMCA1/NAOV }\end{array}$ & $\begin{array}{l}\text { LIDE2-CHLA } \\
\text { VAOV-RHOC }\end{array}$ & $\begin{array}{l}\text { IDE2-CHLA } \\
\text { VAOV }\end{array}$ \\
\hline$\overline{\text { DWARF OREGON-GRAPE }}$ & $2(57)$ & $1(10)$ & $3(76)$ \\
\hline POISON OAK & $1 \quad(7)$ & $(20)$ & $1 \quad(14)$ \\
\hline SALAL & $12(64)$ & $(100)$ & $16(95)$ \\
\hline HAIRY HONEYSUCKLE & 1 (14) & $(30)$ & $1(4)$ \\
\hline WILD ROSE & $1(21)$ & $1 \quad(10)$ & $1(23)$ \\
\hline HAZELNUT & $3(71)$ & $(30)$ & $2(19)$ \\
\hline EVERGREEN HUCKLEBERRY & $39(100)$ & $(100)$ & $31(100)$ \\
\hline RED HUCKLEBERRY & $6(28)$ & $3(60)$ & $4(57)$ \\
\hline RHODODENDRON & $1(7)$ & $6 \quad(80)$ & $9(47)$ \\
\hline VINE MAPLE & $5(21)$ & & $5(9)$ \\
\hline HUCKLEBERRY OAK & $2(7)$ & $2(40)$ & \\
\hline THIMBLEBERRY & $1(21)$ & $3(10)$ & $1(14)$ \\
\hline BLACK CAP & $1(7)$ & (10) & \\
\hline SERVICEBERRY & & $1 \quad(20)$ & \\
\hline WESTERN AZALEA & & $15(100)$ & $3(4)$ \\
\hline TRAILING BLACKBERRY & $1 \quad(57)$ & $1 \quad(40)$ & $2(47)$ \\
\hline
\end{tabular}

HERBS \& GRASSES:

\% COVER (CONSTANCY)

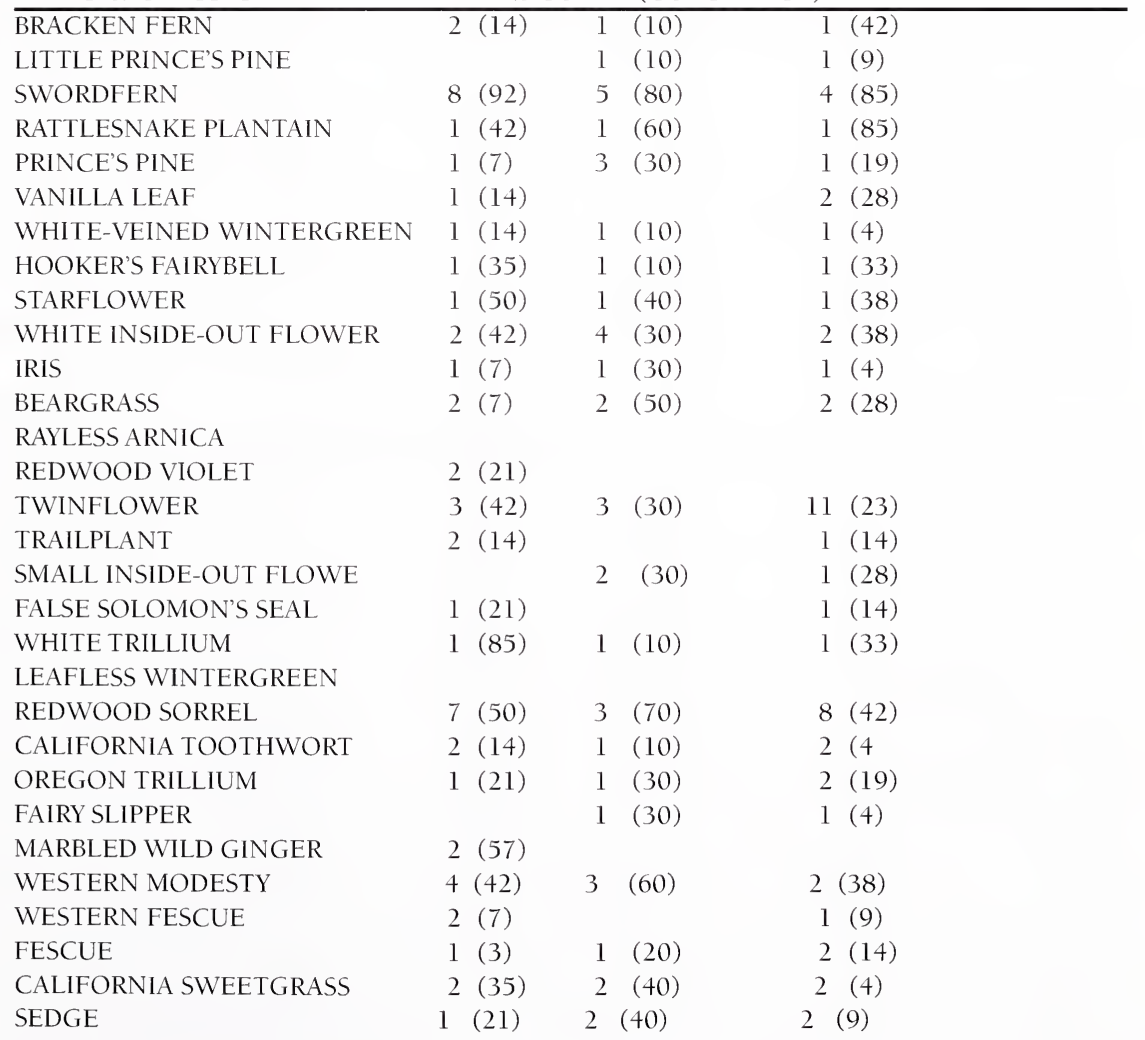




\section{VEGETATION SUMMARY}

PLANT ASSOCIATION:

$\%$ COVER

LIDE2-CHLA/ LIDE2-CHLA LIDE2-CHLA

VEGETATION LAYER: BENEl/LIBOL ALRH/RIPARIAN ACCI

TOTAL COVER

$\begin{array}{lll}95 & 97 & 96 \\ <1 & 1 & 3 \\ 14 & 13 & 12 \\ 18 & 34 & 67 \\ 90 & 85 & 73\end{array}$

TREE COVER

$\%$ COVER (CONSTANCY)

TREE OVERSTORY:

DOUGLAS-FIR
TANOAK
PACIFIC MADRONE
CHINQUAPIN
CANYON LIVE OAK
SUGAR PINE
PACIFIC DOGWOOD
BIGLEAF MAPLE
PACIFIC YEW
INCENSE CEDAR
CALIFORNIA BAY
PORT-ORFORD-CEDAR
WHITE FIR
ALDER

$\begin{aligned} 39 & (100) & 20 & (100) & 35 & (100) \\ 8 & (100) & 11 & (90) & 14 & (100) \\ 13 & (27) & 5 & (10) & 5 & (10) \\ 5 & (18) & 1 & (10) & 2 & (40) \\ 5 & (18) & & & & \\ 3 & (18) & 1 & (10) & & \\ 2 & (27) & 6 & (20) & 3 & (50) \\ 7 & (27) & 4 & (50) & 11 & (30) \\ 2 & (36) & 10 & (50) & 3 & (30) \\ & & & & 3 & (10) \\ 39 & (100) & 33 & (100) & 32 & (100) \\ 3 & (18) & 5 & (10) & 3 & (10) \\ 2 & (18) & 41 & (100) & 25 & (10)\end{aligned}$

TREE UNDERSTORY:

\begin{tabular}{lcccc}
\hline TANOAK & $12(100)$ & 10 & $(90)$ & $11(100)$ \\
DOUGLAS-FIR & $1(72)$ & 2 & $(50)$ & $2(40)$ \\
CANYON LIVE OAK & $2(36)$ & 1 & $(30)$ & $1(10)$ \\
CHINQUAPIN & $1(9)$ & 1 & $(10)$ & $2(40)$ \\
PACIFIC DOGWOOD & $1(9)$ & 1 & $(20)$ & $2(50)$ \\
PACIFIC YEW & $1(36)$ & 1 & $(50)$ & \\
CALIFORNIA BAY & $1(9)$ & 1 & $(10)$ & $2(20)$ \\
PACIFIC MADRONE & $1(9)$ & & & $1(10)$ \\
WHITE FIR & $1(45)$ & 1 & $(20)$ & $4(10)$ \\
BIGLEAF MAPLE & $3(100)$ & $4(90)$ & $1(10)$ \\
PORT ORFORD CEDAR & & & $4(100)$ \\
ALDER & & & & $5(10)$
\end{tabular}


\% COVER (CONSTANCY)

LIDE2-CHLA/ LIDE2-CHLA LIDE2-CHLA/

SHRUBS:

BENE1/LIBOL ALRH//RIPARIAN ACCI

\begin{tabular}{|c|c|c|c|}
\hline DWARF OREGON-GRAPE & $11(100)$ & $2(20)$ & $10(90)$ \\
\hline POISON OAK & & (10) & \\
\hline SALAL & $4(63)$ & $(70)$ & $39(60)$ \\
\hline \multicolumn{4}{|l|}{ HAIRY HONEYSUCKLE } \\
\hline WILD ROSE & $1(63)$ & (10) & $3(50)$ \\
\hline HAZELNUT & $2(54)$ & (10) & $5(50)$ \\
\hline EVERGREEN HUCKLEBERRY & $2(9)$ & & $1(30)$ \\
\hline RED HUCKLEBERRY & $2(72)$ & $1 \quad(30)$ & $2(40)$ \\
\hline RHODODENDRON & $5(18)$ & (20) & $8(40)$ \\
\hline VINE MAPLE & $1(27)$ & $(50)$ & $50(100)$ \\
\hline HUCKLEBERRY OAK & $2(9)$ & & \\
\hline THIMBLEBERRY & & $(50)$ & $5(10)$ \\
\hline BLACK CAP & & & $1(10)$ \\
\hline SERVICEBERRY & $8(9)$ & (10) & \\
\hline WESTERN AZALEA & $4(18)$ & $12(20)$ & $2(10)$ \\
\hline TRAILING BLACKBERRY & $1(36)$ & $2(50)$ & $1(50)$ \\
\hline
\end{tabular}

HERBS \& GRASSES:

$\%$ COVER (CONSTANCY)

BRACKEN FERN
LITTLE PRINCE'S PINE
SWORDFERN
RATTLESNAKE PLANTAIN
PRINCE'S PINE
VANILLA LEAF
WHITE-VEINED WINTERGREEN
HOOKER'S FAIRYBELL
STARFLOWER
WHITE INSIDE-OUT FLOWER
IRIS
BEARGRASS
RAYLESS ARNICA
REDWOOD VIOLET
TWINFLOWER
TRAILPLANT
SMALL INSIDE-OUT FLOWER
FALSE SOLOMON'S SEAL
WHITE TRILLIUM
REDWOOD SORREL
CALIFORNIA TOOTHWORT
OREGON TRILLIUM
BEDSTRAW
FAIRY SLIPPER
MARBLED WILD GINGER
WESTERN MODESTY
WESTERN FESCUE
FESCUE
CALIFORNIA SWEETGRASS
SEDGE

1 (20) 1 (20)

$3(72) \quad 6 \quad(90) \quad 4(80)$

$1(54) \quad 1(30)$

$1(36) \quad 1 \quad(10) \quad 2(40)$

$2(81) \quad 2(40) \quad 3(40)$

$1(27) \quad 1 \quad(10) \quad 1 \quad(10)$

$1(63) \quad l(10) \quad 1(30)$

$1(81) \quad 2(20) \quad 1 \quad(10)$

$2(36)$

$1(45) \quad 1 \quad(30)$

$1(18) \quad 1(20)$

1 (18)

$1(27) \quad 1(20)$

$6(81) \quad 3(30) \quad 10(30)$

1 (9) 1 (20)

$2(9) \quad 1 \quad(20) \quad 2(20)$

1 (27) 1 (10) $1(10)$

$1(9) \quad 1 \quad(40) \quad 1(50)$

$3(18) \quad 4(10)$

CALIFORNIA TOOTHWORT

OREGON TRILLIUM

$1(20)$

1 (30)

1 (50)

$3(72) \quad 2(20) \quad 7(50)$

1 (9)

SEDGE

$2(50)$

l (40) 


\section{VEGETATION SUMMARY}

\section{PLANT ASSOCIATION:}

LIDE2-CHLA/

VEGETATION LAYER:

TOTAL COVER

GRASS COVER

FORB COVER

SHRUB COVER

TREE COVER

\section{VAPA}

95

1

9

17

89

TREE OVERSTORY:

\% COVER GASH

97

2-CHLA TSHE/VAOV

97

$$
<1
$$

64

92

DOUGLAS-FIR
TANOAK
PACIFIC MADRONE
CHINQUAPIN
CANYON LIVE OAK
SUGAR PINE
PACIFIC DOGWOOD
BIGLEAF MAPLE
PACIFIC YEW
INCENSE CEDAR
CALIFORNIA BAY
PORT-ORFORD-CEDAR
WHITE FIR
ALDER
WESTERN HEMLOCK

$\%$ COVER (CONSTANCY)

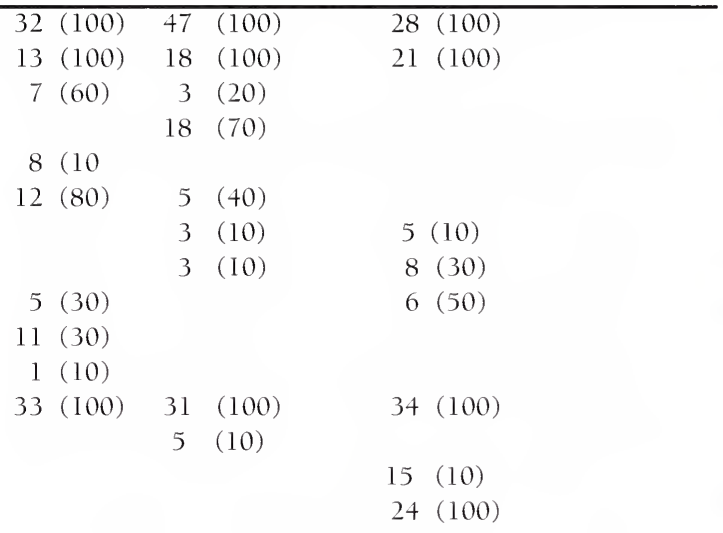

TREE UNDERSTORY:

$\%$ COVER (CONSTANCY)

TANOAK
DOUGLAS-FIR
CANYON LIVE OAK
CHINQUAPIN
PACIFIC DOGWOOD
PACIFIC YEW
CALIFORNIA BAY
PACIFIC MADRONE
WHITE FIR
BIGLEAF MAPLE
PORT ORFORD CEDAR
ALDER
WESTERN HEMLOCK

$30(90)$

$1(60)$

$8(20)$

1 (50)

$1(10)$

$1(40)$

1 (10)

2 (20)

1 (30)

1 (10)

$5(90)$

$2(100)$

$3(70)$

$3(100)$
2 (20)

1 (10)

1 (30)

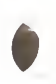




\begin{tabular}{|c|c|c|c|}
\hline PLANT ASSOCIATION: & $\% \mathrm{C}$ & OVER (CONSTA & ANCY) \\
\hline & LIDE2-CHLA/ & LIDE2-CHLA/ & LIDE2-CHLA- \\
\hline SHRUBS: & VAPA & GASH & TSHE/VAOV \\
\hline$\overline{\text { DWARF OREGON-GRAPE }}$ & $1(10)$ & $6(60)$ & $1(40)$ \\
\hline POISON OAK & $1(10)$ & $1 \quad(10)$ & \\
\hline SALAL & $5(50)$ & $70(100)$ & $4(40)$ \\
\hline HAIRY HONEYSUCKLE & & & \\
\hline WILD ROSE & $1(50)$ & $1 \quad(20)$ & \\
\hline HAZELNUT & & $1 \quad(10)$ & \\
\hline EVERGREEN HUCKLEBERRY & $3(50)$ & $3(40)$ & $57(100)$ \\
\hline RED HUCKLEBERRY & $9(100)$ & $3(50)$ & $1(20)$ \\
\hline RHODODENDRON & $2(20)$ & $8 \quad(70)$ & $11(80)$ \\
\hline VINE MAPLE & & & \\
\hline HUCKLEBERRY OAK & $2(30)$ & & \\
\hline THIMBLEBERRY & $1(10)$ & $1 \quad(10)$ & $1(20)$ \\
\hline TRAILING BLACKBERRY & $1(10)$ & $1 \quad(10)$ & $1(10)$ \\
\hline BLACK CAP & $15(10)$ & & \\
\hline SERVICEBERRY & $5(10)$ & & \\
\hline WESTERN AZALEA & $2(10)$ & $2(20)$ & \\
\hline HERBS \& GRASSES: & & 6 COVER (CON & STANCY) \\
\hline$\overline{\text { BRACKEN FERN }}$ & $1(10)$ & l (40) & $1(10)$ \\
\hline LITTLE PRINCE'S PINE & $2(20)$ & I $\quad(20)$ & $1(10)$ \\
\hline SWORDFERN & $1(60)$ & $1 \quad(40)$ & $8(70)$ \\
\hline RATTLESNAKE PLANTAIN & $1(66)$ & $1 \quad(80)$ & $1(60)$ \\
\hline PRINCE'S PINE & $2(60)$ & $2(80)$ & $2(20)$ \\
\hline VANILLA LEAF & $1(10)$ & $3(10)$ & \\
\hline WHITE-VEINED WINTERGREEN & $1(10)$ & $1 \quad(20)$ & $1(30)$ \\
\hline HOOKER'S FAIRYBELL & $1(20)$ & & \\
\hline STARFLOWER & $1(30)$ & $1 \quad(10)$ & $1(10)$ \\
\hline WHITE INSIDE-OUT FLOWER & $1(50)$ & $2(60)$ & $1(40)$ \\
\hline IRIS & $1(50)$ & & \\
\hline BEARGRASS & $4(90)$ & $2(60)$ & \\
\hline RAYLESS ARNICA & $1(20)$ & & \\
\hline REDWOOD VIOLET & & $1 \quad(10)$ & $1(10)$ \\
\hline TWINFLOWER & $2(20)$ & $3(10)$ & \\
\hline TRAILPLANT & & & \\
\hline SMALL INSIDE-OUT FLOWER & $1(10)$ & & $15(10)$ \\
\hline FALSE SOLOMON'S SEAL & $1(30)$ & & $1(10)$ \\
\hline WHITE TRILLIUM & & $1 \quad(20)$ & $1(30)$ \\
\hline REDWOOD SORREL & & & $75(10)$ \\
\hline CALIFORNIA TOOTHWORT & & & \\
\hline OREGON TRILLIUM & & & $2(10)$ \\
\hline BEDSTRAW & $3(10)$ & & \\
\hline FAIRY SLIPPER & $1(30)$ & & \\
\hline MARBLED WILD GINGER & & $1 \quad(10)$ & $1(10)$ \\
\hline WESTERN MODESTY & $1(70)$ & $4 \quad(20)$ & $1(30)$ \\
\hline WESTERN FESCUE & $1(20)$ & & \\
\hline FESCUE & $1(30)$ & & \\
\hline CALIFORNIA SWEETGRASS & & & \\
\hline SEDGE & $1(60)$ & $1 \quad(10)$ & \\
\hline
\end{tabular}


VEGETATION SUMMARY

PLANT ASSOCIATION:

$\%$ COVER

\begin{tabular}{lcccc} 
VEGETATION LAYER: & $\begin{array}{c}\text { CHLA/ } \\
\text { GASH }\end{array}$ & $\begin{array}{c}\text { CHLA/ } \\
\text { RHMA-GASH }\end{array}$ & $\begin{array}{c}\text { CHLA/ } \\
\text { RHOC }\end{array}$ & $\begin{array}{c}\text { CHLA-ABCO/ } \\
\text { QUVA }\end{array}$ \\
\hline TOTAL COVER & 97 & 98 & 95 & 93 \\
GRASS COVER & 1 & $<1$ & 1 & 1 \\
FORB COVER & 11 & 8 & 6 & 13 \\
SHRUB COVER & 61 & 70 & 38 & 22 \\
TREE COVER & 87 & 79 & 77 & 79
\end{tabular}

TREE OVERSTORY: \% COVER (CONSTANCY)

\begin{tabular}{lrrlrl}
\hline PORT-ORFORD-CEDAR & $53(100)$ & 44 & $(100)$ & $42(100)$ & $28(100)$ \\
DOUGLAS-FIR & $31(100)$ & 32 & $(100)$ & $24(100)$ & $29(100)$ \\
WHITE FIR & $2(8)$ & 9 & $(11)$ & $5(7)$ & $16(100)$ \\
SUGAR PINE & $10(16)$ & 6 & $(33)$ & $4(61)$ & $10(60)$ \\
CHINQUAPIN & $2(33)$ & 8 & $(66)$ & $1(30)$ & $3(20$ \\
INCENSE CEDAR & $5(33)$ & 6 & $(22)$ & $9(7)$ & $8(60)$ \\
TANOAK & & & & $5(7)$ & \\
WESTERN WHITE PINE & $4(16)$ & 4 & $(11)$ & $2(30)$ & $1(20)$ \\
PACIFIC MADRONE & & & & & \\
RED FIR & $2(25)$ & $3(22)$ & $5(15)$ & $3(20)$ \\
BREWER'S SPRUCE & $2(25)$ & 2 & $(5)$ & $3(7)$ & \\
PACIFIC YEW & $2(25)$ & 5 & $(22)$ & & \\
ALDER & $2(8)$ & & & & \\
PACIFIC DOGWOOD & $4(8)$ & & & $2(15)$ & 1 \\
BIGLEAF MAPLE & & & & & \\
CANYON LIVE OAK & JEFFREY PINE & &
\end{tabular}

TREE UNDERSTORY:

\% COVER (CONSTANCY)

\begin{tabular}{|c|c|c|c|c|c|}
\hline PORT ORFORD CEDAR & $6(100)$ & 4 & $(100)$ & $9(100)$ & $2(100)$ \\
\hline WHITE FIR & $3(25)$ & 1 & (11) & $2(15)$ & $3(100)$ \\
\hline DOUGLAS-FIR & $1(50)$ & 3 & (44) & $2(53)$ & $2(70)$ \\
\hline TANOAK & $5(66)$ & 2 & (55) & $2(69)$ & $2(20)$ \\
\hline CHINQUAPIN & $1(41)$ & 3 & $(50)$ & $1(30)$ & $1(20)$ \\
\hline PACIFIC YEW & $1(25)$ & 2 & (16) & $1(30)$ & $3(40)$ \\
\hline SUGAR PINE & & 1 & (11) & $1(30)$ & $1(60)$ \\
\hline RED FIR & & & & & $1(10)$ \\
\hline INCENSE CEDAR & & & & & $1(40)$ \\
\hline WESTERN WHITE PINE & & & & $1(7)$ & \\
\hline PACIFIC DOGWOOD & & 1 & (5) & & \\
\hline BREWER'S SPRUCE & & 1 & (5) & & $1(10)$ \\
\hline CALIFORNIA BAY & & 2 & (5) & & $1(10)$ \\
\hline ALDER & & 3 & (5) & & \\
\hline CANYON LIVE OAK & $2(16)$ & & & & \\
\hline JEFFREY PINE & & & & & $1(9)$ \\
\hline
\end{tabular}


PLANT ASSOCIATION:

\begin{tabular}{|c|c|c|c|c|}
\hline SHRUBS: & $\begin{array}{l}\text { CHLA } \\
\text { GASH }\end{array}$ & $\begin{array}{c}\text { CHLA/ } \\
\text { RHMA-GASH }\end{array}$ & $\begin{array}{l}\text { CHLA/ } \\
\text { RHOC }\end{array}$ & $\begin{array}{c}\text { CHLA-ABCO/ } \\
\text { QUVA }\end{array}$ \\
\hline RED HUCKLEBERRY & $3(75)$ & $2(100)$ & $2(76)$ & $5(70)$ \\
\hline HUCKLEBERRY OAK & $2(25)$ & $2(16)$ & $4(53)$ & $11(100)$ \\
\hline TRAILING BLACKBERRY & $1(66)$ & $1 \quad(27)$ & $1(76)$ & $1(60)$ \\
\hline SADLER OAK & $2(16)$ & $7(44)$ & $1(7)$ & $1(70)$ \\
\hline WILD ROSE & l(25) & $1 \quad(38)$ & $1(38)$ & $1(40)$ \\
\hline DWARF OREGON-GRAPE & $3(58)$ & $3(55)$ & $3(38)$ & $2(50)$ \\
\hline WESTERN AZALEA & $9(33)$ & $5 \quad(33)$ & $24(100)$ & $2(10)$ \\
\hline SALAL & $50(100)$ & $36 \quad(94)$ & $12(46)$ & $2(10)$ \\
\hline PACIFIC RHODODENDRON & $3(58)$ & $35(100)$ & $2(30)$ & \\
\hline SLENDER SALAL & $2(16)$ & $4 \quad(11)$ & l (38) & $1(10)$ \\
\hline HAZELNUT & $1(8)$ & & $1(7)$ & $1(10)$ \\
\hline THIMBLEBERRY & l (33) & & $1(7)$ & $1(10)$ \\
\hline THIN-LEAVED HUCKLEBERRY & & & & $2(10)$ \\
\hline PINEMAT MANZANITA & & & $1(7)$ & $1(40)$ \\
\hline OREGON BOXWOOD & $1(8)$ & $2(5)$ & & $1(20)$ \\
\hline VINE MAPLE & $2(8)$ & & & \\
\hline DWARF TANBARK & & 2 (16) & & \\
\hline
\end{tabular}

HERBS \& GRASSES:

\begin{tabular}{|c|c|c|c|c|}
\hline PRINCE'S PINE & $1(58)$ & $3(55)$ & $1(53)$ & $2(70)$ \\
\hline RATTLESNAKE PLANTAIN & $1(58)$ & $1 \quad(77)$ & $1(69)$ & $1(50)$ \\
\hline TWINFLOWER & $2(58)$ & $(66)$ & I $(38)$ & $6(70)$ \\
\hline BEARGRASS & $1(50)$ & $3(83)$ & $2(76)$ & $3(70)$ \\
\hline STARFLOWER & $1(42)$ & $1 \quad(33)$ & $1(38)$ & $1(70)$ \\
\hline WHITE TRILLIUM & $1(58)$ & $1 \quad(50)$ & $1(38)$ & $1(40)$ \\
\hline HOOKER'S FAIRYBELLS & $1(25)$ & $1 \quad(11)$ & $1(7)$ & \\
\hline VANILLALEAF & $2(50)$ & $1 \quad(5)$ & $2(7)$ & $2(20)$ \\
\hline WHITE-VEINED WINTERGREEN & $1(25)$ & $1 \quad(11)$ & $1(7)$ & $1(30)$ \\
\hline QUEENS CUP & $2(8)$ & $1 \quad(5)$ & $2(7)$ & $2(30)$ \\
\hline WESTERN MODESTY & $1(50)$ & $1 \quad(16)$ & $1(23)$ & $2(50)$ \\
\hline IRIS & $1(25)$ & & & $1(60)$ \\
\hline SWORDFERN & $1(58)$ & $1 \quad(33)$ & $1(23)$ & l (20) \\
\hline BRACKEN FERN & $1(25)$ & $1 \quad(27)$ & $1(7)$ & $1(30)$ \\
\hline \multicolumn{5}{|l|}{ THREE-LEAVED ANEMONE } \\
\hline ONE-SIDED WINTERGREEN & $1(8)$ & & & \\
\hline WHITE INSIDE-OUT FLOWER & $2(25)$ & $1 \quad(22)$ & $1(23)$ & $1(40)$ \\
\hline FALSE SOLOMON’S SEAL & $1(16)$ & (5) & $1(15)$ & $1(20)$ \\
\hline LITTLE PRINCE'S PINE & $1(33)$ & $1 \quad(16)$ & $1(7)$ & $1(10)$ \\
\hline HAWKWEED & & & & $1(50)$ \\
\hline TRAILPLANT & & & & l (10) \\
\hline TOOTHED WINTERGREEN & $1(8)$ & $1 \quad(5)$ & l (15) & $1(40)$ \\
\hline REDWOOD VIOLET & $1(25)$ & $1 \quad(11)$ & $1(7)$ & $1(20)$ \\
\hline LADYFERN & $2(50)$ & & $1(7)$ & \\
\hline REDWOOD IVY & $2(37)$ & $1 \quad(22)$ & $1(23)$ & \\
\hline SEDGE & $2(42)$ & $4(11)$ & $2(61)$ & l (20) \\
\hline WESTERN FESCUE & $1(8)$ & & & $1(30)$ \\
\hline
\end{tabular}




\begin{tabular}{lcccc} 
PLANT ASSOCIATION: & \multicolumn{5}{c}{$\begin{array}{c}\text { COVER } \\
\text { CHLA-ABCO } \\
\text { VEGETATION LAYER: }\end{array}$} & $\begin{array}{c}\text { CHLA-ABCO/ } \\
\text { PIMO3/QUVA }\end{array}$ & $\begin{array}{c}\text { CHLA-ABCO// CHLA-ABCO/ } \\
\text { HERB }\end{array}$ & $\begin{array}{c}\text { QUSA } \\
\text { TOTAL COVER }\end{array}$ & 92 & 93 & 96 & 94 \\
GRASS COVER & $<1$ & $<1$ & 2 & $<1$ \\
FORB COVER & 8 & 6 & 43 & 21 \\
SHRUB COVER & 52 & 41 & 13 & 38 \\
TREE COVER & 68 & 75 & 82 & 77
\end{tabular}

TREE OVERSTORY:

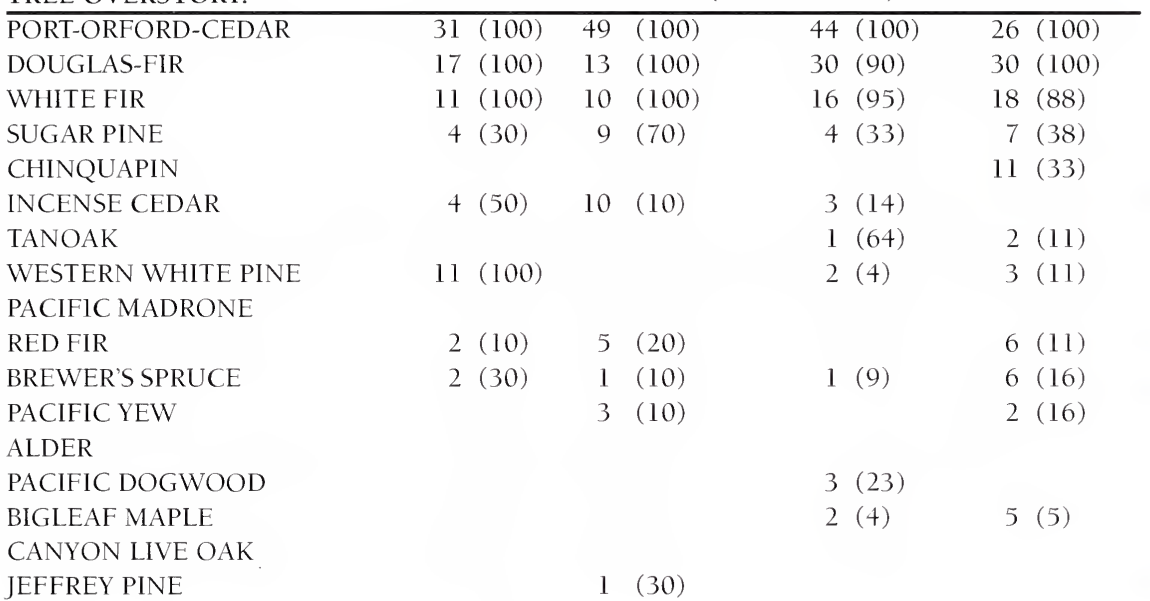

TREE UNDERSTORY:

$\%$ COVER (CONSTANCY)

\begin{tabular}{|c|c|c|c|c|c|}
\hline PORT ORFORD CEDAR & $2(100)$ & 1 & $(100)$ & $3(95)$ & $3(94)$ \\
\hline WHITE FIR & $2(90)$ & 2 & $(100)$ & $2(95)$ & $3(88)$ \\
\hline DOUGLAS-FIR & l (30) & 1 & $(30)$ & $2(42)$ & $1(83)$ \\
\hline TANOAK & & & & $1(9)$ & $2(33)$ \\
\hline CHINQUAPIN & & 2 & (30) & $1(14)$ & $8(50)$ \\
\hline PACIFIC YEW & $1(10)$ & 1 & $(10)$ & l(14) & $2(22)$ \\
\hline SUGAR PINE & $1(10)$ & 1 & $(20)$ & & $1(16)$ \\
\hline RED FIR & l (30) & & & $1(4)$ & $1(5)$ \\
\hline INCENSE CEDAR & $1(10)$ & & & $1(9)$ & $1(5)$ \\
\hline WESTERN WHITE PINE & $1(70)$ & & & & $1(5)$ \\
\hline PACIFIC DOGWOOD & & & & $3(42)$ & \\
\hline BREWER'S SPRUCE & l (10) & & & & $1(22)$ \\
\hline CALIFORNIA BAY & & & & $2(4)$ & \\
\hline \multicolumn{6}{|l|}{ ALDER } \\
\hline CANYON LIVE OAK & & & & & \\
\hline JEFFREY PINE & & 1 & $(10)$ & & \\
\hline
\end{tabular}


PLANT ASSOCIATION:

$\%$ COVER (CONSTANCY)

SHRUBS:

CHLA-ABCO CHLA-ABCO/ CHLA-ABCO// CHLA-ABCO/

RED HUCKLEBERRY

HUCKLEBERRY OAK

TRAILING BLACKBERRY

SADLER OAK

WILD ROSE

DWARF OREGON-GRAPE

WESTERN AZALEA

SALAL

PIMO3/QUVA

RHOC

$16(20) \quad 2(50)$

29 (100) 4 (80)

\begin{tabular}{cc} 
HERB & QUSA \\
\hline $1(28)$ & $6(61)$
\end{tabular}

$2(40) \quad 2(70)$

1 (33)

$3(50)$

4 (60) 1 (50)

$2(80)$

1 (5)

2 (60) 1 (10)

$3(71)$

$22(100)$

$2(20)$

1 (76)

$2(50)$

$7(50)$

3 (28)

5 (61)

$50(10)$

1 (14)

11 (11)

$31(11)$

PACIFIC RHODODENDRON

SLENDER SALAL

HAZELNUT

2 (10) $5 \quad(30)$

$3(11)$

THIMBLEBERRY

$3(10)$

3 (30)

$2(23)$

4 (33)

1 (10)

5 (71)

5 (27)

THIN-LEAVED HUCKLEBERRY

$13(30)$

3 (66)

1 (16)

$8(80)$

2 (20)

l (4)

1 (38)

PINEMAT MANZANITA

OREGON BOXWOOD

VINE MAPLE

DWARF TANBARK

$5(20)$

$\begin{array}{llll}1(19) & 1 & (61) \\ 3(4) & 3 & (11)\end{array}$

HERBS \& GRASSES:

$\%$ COVER (CONSTANCY)

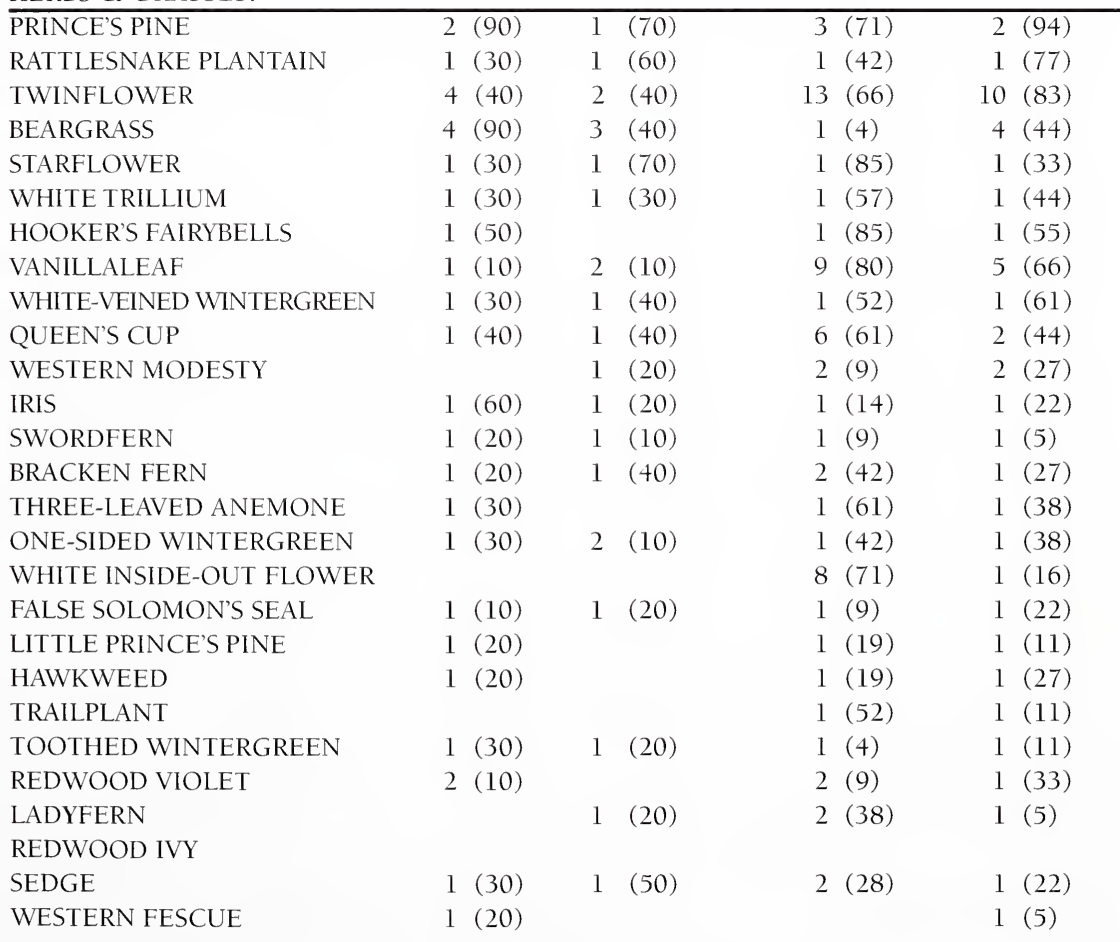




\section{VEGETATION SUMMARY}

PLANT ASSOCIATION: \% COVER

\begin{tabular}{lcccc} 
VEGETATION LAYER : & $\begin{array}{l}\text { CHLA-ABMAS/ CHLA-PSME/ } \\
\text { QUSA-VAME }\end{array}$ & $\begin{array}{c}\text { CHLA-PIMO3/ } \\
\text { QUVA }\end{array}$ & $\begin{array}{c}\text { CHLA- } \\
\text { LIDE3-ALRH }\end{array}$ \\
\hline TOTAL COVER & 94 & 91 & 93 & 98 \\
GRASS COVER & $<1$ & 1 & 5 & 1 \\
FORB COVER & 23 & 9 & 14 & 3 \\
SHRUB COVER & 35 & 33 & 67 & 2 \\
TREE COVER & 79 & 70 & 54 & 98
\end{tabular}

TREE OVERSTORY:

\% COVER (CONSTANCY)

\begin{tabular}{|c|c|c|c|c|}
\hline PORT-ORFORD-CEDAR & $24(100)$ & $28 \quad(100)$ & $28(100)$ & $37(100)$ \\
\hline DOUGLAS-FIR & $19(82)$ & $26(100)$ & $14(100)$ & $30(100)$ \\
\hline WHITE FIR & $25(100)$ & (4) & & \\
\hline SUGAR PINE & $3(35)$ & $(86)$ & $12(10)$ & \\
\hline CHINQUAPIN & & (9) & & \\
\hline INCENSE CEDAR & $11(17)$ & $(40)$ & $10(20)$ & $8(100)$ \\
\hline TANOAK & & $(22)$ & & \\
\hline WESTERN WHITE PINE & $5(35)$ & & $6(100)$ & \\
\hline PACIFIC MADRONE & & $(31)$ & $2(50)$ & \\
\hline RED FIR & $16(94)$ & (4) & & \\
\hline BREWER'S SPRUCE & $3(23)$ & (9) & & \\
\hline PACIFIC YEW & $3(5)$ & (9) & & \\
\hline ALDER & & & & $3(100)$ \\
\hline PACIFIC DOGWOOD & & $1(4)$ & & $1(50)$ \\
\hline BIGLEAF MAPLE & & $3(4)$ & & $5(100)$ \\
\hline CANYON LIVE OAK & & & & \\
\hline JEFFREY PINE & & $13(27)$ & & \\
\hline
\end{tabular}

TREE UNDERSTORY: $\%$ COVER (CONSTANCY)

PORT ORFORD CEDAR

$2(94)$

3 (100)

$3(90)$

l (100)

WHITE FIR

$3(88)$

$1(40)$

$1(50)$

DOUGLAS-FIR

1 (17)

$2(80)$

$5(50)$

TANOAK

$1 \quad(72)$

$9(20)$

1 (50)

CHINQUAPIN

$2(5)$

5 (54)

(20)

PACIFIC YEW

1 (17)

1 (9)

SUGAR PINE

1 (11)

2 (36)

2 (20)

$3(88)$

RED FIR

1 (45)

1 (10)

$1(5)$

1 (45)

$1(10)$

$1(50)$

WESTERN WHITE PINE

1 (11)

1 (100)

PACIFIC DOGWOOD

BREWER'S SPRUCE

1 (17)

1 (4)

CALIFORNIA BAY

ALDER

$7(50)$

$1(50)$

CANYON LIVE OAK

JEFFREY PINE

$1(12$ 
PLANT ASSOCIATION:

$\%$ COVER (CONSTANCY)

CHLA-ABMAS/ CHLA-PSME/ CHLA-PIMO3/ CHLA-

SHRUBS:

QUSA-VAME QUVA

QUVA

RED HUCKLEBERRY

2 (17) $5(81)$

$6(80)$

LIDE3-ALRH

HUCKLEBERRY OAK

$4(58)$

$23(100)$

1 (64) $\quad 1 \quad(31)$

$38(100)$

TRAILING BLACKBERRY

I9 (100) 2 (18)

$1(10)$

$2(10)$

WILD ROSE

DWARF OREGON-GRAPE

2 (64) 1 (45)

5 (64) $2(27)$

1 (30)

$4(30)$

4 (11) 7 (9)

$12(60)$

$2(10)$

SALAL

PACIFIC RHODODENDRON

SLENDER SALAL

HAZELNUT

THIMBLEBERRY

THIN-LEAVED HUCKLEBERRY

PINEMAT MANZANITA

OREGON BOXWOOD

VINE MAPLE
DWARF TANBARK

VINE MAPLE
DWARF TANBARK

1 (4)

$16(30)$

4 (10)

2 (5) 1 (4)

2 (11) 2 (4)

$8(82)$

6 (1I) $2(22)$

$3(10)$

9 (17) 1 (4)

$1(100)$

$2(50)$

HERBS \& GRASSES:

$\%$ COVER (CONSTANCY)

\begin{tabular}{|c|c|c|c|c|c|}
\hline PRINCE'S PINE & $3(94)$ & $1(54)$ & $2(50)$ & & $(50)$ \\
\hline RATTLESNAKE PLANTAIN & $1(88)$ & I $(72)$ & $1(20)$ & & \\
\hline TWINFLOWER & $9(35)$ & $2(36)$ & $3(60)$ & 1 & (50) \\
\hline BEARGRASS & $1(17)$ & $3(77)$ & $3(80)$ & & \\
\hline STARFLOWER & $2(47)$ & $1 \quad(45)$ & $1(20)$ & 1 & (50) \\
\hline WHITE TRILLIUM & $1(76)$ & $1 \quad(4)$ & & & \\
\hline HOOKER'S FAIRYBELLS & $1(76)$ & $1 \quad(18)$ & $1(20)$ & I & $(50)$ \\
\hline VANILLALEAF & $9(52)$ & ( I8) & & 1 & $(100)$ \\
\hline WHITE-VEINED WINTERGREEN & $1(35)$ & $(22)$ & $1(10)$ & & \\
\hline QUEENS CUP & $5(70)$ & & & & \\
\hline WESTERN MODESTY & & $(54)$ & $5(70)$ & 1 & $(50)$ \\
\hline IRIS & $1(5)$ & $1 \quad(63)$ & $2(100)$ & & \\
\hline SWORDFERN & $1(29)$ & $1 \quad(31)$ & $2(60)$ & 1 & (50) \\
\hline BRACKEN FERN & $2(17)$ & $(4)$ & $1(10)$ & & \\
\hline THREE-LEAVED ANEMONE & $2(52)$ & & & & \\
\hline ONE-SIDED WINTERGREEN & $1(70)$ & & $1(10)$ & & \\
\hline WHITE INSIDE-OUT FLOWER & $1(11)$ & $1 \quad(27)$ & l (20) & 1 & $(50)$ \\
\hline FALSE SOLOMON'S SEAL & l (29) & $1 \quad(36)$ & $1(20)$ & & \\
\hline LITTLE PRINCE'S PINE & $1(23)$ & $1 \quad(18)$ & $1(10)$ & & \\
\hline HAWKWEED & $1(11)$ & $(4)$ & l (10) & 1 & (50) \\
\hline TRAILPLANT & l (29) & & & 1 & $(50)$ \\
\hline TOOTHED WINTERGREEN & $1(5)$ & & $1(30)$ & & \\
\hline REDWOOD VIOLET & l (11) & & & & \\
\hline LADYFERN & $15(5)$ & & & & \\
\hline REDWOOD IVY & & 1 (13) & l (20) & & \\
\hline SEDGE & $1(5)$ & 2 (18) & $4(30)$ & & \\
\hline WESTERN FESCUE & & $(9)$ & l (10) & 1 & $(50)$ \\
\hline
\end{tabular}


PLANT ASSOCIATION:

$\%$ COVER

\begin{tabular}{|c|c|c|c|c|}
\hline \multirow{2}{*}{ VEGETATION LAYER : } & \multirow{2}{*}{$\begin{array}{l}\text { LIDE2-CHLA- } \\
\text { SESE2/NAOV }\end{array}$} & \multirow{2}{*}{$\begin{array}{l}\text { LIDE2-CHLA/ } \\
\text { QUVA }\end{array}$} & \multicolumn{2}{|c|}{ LIDE2-CHLA/ LIDE2-THPL } \\
\hline & & & RHMA & VAOV-GASH \\
\hline $\mathrm{N}$ & 9 & 9 & 7 & 3 \\
\hline TOTAL COVER & 95 & 92 & 98 & 99 \\
\hline GRASS COVER & 1 & 2 & 1 & 0 \\
\hline FORB COVER & 26 & 14 & 21 & 33 \\
\hline SHRUB COVER & 45 & 38 & 62 & 26 \\
\hline TREE COVER & 74 & 79 & 87 & 93 \\
\hline
\end{tabular}

TREE OVERSTORY: $\%$ COVER (CONSTANCY)

\begin{tabular}{lccrc}
\hline BIG LEAF MAPLE (ACMA) & $6(44)$ & $-(-)$ & $5(14)$ & $5(33)$ \\
BREWER'S SPRUCE (PIBR) & $-(-)$ & $-(-)$ & $-(-)$ & $-(-)$ \\
DOUGLAS-FIR (PSME) & $26(100)$ & $29(100)$ & $30(100)$ & $32(100)$ \\
INCENSE CEDAR (CADE3) & $1(11)$ & $8(69)$ & $-(-)$ & $6(33)$ \\
JEFFREY PINE (PIJE) & $-(-)$ & $6(10)$ & $-(-)$ & $-(-)$ \\
MADRONE (ARME3) & $5(33)$ & $8(56)$ & $-(-)$ & $12(33)$ \\
MOUNTAIN HEMLOCK (TSME) & $-(-)$ & $-(-)$ & $-(-)$ & $-(-)$ \\
PONDEROSA PINE (PIPO) & $-(-)$ & $7(44)$ & $-(-)$ & $-(-)$ \\
PORT-ORFORD-CEDAR (CHLA) & $13(89)$ & $27(100)$ & $33(100)$ & $10(33)$ \\
RED ALDER (ALRU2) & $16(33)$ & $6(22)$ & $20(14)$ & $-(-)$ \\
REDWOOD (SESE2) & $12(100)$ & $-(-)$ & $-(-)$ & $-(-)$ \\
SHASTA RED FIR (ABMAS) & $-(-)$ & $2(6)$ & $-(-)$ & $-(-)$ \\
SUGAR PINE (PILA) & $5(11)$ & $6(22)$ & $4(57)$ & $4(33)$ \\
TANOAK (LIDE2) & $35(100)$ & $13(100)$ & $30(100)$ & $48(100)$ \\
WESTERN RED CEDAR (THPL) & $-(-)$ & $-(-)$ & $-(-)$ & $21(100)$ \\
WESTERN WHITE PINE (PIMO3) & $-(-)$ & $-(-)$ & $-(-)$ & $-(-)$ \\
WHITE FIR (ABCO) & $-(-)$ & $1(11)$ & $3(14)$ & $-(-)$
\end{tabular}

TREE UNDERSTORY:

\% COVER (CONSTANCY)

\begin{tabular}{|c|c|c|c|c|}
\hline$\overline{\text { BIG LEAF MAPLE (ACMA) }}$ & $-(-)$ & $-(-)$ & $-(-)$ & $2(33)$ \\
\hline BREWER'S SPRUCE (PIBR) & $-(-)$ & $-(-)$ & $-(-)$ & $-(-)$ \\
\hline DOUGLAS-FIR (PSME) & $2(56)$ & $4 \quad(78)$ & $2(29)$ & $2(100)$ \\
\hline INCENSE CEDAR (CADE3) & $-(-)$ & $6 \quad(22)$ & $-(-)$ & $1 \quad(33)$ \\
\hline JEFFREY PINE (PIJE) & $-(-)$ & $-(-)$ & $-(-)$ & $-(-)$ \\
\hline MADRONE (ARME3) & $-(-)$ & $1 \quad(11)$ & $-(-)$ & $1(33)$ \\
\hline MOUNTAIN HEMLOCK (TSME) & $-(-)$ & $-(-)$ & $-(-)$ & $-(-)$ \\
\hline PONDEROSA PINE (PIPO) & $-(-)$ & $-(-)$ & $-(-)$ & $-(-)$ \\
\hline PORT-ORFORD-CEDAR (CHLA) & $2(89)$ & $5 \quad(89)$ & $4(86)$ & $1(33)$ \\
\hline RED ALDER (ALRU2) & $2(11)$ & $1 \quad(11)$ & $-(-)$ & $-(-)$ \\
\hline REDWOOD (SESE2) & $2(56)$ & $-(-)$ & $-(-)$ & $-(-)$ \\
\hline SHASTA RED FIR (ABMAS) & $-(-)$ & $-(-)$ & $-(-)$ & $-(-)$ \\
\hline SUGAR PINE (PILA) & $10(20)$ & $-(-)$ & $1(14)$ & $1(33)$ \\
\hline TANOAK (LIDE2) & $7(100)$ & $(100)$ & $11(100)$ & $8(100)$ \\
\hline WESTERN RED CEDAR (THPL) & $-(-)$ & $-(-)$ & $-(-)$ & $2(67)$ \\
\hline WESTERN WHITE PINE (PIMO3) & $-(-)$ & $-(-)$ & $-(-)$ & $-(-)$ \\
\hline WHITE FIR (ABCO) & $-(-)$ & $1 \quad(11)$ & $-(-)$ & $-(-)$ \\
\hline
\end{tabular}




\begin{tabular}{|c|c|c|c|c|}
\hline \multirow[b]{2}{*}{ SHRUBS:: } & LIDE2-CHLA- & \multirow{2}{*}{$\begin{array}{l}\text { LIDE2-CHLA/ } \\
\text { QUVA }\end{array}$} & \multicolumn{2}{|c|}{ LIDE2-CHLA/ LIDE2-THPL } \\
\hline & $2 / \mathrm{VAOV}$ & & RHMA & VAOV-GASH \\
\hline CALIFORNIA HAZELNUT (COCOC) & $4(67)$ & $-(-)$ & $5(29)$ & $-(-)$ \\
\hline COFFEEBERRY (RHCA) & $-(-)$ & $8(22)$ & $2(55)$ & $-(-)$ \\
\hline DWARF OREGON-GRAPE (BENE1) & $2(33)$ & $5(44)$ & $2(71)$ & $1(33)$ \\
\hline DWARF TANBARK (LIDEE) & $-(-)$ & $-(-)$ & $-(-)$ & $-(-)$ \\
\hline EVERGREEN HUCKLEBERRY (VAOV) & $24(100)$ & $-(-)$ & $28(86)$ & $15(100)$ \\
\hline HUCKLEBERRY OAK (QUVA) & $-(-)$ & $18(100)$ & $-(-)$ & $-(-)$ \\
\hline PACIFIC RHODODENDRON (RHMA) & $2(11)$ & $-(-)$ & $24(100)$ & $5(33)$ \\
\hline PINEMAT MANZANITA (ARNE2) & $-(-)$ & $-(-)$ & $-(-)$ & $-(-)$ \\
\hline POISON OAK (RHDI) & $6(56)$ & $-(-)$ & $-(-)$ & $1(33)$ \\
\hline RED HUCKLEBERRY (VAPA) & $2(44)$ & $5(56)$ & $6(57)$ & $1(67)$ \\
\hline SADLER OAK (QUSA) & $-(-)$ & $-(-)$ & $5(14)$ & $-(-)$ \\
\hline SALAL (GASH) & $12(100)$ & $13(44)$ & $17(100)$ & $10(100)$ \\
\hline SITKA ALDER (ALSI2) & $-(-)$ & $-(-)$ & $-(-)$ & $-(-)$ \\
\hline SLENDER SALAL (GAOV) & $-(-)$ & $-(-)$ & $-(-)$ & $-(-)$ \\
\hline THIN-LEAF HUCKLEBERRY (VAME) & $-(-)$ & $-(-)$ & $-(-)$ & $-(-)$ \\
\hline TRAILING BLACKBERRY (RUUR) & $3(44)$ & $1(11)$ & $2(43)$ & $1(33)$ \\
\hline VINE MAPLE (ACCI) & $25(11)$ & $-(-)$ & $-(-)$ & $5(33)$ \\
\hline WESTERN AZALEA (RHOC) & $3(22)$ & $23(67)$ & $3(14)$ & $-(-)$ \\
\hline WOOD ROSE (ROGY) & $2(22)$ & $1(11)$ & $2(29)$ & $1(33)$ \\
\hline WESTERN LABRADOR TEA (LEGLI) & $-(-)$ & $-(-)$ & $-(-)$ & $-(-)$ \\
\hline
\end{tabular}

HERBS \& GRASSES:

$\%$ COVER (CONSTANCY)

\begin{tabular}{|c|c|c|c|c|}
\hline$\overline{\text { BEARGRASS (XETE) }}$ & $-(-)$ & $10(11)$ & $10(14)$ & $-(-)$ \\
\hline BRACKEN FERN (PTAQL) & $-(-)$ & $-(-)$ & $10(29)$ & $-(-)$ \\
\hline CALIF. PITCHER PLANT (DACA2) & $-(-)$ & $-(-)$ & $-(-)$ & $-(-)$ \\
\hline COMMON LADY FERN (ATFIC) & $-(-)$ & $-(-)$ & $-(-)$ & $-(-)$ \\
\hline DEER FERN (BLSP) & $-(-)$ & $-(-)$ & $-(-)$ & $20(33)$ \\
\hline FIVE-FINGER FERN (ADPEA) & $-(-)$ & $4(44)$ & $-(-)$ & $3(33)$ \\
\hline HOOKER'S FAIRYBELL (DIHO2) & $2(11)$ & $1(11)$ & $-(-)$ & $-(-)$ \\
\hline INSIDE-OUT FLOWER (VAPL) & $-(-)$ & I (11) & $2(57)$ & $-(-)$ \\
\hline IRIS (IRI) & $-(-)$ & $1(22)$ & $1(14)$ & $3(33)$ \\
\hline LILY (LIL2) & $-(-)$ & $1(11)$ & $-(-)$ & $-(-)$ \\
\hline LITTLE PRINCE'S PINE (CHME) & $-(-)$ & $-(-)$ & $1(14)$ & $-(-)$ \\
\hline OREGON TRILLIUM (TRRI) & $-(-)$ & $-(-)$ & l (29) & $-(-)$ \\
\hline PACIFIC ONION (ALVA) & $-(-)$ & $-(-)$ & $-(-)$ & $-(-)$ \\
\hline QUEENS CUP (CLUN2) & $-(-)$ & $-(-)$ & $-(-)$ & $-(-)$ \\
\hline RATTLESNAKE PLANTAIN (GOOB) & I (11) & $1(11)$ & $1(57)$ & $-(-)$ \\
\hline REDWOOD SORREL (OXOR) & $18(22)$ & $-(-)$ & $4(57)$ & $15(33)$ \\
\hline STARFLOWER (TRLA3) & $3(22)$ & $1(33)$ & $2(71)$ & $-(-)$ \\
\hline SWORDFERN (POMU1) & $17(33)$ & $9(67)$ & $12(71)$ & $40 \quad(33)$ \\
\hline TWINFLOWER (LIBOL) & I (11) & $1(11)$ & $3(43)$ & $-(-)$ \\
\hline VANILLA LEAF (ACTR) & $-(-)$ & $-(-)$ & $6(43)$ & $-(-)$ \\
\hline WESTERN MODESTY (WHMO) & $3(22)$ & $5(44)$ & $6(25)$ & $-(-)$ \\
\hline WESTERN PRINCE'S PINE (CHUMO & ) $-(-)$ & $3(22)$ & $2(29)$ & $-(-)$ \\
\hline WHITE HAWKWEED (HIAL) & $2(11)$ & $-(-)$ & $-(-)$ & $-(-)$ \\
\hline WHITE TRILLIUM (TROV2) & $2(11)$ & $1(11)$ & $1(43)$ & $1(33)$ \\
\hline WHITE-VEIN WINTERGREEN (PYPI) & )$-(-)$ & $1(22)$ & $1(14)$ & $-(-)$ \\
\hline WOOLLY RAGWORT (SETR) & $-(-)$ & $-(-)$ & $-(-)$ & $-(-)$ \\
\hline SEDGE (CAR1) & $4(22)$ & $5(11)$ & $1(29)$ & $-(-)$ \\
\hline GRASS SPECIES (GRAM) & $1(33)$ & $3(22)$ & $1(29)$ & $-(-)$ \\
\hline RUSH (JUN2) & $-(-)$ & $-(-)$ & $-(-)$ & $-(-)$ \\
\hline
\end{tabular}




\section{VEGETATION SUMMARY}

PLANT ASSOCIATION:

\% COVER

\begin{tabular}{lcccc} 
VEGETATION LAYER : & $\begin{array}{l}\text { CHLA-ABCO/ } \\
\text { ALSI2 }\end{array}$ & $\begin{array}{l}\text { CHLA-ABCO/ } \\
\text { ACCI }\end{array}$ & $\begin{array}{l}\text { CHLA-ABMAS- } \\
\text { PIBR/QUSA-QUVA ALSI2-QUSA }\end{array}$ \\
\hline $\mathrm{N}$ & 19 & 8 & 20 & 11 \\
TOTAL COVER & 94 & 98 & 91 & 96 \\
GRASS COVER & 5 & 1 & 1 & 4 \\
FORB COVER & 33 & 36 & 12 & 25 \\
SHRUB COVER & 39 & 39 & 60 & 57 \\
TREE COVER & 76 & 85 & 55 & 68
\end{tabular}

TREE OVERSTORY:

\% COVER (CONSTANCY)

\begin{tabular}{lccrr}
\hline BIG LEAF MAPLE (ACMA) & $2(11)$ & $9(63)$ & $-(-)$ & $-(-)$ \\
BREWER'S SPRUCE (PIBR) & $1(5)$ & $-(-)$ & $7(95)$ & $2(55)$ \\
DOUGLAS-FIR (PSME) & $18(89)$ & $29(100)$ & $6(65)$ & $11(64)$ \\
INCENSE CEDAR (CADE3) & $3(26)$ & $1(13)$ & $2(40)$ & $5(45)$ \\
JEFFREY PINE (PIJE) & $-(-)$ & $-(-)$ & $6(10)$ & $-(-)$ \\
MADRONE (ARME3) & $-(-)$ & $-(-)$ & $-(-)$ & $-(-)$ \\
MOUNTAIN HEMLOCK (TSME) & $-(-)$ & $-(-)$ & $4(25)$ & $11(18)$ \\
PONDEROSA PINE (PIPO) & $-(-)$ & $-(-)$ & $8(10)$ & $4(18)$ \\
PORT-ORFORD-CEDAR (CHLA) & $48(100)$ & $44(100)$ & $26(100)$ & $36(100)$ \\
RED ALDER (ALRU2) & $-(-)$ & $2(25)$ & $-(-)$ & $-(-)$ \\
REDWOOD (SESE2) & $-(-)$ & $-(-)$ & $-(-)$ & $-(-)$ \\
SHASTA RED FIR (ABMAS) & $4(26)$ & $-(-)$ & $8(100)$ & $7(91)$ \\
SUGAR PINE (PILA) & $5(26)$ & $-(-)$ & $5(30)$ & $5(27)$ \\
TANOAK (LIDE2) & $5(3)$ & $2(13)$ & $-(-)$ & $-(-)$ \\
WESTERN RED CEDAR (THPL) & $-(-)$ & $-(-)$ & $-(-)$ & $-(-)$ \\
WESTERN WHITE PINE (PIMO3) & $4(21)$ & $-(-)$ & $7(100)$ & $5(36)$ \\
WHITE FIR (ABCO) & $12(100)$ & $15(100)$ & $8(85)$ & $9(82)$
\end{tabular}

TREE UNDERSTORY:

$\%$ COVER (CONSTANCY)

\begin{tabular}{|c|c|c|c|c|}
\hline$\overline{\text { BIG LEAF MAPLE (ACMA) }}$ & $-(-)$ & $1(13)$ & $-(-)$ & $-(-)$ \\
\hline BREWER'S SPRUCE (PIBR) & $-(-)$ & $-(-)$ & $2(70)$ & $1(18)$ \\
\hline DOUGLAS-FIR (PSME) & $1(42)$ & $1 \quad(63)$ & $1(10)$ & $1(9)$ \\
\hline INCENSE CEDAR (CADE3) & $1(11)$ & $1 \quad(13)$ & $1(30)$ & $2(18)$ \\
\hline JEFFREY PINE (PIJE) & $-(-)$ & $-(-)$ & $3(5)$ & $-(-)$ \\
\hline MADRONE (ARME3) & $-(-)$ & $-(-)$ & $-(-)$ & $-(-)$ \\
\hline MOUNTAIN HEMLOCK (TSME) & $-(-)$ & $-(-)$ & $1(15)$ & $3(18)$ \\
\hline PONDEROSA PINE (PIPO) & $-(-)$ & $-(-)$ & $-(-)$ & $-(-)$ \\
\hline PORT-ORFORD-CEDAR (CHLA) & $5(89)$ & $4(100)$ & $4(90)$ & $4(100)$ \\
\hline RED ALDER (ALRU2) & $-(-)$ & $-(-)$ & $-(-)$ & $-(-)$ \\
\hline REDWOOD (SESE2) & $-(-)$ & $-(-)$ & $-(-)$ & $-(-)$ \\
\hline SHASTA RED FIR (ABMAS) & $6(11)$ & $-(-)$ & $2(90)$ & $2(82)$ \\
\hline SUGAR PINE (PILA) & $2(11)$ & $-(-)$ & $2(10)$ & l (9) \\
\hline TANOAK (LIDE2) & $-(-)$ & $3(50)$ & $-(-)$ & $-(-)$ \\
\hline WESTERN RED CEDAR (THPL) & $-(-)$ & $-(-)$ & $-(-)$ & $-(-)$ \\
\hline WESTERN WHITE PINE (PIMO3) & $-(-)$ & $-(-)$ & $3(60)$ & $1(36)$ \\
\hline WHITE FIR (ABCO) & $4(84)$ & $2(50)$ & $2(85)$ & $2(82)$ \\
\hline
\end{tabular}




\begin{tabular}{lllll} 
& \multicolumn{2}{c}{ CHLA-ABCO/ CHLA-ABCO/ } & CHLA-ABMAS- & CHLA-ABMAS/ \\
SHRUBS : & ALSI2 & \multicolumn{2}{c}{ ACCI } & PIBR/QUSA-QUVA ALSI2-QUSA \\
\hline CALIFORNIA HAZELNUT (COCOC) & $5(16)$ & $6(63)$ & $-(-)$ & $-(-)$ \\
COFFEEBERRY (RHCA) & $-(-)$ & $-(-)$ & $2(10)$ & $-(-)$ \\
DWARF OREGON-GRAPE (BENE1) & $1(26)$ & $8(88)$ & $-(-)$ & $2(9)$ \\
DWARF TANBARK (LIDEE) & $2(5)$ & $4(13)$ & $-(-)$ & $-(-)$ \\
EVERGREEN HUCKLEBERRY (VAOV) & $-(-)$ & $-(-)$ & $-(-)$ & $-(-)$ \\
HUCKLEBERRY OAK (QUVA) & $2(37)$ & $4(38)$ & $26(80)$ & $2(18)$ \\
PACIFIC RHODODENDRON (RHMA) & $-(-)$ & $-(-)$ & $-(-)$ & $-(-)$ \\
PINEMAT MANZANITA (ARNE2) & $-(-)$ & $-(-)$ & $15(70)$ & $-(-)$ \\
POISON OAK (RHDI) & $-(-)$ & $1(13)$ & $-(-)$ & $-(-)$ \\
RED HUCKLEBERRY (VAPA) & $1(32)$ & $4(50)$ & $6(50)$ & $2(9)$ \\
SADLER OAK (QUSA) & $2(68)$ & $3(38)$ & $\mathrm{I} 2(80)$ & $12(100)$ \\
SALAL (GASH) & $5(11)$ & $-(-)$ & $-(-)$ & $-(-)$ \\
SITKA ALDER (ALSI2) & $23(100)$ & $2(13)$ & $4(40)$ & $29(100)$ \\
SLENDER SALAL (GAOV) & $8(37)$ & $-(-)$ & $7(55)$ & $4(45)$ \\
THIN-LEAF HUCKLEBERRY (VAME) & $1(11)$ & $-(-)$ & $9(80)$ & $16(82)$ \\
TRAILING BLACKBERRY (RUUR) & $2(53)$ & $1(38)$ & $2(10)$ & $2(27)$ \\
VINE MAPLE (ACCI) & $2(5)$ & $24(100)$ & $-(-)$ & $-(-)$ \\
WESTERN AZALEA (RHOC) & $7(37)$ & $-(-)$ & $13(45)$ & $4(36)$ \\
WOOD ROSE (ROGY) & $2(68)$ & $2(63)$ & $2(25)$ & $3(36)$ \\
WESTERN LABRADOR TEA (LEGL1) & $-(-)$ & $-(-)$ & $-(-)$ & $-(-)$
\end{tabular}

HERBS \& GRASSES:

\% COVER (CONSTANCY)

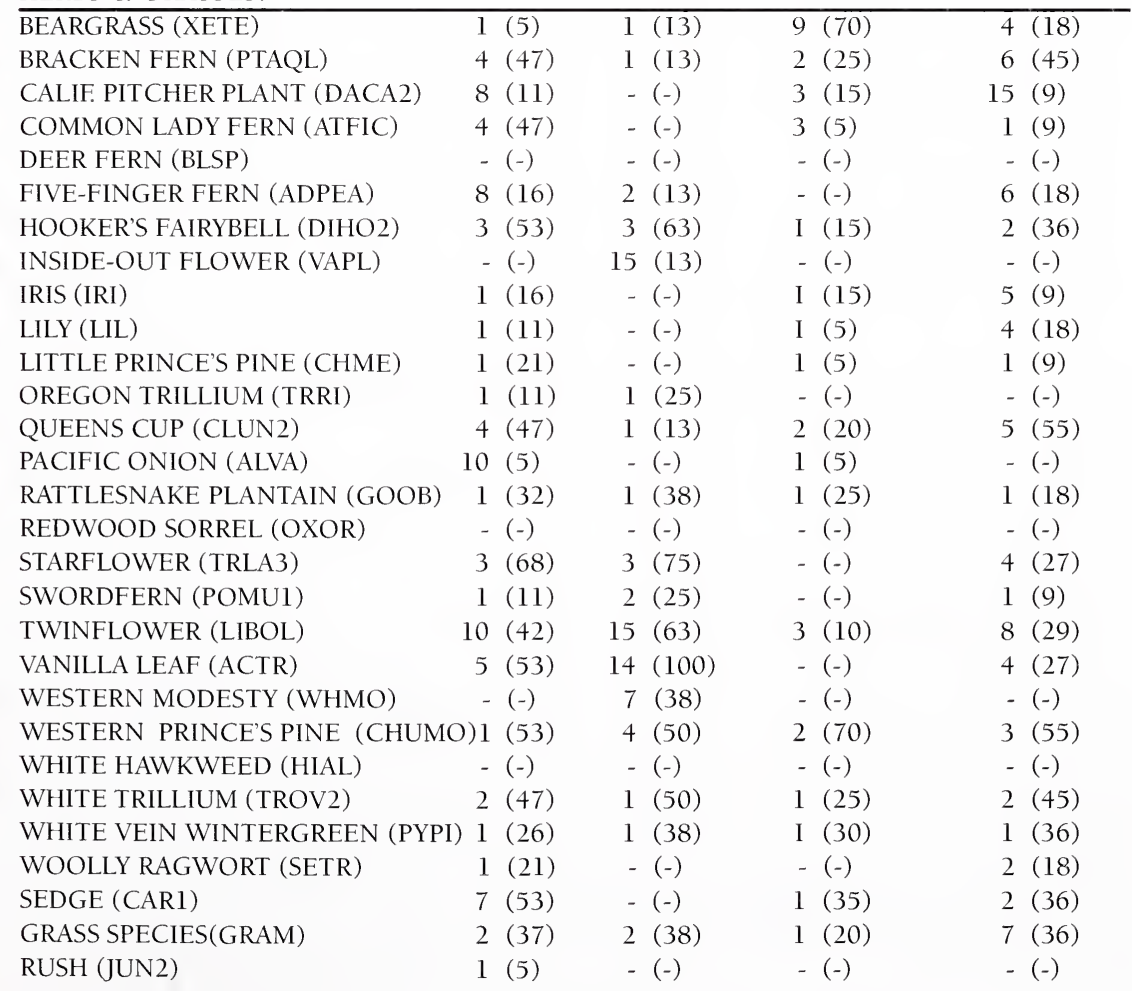




\section{VEGETATION SUMMARY}

\begin{tabular}{|c|c|c|c|}
\hline PLANT ASSOCIATION: & & \% COVER & \\
\hline VEGETATION LAYER : & $\begin{array}{l}\text { CHLA-ABMAS/ } \\
\text { ALSI2/DACA2 }\end{array}$ & $\begin{array}{l}\text { CHLA-PSME/ } \\
\text { COCOC }\end{array}$ & $\begin{array}{l}\text { CHLA-PSME- } \\
\text { ALDER/ACCI-BENE1 }\end{array}$ \\
\hline $\mathrm{N}$ & 3 & 7 & 8 \\
\hline TOTAL COVER & 97 & 89 & 95 \\
\hline GRASS COVER & 48 & 1 & 2 \\
\hline FORB COVER & 53 & 49 & 32 \\
\hline SHRUB COVER & 37 & 35 & 43 \\
\hline TREE COVER & 38 & 66 & 78 \\
\hline
\end{tabular}

TREE OVERSTORY:

\% COVER (CONSTANCY)

\begin{tabular}{|c|c|c|c|}
\hline$\overline{\mathrm{BIG} \text { LEAF MAPLE (ACMA) }}$ & $-(-)$ & $20(43)$ & $10(50)$ \\
\hline BREWER'S SPRUCE (PIBR) & $1(67)$ & $-(-)$ & $-(-)$ \\
\hline DOUGLAS-FIR (PSME) & $1(33)$ & $12(100)$ & $32(100)$ \\
\hline INCENSE CEDAR (CADE3) & $-(-)$ & $-(-)$ & $7(50)$ \\
\hline JEFFREY PINE (PIJE) & $-(-)$ & $-(-)$ & $-(-)$ \\
\hline MADRONE (ARME3) & $-(-)$ & $5(14)$ & $5(25)$ \\
\hline MOUNTAIN HEMLOCK (TSME) & $11(67)$ & $-(-)$ & $-(-)$ \\
\hline PONDEROSA PINE (PIPO) & $-(-)$ & $-(-)$ & $-(-)$ \\
\hline PORT-ORFORD-CEDAR (CHLA) & $26(100)$ & $46(100)$ & $21(100)$ \\
\hline RED ALDER (ALRU2) & $-(-)$ & $20(14)$ & $33(100)$ \\
\hline REDWOOD (SESE2) & $12(100)$ & $-(-)$ & $-(-)$ \\
\hline SHASTA RED FIR (ABMAS) & $3(100)$ & $2(6)$ & $-(-)$ \\
\hline SUGAR PINE (PILA) & $-(-)$ & $-(-)$ & $-(-)$ \\
\hline TANOAK (LIDE2) & $-(-)$ & $-(-)$ & $3(83)$ \\
\hline WESTERN RED CEDAR (THPL) & $-(-)$ & $-(-)$ & $-(-)$ \\
\hline WESTERN WHITE PINE (PIMO3) & $4(100)$ & $-(-)$ & $-(-)$ \\
\hline WHITE FIR (ABCO) & $11(67)$ & $3(43)$ & $4(38)$ \\
\hline TREE UNDERSTORY: & \multicolumn{3}{|c|}{ \% COVER (CONSTANCY) } \\
\hline$\overline{\text { BIG LEAF MAPLE (ACMA) }}$ & $-(-)$ & $2(14)$ & $2(13)$ \\
\hline BREWER'S SPRUCE (PIBR) & $1(100)$ & $-(-)$ & $-(-)$ \\
\hline DOUGLAS-FIR (PSME) & $1(33)$ & $2(71)$ & $5(63)$ \\
\hline INCENSE CEDAR (CADE3) & $-(-)$ & $-(-)$ & $1(13)$ \\
\hline JEFFREY PINE (PIJE) & $-(-)$ & $-(-)$ & $-(-)$ \\
\hline MADRONE (ARME3) & $-(-)$ & $-(-)$ & $-(-)$ \\
\hline MOUNTAIN HEMLOCK (TSME) & $3(67)$ & $-(-)$ & $-(-)$ \\
\hline PONDEROSA PINE (PIPO) & $-(-)$ & $-(-)$ & $-(-)$ \\
\hline PORT-ORFORD-CEDAR (CHLA) & $6(100)$ & $3(86)$ & $3(88)$ \\
\hline RED ALDER (ALRU2) & $-(-)$ & $4(14)$ & $2(63)$ \\
\hline REDWOOD (SESE2) & $-(-)$ & $-(-)$ & $-(-)$ \\
\hline SHASTA RED FIR (ABMAS) & $2(100)$ & $-(-)$ & $-(-)$ \\
\hline SUGAR PINE (PILA) & $-(-)$ & $-(-)$ & $-(-)$ \\
\hline TANOAK (LIDE2) & - (-) & $-(-)$ & $3(38)$ \\
\hline WESTERN RED CEDAR (THPL) & $-(-)$ & $-(-)$ & $-(-)$ \\
\hline WESTERN WHITE PINE (PIMO3) & $3(100)$ & $-(-)$ & $-(-)$ \\
\hline WHITE FIR (ABCO) & $1(67)$ & $1(57)$ & $3(25)$ \\
\hline
\end{tabular}




\begin{tabular}{llcc} 
& CHLA-ABMAS/ & CHLA-PSME/ & CHLA-PSME- \\
SHRUBS : & ALSIDACA2 & COCOC & ALDER/ACCI-BENE1 \\
\hline CALIFORNIA HAZELNUT (COCOC) & $-(-)$ & $26(100)$ & $6(75)$ \\
COFFEEBERRY (RHCA) & $-(-)$ & $1(14)$ & $3(13)$ \\
DWARF OREGON-GRAPE (BENE1) & $-(-)$ & $3(43)$ & $10(75)$ \\
DWARF TANBARK (LIDEE) & $-(-)$ & $-(-)$ & $-(-)$ \\
EVERGREEN HUCKLEBERRY (VAOV) & $-(-)$ & $-(-)$ & $-(-)$ \\
HUCKLEBERRY OAK (QUVA) & $1-(67)$ & $1(43)$ & $3(38)$ \\
PACIFIC RHODODENDRON (RHMA) & $-(-)$ & $-(-)$ & $-(-)$ \\
PINEMAT MANZANITA (ARNE2) & $-(-)$ & $-(-)$ & $-(-)$ \\
POISON OAK (RHDI) & $-(-)$ & $10(14)$ & $10(25)$ \\
RED HUCKLEBERRY (VAPA) & $-(-)$ & $-(-)$ & $4(50)$ \\
SADLER OAK (QUSA) & $2(100)$ & $1(14)$ & $-(-)$ \\
SALAL (GASH) & $-(-)$ & $-(-)$ & $-(-)$ \\
SITKA ALDER (ALSI2) & $20(100)$ & $-(-)$ & $-(-)$ \\
SLENDER SALAL (GAOV) & $3(100)$ & $-(-)$ & $9(25)$ \\
THIN-LEAF HUCKLEBERRY (VAME) & $4(100)$ & $-(-)$ & $-(-)$ \\
TRAILING BLACKBERRY (RUUR) & $-(-)$ & $3(71)$ & $2(38)$ \\
VINE MAPLE (ACCI) & $-(-)$ & $-(-)$ & $12(100)$ \\
WESTERN AZALEA (RHOC) & $5(100)$ & $5(57)$ & $10(63)$ \\
WOOD ROSE (ROGY) & $-(-)$ & $2(57)$ & $2(38)$ \\
WESTERN LABRADOR TEA (LEGL1) & $-(-)$ & $-(-)$ & $-(-)$
\end{tabular}

HERBS \& GRASSES:

\% COVER (CONSTANCY)

BEARGRASS (XETE)
BRACKEN FERN (PTAQL)
CALIF PITCHER PLANT (DACA2)
COMMON LADY FERN (ATFIC)
DEER FERN (BLSP)
FIVE-FINGER FERN (ADPEA)
HOOKER'S FAIRYBELL (DIHO2)
INSIDE-OUT FLOWER (VAPL)
IRIS (IRI)
LILY (LIL2)
LITTLE PRINCE'S PINE (CHME)
OREGON TRILLIUM (TRRI)
QUEENS CUP (CLUN2)
PACIFIC ONION (ALVA)
RATTLESNAKE PLANTAIN (GOOB)
REDWOOD SORREL (OXOR)
STARFLOWER (TRLA3)
SWORDFERN (POMU1)
TWINFLOWER (LIBOL)
VANILLA LEAF (ACTR)
WESTERN MODESTY (WHMO)
WESTERN PRINCE'S PINE (CHUMO)
WHITE HAWKWEED
WHITE TRILLIUM (TROV2)
WHITE VEIN WINTERGREEN (PYPI)
WOOLLY RAGWORT (SETR)
SEDGE (CAR1)
GRASS SPECIES (GRAM)
RUSH (JUN2)

1 (67)

- (-)

$35(100)$

- (-)

$-(-)$

- (-)

$-(-)$

- (-)

- (-)

1 (100)

$-(-)$

$-(-)$

1 (33)

3 (100)

1 (33)

- (-)

- (-)

- (-)

$-(-)$

$-(-)$

$-(-)$

- (-)

- (-)

- (-)

- (-)

2 (100)

- (-)

$48 \quad(100)$

- (-)

- (-)

2 (29)

$-(-)$

- (-)

- (-)

1 (14)

8 (71)

$4(43)$

1 (29)

8 (29)

2 (14)

$-(-)$

$-(-)$

- (-)

1 (71)

- (-)

$3(71)$

1 (14)

$12(57)$

18 (86)

5 (43)

2 (14)

- (-)

1 (29)

- (-)

- (-)

13 (14)

2 (14)

- (-)
- (-)

5 (13)

- (-)

- (-)

- (-)

4 (25)

1 (50)

- (-)

- (-)

1 (13)

1 (13)

- (-)

- (-)

- (-)

1 (13)

- (-)

3 (63)

$10 \quad(75)$

13 (38)

5 (50)

9 (63)

2 (13)

1 (13)

1 (25)

- (-)

- (-)

5 (13)

2 (38)

- (-)

new 7/99 


\section{VEGETATION SUMMARY}

PLANT ASSOCIATION:

$\%$ COVER

\begin{tabular}{lccc} 
VEGETATION LAYER : & $\begin{array}{c}\text { CHLA-PIMO3/ } \\
\text { RHOC-LIDEE-LEGL1 }\end{array}$ & $\begin{array}{l}\text { CHLA-PIMO3/ } \\
\text { LEGL1/DACA2//COASTAL }\end{array}$ & $\begin{array}{l}\text { PIJE-CHLA/ } \\
\text { QUVA }\end{array}$ \\
\hline $\mathrm{N}$ & 9 & 23 & 8 \\
TOTAL COVER & 82 & 87 & 76 \\
GRASS COVER & 11 & 25 & 1 \\
FORB COVER & 4 & 15 & 8 \\
SHRUB COVER & 58 & 56 & 41 \\
TREE COVER & 46 & 54 & 38
\end{tabular}

TREE OVERSTORY:

\% COVER (CONSTANCY)

\begin{tabular}{llcc}
\hline BIG LEAF MAPLE (ACMA) & $-(-)$ & $-(-)$ & $-(-)$ \\
BREWER'S SPRUCE (PIBR) & $-(-)$ & $-(-)$ & $4(25)$ \\
DOUGLAS-FIR (PSME) & $4(78)$ & $6(48)$ & $8(75)$ \\
INCENSE CEDAR (CADE3) & $2(11)$ & $-(-)$ & $3(88)$ \\
JEFFREY PINE (PIJE) & $3(33)$ & $5(22)$ & $14(100)$ \\
MADRONE (ARME3) & $-(-)$ & $3(9)$ & $-(-)$ \\
MOUNTAIN HEMLOCK (TSME) & $-(-)$ & $-(-)$ & $-(-)$ \\
PONDEROSA PINE (PIPO) & $-(-)$ & $-(-)$ & $-(-)$ \\
PORT-ORFORD-CEDAR (CHLA) & $33(100)$ & $39(100)$ & $8(100)$ \\
RED ALDER (ALRU2) & $-(-)$ & $-(-)$ & $2(13)$ \\
REDWOOD (SESE2) & $-(-)$ & $-(-)$ & $-(-)$ \\
SHASTA RED FIR (ABMAS) & $-(-)$ & $-(-)$ & $2(13)$ \\
SUGAR PINE (PILA) & $-(-)$ & $4(13)$ & $6(88)$ \\
TANOAK (LIDE2) & $-(-)$ & $5(9)$ & $-(-)$ \\
WESTERN RED CEDAR (THPL) & $-(-)$ & $-(-)$ & $-(-)$ \\
WESTERN WHITE PINE (PIMO3) & $8(100)$ & $8(100)$ & $4(63)$ \\
WHITE FIR (ABCO) & $-(-)$ & $-(-)$ & $1(38)$
\end{tabular}

TREE UNDERSTORY:

\% COVER (CONSTANCY)

\begin{tabular}{llll}
\hline BIG LEAF MAPLE (ACMA) & $-(-)$ & $-(-)$ & $-(-)$ \\
BREWER'S SPRUCE (PIBR) & $-(-)$ & $-(-)$ & $2(25)$ \\
DOUGLAS-FIR (PSME) & $1(22)$ & $1(26)$ & $1(63)$ \\
INCENSE CEDAR (CADE3) & $-(-)$ & $-(-)$ & $1(88)$ \\
JEFFREY PINE (PIJE) & $1(11)$ & $1(13)$ & $2(88)$ \\
MADRONE (ARME3) & $-(-)$ & $-(-)$ & $-(-)$ \\
MOUNTAIN HEMLOCK (TSME) & $-(-)$ & $-(-)$ & $-(-)$ \\
PONDEROSA PINE (PIPO) & $-(-)$ & $-(-)$ & $-(-)$ \\
PORT-ORFORD-CEDAR (CHLA) & $3(100)$ & $4(100)$ & $2(100)$ \\
RED ALDER (ALRU2) & $-(-)$ & $-(-)$ & $-(-)$ \\
REDWOOD (SESE2) & $-(-)$ & $-(-)$ & $-(-)$ \\
SHASTA RED FIR (ABMAS) & $-(-)$ & $-(-)$ & $1(13)$ \\
SUGAR PINE (PILA) & $-(-)$ & $2(13)$ & $1(38)$ \\
TANOAK (LIDE2) & $-(-)$ & $2(9)$ & $-(-)$ \\
WESTERN RED CEDAR (THPL) & $-(-)$ & $-(-)$ & $-(-)$ \\
WESTERN WHITE PINE (PIMO3) & $2(100)$ & $3(96)$ & $2(50)$ \\
WHITE FIR (ABCO) & $-(-)$ & $-(-)$ & $1(13)$
\end{tabular}


PLANT ASSOCIATION:

$\%$ COVER (CONSTANCY)

CHLA-PIMO3/ CHLA-PIMO3/

PIJE-CHLA/

SHRUBS:

RHOC-LIDEE-LEGL1 LEGL1/DACA2//COASTAL QUVA

CALIFORNIA HAZELNUT (COCOC)
COFFEEBERRY (RHCA)
DWARF OREGON-GRAPE (BENE1)
DWARF TANBARK (LIDEE)
EVERGREEN HUCKLEBERRY (VAOV)
HUCKLEBERRY OAK (QUVA)
PACIFIC RHODODENDRON (RHMA)
PINEMAT MANZANITA (ARNE2)
POISON OAK (RHDI)
RED HUCKLEBERRY (VAPA)
SADLER OAK (QUSA)
SALAL (GASH)
SITKA ALDER (ALSI2)
SLENDER SALAL (GAOV)
THIN-LEAF HUCKLEBERRY (VAME)
TRAILING BLACKBERRY (RUUR)
VINE MAPLE (ACCI)
WESTERN AZALEA (RHOC)
WOOD ROSE (ROGY)
WESTERN IABRADOR TEA (LEGL1)

$3(78)$

$-(-)$

$5(100)$

1 (22)

$10(89)$

$1(11)$

$1(11)$

$-(-)$

$2(78)$

$-(-)$

$-(-)$

- (-)

- (-)

1 (11)

$-(-)$

$-(-)$

$26(100)$

- (-)

$22(67)$
$3(57)$

- (-)

8 (91)

6 (39)

4 (83)

3 (17)

5 (4)

- (-)

2 (52)

- (-)

9 (35)

- (-)

$-(-)$

- (-)

1 (4)

- (-)

15 (100)

1 (4)

29 (100)
- (-)

2 (75)

- (-)

- (-)

- (-)

27 (100)

- (-)

$7(75)$

- (-)

$6(63)$

- (-)

- (-)

- (-)

$-(-)$

- (-)

1 (13)

- (-)

- (-)

1 (25)

- (-)

HERBS \& GRASSES:

$\%$ COVER (CONSTANCY)

\begin{tabular}{|c|c|c|c|}
\hline BEARGRASS (XETE) & $5(33)$ & $4(43)$ & $7(75)$ \\
\hline BRACKEN FERN (PTAQL) & $-(-)$ & $-(-)$ & $-(-)$ \\
\hline CALIF. PITCHER PLANT (DACA2) & $1(11)$ & $11(91)$ & $-(-)$ \\
\hline COMMON LADY FERN (ATFIC) & $-(-)$ & $-(-)$ & $-(-)$ \\
\hline DEER FERN (BLSP) & $-(-)$ & $-(-)$ & $-(-)$ \\
\hline FIVE-FINGER FERN (ADPEA) & $2(44)$ & $3(13)$ & $-(-)$ \\
\hline HOOKER'S FAIRYBELL (DIHO2) & $-(-)$ & $-(-)$ & $-(-)$ \\
\hline INSIDE-OUT FLOWER (VAPL) & $1(33)$ & $-(-)$ & $-(-)$ \\
\hline IRIS (IRI) & $1(11)$ & $2(26)$ & $1(50)$ \\
\hline LILY (LIL2) & $-(-)$ & $1(9)$ & l (13) \\
\hline LITTLE PRINCE'S PINE (CHME) & $-(-)$ & $-(-)$ & $-(-)$ \\
\hline OREGON TRILLIUM (TRRI) & $-(-)$ & $1(39)$ & $-(-)$ \\
\hline QUEENS CUP (CLUN2) & $-(-)$ & $-(-)$ & $-(-)$ \\
\hline PACIFIC ONION (ALVA) & $-(-)$ & $-(-)$ & $-(-)$ \\
\hline RATTLESNAKE PLANTAIN (GOOB) & $1(22)$ & $1(4)$ & $1(13)$ \\
\hline REDWOOD SORREL (OXOR) & $-(-)$ & $-(-)$ & $-(-)$ \\
\hline STARFLOWER (TRLA3) & $-(-)$ & $-(-)$ & $-(-)$ \\
\hline SWORDFERN (POMU1) & $-(-)$ & $2(17)$ & $-(-)$ \\
\hline TWINFLOWER (LIBOL) & $-(-)$ & $-(-)$ & $-(-)$ \\
\hline VANILLA LEAF (ACTR) & $-(-)$ & $-(-)$ & $-(-)$ \\
\hline WESTERN MODESTY (WHMO) & $1(22)$ & $3(4)$ & $2(13)$ \\
\hline WESTERN PRINCE'S PINE (CHUMO) & $-(-)$ & $1(4)$ & $-(-)$ \\
\hline WHITE HAWKWEED (HIAL) & $-(-)$ & $-(-)$ & $-(-)$ \\
\hline WHITE TRILLIUM (TROV2) & $-(-)$ & $-(-)$ & $-(-)$ \\
\hline WHITE VEIN WINTERGREEN (PYPI) & $-(-)$ & $1(4)$ & $1(25)$ \\
\hline WOOLLY RAGWORT (SETR) & $-(-)$ & $-(-)$ & $-(-)$ \\
\hline SEDGE (CAR1) & $7(89)$ & $23(87)$ & $2(25)$ \\
\hline GRASS SPECIES (GRAM) & $4(89)$ & $4(78)$ & $1(25)$ \\
\hline RUSH (JUN2) & $-(-)$ & $10(4)$ & $-(-)$ \\
\hline new 7/99 & 109 & & \\
\hline
\end{tabular}





\section{APPENDIX VI: GLOSSARY}




\section{GLOSSARY}

Definitions. The following definitions are used throughout the Pacific Southwest Region of the Forest Service to standardize the approach to its hierarchical vegetation classification. At the top of the vegetation hierarchy is the series. Series are identified by the presence of the dominant species in all or most of the structural layers present in late seral stage stands. Series are followed in the hierarchy by the sub-series. Here the series name is modified by the addition of a second species that has indicator value across multiple plant associations. At the bottom of the classification hierarchy the finest vegetation units described are plant associations. They are the potential natural community with uniform appearance and definite floristic composition.

SERIES: A vegetation series is an aggregation of taxonomically related plant associations which take the name of the (climatic) climax species that dominate (or have the potential to dominate) the principal vegetation layer in a time frame appropriate to the vegetation or taxonomic group under consideration.

SUB-SERIES: A vegetation sub-series is an aggregation of taxonomically related plant associations within a series that takes the name of that series followed by related species that are dominant, or have indicator value across multiple plant associations.

PLANT ASSOCIATION: A potential natural plant community of definite floristic composition and uniform appearance that repeats itself across the landscape and takes the name of the projected climax type.

INDICATOR SPECIES: A species which is sensitive to important environment features of a site such that its constancy or abundance reflect significant changes in environment.

ECOLOGICAL TYPE: A category of land having a unique combination of potential natural community, soil, landscape features, climate, and differing from other ecological types in its ability to produce vegetation and respond to management.

CHARACTERISTIC COVER: The percent cover one could expect to find in a plant association if a species were present. It is calculated by summing percent cover and dividing by the number of plots containing the species. 
CONSTANCY: The percent of times a species was found to occur in a plant association.

REPRODUCING SUCCESSFULLY: The species is present throughout the structural layers which are represented in the late seral stand.

PRIMARY REGENERATING SPECIES: The species which is higher in cover, or in number of individual stems, than any other species of the principle vegetative layer. 


\section{APPENDIX VII: ECOCLASS CODES}




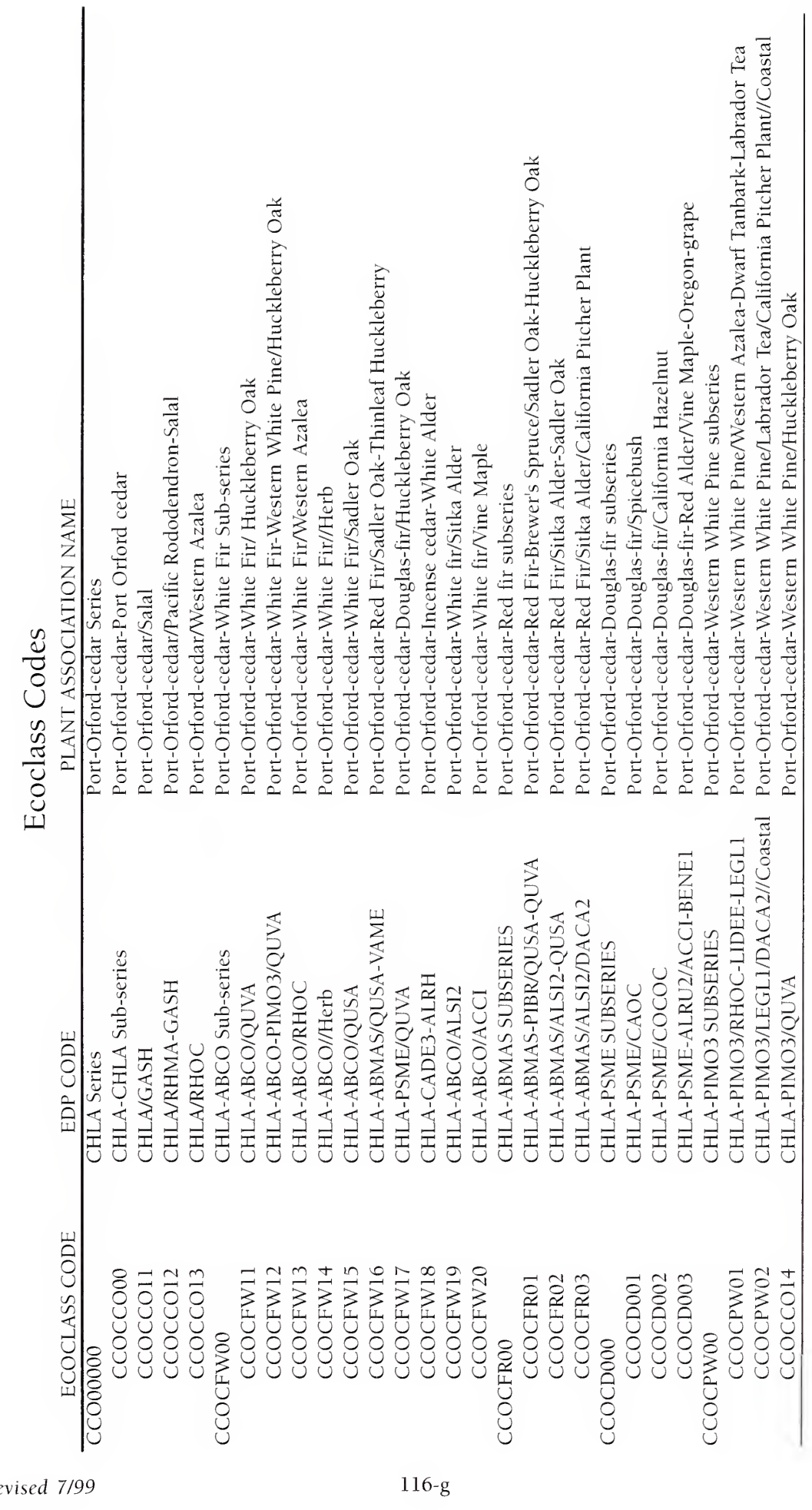



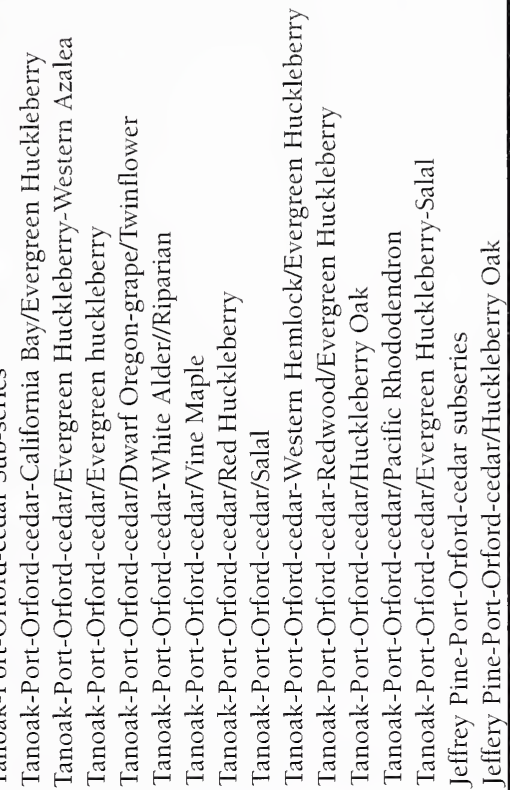

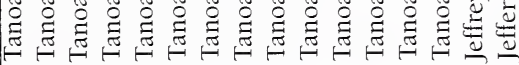

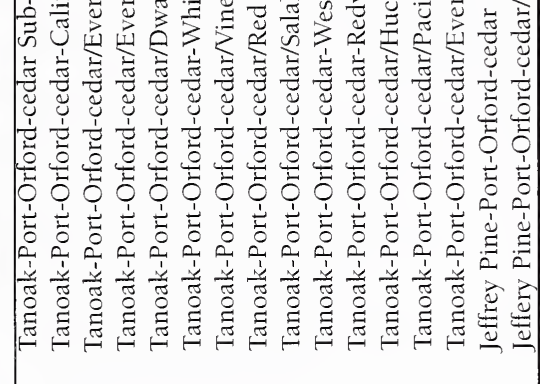

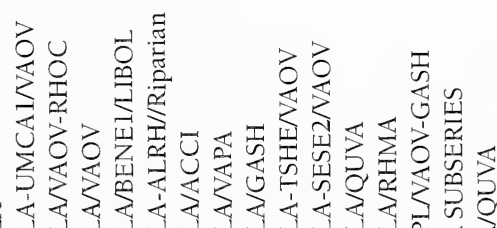

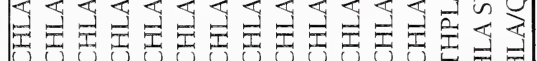

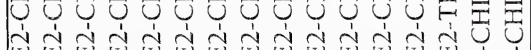

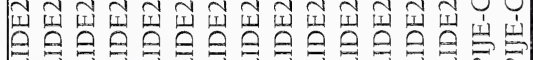

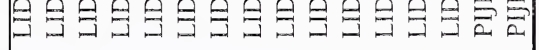

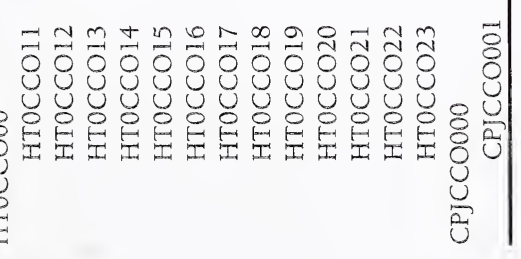




\section{U.S. Forest Service \\ Pacific Southwest Library and Information Center \\ 1323 Ciub Drive \\ Vallejo, CA $94592-1110$}

